Szegedi Tudományegyetem

Bölcsészettudományi Kar

Neveléstudományi Doktori Iskola

Szenczi Beáta

\title{
AZ OLVASÁSI MOTIVÁCIÓ VIZSGÁlATA 8-14 ÉVES TANULÓK KÖRÉBEN
}

$\mathrm{PhD}$ értekezés

Témavezető:

Dr. Józsa Krisztián

egyetemi docens

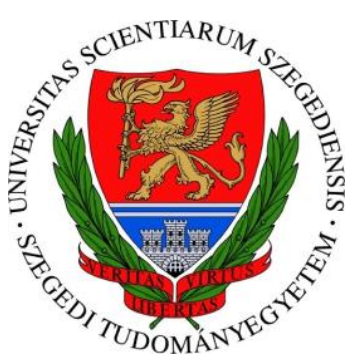

Oktatáselmélet doktori program

Szeged

2012 


\section{TARTALOMJEGYZÉK}

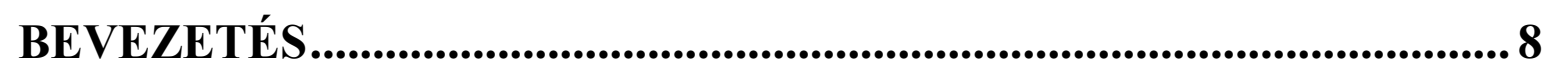

I. ELMÉLETI HÁTTÉR................................................................... 12

1. Motiváció és tanulási motiváción............................................................. 12

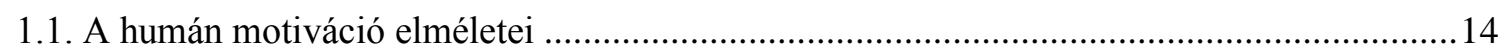

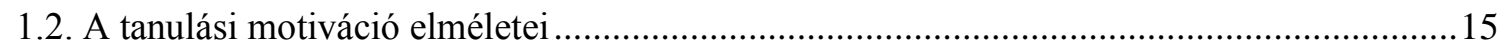

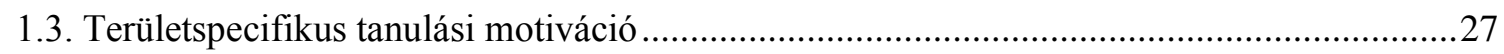

2. Olvasási motiváció ................................................................................ 29

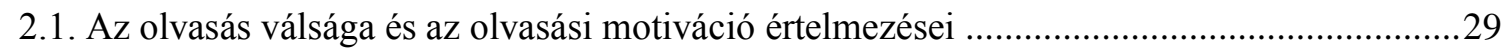

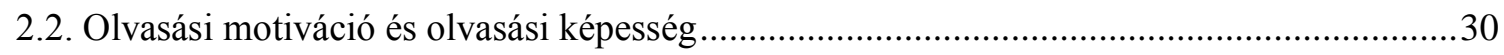

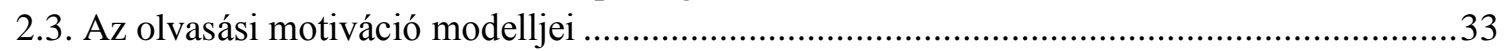

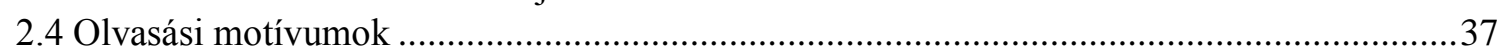

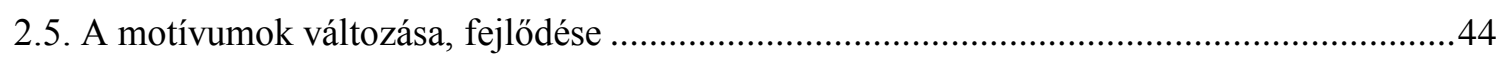

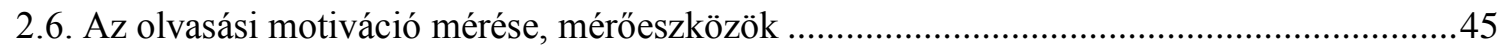

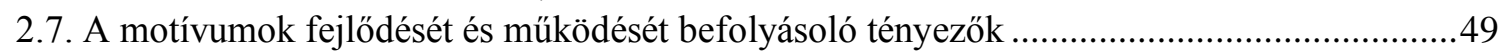

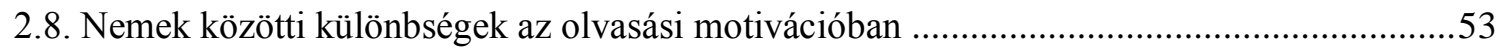

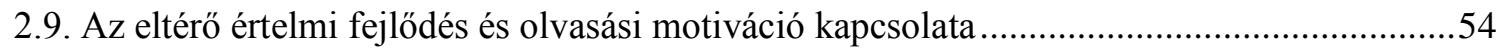

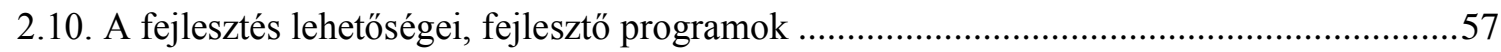

II. AZ EMPIRIKUS KUTATÁS ........................................................68

Az empirikus kutatás célja és koncepciója ..................................................... 68

1. Az első pilot mérés.................................................................................68

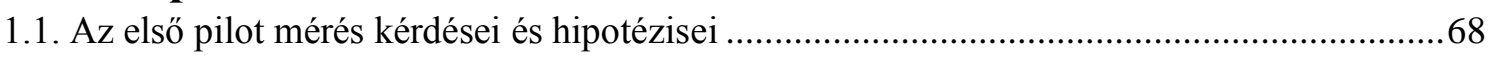

1.2. Adatfelvétel, minta és mérőeszközök az első pilot mérés során ..........................................70

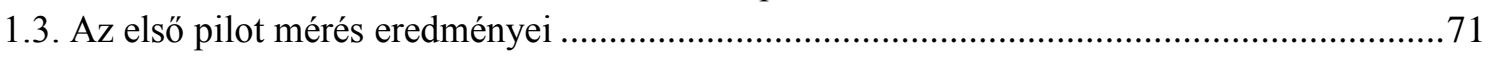

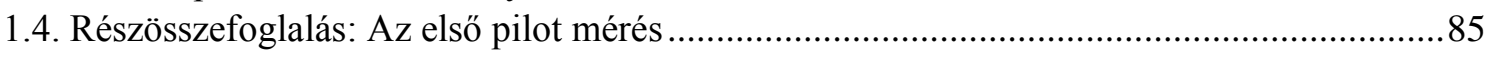

2. A második pilot mérés.....................................................................85

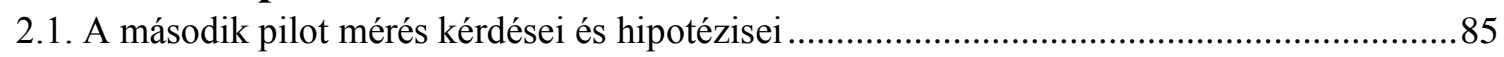

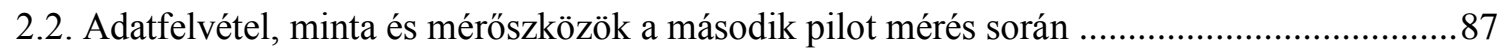

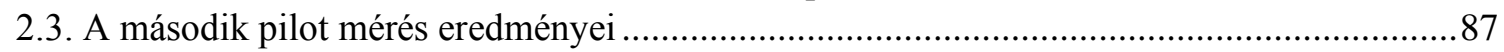

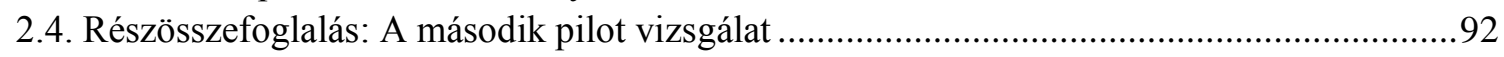

3. A központi empirikus vizsgálat ........................................................93

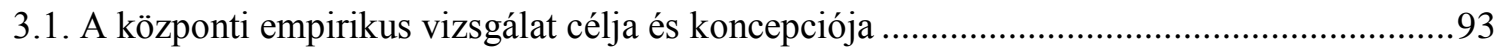

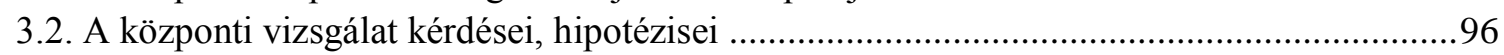

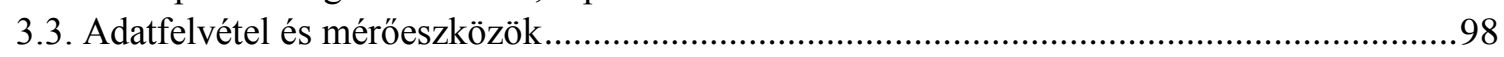

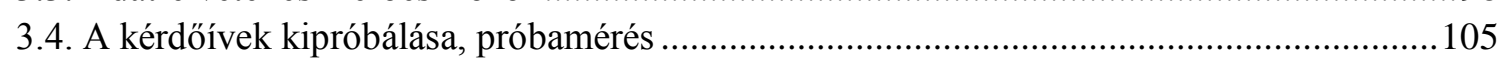

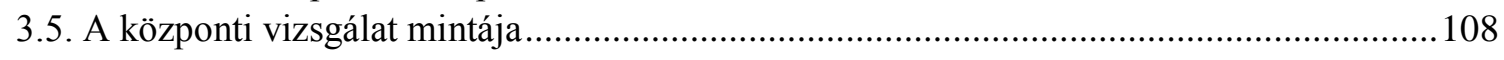

4. A központi vizsgálat eredményei ........................................................... 110

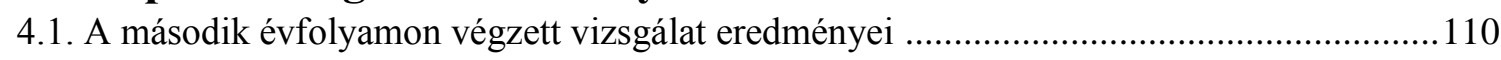

4.2. A negyedik, hatodik és nyolcadik évfolyamon végzett vizsgálat eredményei .....................133

5. Az olvasási motívumok fejlődésének kontextusa ................................... 166

5.1 Az otthoni kontextus jellemzői és összefüggése az olvasási motívumokkal ........................166

$5.2 \mathrm{Az}$ iskolai kontextus jellemzői és összefüggése az olvasási motívumokkal .........................181 
6. Kiegészítő vizsgálat: Leendő és gyakorló pedagógusok olvasással és olvasási motivációval kapcsolatos meggyőződései

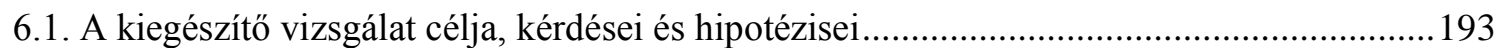

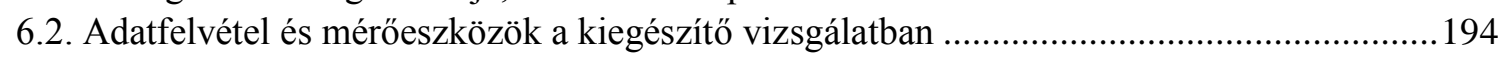

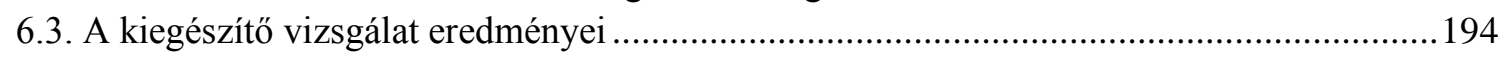

6.4. Részösszefoglalás: Leendő és gyakorló pedagógusok meggyőződései az olvasási

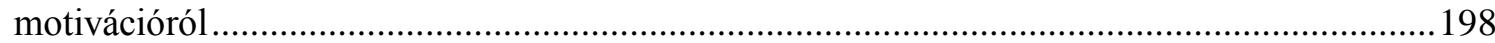

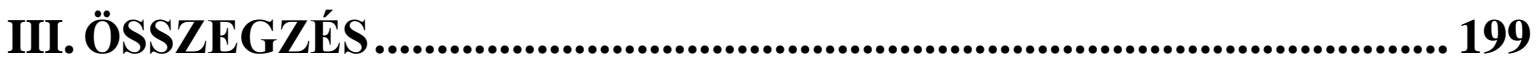
IV. AZ EREDMÉNYEK FELHASZNÁLÁSA ÉS TOVÁBBI KUTATÁSI

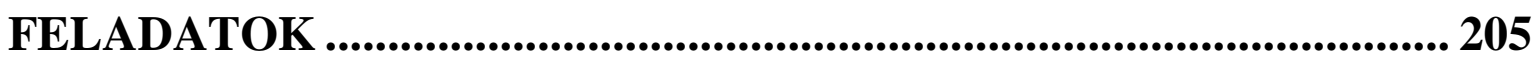

Köszönetnyilvánítás ......................................................................................... 206

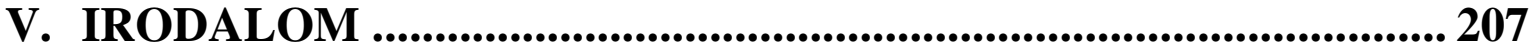

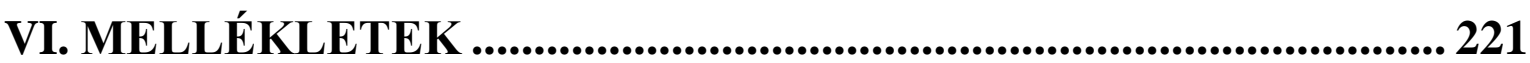




\section{ÁBRAJEGYZÉK}

1. ábra A relatív autonómia öndeterminációs kontinuuma az eredményeként megjelenő különböző motivációtípusokkal és szabályozástípusokkal (Ryan és Deci, 2009, 177. o.)...................19

2. ábra Eccles és munkatársai elvárás-érték modellje (Eccles és Wigfield, 2002) …........................26

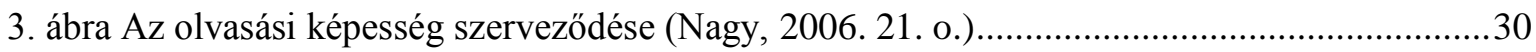

4. ábra A kezdeti olvasási motiváció modellje (Wilson és Trainin, 2007, 258. o.) ...........................35

5. ábra Az olvasási motiváció elvárás-érték modellje (Möller és Schiefele, 2010)...........................36

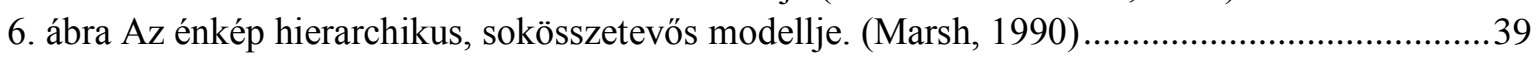

7. ábra Az olvasási képesség és motiváció fejlődésének kontextusai (Kelly, 2003 alapján) .............49

8. ábra. Az elkötelezett és elmélyült olvasás modellje (Guthrie és Wigfield, 2000. 410. o.) ...........65

9. ábra Az énképkomponensek klaszteranalízise (Average Linkage, Between Groups), 3. évfolyam

10. ábra Az énképkomponensek klaszteranalízise(Average Linkage, Between Groups), 5. évfolyam

11. ábra Az énképkomponensek klaszteranalízise (Average Linkage, Between Groups), 7.

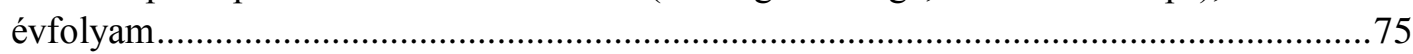

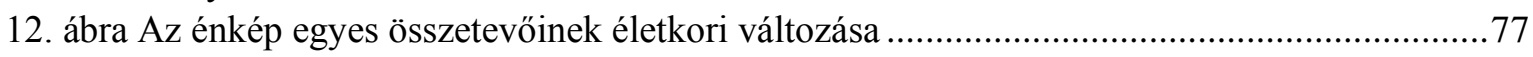

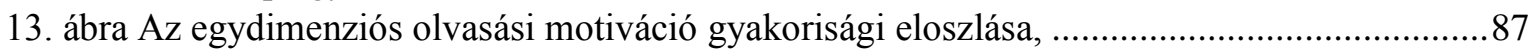

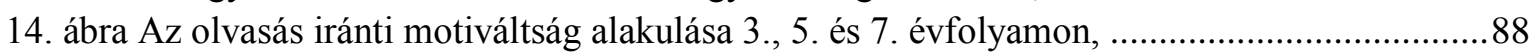

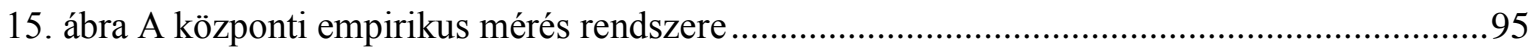

16. ábra A mesehallgatás iránti attitüd eloszlásgörbéje, második osztály ………….....................113

17. ábra Az aktív olvasás iránti attitüdök eloszlásgörbéje, második osztály ...................................113

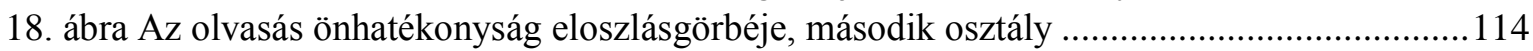

19. ábra Az olvasás során átélt flow eloszlásgörbéje, második osztály ........................................115

20. ábra Az olvasás során átélt antiflow eloszlásgörbéje, második osztály .................................116

21. ábra Az olvasásnak tulajdonított érték eloszlásgörbéje, második osztály ...............................116

22. ábra Az olvasási énkép eloszlásgörbéje, második osztály .................................................117

23. ábra Az olvasási motívumok közötti összefüggések, dendrogram (Average Linkage, Between

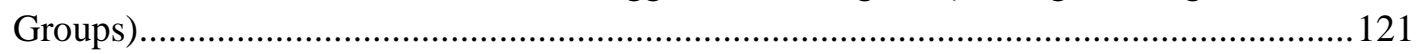

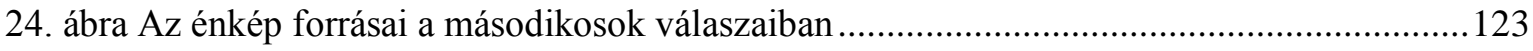

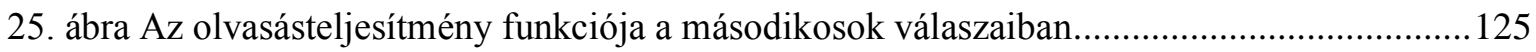

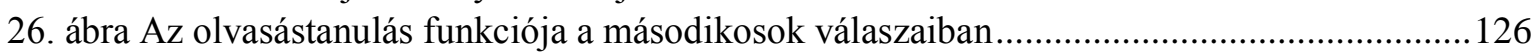

27. ábra Az énkép forrásai a másodikosok válaszaiban nemek szerinti bontásban.........................128

28. ábra Az olvasásteljesítmény funkciója a másodikosok válaszaiban nemek szerinti bontásban 129

29. ábra Az olvasástanulás funkciója a másodikosok válaszaiban nemek szerinti bontásban .........130

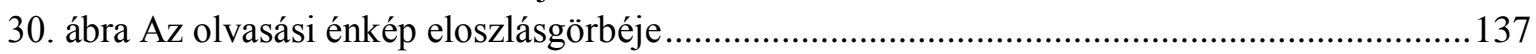

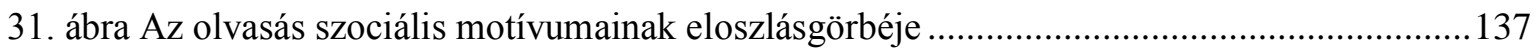

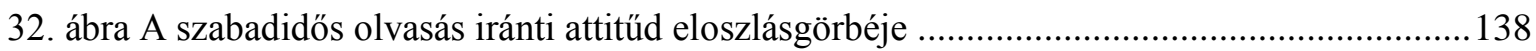

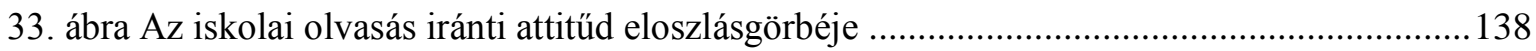

34. ábra Az olvasásnak tulajdonított gyakorlati érték eloszlásgörbéje........................................139

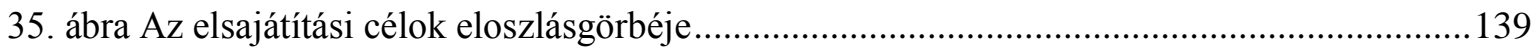

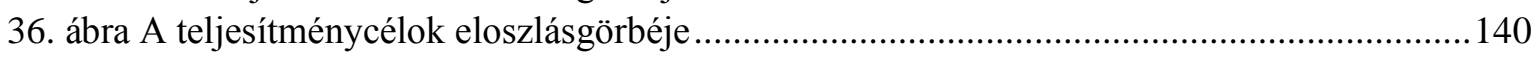

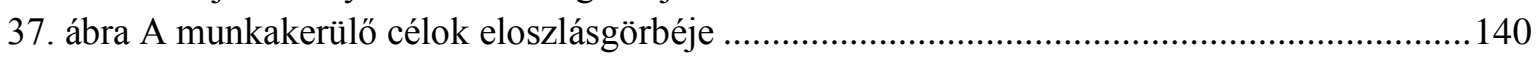

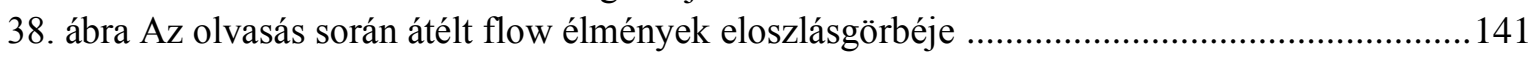

39. ábra Az olvasás során átélt antiflow élmények eloszlásgörbéje ..............................................141

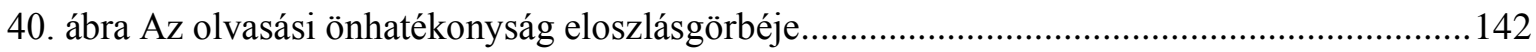

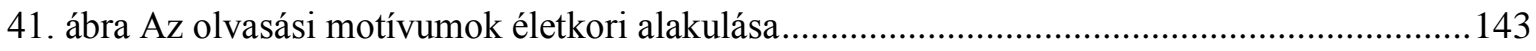

42. ábra Az olvasási motívumok közötti összefüggések, dendrogram, 4. évfolyam ........................148 
43. ábra Az olvasási motívumok közötti összefüggések, dendrogram, 6. évfolyam

44. ábra Az olvasási motívumok közötti összefüggések, dendrogram, 8. évfolyam

45. ábra Az olvasásélményen alapuló otthoni tevékenységek gyakorisága

46. ábra Az olvasást elókészítő tevékenységek gyakorisága az iskoláskor előtt

47. ábra Az olvasmányélményen alapuló otthoni tevékenységek gyakorisága iskoláskorban

48. ábra Az olvasási képesség fejlesztésére irányuló otthoni tevékenységek gyakorisága

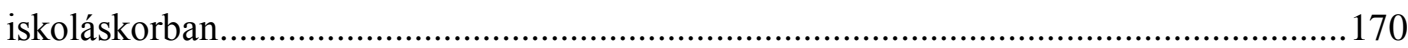

49. ábra A szülők által egy áltagos héten olvasással töltött órák száma ………….........................173

50. ábra A szülők által a „Milyen gyakran olvas saját örömére?” ...................................................174

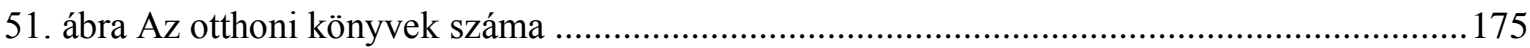

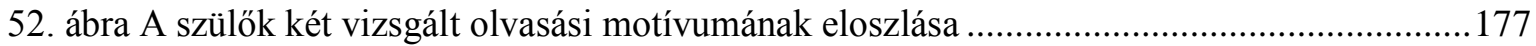

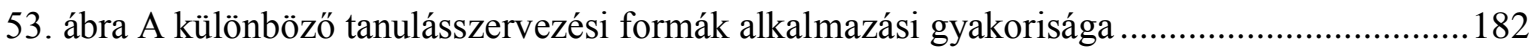

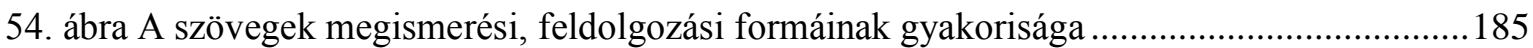

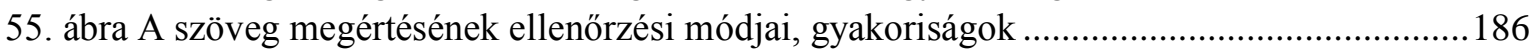

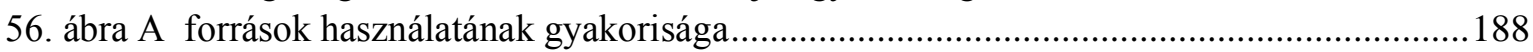

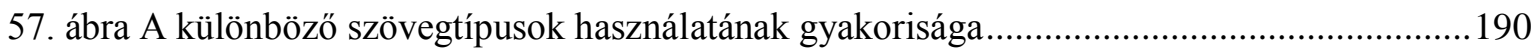

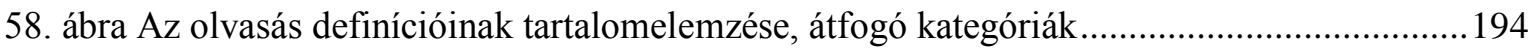

59. ábra Az olvasás definícióinak tartalomelemzése, részletes kategóriák .....................................195

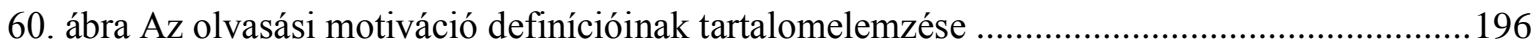

61. ábra Az olvasás iránt motivált tanuló jellemzői a pedagógusok válaszaiban ............................196 


\section{TÁBLÁZATJEGYZÉK}

1. táblázat Az énkép és az önhatékonyság összehasonlítása (Bong és Skaalvik, 2003 alapján)........38

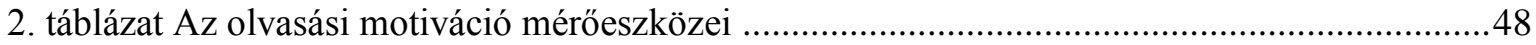

3. táblázat A társadalmi és közösségi, az otthoni és az iskolai kontextusok hatótényezöi (Kelly, 2003 alapján)

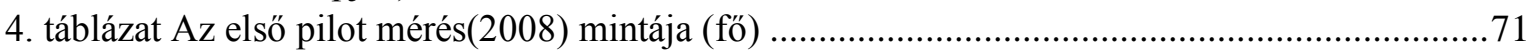

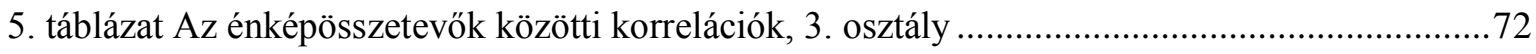

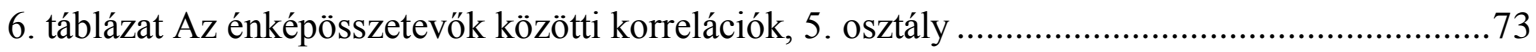

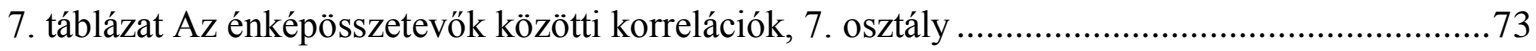

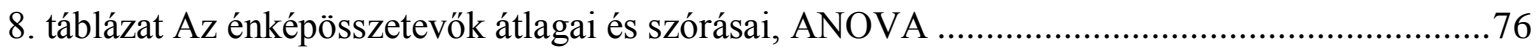

9. táblázat Az énképösszetevők és a tanulmányi eredmények korrelációja, 5. osztály .....................78

10. táblázat Az énképösszetevők és a tanulmányi eredmények korrelációja 7. osztály ....................78

11. táblázat Az énképösszetevők összefüggése az osztályzatokkal, a szövegértés és a matematika teszteken elért eredményekkel, az IQ-val, a szülők iskolai végzettségével és a nemmel,

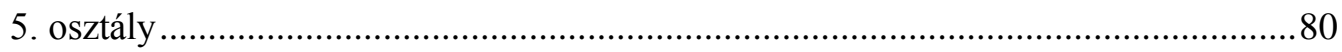

12. táblázat Az énképösszetevők összefüggése az osztályzatokkal, a szövegértés és a matematika teszteken elért eredményekkel, az IQ-val, a szülök iskolai végzettségével és a nemmel, 7. osztály.....

13. táblázat Az énképösszetevők összefüggése az osztályzatokkal, a szövegértés és a matematika teszteken elért eredményekkel, az IQ-val, a szülők iskolai végzettségével és a nemmel, regresszióanalízis.

14. táblázat Az énképösszetevők, a tantárgyi attitűdök, az iskola kedveltsége és a teljesítménnyel való elégedettség összefüggései, 3. osztály

15. táblázat Az énképösszetevők, a tantárgyi attitüdök, az iskola kedveltsége és a teljesítménnyel való elégedettség összefüggései, 5. osztály ............................................................ 82

16. táblázat Az énképösszetevők, a tantárgyi attitüdök, az iskola kedveltsége és a teljesítménnyel

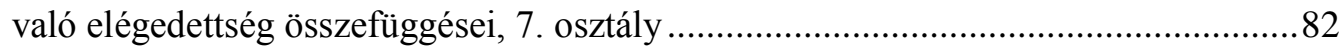

17. táblázat A hátrányos és a nem hátrányos helyzetủ tanulók énképkomponenseinek átlaga,

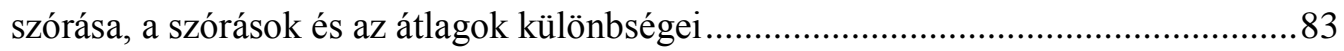

18. táblázat Az énképkomponensek átlaga az apa iskolai végzettsége szerinti bontásban ................84

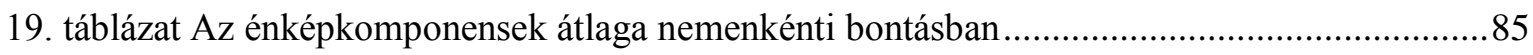

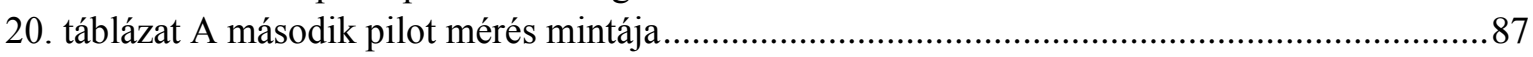

21. táblázat Az olvasási motiváció 3., 5. és 7. évfolyamon, többségi és tanulásban akadályozott

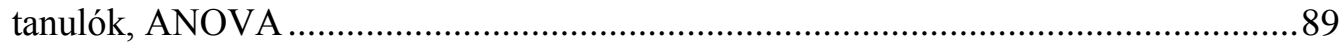

22. táblázat Többségi és tanulásban akadályozott tanulók olvasás iránti motivációja ......................89

23. táblázat Az olvasási motiváció és az olvasási képesség összefüggése, korrelációk ...................90

24. táblázat Az olvasás iránti attitüd és az olvasási képesség összefüggése, regresszióanalízis.

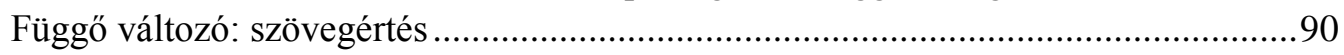

25. táblázat Az olvasás iránti attitűd és az olvasási képesség összefüggése, regresszióanalízis. Függő változó: olvasási motiváció......................................................................90

26. táblázat A szövegértés, az olvasási motiváció, az IQ és az apa iskolai végzettségének

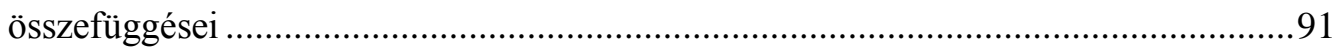

27. táblázat Az olvasási motiváció kérdőívek skálái és a skálák kidolgozásához felhasznált

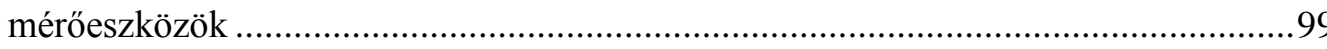

28. táblázat. Az olvasási motiváció mérőeszközének felépítése a második évfolyam vizsgálatában

29. táblázat. Az olvasási motiváció mérőeszközének felépítése a felsőbb évfolyamok vizsgálataiban 
30. táblázat A központi mérés mintája

31. táblázat. A minta korcsoportonkénti elemszáma és az anya iskolai végzettségének a KruskalWallis próba alapján számított szignifikanciája

32. táblázat. A minta korcsoportonkénti elemszáma és az apa iskolai végzettségének a KruskalWallis próba alapján számított szignifikanciája

33. táblázat Az egyes motívumokat vizsgáló skálákhoz tartozó kérdőívtételek száma és megbízhatósági mutatóik

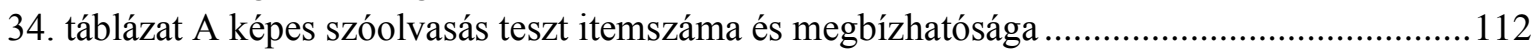

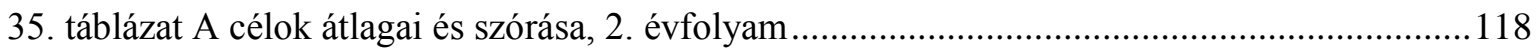

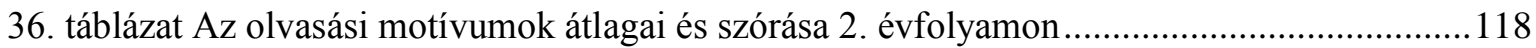

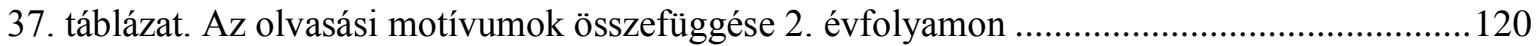

38. táblázat A motívumok közötti összefüggések, regresszióanalízis, 2. osztály............................121

39. táblázat Az énkép forrásaival kapcsolatos kérdésre adott válaszok alapján létrehozott kategóriák

40. táblázat Az olvasásteljesítmény értékére vonatkozó kérdésre adott válaszok alapján létrehozott kategóriák

41. táblázat Az olvasás hasznosságának okára vonatkozó kérdésekre adott válaszok alapján

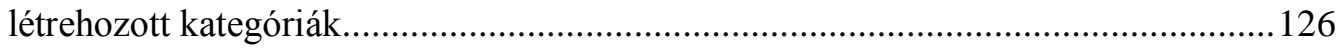

42. táblázat Az olvasási motívumok átlagai nemenkénti bontásban ............................................127

43. táblázat Az énkép forrásai, nemek közötti különbségek ......................................................128

44. táblázat Az olvasásteljesítmény funkciója, nemek közötti különbségek................................129

45. táblázat Az olvasástanulás funkciója, nemek közötti különbségek ......................................130

46. táblázat Összefüggések az olvasási motívumok, a teljesítménymutatók és a családi háttér között

47. táblázat Az olvasási motiváció kérdőív skáláinak megbízhatósága az itemkihagyás előtt és után

48. táblázat Az olvasási motiváció kérdőív skáláinak megbízhatósága évfolyamonkénti bontásban

Az olvasási motivumok életkori alakulása (\%p), ANOVA.

51. táblázat Az olvasási motívumok közötti összefüggések, teljes minta és negyedik évfolyam ..145

52. táblázat Az olvasási motívumok közötti összefüggések, hatodik és nyolcadik évfolyam .........146

53. táblázat A motívumok közötti összefüggések, regresszióanalízis, 4. osztály .............................149

54. táblázat A motívumok közötti összefüggések, regresszióanalízis, 6. osztály ............................150

55. táblázat A motívumok közötti összefüggések, regresszióanalízis, 8. osztály............................150

56. táblázat Összefüggések az olvasási motívumok és a teljesítménymutatók között, 4. évfolyam

57. táblázat Összefüggések az olvasási motívumok és a teljesítménymutatók között, 6 . évfolyam

58. táblázat Összefüggések az olvasási motívumok és a teljesítménymutatók között, 8. évfolyam

59. táblázat Az egyes olvasási motívumok és teljesítménymutatók közötti összefüggések, regresszióanalízis, függő változók: motívumok, 4. osztály .....................................156

60. táblázat $\mathrm{Az}$ egyes olvasási motívumok és teljesítménymutatók közötti összefüggések, regresszióanalízis, függő változók: motívumok, 6 . osztály

61. táblázat Az egyes olvasási motívumok és teljesítménymutatók közötti összefüggések, regresszióanalízis, függő változók: motívumok, 8. osztály

62. táblázat Az egyes olvasási motívumok és teljesítménymutatók közötti összefüggések, regresszióanalízis, függő változók: teljesítménymutatók, 4. osztály 
63. táblázat Az egyes olvasási motívumok és teljesítménymutatók közötti összefüggések, regresszióanalízis, függő változók: teljesítménymutatók, 6 . osztály

64. táblázat Az egyes olvasási motívumok és teljesítménymutatók közötti összefüggések, regresszióanalízis, függő változók: teljesítménymutatók, 8. osztály .....

65. táblázat Az olvasási motívumok átlagai nemenkénti bontásban, 4. évfolyam

66. táblázat Az olvasási motívumok átlagai nemenkénti bontásban, 6. évfolyam .........................161

67. táblázat Az olvasási motívumok átlagai nemenkénti bontásban, 8. évfolyam .........................162

68. táblázat Az olvasási motívumok fejlettsége az apa iskolai végzettsége szerinti bontásban ......163

69. táblázat Az olvasásfejlesztésre irányuló otthoni tevékenységek az apa iskolai végzettsége szerinti bontásban

70. táblázat Az olvasásfejlesztésre irányuló otthoni tevékenységek összefüggése az olvasási motívumokkal

71. táblázat Az olvasmányélményen alapuló és az olvasási képesség fejlesztését célzó otthoni tevékenységek az apa iskolai végzettsége szerinti bontásban.

72. táblázat Az olvasmányélményen alapuló és az olvasási képesség fejlesztését célzó otthoni tevékenységek összefüggése az olvasási motívumokkal

73. táblázat Az olvasmányélményen alapuló és az olvasási képesség fejlesztését célzó otthoni tevékenységek összefüggése az olvasási motívumokkal, regresszióanalízis

74. táblázat Az olvasási motívumok átlaga a szülők olvasással töltött idejének függvényében, ANOVA

75. táblázat Az olvasási motívumok átlaga a szülők szabadidős olvasásának gyakorisága függvényében, ANOVA

76. táblázat Az olvasási motívumok átlaga az otthoni könyvek számának függvényében.

77. táblázat A szülők olvasási motívumainak átlaga az apa iskolai végzettségének függvényében, ANOVA.

78. táblázat A szülők és gyermekeik olvasási motívumainak összefüggései

79. táblázat A szülők elvárásainak átlaga az apa iskolai végzettségének függvényében, ANOVA178

80. táblázat. A szülői elvárások és a tanulók olvasási motívumainak összefüggései

81. táblázat A pedagógusok mintájának korcsoportonkénti elemszáma és a pedagógusok életkorának a Kruskal-Wallis próba alapján számított szignifikanciája

82. táblázat A tanulásszervezési formák és az olvasási motívumok összefüggései

83. táblázat A tanulásszervezési formák és az olvasási motívumok összefüggései, regresszióanalízis

84. táblázat A szövegértés ellenőrzésének módjai és az olvasási motívumok összefüggése .........187

85. táblázat A források használata és az olvasási motívumok összefüggései.................................189

86. táblázat A szövegtípusok és az olvasási motívumok összefüggései ……..............................190

87. táblázat A pedagógusok elvárásai

88. táblázat Leendő és gyakorló pedagógusok az olvasási motiváció fejlesztésének módszereiről 


\section{BEVEZETÉS}

A 21. század tanuló társadalma számára nélkülözhetetlenné vált az olvasási képesség megfelelő fejlettségének biztosítása. Az olvasás funkciója és jelentősége a társadalomban és az iskolában is átértékelődött: az élethosszig tartó (life-long) és az élet minden területére kiterjedő (life-wide) tanulás egyik alapfeltételeként jelenik meg, ezáltal fejlesztése az iskola egyik legfontosabb feladatává vált (OECD, 2006).

Az olvasás tágabb értelemben nem csupán az írott szövegek dekódolása és megértése, hanem magában foglalja az olvasás iránti igényt, az abban való elmélyülés képességét és a mindezt lehetővé tevő olvasási motívumok sokaságát. A nemzetközi felmérések értelmezése szerint az olvasás az írott szövegek megértésének, használatának, a rájuk való reflexiónak a képessége, valamint a bennük való elmélyedés igénye abból a célból, hogy az egyén elérje személyes céljait, fejlessze tudását, képességeit és részt vegyen a társadalomban $(O E C D, 2009)$. Az elmélyülés igénye ebben az értelemben az olvasás iránti motiváltságra utal és egy sor affektív és viselkedéses jellemzőt foglal magában (Mullis, Kennedy, Martin és Sainsbury, 2006; OECD, 2009).

Az egyén olvasás iránt mutatott érdeklődése, olvasás iránti attitüdjei és az olvasással töltött idö mennyisége szoros összefüggésben áll a szövegértésével (Cox és Guthrie, 2001). Minél motiváltabb valaki az olvasás iránt, annál több időt fog azzal tölteni, amely a gyakorlási lehetőségek számának növekedését nyújtja számára. Az ilyen jellegü egyéni gyakorlás végső soron akár a többéves iskolai tanulást (Guthrie és Wigfield, 2000) vagy a szocioökonómiai helyzetből eredő hátrányokat is kompenzálhatja (Kirsch, deJong, Lafontaine, McQueen, Mendelovits és Monseur, 2002). A motivum- és képességrendszer szorosan összefonódva müködik (Józsa, 2005), a képességfejlesztés mellett így az olvasás iránti motiváltság alakítása is az iskola alapvető feladata. Annál is inkább, mivel az olvasási képesség fejlettsége és az olvasási motiváció között a kutatások aszimmetrikus kapcsolatot tártak fel, ahol a motiváció jó előrejelzője a képesség fejlettségének, azonban a jó olvasók nem feltétlenül motiváltak az olvasásra (Guthrie, Hoa, Wigfield, Tonks, Humenick és Littles, 2006; Viljaranta, Lerkkanen, Poikkeus, Aunola és Nurmi, 2008). Így a hosszú távú elköteleződés kialakítása, az olvasóvá nevelés érdekében így elengedhetetlen az olvasásra késztető belső eredetű, pszichikai mozgatóerők kialakítása és fejlesztése.

A nemzetközi és a hazai nagymintás vizsgálatok rámutattak arra, hogy a hazai tanulók olvasási teljesítménye nem felel meg a 21. század által támasztott követelményeknek (Csikos, 2006; Horváth, 1994, 1996; Vári, 1997, 2003). A hazai tizenöt éves tanulók olvasás-szövegértés teljesítménye a 2000-es PISA (Programme for International Student Assessment) méréseken a részt vevő országok átlagától elmaradt (Vári, 2003), és bár a 2009-es évre relatív javulást tapasztaltak az eredményeket illetően (ennek egyik oka a részt vevő országok körét illető bővülésnek), az eredmények még mindig nem megnyugtatóak.

A nemzetközi vizsgálatok az olvasás-szövegértés teljesítmény mellett több esetben az azt befolyásoló affektív, ezen belül pedig motivációs jellemzőket is vizsgálták (Kirsch, deJong, Lafontaine, McQueen, Mendelovits és Monseur, 2002). E vizsgálatok eredményei szintén a hazai tanulók lemaradásáról számolnak be. Míg az olvasásteljesítmény tekintetében élen járó országok, például Finnország, olvasási motivációs mutatói az átlagnál szintén szignifikánsan jobbak, addig Magyarországon a tanulók motivációs meggyőződései az 
átlagtól negatívabb irányba térnek el. Az IEA (International Association for Evaluation of Educational Achievement) 1990-91-ben zajlott olvasásmérése szerint például a hazai tanulók inkább rossz olvasóknak látják magukat (Csíkos, 2006). A 2000-es PISA-vizsgálat arra mutatott rá, hogy a magyar tizenöt éves tanulók az OECD-országok átlagához képest kevésbé érdeklődnek az olvasás iránt, valamint kevésbé tartják hatékonynak saját olvasási képességüket (Artelt, Baumert, Julius-Mc-Elvany és Peschar, 2003). A negyedikes korosztályt vizsgáló PIRLS (Progress in International Reading Literacy Study) eredményei az előzőeknél valamivel kedvezőbb képet mutat az olvasási motívumok területén: a hazai negyedik osztályos tanulók olvasás énképe és olvasás iránti attitüdje is átlagos (Balázsi, Balkányi, Felvégi és Szabó, 2007).

A nemzetközi rendszerszintü mérések hatására egyre nagyobb figyelem fordult hazánkban is az olvasási képesség fejlettségének vizsgálatára, fejlesztési lehetőségeinek feltárására (lásd például Józsa, 2006). Ugyanakkor kevés vizsgálat irányul az olvasási képesség fejlődésének motivációs hátterére. Annak feltárására, hogy milyen a hazai tanulók viszonya az olvasáshoz, mit és mennyire szeretnek olvasni, miért olvasnak, hogyan látják saját olvasási képességüket és iskolai teljesítményüket, és hogy minderre milyen háttértényezők vannak hatással. Számos hazai kutató és szakértő hívja fel a figyelmet a tanulók olvasási motivációjának fejlesztési lehetőségére és fontosságára (Adamikné, 2006; Cs. Czachesz, 1999; Nagy, 2006), azonban empirikus kutatások alig születtek a témában.

Mind a hazai, mind az általunk ismert nemzetközi olvasásimotiváció-kutatások az olvasási motiváció egy-egy aspektusát ragadják meg, például az olvasási énképet (PIRLS, 2006; PISA 2000) vagy az olvasás élvezetét (PISA, 2009). Nem ismerünk olyan kutatást, amely a tanulási motiváció jól megalapozott elméleteiböl kiindulva az olvasási motivációt vagy annak egyszerre több összetevőjét és ezek kapcsolatát átfogóan vizsgálta volna.

A jelen dolgozat által bemutatott kutatás célja, hogy átfogó képet kapjunk a hazai 8-14 éves tanulók olvasási motívumairól, azok kapcsolatáról, alakulásáról és olvasási teljesítménnyel való összefüggéséről. Sem a hazai sem pedig a nemzetközi szakirodalom nem rendelkezik az olvasási motiváció egy általánosan elfogadott, empirikusan alátámasztott modelljével, ezért első lépésként az olvasásban szerepet játszó motívumok összegyüjtésére és egy olvasási motiváció modell megalkotására van szükség. Ezt követően célunk egy olyan olvasási motivációt vizsgáló mérőeszközcsalád kidolgozása, amely a szakirodalom által azonosított motívumokat 8-14 éves kor között vizsgálja.

Empirikus kutatásunkban a szakirodalmi feltárás által azonosított olvasási motívumokat az általános iskola második, negyedik, hatodik és nyolcadik évfolyamán strukturált és félig strukturált interjúkkal, valamint kérdőíves módszerrel vizsgáltuk. Célunk, hogy részletes, ugyanakkor átfogó képet nyerjünk az olvasás motívumainak fejlettségéről az olvasástanulás kezdeti fázisától az általános iskola végéig. Az egyes motívumok fejlettségét külön-külön és a motívumrendszer felépülését, a motívumok egymással való összefüggéseit is vizsgáljuk. Áttekintjük az olvasási motívumok rendszerének alakulását az általános iskolai évek alatt. Megvizsgáljuk az olvasási motívumok összefüggéseit az olvasási készség és képesség fejlettségével, valamint több háttértényezővel (például a családi háttér, nem, eltérő értelmi fejlődés). A családi és az iskolai kontextus egyes jellemzőinek hatását részletesen is tárgyaljuk. Végül egy leendö és gyakorló pedagógusokkal végzett kérdőíves vizsgálat eredményeit mutatjuk be, ami a populáció olvasásfejlesztéssel és olvasási motivációval kapcsolatos nézeteire és meggyőződéseire világít rá. 
A dolgozat első nagyobb fejezetében a kutatás alapjául szolgáló elméleti áttekintés a tanulási és az olvasási motiváció nemzetközi szakirodalmának elemzésével felvázolja azokat az irányvonalakat és elméleti kereteket, amelyek mentén az olvasási motiváció, mint az olvasási tevékenység megindítója és fenntartója operacionalizálhatóvá válhat. Kutatásunk elméleti hátterét egyrészt a tanulási motiváció elméletei, másrészt az olvasási motiváció nemzetközi vizsgálati koncepciói és eredményei, harmadrészt az olvasáskutatások adják. Ennek megfelelően a szakirodalmi áttekintés első részében a humán motiváció majs a tanulási motiváció különböző elméleteit vázoljuk fel, azokat az elméleteket, amelyek az tanulásban szerepet játszott motívumokat elöször azonosították. Bemutatjuk a motiváció területspecifikus értelmezését, mely megközelítés vizsgálódásunk alapjául szolgál.

Az értekezés következő fejezetében áttekintjük az olvasás válságának nevezett jelenséget, mely az olvasási motiváció különböző értelmezéseit hívta életre. Kitérünk az olvasási képesség fejlődésére, ezen belül az olvasási motiváció szerepére. Ezt követően az olvasási tevékenység megindítását és fenntartását szolgáló motívumok rendszerét vázoljuk fel, majd az olvasási motiváció mint komplex egész modelljeit tárgyaljuk. Áttekintjük az olvasási motiváció és az olvasási képesség összefüggéseit vizsgáló kutatási eredményeket, rámutatva a szakirodalom ellentmondásaira is. Kitérünk azokra a tényezőkre, amelyek a motívumok fejlődésében és aktiválásában szerepet játszhatnak, megvizsgáljuk az olvasási képesség és motiváció fejlődésének kontextusait, illetve a különböző szövegtípusok jellemzőit. Bemutatjuk az olvasási motiváció osztálytermi vizsgálatának és fejlesztésének lehetőségeit, a gyakorlat számára releváns ajánlásokat fogalmazunk meg.

Az empirikus rész a kutatás céljának és koncepciójának bemutatásával kezdődik. Az ezt követő első és második fejezet a központi kutatást megelőző két empirikus kutatásunkat ismerteti, melyek közül az első egyetlen olvasási motívumra, az olvasási énképre fókuszál, a második az olvasási motiváció egydimenziós mérésére tesz kísérletet. A központi empirikus kutatás célját, koncepcióját a harmadik fejezet tárgyalja, eredményeit a mérési koncepciónak megfelelöen a negyedik fejezet két alfejezetében tárgyaljuk. Ennek megfelelően a negyedik fejezet első része a második osztályos tanulók olvasási motívumainak jellemzőit mutatja be az interjúk alapján, a második rész a felsőbb évfolyamok olvasási motívumainak jellemzőjét, teljesítménnyel és képességfejlettséggel való összefüggését veszi sorra. A családi háttér hatását és a nemek közötti különbségeket a másodikos mintán és a felsőbb évfolyamok esetében is tárgyaljuk.

A központi empirikus kutatás eredményeit bemutató utolsó fejezet a motívumok fejlődésének kontextusait jellemzi. Kitér az otthoni és az iskolai fejlesztés módszereire és eszközeire, a szülők és a pedagógusok által közvetített elvárásokra, valamint ezek összefüggéseire a tanulók olvasási motívumainak jellemzőivel. A dolgozat utolsó, hatodik fejezete egy kiegészítő kvantitatív vizsgálat eredményeit tárgyalja, melynek keretén belül leendő és gyakorló pedagógusok olvasással és olvasási motivációval kapcsolatos meggyőződéseit vizsgáltuk.

Az empirikus rész minden fejezetét részösszefoglalással zárjuk, melyben a legföbb eredményeket és a következtetéseket tárgyaljuk. A dolgozat utolsó előtti fejezete a teljes kutatás - beleértve a két pilot mérést, a központi kutatást és a kiegészítő vizsgálatot is eredményeit összegzi. Az utolsó fejezetben az eredmények felhasználási lehetőségeit tárgyaljuk, és további kutatási feladatokat fogalmazunk meg.

A fejezetek közül néhánynak egy-egy korábban önállóan vagy másokkal megírt tanulmány az alapja. Az énkép és a tanulmányi eredményesség nemzetközi kutatásáról írt 
szakirodalmi áttekintésem az Iskolakultúra Online folyóiratban került közlésre (Szenczi, 2008). Az olvasási motiváció nemzetközi kutatási irányairól, modelljeiről a Magyar Pedagógiában jelent meg tanulmányom (Szenczi, 2010). A tanulásban akadályozottság fogalmát, nemzetközi és hazai diagnosztikáját Fejes József Balázzsal közös tanulmányunkban elemeztük, mely a Gyógypedagógiai Szemlében jelent meg (Fejes és Szenczi, 2010). A tanulási motiváció innovatív mérési lehetőségeiről pedig Józsa Krisztiánnal és Hricsovinyi Juliannával írtunk (Józsa, Szenczi és Hricsovinyi, 2011) egy szerkesztett kötetben (Csapó és Zsolnai, 2011).

A dolgozat tartalmazza továbbá azokat az eredményeket is, amelyeket korábban egy-egy konferencia-előadás keretében már közöltünk. Az olvasási énképpel kapcsolatos eredményeinket az Országos Neveléstudományi Konferenciák és a Pedagógiai Értékelési Konferenciák alkalmaival mutattuk be (Szenczi és Józsa, 2008, 2009), a tanulásban akadályozott és többségi tanulók olvasási motivációjáról a 12th International Conference on Motivation nemzetközi konferencián számoltunk be (Kelemen, Józsa és Szenczi, 2010). A központi mérést megelőző pilot vizsgálat tanulságairól beszéltem a X. Országos Neveléstudományi Konferencián és a European Association on Research on Learning and Instruction által szervezett JURE konferencián (Szenczi, 2011a). A IX. Pedagógiai Értékelési Konferencia alkalmával a kiegészítő vizsgálat eredményeit és tanulságait elemeztem (Szenczi, 2011b), a X. Pedagógiai Értékelési Konferencián pedig a központi mérés során felvett tanulói interjúk elemzését mutattam be (Szenczi, 2012). 


\section{ELMÉLETI HÁTTÉR}

\section{Motiváció és tanulási motiváció}

A motiváció szó latin gyökere a „movere”, magyarul „mozogni” (Józsa, 2007). A motiváció kifejezés így a cselekvés hátterében álló mozgatórugókra, késztető erőkre utal. Nagy (2000) a motiváció folyamatát négy lépésben írja le, melyek alapja az érdekértékelés. Az érdekértékelés kognitív folyamat, melynek eredményeképp döntés születik arról, hogy létrejöjjön-e aktivitás. Az első lépés egy kiindulási feltételrendszer, egy külső vagy belső inger, amit észlelünk. Amennyiben ez az inger érdekértékelésre késztet, motivátorrá válik, és elkezdödik a második fázisban az érdekértékelés. Ennek során döntés születik arról, hogy a tényleges vagy várható állapotváltozás előnyös vagy hátrányos-e az egyén számára. Az érdekértékelési döntés viszonyítási alapja mindig valamely motívum. A harmadik lépés a döntés jelzését, a negyedik pedig az aktivitásra késztetést takarja. Ha például látunk egy tányért tele a kedvenc ételeinkkel (motivátor), elkezdjük értékelni, hogy vajon az elfogyasztása (aktivitás) pozitív jóllakottság-érzetet (előnyös állapotváltozás) vagy negatív telítettség-érzetet (hátrányos állapotváltozás) okozna-e számunkra. Ami alapján ezt eldöntjük, az az éhségünk (motívum). Ha már így is tele vagyunk, akkor negatív változást hozna jelenlegi állapotunkhoz képest az étkezés, így valószínüleg nem fogunk nekilátni. Ha azonban éhesek vagyunk, az előnyös állapotváltozás érdekében elfogyasztjuk az ételt. Az egzisztenciális jelentőségü biológiai motívumok mellett számos egyéb motívumfajta is létezik, például az érdekértékelés alapjául szolgálhatnak öröklött hajlamaink, tanult szokásaink, meggyőződéseink és adoptált értékeink.

Az emberi motívumok egy része veleszületett alapokkal bír és már a fejlödés korai szakaszában működőképes. Ilyenek például a homeosztázis fenntartására szolgáló biológiai motívumaink (Nagy, 2000), és a tanulási motívumrendszer alapját képező elsajátítási motívum (Józsa, 2007). Más motívumokat az életünk során sajátítunk el, vagyis a motívumok egy részét is tanuljuk. A veleszületett alapú motívumok esetén ez ráépülést és változást jelent, míg a tanult motívumok esetében kiépülést, szerveződést és hierarchizálódást (Józsa és Fejes, 2010; Nagy, 2000).

Mivel a tanulás erőfeszítést és tudatos energiabefektetést igénylő cselekvés, a kutatókat régóta foglalkoztatja, hogy mi mozgatja, mi motiválja az embereket a tanulásra. A tanulási motiváció kutatásában a motiváció mint ernyőfogalom jelenik meg, és magában foglalja egyrészt a tanulót érő külső hatásokat, amelyek a tanulási tevékenységet megindítják, és amelyek a tanulás külső feltételrendszereit megteremtik, másrészről azokat a belső pszichikus komponenseket, amelyek a tanulási tevékenység megindításában és fenntartásában szintén szerepet játszanak. Ebből adódóan a motiváció a gyakorlati pedagógiában kettős értelemben jelenik meg: egyrészt vonatkozik a tanári tevékenységre, azokra az erőfeszítésekre, amelyet a tanár tesz, hogy felkeltse a tanulók érdeklődését, figyelmét, ezzel megteremtve a tanítás-tanulási folyamat feltételét, másrészt utal a tanulók motiváltságára, azaz azon pszichikus komponenseik fejlettségére, amelyek az eredményes tanulás belső feltételeit jelentik (Józsa, 2007).

A hagyományos pedagógia a motiváció alatt legtöbbször a kiindulási feltételrendszert, azaz a motivátorok jellemzőit ragadja meg. Ebben az értelemben a motivációt a tan- 
óra részeként, a tanórai aktivitás kiváltójaként definiálják (Józsa és Fejes, 2010). A tanórai motiválás technikái kiemelt pedagógiai jelentőséggel bírnak (Réthyné, 1995), hiszen ezek teremtik meg a sikeres tanóra lehetőségét, azonban pedagógiai szempontból még ennél is fontosabb a motívumoknak, azaz a viselkedés viszonyítási alapjainak a fejlesztése, amelyek a tanulás hátterében állnak (Nagy, 2000). Két egyszerü példával illusztrálva: hiába kezdi az olvasásórát a tanító egy nagyon izgalmas mese (motivátor) elolvastatásával, az a tanuló, aki feltételezi magáról, hogy nem rendelkezik olyan olvasástudással, hogy képes legyen értően elolvasni az elé tett mesét (énkép mint motívum), valószínüleg nem fog sok energiát fektetni annak olvasásába. Hasonlóképp, hiába ajánl fel egy jutalmat (motivátor) a tanár egy matematikapélda megoldásáért, azok a tanulók, akik negatív attitüdökkel (motívum) rendelkeznek a matematika iránt, bele sem kezdenek a példa megoldásába, hiszen előfordulhat, hogy úgy értékelik, hogy nem éri meg számukra az erőfeszítést. A motívumok fejlesztése nélkül tehát a motivátorok alkalmazása sokszor nem elégséges.

A tanulási motívumok fejlesztése csak a képességek fejlesztésével együtt képzelhető el: a tanulási motívumok és a képességek, valamint az alapját képző készségek fejlődése egymást feltételező folyamatok (Józsa, 2005). Nagy (2010) személyiségelméletében a személyiség két alapvető komponensrendszerét határozza meg: a motívum- és a tudásrendszert. A személyiség alapkomponensei, a speciális funkciókat ellátó kompetenciák motívum- és tudásrendszerek, amely rendszerben a döntésért a motívumok, a kivitelezésért a képességek és ismeretek felelősek. Ebből következik, hogy a kompetenciák fejlesztése az azokat alkotó motívumok és képességek együttes fejlesztésével valósulhat meg (Nagy, 2000). Józsa (2005) példájával élve: hiábavaló az olvasási képesség fejlesztése, ha közben a tanulók megutálják az olvasást. Hasonlóképp, hiábavalók az olvasás megszerettetése érdekében tett erőfeszítések, ha a tanulók olvasási képességének fejlettsége nem teszi lehetővé számukra az önálló szövegértő, élményszerző olvasást.

Mind a képességek, mind a tanulási motívumok fejlesztéséhez nélkülözhetetlen, hogy megismerjük az azokat alkotó komponenseket. A tanulási motiváció kutatásával az 1900-as évek közepén kezdtek el intenzívebben foglalkozni. E kutatások célja elsősorban az érdekértékelési döntés alapjául szolgáló motívumok feltárása volt. Az egyes motivációelméletek az uralkodó személyiségelméleteknek megfelelően igyekeztek leírni a motívumok rendszerét, azaz arra a kérdésre keresték a választ, vajon mi alapján döntünk a tanulási tevékenységünkröl. A következő fejezetekben ezeket az elméleteket tekintjük át röviden. A tanulási motiváció elméleteit a humán motiváció versengő elméletei nagyban meghatározták, ezért elsőként ezeket mutatjuk be. Ezt követően az utóbbi évtizedek tanulási motiváció elméleteit tárgyaljuk és rendszerezzük, miközben a tanulási motiváció nemzetközi kutatásának jelenleg is megfigyelhető és folyamatban lévő trendjének szellemében kísérletet teszünk az elméletek integrálására, a közös elemek kiemelésére is. Végül a tanulási motiváció területspecifikus megközelítésére térünk rá, melyen elméleti kereten belül az olvasási motivációt is értelmezzük. 


\subsection{A humán motiváció elméletei}

Cselekvéseink hátterében számos indíték állhat. A humán motiváció elméletei a különböző emberi viselkedések mögött meghúzódó indítékokat tárgyalják. A történeti jelentőségü elméletek közül a behaviorista irányzathoz kötődő, a viselkedést inger-válasz reakcióként leíró szemlélet a motivációban a megerősítés szerepére hívta fel a figyelmet (Biehler és Snowman, 1994). A megközelítés szerint például a tantárgyi attitüdök egy folyamat eredményeként jönnek létre, melynek során a diák számos pozitív vagy negatív élményt él át, amely élmények jutalomként vagy büntetésként funkcionálnak. A viselkedés megindításában további fontos szerepet játszanak a fontos mások. A szociális tanulás elmélete a megfigyelés és utánzás szerepére hívja fel a figyelmet a tanulásban. Mások megfigyelése, a velük való azonosulás bizonyos hasonló viselkedéseket válthatnak ki a megfigyelöben, például egy tantárgy megkedvelése is adódhat a tanár csodálatából (Biehler és Snowman, 1994).

Szintén a viselkedéslélektan szemléletmódját tükrözik a drive-redukciós elméletek (Józsa, 2007). Ezek értelmében bizonyos negatív feszültséggel járó pszichikus állapotok drive-ként müködnek, és arra késztetik az állatokat és az embereket, hogy az átélt negatív feszültséget mihamarabb csökkentsék. Ilyen drive-ként értelmezhető például az éhség vagy a szomjúság és a szexuális vágy is. Azonban a drive-elmélet nem csupán a biológiai szükségletekre korlátozódik, számos más emberi viselkedésforma hátterében is azonosíthatunk drive-okat, például az aktivitásszükséglet kielégítésére szolgáló aktivitás-drive-ot (White, 1959 idézi Józsa, 2007) vagy a külső környezet megváltoztatására irányuló manipulációs drive-ot (Harlow, 1953 idézi Józsa, 2007).

A Maslow nevével szorosan összefonódó humanisztikus szemléletmód motivációfelfogása szintén bizonyos szükségletek kielégítésének vágyaként értelmezi az emberi motivációt. Azonban Maslow szükséglethierarchiájában már nem csak a negatív feszültség leküzdésére irányuló hiánymotívumok - például éhség, biztonságszükséglet - kapnak helyet, hanem a pozitív feszültséget gerjesztő fejlődési motívumok is, például a tudás és megértés vágya vagy az önmegvalósítás szükséglete (Biehler és Snowman, 1994).

A drive-redukciós elmélet csakúgy, mint a szükségletek hierarchiáján alapuló megközelítés csak nagyon korlátozottan magyarázza az emberi viselkedést, illetve azon döntéseinket, hogy milyen tevékenységbe kezdünk bele és meddig vagyunk hajlandóak azt végezni. A kognitív forradalommal a motivációkutatókat is egyre inkább foglalkoztatni kezdte az a gondolat, hogy a viselkedést szükségleteink és vágyaink mellett gondolataink is befolyásolni tudják. A figyelem ezentúl nemcsak a viselkedés megindítójára, hanem annak irányára is fókuszálódott. A kérdés már nem csak az volt, hogy mi vált ki bizonyos viselkedésformákat, hanem hogy miért éppen azok a viselkedésformák jönnek létre, és hogy miért végzünk valamilyen tevékenységet kitartóan, míg másokat éppen csak megpróbálunk. A kognitív megközelítés az egyénre mint aktív, gondolkodó lényre tekintett, szemben a korábbi elméletek passzív, végrehajtó gépezetével (Pintrich és Schunk, 1996).

Atkinson (1957) az 1950-es évek végén a kockázatvállaló, sikerorientált viselkedés motivációs bázisát írta le. Nagy Józsefhez (2000) hasonlóan a motivációt racionális értékelés és döntés folyamataként képzeli el. A döntés alapjául szolgáló motívumoknak két alapvető típusát különíti el. Elméletében az egyén aktivitással kapcsolatos döntéseit azon észlelései alapján hozza meg, hogy (1) milyen valószínüséggel fog az adott viselkedés a kívánt 
célhoz vezetni, valamint, hogy (2) mennyire szeretné az adott célt elérni. A teljesítménykereső viselkedés három tényező függvényeként jelenik meg, melyek a sikerorientáltság, a siker valószínüsége és a siker ösztönző értéke. A teljesítménykeresés a három tényező szorzata:

$$
T=M \times P \times I
$$

A teljesítménymotívum vagy sikerorientáltság (M), amely elméletileg egy viszonylag stabil személyiségjellemző, tanult motívum, és az élet kezdeti fázisában sajátítjuk el folyamatosan. A siker valószínüsége (P) 0 és 1 közötti értéket vehet fel, ahol a magasabb érték a nagyobb valószínüséget jelöli a sikerre, azaz a könnyebb feladatokat. Az ösztönzö érték, ami nem más mint a büszkeség érzése, a modellben fordítottan arányos a siker valószínűségével. Azaz, minél kisebb az esély a sikerre, minél nehezebb a feladat, annál nagyobb ösztönző erőt fog jelenteni az egyén számára, hiszen annál nagyobb büszkeséget fog majd átélni teljesítés esetén. Atkinson ezáltal először írta le, hogy a teljesítménykereső egyén nem biztos, hogy a legnagyobb jutalommal járó feladatot fogja választani, ehelyett választása, mérlegelés eredményeképpen, a közepes nehézségü feladatokra fog esni, ahol az érzett büszkeség ugyan csak közepes erösségü, de elérhetőnek ígérkezik. Emiatt Atkinsont az első elvárás-érték elmélet megalkotójaként tartják számon.

\subsection{A tanulási motiváció elméletei}

A tanulási motiváció elméletei különböző intellektuális tradíciókból eredeztetők (Weiner, 1992), így szinte minden pszichológiai irányzatnak létezik egy saját motivációelmélete, amely a tanulásra vonatkoztatva is értelmezhető. A tanulási motiváció kutatásának kezdetén a motivációelméletek szélsőségekben gondolkoztak és dichotóm kategóriákat alkottak. Ezek a kategóriák a jó és a rossz paradigmán belül mozogtak, Fülöp Márta találó metaforájával a „Szépség és a szörnyeteg” jellemzőit öltötték magukra (Fülöp, 2010). Az évek múlásával a motivációkutatók az egymásnak ellentmondó, egymással versengő elméletek helyett egyre inkább a felhalmozott tudás integrációjára törekedtek, így az egyes megközelítések egymás jó kiegészítőjévé váltak. Egységes motivációelmélet még ma sem létezik, ugyanakkor a történeti jelentőségü és az azokon alapuló, arra szervesen építő modern motivációelméletek áttekintése, az egymást kiegészítő szemléletmódok megismerése megfelelő fogódzóul szolgálhat a tanulási motiváció mint komplex egész megismerésében.

A motivációkutatáson belül a tanulási motiváció kutatásában is kezdetben a teljesítménymotivációra fókuszáltak, és a tanulók motivált viselkedését elsősorban a sikerorientált és kudarckerülő dichotómiában látták megragadhatónak. Az Atkinson által leírt teljesítménykereső viselkedés meghatározói a pedagógiára is nagy hatással voltak, a siker- és kudarcelvárások meghatározói hosszú időn keresztül meghatározták a tanulási motiváció kutatásának irányait.

Az 1980-as évektől kezdve a kutatók figyelme egyre inkább újabb motivációs jellemzők felé fordult, például a tanulási célok, a célorientáció (lásd például Ames, 1992, Nicholls, 1984) vagy az önhatékonyság (lásd például Bandura, 1997) irányába. Ugyanakkor a modern motivációelméletek szinte mindegyike beilleszthető az elvárás-érték elméletbe, hiszen tulajdonképp mindegyikük valamely elvárás- vagy értékmotívumot ír le (Eccles és Wigfield, 2002). Az elméletek így jól kategorizálhatók aszerint, hogy az említett két 
konstruktum melyikével foglalkoznak. Az elvárás konstruktumhoz kapcsolódó elméletek az egyén saját képességeivel kapcsolatos meggyőződésekre fókuszálnak, és a „,Meg tudome csinálni? Képes vagyok-e rá?" kérdéseinkre való válaszadáshoz nyújtanak viszonyítási alapot. Az értékmotívumok a „Meg akarom-e csinálni? Miért akarom megcsinálni?” jellegü kérdésekre adják meg a választ. A következőkben a motiváció modern elméleteit tekintjük át Eccles és Wigfield (2002) nyomán a fenti szempontok alapján három kategóriába rendezve: (1) elváráselméletek (expectancy theories), (2) feladat-érték elméletek (taskvalue theories) és (3) az elvárásokat és a feladatértéket is számba vevő elméletek (theories integrating expectancy and task-value).

\section{Elváráselméletek}

Az elváráselméletek a motiváció azon aspektusát képviselik, mely szerint akkor leszünk motiváltak valamely cselekvés végzésére, ha feltételezzük, hogy jó esélyünk van a sikerre, azaz, ha úgy gondoljuk, képesek vagyunk annak a tevékenységnek az elvégzésére. Az elváráselméletek az egyén saját képességeire és hatékonyságára vonatkozó meggyőződéseire, vélekedéseire fókuszálnak, és leginkább a cselekvés fenntartásában játszanak szerepet. Alapvetésük, hogy a saját magunkba vetett hit a teljesítményt pozitív irányba befolyásolja (Eccles és Wigfield, 2002).

Önhatékonyság (self-efficacy) elmélet. Bandura (1997) szociokognitív modelljében az egyént önreflektív, proaktív, saját viselkedésének eredményét elörevetíteni képes lénynek tekinti. Motivációelméletében a hatékonyságérzésre helyezi a hangsúlyt. Az önhatékonyságot az egyén azon észleléseiként és meggyőződéseiként definiálja, amelyek arra vonatkoznak, hogy milyen valószínűséggel tud megtervezni és kivitelezni egy cél eléréséhez szükséges cselekvéssort. Nem azonos az eredményelvárásokkal (outcome expectations), mert nem azokra a meggyőződésekre vonatkozik, hogy milyen cselekvéssorok milyen eredményekhez vezetnek, hanem arra, az egyén ezeket a cselekvéssorokat vajon hatékonyan végre tudja-e hajtani.

Az egyének különbözhetnek önhatékonyságuk erőssége, szintje és terjedelme alapján. Egyesek erős önhatékonyság-érzéssel rendelkeznek, míg mások gyengébbel; van, aki erős önhatékonyságot mutat a nehezebb feladatok esetében is, míg mások mindig csak a könnyebb feladatok esetén számolhatnak be erröl, végül lehet valaki önhatékony az élet szinte minden területén, míg mások esetében jól körülhatárolhatók azok a területek, ahol hatékonynak érzik magukat.

Az önhatékonyság hatását számos tanulási szituációban vizsgálták. A tanulás során hatással van a tevékenységek megválasztására, a kitartás és az erőfeszítés mennyiségére, az érdeklődésre és a teljesítményre (Schunk és Pajares, 2009). Ez utóbbival való szoros öszszefüggését kimutatták a matematika (Pajares és Miller, 1994), az olvasás és az írás (Shell, Colvin és Bruning, 1995), valamint a természettudományok (Britner és Pajares, 2001) területén is.

Kontrollelméletek. Az észlelt kontroll az autonómiaérzéshez (Ryan és Deci, 2000) hasonló konstruktum. Arra utal, hogy az egyén milyen lehetséges okokat tulajdonít bizonyos vágyott és nem vágyott kimeneteleknek, illetve, hogy mennyi szerepet tulajdonít ezekben saját magának, saját döntéseinek, választásainak és viselkedésének (Skinner, 
1995). Connell és Wellborn (1991) szerint az embereknek három alapvető pszichológiai szükségletük van: kompetencia, autonómia és valahová tartozás. A kontrollal kapcsolatos meggyőződéseket a kompetenciaérzettel hozták összefüggésbe. Azt feltételezik, hogy azok az egyének, akik úgy érzik, kontrollálni tudják saját cselekvéseik eredményét, kompetensebbnek érzik magukat. A kontrollnak általában két helyét szokták megkülönböztetni, így léteznek külső és belső kontrollos egyének (Findley és Cooper, 1983), illetve létezik az ismeretlen kontroll, amikor az egyén nem tudja megnevezni az általa végzett cselekvés kimenetének okát. Ez utóbbi általában fiatal gyermekeknél fordul elö, és alacsony motiváltsághoz vezet (Connell, 1985).

Önbecsülés (self-worth) elmélet. Covington (1992), hasonlóan Connell és Wellborn (1991) elméletéhez, szintén a kompetenciaérzést nevezi meg az ember alapvető szükségletének. Abból indul ki, hogy az egyén saját kompetenciaérzését, önbecsülését minden áron meg kívánja védeni mentális egészségének védelme érdekében. Az önbecsülés forrása a mások által nyújtott visszajelzés, így az önbecsülés úgy őrizhető meg, ha mások számára pozitívan tüntetjük fel magunkat. Ez azonban azzal járhat, hogy annak érdekében, kompetensnek tüntessük fel magunkat, az olyan feladatokat, amelyek esetében azt anticipáljuk, hogy nem fogunk sikerrel járni, inkább meg sem próbáljuk megoldani. Így elérhető, hogy a sikertelenséget az erőfeszítés és nem a képességek hiányának tulajdonítsuk.

Iskolai kontextusban nehezen elkerülhetők azok a helyzetek, amikor a tanulóknak saját képességeikröl kell elárulniuk valamit. A próbálkozás a siker kulcsa, ugyanakkor, ha az egyén próbálkozik, erőfeszítést tesz, de nem jár sikerrel, nehezen elkerülhető a konklúzió levonása, hogy nem rendelkezik a képességek megfelelő szintjével. Ilyenkor az önbecsülés sérülhet, ezért a tanuló, ha azt feltételezi, hogy kudarcot fog átélni, inkább nem is próbálkozik (Covington, 1992, 2009).

Az elmélet kritikusai ugyanakkor rámutattak arra, hogy a tanulmányi eredményességen alapuló kompetenciaérzés nem feltétlenül azonosítható az önbecsüléssel, hiszen a tanulók más területhez (például szociális, fizikális megjelenés) kapcsolódó önértékelései a tanulmányi területnél erőteljesebben meghatározzák önbecsülésüket (Harter, 1990), illetve, hogy minden terület csak annyiban járul hozzá az önértékeléshez, amekkora értéket annak a területnek az egyén tulajdonít (Eccles, 1993).

\section{Feladat-érték elméletek}

A kutatókat régóta foglalkoztatja, milyen különbségek vannak a motiváció tekintetében a mennyiségi szempontok mellett minőségileg is. Amellett ugyanis, hogy az egyének motiváltsága különbözhet az alapján, hogy mennyire motiváltak, jelentős eltérés tapasztalható aközött, ha valaki azért végez egy cselekvést, mert belső örömet él át közben, vagy ha azért, mert csak ezáltal érhet el egy külső célt.

A feladat-érték elméletek az elváráselméletekkel szemben inkább a cselekvés kiváltásában szerepet játszó motívumokra fókuszálnak. Azon motívumokra helyezik a hangsúlyt, amelyek arra ösztönzik az egyént, hogy belekezdjen valamibe, mégpedig azért mert valamilyen objektív értéket vagy szubjektív fontosságot tulajdonít az adott cselekvésnek. Ez az érték adódhat abból, hogy a viselkedés egy cél elérését szolgálja, hogy az egyén számára szubjektíve érdekesnek minősül, vagy éppen hogy az adott cselekvés végzése örömet, elégedettségérzést vált ki az egyénből (Eccles és Wigfield, 2002). 
A motívumok minőségi, irány alapú kategorizálása nem új keletủ dolog. A cselekvések hátterében álló „miért”-ek sokfélék lehetnek. Mégis kezdetben a motiváció két alapvető típusát különböztették meg: az extrinzik és az intrinzik motivációt, amelyeket egymást kizáró kategóriáknak tekintettek (Szabó, 2004). Az extrinzik motiváció valamely külső cél, jutalom, nyereség elérésére vagy elkerülésére irányul (Szabó, 2004), míg az idegrendszeri eredetü intrinzik (önjutalmazó) motiváció egy tevékenység megkezdésére, folytatására való késztetés sokkal inkább a tevékenységben lelt örömért, mint valami cél elérése érdekében (Hidi, 2000 idézi Józsa, 2007). A kétféle motiváció egymást kizáró kategóriaként való értelmezése a kutatásoknak köszönhetően viszonylag gyorsan tarthatatlanná vált, és az újabb kutatások a témában már a kétfajta motiváció ötvöződéséröl, egymásra hatásáról és az éles határok elmosódásáról számolnak be (Ryan és Deci, 2000; Szabó, 2004).

Az extrinzik és az intrinzik motívumok közötti éles kettéválást, majd a kettő ötvöződésének vizsgálatait is azok a kutatások motiválták, amelyek a külső jutalmak önjutalmazó motivációra való hatását vizsgálták. E kutatások kezdetben az extrinzik motivációt negatív, az önjutalmazást aláásó, az intrinzik motivációval teljes mértékben ellentétes jelenségként írták le (Deci, 1992). A kezdeti szembenállást hamarosan a kétféle motiváció együttes vizsgálata váltotta fel, és egy olyan szemléletmód, melyben a különböző motívumok egymásra hatnak, egymást kiegészítik, illetve amely meg az extrinzik és az intrinzik motiváció közötti éles határokat elmossa (lásd például Hidi és Harakiewicz, 2000; Deci és Ryan, 2000, Ryan és Deci, 2009).

Réthyné (2003) négyes felosztásában az extrinzik és az intrinzik motiváció már egy kontinuum két végpontjaként jelenik meg. A modellben a kontinuum két végpontja a külső motiváció, amikor a cselekvés valami külső jutalom elérésére irányul, és az intrinzik motiváció, amikor az aktivitás megindítója és fenntartója maga a cselekvés, a végzett feladat. A két végpont között helyezkedik el a beépült (internalizált) motiváció és a presztízsmotiváció. Előbbi esetében az egyén egy értékrendet sajátít el, amely bár kezdetben külső motivációként müködik, az elsajátítás során az egyén sajátjává válik. Jó példa erre a családban a tanulásnak tulajdonított érték, amit a gyermek a különböző külső hatásoknak köszönhetően fokozatosan tesz belső értékké, mígnem saját meggyőződésévé is válik és így már saját kötelességtudata és lelkiismerete miatt fog tanulni. A presztízsmotiváció Réthyné szerint szintén belső és külső motiváció egyben, hiszen a tanulót saját énérvényesítő tendenciái motiválják egy külső cél, a verseny megnyerése és mások elismerésének elérésére.

Deci és Ryan (1985) is különböző motívumfajtákat különböztet meg. Alapvető különbséget tesznek az intrinzik és az extrinzik motívumok között. Értelmezésükben intrinzik motivációról akkor van szó, ha azért végzünk egy tevékenységet, mert az önmagában érdekes és élvezettel jár, míg az extrinzik motiváció arra utal, hogy a cselekvés végzésének oka egy külső cél. Nagy (2011) ugyanezen kategóriák megnevezésére az élményérdekelt és az eredményérdekelt aktivitás/motiváció terminusokat alkalmazza, ahol az eredményérdekelt aktivitás hátterében állhat kényszer, engedelmesség vagy késztetés. Az éles elhatárolás után Ryan és Deci (2000) is kiterjeszti kategóriarendszerét, és az extrinzik motívumok számos típusát veszi számba, melyek a viselkedés szabályozásának forrásában és minőségében különböznek. Ha például egy tanuló megcsinálja a házi feladatát, mert fél, hogy ha nem teszi, a szülei megbüntetik, akkor ő extrinzik motivált és a külső cél a büntetés elkerülése. Ugyanakkor, ha ugyanez a tanuló azért csinálja meg a házi feladatát, mert fontosnak tartja adott tantárgyat későbbi karrierje érdekében, szintén extrinzik motivált, hiszen nem a tevékenységben lelt öröm a motiváció forrása, hanem egy külső cél, adott esetben a kívánt 
karrier. Bár mindkét esetben a tevékenység eszközjellegü, az átélt élmény minősége nagyban különbözik. A legfontosabb különbség az autonómiaérzés mértékét érinti. Míg az első esetében az egyén elfogadja és behódol a külső kontrollnak, addig a második esetben egyéni bevonódásról, akaratlagosságról és saját szándékról van szó (Ryan és Deci, 2000).

$\mathrm{Az}$ autonómia mértékétől függően az extrinzik motiváció négy típusát írták le, melyeket eleinte külön kategóriákként (Ryan és Deci, 2000), majd egy kontinuum állomásaiként (Ryan és Deci, 2009) kezeltek (1. ábra). Ez utóbbi megközelítésmód magában foglalja azt a feltételezést is, hogy a külsőleg szabályozott viselkedésformák idővel egyre autonómabbá válhatnak, azaz az egyén egyre inkább érezheti saját döntésének a cselekvés kivitelezését. A folyamat, amelyen keresztül a szabályozás egyre inkább belsővé válik, az internalizáció (Ryan és Deci, 2009). Az internalizáció élethosszig tart, de nem feltétlenül a hagyományos értelemben vett fejlődési folyamat. Az internalizálás során ugyanis nem feltétlenül a külső szabályozás az első lépés, és az egyes állomások sorrendje is változhat. A lehetőség ugyanakkor megvan arra, hogy a külsőleg szabályozott viselkedés egyre inkább autonóm szabályozottá váljon, azaz internalizálódjon. A legtöbb meggyőződésünk és értékünk hasonló módon fejlődik.

\begin{tabular}{|c|c|c|c|c|c|}
\hline Motiválatlanság & \multicolumn{4}{|c|}{ Extrinzik motiváció } & $\begin{array}{c}\text { Intrinzik moti- } \\
\text { váció }\end{array}$ \\
\hline Nincs szabályozás & $\begin{array}{c}\text { Külső szabá- } \\
\text { lyozás }\end{array}$ & $\begin{array}{c}\text { Introjektált } \\
\text { (bevetített) } \\
\text { szabályozás }\end{array}$ & $\begin{array}{c}\text { Szabályozás } \\
\text { azonosuláson } \\
\text { keresztül }\end{array}$ & $\begin{array}{c}\text { Integrált sza- } \\
\text { bályozás }\end{array}$ & $\begin{array}{c}\text { Intrinzik szabá- } \\
\text { lyozás }\end{array}$ \\
\hline A motiváció hiánya & Kontrollált motiváció & \multicolumn{3}{|c|}{ Autonóm motiváció } \\
\hline $\begin{array}{c}\text { Legalacsonyabb relatív } \\
\text { autonómia }\end{array}$ & \multicolumn{3}{|c}{} & $\begin{array}{c}\text { Legmagasabb } \\
\text { relatív autonó- } \\
\text { mia }\end{array}$ \\
\hline
\end{tabular}

\section{1. ábra}

A relativ autonómia öndeterminációs kontinuuma az eredményeként megjelenö különbözö motivációtípusokkal és szabályozástípusokkal (Ryan és Deci, 2009, 177. o.)

A legnagyobb kontrollal és a legkisebb autonómiaérzéssel járó extrinzik motivált viselkedés esetében a szabályozás külső. Ez dominál, ha egy jutalom megszerzéséért, egy jó jegyért tanulunk. Ilyenkor a viselkedést egy külső tényező váltja ki és tartja fenn, és az élményt meglehetősen kontrolláltnak érezzük. Az autonómia valamivel magasabb fokát nyújtja az introjektált (bevetített) szabályozás. Ilyenkor a viselkedés szabályozásáért már nem a külső kontroll felelős, hanem a már részben beépült szabály, a lelkiismeretesség, a jutalomért járó büszkeség, a kudarccal járó szégyenérzet. Az említett belső szabályozók ugyanazt a funkciót látják el, mint külső jutalmak vagy büntetések. A kontroll tehát adott, csupán annak helye más: a külső kontrollból belső kontroll lesz. Az extrinzik motiváció harmadik típusa az azonosuláson alapuló szabályozás. Az ember képes arra, hogy azonosuljon a motivált viselkedés céljával, és értéknek tekintse azt. Az azonosulás által motivált cselekvés végzése közben az egyén az előbbieknél erőteljesebb autonómiaérzést él át, és a tevékenység megkezdését saját akaratából eredőnek érzi. Végül az integrált szabályozás esetén az egyén már nem csupán azonosul a viselkedés szabályozójával, hanem azt már beillesztette saját értékrendszerébe és saját énjének részét képezi. Az integrált szabályozott cselekvés élménye számos ponton megegyezik az intrinzik motivált viselkedés élményével, azonban alapvető különbség, hogy míg az intrinzik motivált viselkedést az aktivitás 
nyújtotta élmény motiválja és öröklött, idegrendszeri alapon müködik, addig az integrált meggyőződések által motivált viselkedést azért produkálja az egyén, mert valamilyen fontosságot, értéket tulajdonít annak (Ryan és Deci, 2009).

A következőkben elöször az intrinzik motiváció megközelítéseit, majd az internalizált meggyőződéseket mint motívumokat középpontba helyező motivációelméleteket tekintjük át.

\section{Az intrinzik motiváció elméletei}

Pedagógiai szempontból az intrinzik motivációnak kiemelt szerepe van: az elsajátítás és megértés mélységével, valamint a teljesítmény magas fokával hozzák összefüggésbe (Grolnick és Ryan, 1990; Kage és Namiki, 1990; Deci és Moller, 2005). A viselkedéslélektan motivációfelfogásának kritikájaként már korán felvetették, hogy az embernek létezik egyfajta veleszületett alapvető kompetenciaszükségete, ami arra készteti, hogy felfedezze környezetét és kielégítse kíváncsiságát (White, 1959). A kompetenciaszükséglet által motivált aktivitás akkor is kiváltódik, ha semmiféle jutalom vagy külső cél nem kapcsolódik a szóban forgó cselekvéshez. A jelenség magyarázatára számos elméleti megoldás született, amelyek mindig az éppen uralkodó személyiség-felfogáshoz kapcsolódtak. Hazánkban elöször a fogalmat Réthyné használta.

A behaviorizmus pártfogói a jelenség felismerése után is fenntartották, hogy minden cselekvés hátterében valamiféle jutalomkereső viselkedés áll, az önjutalmazó módon motivált aktivitás csupán annyiban különbözik az extrinzik motivációtól, hogy a jutalom maga a cselekvés, az abban rejlö öröm (Skinner, 1953 idézi Ryan és Deci, 2000). Ebben a felfogásban az intrinzik motívum a feladathoz kapcsolódik, tehát vannak olyan tevékenységek, amelyek intrinzik motiválnak és vannak olyanok, amelyek jellegüknél fogva nem alkalmasak erre. A drive-elmélet képviselöi ugyanakkor azt tartották, hogy az intrinzik motívum is egy belső drive, egy késztetés (Hull, 1943 idézi Ryan és Deci, 2000), ilyen szempontból pedig az egyén sajátja. A kutatók így azt kezdték vizsgálni, milyen alapvető belső szükségleteket elégítenek ki az intrinzik motivált aktivitások. A modern elméletek ezzel szemben az önjutalmazó motivációt az egyén és a tevékenység közti interakcióban ragadják meg, azaz bizonyos jellemzőkkel rendelkező feladatok bizonyos egyénekben bizonyos feltételek mellett mozgósíthatnak intrinzik motívumokat. E megközelítések közé tartozik az öndeterminációs elmélet, a flow-elmélet és az elsajátítási motiváció elmélete is.

Az öndeterminációs elmélet elfogadja azt a feltételezést, miszerint az ember alapvető, veleszületett szükségletei közé tartozik (1) a kompetenciaszükséglet, amely a környezettel való hatékony bánásra utal; (2) az autonómiaszükséglet, azaz az egyén azon észlelete, hogy kauzális ágense saját életének; és (3) a valahová tartozás szükséglete, azaz az igény a másokkal való interakciókra, kapcsolatokra és közösségre (Deci és Vansteenkiste, 2004). Mindhárom szükséglet univerzális, kielégítésük a mentális egészség és jóllét alapvető feltétele (Deci és Ryan, 2000). Deci és Ryan (2000, 2009) szerint az emberek kompetenciaszükségletüket kielégítendö keresik az optimális kihívással járó feladatokat, és azért találják ezeket önjutalmazónak, mert kielégítik azt. Az aktivitás megindítója ennek értelmében a kompetencia iránti igény, azonban fenntartása csak akkor őrizhető meg hosszú távon, ha a kompetenciaérzethez megfelelő autonómiaérzet is társul, azaz, ha az egyén érzi saját szerepét saját viselkedése megválasztásában és eredményének befolyásolásában (Ryan és Deci, 2000, 2009). Az autonómia és a kontroll szerepét az intrinzik motiváció 
fenntartásában iskolai kontextusban empirikus kutatások is alátámasztották (lásd például Ryan és Grolnick, 1986; Reeve és Jang, 2006, Roth, Assor, Kanat-Maymon és Kaplan, 2007).

Míg az öndeterminációs elmélet az intrinzik motivációt néhány alapvető szükséglet kielégítésében ragadja meg, addig a Csíkszentmihályi nevével fémjelzett flow-elmélet (áramlatélmény) a motiváció forrását a tevékenység végzése közben átélt szubjektív élményben látja (Csíkszentmihályi, 1997). A megközelítés szerint mikor teljesen elmélyülünk valamiben, olyan érzelmi állapotba kerülünk, amelyet optimális élményként élünk meg. Az optimális élmény önjutalmazó jellege folytán az áramlatban kivitelezett cselekvések megismétlésére, folytatására törekszünk. A flow jutalom, ami biztosítja, hogy az adott tevékenységbe újra és újra belekezdjünk (Csíkszentmihályi és Massimi, 1985), azaz élményérdekelt motivációt eredményez. Mivel a tökéletesnek nevezett flow csak akkor élhető át, ha a tevékenység, amit végzünk, kihívással jár számunkra, keresése a kompetencia növelését szolgálja (Csikszentmihályi és Massimi, 1985).

A tökéletes élménynek nyolc eleme különböztethető meg, melyeket az élményt átélő személyek általában együttesen említenek: (1) világos célok, (2) a kihívás és a képességek egyensúlya, (3) a feladatra való összpontosítás, (4) a kontroll paradoxona, (5) folyamatos visszajelzések, (6) a cselekvés és a figyelem eggyé olvadása, (7) az idő átalakulása, (8) az éntudat elvesztése. Megjegyzendő, hogy a Csíkszentmihályi (1991) által leírt éntudat nem azonos a Nagy (2000) által definiált éntudattal. Előbbi szerint az énnel kapcsolatos tudatosságot, az arra való koncentrálást jelenti, míg utóbbi szerint az énképpel azonos pszichológiai komponensre utal.

A komplex flow-élmény akkor alakulhat ki, ha az egyén a képességeihez képest optimális kihívást jelentő tevékenységet végez. Ilyenkor a feladat kínálta kihívások és az elvégzésükhöz szükséges képességek egyensúlyban vannak, az egyén képes teljes figyelmét a végzett tevékenységre fókuszálni, és úgy érzi, sikeres lehet annak megoldásában.

Csíkszentmihályi (1997) szerint szinte bármilyen tevékenység végzése során átélhetünk áramlatélményt. Azonban vannak olyan tevékenységek, amelyek jellegüknél fogva sokkal inkább megteremtik az áramlatélmény elérésének lehetőségeit. Ilyen tevékenység például a sport, a tánc, a zenei tevékenységek és az olvasás is (Csíkszentmihályi, 1997). Csíkszentmihályi ugyanakkor arra is felhívja a figyelmet, hogy léteznek olyan személyiségjellemzők, amelyek nyitottabbá tesznek az áramlatélmény átélésére. Ezeket a jellemzőket nevezi az autotelikus személy jellemzőinek. A flow által eredményezett intrinzik motiváció ennek értelmében nem személyiségjellemző és nem is kizárólag az aktivitás jellemzőitől függ, hanem az egyén és tevékenység interakciójában alakul ki.

Az eddig tárgyalt elméletek két intrinzik motivációról első ránézésre viszonylag kevés közös elemet tartalmaznak. A flow-elmélet az intrinzik motivált tevékenység közben átélt aktuális élménnyel foglalkozik (Janurik, 2007), míg az öndeterminációs elmélet a tevékenység hosszú távú, szükségleteket kielégítő céljával. Azonban a két elmélet valójában jól kiegészíti egymást. Csíkszentmihályi és kollégái behatóan tanulmányozták, hogy milyen élményeket élnek át az emberek, mikor számukra megfelelő kihívással járó, a képességeiket optimálisan kihasználó tevékenységeket végeznek. Az élmények minőségét vették górcső alá, anélkül, hogy megkérdőjelezték volna azoknak a szükségleteknek a létét, amelyek az ilyen élmények létezését lehetővé teszik. Annak ellenére tehát, hogy az öndeterminációs elmélet és a flow-elmélet alapvetései között első ránézésre nem találunk összhangot, tulajdonképpen azonos viselkedés veleszületett megindítóját és aktuális fenntartó- 
ját írják le. Elképzelhető ugyanis, hogy az öndeterminációs elmélet által leírt szükségletek kielégítésére végzett tevékenységek az átélt pozitív élmény miatt önjutalmazóak, azaz a két folyamat támogatja egymást, és a fejlődés, az elsajátítás irányába tereli az egyént (Csikszentmihályi, Abuhandeh és Nakamura, 2005; Eccles és Wigfield, 2002).

Az elsajátítási motiváció elméletének szintén előzményeként tekinthető White (1959) kompetencianövelési motiváció fogalma, azaz az egyén azon késztetése, hogy megismerje és hatékonyan bánjon környezetével. Az elsajátítási motiváció elmélete továbbá számos ponton egyezik az öndeterminációs és a flow-elmélet felvetéseivel. Az elsajátítási motiváció kutatása Yarrow (Yarrow, Rubenstein és Pedersen, 1975, idézi Józsa, 2007) csecsemőkkel és kisgyermekekkel végzett vizsgálataival vette kezdetét. Felfogásában az elsajátítási motiváció a csecsemőket és a gyermekeket arra ösztönzi, hogy minél jobban megismerjék és felderítsék környezetüket. Az ilyen jellegü tevékenység nem jár semmiféle jutalommal, a gyermek pusztán a tevékenységben lelt öröm kedvéért explorál (Józsa, 2007). Az eredeti, Yarrow-féle elsajátítási motiváció fogalma az évek során jelentősen változott. Egyrészröl leszükült, hiszen önmagában véve az explorációs és manipulációs vágyat már nem értik bele, hanem mint elsajátításra irányultságot értelmezik (Dweck és Leggett, 1988). Másrészről a fogalom tágult is, hiszen az újabb kutatások már nem csupán a csecsemő- és kisgyermekkorra fókuszálnak, a jelenséget a későbbi életszakaszokban is megragadhatónak látják (lásd Józsa, 2007). A terület egyik legismertebb kutatója, George A. Morgan és munkatársai megfogalmazásában az elsajátítási motiváció „olyan pszichológiai mozgatóerő, amely arra ösztönzi az egyént, hogy önállóan, koncentráltan és kitartóan próbálkozzon olyan probléma, feladat megoldásán, készség elsajátításán, ami legalább kismértékben kihívást jelent számára" (Morgan, Harmon és Maslin-Cole, 1990, 319. o, idézi Józsa, 2007, 45. o.). Barrett és Morgan (1995) később kitágítják az elsajátítási motiváció meghatározását, és azt többkomponensü, intrinzik pszichikus késztetésként definiálják. Megkülönböztetik az elsajátítási motiváció instrumentális és expresszív komponensét, melyek egymásra épülnek és kiegészítik egymást. Az instrumentális komponenst három további összetevőre bontják: (1) értelmi/kognitív, (2) szociális, (3) motoros elsajátítási motívum (Józsa, 2002, 2007).

Az intrinzik motiváció eddig bemutatott elméleteiben közös, hogy a tevékenységet egy idegrendszeri eredetü késztetés, a White-féle kompetenciakésztetés váltja ki. A kompetenciakésztetés mindhárom elmélet esetében csak optimális kihívással járó tevékenység végzésével váltható ki, amely egyben a fejlödést szolgálja. Az elsajátítási motiváció elméletének új eleme, hogy itt már megjelenik a végcél is, amire az elsajátítás irányul (Józsa, 2007).

\section{Internalizált meggyőződések mint motívumok}

Az intrinzik motívumokkal szemben, melyek idegrendszeri eredetủek és veleszületett késztetések alapján müködnek, számos olyan motívum létezik, amelyek kizárólag tanultak. E motívumok hátterében a kutatóknak eddig nem sikerült öröklött alapokat azonosítaniuk, feltételezhetően a szociális környezet hatására egy internalizációs folyamat eredményeként alakulnak ki. E folyamatban természetesen az egyén aktív résztvevő, és a kimenetet számos pszichológiai tényező befolyásolja. Annak érdekében, hogy megkülönböztessük eze- 
ket a motívumokat az öröklött alapon müködő önjutalmazó motívumoktól, internalizált meggyőződésekként kezeljük őket.

Érdeklődés-elmélet. Az érdeklődés fogalma a motiváció szakirodalmának egyik legtöbbször és legtöbb értelemben használt kifejezése, gyakran definiálatlanul, a motiváltság szinonimájaként értelmezett kategória (Murphy és Alexander, 2000). Általánosságban kétféle megközelítés létezik az érdeklődés megragadására. Értelmezhető bizonyos állapotokat, élményeket - például flow-élmény, elmélyülésélmény - kísérö érzelmi állapotként (Schiefele, 1999). Tekinthető internalizált, affektív elemekkel is átszőtt kogníciónak, ami személyes szubjektív értéket és pozitív érzéseket tulajdonít egy-egy tevékenységnek vagy tárgynak (Schiefele, 1999). E különbségtétel némi átfedést mutat a szakirodalom által definiált két érdeklődésfajtával is: a szituatív (situational) és egyéni (individual) érdeklödéssel (Hidi, 1990; Krapp, 2000). A szituatív érdeklődést általában az egyén közvetlen környezetében található inger váltja ki, amely hosszabb-rövidebb időn keresztül a figyelem összpontosítását és pozitív vagy negatív affektív reakciók kiváltását eredményezi (Hidi, 1990, 2001). Az egyéni érdeklődés ezzel szemben hosszabb fejlődés eredményeként jön létre, és arra készteti az egyént, hogy bizonyos tartalmakban újra és újra elmélyedjen. Másrészt egy olyan pszichológiai állapotra utal, amely akkor jön létre, amikor az elöbbi prediszpozíció aktiválódik (Renninger, 2000).

Az érdeklődés mint pszichológiai konstruktum empirikus kutatásának eredményei szerint az érdeklődés előbbi két típusa értelmezhető az érdeklődés fejlődésének két fázisaként is, amelynek során a kezdeti, külvilágból érkező stimulusok hatására aktuálisan érdeklődést kiváltó tevékenységek vagy tárgyak iránt az egyén hosszú távú affektív és kognitív beállítódásokat hoz létre. A fejlett egyéni érdeklődés egy hosszabb fejlődési folyamat eredménye, amely négy fázisban írható le (Hidi és Renninger, 2006). A modell értelmében az érdeklődés fejlődésének négy fázisa a következő:

Első fázis: kiváltott szituatív érdeklődés. Olyan pszichológiai állapot, amely az affektív és kognitív müködés rövid távú változásának eredményeként jön létre. Bizonyos osztálytermi tevékenységek, feladatok, például a csoportmunka vagy a rejtvények az érdeklődés e típusát váltják ki (Cordova és Lepper, 1996).

Második fázis: fenntartott szituativ érdeklődés. Az egyén már huzamosabb ideig és kitartóan képes figyelmét fókuszálni és bevonódni egy cselekvésbe, azonban mindehhez még továbbra is külső megerősítések szükségesek.

Harmadik fázis: bontakozó egyéni érdeklödés. Az egyén már önmaga keresi a lehetőségeket, hogy bizonyos tárgyakban/tevékenységeken/ideákban újra és újra elmélyüljön. Az ilyen tevékenységeket az egyén többnyire maga generálja, de az érdeklődés fenntartásához szükség lehet (némi) támogatásra, például modellek, társak, klubok, tanárok, források stb. formájában (Renninger, 2000).

Negyedik fázis: fejlett egyéni érdeklődés. Az egyén önállóan kialakítja maga számára annak a lehetőségét, hogy bizonyos tárgyakban/tevékenységeken/ideákban újra és újra elmélyüljön (Hidi és Renninger, 2006).

Egy példával illusztráljuk a négy fázist és egymásra épülésüket. Tegyük fel, hogy egy tanuló még soha nem hallott a dinoszauruszokról. Mikor a tanára néhány képet és szöveget mutat a dinoszauruszokról, a tanuló figyelme felélénkül, leköti a téma olvasása. Ez a kiváltott szituatív érdeklődés fázisa. Kicsöngetnek, vége az órának. Ha a tanuló otthon tovább olvassa a szöveget, és tovább tanulmányozza a dinoszauruszokat, akkor a fenntartott szituatív érdeklődés figyelhető meg. Ha ellátogat a könyvtárba, megvesz egy könyvet vagy 
keresgél az interneten, hogy többet tudjon meg ezekről az állatokról, akkor már külső serkentés nélkül, önmaga keresi a lehetőséget arra, hogy elmélyüljön a témában, tehát egyéni érdeklődése bontakozóban van. Ha érdeklődése tovább fejlődik, a tanuló újabb és újabb alkalommal keresi az alkalmat, hogy foglalkozhasson a témával, amely pozitív érzelmekhez juttatja, és ami egyre nagyobb jelentőséget tulajdonít. Esetleg úgy dönt, felnőttkorában ezzel szeretne foglalkozni. Ez a fejlett egyéni érdeklődés fázisa.

Célelméletek. Az emberi viselkedés célirányos jellegét korán felismerték, azonban a tanulási motiváció kutatásában csak viszonylag későn jelentek meg a célok mint motívumok elméletei. Számos célelmélet született, melyeket a konstruktum különböző megközelítései hívtak életre. A tanulási célok kutatásában alapvetően három irányzat figyelhetö meg: a célokra mint az elérni kívánt állapotok belső reprezentációjára (Austin és Vancouver, 1996) fókuszáló elméletek, az egyéni személyiségjellemzőkre utaló célorientációs elmélet (Ames, 1992) és a tanulási környezet motivációs hatását leíró osztálytermi célstruktúrákra irányuló elméletek (Fejes, 2011).

A legtöbb célelmélet egyezik abban, hogy az egyén céljai hierarchiába szerveződnek, azaz léteznek alacsonyabb és magasabb rendủ célok, s a hierarchia csúcsán az önmegvalósítás, az ideális én helyezkedik el (Molnár, 2009). A célok további kategorizálását takarja a közeli és a távoli jövőre vonatkozó célok megkülönböztetése. Az ilyen jellegü csoportosítások arra a kérdésre keresik a választ, hogy mit kíván elérni az egyén egy feladat teljesítésével. A második megközelítés, a célorientációs elmélet képviselői ezzel szemben azt vizsgálják, hogy az egyén miért és hogyan vesz részt a feladat teljesítésében. Ennek értelmében Dweck és Leggett (1988) a teljesítményszituációban érvényesülő céloknak két fajtáját különbözteti meg: az elsajátítási célokat (mastery goals) és a teljesítménycélokat (performance goals) (ez utóbbit Józsa (2007) személyes célnak, Fejes (2011) viszonyítócélnak is nevezi). Míg az elsajátítási cél az egyén kompetenciaérzetének növelésére, addig a teljesítménycél mások elismerésének megszerzésére irányul (Fejes, 2011; Józsa, 2007). A célok egy másik dimenzió mentén is feloszthatók aszerint, hogy az egyén a teljesítmény keresésére vagy elkerülésére törekszik (Linnenbrink és Pintrich, 2001). A két dimenzió mentén a célok négy kategóriába sorolhatók be: teljesítménykereső személyes célok, teljesítménykereső elsajátítási célok, teljesítménykerülő személyes célok és teljesítménykerülő elsajátítási célok (Fejes, 2011).

\section{Az elvárás- és a feladatérték-motívumokat egyesítő elméletek}

Az elvárás- és feladatérték-motívumokat egyesítő elméletek kapcsolatot keresnek az egyén saját képességeivel kapcsolatos meggyőződései és a tevékenység végzésének okai között. Ezek közé tartozik az attribúcióelmélet, mely szerint a siker és a kudarc okainak elemzése a feladatnak tulajdonított értékre hatással van, valamint a modern elvárás-érték elmélet, mely előbbi szük metszetéhez képest szinte valamennyi elvárás- és értékmotívum egymásra hatását feltételezi (Eccles és Wigfield, 2002).

Attribúcióelmélet. Az, hogy sikereinket és kudarcainkat milyen okoknak tulajdonítjuk, kulcsfontosságú szerepet tölt be későbbi motiváltságunkban, erőfeszítéseinkben. Az attribúcióelmélet, azaz az oktulajdonítás elmélete az egyén eredményességének hátterében álló észlelt okokat kategorizálja. Az elvárásmotívumokat és a feladatértéket egyesítő elmélet, hiszen az oktulajdonítás előzménye és következménye saját képességeink megítélésének, és hatással van az adott feladatnak tulajdonított értékre (Eccles és Wigfield, 2002). 
Weiner (1985) a siker és a kudarc attribúcióinak három dimenzióját különbözteti meg: az okság helyét, az okok stabilitását és kontrollálhatóságát. Ha a tanuló egy-egy sikerét csupán a szerencsének tulajdonítja, amely tünékeny, ám rajtunk kívül álló, kontrollálhatatlan, nem lesz motivált a későibbekben erőfeszítéseket tenni egy újabb siker elérése érdekében. Még kevésbé ösztönöző, ha egy-egy siker vagy kudarc hátterében rajtunk kívülálló, ráadásul megváltoztathatatlan okokat feltételezünk. Ugyanakkor, ha úgy érezzük, hogy az okok változhatnak és tölünk függnek, hajlamosabban leszünk erőfeszítéseket tenni a változtatás érdekében (Weiner, 1985).

Graham és Williams (2009) szerint a siker és a kudarc attribúcióinak mindhárom dimenziója más-más pszichológiai, érzelmi és viselkedéses következményekkel társítható. Az okság helye az önbecsülés és az ahhoz kapcsolódó érzelmekre van hatással, például a büszkeség- vagy a szégyenérzetre. A stabilitás dimenzió a siker- vagy kudarcelvárásokat befolyásolja, míg a kontrollálhatóság az önmagunkra vonatkozó ítéletekben és érzelmekben mutatkozik meg.

Modern elvárás-érték elmélet. A modern elvárás-érték elméletek az Atkinson (1964) által először leírt elvárás-érték megközelítésen alapulnak: az egyén teljesítményét, feladatvégzéssel kapcsolatos választásait és kitartását sikerelvárással kapcsolatos és feladatérték meggyőződéseivel hozzák összefüggésbe. Viszont fontos különbség, hogy a modern megközelítésekben az elvárás- és az értékmotívumok egyenesen és nem fordítottan arányosak egymással. Atkinson (1964) feltételezte, hogy azok a feladatok, amelyeknek az egyén a legnagyobb értéket tulajdonítja, egyben a legnehezebb feladatok is, ezért legkisebb a siker valószínűsége. Ennek következménye, hogy az egyén a közepes nehézségü feladatok végzésére lesz a leginkább motivált. A modern elméletek ezzel szemben azt állítják, hogy az esélyelvárásokkal és az értéktulajdonítással kapcsolatos meggyőződések különkülön járulnak hozzá a motiváltsághoz, vagyis az olyan feladatok végzésére leszünk leginkább motiváltak, amelyeknek magas értéket tulajdonítunk és a siker is valószínünek ígérkezik (Eccles és Wigfield, 2002; Feather, 1992).

A legismertebb és legtöbbet kutatott elvárás-érték elmélet kidolgozása és folyamatos továbbfejlesztése Eccles és munkatársai munkájához kötődik (Eccles, Andler, Futteman, Goff, Kaczala, Meece és Midgley, 1983; Wigfield és Eccles, 2000; Eccles és Wigfield, 2002). A modell szerint az elvárásokat és a feladatnak tulajdonított értéket olyan feladatspecifikus meggyőződések alakítják, mint a kompetenciaérzet, a feladat észlelt nehézsége, az egyén céljai és énsémája. Ezeket a szociokognitív változókat a szignifikáns mások gyermek által észlelt attitüdjei, elvárásai, a gyermek saját korábbi teljesítményhez kapcsolódó élményei, valamint az ezekkel kapcsolatos érzelmek és oktulajdonítások befolyásolják. A gyermek saját magával és feladattal kapcsolatos észleleteire a szocializáló személy viselkedése, meggyőződései és a kulturális miliő is hatással vannak.

A gyermekek saját korábbi élményei meghatározhatják saját képességeikkel kapcsolatos meggyőződésüket, másrészről hatással lehetnek arra, hogy mennyire kedvelnek, vagy mekkora értéket tulajdonítanak adott feladatnak (Higgins, 2007). Az empirikus eredmények azt mutatják, hogy bár az iskola kezdetekor jól megkülönböztethető a gyermekek azon meggyőződései, hogy mit tartanak fontosnak és miben látják magukat jónak (Eccles, Wigfield, Harold és Blumenfeld, 1993), az évek folyamán a tanulók egyre inkább annak tulajdonítanak nagyobb értéket, amiben sikeresek (Jacobs, Lanza, Osgood, Eccles és Wigfield, 2002). A szülők és a tanárok szintén információforrások a tekintetben, hogy milyen fontos egy-egy tevékenység vagy tantárgy, azaz a szülők és a tanárok saját értéktulaj- 
donításai hatással vannak a tanulók értéktulajdonításaira. Hasonlóképp a tanulók saját értékeiket társaikéhoz is hasonlítják. Végül, egy szélesebb szociális kontextusban gondolkodva, a kulturális normák és egy közösség elképzelései arról, hogy milyen tevékenységek, foglalkozások megfelelőek egy-egy jellemzővel leírt populáció számára (például a nők számára), szintén hatással lesz arra, milyen jelentőséget tulajdonítanak a tanulók egy-egy feladatnak vagy tantárgynak (Wigfield, Tonks és Klauda, 2009).

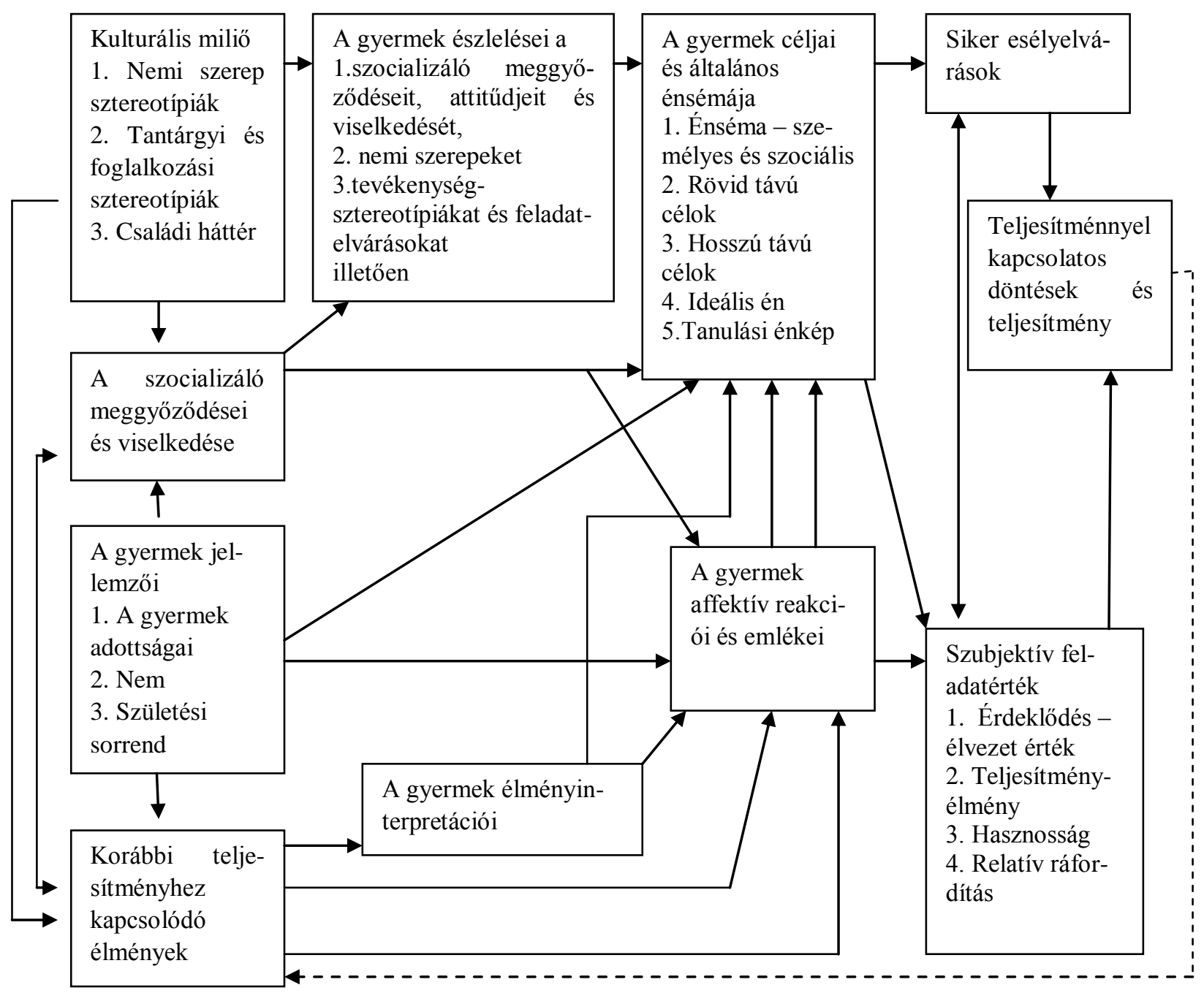

2. ábra

Eccles és munkatársai elvárás-érték modellje (Eccles és Wigfield, 2002)

Az Eccles és munkatársai által kidolgozott motivációmodell jelentősége, hogy számos más-más elméletek által korábban vagy később azonosított motívumot is integrál. Wigfield és Eccles (2000) a siker esélyelvárásait úgy definiálja, mint az egyén azzal kapcsolatos meggyőződéseit, hogy milyen jól fog teljesíteni egy előtte álló feladaton a közel- vagy távoli jövőben. A sikerelvárások definíciójuk szerint tehát analógok a Bandura (1997) által leírt önhatékonyság konstruktummal. Hasonlóképp, az Eccles és munkatársai (2002) által kidolgozott modellben a szubjektív feladatérték komponensek között szerepel az érdeklődés mint motívum, mely megfeleltethető Schiefele (1999) érdeklődésfogalmának. Ebben a modellben is megjelenik továbbá az élvezeti érték, mely szoros összhangban áll a flow 
elmélet áramlatélményével (Csíkszentmihályi, 1997). A modellben központi szerepet töltenek be célelméletek által is definiált hosszú és rövid távú célok is.

Az előbbiekben áttekintettük a tanulási motiváció korai irányadó és az utóbbi évtizedeket meghatározó elméleteit. Az elméletek mindegyike egy-egy tanulási motívumra vagy egy több motívumot átfogó motívumrendszerre mutatott rá. A motivációkutatás paradigmaváltás jelentőségü mozzanataként értelmezhető az a kontextuális fordulatként emlegetett jelenség, amely az elméletalkotók részéről a motiváció folyamatában a társas kontextus szerepére, a motívumok kontextusfüggőségére mutatott rá (Józsa és Fejes, 2010). Bár az elöbbiekben bemutatott megközelítések nem mindegyike definiálja magát szociokognitív elméletként, a szociális kontextus valamennyi elméletben tetten érhető a motívumok fejlödésében és müködésében (részletesebben lásd Martin és Dowson, 2009). Ennek értelmében valamennyi elméletet a kontextus szerepének figyelembe vételével értelmezünk.

\subsection{Területspecifikus tanulási motiváció}

A tanulási motiváció előbbiekben bemutatott elméletei a különböző motívumok összetett rendszerét tárták föl (Józsa, 2007). Az utóbbi évtized tanulási motivációval kapcsolatos kutatásai a tanulási motiváció egyes összetevőire, az egyes motívumokra - például a tanulási célokra (Harter, 1981; Elliot, 1997; Pintrich és Schunk, 1996) vagy a tanulási énképre (Marsh, 1984; Marsh és Craven, 1997; Van Damme, Opdenakker, de Fraine és Mertens, 2004) mint motívumra - fókuszáltak, és azokat képességeken és teljesítményterületeken átívelő módon vizsgálták.

A kutatások eredményei alapján az egyes motívumok képesség- vagy területspecifikus vizsgálata részletesebb információval szolgálna a motívumok müködéséről, mint az általános motívumok vizsgálata. Kérdéses ugyanis, hogy vajon az előbbiekben említett motivációs konstruktumok ugyanazt jelentik-e minden életkorban és minden teljesítményterület esetén. A motívumok területenként más készségekre és képességekre vonatkoznak, ezért nem feltételezhetjük, hogy müködésük hasonló módon történik. Míg az olvasási önhatékonyság (reading self-efficacy) például a szövegértés és a nyelvi készségek területén való magabiztosságot jelenti, addig a matematika önhatékonyság ettől merőben eltérő készségek, képességek hatékony müködtetésének észlelését takarja. Ismeretes továbbá, hogy az iskoláskorú tanulók bizonyos képességeiket inkább fejleszthetőnek tartják, mint másokat, így e képességek müködtetésébe több energiát is fektetnek (FreedmanDoan, Wigfield, Eccles, Blumenfeld, Arbreton és Harold, 2000). Előfordulhat például, hogy a tanuló úgy érzi, teljesen reménytelen matematikából, de fejlődőképesnek látja magát az olvasás területén. Így az önhatékonyság-érzés a két területen nemcsak különböző képességekre, készségekre vonatkozik, de különbözően is müködik.

A minőségi különbségek mellett a mennyiségi szempontok alapján is léteznek eltérések a motívumok között területenként. A tanulási motiváció kutatásában jól megalapozott konstruktumok, például az érdeklődés, az észlelt kompetencia, az intrinzik motiváció vagy az önhatékonyság, eltérő erősségüek lehetnek teljesítmény- vagy képességterületenként (Eccles, Wigfield, Harold és Blumenfeld, 1993; Gottfried, 1990). Elöfordulhat, hogy egy egyén magas önhatékonyságot mutat vagy jó énképpel rendelkezik az olvasás területén, de kevésbé érzi magát hatékonynak vagy jól teljesítőnek matematikából. A tanulók 
ilyen jellegü motivációs meggyőződései és észlelései az egyes teljesítményterületek szerint már óvodáskortól jól megkülönböztethetök, elkülöníthetők (Eccles és mtsai, 1993; Gottfried, 1990; Valentine, DuBois és Cooper, 2004). A területspecifikus vizsgálódás melletti további érvként merülhet fel, hogy a területspecifikus motívumok jobban megjósolják a tanulmányi eredményességet egy adott területen belül, mint a nem területspecifikus motívumok (Eccles és mtsai, 1993).

Végül feltételezhetjük, hogy a tanulók egyes tantárgyak vagy tevékenységek iránti motiváltságának hátterében területspecifikus tényezők is jelen vannak. Ilyenek például az olvasási motiváció esetén a szociális motívumok, melyek arra utalnak, hogy a tanuló azért olvas el egy könyvet, hogy bizonyos társas tevékenységekben - például a könyvröl való beszélgetésekben, az olvasmányélmények megosztásában - részt vehessen (Wigfield és Guthrie, 1997). Az olvasott szöveg jellemzői hasonló területspecifikus motivátorként értelmezhetök (Adamikné, 2006; Nagy, 2006). 


\section{Olvasási motiváció}

\subsection{Az olvasás válsága és az olvasási motiváció értelmezései}

Az utóbbi évtizedekben világszerte megjelent az olvasás válságának (literacy crisis) nevezett jelenség, noha az értelmezési módjai nagy eltéréseket mutatnak attól függően, hogy mely populációra vonatkoztatjuk azt (Verhoeven és Snow, 2001). A fejlődő országokban az olvasás válsága elsősorban a lakosság körében tapasztalható olvasás- és írástudatlanság, az analfabetizmus magas arányára utal, és az iskolázás kiterjesztésére, valamint a felnőtt lakosság írástudóvá tételének sürgető szükségességére hívja fel a figyelmet. A fejlett országokban, ahol az olvasás- és írástudás univerzálisnak mondható, az olvasás válsága más formában jelenik meg. Az egyik értelmezési mód szerint az olvasás válsága nem más, mint a szépirodalom (good literature) olvasásának és a szabadidős olvasás visszaszorulása, és az esztétikailag kevésbé értékesnek nevezhető irodalom, valamint média előtérbe kerülése. E megközelítés fényében előtérbe kerül az irodalmi nevelés fontossága és az olvasási szokások formálása. A fejlett országokat érintő másik értelmezési mód elsősorban a gazdaságilag fejlett társadalmakból indult ki, és az olvasás válságán a szövegértés és a mindennapi életben valamint a munkaeröpiacon való érvényesüléshez szükséges olvasási képesség nem megfelelő fejlettségi szintjét érti. Az értelmezés arra mutat rá, hogy még a gazdaságilag fejlett országokban is jelentőskülönbségek vannak az egyének között az olvasástudást illetően. A lakosság egy része nem rendelkezik azokkal a készségekkel, amelyek lehetővé tennék számukra az olvasás eszközszerü használatát. A megközelítés keretein belül értelmezett olvasásimotiváció-kutatások arra keresik a választ, melyek azok a belső pszichikus mozgatóerők, amelyek az olvasást mint tevékenységet tartalomtól függetlenül ösztönzik (Verhoeven és Snow, 2001).

Hazánkban az 1980-as és 1990-es évektől kezdve fordult figyelem az olvasás válságának jelenségére, elsősorban a második megközelítési mód szellemében a szépirodalom háttérbe szorulásának kapcsán (lásd pl. Adamikné, 2007; Csáky, 1996; Tóth, 1999). Az úgynevezett olvasásra nevelés mozgalom az olvasási szokások megváltozása, a szabadidős olvasás mennyiségi és az olvasott tartalmak minőségi változása ellen szólalt fel, hangsúlyozva az irodalmi mủveltség fontosságát. A mozgalom jelentősége, hogy, habár csak a tartalmak egy szük körére vonatkozóan felhívta a figyelmet az olvasás elsajátításában és fejlődésében az affektív-motivációs tényezőkre, és megteremtette az igényt olyan pszichológiai komponensek fejlesztésére az iskolában, melyek az olvasási kedv felkeltését és az olvasóvá válást segíthetik.

Ezzel párhuzamosan, a hazai és a nemzetközi nagymintás mérések nyomán hazánkban is megjelent az olvasás válságának előbbiekben tárgyalt harmadik értelmezési módja, mely az olvasás válságán a funkcionális analfabetizmus nagyarányú elterjedését érti (Steklács, 2005). A Monitor- (Horváth, 1994, 1996) majd a PISA-vizsgálatok (Csíkos, 2006; Vári, 2003) nyomán az olvasás mint eszköztudás nehézségei kerültek a figyelem középpontjába, s az olvasási motiváció mint az olvasási tevékenységet elindító, tartalomtól független belső ösztönzőrendszer jelent meg. Az olvasási motiváció ezen átfogó, tartalomtól független értelmezési módjának elméleti kereteinek kidolgozása a tanulási motívumok adaptálásával már kezdetét vette (lásd Möller és Schiefele, 2010). Az olvasási motiváció 
ebben az értelmezésben területspecifikus tanulási motiváció, azaz mindazoknak a motívumoknak az összessége és rendszere, amelyek az olvasási tevékenység megindításában és fenntartásában szerepet játszanak.

\subsection{Olvasási motiváció és olvasási képesség}

A képességek és a motívumok fejlődése már korán összefonódik, a két folyamat egymást támogatja (Józsa, 2005; Réthyné, 2001). Nagy (2010) személyiségmodelljében a személyiség alapvető komponensrendszereit, a kompetenciákat, tudás- és motívumrendszerekként definiálja, ahol a tudásrendszerek elemi a képességek és ismeretek. A tudás- és a motívumrendszer ebben a megközelítésben egymástól elválaszthatatlan, egymás nélkül létezésük értelmetlen. Az olvasási motiváció modelljeinek ismertetése elött ezért az olvasási képesség Nagy József-i modelljét tekintjük át.

Az olvasási képesség sajátos rutinokból, készségekből és ismeretekből szerveződő pszichikus rendszer (Nagy, 2006). Az olvasási képesség egyes rutinjai a beszédhangfelismerö, a beszédhang-kiemelö, hangszófelismerő, betüfelismerő, betükapcsoló, betűszófelismerő rutin. Az olvasási képesség készségei a beszédhanghalló készség, a betüolvasó készség, a szóolvasó készség, a mondatolvasó készség, a szövegolvasó és szövegértő készség, valamint a szövegfeldolgozó és szövegértelmezö készség (3. ábra).

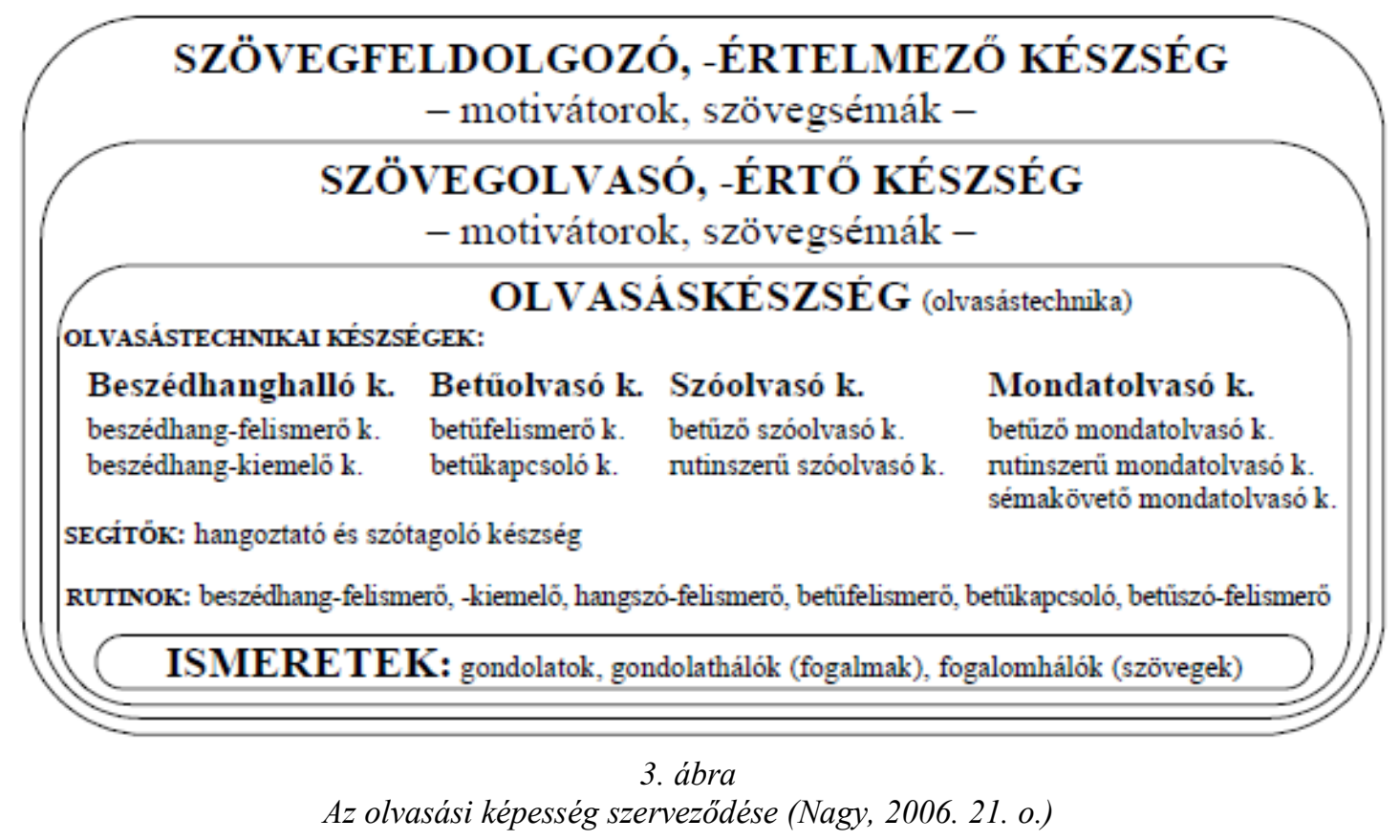

Az olvasási képesség müködésének feltétele komponenseinek kiépülése és begyakorlottsága. Az optimális szövegfeldolgozás és szövegértelmezés feltétele az olvasási képesség valamennyi komponensének kiépülése és begyakorlódása: a beszédhang-felismeréstől egészen a szövegértésig (Nagy, 2006, 2010).

Az olvasáskészség (olvasástechnika) elsajátításának, amely a betüző olvasást teszi lehetővé, önálló motivátorai nincsenek, elsajátítása a szövegértést szolgálja (Nagy, 2006). Az olvasástechnika elsajátítását, gyakorlását tehát az a felismerés kell, hogy motiválja, hogy eredményeképp lehetővé válik a szövegértés. A szövegértés motivátora mindig éppen 
az adott olvasási cél, az olvasás aktuális funkciója. Nagy (2006) az olvasás funkciója szerint különböztet meg szövegtípusokat. Ennek értelmében az élménykínáló szövegek azáltal motiválnak, hogy élményszerzési lehetőséget biztosítanak, az informáló szövegek valamely feladat vagy probléma megoldásában, egy cél kivitelezésében segítenek azáltal, hogy információt szolgáltatnak, míg a tudáskínáló szövegek tanulási lehetőséget nyújtanak, kielégítik tanulási vágyunkat.

Nem ismerünk olyan kutatást, amely az olvasási motiváció mint komplex egész alakulását a szövegtípusok és müfajok függvényében vizsgálná, így csak feltételezhetjük, hogy a szövegtípusok és müfajok mint az olvasás tárgyának jellemzői, inkább aktuálisan hatnak az olvasási motiváltságra, azaz motivátorként müködnek. Azonban a különböző szövegtípusok és müfajok olvasása hatással lehet a motívumok fejlődésére is, és hasonló különbségekkel szolgálhat az olvasási motívumok alakulásában, mint a területspecifikusság a tanulási motívumokéban. Érezheti magát hatékonynak valaki folyamatos szövegek olvasásakor, és ugyanakkor reménytelennek nem folyamatos szövegek értelmezésében (énhatékonyság), vagy ugyanazon személy élhet át gyakran flow élményt élményszerző szövegek olvasásakor, de soha tudásszerzés céljából történő olvasáskor. Hasonlóképpen elképzelhető, hogy az egyén jó olvasónak tartja magát (énkép), ha hétköznapi szövegek olvasásáról van szó, de nehezen igazodik el az irodalmi müveken. Azonban az, hogy a tanulók milyen szövegekkel találkoznak az iskolában, hosszú távú hatással is van motiváltságukra. Kérdéses lehet például, hogy a jelenleg kötelezővé tett iskolai olvasmányok, melyek közül több is akár több tíz vagy száz évvel ezelött íródott, alkalmasak-e az olvasás megszerettetésére (Józsa és Steklács, 2010).

Az olvasási motívumok és az olvasási képesség fejlettsége közötti kapcsolattal foglalkozó kutatások alapjául az olvasás fejlődésének elmélyülés és elköteleződés modellje (engagement model of reading development) szolgál (Guthrie és Wigfield, 2000). E modell értelmében a szövegértő képesség fejlődése a gyakori elmélyült olvasás folyamán valósul meg, azaz minél többet olvas valaki elmélyülten, annál fejlettebb lesz az olvasási képessége. A modell az elmélyült olvasás négy alapvető jellemzőjét különbözteti meg: (1) motivált, (2) stratégiahasználaton alapul, (3) tudásvezérelt és (4) társas interakció követi. Az olvasási képesség fejlettsége a modell értelmében szoros összefüggésben áll az olvasás iránti motivációval, mégpedig azáltal, hogy a motivált, értő olvasás elősegíti a szövegértő képesség fejlődését. A modellben az elmélyültség a minőségi oldalt jelenti, amelynek egyik fő alappillére a motiváltság. Ugyanakkor a modellben a szövegértés fejlödése feltételezi az olvasás minél gyakrabban történő gyakorlását, végzését is és az olvasás iránti elköteleződést. Feltételezhető, hogy az ilyen értelemben vett mennyiségi oldalra szintén hatással van a tanulók motiváltsága: az olvasási motiváció és az olvasás mennyisége között szoros összefüggést talált Wigfield és Guthrie (1997), valamint Cox és Guthrie (2001).

A PISA 2000-es vizsgálat egyoldalúbb értelmezést vesz alapul, és az olvasási képesség fejlődésében csak az elköteleződésnek tulajdonít szerepet. Az elkötelezettség az elmélyüléssel szemben kizárólag a mennyiségi oldal biztosításával segíti elő az olvasási képesség fejlődését. Guthrie és Wigfield (2000) modelljében és a PISA 2000-vizsgálat frameworkjében eredetileg egyaránt az ,engagement” kifejezés szerepel. A minőségi és a mennyiségi oldal együttes jelenlétét hangsúlyozandó Guthrie és Wigfield (2000) modelljének leírásakor az „elmélyülés és elköteleződés”, míg a PISA 2000-koncepció ismertetésekor a szükebb értelmezést figyelembe véve csak az „elköteleződés” kifejezést használjuk. 
A PISA 2000 az elkötelezettség három dimenzióját határozza meg: (1) az olvasással eltöltött idő, (2) az olvasott szövegek változatossága és (3) az olvasás iránti érdeklődés és attitüdök. Elkötelezett olvasó az, aki sok időt tölt olvasással, sokféle szöveget olvas, érdeklődő és pozitív attitüdökkel rendelkezik az olvasás iránt. A koncepció abból a feltételezésből indul ki, hogy az olvasás iránti elkötelezett tanulók szabadidejükben többet olvasnak, mint nem elkötelezett társaik. A gyakoribb olvasás így a gyakorlási lehetőségek megnövekedett számát nyújtja a tanulóknak, ami akár több éves iskolai tanulást vagy a hátrányosabb szocioökonómiai helyzetet is kompenzálhatja (Guthrie és Wigfield, 2000). A nemzetközi adatok alátámasztják e feltételezést, hiszen a felmérés eredményei szerint mindazok a tanulók, akik erősen elkötelezettek az olvasás iránt, szocioökonómiai státusztól függetlenül a legjobb olvasók közé tartoznak, míg azok, akik alacsony elköteleződést mutatnak az olvasás iránt, bármilyen családi háttérrel is rendelkeznek, a nemzetközi átlag ala tt teljesítenek (Kirsch, deJong, Lafontaine, McQueen, Mendelovits és Monseur, 2002). Az olvasás iránti elkötelezettség és az ebből következő belső indíttatásból fakadó gyakori olvasás képes kompenzálni azokat a hátrányokat, amelyek esetlegesen a családi háttérből fakadnak.

Wilson és Trainin (2007) a formális olvasástanítás kezdeti szakaszára jellemző olvasási motiváció modelljükben az olvasási motiváció és a teljesítmény kapcsolatát körkörös folyamatként ábrázolják. E szerint a korábbi teljesítmény meghatározza a későbbi motivációt és fordítva, a korábbi olvasási motiváció később hatással lesz az olvasási teljesítményre. Onatsu-Arvillomi és Nurmi (2000) hasonló reciprok kapcsolatot mutatott ki óvodáskorú gyermekek olvasási motivációja - feladatorientáltsága - és teljesítménye között. Guay, Marsh és Boivin (2003) az olvasási énkép vizsgálatakor jutott hasonló eredményekre.

Az empirikus eredmények többsége ugyanakkor kétirányú helyett egyirányú kapcsolatot támaszt alá az olvasási motiváció és szövegértés fejlettsége között, ahol a motiváció jó előrejelzője a későbbi szövegértési teljesítménynek, de a teljesítmény nem befolyásolja a motivációt (Guthrie, Hoa, Wigfield, Tonks, Humenick és Littles, 2006; Guthrie és mtsai, 2007; Viljaranta, Lerkkanen, Poikkeus, Aunola és Nurmi, 2008). Az egyes motívumok és az olvasási teljesítmény közötti kapcsolat az előbbieknél árnyaltabb képet mutat, és a motívumok közötti különbségekre hívja fel a figyelmet. Wang és Guthrie (2004) szerint a teljesítményre csupán az intrinzik motiváció hat, míg az extrinzik motiváció negatív összefüggésben áll a szövegértéssel. Bouffard, Marcoux, Vezeau és Bordeleau (2003) vizsgálatában épp az intrinzik motiváció nem áll kapcsolatban az olvasás eredményekkel, a regresszióanalízis eredményei szerint arra hatással csak az észlelt kompetencia van. Morgan, Fuchs, Compton, Cordray és Fuchs (2008) gyenge olvasókkal végzett intervenciós kísérletükben a szóolvasó készség fejlesztésének hatásait vizsgálták az olvasási énképre, az olvasás intrinzik motívumaira, az olvasás iránti érdeklődésre és az olvasási szokásokra. Eredményeik szerint a szóolvasás készségeinek fejlesztése a vizsgált motivációs tényezők egyikére sem volt hatással, alátámasztva ezzel az egyirányú kapcsolat modelljét. Retelsdorf, Köller és Möller (2011) longitudinális vizsgálatukban az olvasás iránti intrinzik motiváció, érdeklődés, a versengés mint extrinzik motívum és az olvasási énkép kapcsolatát vizsgálták a dekódolás és a szövegértés teljesítményre. A vizsgált konstruktumok közül a versengés esetében negatív, a többi motívum esetében pozitív hatásról számoltak be az olvasás fejlődésében. Míg az énkép, és az intrinzik motiváció esetében a hatás a kezdeti 
olvasásteljesítményben volt tetten érhető, addig az érdeklődés a teljesítmény időbeli változására volt hatással.

Möller és Schiefele (2010) az olvasási motiváció és az olvasási teljesítmény kapcsolatában a közvetítő tényezők, azaz a stratégiahasználat, az olvasás mennyisége és az olvasási szokások mediáló szerepére mutat rá. Hasonlóképp, Guthrie és Wigfield (2000) elmélyülés és elköteleződés modellje is az olvasás iránti elköteleződés alapjának tekinti az olvasás iránti motiváltság mellett az olvasási stratégiák használatát és a gyakori olvasást.

Az olvasásistratégia-használat és az olvasási motiváció közötti kapcsolatot mind a motiváció mind pedig a stratégiahasználat szakirodalma tárgyalja. Az olvasási motiváció szakirodalma a stratégiahasználatot mint az olvasási önhatékonyság érzése növelésének egyik eszközét vizsgálják. E kutatások szerint az olvasási stratégiák tanítása a megfelelö olvasási motívumok fejlesztésével ötvözve az önhatékonyság fejlesztésének jó eszköze (Wigfield, Guthrie, Tonks és Perencevich, 2004). Almasi (2003) az olvasási stratégiákat „az olvasás célja érdekében, a kiválasztás, a végrehajtás és a monitorizálás szándékosan alkalmazott kognitív folyamata" határozza meg (Almasi, 2003. 5. o.). A definícióból következik, hogy a jó stratégiahasználókat a kiterjedt háttértudás, a metakognitív faktor ismerete, a jó feladatelemző készség és a változatos stratégiák használata mellett erős motiváltság is jellemzi (Pressley, Symons, Snyder és Cariglia-Bull, 1989 idézi Józsa és Steklács, 2010). Csíkos (2007) a stratégiahasználat kapcsán előbbi szerzőkkel összhangban szintén a metakogníció szerepére hívja fel a figyelmet. Steklács (2011) szerint az olvasásra vonatkozó tudatosság kétféle szinten jelenhet meg: kognitív és metakognitív szinten. Kognitív szinten a tapasztalatok a tárgyakra és a környezetre vonatkoznak, míg metakognitív szinten ezek a tapasztalatok a saját képességekre, saját olvasási folyamatokra vonatkozó meggyőződéseket alakítják. Ez utóbbi meggyőződések közel állnak az önhatékonyság érzése és az énkép elméleti konstruktumaihoz.

Összességében véve tehát elmondható, hogy bár az egyes motivációs tényezők teljesítményre való hatását illetően fellelhető némi ellentmondás a szakirodalomban, az olvasási motívumok általában véve jó - direkt vagy indirekt - előrejelzői a későbbi teljesítménynek. Azonban az összefüggés azonban nem megfordítható: az olvasási motiváltság növeléséhez nem elegendő az olvasási képességet fejleszteni, ahhoz célirányos motívumfejlesztésre van szükség.

\subsection{Az olvasási motiváció modelljei}

Az olvasási motivációt illetően a komponensek pontos listájával vagy egy általánosan elfogadott, empirikus adatokkal is alátámasztott modellel a szakirodalom nem rendelkezik (Watkins és Coffey, 2004). Érdemes ugyanakkor áttekinteni azokat az elméleti modelleket, amelyek egy-egy kutatás hátterében álltak, minthogy azok a teljes konstruktum egy-egy aspektusáról hasznos információval szolgálhatnak. A következő, több motívumot átfogó vizsgálatok az olvasási motiváció valamely elméleti modelljére támaszkodnak. Az előbbiekben bemutatott kutatásokkal szemben egyszerre több motívumot tesznek a vizsgálat tárgyává, és egyes esetekben a motívumok közötti összefüggés- vagy hatásrendszert is megkísérlik felvázolni. Ilyen értelemben információt hordoznak arról is, hogyan képzelhető el az olvasási motiváció mint önálló konstruktum felépítése.

Az olvasási motiváció egy sokösszetevős modelljét írta le Wigfield és Guthrie (1997). Modelljükben a tanulási motívumok három csoportját adaptálták az olvasásra: (1) 
az egyének saját teljesítményhatékonyságukkal kapcsolatos meggyőződéseikre épülő motívumaikat, (2) a tevékenység végzésének indokaira vonatkozó motívumokat és (3) a motiváció társas aspektusaira vonatkozó motívumokat. Ez utóbbi az olvasási tevékenységre nézve specifikusnak tekinthetö, hiszen a nem társas közegben folytatott olvasási tevékenységnek is lehetnek társas vonatkozásai (például az olvasmányélmény megosztása másokkal; Wigfield és Guthrie, 1997). A modell az olvasási motiváció összesen 11 lehetséges komponensét különbözteti meg: önhatékonyság (self-efficacy), kihívás (challenge), teljesítménykerülés (work avoidance), kíváncsiság (curiosity), beleélés (involvement), fontosság (importance), elismerés (recognition), osztályzatok (grades), versengés (competition), társas kapcsolatok (social), megfelelés (compliance). Az olvasási motiváció e modellje által leírt néhány dimenzió létét az elméleti modell alapján kifejlesztett Motivations for Reading (MRQ) kérdöív segítségével empirikus adatokkal is sikerült alátámasztani, és a mérőeszköz széles körben elterjedtté vált. Az összes komponens létezését azonban nem sikerült igazolni, a teljes modell így az empirikus adatok szerint nem állja meg a helyét (Watkins és Coffey, 2004). Feltételezhető továbbá, hogy az olvasási motiváció egyéb dimenziói is léteznek, így a modell korántsem tekinthető az olvasási motiváció átfogó modelljének (Baker és Wigfield, 1999).

Guthrie, Hoa, Wigfield, Tonks, Humenick és Littles (2006) az olvasási motiváció komponenseinek felderítése céljából félig strukturált interjúkat készített negyedik osztályos tanulókkal. Az interjúk elemzése alapján öt motívumot különítettek el az olvasási motivációt illetően: érdeklődés, észlelt kontroll, együttmüködés, önhatékonyság és beleélés. Kutatásuk jelentősége, hogy olvasási motiváció modelljüket nem elméleti alapon, hanem kvalitatív módon gyüjtött és elemzett adatok alapján állították össze.

Wilson és Trainin (2007) az olvasási motiváció egy másik lehetséges modelljét írta le (4. ábra). E modell az olvasási motiváció három komponensét jelöli meg: az önhatékonyságot, az észlelt kompetenciát és az attribúciókat. A Wilson és Trainin (2007) által leírt modellben szereplö összes motívum jól ismert az elsajátítási motiváció szakirodalmából, az olvasási motivációnak specifikus motívumokat nem tulajdonít. Ugyanakkor modelljük továbblépést jelent az előzőhöz képest annyiban, hogy az egyes motívumok közötti lehetséges kapcsolatokat és hatásokat is megkísérli modellálni. A modell alapjául Schunk (1999) teljesítményközegben érvényes társas én interakció elmélete szolgál, mely szerint a különböző társas visszajelzések - akár direkt, például a tanár megerősítő viselkedése, akár indirekt, például mások teljesítménye - az egyén teljesítménye és az énséma egymással korrelálnak. Wilson és Trainin (2007) olvasási motiváció modelljében az énséma két alapkomponense, az észlelt kompetencia és az önhatékonyság szerepel, melyek között erős összefüggés és reciprok kapcsolat feltételezhető. A teljesítmény felől érkező visszajelzések nem direkt módon, hanem az attribúciók által közvetítetten kapcsolódnak az énsémához (Wilson és Trainin, 2007). A visszajelzések szoros összefüggésben vannak az énséma komponenseivel, ez utóbbiak tartalma nagyban fog függni az attribúciós mechanizmusok kimenetétöl, azaz attól, hogy az egyén adott körülmények között a pozitív vagy a negatív visszajelzést külső vagy belső okoknak tulajdonítja (Weiner, 1985). 


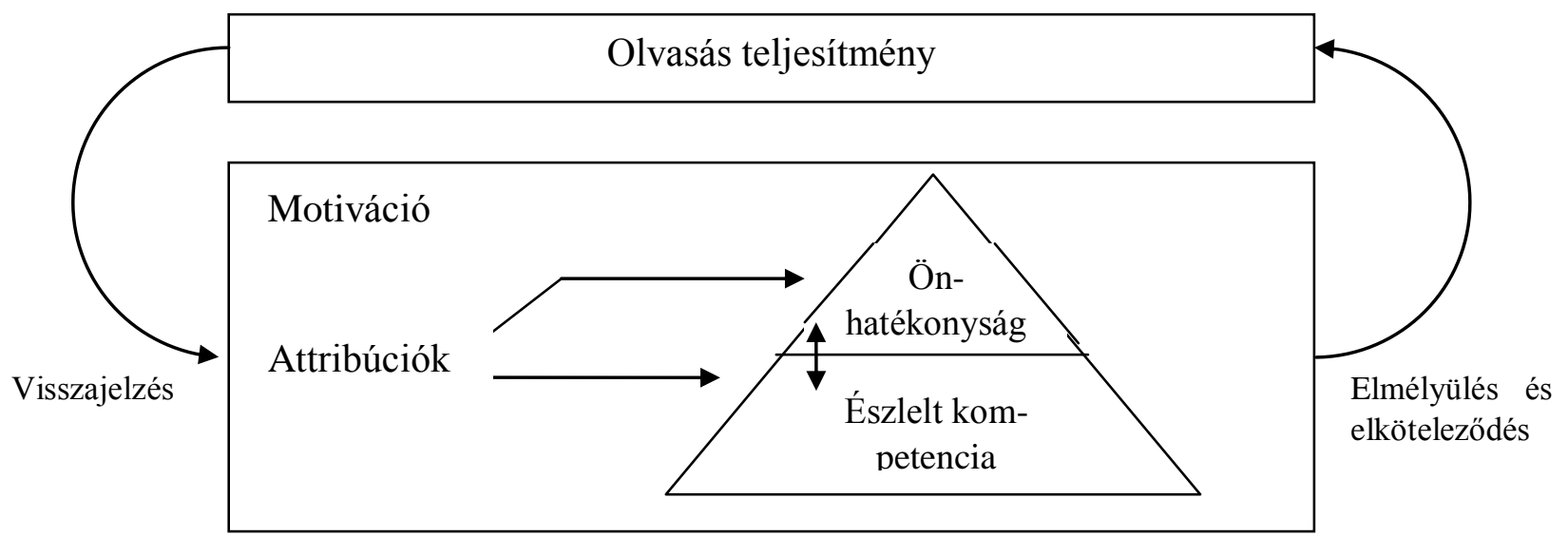

4. ábra

A kezdeti olvasási motiváció modellje (Wilson és Trainin, 2007, 258. o.)

Az előbbiekben bemutatott olvasásimotiváció-modellek a konstruktum leírásának első lépéseit képviselik. Egyetlen modell sem törekszik arra, hogy az olvasási motiváció komponenseinek átfogó listáját adja, vagy a komponensek között határozott és kizárólagos kapcsolatokat feltételezzen. Az első modellek célja, hogy a tanulási motiváció elméletéből megismert motívumokat értelmezze az olvasásra, és hogy bizonyos komponensek között lehetséges kapcsolatokat vázoljon fel. A további komponensek, valamint a komponensek közötti összefüggés- és hatáshálózatok azonosítása további kutatási feladat. Ehhez egy jó alapnak mutatkozik a tanulási motiváció többkomponensü modelljeinek, így például a legtöbb tanulási motívumok integráló elvárás-érték elméletnek az olvasás területére történő adaptálása, mely lehetővé tenné az olvasási motívumok elméleti modell szerinti együttes vizsgálatát.

A Möller és Schiefele (2010) által kidolgozott az Olvasási motiváció elvárás-érték elmélete Wigfield és Eccles (2000) teljesítménymotivációs elméletén alapul. Ebben a két szerző megkülönbözteti a tárgyspecifikus és a tevékenységpecifikus olvasási motivációt. Előbbi bizonyos tartalmak olvasására vonatkozik, tehát tartalomspecifikus, míg utóbbi az olvasással mint tartalomfüggetlen tevékenységgel kapcsolatos motivációt takarja. Hasonlóképp különbséget tesznek az aktuális, azaz egy bizonyos olvasási eseménnyel kapcsolatos, és a szokásalapú, azaz a rendszeres olvasásra vonatkozó olvasási motiváció között. A modell azokat a motivációs tényezőket foglalja össze, amelyek az ezen dimenziók mentén leírható olvasási motivációhoz járulnak hozzá (5.ábra). 
Társas kör- Szubjektív nyezet feldolgozás

\section{Motivációs \\ meggyözödések}

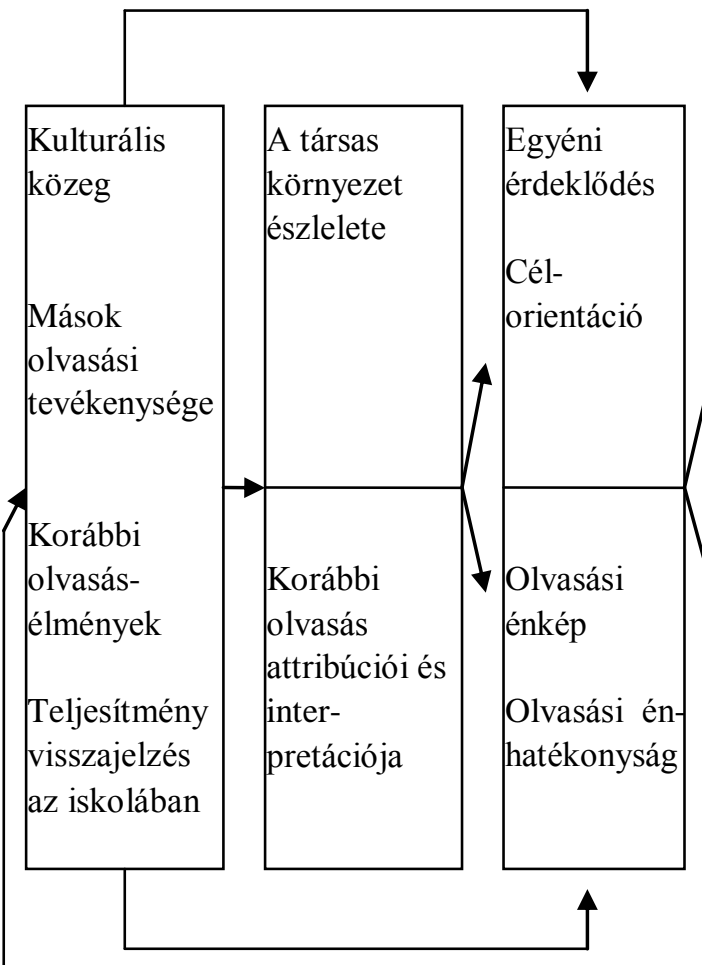

Olvasás-

specifikus

érték-és

elvárás-

kogníciók

$$
\begin{array}{ccc}
\text { Aktuális/ } & \text { Aktuális/ } & \text { Olvasás } \\
\text { szokásjellegü } & \text { szokásjellegü } & \text { teljesitmény } \\
\text { motiváció } & \text { olvasási tevé- } \\
& \multicolumn{3}{c}{\text { kenység }}
\end{array}
$$
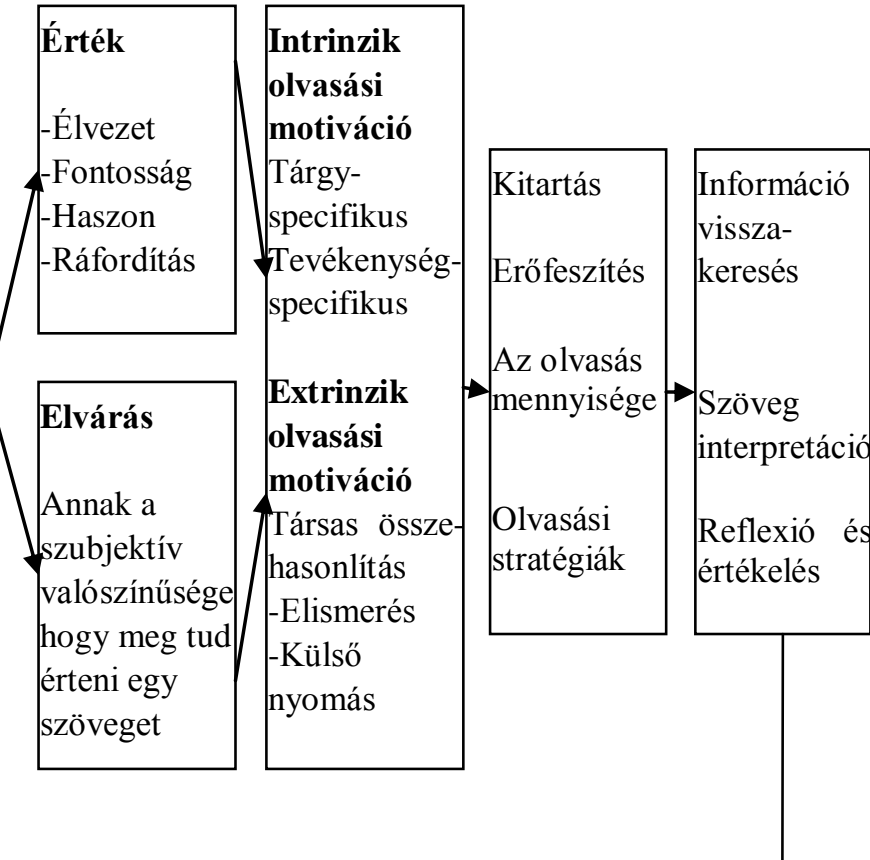

5. ábra

Az olvasási motiváció elvárás-érték modellie (Möller és Schiefele, 2010)

Az Olvasási motiváció elvárás-érték modellje - a modern elvárás-érték elméletekkel összhangban - épít arra a feltételezésre, hogy a motiváció nagyban függ egyrészt az egyén saját olvasási képességével kapcsolatos meggyőződéseitől, olvasási énképétől és önhatékonyság érzésétől, másrészről attól a szubjektív értéktől, amit az egyén saját maga az olvasásnak tulajdonít. Ennek értelmében minél valószínübbnek tartja, hogy sikeresen elsajátíthatja és használhatja olvasási képességét, illetve minél fontosabbnak tartja különbözö okoknál fogva az olvasást, annál motiváltabb lesz arra.

Az olvasási tevékenység, illetve már az olvasás elsajátítása is, valamilyen szociokulturális közegben zajlik. A közeg jellemzői, a szignifikáns mások olvasási teljesítménye, olvasási meggyőződései, az általuk nyújtott teljesítményvisszajelzések, illetve a korábbi olvasásélmények, a sikerek és kudarcok egyrészt direkt módon, másrészt indirekt módon, a szubjektív feldolgozás szüröin keresztül is hatással lesznek az olvasás motívumaira: az egyéni érdeklődésre, a célokra és célorientációra, az énképre és önhatékonyságra. E motívumok alapján alakítjuk ki azután olvasásspecifikus elvárás- és értékkognícióinkat, amelyek intrinzik vagy extrinzik motivációt létrehozva hatással lesznek az olvasás mennyiségi és minőségi mutatóira, például a stratégiahasználatra. Az olvasással eltöltött idő és a stratégiahasználat jellemzői befolyásolják a különböző szintű olvasási teljesítményt (Möller és Schiefele, 2010). 
Az áttekintett olvasásimotiváció-modellek egyszerre több motívum együttes szerepét hangsúlyozták az olvasás iránti motiváció alakulásában. Az olvasási motivációról való tudásunkhoz jelentős mértékben hozzájárultak ugyanakkor azok a kutatások is, amelyek egy-egy olvasási motívumot tettek a vizsgálat tárgyává. Ezeket a következő fejezetben, az olvasási motívumok áttekintésekor tárgyaljuk.

\subsection{Olvasási motívumok}

Az olvasási motiváció területspecifikus értelmezése mint elméleti keret az olvasási motívumokat az olvasás területén érvényesülő általános viselkedési és tanulási motívumoknak tekinti. A következökben ezt az elméleti keretet követve azokat a tanulási motiváció elméleteiben is azonosított motívumokat tekintjük át, amelyekre az olvasási motivációs kutatások is irányulnak, és amelyek az eddigi kutatások alapján kiemelkedő szerepet játszanak az olvasás iránti motiváltság alakulásában. Mivel az olvasási motiváció elméletében használatos motívumfogalmak és -értelmezések eltérhetnek az általános motiváció szakirodalmából ismeretes definícióktól - minthogy más készségekre és tevékenységekre vonatkoznak - a szerkesztő elv, mely mentén az olvasás motívumait bemutatjuk, az általános motivációelmélet és az olvasási motiváció elmélete közötti különbségtételen alapul. Minden motívum esetében először az általános motivációelmélet szerinti értelmezést, majd az olvasás területére vonatkozó jelentéstartalmat és az ahhoz kapcsolódó legfontosabb kutatási eredményeket vázoljuk fel.

Célunk a nemzetközi és a hazai kutatások nyomán azoknak a belső pszichikus konstruktumoknak az áttekintése, amelyek a szokás-jellegű olvasás iránti motiváltságot hosszú távon fenntartják. A következőkben Ryan és Deci (2000) és Réthyné (2003) kategóriái nyomán a beépült (internalizált) és az önjutalmazó (intrinzik) motívumokat tárgyaljuk.

\subsubsection{Olvasási énséma: énkép és önhatékonyság}

Az énsémához kapcsolódóan az olvasási motiváció területén végzett kutatások három motívumot azonosítottak: énkép, önhatékonyság, észlelt kompetencia. Bár a három énséma komponens egymással szoros összefüggésben álló pszichológiai konstruktum, vizsgálati szempontból szükségszerü elkülönítésük. Az énséma más-más aspektusát írják le, minthogy (1) kialakulásukban más forrásokra támaszkodnak, (2) központi elemüket és összetételüket tekintve különböznek, (3) időbeli orientációjuk eltérő, (4) a területspecifikusság különbözö fokát jelenítik meg, (5) eltérö stabilitásúak, (6) különböző kimeneteket, teljesítményeket jósolnak be (Bong és Skaalvik, 2003). Az 1. táblázat az énképet és önhatékonyságot mint énséma-összetevőket hasonlítja össze. A táblázatban kiemeltük az észlelt kompetenciát, azaz a harmadik komponenst, amelyet Bong és Skaalvik (2003) alapján az énkép központi elemének tekintünk. 
1. táblázat. Az énkép és az önhatékonyság összehasonlitása (Bong és Skaalvik, 2003 alapján)

\begin{tabular}{lll}
\hline \hline Szempontok & Énkép & Önhatékonyság \\
\hline Forrása & normatív és ipszatív viszonyítás & célreferenciájú és normatív viszonyítás \\
Központi elem & észlelt kompetencia & észlelt magabiztosság \\
Összetétel & kognitív és affektív elemek & kognitív elemek \\
Idő-orientáció & múlt & jövő \\
Specifikusság & terület- vagy képességspecifikus & feladatspecifikus, kontextusfüggő \\
Stabilitás & viszonylag stabil & változó \\
Kimenetek & motiváció, érzelmek, teljesítmény & $\begin{array}{l}\text { motiváció, érzelmek, kognitív és önszabályo- } \\
\text { zó folyamatok, teljesítmény }\end{array}$ \\
\hline
\end{tabular}

Az énkép (self-concept) Nagy (2000) fogalomhasználatával az éntudat, az egyén önészleléseit tartalmazza: azokat a meggyőződéseket, vélekedéseket, amelyeket magára nézve az egyén igaznak gondol (Nagy, 2000). Terület- vagy képességspecifikus, de nem függ a kontextustól. Viszonylag stabil, múltbeli emlékekből táplálkozik, forrása a normatív, azaz a társak teljesítményéhez és az ipszatív, avagy a saját korábbi teljesítményhez való viszonyítás (Bong és Skaalvik, 2003). Az önhatékonyság Bandura (1997) megfogalmazásában az egyén saját képességeibe vetett bizalma, illetve saját ítéletei azt illetően, mennyire képes megszervezni és végrehajtani bizonyos kitüzött teljesítmény eléréséhez szükséges cselekvéssorozatokat.

Az énkép és az önhatékonyság közötti különbség - az előbbi definíció alapján - elsősorban az, hogy míg előbbinél az egyénnek azzal kapcsolatban alakulnak ki meggyőződései, hogy milyen képességekkel, adottságokkal rendelkezik, addig utóbbinál az észlelések arra vonatkoznak, mit tehet az egyén ezekkel a képességekkel és adottságokkal az adott feladat megoldásakor adott kontextusban (Bong és Skaalvik, 2003). Az önhatékonyság az egyén előzetes értékeléseit tartalmazza azzal kapcsolatban, hogy milyen sikeres lesz az elötte álló feladat végzésében, ilyen értelemben inkább jövőorientált. Az énsémához köthető harmadik komponens, az észlelt kompetencia (perceived competence) az egyén önértékelő ítélete saját képességei fejlettségét illetően (Pintrich és Schunk, 1996). Bong és Skaalvik (2003) az észlelt kompetenciát az énkép központi elemének tekinti, minthogy ahhoz hasonlóan a saját képességfejlettségre vonatkozó meggyőződéseket tartalmazza, ugyanakkor az énképpel szemben feladatspecifikus. Az egyén észlelt kompetenciája magasnak mondható, ha úgy érzi, az adott feladat teljesítéséhez megfelelő képességekkel rendelkezik. Az észlelt kompetencia mindig valamely feladathoz kapcsolódóan és valamely képességekre vonatkoztatva értelmezhető. Jelenorientált, az adott teljesítményszituációban érvényesül. 


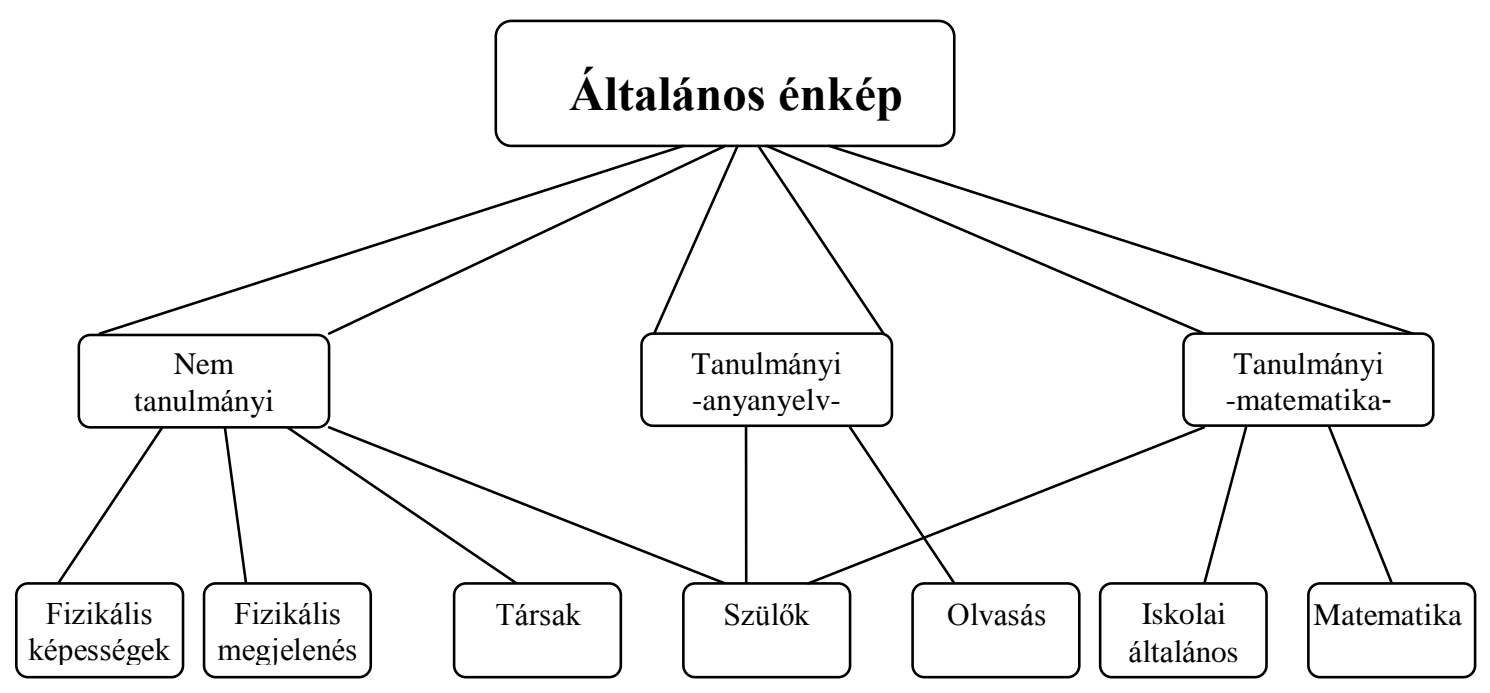

6. ábra

Az énkép hierarchikus, sokösszetevös modellje (Marsh, 1990)

Olvasási énkép. Az énkép struktúrájának pedagógiai szempontú, empirikus vizsgálatai (Józsa, 1999; Marsh, 1990; Szenczi és Józsa, 2008) rámutattak, hogy nem létezik egyetlen tanulási énkép, hanem több, egymástól viszonylag független tantárgy- és képességspecifikus énkép különböztethető meg, melyek csak lazábban kapcsolódnak egymáshoz. Ilyen képességspecifikus énképként értelmezhető az olvasási énkép is. Az énkép Marsh/Shavelson-féle sokösszetevős, hierarchikus modellje szerint (6. ábra) az olvasási énkép a tanulók saját olvasási készségeikkel, képességeikkel és érdeklődésükkel kapcsolatos értékeléseit foglalja magában (Marsh, 1993).

A tanulási motiváció alakulásában nagy szerepe van az elemi alapkészségek elsajátításának, az itt tapasztalt kudarcoknak és sikereknek. Chapman és Tunmer (2002) a tanulási énkép mint tanulási motívum alakulásában a korai olvasási énkép szerepét hangsúlyozzák. Állításuk szerint a gyermek azon siker- vagy kudarcélményei, melyeket az olvasástanulás kezdeti fázisában él át, központi szerepet fog kapni a tanulmányi énképében is. A korábbi tanulmányi énkép hatással van a későbbi teljesítményre (Guay, Marsh és Boivin, 2003; Marsh, 1990; Van Damme és munkatársai, 2004), a korai olvasási énkép így meghatározója lehet az iskolai sikerességnek (Chapman és Tunmer, 2002).

A PIRLS 2001-es és 2006-os felmérés szükebb értelemben, kifejezetten az olvasási képesség fejlődésében szerepet játszó egyik központi tényezőként vizsgálja az olvasási énképet (Kelly, 2003). Az eredmények az olvasási énkép és az olvasási teljesítmény között nem mutatnak egyértelmü kapcsolatot. Minden országban azok a tanulók, akik az énképskálán a legjobb egyharmadba kerültek, szignifikánsan jobb eredményekkel rendelkeznek, mint gyengébb énképpel rendelkező társaik. Ugyanakkor azoknak az országoknak a tanulói, akik jól teljesítettek az olvasásfeladatokon, nem feltétlenül rendelkeznek átlagosan jobb énképpel is, mint az átlagnál gyengébben teljesítő országok tanulói. A jelenség egyik lehetséges magyarázata, hogy az énkép alakulásában meghatározó szerepet tölt be a társas összehasonlítás és a másoktól kapott visszajelzések. Ez utóbbit bizonyítja, hogy az olvasási 
énképpel az olvasásteljesítmény csak gyenge, míg az olvasás/irodalom osztályzat jóval erősebb összefüggést mutat (Szenczi és Józsa, 2009).

Az énkép alapját képező észlelt kompetencia meghatározó szerepet tölt be a teljesítmény alakulásában már egészen kicsi gyermekeknél is (Harter és Pike, 1984). Az olvasásra vonatkozóan Ehrlich, Kurtz-Costes és Loridant (1993) azt állapította meg, hogy míg a gyengébb olvasók esetén az olvasási teljesítmény legjobb bejóslója a szófelismerés fejlettsége, addig azon tanulók esetében, akiknek olvasási képessége fejlettebb, a teljesítményt leginkább az olvasási észlelt kompetencia befolyásolja.

Olvasás önhatékonyság. Wilson és Trainin (2007) korai olvasási motiváció modelljében az olvasási önhatékonyság arra vonatkozik, hogy a tanuló saját megítélése szerint mennyire teljesítene jól egy-egy specifikus olvasási feladaton, például egy szó kibetűzésében. Guthrie, Hoa, Wigfield, Tonks, Humenick és Littles (2006) az olvasási önhatékonyságot ennél átfogóbban értelmezik, és az önhatékonyság fejlődésének egyik központi elemének a saját képességfejlettséggel és fejlődési lehetőségekkel kapcsolatos önértékeléseket tekintik.

Wilson és Trainin (2007) ugyanebben a modellben az irásbeliség területhez kapcsolódó észlelt kompetencián a gyermekek azzal kapcsolatos észleléseit értik, hogy milyen jól olvasnak, betüznek és írnak. Az olvasáshoz kapcsolódó észleltkompetencia-mérések olyan kérdéseket tartalmaznak, amelyek az iránt érdeklődnek, hogy a tanulók mennyire találtak egy-egy szöveget vagy az ahhoz kapcsolódó feladatokat nehéznek, illetve mennyiben érezték, hogy megfelelő erőfeszítések mellett képességeik elegendőek a feladat megoldásához (Kaplan és Midgley, 1997; Wilson és Trainin, 2007).

Chapman és Tunmer (2002) a kisgyermekkori sikerek és kudarcok hatására hívja fel a figyelmet az olvasástanulásban. Az első élmények, valamint a sikereknek és kudarcoknak tulajdonított okok végigkísérhetik a tanulót egész iskolai pályafutásán. Kutatások ugyanakkor arra is rámutatnak, hogy az iskolázás elején a tanulók még nehezen különböztetik meg az események bekövetkeztének különféle okait (Wilson és Trainin, 2007), ezek csak később válnak különálló kategóriákká. E folyamatban a tanárok visszajelzései nagy szerepet töltenek be, a külső vagy belső okok hangsúlyozása a sikerek vagy kudarcok magyarázatában a formális olvasástanítás korai szakaszában jó előrejelzője a későbbi olvasás iránti motiváltságnak (Natale, Viljaranta, Lerkkanen, Poikkeus és Nurmi, 2009).

\subsubsection{Az olvasásnak tulajdonított érték}

A motiváció elvárás-érték elmélete (expectancy-value theory; Eccles, Adler, Futterman, Goff, Kaczala, Meece és Midgley, 1983; Wigfield és Eccles, 2000) szerint az egyén motiváltsága a sikerre való esélyével és az általa a feladatnak tulajdonított fontossággal növekszik. Minél nagyobb esélyt látunk arra, hogy sikerrel teljesítsünk egy feladatot és minél nagyobb értéket tulajdonítunk annak a feladatnak, annál motiváltabbak leszünk a feladat végzésére. Azt, hogy mekkora esélyt látunk a sikerre, jó néhány, az előbbiekben említett motívum határozza meg. Ilyen például az önhatékonyság vagy az észlelt kompetencia. Az egyén által a feladatnak tulajdonított értéknek is több típusát határozhatjuk meg (Wigfield és Eccles, 2000). A gyakorlati érték (utility value vagy usefulness) az egyén szubjektív megítélése, hogy mennyire tartja hasznosnak egy adott feladat teljesítését vagy egy készség elsajátítását más feladatok teljesítésében (Eccles és munkatársai, 1983). Az például, hogy 
mennyire tartja hasznosnak és fontosnak valaki az olvasást az életben való boldoguláshoz, nagyban meghatározza, mennyi energiát kíván annak tanulásába és gyakorlásába fektetni. A teljesítményérték (attainment value vagy importance), azaz az egyén vélekedése arról, hogy mennyire fontos számára, hogy jól teljesítsen egy adott feladaton, hasonlóképp müködik. Ha fontos számára, hogy jól megtanuljon olvasni, hogy képes legyen a munkája során hatékonyan használni ezt a képességet, motiválttá teszi az olvasásra. Ha mindennek a tudásnak csak alacsony értéket tulajdonítunk, nem lesz számunkra fontos a tudáshoz vezető út sem (Wigfield és Eccles, 2000).

Anmarkrud és Braten (2009) az olvasási önhatékonyság és az olvasás értékének hatását vizsgálták a későbbi olvasási teljesítményre. Kutatásuk az elvárás-érték elmélettel szemben az olvasás értékének elsődleges szerepére utalnak az elvárásváltozókkal szemben a szövegértés fejlődésében. Eredményeik szerint míg az olvasásnak tulajdonított szubjektív érték jól megjósolja a későbbi szövegértés-teljesítményt, addig az önhatékonyságnak a szövegértésre nincs szignifikáns hatása. Durik, Vida és Eccles (2006) szintén az olvasásnak tulajdonított érték szerepét hangsúlyozza: longitudinális vizsgálatuk eredménye szerint a negyedik osztályos tanulók által az olvasásnak tulajdonított érték jó megjóslója a tanulók középiskolai óraválasztásával kapcsolatos döntéseinek.

\subsubsection{Olvasási célok}

Józsa (2007) szerint a gyermek céljai már egészen kisgyermekkortól kezdve tanulási motívumként müködhetnek, bár általában az egyén céljai ekkor még nem tudatosak. A tudatos célok általában erősebben befolyásolják a viselkedést, a nem tudatos célok is hatással lehetnek arra.

Meece és Miller (2001) longitudinális vizsgálatukban 3-5. évfolyamig vizsgálták az olvasással és írással kapcsolatos célorientáció stabilitását, abban az időszakban, mikor az egyén önálló olvasóvá válik. Az olvasási kultúrához kapcsolódó célorientáció ebben az életkori szakaszban viszonylag stabil, az alacsonyabban fejlett képességekkel rendelkező tanulók nagyobb valószínüséggel követtek teljesítménykereső személyes vagy teljesítménykerülő célokat, míg az olvasás és írás területén jobban teljesítő társaik inkább számoltak be teljesítménykereső elsajátítási célokról.

Olkinuora és Salonen (1992) nyomán Lepola (2000) különböző célorientációkat különböztetett meg az alapján, hogy milyen megküzdési stratégiákat alkalmaznak az egyének társas közegben történő tanulási helyzetekben. A feladatorientált (task-oriented) tanulók többnyire belsőleg motiváltak arra, hogy megközelítsék, felderítsék és elsajátítsák a környezet által kínált kihívással járó feladatokat. Ezzel szemben a szociálisfüggőségorientált tanulók elsősorban mások elismerését szeretnék megszerezni. Végül az énvédelem-orientált tanulók legföbb célja, hogy megvédjék saját énjüket a negatív érzések átélésétől. Az ilyen tanulók gyakran kerülik a kihívásokkal járó feladatokat, érzékenyek a társas környezet visszajelzéseire, azokat gyakran fenyegetőnek érzik. Első osztályos tanulók olvasási készségének fejlettségi vizsgálata rámutatott arra, hogy a kezdeti olvasási sikerességet a beszédhanghallás fejlettsége mellett a feladatorientáltság foka is szignifikánsan befolyásolja (Salonen, Lepola és Niemi, 1998). Azok a gyermekek, akik erős feladatorientáltságot mutattak iskoláskor előtt, az első évfolyamon jobban teljesítettek a szóolvasási feladatokban, mint azok, akik magasabb énvédő orientáltságot vagy szociális függőséget 
tanúsítottak iskoláskoruk előtt. A feladatorientált tanulók egyébként már iskoláskort megelőzően is a beszédhanghalló készség magasabb fejlettségét mutatják, mint nem feladatorientált társaik (Lepola, Salonen és Vauras, 2000).

\subsubsection{Az olvasás szociális motívumai}

A szociális motívumok az egyén szociális kompetenciájának részei (Nagy, 2000). A szociális kompetencia ,a szociális megismerés, a szociális motívumok és a szociális képességek, szokások, készségek, ismeretek komplex rendszere" (Zsolnai, 1998. 188.o.), amely hatással van többek között a tanulók iskolai teljesítményére és motivációjára is (Kasik, 2006; Zsolnai, 1998, 2008).

Wigfield és Guthrie (1997) a szociális motívumokat az olvasási motiváció területspecifikus motívumaiként definiálta. Az átfogó kategóriába mindazok a motívumok tartoznak, amelyek az olvasás eredményeként létrejövő jelentés másokkal történő megosztására vonatkoznak (Wigfield, Guthrie és McGough, 1996). Az olvasmányélmények megosztása, a közös jelentéskonstrukció vagy egy közösségbe való bekerülés jó motivátora lehet az olvasásnak, ugyanakkor nem tekinthetők területeken átívelő általános motívumoknak. Ha elolvasunk egy könyvet, arról diszkussziót folytathatunk azokkal, akik szintén olvasták, s ezen keresztül bekerülhetünk például az adott szerzőt vagy regényt olvasók közösségébe. Ugyanez ritkábban mondható el például egy matematikapélda megoldásáról vagy egy rajz elkészítéséről, amelyek nem tipikusan hoznak létre ilyen közös diszkusszióhoz alapot nyújtó élményt. Az olvasási motivációnak tehát feltételezhetően olyan komponensei ezek, amelyek szükebb értelemben kifejezetten az olvasásra érvényesek, tágabb értelemben pedig hasonlóak lehetnek más szabadidős vagy müvészeti tevékenységek például egy zenemủ meghallgatása vagy egy film megnézése - motivációs mechanizmusaihoz.

Ábrahám (2006) vizsgálatai alapján rendelkezünk hazai adatokkal az olvasás szociális motívumainak érvényesülési lehetőségeiről. Ábrahám 12-14 éves magyar tanulók olvasási szokásait vizsgálta, s azt találta, hogy 1977-től 2004-ig folyamatosan csökkent azoknak a gyermekeknek az aránya, akiknek lehetőségük nyílik olvasásélményeik megosztására. A vizsgált időszakaszban különösen nagyfokú esést mutat a kortársakkal és a szülőkkel való eszmecserék gyakorisága, de jelentősnek tekinthető az iskolai, pedagógussal folytatott beszélgetések számának csökkenése is.

\subsection{5. Érdeklődés az olvasás iránt, attitűdök}

Az érdekődés mint motívum egy olyan pszichológiai állapotként vagy prediszpozícióként írható le, amely arra készteti az egyént, hogy bizonyos jellemzőik alapján egy csoporthoz tartozó tárgyakban, eseményekben vagy ideákban újra és újra elmélyedjen (Hidi és Renninger, 2006). Az érdeklődés mindig valamely egyén és tartalom közötti interakció eredménye (Krapp, 2000), azaz csak és kizárólag tartalomspecifikusan létezik, nem értelmezhető tevékenységeken átívelően.

A neveléstudományi kutatások az érdeklődés két típusát különböztetik meg: a szituatív (situational) és az egyéni (individual) érdeklődést (Hidi, 1990; Krapp, 2000), amelyek az érdeklődés négyfázisü fejlődésmodellje értelmében felfoghatók fejlődési stádiu- 
moknak is (lásd 3.2.2.2 fejezet). A modellt az olvasásra vonatkoztatva, az olvasás iránti érdeklődés vizsgálható egyrészt bizonyos szövegekre aktuálisan vonatkoztatva szituatív érdeklődésként (Alexander, Jetton és Kulikovich, 1995), vagy általánosabban véve hosszú távú, bizonyos tartalmak, témák iránti egyéni érdeklődésként értelmezve (Schiefele, 1999). Azok a kutatások, amelyek az adott szövegek iránti aktuális érdeklődést tették vizsgálatuk tárgyává, a szöveg jellemzőire és a szövegtípusok különbségeire, míg az egyéni érdeklődést vizsgáló kutatások inkább az egyének közötti különbségekre fókuszáltak. A fejlődésmodell értelmében a rövid távú szituatív érdeklődés az olvasás iránt megfelelö körülmények között hosszú távú egyéni érdeklődéssé (Hidi és Renninger, 2006), majd pedig hosszú távú (olvasási) motiváltsággá fejlődhet (Guthrie, Hoa, Wigfield, Tonks és Perencevich, 2006). Ehhez azonban a szövegtípusok és az egyének közötti érdeklődésbeli különbségekre egyaránt fókuszálni kell.

Az olvasás iránti érdeklődés és a teljesítmény kapcsolatát illetően Schiefele (1992) rámutatott, hogy azok a tanulók, akik magas fokú érdeklődésről számoltak be egy tevékenység iránt, gyakrabban számoltak be a koncentráció magasabb szintjéről, a feladatban való elmerülésről, mint a tevékenység iránt alacsonyabb érdeklődést mutató társaik. Továbbá az olvasás közben magas fokú érdeklődést mutató tanulók a beleélés-bevonódás, az élvezet és a stimuláltság magasabb fokát is mutatják (Renninger, 2000). Azok az egyének, akik az olvasott szöveg iránt érdeklődnek, könnyebben idézik fel az olvasottakat, mint érdeklődést nem mutató társaik (Renninger, 1992). Az érdeklődés a mennyiségi mutatókon túl a minőségi mutatókra is hatással van: a szövegek mélyebb feldolgozását (deep processing) (Schiefele, 1999), a szövegértés magasabb szintjét igénylő kérdések megválaszolását és a tudásszerveződést is elősegíti (Schiefele és Krapp, 1996).

A kutatók az érdeklődés alapjaiként említik egyrészről az öröklött alapú kíváncsiságot másrészröl pedig a tanult attitüdöket, értékelő viszonyulásokat. Nagy (2000, 140. o.) meghatározása szerint az érdeklődés ,,a kíváncsiság öröklött motívumát valamely dologra specifikáló tanult motívum, a vonatkozó ismeretekbe beépült attraktív attitüdrendszer, amely a dolog további megismerésére késztet”. Érdeklődés csak olyan dolog iránt alakulhat ki, amelyről van ismeretünk, és ezek alapján vonzónak tartjuk azt, azaz pozitív attitüdökkel rendelkezünk iránta.

Az attitüdök értelmezhetők úgy, mint egyfajta kedveltségérzés, egy kontinuum melynek két végpontja az abszolút pozitív és az abszolút negatív (Thurstone, 1928 idézi McKenna, 2001). Alexander és Filler (1976) az olvasásspecifikus attitüdöket úgy definiálta, mint ,az olvasásra vonatkozó érzések rendszere, amelyek az olvasási szituáció megközelítésére vagy elkerülésére késztetik az egyént" (Alexander és Filler, 1976, 1. o.). McKenna (2001) az attitüdök szakirodalomban fellelhető definícióinak áttekintésekor ezzel szemben hangsúlyozza, hogy az attitüdök a legtöbb definíció szerint affektív természetüek, ugyanakkor kognitív komponenseket is tartalmaznak. Alexander és Filler (1976) meghatározásával ellentétben kiemeli, hogy az attitüdök, bár elöfutárai a viselkedésnek, önmagukban nem indukálnak viselkedést (McKenna, 2001). Az olvasás iránti attitüdöknek két fajtáját szokták megkülönböztetni az olvasás funkciója szerint: a rekreációs célú és a tanulási célú olvasás iránti attitüdöt (McKenna és Kerr, 1990). 


\subsubsection{Az olvasás mint flow tevékenység}

A Csíkszentmihályi (1991) által definiált flow vagy áramlatélmény nem egyetlen motívum, hanem egy olyan pszichológiai állapot, amely több dimenzió, több motívum együttes müködésének eredményeként jöhet létre, és amely maga is motivátora lehet bizonyos tevékenységeknek. A flow élmény 1.2. fejezetben említett nyolc eleme közül több is átfedést mutat az olvasásban szerepet játszó eddig említett motívumokkal. A flow élmény feltétele, hogy a tevékenység végzése közben mindig világos, hogy mit kell tenni, úgy érezzük, maguk kontrolláljuk az eseményeket. Ez magas önhatékonyságra utal. Mindig világosan látható a cél, melynek elérésére folyamatosan törekszünk. Ez a célorientáltsággal van összhangban. Végül a feladatra való teljes összpontosítás, az olvasásban való elmélyüléssel mutat közös elemeket.

Az áramlatélmény feltétele, hogy a végzendő tevékenység vagy feladat az optimális kihívást biztosítsa. Ehhez a feladat nehézsége és a feladatvégző képességei egyensúlyban kell, hogy legyenek. Ha ez a feltétel teljesül, a tevékenységet végzö egyén észlelt kompetenciája magas lesz (Csíkszentmihályi, 1991). Az olvasástanulás során a kihívást fejlett szövegértés hiányában az olvasási feladat leküzdése jelenti. Később, mikor már a szövegértés fejlettsége olyan szinten áll, hogy a szöveg dekódolása és értelmezése nem okoz problémát, a kihívást az adott olvasási tevékenység célja, motivátora, azaz az élményszerzés, az információkeresés vagy a tudásszerzés adja. Ilyenkor az olvasási tevékenység mindaddig tart, amíg a kívánt célt el nem érjük, és a kihívás meg nem szünik, azaz amíg például a regény végére nem érünk, a kívánt információt meg nem találjuk, vagy az adott ismerethalmazt el nem sajátítjuk.

Az áramlatélmény az élet számos területén megjelenhet, a leggyakrabban idézett kutatások a munkavégzés (Csíkszentmihályi, 1991), a sport (Jackson és Csíkszentmihályi, 1999), a zene (Janurik, 2007, 2009), és legújabban az internethasználat (Chen, 2006) területét érintik. Csikszentmihályi (1991) az olvasást az áramlatélmény egyik legfontosabb forrásaként említi. Azonban az olvasás közben átélt tökéletes élmény vizsgálatára ezidáig csak kevés empirikus vizsgálat irányult (lásd például McQuillan és Conde, 1996).

\subsection{A motívumok változása, fejlődése}

Harter (1990) gyermekek tanulási énképfejlődése kapcsán azt feltételezte, hogy az iskoláskor kezdetén a gyermekeknek csupán egy általános benyomásuk van arról, hogy ök épp okosak vagy buták, és ez a kép az évek folyamán fog fokozatosan differenciálódni, területspecifikussá válni. Eccles és munkatársai (1993) vizsgálatai ugyanakkor már első osztályos tanulók esetében az elvárás motívumok területspecifikus jellegére mutattak rá. Vizsgálatuk eredményei szerint a gyermekek sikerelvárásai a matematika, az olvasás, a zene és a sportok esetében jól elkülönültek, azaz gyakran tartották saját képességeiket jónak egy területen, míg kevésbé jónak egy másikon. Hasonló eredményekre jutott Marsh, Craven és Debus (1991) is fiatal gyermekek énképének vizsgálatakor: a tanulók énképe nagyfokú differenciáltságot mutatott az egyes teljesítményterületek szerint.

A területspecifikusság mellett a motívumok differenciálódása is viszonylag korán megtörténik: már a hatéves gyermekek is különbséget tesznek a saját képességeikkel kapcsolatos meggyőződéseik és a feladatnak tulajdonított szubjektív érték, fontosság között 
(Eccles és munkatársai, 1993). Azonban az önhatékonyság és az énkép elkülönülése viszonylag későbbre tehetö (Wigfield és Eccles, 2000).

A motívumrendszer struktúrája, a motívumok differenciálódása és egymáshoz való viszonyuk változása mellett a motívumok alakulásának mutatója az évek folyamán növekedésük vagy csökkenésük. A tanulási motiváció kutatásai általánosságban az iskolai évek folyamán a motiváció csökkenéséről számolnak be (Jacobs, Lanza, Osgood, Eccles és Wigfield, 2002; Józsa, 2002). Összességében véve a tanulók saját képességeikkel kapcsolatos meggyőződéseik és az általuk a tanulásnak tulajdonított érték sok szempontból negatívabbá válik a kisiskolás- és a serdülőkor időszakában (Wigfield és Eccles, 2000). Az általános csökkenés nagyságában mélypontot jelent az alsó tagozatból a felső tagozatba kerülés időszaka. Anderman és Midgley (1997) a felső tagozatba (middle school) kerülés hatásait vizsgálta az elsajátítási célokra és a tanulási énképre. Eredményeik szerint ugyanazon tanulók az alsó tagozatban (elementary school) erőteljesebb elsajátítási célokkal rendelkeztek és sokkal kompetensebbnek érezték magukat, mint felső tagozatos korukban. Ezzel összhangban a felső tagozaton a teljesítménycélok a társas összehasonlítás erőteljesebb érvényesüléséről számoltak be. Schunk és Meece (2006) szerint a felső tagozatba kerülés az iskolai feltételrendszer olyan szintü megváltozásával jár, ami a tanulók motívumaira, különösen a saját képességészleleteikre, negatív hatással van. Az alsó tagozaton az osztálytanítók a gyermekeket jól ismerik és több éven keresztül nyomon követik fejlödésüket. Az egyes gyermekek sok figyelmet kapnak, és gyakran hangsúlyozzák egyéni fejlődésüket. Mindezzel szemben a felső tagozaton a tanárok váltják egymást a különböző tantárgyak tanításában, az értékelés normatívvá válik és az egyénre egyre kevesebb figyelem irányul. Ezt a feltételezést támasztja alá Józsa és Fazekasné (2007) kutatási eredménye is, miszerint a tanulási motiváció többségi tanulók esetében az ötödik osztálytól kezdve nagymértékü visszaesést mutat, amely esés viszont nem mutatkozik meg a külön intézményekben oktatott tanulásban akadályozott tanulóknál.

Az olvasás motívumait illetően McKenna, Kear és Ellsworth (1995) az olvasás iránti attitüdök csökkenésére hívta fel a figyelmet. Több mint 18000 tanulóval végzett kérdőíves felmérésük adatai szerint a tanulók meglehetősen pozitív attitüdökkel rendelkeznek mind a szabadidős, mind a tanulási célú olvasás iránt az iskola első éveiben. Azonban az első hat év folyamán számottevő romlás megy végbe. A negatív attitüdök szoros összefüggést mutattak a teljesítménnyel: a gyengébben olvasó tanulók attitűdjei szignifikánsan erőteljesebb csökkenést mutattak a jó olvasókénál. Wigfield és Guthrie (1997) az olvasási önhatékonyság, a beleélés és a szociális motívumok esetén talált hasonló csökkenést az iskolai évek alatt.

\subsection{Az olvasási motiváció mérése, mérőeszközök}

Az olvasási motivációt egyetlen, mindenki által elfogadott modell hiányában a szakirodalomban általában kétféle módon vizsgálják. Léteznek a már említett egymotívumos vizsgálatok, amelyek a tanulási motiváció elméletében megalapozott egy-egy motívumot vizsgálnak az olvasás területére - és gyakran egyidejüleg más területekre, például a matematikára - vonatkozóan. Ezekben a kutatásokban a mérőeszközök olvasási motivációt mérő skálái valamely tanulási motiváció mérőeszköz olvasásra adaptált skálái, lásd például Meece és Miller (2001) olvasási célorientáció skáláját. Egy másik kategóriába sorolhatók azok a szintén egymotívumos kutatások, amelyek egy tanulási motívum területspecifikus jellegé- 
nek felismerése nyomán jöttek létre. E kutatásokban az olvasási motívum egy területspecifikus tanulási motívum, mérése az adott tanulási motívum méröeszközének egy alskáláját alkotja, lásd például Marsh (1993) énképet vizsgáló Self-Description Questionnaire mérőeszközének olvasás énkép alskáláját.

Az olvasási motiváció mérésének harmadik típusát a többmotívumos vizsgálatok adják, amelyek alapja mindig az olvasási motiváció valamely sokösszetevős modellje. Az olvasási motiváció mint komplex és önálló konstruktum mérése leggyakrabban kérdőíves módszerrel történik, de találunk példát a szakirodalomban interjúmódszerrel történő vizsgálatokra is. A mérőeszközök felépítése, skálái megfelelnek a kutatás hátterében álló olvasásimotiváció-modell által tárgyalt motívumokkal. A tanulási motiváció kutatásai által feltárt területspecifikus motívumok mellett e mérőeszközök skálái között gyakran találhatunk kifejezetten az olvasási tevékenységre vonatkozó motívumokat vizsgáló skálákat. A nemzetközi és a hazai szakirodalomban fellelhető ilyen típusú mérőeszközök listáját, a szerzők nevével és az általuk vizsgált motívumok felsorolásával a 2. táblázat tartalmazza.

Gambrell, Palmer, Codling és Mazzoni (1996) Motivation to Read Profile méröeszköze az olvasási énképet, az olvasásnak tulajdonított értéket és az olvasás funkcióit vizsgálja. Az értéket és az énképet vizsgáló kérdőívet kiegészíti egy egyéni interjú, mely az olvasási szokásokra kérdez rá különböző kontextusok és szövegtípusok esetében. Hatékony eszköz lehet a tanárok kezében a tanulók olvasási motiváltságának megismerésére tantermi kontextusban, kutatási célra azonban kevéssé alkalmas (van Kraayenoord és Schneider, 1999). Wigfield és Guthrie (1997) Motivations for Reading Questionnaire elnevezésü kérdőíve az olvasási motiváció legelterjedtebb mérőeszköze. A kérdőív 1995-ben publikált első változata egy 82 tételből állő önkitöltéses tanulói kérdőív, melyet 1997-ben a szerzők tanulókkal folytatott interjúk és a tanulási motiváció kutatások eredményeinek alapján 1997-ben átdolgoztak. Az így létrejött 53 kérdőívtételből álló mérőeszköz 11 alskálával rendelkezik, amelyek egy-egy olvasási motívumnak feleltethetők meg. A skálák reliabilitása több esetben meglehetősen alacsonyak: 0,43-0,81 között mozognak. A szerzök által végzett validitásvizsgálatok alátámasztották az eredeti struktúrát (Wigfield és Guthrie, 1997), a későbbi vizsgálatok azonban számos validitásproblémára mutattak rá (Watkins és Coffey, 2004).

Guthrie, Taboada és Coddington (2007) Reading Engagement Index mérőeszköze egy nyolc tételből álló tanári kérdőív, melynek segítségével az osztálytanító a tanulói olvasás iránti elköteleződését értékeli. A kérdőív a motiváltság mellett az elkötelezett olvasás kognitív és viselkedéses elemeire vonatkozó tételeket is tartalmaz. Az olvasási motiváció három aspektusát vizsgálja: az intrinzik motivációt, az önhatékonyságot és a szociális motívumokat. A kérdőív megbízhatósága Wigfield, Guthrie, Perencevich, Taboada, Klauda, McRae és Barbosa (2008) 4. évfolyamos tanulókkal végzett vizsgálatában 0,89.

Az iskola kezdő szakaszában az olvasási motívumok vizsgálatának egyik módja az interjúmódszer vagy a strukturált interjúk keretében felvett kérdőíves módszer. Wilson és Trainin (2007) Early Literacy Motivation Survey elnevezésű mérőeszköze egy kérdőív, amelyet strukturált interjúk formájában vettek fel első évfolyamos tanulókkal. Az olvasási - és emellett az írás és a helyesírás területéhez kapcsolódó - motiváció három komponensét vizsgálja: az észlelt kompetenciát, a sikerek és kudarcok attribúcióit és az önhatékonyságot. Míg előbbi két motívum esetében a kérdések területspecifikusak, azaz vagy az írás vagy az olvasás területére vonatkoznak, az önhatékonyságra vonatkozó kérdések feladatspecifikusak, azaz egy adott feladat megoldására vonatkozó meggyőződéseket vizs- 
gálják. Guthrie, Hoa, Wigfield, Tonks, Humenick és Littles (2006) szintén interjúmódszerrel dolgozott, azonban céljuk elsősorban az olvasás iránti motiváció komponenseinek felderítése volt, így félig strukturált interjúkat készítettek negyedik osztályos tanulókkal. Az interjúk elemzése során az olvasási motiváció öt komponensét azonosították.

Hornery, Craven, Yeung és Ali (2008) célja egy olyan mérőeszköz fejlesztése volt, amely az olvasási motiváció egyszerre több dimenzióját vizsgálja. A mérőeszköz hátterében álló olvasási motiváció modell a célorientációs elmélet által tárgyalt konstruktumokat veszi számba. Az olvasási célorientációs kérdőív alskálái az elsajátítási célok, az intrinzik célok, a versengés, a kooperáció és az egyéni célok. A Young Reader Motivation Questionnaire (Coddington és Guthrie, 2009) az elöbb felsorolt mérőeszközöktöl annyiban különbözik, hogy a kérdöív tanulói változata mellett elkészítették a tanári változatot is, amelynek segítségével a tanító egyénileg értékelheti diákjainak olvasás iránti motiváltságát. A mindössze tizenkét kérdőívtételt tartalmazó tanulói kérdőív és a tizenöt tételből álló tanári mérőeszköz az olvasási motiváció három komponensét vizsgálja: önhatékonyság, olvasás (feladat-) orientáció és észlelt nehézségek. 
2. táblázat. Az olvasási motiváció mérőeszközei

\begin{tabular}{|c|c|c|c|c|}
\hline Szerzö & Méröeszköz & Vizsgált motívumok & Életkori populáció & $\begin{array}{c}\text { Megbizhatóság } \\
\text { (Cronbach- } \alpha)\end{array}$ \\
\hline $\begin{array}{l}\text { Gambrell, Palmer, } \\
\text { Codling és Mazzoni } \\
\text { (1996) }\end{array}$ & $\begin{array}{l}\text { Motivation to } \\
\text { Read Profile (MRP) } \\
\text { tanulói kérdőív, interjú }\end{array}$ & $\begin{array}{l}\text { énkép } \\
\text { olvasás értéke } \\
\text { olvasás funkciói }\end{array}$ & $\begin{array}{l}\text { általános iskola } \\
\text { 3. és } 5 \text {. évfolyam }\end{array}$ & $0,70-0,76$ \\
\hline Wigfield és Guthrie (1997) & $\begin{array}{l}\text { Motivations for } \\
\text { Reading Questionnaire (MRQ) } \\
\text { tanulói kérdöív }\end{array}$ & $\begin{array}{l}\text { önhatékonyság } \\
\text { kihívás } \\
\text { teljesítménykerülés } \\
\text { kíváncsiság } \\
\text { beleélés } \\
\text { olvasás értéke } \\
\text { elismerés } \\
\text { osztályzatok } \\
\text { versengés } \\
\text { szociális motívumok } \\
\text { megfelelés másoknak }\end{array}$ & $\begin{array}{l}\text { általános iskola } \\
\text { 3-8. évfolyam }\end{array}$ & $0,43-0,81$ \\
\hline $\begin{array}{l}\text { Guthrie, Taboada } \\
\text { és Coddington (2007) }\end{array}$ & $\begin{array}{l}\text { Reading Engagement } \\
\text { Index (REI) } \\
\text { tanári kérdőív }\end{array}$ & $\begin{array}{l}\text { intrinzik motiváció } \\
\text { önhatékonyság } \\
\text { szociális motívumok }\end{array}$ & $\begin{array}{l}\text { általános iskola } \\
\text { 4. évfolyam }\end{array}$ & \\
\hline Wilson és Trainin (2007) & $\begin{array}{l}\text { Early Literacy Motivation Survey (ELMS) } \\
\text { strukturált interjú }\end{array}$ & $\begin{array}{l}\text { észlelt kompetencia } \\
\text { önhatékonyság } \\
\text { attribúciók }\end{array}$ & általános iskola kezdete & \\
\hline $\begin{array}{l}\text { Guthrie, Hoa, Wigfield, } \\
\text { Tonks, Humenick és } \\
\text { Littles (2007) }\end{array}$ & (interjúmódszer) & $\begin{array}{l}\text { érdeklődés } \\
\text { észlelt kontroll } \\
\text { kollaboráció } \\
\text { önhatékonyság } \\
\text { beleélés }\end{array}$ & $\begin{array}{l}\text { általános iskola } \\
\text { 4. évfolyam }\end{array}$ & - \\
\hline $\begin{array}{l}\text { Hornery, Craven, Yeung és Ali } \\
\text { (2008) }\end{array}$ & $\begin{array}{l}\text { Reading Motivation } \\
\text { Questionnaire (RMQ) }\end{array}$ & $\begin{array}{l}\text { elsajátítási célok } \\
\text { intrinzik célok } \\
\text { versengés } \\
\text { egyéni célok } \\
\text { együttmüködés }\end{array}$ & $\begin{array}{l}\text { óvodától általános iskola } \\
\text { 6. évfolyamig }\end{array}$ & $0,74-0,92$ \\
\hline Coddington és Guthrie (2009) & $\begin{array}{l}\text { Young Reader Motivation Questionnaire } \\
\text { (YRMQ) tanulói és tanári kérdőív }\end{array}$ & $\begin{array}{l}\text { önhatékonyság } \\
\text { olvasási orientáció } \\
\text { észlelt nehézségek }\end{array}$ & $\begin{array}{l}\text { általános iskola } \\
\text { 1. évfolyam }\end{array}$ & 0,70 \\
\hline
\end{tabular}




\subsection{A motívumok fejlődését és működését befolyásoló tényezők}

\subsubsection{A tárgyi és a szociális kontextus szerepe}

Az írásbeliség szociokulturális megközelítése (Salomons és Perkins, 1998) szerint az olvasás mindig szociális közegben zajló tevékenység, ezáltal egy bizonyos helyhez, idöhöz és miliőhöz kötött. Az olvasás két nyilvánvaló kontextusa: az iskolai és az iskolán kívüli (otthoni vagy szabadidős) olvasás (Guthrie és Cox, 2001). Mind a két terület a társadalmi és közösségi kontextus része (Kelly, 2003; 7. ábra).

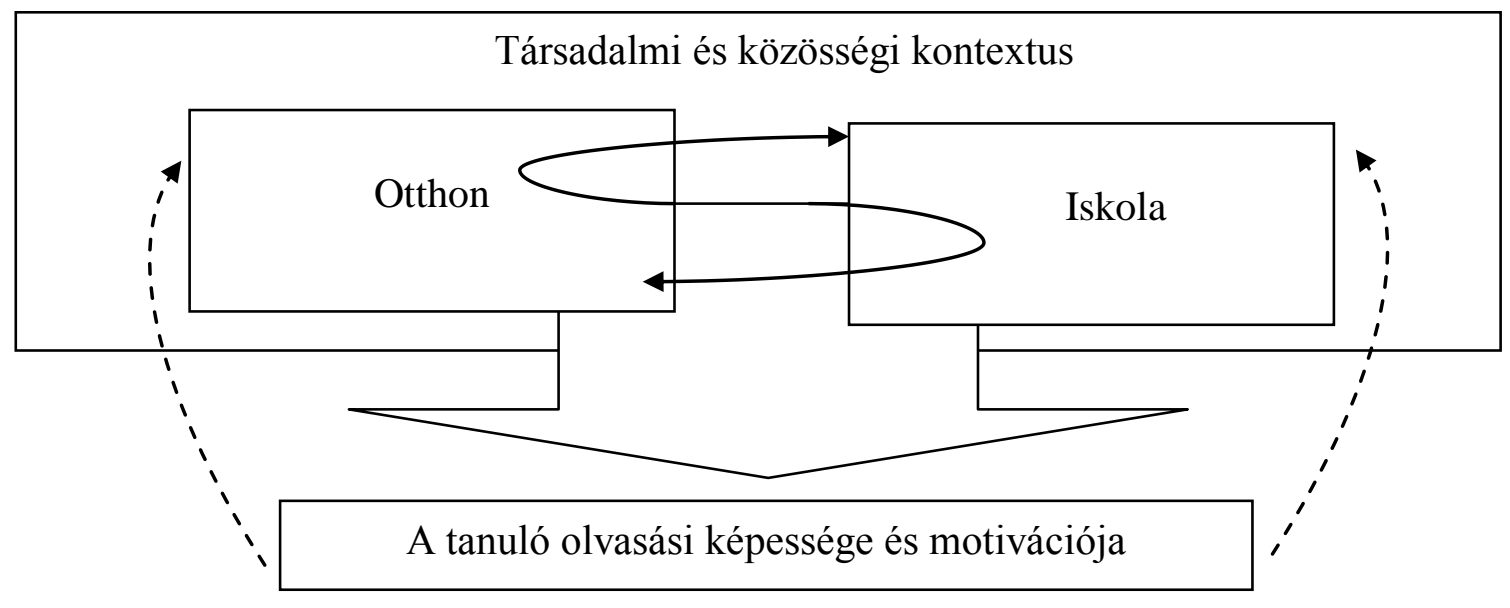

7. ábra

Az olvasási képesség és motiváció fejlödésének kontextusai (Kelly, 2003 alapján)

A különböző közegben felnevelkedett tanulók eltérő mennyiségü és minőségü tapasztalatot szereznek az olvasás és az írásbeliség értékére vonatkozóan. Az olvasás különböző kontextusai mind tartalmaznak olyan elemeket, amelyek alapjaiban meghatározhatják a tanulók olvasási képességfejlődésének affektív hátterét. A kontextusok elemeinek kiterjedt leírását adja Kelly (2003), melyet Wang és Guthrie (2004) munkája alapján egészítettünk ki (3. táblázat).

3. táblázat. A társadalmi és közösségi, az otthoni és az iskolai kontextusok hatótényezői (Kelly, 2003 alapján)

\begin{tabular}{|c|c|c|}
\hline Társadalmi és közösségi kontextus & Otthoni kontextus & Iskolai kontextus \\
\hline $\begin{array}{l}\text { demográfiai és gazdasági } \\
\text { jellemzők }\end{array}$ & $\begin{array}{l}\text { az olvasási képesség fejlesztését } \\
\text { elősegítő tevékenységek }\end{array}$ & iskolai környezet és források \\
\hline az oktatási rendszer szerkezetének & otthoni nyelvhasználat & $\begin{array}{l}\text { tanárképzés és a tanárok felké- } \\
\text { szültsége }\end{array}$ \\
\hline \multirow{3}{*}{$\begin{array}{l}\text { tantervi és törvényi jellemzők; } \\
\text { kulturális sajátosságok }\end{array}$} & otthoni források & $\begin{array}{l}\text { osztálytermi környezet és az osz- } \\
\text { tály struktúrája }\end{array}$ \\
\hline & $\begin{array}{l}\text { a tanulók iskolán kívüli olvasási } \\
\text { tevékenysége }\end{array}$ & $\begin{array}{l}\text { oktatási stratégiák és } \\
\text { tevékenységek }\end{array}$ \\
\hline & a szülők elvárásai & $\begin{array}{l}\text { oktatási segédanyagok, taneszkö- } \\
\text { zök és technológiák }\end{array}$ \\
\hline
\end{tabular}




\subsubsection{Társadalmi és közösségi kontextus}

Egy ország demográfiai és gazdasági jellemzői elsősorban a források elérhetőségének biztositása szempontjából vizsgálandó az olvasási motiváció szempontjából. Az elérhető források mennyisége és az olvasás gyakorisága között pozitív összefüggés áll fenn (McQuillan és $A u, 2001$ ). Számos különbség fedezhető fel továbbá egy-egy kultúra olvasáshoz való viszonyát illetően is. Az olvasás makroszintủ értéke, az adott kultúra által elfogadott kánon, az értékesnek és kevésbé értékesnek titulált szövegek jellemzői szintén hatással lehetnek az egyén olvasási motivációjának alakulására (Wang és Guthrie, 2004).

Az adott ország oktatási rendszerének szerkezeti és irányítási jellemzői, illetve az oktatás-nevelés céljait és tartalmát meghatározó dokumentumokban leírtak szintén információt hordozhatnak az olvasási motiváció vizsgálatát illetően. A tanulók motiváltságát nagymértékben befolyásolják iskolai tapasztalataik (Stipek, 2002). Azokban az országokban, iskolákban, ahol tanterv szerint a tantárgyak jól elkülöníthetöek és az olvasási képesség fejlesztése elsősorban külön tanórákon, külön tantárgy keretében történik, a tanulók olvasási motivációja inkább elhatárolható, területspecifikus lesz, mint azokon a helyeken, ahol az olvasási képesség fejlesztése más tantárgyak kereteibe integrálódik (Wigfield, Guthrie, Tonks és Perencevich, 2004). Az olvasási képesség, az olvasás iránti attitüdök és az olvasáshoz kapcsolható motívumok fejlesztésének hangsúlyossága, az ajánlott stratégiák és módszerek, az olvasástanítás szervezeti keretei szintén befolyásoló tényezők (Kelly, 2003).

Hazánkban az olvasási képesség fejlesztésére irányuló törekvések az iskolában nem válnak el az irodalomtanítástól, az olvasásfejlesztés nagyrészt irodalom órán történik. Az olvasástanításban kitüntetett szerepe van bizonyos szövegtípusoknak és müfajoknak, az olvasás iránti motiváltságot így gyakran azonosítják bizonyos kanonizált tartalmak iránti attitüddel, viszonyulással. A NAT (2007) lehetőséget biztosított az olvasási képesség tantárgyakon átívelö fejlesztésére, mely az olvasástanításban a multi- és interdiszciplináris megközelítést erősítette. A megközelítés előtérbe kerülésével a tanulók élethez közelibb szituációkban és életszerủ célok elérése érdekében változatos szövegeket olvashatnának, ami az olvasás tartalomtól független motívumait erösíthetné. A jelenleg rendelkezésünkre álló NAT (2012) vitaanyagában ezzel szemben ismét egy erőteljesebben tartalomközpontú, az olvasástanítást az irodalom-, esetleg a társadalomtudományok, tanításához kötő szemlélet érvényesül.

\subsubsection{Otthoni kontextus}

Az otthoni kontextus egyik meghatározó eleme az otthoni olvasási tevékenység és az olvasási képesség fejlesztésére irányuló olyan törekvések, például a szülők és a gyermekek közös olvasási tevékenysége vagy a gyermekeknek való felolvasás. A gyermekek első találkozása az írott szövegekkel meghatározó lehet a későbbi olvasási motiváció alakulásában (Baker és Scher, 2002; Baker, Scher és Mackler, 1997). Sonnenschein és Munsterman (2002) ötéves gyermekek és szüleik otthoni együttolvasási szokásait vizsgálva azt találták, hogy a gyermekek írott szövegekkel való találkozásának gyakorisága összefüggést mutat a későbbi olvasásiképesség-fejlettségükkel, ugyanakkor nincs hatással olvasás iránti motiváltságukra. Az olvasás iránti motiváltságot inkább az olvasási tevékenységet követő, illet- 
ve kísérő interakciók affektív jellege befolyásolja (Sonnenschein és Munsterman, 2002). Azon szülők gyermekei, akik az olvasás élményszerző jellegét hangsúlyozzák, szemben a képességfejlesztéssel (Baker, Scher és Mackler, 1997), illetve akik az olvasott szöveg tartalmához füznek kommentárokat a gyermekkel való közös olvasás alkalmával (Sonnenschein és Musterman, 2002), az olvasási motiváltság magasabb fokát mutatták.

A szülők iskolai végzettsége, olvasással és iskolával kapcsolatos attitüdjei szintén befolyásolják a tanulók olvasás iránti motivációját. Az olvasás iránti motiváltsággal erős, pozitív összefüggést mutat a szülők érdeklődése az olvasás iránt, illetve az általuk végzett élményszerző olvasás mennyisége (Baker és Scher, 2002).

Az otthoni kontextus egy meghatározó indikátora a hátrányos helyzet. Fejes és Józsa $(2005,2007)$ anyagilag, érzelmileg és nyelvileg hátrányos és nem hátrányos helyzetủ tanulók tanulási motivációjának összehasonlításakor az olvasási énképet külön változóként vizsgálták. A három fenti szempont bármelyike alapján hátrányos helyzetü és nem hátrányos helyzetü tanulók olvasás énképe között szignifikáns különbséget mutattak ki. Mindhárom esetben a hátrányos helyzetü tanulók olvasási énképe mutatkozott alacsonyabbnak többségi társaikénál.

\subsubsection{Az iskola előtti intézményes fejlesztés kontextusa}

Az olvasás kognitív és affektív tényezői egymással kölcsönhatásban fejlődnek már az iskolázás kezdete előtt (Salonen, Lepola és Niemi, 1998). Az iskolai olvasástanítás megkezdése elötti fejlesztés kontextusa, a megvalósító intézményi környezet, a felhasznált módszerek és eszközök szintén hatótényezői lehetnek az olvasási motiváció alakulásának, csakúgy, mint az olvasási képesség alapkészségeinek (Nolen, 2001).

Az olvasás előkészítésének egyik megközelítése, a bontakozó írásbeliség (emergent literacy) elmélete szerint a gyermek írásbeliségének fejlődése már születésekor elkezdődik azáltal, hogy folyamatosan találkozik környezetében azzal (Crawford, 1995). Az iskola elötti fejlesztés elsődleges feladata így a gazdag nyelvi és írásos környezet biztosítása, amely akár a hátrányos szociokulturális hátteret is kompenzálhatja az olvasás fejlődésében (Neuman, 1999). A megközelítés a bontakozó írásbeliség korszakának azt a születéstől egészen a formális és tudatos olvasástanítás megkezdéséig tartó időszakot nevezi, melynek során a gyermek spontán módon az írásbeliséggel való találkozásai folyamán bizonyos attitüdöket, érdeklődést és meggyőződéseket alakít ki az olvasás iránt. A bontakozó írásbeliséget figyelembe vevő, programjában arra építő óvodák a gyermekek olvasás iránti természetes kíváncsiságára építenek, és lehetővé teszik számukra e kíváncsiság önálló vagy társas kielégítését. Az ilyen intézmények csoportszobáiban gyakoriak a könyvtársarkok, mesesarkok, sőt, a mindennapi játékba is beépül az írásbeliség (Szinger, 2007).

Az írásbeliség előkészítésének másik szemléletmódja a kiváráson alapul, és elsősorban az olvasási képesség fejlődésének alapfeltételeit képező részkészségek (reading readiness skills), például a fonématudatosság fejlesztését célozza meg (Szinger, 2007). A pusztán a készség- és képességfejlesztésre, a formális olvasástanítás előkészítésére épülö programok inkább az olvasás mint tevékenységhez kapcsolódó ismeretekkel és készségekkel látják el a gyermeket, mintsem magával a tevékenység megismertetésével. Az olvasáshoz szükséges készségek fejlesztése alapvető fontosságú és nélkülözhetetlen az olvasási képesség későbbi fejlődéséhez (lásd például Adamikné, 1993; Fazekasné, 2000, 2006), az 
olvasás iránti motiváltság szempontjából a bontakozó írásbeliség megközelítés olvasásra szocializáló és természetes kíváncsiságra építő elemeinek integrálása kiemelkedő fontosságú lehet.

A két megközelítés integrálását kísérli meg a DIFER (Diagnosztikus Fejlődésvizsgáló Rendszer) Programcsomag mesékre épülő anyanyelvfejlesztő programja (Nyitrai, 2009). A 4-8 éves gyermekek számára kidolgozott program a gondolkodási, verbális és szociális képességek fejlesztését célozza meg, tartalmi hátterét pedig mesék adják. A szövegértést megalapozó készségek fejlesztése egyidejüleg történik az írásbeliségbe való bevezetéssel, méghozzá a gyermek számára vonzó írásos anyagokon keresztül.

\subsubsection{Az iskolai fejlesztés kontextusa}

Az olvasás elsajátításának formális kereteit az iskolai adja. Az iskolai kontextus bizonyos jellemzői feltételezhetőleg hozzájárulnak a tanulók olvasási motivációjának alakításán keresztül az olvasás elsajátításának sikerességéhez (Kelly, 2003).

Az iskolai olvasástanítás módszertanában hazánkban is sokáig kiemelt jelentőségü dilemmának számított a szóképes (globális) vagy a szintetikus (összerakó) módszer alkalmazása (Gósy, 2005). A két módszer két merőben eltérő olvasáspszichológiai felfogásból eredeztethető, amely felfogások motivációs szempontból is alapvető feltételbeli különbségeket teremtenek a tanulók számára. A szóképes olvasástanítás hagyománya az olvasás azon felfogására vezethető vissza, amely az olvasási folyamat és a nyelv elsajátítása között nem tesz lényegi különbséget. A Kenneth Goodman nevével fémjelzett irányzat hirdetői szerint az olvasás nem más, mint pszicholingvisztikai kitalálósjáték, amikor is az olvasó megpróbálja kitalálni az író szándékát. E felfogásban az írott szöveg megértése a már meglévő tapasztalatok alapján megy végbe, a dekódolásnak kevés szerepet tulajdonítva. Az olvasástanítás ebben a megközelítésben a gyermek segítése, hogy a szöveg jelentését feldolgozza. A módszer nem tekinti problémának a dekódolási hibákat, kivéve, ha a hiba következtében a jelentés is sérül. A később egésznyelvi megközelítésként vagy felfedező olvasásnak nevezett módszeregyüttes egyik előnyének tekintették, hogy kiiktatta a dekódolás tanulását, azaz az önmagában nem motiváló drillezést, és már az olvasástanítás kezdeti szakaszában igyekezett a megértést, az olvasás által nyújtott élményt elérhetővé tenni a tanulók számára. Azonban a megközelítés azonban számos kritikát kapott, melyek közül a legjelentősebb, hogy az általa felvázolt olvasási modell a gyakorlott olvasókra jellemző, ám a kezdő olvasók számára azonban elérhetetlen (Gósy, 2005). A módszer finomultabb formája a szóképes olvasás, amely továbbra is a jelentésböl, a megértésböl indul ki, és ahhoz kapcsolja a szavak vizuális, írott képét, azonban a betủzés itt már egy későbbi szakaszban ugyan, de fontos szerepet kap. A szintetikus módszer a hang-betű megfeleltetésből indul ki és halad az összeolvasás, a szavak, a mondatok és a szövegek olvasása felé. A módszer a nyelvi tudatosság olvasástanulásban betöltött szerepét hangsúlyozó pszicholingvisztikai irányzatból eredeztethető, és hangsúlyozza, hogy az olvasás tanulásának feltétele a nyelvröl való tudás, mely megfelelö eszközökkel fejleszthető (Gósy, 2005). Motivációs szempontból a tiszta szintetikus módszer hátránya, hogy a jelentés sokszor a háttérbe szorul, az előkészítés szakasza elnyúlhat és a jelentésszerzés mint motivátor nem érvényesül. Előnye azonban, hogy az apró lépések, a részekből való építkezés feltételezhetően több sikerélményt és erőteljesebb fejlődésérzést nyújt, mint a felfedező olvasástanu- 
lás. Manapság szinte sehol sem használják a tiszta szintetikus vagy egésznyelvi megközelítést (Adamikné, 2002), így Magyarországon is a két véglet között elhelyezkedő ú.n. hangoztató-elemzö-összetevő módszer terjedt el.

Lepola, Salonen és Vauras (2000) kutatása az iskolai tapasztalatok, a siker és kudar megélésének hatására mutat rá az olvasási motiváció fejlődésében. Óvodáskortól másodikos korig fejlődési szempontból vizsgálták a célorientáció és az olvasási képesség összefüggéseit. Eredményeik szerint az azonos készségfejlettségü, de progresszív és regresszív szóolvasó készségfejlődést mutató gyermekek, azaz azok, akik a kezdeti olvasásteljesítményük alapján elvárható szinthez képest relatíve jobban vagy rosszabbul teljesítettek évek múlva, az iskolázás kezdete előtt nem különböztek feladatmotiváltságukat illetően. A különbség csak második osztályra vált szignifikánssá, amikor a regressszív készségfejlödést mutató tanulók kevesebb feladatorientáltságot, viszont erőteljesebb szociális függőséget és énvédelem-orientáltságot mutattak.

Az iskolai környezet és a rendelkezésre álló források mennyisége és minősége, csakúgy, mint az otthoni vagy a társadalmi kontextus esetén, szintén hatással vannak a tanulók olvasási szokásaira, gyakoriságára (McQuillan és Au, 2001). A PIRLS 2001-es vizsgálat az olvasási képesség fejlődés iskolai kontextusának vizsgálatakor a tantermekben és az iskolai könyvtárakban a tanulók rendelkezésére álló könyvek számára is rákérdezett. A nemzetközi összehasonlításban az eredmények alapján Magyarország e szempontból a rangsor végén helyezkedett el. A rangsor elején álló Izlandon az osztálytermek 96\%-ában, Svédországban 76\%-ában több mint 500 könyv található. Magyarországon az osztálytermekben egyáltalán nem jellemző a könyvek jelenléte, és a teljes iskolai könyvtáraknak is mindössze 7\%-ában található több mint 500 könyv (Mihály, 2003).

Wigfield, Eccles és Rodrigues (1997) átfogó tanulmánya általánosságban véve a tanulási motívumok iskolai keretekben történő alakulásának befolyásoló tényezőit tárgyalja. A tényezők között említi, többek között, az osztály és a tanórák légkörét, az osztály csoportdinamikai jellemzőit és a csoport összetételét. Az osztály mint pszichológiai értelemben vett csoport olvasási motivációt befolyásoló hatása az olvasás szociális motívumain (Wigfield és Guthrie, 1997) keresztül érvényesül.

Az iskolai környezeten belül az osztálytermi tevékenységek jellegére, ezen belül a tanári és a tanulói kontroll egyensúlyának és a tevékenységek megválasztásának lehetőségére hívja fel a figyelmet Deci, Schwartz, Sheinman és Ryan (1981) is a tanulók intrinzik motivációjának erősítésében. Connell és Wellborn (1991) osztálytermi elmélyülés (engagement) modellje szerint a tanulóknak három alapvető igénye van: a kompetenciaérzet, az autonómia és a valahová tartozás érzése. Amennyiben az osztálytermi kontextus és a tanítási stratégiák kielégítik és támogatják ezeket az igényeket, az elmélyülés bekövetkezik.

\subsection{Nemek közötti különbségek az olvasási motivációban}

A PISA-vizsgálatok az olvasásteljesítmény esetében a lányok fölényéről számoltak be: a lányok mind a négy PISA-vizsgálaton jobban teljesítettek a fiúknál (OECD, 2010). A nemek közötti különbségeket az olvasásteljesítmények hatfokú skáláján való teljesítményeloszlások is alátámasztják: míg a fiúknak csaknem fele nem éri el a hármas szintet, addig a lányoknak csupán egyharmada esik e szint alá. A fiúk alulteljesítése minden ország esetében megmutatkozik. 
Szignifikáns különbségről számoltak be a nemzetközi mérések a nemek között az olvasási motivációt illetően is. A PISA 2000 vizsgálat eredményei szerint a lányok szignifikánsan magasabb érdeklődést mutatnak az olvasás iránt Korea kivételével valamennyi országban. A lányok olvasási énképe 18 ország esetében jobb a fiúk olvasási énképénél (Artelt, 2003), és az olvasási szokások terén is jelentős különbségek mutathatók ki a nemek között: a lányok gyakrabban, többet és változatosabb müfajokat olvasnak, mint a hasonló korú fiúk (Kirsch, deJong, Lafontaine, McQueen, Mendelovits és Monseur, 2002). A legutóbbi PISA-mérés eredményei szerint az olvasási motiváció nemek közötti különbségei szélesedtek, akárcsak a teljesítménybeli különbségek (OECD, 2010).

Az olvasási motiváció terén a nemek között az eltérések már az iskoláskor kezdetén is jelen vannak. Lepola (2004) kutatásában az olvasáshoz szükséges előfeltételkészségek alulfejlettségével jellemezhető fiúk nagyobb motivációvesztést éltek át, mint a hasonlóan gyenge előfeltételkészségekkel rendelkező lányok. A fiúk ezen túl az iskoláskor kezdetén a feladatelkerülés magasabb fokával is jellemezhetők (Onatsu-Arvillomi és Nurmi, 2000). A lányok pozitívabb motivációs jellemzői már ebben az életkorban is megjelennek, ám míg a fiúk motivációs önjellemzései erős korrelációt mutatnak a tanári jellemzésekkel, a lányok esetében a tanulói önértékelések és róluk készült tanári értékelések nincsenek összhangban (Coddington és Guthrie, 2009).

A nemek közötti teljesítménybeli és motivációs különbségek magyarázatára nagyon hasonló elméletek születtek. Az egyik megközelítés a különbségeket biológiai, genetikai változókkal és az ezekből eredeztetett állandósult személyiségváltozókkal és attribúciós stílusokkal magyarázza (Keller, 2008). A másik megközelítés a nemi sztereotípiákat és a fiúk egyéni érdeklődésétől távol álló iskolai szövegeket tekinti a különbségek forrásának. A fiúk elmaradása az olvasás gyakoriságát illetően a maszkulinitás szociális normáival is magyarázható (Young és Brozo, 2001). Ezt támasztja alá Meece, Glinke és Burg (2006) felső tagozatos tanulókkal végzett kutatása is, mely szerint a fiúk és a lányok erősen sztereotip módon gondolkodnak saját képességeikről: a lányok általában a nyelvi képességek területén érzik magukat hatékonyabbnak, míg a fiúk a matematika és a természettudományok területén rendelkeznek magasabb önhatékonysággal.

\subsection{Az eltérő értelmi fejlődés és olvasási motiváció kapcsolata}

A képességek fejlődésének üteme, az eltérő fejlődés szintén hatással lehet a tanulók tanulási és olvasási motívumainak fejlődésére. Az eltérő fejlődés leírására az általános pedagógiai és gyógypedagógiai szakirodalomban számos fogalmat találunk, melyek más-más populációra utalnak. A hazai szakirodalomban a kontextuális fordulat hatására, a tanulási korlátok kialakulásában a környezeti tényezők figyelembevételével alakult ki és terjedt el a tanulásban akadályozottság fogalma. Tanulási akadályozottság esetében több képességterületet érintő, súlyos, tartós problémáról van szó. Jellemző a kognitív funkciók és a beszéd lassabb fejlődése, diszpraxiás tünetek, figyelem-összpontosítási és viselkedési problémák megjelenése. A tanulási akadályozottságon belül a szakirodalom az enyhén értelmi fogyatékosok és a nehezen tanulók csoportját különbözteti meg.

Az eltérő fejlődés hatását vizsgáló kutatások számára kiemelt nehézséget jelent, hogy a hazai és nemzetközi fogalomhasználat és kategorizálási rendszer nagyban eltér ( $F e$ jes és Szenczi, 2010). Szintén nehezíti az eredmények összevetését, hogy sem a hazai, sem pedig a nemzetközi szakirodalom nem bővelkedik eredményekben az eltérő értelmi fejlő- 
désü tanulók olvasási motivációjával kapcsolatban. A következőkben ezért az olvasási motívumok mellett, a tanulási motiváció jellemzőire is figyelmet fordítunk.

\subsubsection{Enyhén értelmi fogyatékos tanulók tanulási és olvasási motivációja}

Mesterházi (1998) a tanulásban akadályozott, ezen belül az enyhén értelmi fogyatékos tanulók tanulási motivációjával kapcsolatban a motiváltság alacsony szintjéröl és általában véve a többségi tanulóknál tapasztaltabbaknál negatívabb orientációkról beszél. Chan és Koegh (1974) a siker és kudarc attribúcióját vizsgálta tanulásban enyhe fokban értelmi fogyatékos tanulóknál. Eredményei szerint ezek a tanulók hajlamosabbak sikereiket külső okoknak, kudarcaikat pedig belső okoknak tulajdonítani. Ugyanakkor kevésbé hiszik, hogy a sikerek hátterében álló nem állandó tényezők megváltoztathatók, kontrollálhatók; a tanulásban akadályozott tanulók többsége az erőfeszítés, a képesség és a szerencse kisebb alacsonyabb mértékü kontrolljáról számolt be, mint többségi társaik (Turner, 1996). Az erőfeszítést egyáltalán nem tartják a sikerhez vezető út kulcsfontosságú tényezőjének (Switzky, 2001). Ezt bizonyítja az az eredmény is, miszerint, ha enyhe fokú értelmi fogyatékos tanulók sikereiről olyan visszajelzéseket adunk, mely szerint az elért eredmény a képességeiknek tulajdonítható, az a későbbi teljesítményt növelte. Ugyanez a hatás ugyanakkor nem volt kimutatható a sikerek erőfeszítésnek való tulajdonításakor (Turner, 1998).

A visszajelzések egyébként is fontos szerepet töltenek be az enyhe fokban értelmi fogyatékos tanulók tanulási motiváltságában. Switzky (2001) szerint ugyanis ezekre a tanulókra nagyfokú kifelé irányultság (outerdirectedness) (Bybee és Zigler, 1992) jellemző. A kifelé irányuló személyek aktív problémamegoldó stratégiák használata helyett inkább hagyatkoznak a helyzet által kínált segítő elemekre, például mások viselkedésének utánzására vagy a direkt segítségkérésre. Ezzel összhangban Haywood (1968 idézi Lepola, 2000) szerint az alacsonyabb képességfejlettségű személyek hajlamosabban a kifelé irányultságra, esetükben a szociális függőség is jellemzőbb.

Az enyhe fokú értelmi fogyatékos tanulókra általában inkább az extrinzik motiváció jellemző (Haywood és Switzky, 1986), a különböző, felnőttek által nyújtott szociális vagy tárgyi jutalmak fontos szerepet töltenek be náluk. Az általuk kitüzött tanulási célokat nagy mértékben befolyásolják szükségleteik, a kapott visszajelzések, illetve a saját képességeikkel kapcsolatos meggyőződéseik (Switzky, 2001).

Piers és Harris (1964 idézi Switzky, 2001) enyhe értelmi fogyatékos tanulók számára készített észleltkompetencia-kérdőívükkel történő vizsgálataik alapján azt találták, hogy a vizsgált tanulók kevésbé érzik magukat kompetensnek, mint nem akadályozott társaik. Morena és Litrownik (1974) szintén az alacsony önértékelésre hívta fel a figyelmet az értelmi fogyatékos tanulók affektív jellemzőit illetően.

A szakirodalom alapján tehát feltételezhető, hogy az enyhe értelmi fogyatékos tanulók általánosságban véve kedvezőtlenebb motivációs jellemzőkkel rendelkeznek, mint nem fogyatékos társaik. Ez alapján várható lenne, hogy a negatív motivációs jellegzetességek miatt a tanulók egyre inkább elvesztik érdeklödésüket az iskolai tanulás iránt. Józsa és $F a$ zekasné (2007) ugyanakkor ennek éppen az ellenkezőjét mutatta ki. 


\subsubsection{Tanulási képességzavar (learning disability) és motiváció}

Az angolszász szakirodalomban az eltérő fejlődést mutató tanulópopulációval kapcsolatban leggyakrabban megjelenő kategória a tanulási képességzavar (learning disability, LD). Szakirodalmi áttekintésünkben az angol learning disability kifejezés fordítására szándékosan használunk a magyar tanulási korlátok rendszerétől eltérő kifejezést, ezzel is jelezve, hogy a kategória egy az egyben egyetlen hazai kategóriának sem feleltethető meg. Az Individuals with Disabilities Education Act (IDEA) meghatározása szerint a tanulási képességzavar ,a megértésben és a beszélt vagy írott nyelv használatában szerepet játszó pszichológiai folyamatok zavarát jelenti, amely a figyelem, a gondolkodás, a beszéd, az olvasás, az írás, a betüzés vagy a matematikai müveletvégzés készségeinek tökéletlenségében nyilvánul meg. A kifejezés magában foglalja az olyan állapotokat, mint például az érzékelési zavarok, az agysérülések, a minimális agyi diszfunkció, a diszlexia vagy a fejlődési afázia. A kategóriába ugyanakkor nem értendők bele azok az esetek, amikor a problémát elsősorban látás-, hallás-, motoros vagy értelmi akadályozottság okozza, illetve ha az érzelmi zavar, környezeti, kulturális vagy gazdasági hatás eredménye” (IDEA 2004, 2657 2658. o.).

A tanulási képességzavar definíciója csupán azt határozza meg, hogy mely tényezők nem tekinthetők a tanulási képességzavar okának, de nyitva hagyja azt a kérdést, hogy melyek azok a tényezők, amelyek ugyanakkor felelősek az alulteljesítésért és lemaradásért. Több kognitív változó is elégtelen magyarázó erejünek bizonyult a tanulási képességzavar azonosítására (Watkins, 2005; Watkins, Kush és Glutting, 1997). Sideridis, Morgan, Botsas, Padeliadu és Fuchs (2006) ugyanakkor öt összefüggő vizsgálaton keresztül rámutattak, hogy a motivációs jellemzők jó előrejelzői lehetnek a tanulási képességzavarnak. Az általuk vizsgált öt motívum különbségei - önhatékonyság (self-efficacy), motivációs erő (motivational force), feladatkerülés (task-avoidance), célkövetés (goal commitment) és énkép (self-concept) - meglehetős pontossággal azonosították a tanulási képességzavarral küzdő vagy annak kitett tanulókat (Sideridis és munkatársai, 2006).

Számos kutatás mutat rá a tanulási motiváció tanulási képességzavarral küzdő tanulók teljesítményére gyakorolt hatására is (Deci és Chandler, 1986; Pintrich, Anderman és Klobucar, 1994; Bouffard és Couture, 2003). Összhangban Wigfield és munkatársai (2004) eredményeivel többségi tanulók esetén Morgan és Sideridis (2006) az olvasási képesség fejlesztését célzó, tanulási képességzavarral küzdő tanulók számára kidolgozott fejlesztő programok metaanalízisekor arra jutott, hogy azok a programok voltak a legsikeresebbek, amelyek nagyban építettek a motívumok fejlesztésére is.

A motivációs orientáció tekintetében a tanulási képességzavarral küzdő tanulók vizsgálati eredményei ellentmondásosak. Sideridis, Mouzaki, Simos és Protopapas (2006) olvasási nehézségekkel küzdő tanulók vizsgálatakor azt találták, hogy az olvasási nehézség egyik előrejelzője lehet a szociális függőség és versengés, ha az alacsony fejlettségü kognitív és metakognitív készségekkel társul. A tanulási képességzavaros tanulók túlzott kifelé irányultságára (outerdirectedness) mutatott Torgesen (1986), Deci és Chandler (1986) és Grolnick és Ryan (1990) is. Pintrich, Anderman és Klobucar (1994) ugyanakkor kismintás vizsgálatukban tanulási képességzavaros és többségi tanulók kognitív, metakognitív és motivációs jellemzőik alapján való klaszterezésekor azt találták, hogy tanulási képességzavarral küzdő tanulók többségére alacsony kognitív és metakognitív készségfejlettség mel- 
lett magas szintű intrinzik motiváció jellemző. Sideridis (2006) tanulási képességzavaros és többségi tanulók osztálytermi tanulási tevékenységének megfigyelésekor azt fedezte fel, hogy bár a tanulási képességzavaros tanulók nagyobb fokú szociális függőséget, a jutalomra és büntetésre nagyobb fokú fogékonyságot, ugyanakkor pedig a feladatban való kisebb mértékü elmélyülést mutatnak, mint többségi társaik, mind a két tanulócsoport számára az elsajátítási célok hangsúlyozása bizonyult hatékonyabbnak az elsajátítás szempontjából. Míg az elsajátítási célok erősebb elmélyüléshez vezettek, a teljesítménycélok negatív vagy semleges hatásúnak bizonyultak (Sideridis, 2006).

\subsection{A fejlesztés lehetőségei, fejlesztő programok}

\subsubsection{Az olvasási motiváció megismerése osztálytermi kontextusban}

Az olvasási motiváció fejlesztésének előfeltétele a diagnózis, azaz, hogy a fejlesztést végző pedagógus ismerje meg diákjai olvasási motivációs jellemzőit. Ennek érdekében gyüjtöttük össze az erős olvasás iránti motiváltsággal rendelkező egyének jellemzőit az általános iskola kezdő szakaszától az egyes motívumok szerinti bontásban. A fentiekben bemutatott szakirodalom alapján általunk fejlesztett követelményrendszer azokat a viselkedéses elemeket tartalmazza, amelyek jó indikátorai lehetnek az olvasási motívumok megfelelö fejlettségének, és amelyeket a pedagógus könnyedén megfigyelhet, nyomon követhet minden egyes diák esetében. Egy-egy viselkedési mintázat mögött számos motívum húzódhat meg, hasonlóképp, egy-egy motívum müködése egyénenként eltérő viselkedést eredményezhet. A követelményrendszer így csak irányadó példákat hoz a motívumok fejlettségének megítélésére, a pedagógus (és a szülö) diagnosztikus célú megfigyelései, a fejlődés nyomon követése az, amely megbízható képet nyújthat az olvasási motiváció fejlettségéről.

Az 1-2. osztályt lefedő életkori szakaszban a motívumok egyrészt az olvasástechnika elsajátítására (az olvasás előfeltétel készségeit, a beszédhanghallást, betüzést, szóolvasást és mondatolvasást fejlesztő feladatok végzésére) vonatkoznak, másrészről az olvasás tartalmára (a hallott vagy olvasott történetre, mesére, ismeretterjesztő írásra stb). Az nevezhető motiváltnak, aki az olvasástanulás iránt motivált, és/vagy érdeklődik az olvasottak tartalma iránt, örömforrást jelent számára az olvasásélmény. A felsőbb évfolyamon a motívumok már az önálló jelentésalkotásra, a tanulási, információszerzési és élményszerzési célú olvasásra vonatkoznak.

Már az olvasástanulás kezdeti szakaszában erőteljesen működnek az olvasásra vonatkozó önjutalmazó motívumok, és az óvodai nevelés erőteljesen épít rájuk az élvezettel végzett indirekt tanulási célú tevékenységek során (Nagy, 2011). Az egyik legismertebb önjutalmazó késztető erő az olvasástechnika elsajátításakor erőteljesen érvényesülő olvasás-elsajátítási motívum. Az erős olvasás-elsajátítási motivációval rendelkező tanuló jellemzői:

- Az életkorának és képességeinek megfelelő olvasási feladatokat önállóan, kitartóan végzi, azokban láthatóan elmélyül olyan teljesítményhelyzetben is, mely nem helyez kilátásba külső forrásból származó jutalmat vagy büntetést.

- Kitartóan gyakorol, nem vagy csak ritkán adja fel, mindaddig próbálkozik a feladat elvégzésével, míg sikerrel nem jár. 
- Akkor is foglalkozik az olvasás feladatokkal, ha nem kötelező, később önállóan, saját örömére is olvas.

- Otthon is, szabadidejében is gyakorol, olvas még akkor is, ha erre semmi és senki nem kötelezi.

- Értékeli és büszke a teljesítményére, a saját fejlődésére, még akkor is, ha azért nem kap jutalmat (pl. boldogan újságolja el, ha önállóan kibetüz egy feliratot, később elolvas egy mesét, viccet, képregényt stb.).

- Egy-egy olvasás feladat megoldásán addig dolgozik, addig nem adja fel, amíg a teljes elsajátítás végbe nem megy, vagy amíg a teljes megoldás meg nem születik (kezdetben addig gyakorolja a hangos olvasás, a szótagolást, amíg egyre sikeresebb nem lesz, később például addig böngészik egy dokumentumot, amíg meg nem találja a kívánt információt).

Az olvasásra irányuló elsajátítási motívum általában erőteljesen megmutatkozik az olvasástanulás kezdeti fázisában, az olvasástechnika elsajátításakor. Ez elsősorban a viszonylag gyorsan elérhető eredményeknek, a jól látható céloknak és a fejlődés pontos nyomon követhetöségének köszönhetö. A kisgyermek észleli, hogy fokozatosan egyre több betüt és szót el tud olvasni, és nagyban motiválja az, hogy az összes betüt, szót el tudja majd olvasni. A felsőbb évfolyamos tanuló ideális esetben felismeri, hogy az olvasástanulás nem csupán az olvasástechnika elsajátítását jelenti és új olvasási célokat tüz ki maga elé (például el tudjon olvasni és meg tudjon érteni egy hosszabb történetet vagy akár egy regényt, képes legyen kibetủzni a legbonyolultabb szavakat is, képes legyen megtalálni egy szövegben bizonyos információkat stb.).

Az elsajátítási motiváció része az elsajátítási öröm, mely az olvasás elsajátítása során megjelenő pozitív érzelmi reakció (Józsa, 2007). Úgy is tekinthető, mint az elsajátítási motívum müködését jelző érzelmi, viselkedéses mechanizmus. Az elsajátítási öröm jelei az olvasástanulás során:

- A tanuló láthatóan örül, elégedettség érzés tölti el az önálló elsajátítást vagy egy feladat elvégzését követően.

- Örül, mosolyog, ha elolvas valamit, megért egy szót, mondatot, megold egy olvasási feladatot.

- Az elsajátítást, a feladat teljesítését gyakran látható mosoly követi olyan helyzetben is, ha az nem jár külső jutalommal.

Áramlatélményről (flow) akkor következik be, amikor az egyén egy számára optimális kihívással járó feladatba vagy tevékenységbe idő- és térérzékét elveszítve elmerül, mégpedig úgy, hogy az boldogságérzetet alakít ki benne (Csíkszentmihályi, 1997). Az olvasástanulás kezdetén a betüzés, a szótagolás, a mondókák és mesék tanulása, hallgatása járhat hasonló élménnyel. Az általános iskola elején, az olvasástechnika elsajátítása alatt, az olvasástanulás során, olvasásfeladatok végzése közben, később majd a szövegértő (tudás-, információ- vagy élményszerzés céljából végzett) olvasás során élheti át az egyén mindezeket. Az olvasási tevékenység közben áramlatélményt átélni képes tanuló jellemzői:

- A képesség-kihívás egyensúlyának megfelelő olvasási feladatok/olvasási tevékenység esetében az alábbiak jellemzik: csak az olvasásra fókuszál, figyelmét 
összpontosítja, kizárja a külvilágot, képes teljesen elmélyülni az olvasásban, a cselekvése és a figyelme eggyé olvad, nem foglalkozik közben semmi mással, figyelmen kívül hagyja a zavaró tényezőket, az idő gyors múlásáról számol be.

- Érzelmileg és gondolatilag is elmélyül az olvasásban, nehéz kizökkenteni, figyelme nem kalandozik el gyakran (kezdetben pl. nem veszi észre, hogy véget ért az óra, vagy hogy a társa próbálja magára vonni a figyelmét, vagy épp annyira elmélyül, hogy elfelejti, ha valami sérelem érte előtte (például abbahagyja a sírást), később elmerül egy szövegben.

A felsőbb évfolyamos általános iskolás tanuló az áramlatélményt, azaz az olvasásba való teljes belefeledkezést már a szövegértő (tudás-, információ- vagy élményszerzés céljából végzett) olvasás során is átélheti.

A gyermekek és a felnőttek is rendelkeznek egyfajta kíváncsisággal, igyekeznek megismerni és felfedezni saját szükebb és tágabb környezetüket, válaszokat várnak a kérdéseikre. Az olvasás eszköze a válaszok megtalálásának. A természetes kíváncsiság és érdeklődés tehát jó motivátora lehet az olvasásnak. Az olvasás iránt erőteljes érdeklödéssel rendelkező tanuló jellemzői:

- Kezdetben még passzív befogadóként érdeklődő, kérdéseket tesz fel (pl. mesehallgatáskor, a szereplőkről, a helyszínről kérdez). Szívesen továbbkölti vagy eljátssza a mesét, szerepjátékra használja az olvasottakat (pl. felvesz egy szoknyát és a mesebeli királykisasszonynak képzeli magát), lerajzolja a hallottakat. Az olvasás elsajátításának kezdetén szívesen hallgatja, ha felolvasnak neki, maga is kéri erre a körülötte lévő felnőtteket, később pedig maga is aktívan és szívesen olvas és utánaolvas bizonyos dolgoknak (pl. ha az iskolában valamilyen állatról tanulnak, otthon is az állatról olvas, megkeresi saját könyveiben vagy akár az interneten segítséggel).

- Érdeklődik a betü-hang megfeleltetés iránt (közös olvasás közben kérdezi: ez milyen betü), utánozza az olvasási tevékenységet (kinyitja az ismert könyvet vagy újságot, nézegeti, elmondja, mi van benne)

- Megfogalmazza, milyen meséket/történeteket szeret hallgatni.

- Érdeklődést mutat egy-egy konkrét téma iránt, könnyen felkelthető és fenntartható az érdeklődése (pl. várja, hogy egy új történetet, mesét kezdjen olvasni, figyelmét csak arra koncentrálja, könnyü lekötni az olvasási feladatokkal, a betüzéssel).

Az olvasás iránt erőteljes érdeklődéssel rendelkező felsőbb évfolyamos tanuló viselkedéses jellemzői:

- Érdeklődése nem csupán a tanórára, de azon túlra is kiterjed: aktívan és szívesen olvas, utánaolvas bizonyos dolgoknak (pl. ha az iskolában valamilyen állatról tanulnak, otthon is az állatról olvas, megkeresi saját könyveiben vagy akár az interneten segítséggel, kikölcsönöz egy hasonló témájú könyvet a könyvtárból, következő órán még mindig foglalkoztatja a téma). 
- Kialakulóban van egyéni érdeklődése (pl. megfogalmazza, mi érdekli, az általa érdekesnek talált témákról - például állatokról, természeti jelenségekről - bíztatásra szívesen olvas szabadidejében is saját könyveiben vagy az interneten).

- Később fejlett egyéni érdeklődés jellemzi (pl. elmondása, viselkedése, az általa birtokolt tárgyak egyértelmüen tükrözik, mi iránt érdeklődik a tanuló; az érdeklődés tárgyát képező dolgokról, témákról saját indíttatásból szívesen olvas szabadidejében is.)

Nem elég azonban, ha érdeklődünk valami iránt vagy szeretnénk azt megtanulni, a folyamatos kudarcélmények, a félelem a sikertelenségtől könnyen eltántoríthat bárkit még a korábban kedvelt tevékenységtôl is. Az olvasási motiváció elvárás-érték modellje szerint (Möller és Schiefele, 2010) olvasási tevékenység elkezdése és folytatása nagyban függ attól, hogy mennyi esélyt látunk arra, hogy sikeresek lehetünk benne. Hogy kivitelezhetőnek láthatjuk-e bizonyos célok elérését, és hogy milyen esélyt jósolunk magunknak a feladat megoldására, nem csupán az adott feladat nehézségétől, hanem saját belső komponenseinktől, például énképünktől és önhatékonyság-érzésünktől függ. Ezek fontosak az előrevetített siker vagy kudarc esélyeire vonatkozóan. Nagyban meghatározzák, hogy egyáltalán hozzákezdünk-e bizonyos tevékenységekhez vagy bizonyos feladatok megoldásához, s hogy mennyi energiát vagyunk hajlandóak fektetni azokba (Szenczi, 2008). A pozitív és fejlett olvasási énképpel és önhatékonysággal rendelkező egyén jellemzői:

- A képességeinek megfelelő olvasási feladatoknak magabiztosan áll neki (pl. nem nézi, hogyan kezd neki a másik, nem kér azonnal segítséget, nem kezd előtte mást csinálni (pl. minden egyes alkalommal ceruzát hegyezni), keveset hezitál, nem halogatja a feladatvégzést).

- Hatékonynak érzi saját olvasási tevékenységét; a saját olvasási teljesítményét, fejlődését pozitívan ítéli meg (pl. ha megkérdezzük tőle, meg tud-e oldani egy reálisan kitüzött feladatot, azonnal igennel válaszol).

- Bátran kezd neki az általa ismert olvasási feladatoknak; nem vagy csak ritkán hezitál.

- Képesnek tartja magát új problémák megoldására, a számára ismeretlen típusú feladatok kivitelezésére (új, számára ismeretlen típusú feladatot is először maga próbálja megoldani, nem kér azonnal segítséget, nem ijed meg, nem kezd el láthatóan szorongani, kitartóan dolgozik rajta).

- Olvasáskor vagy olvasáshoz kapcsolódó feladatok megoldásakor csak indokolt esetben kér segítséget.

- Szívesen és gyakran vállalkozik önként is olvasási feladatok megoldásra.

- Szívesen és gyakran olvas hangosan, akár mások előtt is.

- Szívesen és gyakran osztja meg véleményét, válaszait másokkal, nem fél a kudarctól, a visszautasítástól.

- Nem szégyelli, nem szorong, ha nem sikerül egy olvasás feladat, vagy nem megfelelö módon teljesít.

- A kritikát elfogadja, felhasználja saját fejlődése érdekében (pl. nem kezd el sírni, ha a tanító elmondja, min javítson hangos olvasás közben, és következő alkalommal igyekszik megfelelni az elvárásnak). 
- Saját teljesítményében jobban megbízik, mint másokéban (pl. egyéni feladatmegoldáskor nem nézi állandóan, hogy mit csinál a társa, nem les, csak a saját feladatával foglalkozik).

Az általános iskola felsőbb évfolyamain az önhatékonyság érzése már a szövegértésre is vonatkozik. Ennek megfelelően az adott életkorú, megfelelő önhatékonysággal és énképpel rendelkező tanulók viselkedéses jellemzői a következők:

- Hatékonynak érzi saját olvasási tevékenységét; a saját olvasási teljesítményét, fejlödését pozitívan ítéli meg (pl. ha megkérdezzük tőle, el tudna-e olvasni egy szöveget, és tudna-e válaszolni néhány kérdésre azzal kapcsolatban, igennel válaszol).

- Képesnek tartja magát olyan problémák megoldására, amelyek fejlett olvasási képességet feltételeznek, a számára ismeretlen típusú feladatok megoldására, ismeretlen szövegek hangos vagy néma olvasására.

- Olvasáskor vagy olvasás-szövegértés feladatok megoldásakor csak indokolt esetben kér segítséget, de akkor igen.

- Szívesen és gyakran vállalkozik önként olvasás-szövegértés feladatokra.

Azt, hogy milyen jó az énképünk és mennyire tartjuk magunkat hatékonynak bizonyos célok eléréséhez szükséges cselekvéssorozatok kivitelezésében, nagyban meghatározza, hogy sikereinket és kudarcainkat milyen okoknak tulajdonítjuk (Wilson és Trainin, 2007). Ilyen értelemben az olvasási énképet és önhatékonyságot erőteljes mértékben formálják $a z$ olvasással kapcsolatos sikerek és a kudarcok attribúciói. Az énkép és önhatékonyság fejlődése szempontjából ideális attribúciós jellemzők a következők:

- Reálisan látja sikereinek és kudarcainak nagyságát és okát (megfelelő jelentőséget tulajdonít a sikereknek és kudarcoknak, egy kisebb kudarc például hangos olvasás közben nem veszi el a kedvét hosszú időre a hangos olvasástól, láthatóan tud örülni a sikereinek, büszke magára; kudarc átélésekor kellemetlen érzés tölti el, de csak rövid időre)

- Az, hogy sikereket vagy kudarcokat ér el az olvasásban, saját maga által befolyásolhatónak tartja. Az olvasás gyakorlását az olvasási képessége fejlődésének eszközeként tekinti. Képességeire úgy tekint, mint amelyek fejleszthetőek, nem tekinti öket veleszületett adottságnak (pl. nem keseredik el és nem mutat tehetetlenséget, ha kudarcot él át az olvasás tanulásakor, inkább többet gyakorol, több energiát fektet az olvasás tanulásába, esetleg segítséget kér; később nem keseredik el és nem mutat tehetetlenséget, ha nem sikerül első olvasásra megértenie egy adott szöveget, inkább több energiát fektet az olvasásba, újraolvassa a szöveget, megpróbál hatékonyabbnak gondolt stratégiákat alkalmazni, esetleg segítséget kér).

- Büszke az elért sikerekre és azokat saját képességeinek valamint az általa befektetett energiának és a megtett erőfeszítéseknek tulajdonítja (pl. egy jó olvasási teljesítmény után vállalja, milyen sokat gyakorolt, mennyi időt töltött az olvasással). 
- Az olvasástanulás közben átélt kudarcok miatt nem keseredik el, túl tud azokon lépni, hosszú távon nem befolyásolják saját önértékelését (pl. nem válik visszahúzódóbbá egy kudarcélmény után).

Azt, hogy mennyi energiát vagyunk hajlandóak fektetni valamibe, befolyásolja, hogy mennyire tarjuk értékesnek, fontosnak egyéb célok elérése és saját magunk fejlődése céljából azt a tevékenységet (Wigfield és Eccles, 2000). Ez legtöbbször az egyén szubjektív megítélése. Az olvasási motiváció szempontjából ideális, ha a tanuló már az olvasástanulás kezdetén:

- Gyakorlati értéket tulajdonít az olvasásnak (tud a közeli jövőből példát említeni arra, hogy miért jó, ha az ember tud olvasni - pl. fel tud majd olvasni a kistestvérének a kedvenc mesekönyvéből vagy el tudja majd olvasni, hogy mikor indul a busz).

- Felismeri, hogy az olvasástechnika elsajátítása a későbbi szövegértő olvasást szolgálja: érti, hogy azért kell megtanulnia a betüket, hogy később egyedül elolvashasson például egy mesét (pl. tud példát említeni arra, hogy miért jó a betűket megtanulni; mesehallgatás közben kérdezget: hogyan betüzik a főszereplő nevét; mutogat a könyvben és kérdezi: mi van ide vagy oda írva; gyakran írja le a hallott vagy olvasott mese föszereplöjének nevét).

- Értéket tulajdonít az olvasás terén elért teljesítményének, fontosnak tartja, hogy jól teljesítsen (pl. elújságolja szüleinek, ha jól teljesített olvasás órán, elmondja a tanítónak, ha önállóan elolvasott valamit és ezt sikerként élte meg).

- Fontosnak ítéli, hogy megtanuljon olvasni és hogy jól teljesítsen az olvasás feladatokon (pl. kinyilvánítja vagy láthatóan rossz érzés számára, ha sikertelen).

- Fontosnak tartja az olvasás órát, aktív résztvevője annak (pl. úgy helyezkedik, hogy mindent lásson és halljon, jelentkezik, nem szívesen hiányzik az olvasás óráról, a hiányzásait mindig bepótolja).

A felsőbb évfolyamokon e jellemzők kiegészülnek még a fejlett szövegértésre vonatkozó értékekkel és célokkal:

- Gyakorlati értéket tulajdonít az olvasásnak (tud példákat említeni a távolabbi jövőből arra, hogy miért jó, ha megtanul olvasni: a tanuláshoz, a továbbtanuláshoz, a munkahelyen hasznos)

- Az olvasást saját céljai elérésére használja (például ha szüksége van egy információra, papíralapú vagy internetes könyveket, enciklopédiákat, szótárakat, keresőket hív segítségül).

Az olvasás szociális (társas) motívumai mindazok a motívumok, amelyek az olvasás eredményeként létrejövő jelentés másokkal történő megosztására vonatkoznak (Wigfield, Guthrie és McGough, 1996). Ide tartozik például az olvasmányélmények megbeszélése, a közös olvasás és a kommunikáció, a kapcsolattartás célú olvasás.

Az iskola kezdetén az olvasási képesség fejlettsége feltehetően még nem áll azon a fejlődési szinten, amely lehetővé tehetné az olyan motívumok müködését, mint az olvasói közösségekbe való bekerülés (például akik olvastak egy adott regényt vagy akik ismernek 
egy népszerü képregényt) vagy az olvasmányélmények megbeszélése mint motívum. Az 1-2. osztályos korosztály számára irányadó követelmények elökészítői a későbbi szociális motívumoknak:

- Szívesen és gyakran beszél önmagáról, saját élményeiről másokkal.

- Szívesen és gyakran beszél mesehallgatási élményeiről, meséli tovább a meséket, beleéli magát mondandójába.

- Szívesen dolgozik együtt másokkal olvasás órán, aktív tagja a csoportjának.

- Hatékonyan kommunikál kortársaival.

- Él a társas összehasonlítás lehetőségével, reálisan hasonlítja saját olvasásteljesítményét, elvárásait másokhoz.

A felsőbb évfolyamokon az olvasás-szövegértés fejlettsége már lehetővé teszi a szociális motívumok működését, az olvasmányélmények megosztását. A szociális motívumok müködése ilyenkor a következő viselkedéses jellemzőkben érhető tetten:

- A tanuló szívesen és gyakran beszél olvasás élményeiről, az általa olvasott történetekröl, eseményekről, dolgokról.

- Elöfordul, hogy azért olvas el valamit, mert mások ajánlották.

- Előfordul, hogy azért olvas el valamit, hogy be tudjon kapcsolódni bizonyos beszélgetésekbe.

- Előfordul, hogy olvasmányt (mesét, regényt, újságot, internetes oldalt stb.) ajánl kortársainak.

- Az olvasást kapcsolatépítésre használja.

A tanulóknak vannak bizonyos beállítódásaik, értékelő viszonyuk az olvasáshoz és az olvasás tanulásához. Az olvasás attitüdök javarészt múltbéli emlékekböl, tapasztalatokból, az ezek alapján létrehozott sikerelvárásokból, másrészt az egyén számára fontos mások hasonló attitüdjei alapján szerveződnek (McKenna, 2001). Az olvasási motiváció szempontjából fontos attitüdbeli jellemzők az iskolázás kezdetén:

- Aktív befogadóként elmélyült mesehallgatás jellemzi, majd aktív olvasóként pl. örömmel végzi a betűk tanulását, betüzést, szóolvasást (ilyenkor felélénkül, aktívvá válik, bevonja magát a történésekbe, ő szeretne elsőként válaszolni stb.).

- Láthatóan szívesen vesz részt az olvasás órákon, kedveli az olvasás feladatokat.

- Szívesen és gyakran gyakorolja az olvasást otthon is és az iskolában is.

- Különböző tartalmakhoz, szövegekhez pozitívan viszonyul, preferenciákat fogalmaz meg (pl. a tündéres meséket szereti).

- Jelen vannak az életében az olvasás iránti pozitív attitüd tárgyiasult és szokásjellegü jellemzői (pl. saját könyvei vannak, szívesen jár könyvtárba, könyvesboltba, szívesen kap könyvet ajándékba).

A felsőbb évfolyamos általános iskolás tanuló az olvasás területén számos pozitív és negatív tapasztalattal, saját élménnyel rendelkezik. Olvasás iránti értékelő beállítódásaik, attitüdjeik főként ezekből táplálkoznak. Az olvasástanulás e szakaszában fontos, hogy a tanulók múltbéli élményeiket úgy értékeljék, hogy az olvasás iránt továbbra is túlnyomórészt 
pozitív attitüdökkel rendelkezzenek. Az olvasási motiváció szempontjából fontos attitüdbeli jellemzők ebben az életkorban:

- Közös olvasáskor, szövegértés feladatok végzésekor pozitívan áll a munkához (pl. ilyenkor felélénkül, aktívvá válik, bevonja magát a történésekbe, ő szeretne elsőként válaszolni)

- Megfogalmazza, milyen múfajú olvasmányokat kedvel.

- Gyakran olvas saját kedvtelésére.

- Szívesen olvas utána bizonyos dolgoknak, amelyek foglalkoztatják.

- Szívesen és gyakran olvas otthon is és az iskolában is.

- Különböző tartalmakhoz, szövegekhez, müfajokhoz pozitívan viszonyul, képes megfogalmazni preferenciákat (pl. szereti a háziállatokról szóló ismeretterjesztő könyveket, internetes oldalakat, újságokat, de nem szereti a háziállatokról szóló meséket).

- Pozitív viszonyulás jellemzi a szabadidős és a tudásszerző olvasáshoz (szívesen választja szabadidős tevékenységnek az olvasást és szívesen olvas tanulás céljából).

- Jelen vannak az életében az olvasás iránti pozitív attitüd tárgyiasult és szokásjellegü jellemzői (pl. saját könyvei vannak, rendszeresen jár könyvtárba, könyvesboltba, szívesen kap könyvet ajándékba, rendszeres olvasója bizonyos elektronikus vagy papíralapú újságoknak, ifjúsági szaklapoknak).

\subsubsection{Az olvasási motiváció fejlesztése osztálytermi kontextusban, a Concept Oriented Reading Instruction programja}

Az olvasási motiváció osztálytermi fejlesztési lehetőségeit tárgyalja az elmélyült és elkötelezett olvasás modellje, melynek értelmében az olvasás fejlődése - az osztályzatok és a tanár étékelései által képviselt teljesítmény, a standardizált tesztekkel mérhető tudás, valamint a látható viselkedés, például az olvasás gyakoriságának növekedése - a minél gyakoribb elmélyült olvasás eredménye (Guthrie és Wigfield, 2000).

Az elmélyült olvasás motivált, tudás alapú stratégiahasználatot feltételez és társas interakció követi. Az elmélyült olvasást tanórai környezetben a megfelelő tanulási célok kitüzése, az életszerüség erősítése, a tanulói autonómia támogatása, az érdekes szövegek, az olvasási stratégiák tanítása, a kollaboráció lehetőségének biztosítása, a tanár megfelelő mértékü bevonódása, a jutalmazás és az értékelés megfelelő eszközei és módjai, valamint az alkalmazott stratégiák és módszerek közötti koherencia megteremtése segíti elő (8.áb$r a)$. 


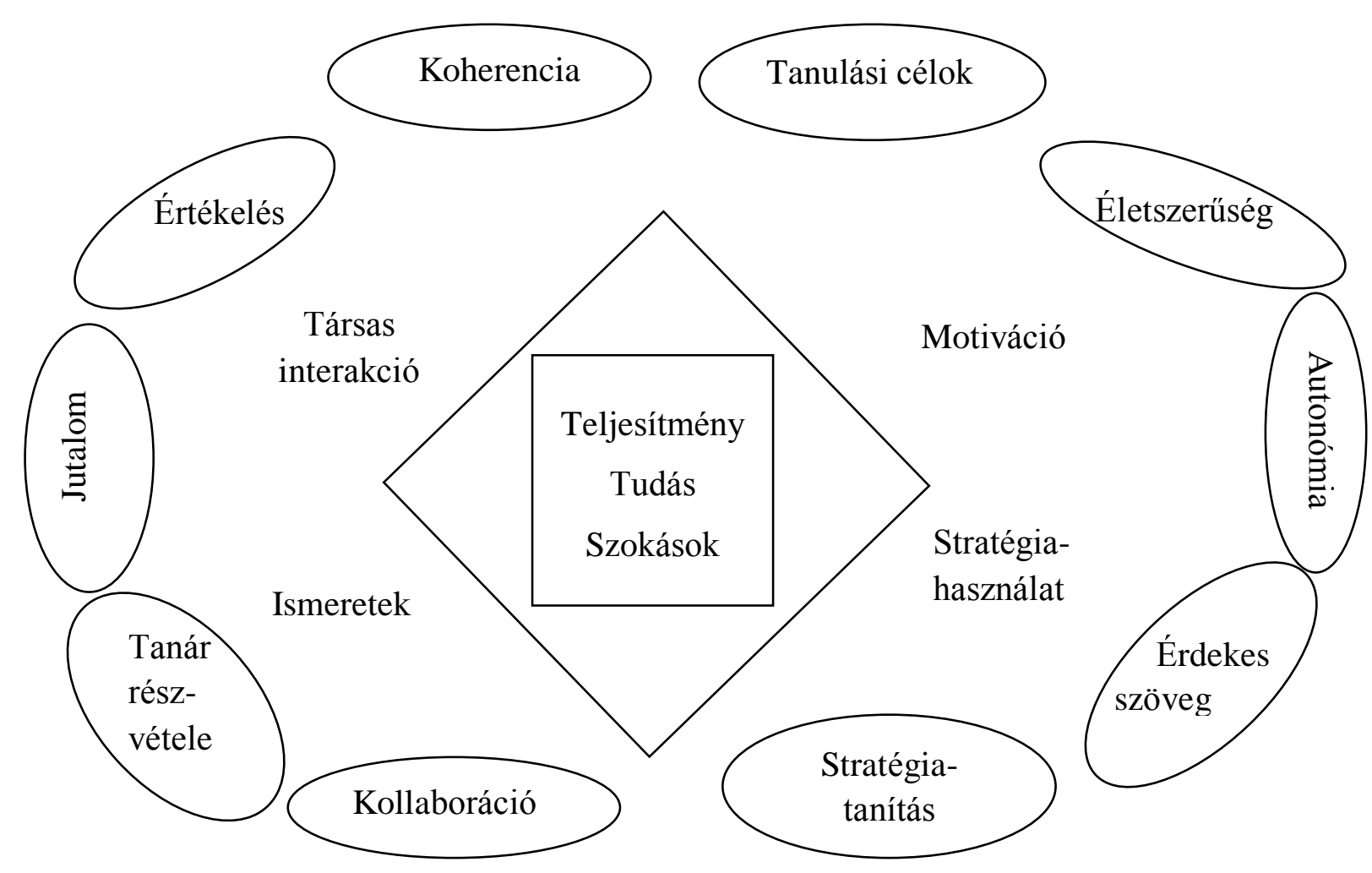

8. ábra

Az elkötelezett és elmélyült olvasás modellje (Guthrie és Wigfield, 2000. 410. o.)

Az elkötelezett és elmélyült olvasás modellje az olvasási motiváció fejlesztésében öt alapmotívumra épít. Ezek az olvasási elsajátítási célok, az olvasás észlelt kontroll vagy autonómiaérzés, az olvasás önhatékonyság, az olvasás szociális motívumai és az olvasás önjutalmazó motiváció. A modell által tárgyalt motívumok fejlesztésének módjait Guthrie és Wigfield (2000), Guthrie és Cox (2001), valamint Guthrie, McRae és Klauda (2007) alapján mutatjuk be, ezt egészítjük ki a további motívumok fejlesztési lehetőségeivel. A tárgyalt alapelvek egyben az olvasási motiváció fejlesztésére irányuló, a stratégiahasználat és az olvasási képesség növelését szintén célként kitüző Concept-Oriented Reading Instruction (CORI) program építőkövei is.

Ha egy tanuló olvasás közben elsősorban a megértésre törekszik, akkor föként elsajátítási célokat követ. Az elsajátítási célok követése általában jobb teljesítményt eredményez (Meece és Miller, 2001; Meece, Anderman és Anderman, 2006). Iskolai keretek között az elsajátítási célok követését olvasáskor a világos tanulási célok kitüzése és az olvasásfejlesztés tartalomba ágyazása teszi lehetővé. A tartalomba ágyazott fejlesztés elősegíti, hogy az olvasás eszközzé váljon az ismeretszerzésben, azaz a fejlesztés ne váljon öncélúvá. Az olvasás tehát mindig valamilyen cél elérését szolgálja, amely cél az értő olvasáson keresztül valósulhat meg. Hazánkban a szövegfeldolgozó képességfejlesztés (SZÖVEGFER) módszertana is épít ezekre a technikákra (Pap-Szigeti, Zentai és Józsa, 2006).

A tanulók azon érzése, hogy saját maguk irányítják viselkedésüket és cselekedeteiket, azaz az autonómiaérzés, szintén hatással van az olvasási teljesítményre (Sweet, Guthrie és $N g$, 1998): az önjutalmazó motívumok müködésének alapfeltétele (Ryan és Grolnick, 1986; Reeve és Jang, 2006, Roth, Assor, Kanat-Maymon és Kaplan, 2007). A tanulók autonómiaérzését elsősorban választási lehetőségek felkínálásával növelhetjük. Az 
olvasásórán számos mód adódik a tanulói autonómia növelésére. Ilyen például a szabad téma- vagy szövegválasztás, a szöveggel kapcsolatos szabad véleménykifejtés, az olvasandó szövegrészletek megválasztásának lehetősége vagy az önálló kérdésfeltevés (Assor, Kaplan és Roth, 2002).

Turner $(1995,1997)$ kétféle olvasási feladatot különböztet meg: nyílt és zárt feladatokat. A nyílt feladatok jellemzői, hogy választhatóak, különböző stratégiák használatát kívánják meg és érdekes szövegekre építenek. A zárt feladatok ezzel szemben sokkal több korlátozást tartalmaznak arra nézve, hogy mit és hogyan kell véghezvinnie a tanulónak. Nyílt olvasási feladat például, ha a gyermekek egy érdekes jelenséggel találják szemben magukat (pl. videót néznek a kacsacsőrü emlősről), amellyel kapcsolatban azután megfogalmazzák saját kérdéseiket. A kérdések megválaszolásához különböző szövegek közül választhatnak, amelyekböl saját stratégiáik alapján szürhetik ki a válaszokat. Zárt feladat például, ha a gyermekek egy a tanár által válaszott témájú és típusú szöveget olvasnak, hogy a tanár kérdéseit a tanár által felkínált módszerekkel, stratégiákkal megválaszolják (pl. Húzd alá a szövegben azokat a mellékneveket, amelyek a kacsacsőrü emlőst írják le!) Azokban az osztályokban, ahol a tanár több nyílt olvasási feladatot adott a tanulóknak, a tanulók magasabb motivációról számoltak be, mint azokban az osztályokban, ahol a zárt feladatok domináltak (Turner, 1997).

Az autonómiaérzés fejlesztésének egyik alapelve, hogy értelmes választási lehetőségeket kínáljunk fel, olyanokat, amelyek valódi választást tesznek lehetővé a tanuló számára. Ehhez szükséges, hogy a tanár ismerje a tanuló érdeklődését, preferenciáit és fejlettségi szintjét. A tanulók egyéni érdeklődésének megismerését teszi lehetővé például a $M y$ Interest Now for Engagement (MINE; Ely, Ainley és Pearce, 2010) szoftver, amely az érdeklődés fejlődésének négyfázisú modelljére épül (Hidi és Renninger, 2006).

Az önjutalmazó (intrinzik) motiváció az olvasásban a magáért a tevékenységben lelt örömért és az eredményesség érzéséért történő olvasást elősegítő mozgatóerőt jelenti. Az önjutalmazó motiváció és a sztenderdizált szövegértési tesztek eredményei között pozitív összefüggés mutatkozik (Wigfield és Guthrie, 1997). Számos módja van annak, ahogyan egy tanár elősegítheti az olvasás iránti önjutalmazó motiváció fejlődését. Az egyik ilyen a kíváncsiság és az érdeklődés felkeltése. Az olvasási gyakorlatok tartalomba ágyazása jó lehetőséget kínál arra, hogy az olvasási tevékenységet egyéb, érdeklődést keltő, kézzelfogható vagy cselekvéses feladatokhoz kapcsoljuk. Ilyen feladatok például a természettudományokban a kísérletezések, a megfigyelések, a természetjárás vagy a társadalomtudományokban a történelmi események dramatizálása. Az ilyen jellegü, cselekvéses és életszerü tevékenységeket a szóban forgó életkorban a gyermekek általában élvezik. Az így létrejövő szituatív, kontextushoz kötődő érdeklődés könnyen alakítható viszonylag hosszabb távú érdeklődéssé a téma iránt (Hidi és Renninger, 2006). A cselekvéses, életszerü tevékenységek jó lehetőséget adnak a gyermekeknek, hogy megfogalmazzák saját kérdéseiket, majd azokra az olvasás útján keressék a válaszokat. Egy állatkerti séta után például számos kérdés fogalmazódik meg a gyermekekben egy-egy állat életével, szokásaival, biológiai felépítésével kapcsolatban. A kérdésekre a válaszokat releváns és érdekes szövegek feldolgozásával kaphatják meg.

Az olvasási önhatékonyság arra vonatkozik, hogy a tanuló saját megítélése szerint mennyire teljesítene jól egy-egy specifikus olvasási feladaton, például egy szó betűzésében. A magas önhatékonysággal rendelkező tanulók a nehéz olvasási feladatokat kihívásnak tekintik és kitartóan dolgoznak a megoldásukon (Schunk és Zimmerman, 1997). Az 
önhatékonyság alakulásában meghatározó szerepe van a tanári visszajelzéseknek. A rendszeres, személyre szabott értékelés (pl. portfolió formájában) segíti a tanulót, hogy reálisan lássa saját képességeit és reális célokat tüzzön ki maga elé. Az olvasási sikerek biztosítása szintén hozzájárul az önhatékonyság fejlődéséhez. Annak érdekében, hogy minden tanulónak legyen része kisebb-nagyobb sikerélményben a különböző fejlődési szinten álló tanulók számára különböző nehézségü, de azonos témájú szövegeket kell biztosítani. Ilyen módon a csoportmunkában azonos hozzájárulással vehetnek részt, miközben a saját fejlödési szintjükhöz közel álló, optimális kihívással járó szöveget dolgoznak fel. Az olvasási stratégiák tanitása szintén pozitív hatással bír az önhatékonyság érzésére (Wigfield, Guthrie, Tonks és Perencevich, 2004).

Stajkovich és Sommer (2000) szerint az attribúciók és az önhatékonyság között reciprok kapcsolat van, azaz egyik a másikat erősítheti és gyengítheti is, ezért az adaptív attribúciós stratégiák tanítása az önhatékonyságra is pozitív hatással van. Ebböl adódóan a tanári értékelés egy része az erőfeszítésre kell, hogy irányuljon, ezáltal erösítve a sikerek és a kudarcok erőfeszítésnek való tulajdonítását (Margolis és Mccabe, 2006).

A direkt fejlesztés mellett Graham és Williams (2009) az indirekt attribúciós hatásokra hívja fel a figyelmet. A tanárok viselkedésükkel, az általuk nyújtott értékelés eszközeivel és módszereivel indirekt attribúciós információkkal látják el a tanulókat. Ilyen például a túlzott segítségnyújtás, melynek indokát a tanulók a gyenge képességeikben látják. Ha tehát egy tanár túl sokszor segít egy tanulónak, a tanuló számára ez azt az információt hordozza, hogy az ő képességei nem megfelelőek, hiszen saját erőfeszítései a tanár szerint nem elegendőek a feladat megoldásához. Hasonlóképp müködik a túlzott dicséret vagy jutalmazás is: a viszonylag kis teljesítményért járó elismerés könnyen kiválthat olyan teljesítményattribúciókat, miszerint a diák képességei alacsonyak, ezért a kis teljesítmény is jutalmat érdemel.

Az olvasás szociális motívumai szintén fejleszthetők osztálytermi kontextusban (Wigfield és Guthrie, 1997). A könyvismertetések, könyvajánlók az iskolában jó lehetőséget teremtenek az olvasmányélmények megosztására, ezek gyakori megrendezése a szokásformálás egyik eszköze is lehet. Az olvasásórán vagy irodalomórán a tanulók együttmüködésére építő (kollaboratív) olvasási feladatok megoldása produktív társas helyzeteket is teremtenek. Ha a tanulóknak lehetőségük van kérdéseiket, a szövegben található érdekességeket és az újonnan szerzett információkat megosztani társaikkal, akkor az hatással van önjutalmazó motivációjukra és az önhatékonyságukra is (Gambrell, Mazzoni és Almasi, 2000).

Az előző néhány bekezdésben a motívumfejlesztés technikáit, módszereit egyesével tárgyaltuk. A sikeres fejlesztéshez azonban szükséges az alapelvek közötti koherencia megteremtése. A tanár részvétele nem csupán a személyre szabott értékeléshez szükséges, a megfelelő szövegek kiválasztásában, az érdeklődést kiváltó tevékenységek megszervezésében ugyanannyi szerepe van a tanulók fejlettségi szintjének, személyes érdeklődésének ismeretének, mint a portfoliók értékelésében. A sikerek biztosítása a tanulói autonómia támogatásával együtt még inkább növeli az önhatékonyság érzést, akárcsak a tanulási célok párosítása a megfelelő olvasási stratégiákkal. 


\section{AZ EMPIRIKUS KUTATÁS}

\section{Az empirikus kutatás célja és koncepciója}

Empirikus kutatásunk célja, hogy feltárjuk a hazai 8-14 éves tanulók olvasási motivációjának jellemzőit, motívumaik fejlődését, valamint az azt befolyásoló tényezőket. Központi kutatásunkban az olvasási motiváció többmotívumos vizsgálatát valósítottuk meg, azaz egyszerre több, a szakirodalom által azonosított tanulási és olvasási motívumot vizsgáltunk az olvasás területén. A központi mérés fontos előzményének tekinthető két korábbi vizsgálatunk, amelyek közül az első az olvasási motiváció egy komponensére irányult, míg a második maga az olvasási motiváció mint önálló konstruktum egydimenziós vizsgálatára tett kísérletet. Az első - Józsa Krisztiánnal közösen végzett - vizsgálatunk középpontjában az olvasási énkép mint a tanulási énkép egyik alapvető komponense állt (Szenczi és Józsa, 2008, 2009). A második kutatás az egydimenziós olvasási motivációt vizsgálta többségi és tanulásban akadályozott tanulóknál. A kutatásban Józsa Krisztián, Fazekasné Fenyvesi Margit és Kelemen Rita és Szenczi Beáta vett részt (Józsa és Fazekasné, 2008; Kelemen, Józsa és Szenczi, 2010). A központi mérés kiegészítő vizsgálataként leendő és gyakorló pedagógusok olvasással, olvasástanítással és olvasási motivációval kapcsolatos meggyőződéseit tártuk fel egy kismintás kvalitatív és kvantitatív módszereket is alkalmazó kutatás keretében. Ez utóbbi felmérést Nagy Zsuzsannával közös mintán végeztük.

A következő fejezetekben elsőként a két előzmény mérés célját, hipotéziseit és eredményeit mutatjuk be. Ezt követően a központi vizsgálat koncepcióját és hipotéziseit, majd az eredményeket tárgyaljuk részletesen. Az empirikus rész végén a kiegészítő vizsgálat koncepcióját és eredményeit közöljük.

\section{Az első pilot mérés}

\subsection{Az első pilot mérés kérdései és hipotézisei}

A tanulási motívumok területspecifikus jellegére elsőként a tanulmányi énkép kutatásai mutattak rá. Kezdetben az énképmodellek kidolgozása párhuzamosan történt az intelligenciamodellekkel, így nem meglepő, hogy az elsőként elkészült énképstruktúrák csupán egyetlen faktorral számoltak. Az egydimenziós, általános faktor modell szerint az énkép vagy csupán egyetlen faktorból áll (Piers, 1969), vagy az összes faktort egyetlen általános faktor dominálja (Coopersmith, 1967). E tekintetben ez a megközelítés Spearman kétfaktoros intelligenciamodelljére emlékeztet. A Guilford-féle 120 faktoros intelligenciamodell inspirálta a Tennessee Self Concept Instrument (Fitts, 1965) alapját képező énképmodellt. A többdimenziós énképstruktúrában az 5 külső alskálát (fizikai, erkölcsi, individuális, családi és szociális énkép) a 3 belső alskálát (identitás, elégedettség, viselkedés) különböztet meg. A belső skálák a külsők mindegyikében megnyilvánulnak, 15 alskálát alkotva. Bár a Tennessee Self Concept Instrument nem bizonyult az énképvizsgálatok megbízható méröeszközének (Marsh és Richards, 1988), a modell, amelyen alapul, egyedülálló az énképku- 
tatásban és alapjául szolgált a további kutatásoknak is, amelyek az énképet mint sokösszetevős rendszert vizsgálják.

A legszélesebb körben elismert énképmodell kidolgozása Shavelson, Hubner és Stanton (1976) nevéhez köthető. Hierarchikus, sokösszetevős modelljük alapjául szolgál a témában folytatott szinte valamennyi további kutatásnak. Shavelson és munkatársai elméleti modelljükben az énképet egy olyan hierarchikus rendszernek mutatták be, amely különböző csomópontok és dimenziók mentén szerveződik. A hierarchia csúcsán az általános énkép áll, a következő szinten a tanulmányi és a nem tanulmányi énkép foglal helyet. A hierarchiában lefelé haladva az énkép egyre specifikusabb részeit találjuk meg, melyek között központi szerepet tölt be az olvasási énkép. Ez a modell egyébként alapjául szolgált és koncepciójában megfelel az éntudat Nagy József-i modelljének is (Nagy, 2000).

A shavelsoni modellt Marsh (1990) fejlesztette tovább felismerve, hogy az egyes énképkomponensek - például a tanulmányi énképhez köthető matematikai és anyanyelvi énkép - között az összefüggés nagyon gyenge, megközelítőleg nullával egyenlö (Marsh, 1993). Feltételezhető volt tehát, hogy nem létezik egyetlen általános tanulmányi énkép, hanem több egymástól relatív független tantárgyi és képességspecifikus énkép müködik egymás mellett. Az átdolgozott, empirikus adatokkal is alátámasztott modell ezért az egyes énképösszetevők között gyengébb, ám sokrétübb kapcsolatot feltételez, mindamellett, hogy az összetevők relatív önállóságát is figyelembe veszi. A Marsh/Shavelson-modell (1990) így ugyan megőrizte az eredeti modell struktúráját, ugyanakkor nem feltételez erös hierarchikus jelleget (Marsh, 1993). Az énképösszetevők közötti gyenge összefüggésröl számolt be - alátámasztva ezáltal a Marsh/Shavelson-modellt - továbbá Hattie (1992) és Józsa (1999) is.

A tanulmányi énkép strukturájára, a Marsh/Shavelson modell tesztelésére számos vizsgálat irányult világszerte. Nem ismeretes ugyanakkor olyan kutatás hazánkban, amely a nemzetközi trendeknek megfelelően vizsgálná a hazai tanulók tanuláshoz kötődő énképkomponenseit. Kutatásunkban ezért célul tüztük ki, hogy felderítsük, a hazai tanulók énképstruktúrája mennyiben egyezik meg a Marsh/Shavelson-féle modellnek, vajon kimutatható-e ugyanaz a területspecifikus jelleg, mint az ausztrál és az amerikai mintákon. Vizsgálatunk középpontjában a modellnek megfelelően a két központi képességspecifikus énkép állt: az olvasási énkép és a matematikai énkép.

Az első pilot vizsgálat kérdései négy nagyobb problémakör szerint szerveződnek:

1. Területspecifikusság: Azonosíthatók-e ugyanazok az énképkomponensek a hazai tanulók mintáján, mint a külföldi mintákon? Elkülönül-e az olvasási énkép más területspecifikus komponensektől vagy az elkülönülés kulturálisan meghatározott?

2. Az énképkomponensek jellemzői: Mi jellemzi a hazai általános iskolás korú tanulók énképkomponenseit? Hogyan alakulnak az egyes énképkomponensek jellemzői az életkor elörehaladtával? Milyen tendenciát mutat az olvasási énkép változása más énképkomponensekhez képest? Ugyanolyan tendencia figyelhető-e meg az egyes énképkomponsek alakulásában?

3. Belsö összefüggésrendszer: Milyen kapcsolatrendszer áll fenn a különbözö területspecifikus énképek között? Az egyes tantárgyi énképkomponensek alkotnak-e felsőbb szinten egy általános tanulási énképet, tehát létezik-e egy általános énkép? 
4. Az énképkomponensek és a teljesitmény összefüggése: Milyen összefüggés mutatható ki az énképkomponensek és a teljesítménymutatók között? Szorosabb összefüggés van-e a területspecifikus énképkomponensek és a megfelelő területen nyújtott teljesítmény között - például az olvasás énkép és a szövegértés-teljesítmény - mint az általános énkép és a tantárgyakat átfogó tanulmányi átlag között?

5. Külső összefüggésrendszer: Van-e összefüggés az énképkomponensek és a családi háttér, valamint a nem között? Van-e összefüggés a tantárgyak kedveltsége és a megfelelö tantárgyi énképek között? Mutatkozik-e összefüggés az IQ és az énképkomponensek között?

A szakirodalom alapján a következő hipotéziseket fogalmazzuk meg:

$H_{1}$ : Területspecifikusság: A szakirodalom által azonosított énképkomponensek a hazai tanulóknál is azonosíthatók, az egyes énképkomponensek elkülönülnek.

$\mathrm{H}_{2}$ : Az énképkomponensek jellemzői: Az általános iskolás tanulók pozitív tantárgyi énképekkel rendelkeznek, az egyes tantárgyi, valamint a nem tantárgyi énképkomponensek jellemzői is eltérnek egymástól. Az életkor növekedésével a tanuláshoz kötődő énképkomponensek romlanak, a tanuláshoz nem kötődő komponensek nem változnak. A tanulmányi énképkomponensek közül az olvasási énkép kevésbé romlik a matematikai énképhez képest.

$H_{3}$ : Belső összefüggésrendszer: Az énképkomponensek között közepes erősségü kapcsolatok vannak. Az énképkomponensek hierarchiát alkotnak, a tanulmányi énképkomponensek a felsőbb szinteken egy tanulmányi énképbe, a felsőbb szintek egy minden énképkomponenst átfogó általános énképpé szerveződnek a hierarchia csúcsán. Az életkor növekedésével az alsóbb szinteken az összefüggések gyengülnek, a tanulók saját képességeikkel kapcsolatos elképzelései egyre differenciáltabbá válnak.

$H_{4}$ : Az énképkomponensek és a teljesitmény összefüggése: Az énkép és a teljesítmény között pozitív irányú kapcsolatot feltételezünk. Az egyes területspecifikus énképkomponensek legszorosabban az adott területen nyújtott teljesítménnyel függnek össze, például az olvasási énkép szoros kapcsolatban áll az olvasás-szövegértés teljesítménynyel és az olvasás/irodalom osztályzattal.

$H_{5}$ : Külső összefüggésrendszer: Az énképkomponensek összefüggésben állnak a családi háttér egyes jellemzőivel és az IQ-val. Az egyes tantárgyak kedveltsége és a megfelelő tantárgyi énképek között szoros pozitív kapcsolatot feltételezünk, a tanulók azokat a tantárgyakat kedvelik, amelyekben jónak látják saját teljesítményüket. Szignifikáns nemek közötti különbségeket feltételezünk továbbá az egyes énképkomponensek jellemzőit illetően.

\subsection{Adatfelvétel, minta és mérőeszközök az első pilot mérés során}

A hazai tanulók énképkomponenseinek vizsgálatához a Shavelson és munkatársai által kidolgozott énképmodellt alapul vevő Shavelson/Marsh modell alapján kifejlesztett SDQ I. (Self-Description Questionnaire I.) méröeszközt adaptáltuk. A magyar nyelvü adaptált mérőeszköz (1. melléklet) az eredeti, angol nyelvű változathoz hasonlóan egy 76 itemből álló ötfokú Likert-skálás önértékelő kérdőív, mely prepubertás korú gyermekek énképét 
vizsgálja. A válaszadónak rövid állításokat kell értékelnie annak megfelelően, hogy menynyire igazak rá az adott állítások. A lehetséges válaszok a „hamis”-tól (1) az ,igaz”-ig (5) terjednek. A közbülső válaszlehetőségek: „többnyire hamis” (2), „néha igaz, néha hamis” (3), „többnyire igaz” (4).

Az SDQI által vizsgált énképösszetevők megegyeznek az alapjául szolgáló modell egyes komponenseivel: (1) fizikális képességek (physical abilities) énkép, (2) fizikai megjelenés (physical appearance) énkép (a továbbiakban a hazai terminusnak megfelelően „testkép”), (3) olvasás (reading) énkép, (4) matematika (mathematics) énkép, (5) kortársakkal való kapcsolat (peer relations) énkép, (6) szülőkkel való kapcsolat (parent relations) énkép, (7) általános én (general self), (8) iskolával kapcsolatos (general school) énkép. Az egyes faktorok részletes leírását az 4. táblázat tartalmazza. A nem tanulmányi énkép esetén minden egyes faktorhoz kilenc item tartozik, míg a tanulmányi énképhez köthető összetevőkhöz tíz.

A mérőeszköz fordításakor figyelembe vettük a Nemzetközi Teszt Bizottság (International Test Commission, ITC) pedagógiai és pszichológiai mérőeszközök fordításával kapcsolatos követelményeit (Van de Vijver és Hambleton, 1996), illetve a kifejezetten az SDQ (Self-Description Questionnaire) mérőeszközök fordítására vonatkozó elöírásokat (Byrne, 2000). A magyar nyelvü mérőeszköz skáláinak reliabilitásmutatói 0,72 és 0,91 közöttiek; az olvasásiénkép-skála reliabilitása a Cronbach- $\alpha$ mutató alapján 0,90. A tanulók egy háttérkérdőívet is kitöltöttek, mely a nemükre, családi hátterükre, iskolai és tantárgyi attitüdjeikre valamint érdemjegyeikre vonatkozó kérdéseket tartalmazott. A vizsgálatban öt település, Okány, Sarkad, Zsadány, Méhkerék és Kötegyán 3. (N=218), 5. ( $\mathrm{N}=194)$ és 7. $(\mathrm{N}=174)$ osztályos tanulói $(\mathrm{N}=586)$ vettek részt. A nemek aránya mindhárom részmintában azonosnak. A fiúk aránya harmadik osztályban 59\%, ötödikben 56\%, hetedikben pedig 51\%. Az adatfelvételre 2008 elején került sor.

4. táblázat. Az elsö pilot mérés(2008) mintája (fö)

\begin{tabular}{lccc}
\hline \hline \multicolumn{1}{c}{ Korcsoport } & $n$ & Fiú & Lány \\
\hline 3. évfolyam & 218 & 128 & 90 \\
5. évfolyam & 194 & 109 & 85 \\
7. évfolyam & 174 & 89 & 85 \\
\hline Összesen & 586 & 326 & 260 \\
\hline \hline
\end{tabular}

\subsection{Az első pilot mérés eredményei}

Az SDQ kérdőív magyar adaptációjával végzett vizsgálatunk alátámasztotta az énkép területspecifikusságát. A faktoranalízis alapján az eredeti Marsh/Shavelson-féle énképmodell rajzolódott ki.

A 5., 6. és 7. táblázat az énképkomponensek közötti összefüggéseket mutatja évfolyamonként. A 3. évfolyamon az énkép majdnem valamennyi komponense korrelál a többi komponenssel. A fizikális képességekre vonatkozó énkép erős összefüggést mutat a kortárskapcsolat és a testképpel. Alsó tagozatban a gyermekek gyakran játszanak olyan játékokat, melyben a fizikális képességek, az ügyesség nagy szerepet játszik. Azok a gyerme- 
kek, akik érdeklődnek az ilyen jellegü játékok iránt és úgy érzik, jól teljesítenek ezekben, valószínüleg könnyebben szereznek barátokat, mint társaik. Így tehát a fizikális képességek feltehetően nagy szerepet játszanak a gyermekek azzal kapcsolatos vélekedésiben, hogy mennyire népszerüek, elfogadottak saját kortársaik körében. Az életkor növekedésével az énkép e két összetevője között az összefüggés egyre gyengül, ahogyan az a korrelációk mátrixából is látható.

A kortárskapcsolatok énképpel a legerősebb korrelációt a testkép mutatja a 3. és az 5. évfolyamon. A korreláció a két komponens között még a 7. évfolyamon is szignifikáns, itt azonban már gyengébb az összefüggés. Bár a két változó közötti ok-okozati viszonyt nem ismerjük, feltételezhető, hogy a vonzóbb külsővel rendelkező, magabiztosabb tanulók több baráttal rendelkeznek, magukat népszerübbnek élik meg, mint kevésbé vonzó, vagy magukat kevésbé vonzónak tartó kortársaik. Azonban elképzelhető az is, hogy éppen a népszerütlenség érzése miatt vélheti egy-egy tanuló saját külsejét kevésbé előnyösnek.

Ami az egyes tantárgyi énképeket illeti, az életkor növekedésével egyre kevésbé vannak hatással a tanulók énképének más összetevőire. Míg 3. évfolyamon az olvasási és a matematikai énkép a fizikális képességek énképen kívül valamennyi énképkomponenssel szignifikáns korrelációt mutat, addig 7. évfolyamon a matematikai énkép a többi hat komponens közül csupán kettővel, az olvasási énkép pedig hárommal mutat szignifikáns összefüggést. Ugyanakkor a tantárgyi énképek mindhárom évfolyamon erősen korrelálnak az iskolai énképpel. Mindez azonban nem meglepö, hiszen a serdülőkor közeledtével az énkép iskolához nem kapcsolódó komponensei feltételezhetően hangsúlyosabbá válnak az egyén énképének alakulásában, míg a tantárgyi énképek kizárólag az iskolához, tanuláshoz szorosan kötődő komponenseket kezdik alakítani.

5. táblázat. Az énképösszetevők közötti korrelációk, 3. osztály

\begin{tabular}{|c|c|c|c|c|c|c|c|c|}
\hline Énképösszetevők & $\begin{array}{c}\text { Fizikális } \\
\text { kép. } \\
\text { énkép }\end{array}$ & Testkép & $\begin{array}{c}\text { Olvasás } \\
\text { énkép }\end{array}$ & $\begin{array}{l}\text { Mat. } \\
\text { énkép }\end{array}$ & $\begin{array}{c}\text { Kortárs- } \\
\text { kapcs. } \\
\text { énkép }\end{array}$ & $\begin{array}{l}\text { Szülö- } \\
\text { kapcs. } \\
\text { énkép }\end{array}$ & $\begin{array}{c}\text { Ált. } \\
\text { énkép }\end{array}$ & $\begin{array}{l}\text { Iskolai } \\
\text { énkép }\end{array}$ \\
\hline \multicolumn{9}{|l|}{ Fizikális kép. énkép } \\
\hline Testkép & $0,41 * *$ & & & & & & & \\
\hline Olvasás énkép & 0,07 & $0,33 * *$ & & & & & & \\
\hline Matematika énkép & 0,12 & $0,20 * *$ & $0,34 * *$ & & & & & \\
\hline Kortárskapcs. énkép & $0,44 * *$ & $0,66^{* *}$ & $0,30 * *$ & $0,18^{*}$ & & & & \\
\hline Szülőkapcs. énkép & $0,26 * *$ & $0,47 * *$ & $0,41 * *$ & $0,34 * *$ & $0,56^{* *}$ & & & \\
\hline Általános énkép & $0,34 * *$ & $0,64 * *$ & $0,51 * *$ & $0,41 * *$ & $0,64 * *$ & $0,66^{* *}$ & & \\
\hline Iskolai énkép & $0,16^{*}$ & $0,35 * *$ & $0,74 * *$ & $0,53 * *$ & $0,33 * *$ & $0,45^{* *}$ & $0,55^{* *}$ & \\
\hline
\end{tabular}

Megjegyzés: ** 0,01 szinten szignifikáns; $* 0,05$ szinten szignifikáns 
6. táblázat. Az énképösszetevök közötti korrelációk, 5. osztály

\begin{tabular}{|c|c|c|c|c|c|c|c|c|}
\hline Énképösszetevők & $\begin{array}{c}\text { Fizikális } \\
\text { kép. } \\
\text { énkép }\end{array}$ & Testkép & $\begin{array}{c}\text { Olvasás } \\
\text { énkép }\end{array}$ & $\begin{array}{l}\text { Mat. } \\
\text { énkép }\end{array}$ & $\begin{array}{c}\text { Kortárs- } \\
\text { kapcs. } \\
\text { énkép }\end{array}$ & $\begin{array}{l}\text { Szülö- } \\
\text { kapcs. } \\
\text { énkép }\end{array}$ & $\begin{array}{c}\text { Ált. } \\
\text { énkép }\end{array}$ & $\begin{array}{l}\text { Iskolai } \\
\text { énkép }\end{array}$ \\
\hline \multicolumn{9}{|l|}{ Fizikális kép. énkép } \\
\hline Testkép & $0,45^{* *}$ & & & & & & & \\
\hline Olvasás énkép & 0,02 & $0,19 * *$ & & & & & & \\
\hline Matematika énkép & 0,13 & $0,18 *$ & $0,39 * *$ & & & & & \\
\hline Kortárskapcs. énkép & $0,37 * *$ & $0,64 * *$ & $0,23 * *$ & $0,26 * *$ & & & & \\
\hline Szülőkapcs. énkép & $0,18^{*}$ & $0,24 * *$ & $0,32 * *$ & $0,31 * *$ & $0,32 * *$ & & & \\
\hline Általános énkép & $0,39 * *$ & $0,62 * *$ & $0,42 * *$ & $0,32 * *$ & $0,63 * *$ & $0,42 * *$ & & \\
\hline Iskolai énkép & $0,18^{*}$ & $0,39 * *$ & $0,66 * *$ & $0,62 * *$ & $0,39 * *$ & $0,41 * *$ & $0,61 * *$ & \\
\hline
\end{tabular}

Megjegyzés: ** 0,01 szinten szignifikáns; $* 0,05$ szinten szignifikáns

7. táblázat. Az énképösszetevők közötti korrelációk, 7. osztály

\begin{tabular}{|c|c|c|c|c|c|c|c|c|}
\hline Énképösszetevők & $\begin{array}{c}\text { Fizikális } \\
\text { kép. } \\
\text { énkép }\end{array}$ & Testkép & $\begin{array}{c}\text { Olvasás } \\
\text { énkép }\end{array}$ & $\begin{array}{l}\text { Mat. } \\
\text { énkép }\end{array}$ & $\begin{array}{c}\text { Kortárs- } \\
\text { kapcs. } \\
\text { énkép }\end{array}$ & $\begin{array}{l}\text { Szülö- } \\
\text { kapcs. } \\
\text { énkép }\end{array}$ & $\begin{array}{c}\text { Ált. } \\
\text { énkép }\end{array}$ & $\begin{array}{l}\text { Iskolai } \\
\text { énkép }\end{array}$ \\
\hline \multicolumn{9}{|l|}{ Fizikális kép. énkép } \\
\hline Testkép & $0,38 * *$ & & & & & & & \\
\hline Olvasás énkép & 0,05 & 0,03 & & & & & & \\
\hline Matematika énkép & $0,16^{*}$ & 0,06 & $0,15^{*}$ & & & & & \\
\hline Kortárskapcs. énkép & $0,34 * *$ & $0,56^{* *}$ & 0,13 & $0,18 *$ & & & & \\
\hline Szülőkapcs. énkép & 0,09 & $0,23 * *$ & $0,37 * *$ & 0,12 & $0,32 * *$ & & & \\
\hline Általános énkép & $0,29 * *$ & $0,68 * *$ & $0,19 * *$ & $0,21 * *$ & $0,68 * *$ & $0,44 * *$ & & \\
\hline Iskolai énkép & $0,20 * *$ & $0,19 * *$ & $0,63 * *$ & $0,49 * *$ & $0,22 * *$ & $0,36 * *$ & $0,42 * *$ & \\
\hline
\end{tabular}

Megjegyzés: ** 0,01 szinten szignifikáns; ${ }^{*} 0,05$ szinten szignifikáns

Harmadik évfolyamon a korrelációk általában erősebbek, mint ötödik évfolyamon, ötödik évfolyamon pedig erősebbek, mint a hetedik évfolyamon. Ebböl következik, hogy az énkép struktúrája valószínüleg jelentős változáson megy keresztül az évek folyamán, amelynek eredményeként az énképösszetevők közötti kapcsolatok gyengülnek. A komponensek közötti egyre gyengülő kapcsolatokból az következik, hogy a tanulók énképét az életkor növekedésével egyre kevésbé jellemezhetjük egyetlen mutatóval. Ehelyett az egyes komponenseket külön kell kezelnünk, azaz azok mérése és fejlesztése is külön kell, hogy történjék. Az énképösszetevők közötti összefüggésrendszert a három évfolyamon a 9., a 10. és a 11. ábra jeleníti meg. 


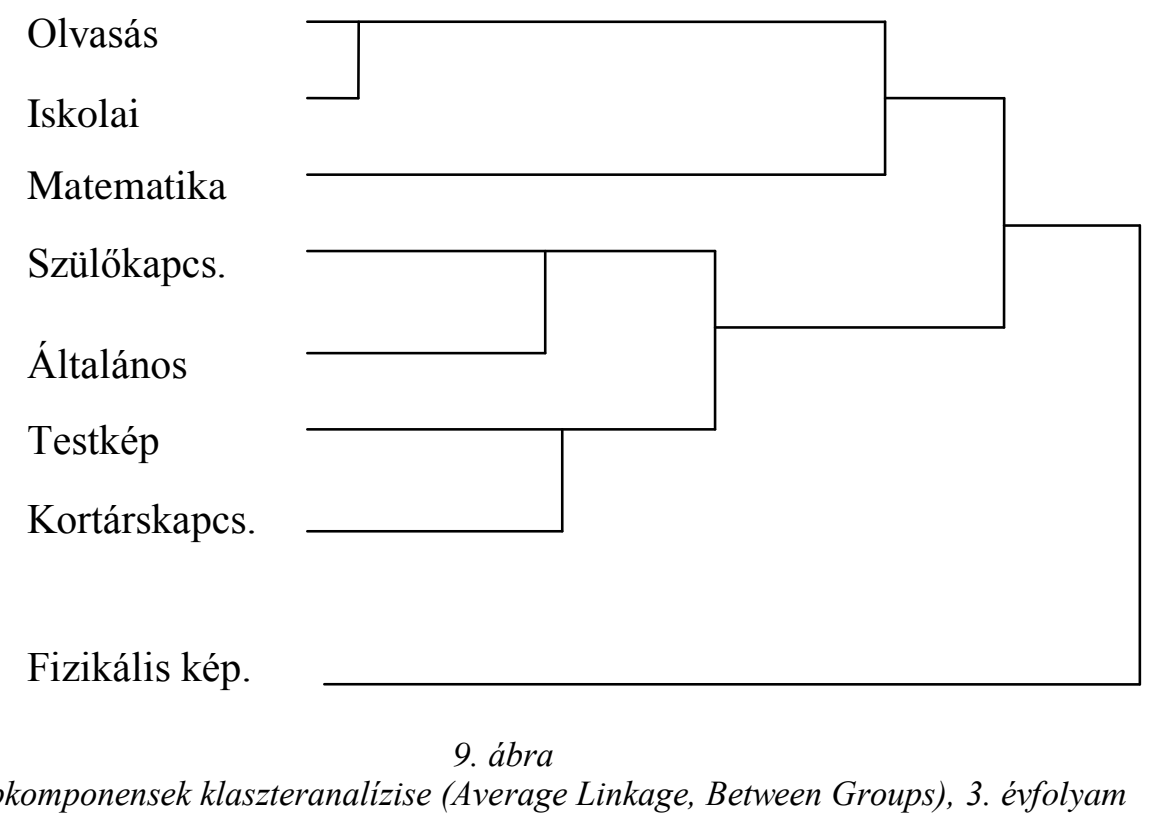

Az énképkomponensek klaszteranalizise (Average Linkage, Between Groups), 3. évfolyam

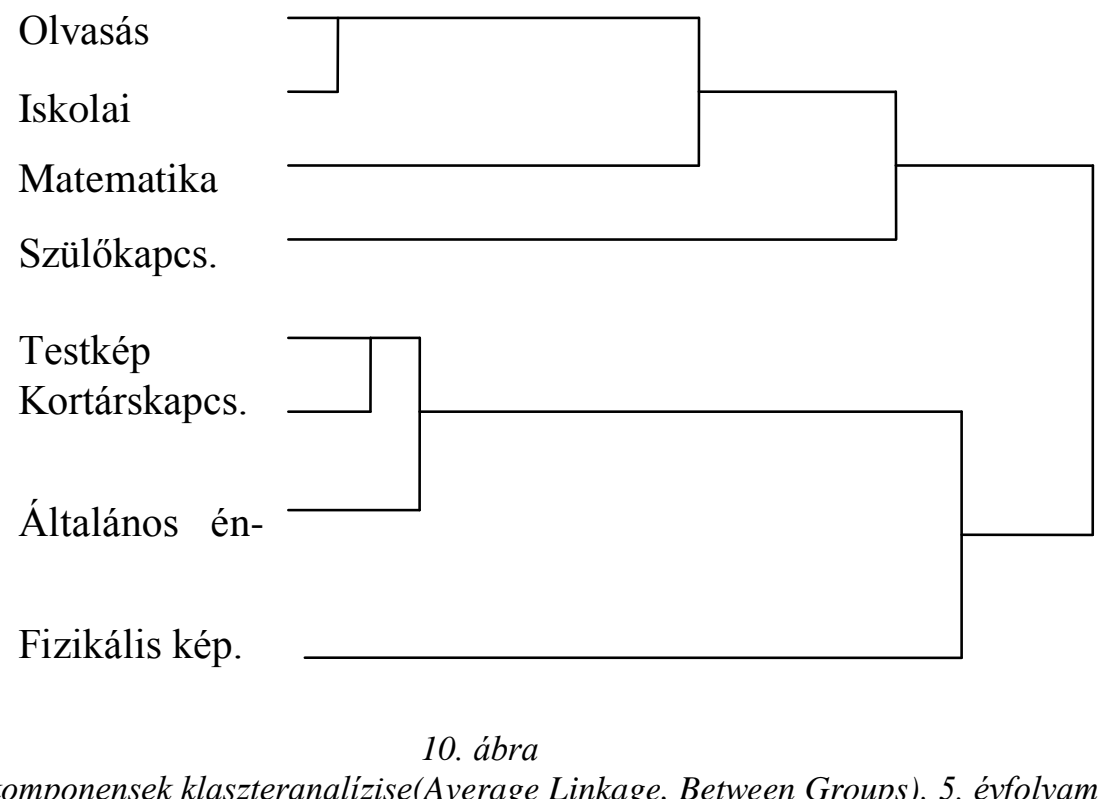

Az énképkomponensek klaszteranalízise(Average Linkage, Between Groups), 5. évfolyam 


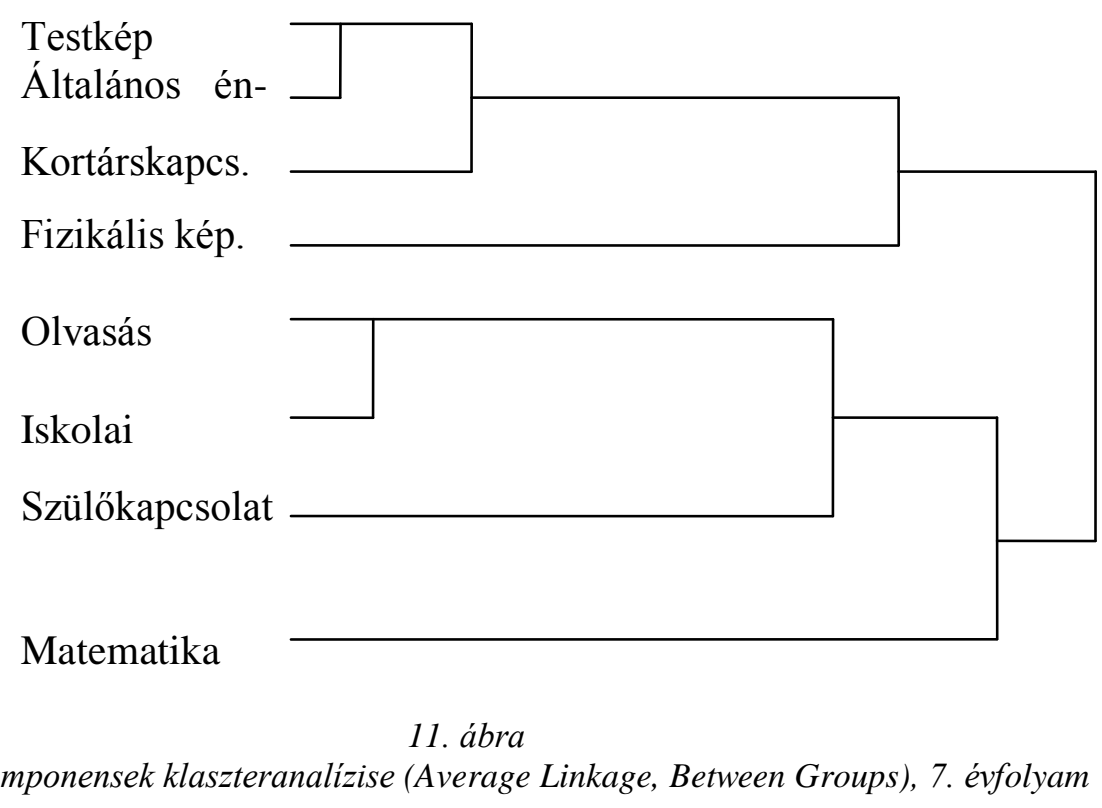

A klaszteranalízis 3. évfolyamon az összetevőket két nagy fürtbe rendezi. Egy fürtté állt össze az olvasási, az iskolai és a matematika énkép, míg a szülőkkel való kapcsolat énkép, az általános énkép, a testkép és a kortárskapcsolat énkép egy újabb fürtöt alkotnak. Ez alapján indokolható lehetne a tanulmányi és a nemtanulmányi énkép elkülönítése a Shavelson és mtsai (1976) által kidolgozott énképmodell értelmében, azonban az ötödik és a hetedik évfolyamosok válaszai alapján kapott eredmények már kevésbé támasztják alá e modellt.

A 4. ábráról, mely az ötödikes tanulók válaszaira épül, jól leolvasható viszont, hogy egyfajta átrendeződés ment végbe, melynek eredményeként az első szinten egy fürtté rendeződő olvasás, matematika és iskolai énkép mellé a következő szinten a szülőkapcsolat énkép kapcsolódik. A testkép, a kortárskapcsolat énkép és az általános énkép egy másik fürtté szerveződik, melyhez a következő szinten kapcsolódik a fizikális képességek énkép.

Hetedik évfolyamon az átrendeződés még szembetünőbb (11. ábra). Az általános énképhez szorosan kapcsolódik a testkép és a kortárskapcsolatok énkép, mutatva ezzel a serdülökor közeledtével egyre fontosabbá váló kortárskapcsolatok és a testkép, a fizikális megjelenés kiemelt szerepét az énképben. Ezt a gyakran ,átpártolás”-nak is nevezett jelenség (Mérei és Binét, 2003) a tanulási motiváció szempontjából is fontos: Zsolnai (1998) szerint 12 éves kor után a tanulást segítő motívumok szempontjából a család motiváló hatása kevésbé meghatározó, mint azelőtt. Serdülőkorban és azt követően a kortársak szerepe erőteljesebb a szülőkénél.

Külön fürtöt alkot az olvasás és iskolai énkép, melyhez a matematika énkép csupán a harmadik kapcsolódási szinten csatlakozik. A hazai eredmények is alátámasztják tehát Marsh és Shavelson (1985) megállapítását, miszerint a matematika és olvasás énképeket nem lehet egyetlen mutatóval jellemezni, nem sorolhatók egy általános tanulási énkép alá.

A klaszteranalízis eredményei alapján az is megállapítható, hogy az énkép struktúrája a vizsgált évfolyamokon eltérő; egyes komponensek között gyengül, míg máshol erősödik a kapcsolat. A klaszterábráról jól leolvasható, hogy az iskolai általános énkép legszorosabban az olvasás énképhez kapcsolódik, míg a kettő alkotta fürthöz minden évfolyamon a matematika csak távolabbról kapcsolódik. Ez az eredmény alátámasztja azt a feltételezést, miszerint az olvasási énkép központi helyet kap a teljes iskolai énkép alakulásában. 
Az SDQ méröeszközök fejlesztésekor az énkép életkori változásait figyelembe véve Marsh és munkatársai három korosztály számára három külön kérdőívet dolgoztak ki. Azonban feltételezhetö, hogy a fejlődés folytonos, így az az egyes életkori szakaszokon belül is kimutatható. Mivel mintánkban prepubertás korú tanulók három korcsoportja is szerepelt, lehetőség van a prepubertás koron belüli változások feltérképezésére. A 8. táblázat az énképösszetevők átlagait és szórását mutatja évfolyamonként. A szórások közötti különbségek a kortárskapcsolat, a szülőkkel való kapcsolat, és az általános énkép esetén nem szignifikánsak, a többi komponens esetén az egyes életkorok között a különbség szignifikáns. A vizsgált életszakaszban a legnagyobb, közel azonos mértékü, változás a matematikai énképben és az iskolai énképben következik be, ezt követi az olvasási énkép, a fizikális képességek énkép és a testkép.

8. táblázat. Az énképösszetevők átlagai és szórásai, ANOVA

\begin{tabular}{lccccccc}
\hline \multirow{2}{*}{ Énképösszetevök } & \multicolumn{2}{c}{ 3. osztály } & \multicolumn{2}{c}{5. osztály } & \multicolumn{2}{c}{ 7. osztály } & \multirow{2}{*}{$F$} \\
\cline { 2 - 6 } & átlag & szórás & átlag & szórás & átlag & szórás \\
\hline Fizikális képességek énkép & 78,77 & 18,74 & 72,10 & 23,57 & 69,06 & 22,52 & 9,49 \\
Testkép & 70,00 & 21,91 & 62,96 & 22,46 & 61,58 & 23,16 & 7,25 \\
Olvasás énkép & 71,57 & 23,24 & 69,55 & 23,06 & 60,76 & 23,57 & 11,82 \\
Matematika énkép & 73,87 & 21,40 & 66,42 & 24,96 & 52,70 & 26,79 & 36,22 \\
Kortárskapcsolat énkép & 71,96 & 18,57 & 69,81 & 17,75 & 69,13 & 18,56 & $1,18^{\mathrm{NS}}$ \\
Szülökapcsolat énkép & 87,27 & 12,27 & 85,72 & 11,86 & 84,80 & 14,48 & $1,71^{\mathrm{NS}}$ \\
Általános énkép & 77,06 & 16,82 & 76,62 & 15,83 & 75,08 & 17,58 & $0,75^{\mathrm{NS}}$ \\
Iskolai énkép & 70,89 & 18,89 & 62,44 & 19,38 & 54,21 & 18,64 & 36,23 \\
\hline \hline Megjegyzés: NS = nem szignifikáns; az összes többi 0,05 szinten szignifikáns & & &
\end{tabular}

A 12. ábra az egyes énképkomponensek életkori változását mutatja. Összességében megállapítható, hogy a legtöbb énképkomponens a vizsgált életkorban vagy stagnál, vagy csökkenő, romló tendenciát mutat. Harmadiktól hetedik évfolyamig a tanulók összes iskolával és tanulással kapcsolatos énképösszetevője csökken, általános énképük, bár kismértékben, de romlik.

A legszembetünőbb az iskolai énkép nagymértékü, negatív irányú változása. Harmadik évfolyamon az iskolai énkép átlaga $71 \%$ p, hetedik évfolyamra ugyanez $54 \%$ p, azaz harmadiktól hetedikig a tanulók iskolai énképe 17\%p-os csökkenésen megy keresztül. Hasonlóan alakul a matematikai énkép is: míg harmadik osztályban ennek átlaga 74\%p, addig hetedik osztályban 53\%p, azaz a csökkenés $21 \%$ p-os. Mind a két összetevő esetén szignifikáns a különbség a harmadikosok és az ötödikesek, valamint az ötödikesek és a hetedikesek átlagai között is, ám míg az iskolai énkép esetén a romlás folyamatos és azonos intenzitású harmadiktól hetedikig, a matematika énkép esetén a kezdeti lassabb romlást ötödiktől nagyobb intenzitású romlás jellemzi. 


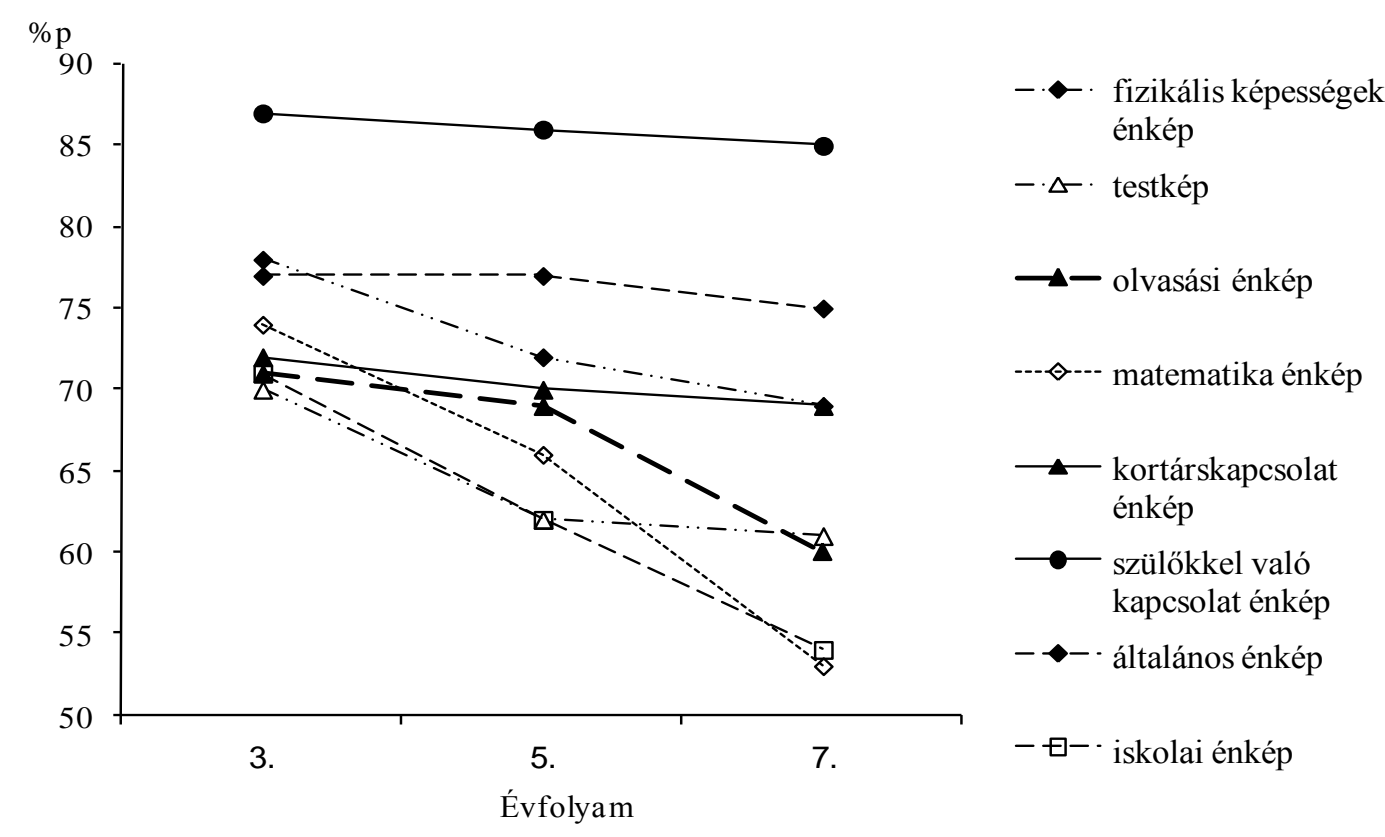

12. ábra

Az énkép egyes összetevőinek életkori változása

Az egyes énképösszetevők eloszlása (2. melléklet) azt mutatja, hogy az iskolai énkép és a matematika énkép esetén is a legnagyobb különbség az évfolyamok között azok számában van, akik a legjobb énképpel rendelkeznek. Míg például a matematika énkép esetén a harmadik osztályosok több mint 26\%-a értékeli saját matematikai, számolási képességeit, készségeit, érdeklödését kiválónak, addig a hetedik évfolyamon ugyanez az arány már csak alig több mint $10 \%$. Az iskolai énkép esetén is hasonló a helyzet: harmadik évfolyamon a tanulók 14\%-a értékeli saját tantárgyakhoz kapcsolódó attitüdjeit, készségeit, képességeit, érdeklődését kiválónak, ötödikre ugyanez az arány már csak 4,7\%, hetedikre pedig 2,5\%.

Ehhez hasonló, bár valamivel kisebb arányú változáson megy keresztül az olvasási énkép is. Harmadik osztálytól ötödik osztályig nem megy végbe szignifikáns változás az énkép alakulásában, hetedik osztályig azonban szignifikáns, 11\%p-os, romlás tapasztalható itt is. Ez az eredmény összhangban van azokkal a hazai és nemzetközi kutatásokkal, amelyek a felső tagozatba lépés okozta változásokkal magyarázzák az iskolai évek alatt a tanulási motivációban bekövetkező változásokat. Hasonlóan a matematika és az iskolai énkép változásaihoz, az olvasási énkép esetében is a legnagyobb különbség azoknak a számában jelentkezik, akik a legmagasabban értékelték saját olvasási képességeiket, készségeiket.

A saját külső, a fizikai megjelenés megítélésében a harmadik és az ötödik évfolyamok között mutatható ki szignifikáns romlás csakúgy, mint a fizikális képességek értékelésében. A kortárskapcsolatok énképben, a szülőkapcsolat énképben és az általános énképben szignifikáns változás nem megy végbe a vizsgált életszakaszban. Azonban pozitívum, hogy a legtöbb komponens esetén az eloszlási görbe jobbra tolódik, ami azt jelenti, hogy többen vannak azok, akik az átlagosnál jobb énképpel rendelkeznek. Kivétel ez alól a hetedikesek iskolai énképe, mely standard eloszlást mutat.

Az énkép és a tanulmányi eredmények összefüggésére számos kutató rámutatott (Hansford és Hattie, 1982; Byrne, 1984; Marsh és Craven, 1997), vizsgálataik alapján a 
két változó közötti hatás reciprok (Marsh, 1990; Guay, Marsh és Boivin, 2003; Van Damme és munkatársai, 2004). Bár két változó közötti ok-okozati viszony megállapításához longitudinális vizsgálatra lenne szükség, keresztmetszeti vizsgálatunkban is lehetőség van az említett változók, a tanulmányi eredmények és az énkép egyes összetevői közötti összefüggések vizsgálatára.

A 9. és 10. táblázat az egyes énképösszetevők és érdemjegyek közötti korrelációs együtthatókat mutatja ötödik és hetedik évfolyamon. A tantárgyi érdemjegyek és a tanulmányi átlag mellett a magatartás- és szorgalomjegyeket is vizsgáljuk, hiszen ezek a tanárok tanulóról alkotott globális képének mutatói. A két vizsgált tantárgyi énkép érdemjegyei mellett a nyelvtanjegyeket is szerepelnek, hiszen a hazai tantárgyi rendszerben ezek gyakran együtt jelennek meg. Az érdemjegyek a tanulók 2007/2008. évi félévi jegyei.

Mindkét évfolyam esetén az egyes tantárgyi énképek, illetve az iskolai énkép szorosan kapcsolódik az érdemjegyekhez. A tanulók saját tantárgyakkal és iskolával kapcsolatos képességeikről, érdeklődésükről való vélekedéseik szoros összefüggésben állnak a kapott érdemjegyekkel: a reciprokhatás-modell (Marsh, 1990) alapján feltételezhetően kölcsönösen gyengítik vagy erősítik egymást. Az általános énkép 0,2-0,3 körüli korrelációt mutat a jegyekkel, amely megegyezik a Hansford és Hattie (1982) által elemzett kutatások eredményeivel.

9. táblázat. Az énképösszetevők és a tanulmányi eredmények korrelációja, 5. osztály

\begin{tabular}{lcccccccc}
\hline \hline Énképösszetevök & $\begin{array}{c}\text { Fizikális } \\
k e ́ p . \\
\text { énkép }\end{array}$ & Testkép & $\begin{array}{c}\text { Olvasási } \\
\text { énkép }\end{array}$ & $\begin{array}{c}\text { Mat. } \\
\text { énkép }\end{array}$ & $\begin{array}{c}\text { Kortárs- } \\
\text { kapcs. } \\
\text { énkép }\end{array}$ & $\begin{array}{c}\text { Szülö- } \\
\text { kapcs. } \\
\text { énkép }\end{array}$ & $\begin{array}{c}\text { Alt. } \\
\text { énkép }\end{array}$ & $\begin{array}{c}\text { Iskolai } \\
\text { énkép }\end{array}$ \\
\hline Matematikajegy & $-0,01$ & $-0,06$ & $0,30^{* *}$ & $0,51^{* *}$ & $0,15^{*}$ & $0,16^{*}$ & $0,24^{* *}$ & $0,39^{* *}$ \\
Nyelvtanjegy & $-0,13$ & $-0,02$ & $0,44^{* *}$ & $0,26^{* *}$ & 0,11 & 0,11 & $0,23^{* *}$ & $0,41^{* *}$ \\
Irodalomjegy & $-0,13$ & $-0,05$ & $0,53^{* *}$ & $0,35^{* *}$ & $0,16^{*}$ & $0,16^{*}$ & $0,22^{* *}$ & $0,41^{* *}$ \\
Magatartás & $-0,09$ & $-0,04$ & $0,26^{* *}$ & 0,12 & $0,17^{*}$ & $0,19^{* *}$ & 0,12 & $0,22^{* *}$ \\
Szorgalom & $-0,11$ & $-0,05$ & $0,34^{* *}$ & $0,22^{* *}$ & 0,06 & 0,12 & $0,21^{* *}$ & $0,42^{* *}$ \\
Tanulmányi átlag & 0,03 & 0,02 & $0,38^{* *}$ & $0,32^{* *}$ & $0,24^{* *}$ & 0,14 & $0,28^{* *}$ & $0,41^{* *}$ \\
\hline \hline
\end{tabular}

Megjegyzés: ** 0,01 szinten szignifikáns; *0,05 szinten szignifikáns

10. táblázat. Az énképösszetevők és a tanulmányi eredmények korrelációja 7. osztály

\begin{tabular}{|c|c|c|c|c|c|c|c|c|}
\hline Énképösszetevők & $\begin{array}{c}\text { Fizikális } \\
\text { kép. } \\
\text { énkép }\end{array}$ & Testkép & $\begin{array}{l}\text { Olvasási } \\
\text { énkép }\end{array}$ & $\begin{array}{l}\text { Mat. } \\
\text { énkép }\end{array}$ & $\begin{array}{c}\text { Kortárs- } \\
\text { kapcs. } \\
\text { énkép }\end{array}$ & $\begin{array}{l}\text { Szülö- } \\
\text { kapcs. } \\
\text { énkép }\end{array}$ & $\begin{array}{c}\text { Ált. } \\
\text { énkép }\end{array}$ & $\begin{array}{l}\text { Iskolai } \\
\text { énkép }\end{array}$ \\
\hline Matematikajegy & 0,01 & 0,05 & $0,171^{*}$ & $0,57 * *$ & 0,09 & $0,23 * *$ & $0,23 * *$ & $0,43 * *$ \\
\hline Nyelvtanjegy & $-0,05$ & $-0,03$ & $0,463 *$ & $0,35 * *$ & 0,05 & $0,30 * *$ & $0,20 * *$ & $0,54 * *$ \\
\hline Irodalomjegy & $-0,10$ & 0,05 & $0,47 * *$ & $0,25 * *$ & 0,06 & $0,31 * *$ & $0,28 * *$ & $0,53 * *$ \\
\hline Magatartás & $-0,07$ & $-0,05$ & $0,23 * *$ & $0,27 * *$ & $-0,01$ & $0,32 * *$ & 0,14 & $0,35 * *$ \\
\hline Szorgalom & $-0,03$ & 0,09 & $0,30 * *$ & $0,32 * *$ & 0,09 & $0,32 * *$ & $0,30 * *$ & $0,49 * *$ \\
\hline Tanulmányi átlag & 0,02 & 0,04 & $0,35 * *$ & $0,39 * *$ & 0,12 & $0,26 * *$ & $0,29 * *$ & $0,53 * *$ \\
\hline
\end{tabular}

Megjegyzés: ** 0,01 szinten szignifikáns; $* 0,05$ szinten szignifikáns 
Megerősítve az eredeti Marsh/Shavelson modellt a tanulmányi eredmények egyik évfolyamon sem mutatnak szignifikáns összefüggést a fizikális képességek énképpel vagy a testképpel. Szintén egyik évfolyamon sem meghatározói egymásnak a magatartásjegyek és az általános énkép. A tanárok által rossz magatartásúnak ítélt tanulók is tarthatják magukat cselekvőképes, teljesítőképes egyénnek csakúgy, mint a jó magatartásúnak tartott gyermekek is rendelkezhetnek alacsony általános énképpel.

A két évfolyam közötti legszembetünőbb különbség a kortárskapcsolat énkép és a tanulmányi énkép összefüggésében van. Míg ötödik évfolyamon az énkép e komponense szignifikáns összefüggést mutat a matematika és az irodalom osztályzatokkal, valamint a tanulmányi átlaggal és a magatartásjegyekkel is, addig hetedikben a kortárskapcsolat énkép nem áll összefüggésben sem a tanulmányi eredményekkel, sem a magatartás jegyekkel. Ezzel szemben a szülőkapcsolat énkép összefüggése a tanulmányi eredményekkel éppen az ellenkező módon alakul. Míg ötödikben a szülőkapcsolat énkép egyedül a tanuló magatartásával mutat 0,01 szinten szignifikáns korrelációt, addig hetedikben az említett énképkomponens az összes osztályzattal 0,01 szinten korrelál. Ez is mutatja, hogy ebben az életkorban, tehát ötödik osztálytól hetedik osztályig a szülökapcsolat és a kortárskapcsolat énkép nagy változáson meg keresztül. Hetedik osztályra a szülővel való kapcsolat énkép szoros összefüggésben lesz az iskolai teljesítménnyel, tehát a jól teljesítő tanulók szülökapcsolatai is jónak tekinthetővé válnak és, mivel reciprok kapcsolatot feltételezhetünk, a jó szülökapcsolattal rendelkező tanulók az iskolában is jobban teljesítenek majd. Ezzel szemben a kortárskapcsolat énkép és a tanulmányi eredmények között a kapcsolat csökkenni fog, tehát a magát népszerünek tartó tanuló nem feltétlenül fog jó tanulmányi eredményekkel rendelkezni, és a magát rossz kortárskapcsolatokkal jellemző gyermek is lehet jó tanuló.

Az eredmények alapján megállapítható, hogy hetedik osztályra egyértelmúen kirajzolódik, hogy az énkép mely komponensei lesznek kapcsolatban az iskolai eredményekkel és melyek nem. Mivel az osztályzatok belső összefüggésrendszere nagyon erős, érthető, hogy az énkép tantárgyi összetevői minden osztályzattal közel azonos erösségü korrelációt mutatnak mindkét évfolyamon. A szülőkapcsolat énkép és a tanulmányi eredmények szoros összefüggése hetedik évfolyamon a pályaválasztás elött a szülök tanulmányi eredmények iránti érdeklődése növekedésének jelzője lehet, míg a kortárskapcsolat énkép tanulmányi eredményektől való függetlenedése a baráti és kortárskapcsolatok jellegének megváltozására utalhat.

Az énkép és a tanulmányi eredményesség közötti kapcsolattal foglalkozó kutatásokban a tanulmányi eredményesség mutatója legtöbb esetben az osztályzat, ritkábban a különböző képességteszteken elért eredmények. Az eredmények értelmezése szempontjából azonban nem mellékes, hogy hogyan definiáljuk a tanulmányi teljesítményt. Kutatásunkban a tanulókkal szövegértési tesztet és matematikai képességtesztet is kitöltettünk, így lehetőségünk van arra, hogy megvizsgáljuk mind az iskolai osztályzatok, mind a képességfejlettség összefüggéseit a tanulási énkép megfelelő komponenseivel. Az olvasási képesség fejlettségét szövegértést vizsgáló feladatokkal (Cronbach- $\alpha=0,91$ ), a matematikai készségek fejlettségét a négy alapmüvelet mellett sorozatok és szöveges feladatok (Cronbach- $\alpha=0,95)$ segítségével mértük. Emellett minden tanulóval felvettünk a Ravenféle IQ tesztet is. A tanulási énkép komponenseinek összefüggéseit az osztályzatokkal, a szövegértés és a matematika teszteken elért eredményekkel, az IQ-val, valamint a szülők iskolai végzettségével és a nemmel 5. és 7. évfolyamon a 11. és a 12. táblázat mutatja. 
11. táblázat Az énképösszetevök összefüggése az osztályzatokkal, a szövegértés és a matematika teszteken elért eredményekkel, az IQ-val, a szülők iskolai végzettségével és a nemmel, 5. osztály

\begin{tabular}{lccc}
\hline \hline Énképösszetevök & Iskolai énkép & Matematikai énkép & Olvasási énkép \\
\hline Osztályzatok & $0,41^{* *}$ & $0,51^{* *}$ & $0,53^{* *}$ \\
Szövegértés & $0,20^{* *}$ & $0,13^{*}$ & $0,27^{* *}$ \\
Matematikai képesség & $0,24^{* *}$ & $0,36^{* *}$ & 0,11 \\
Raven IQ & $0,24^{* *}$ & $0,14^{*}$ & $0,17^{*}$ \\
Szülök iskolázottsága & $0,27^{* *}$ & 0,16 & $0,28^{* *}$ \\
Nem & 0,02 & 0,07 & 0,10
\end{tabular}

Megjegyzés: ** 0,01 szinten szignifikáns; * 0,05 szinten szignifikáns

12. táblázat Az énképösszetevők összefüggése az osztályzatokkal, a szövegértés és a matematika teszteken elért eredményekkel, az IQ-val, a szülök iskolai végzettségével és a nemmel, 7. osztály

\begin{tabular}{lccc}
\hline \hline Énképösszetevök & Iskolai énkép & Matematikai énkép & Olvasási énkép \\
\hline Osztályzatok & $0,53^{* *}$ & $0,57^{* *}$ & $0,47^{* *}$ \\
Szövegértés & $0,26^{* *}$ & 0,11 & $0,24^{* *}$ \\
Matematikai képesség & $0,25^{* *}$ & $0,34^{* *}$ & $0,15^{*}$ \\
Raven IQ & $0,33^{* *}$ & $0,28^{* *}$ & $0,16^{*}$ \\
Szülök iskolázottsága & $0,31^{* *}$ & $0,26^{* *}$ & $0,19^{* *}$ \\
Nem & $-0,01$ & $-0,16$ & $0,31^{* *}$ \\
\hline \hline
\end{tabular}

Megjegyzés: ** 0,01 szinten szignifikáns; * 0,05 szinten szignifikáns

Az eredmények szerint a tanulási énkép egyes komponensei erősebben korrelálnak az osztályzatokkal, mint bármely más vizsgált változóval; a korrelációs együtthatók 0,4 és 0,6 között mozognak. A matematika énkép szignifikánsan összefügg a matematikai készségek fejlettségével, az olvasási énkép a szövegértéssel, ám ezek az összefüggések csupán 0,3 körüliek. A szülők iskolai végzettsége hasonlóan gyengébb, 0,3 körüli a korreláció a tanulási énkép különböző komponenseivel.

$\mathrm{Az}$ énképösszetevőket függő változóként megtevő regresszióanalízis eredménye (13. táblázat) arra is rámutatott, hogy a tanulási énkép egyes komponenseinek varianciáját kizárólag az osztályzatok magyarázzák szignifikánsan. Ötödik évfolyamon a matematikajegy a matematikai énkép varianciájának $24,2 \%$-át, az irodalomjegy az olvasás énkép varianciájának 32,7\%-át magyarázza meg. Ugyanez az arány hetedik évfolyamon 35,1\% és $11,7 \%$. Hasonlóképp, az iskolai általános énkép legerősebben a félévi osztályzatok átlagával korrelál, az átlag ötödikben az énkép varianciájának 13,6\%-át, hetedikben 23,7\%-át magyarázza. Az iskolai általános énkép alakulásában sem az IQ, sem a szülők iskolai végzettsége, sem a képességfejlettség nem bír magyarázó erővel. Az eredmények tehát azt mutatják, hogy az énkép alakulásában a vizsgált tényezök közül egyedül az osztályzatoknak van szerepük, amely a tanárok értékelö munkájának kiemelt motivációs jelentőségére hívja fel a figyelmet. 
13. táblázat Az énképösszetevök összefüggése az osztályzatokkal, a szövegértés és a matematika teszteken elért eredményekkel, az IQ-val, a szülők iskolai végzettségével és a nemmel, regresszióanalizis

\begin{tabular}{|c|c|c|c|c|c|c|}
\hline \multirow{3}{*}{$\begin{array}{l}\text { Énképösszetevök } \\
\text { Független változók }\end{array}$} & \multicolumn{2}{|c|}{ Iskolai énkép } & \multicolumn{2}{|c|}{ Matematikai énkép } & \multicolumn{2}{|c|}{ Olvasási énkép } \\
\hline & 5. évf. & 7. évf. & 5. évf. & 7. évf. & 5. évf. & 7. évf. \\
\hline & \multicolumn{2}{|c|}{$\mathrm{r} \beta$} & \multicolumn{2}{|c|}{$\mathrm{r} \beta$} & \multicolumn{2}{|c|}{$\mathrm{r} \beta$} \\
\hline Osztályzatok & $14 *$ & $24 *$ & $24 *$ & $35^{*}$ & $33 *$ & $12 *$ \\
\hline Szövegértés & 0 & 3 & - & - & -3 & 2 \\
\hline Mat. képesség & -2 & -6 & 3 & 3 & - & - \\
\hline Raven IQ & 4 & 7 & 0 & -3 & 1 & 0 \\
\hline Szülők isk. & 4 & 0 & 0 & -2 & 2 & 0 \\
\hline $\mathrm{Nem}$ & 0 & 0 & 0 & $3^{*}$ & 0 & $8^{*}$ \\
\hline
\end{tabular}

Megjegyzés: * 0,05 szinten szignifikáns

Az, hogy saját teljesítményünket, képességeinket egy-egy tantárgyból hogyan ítéljük meg, összefüggésben lehet azzal, mennyire kedveljük az adott tantárgyat. Azonban lehet-e öszszefüggés egy-egy tantárgy vagy éppen az iskola kedveltsége és az énkép egy-egy komponense között? Van-e kapcsolat például aközött, hogy mennyire szeretnek a tanulók iskolába járni és, hogy milyennek látják kortárskapcsolatainkat? Összefügg-e a diákok szüleikkel való kapcsolatukról alkotott vélekedése saját teljesítményeikkel való elégedettségükkel? A következőkben azt vizsgáljuk, hogyan viszonyulnak egymáshoz a tantárgyi attitüdök, a diákok teljesítményükkel kapcsolatos értékelései, az iskola kedveltsége, valamint a családi háttér egyes jellemzői és az énkép egyes komponensei.

A 14., a 15. és a 16. táblázat a harmadik, ötödik és hetedik osztályos tanulók énképének és tantárgyi és iskolai attitüdjeinek, valamint elégedettségének összefüggéseit mutatja. Hipotézisünknek megfelelöen, az egyes tantárgyi attitüdök mindhárom korosztály esetén erős, 0,7-0,8 körüli korrelációt mutatnak az adott tantárgyi énképpel, azaz azok a tanulók, akik saját készségeiket, képességeiket, érdeklődésüket jónak értékelik matematikából vagy irodalomból, jobban kedvelik az adott tantárgyat, míg akik saját képességeiket, érdeklődésüket az adott tantárgy iránt kevésbé jónak értékelik, negatívabb attitüddel rendelkeznek a tantárgyat illetően.

14. táblázat Az énképösszetevök, a tantárgyi attitüdök, az iskola kedveltsége és a teljesitménnyel való elégedettség összefüggései, 3. osztály

\begin{tabular}{|c|c|c|c|c|c|c|c|c|}
\hline Énképösszetevők & $\begin{array}{c}\text { Fizikális } \\
\text { kép. } \\
\text { énkép }\end{array}$ & Testkép & $\begin{array}{c}\text { Olvasási } \\
\text { énkép }\end{array}$ & $\begin{array}{l}\text { Mat. } \\
\text { énkép }\end{array}$ & $\begin{array}{c}\text { Kor- } \\
\text { társ- } \\
\text { kapcs. } \\
\text { énkép }\end{array}$ & $\begin{array}{l}\text { Szülö- } \\
\text { kapcs. } \\
\text { énkép }\end{array}$ & $\begin{array}{c}\text { Ált. } \\
\text { énkép }\end{array}$ & $\begin{array}{l}\text { Iskolai } \\
\text { énkép }\end{array}$ \\
\hline Matematika attitüd & 0,07 & $0,18^{*}$ & $0,24 * *$ & $0,69 * *$ & 0,09 & 0,12 & $0,25 * *$ & $0,39 * *$ \\
\hline Nyelvtan attitüd & 0,09 & $0,17 *$ & $0,37 * *$ & 0,14 & $0,22 * *$ & $0,20 *$ & $0,20 * *$ & $0,39 * *$ \\
\hline Irodalom attitüd & 0,05 & $0,22 * *$ & $0,71 * *$ & 0,15 & 0,15 & $0,30 * *$ & $0,26 * *$ & $0,53 * *$ \\
\hline Elégedettség & $0,19 *$ & $0,32 * *$ & $0,30 * *$ & $0,36^{* *}$ & $0,41 * *$ & $0,32 * *$ & $0,50 * *$ & $0,37 * *$ \\
\hline Iskola kedveltsége & 0,10 & $0,20 *$ & $0,32 * *$ & $0,34 * *$ & $0,16^{*}$ & 0,09 & 0,16 & $0,36 * *$ \\
\hline
\end{tabular}

Megjegyzés: ** 0,01 szinten szignifikáns; *0,05 szinten szignifikáns 
15. táblázat Az énképösszetevők, a tantárgyi attitüdök, az iskola kedveltsége és a teljesítménnyel való elégedettség összefüggései, 5. osztály

\begin{tabular}{lllllllll} 
Énképösszetevők & $\begin{array}{c}\text { Fizikális } \\
\text { kép. } \\
\text { énkép }\end{array}$ & Testkép & $\begin{array}{c}\text { Olvasási } \\
\text { énkép }\end{array}$ & $\begin{array}{c}\text { Mat. } \\
\text { énkép }\end{array}$ & $\begin{array}{c}\text { Kortárs- } \\
\text { kapcs. } \\
\text { énkép }\end{array}$ & $\begin{array}{c}\text { Szülö- } \\
\text { kapcs. } \\
\text { énkép }\end{array}$ & $\begin{array}{c}\text { Alt. } \\
\text { énkép }\end{array}$ & $\begin{array}{c}\text { Iskolai } \\
\text { énkép }\end{array}$ \\
\hline Matematika attitüd & 0,09 & 0,04 & $0,27^{* *}$ & $0,78^{* *}$ & $0,16^{*}$ & $0,26^{* *}$ & $0,19^{*}$ & $0,45^{* *}$ \\
Nyelvtan attitüd & $-0,01$ & 0,10 & $0,51^{* *}$ & 0,09 & 0,08 & $0,19^{* *}$ & $0,25^{* *}$ & $0,38^{* *}$ \\
Irodalom attitűd & 0,07 & $0,18^{*}$ & $0,76^{* *}$ & $0,21^{* *}$ & $0,18^{*}$ & $0,25^{* *}$ & $0,38^{* *}$ & $0,50^{* *}$ \\
Elégedettség & 0,07 & 0,07 & $0,31^{* *}$ & $0,23^{* *}$ & $0,15^{*}$ & $0,22^{* *}$ & $0,30^{* *}$ & $0,34^{* *}$ \\
Iskola kedveltsége & 0,11 & 0,08 & $0,39^{* *}$ & $0,26^{* *}$ & 0,14 & $0,20^{* *}$ & $0,37^{* *}$ & $0,49^{* *}$ \\
\hline
\end{tabular}

Megjegyzés: **0,01 szinten szignifikáns; * 0,05 szinten szignifikáns

16. táblázat Az énképösszetevők, a tantárgyi attitüdök, az iskola kedveltsége és a teljesitménnyel való elégedettség összefüggései, 7. osztály

\begin{tabular}{lllllllll}
\hline Énképösszetevök & $\begin{array}{c}\text { Fizikális } \\
\text { kép. } \\
\text { énkép }\end{array}$ & Testkép & $\begin{array}{c}\text { Olvasá- } \\
\text { si énkép }\end{array}$ & $\begin{array}{c}\text { Mat. } \\
\text { énkép }\end{array}$ & $\begin{array}{c}\text { Kortárs- } \\
\text { kapcs. } \\
\text { énkép }\end{array}$ & $\begin{array}{c}\text { Szülö- } \\
\text { kapcs. } \\
\text { énkép }\end{array}$ & $\begin{array}{c}\text { Alt. } \\
\text { énkép }\end{array}$ & $\begin{array}{c}\text { Iskolai } \\
\text { énkép }\end{array}$ \\
\hline Matematika attitüd & $0,15^{*}$ & 0,01 & $0,15^{*}$ & $0,80^{* *}$ & 0,12 & 0,09 & $0,15^{*}$ & $0,45^{* *}$ \\
Nyelvtan attitűd & 0,05 & $-0,09$ & $0,64^{* *}$ & $0,20^{* *}$ & 0,05 & $0,31^{* *}$ & 0,07 & $0,47^{* *}$ \\
Irodalom attitüd & $-0,01$ & $-0,07$ & $0,70^{* *}$ & 0,01 & 0,04 & $0,18^{* *}$ & 0,06 & $0,36^{* *}$ \\
Elégedettség & 0,06 & 0,13 & $0,34^{* *}$ & $0,26^{* *}$ & 0,12 & $0,17^{*}$ & $0,25^{* *}$ & $0,46^{* *}$ \\
Iskola kedveltsége & $0,14^{*}$ & 0,03 & $0,37^{* *}$ & $0,24^{* *}$ & 0,08 & $0,16^{*}$ & $0,18^{*}$ & $0,44^{* *}$ \\
\hline \hline
\end{tabular}

Megjegyzés: ** 0,01 szinten szignifikáns; * 0,05 szinten szignifikáns

A tanulók családi hátterét két mutatóval jellemeztük: a hátrányos helyzettel és a szülők iskolai végzettségével. A 17. táblázatban a hátrányos és a nem hátrányos helyzetü tanulók énképének egyes dimenzióit hasonlítottuk össze. Az átlagokat és a szórásokat tekintve a hátrányos helyzetü tanulók minden énképkomponense negatívabb, mint nem hátrányos helyzetü társaiké. A kétmintás t-próba szerint a különbség négy énképösszetevő esetén szignifikáns, melyek közül az olvasás énkép esetében a legnagyobb az eltérés. 
17. táblázat. A hátrányos és a nem hátrányos helyzetü tanulók énképkomponenseinek átlaga, szórása, a szórások és az átlagok különbségei

\begin{tabular}{|c|c|c|c|c|c|c|c|c|}
\hline \multirow{3}{*}{$\begin{array}{c}N \\
\text { Énképösszetevők }\end{array}$} & \multirow{2}{*}{\multicolumn{2}{|c|}{$\begin{array}{c}\text { Hátrányos } \\
184\end{array}$}} & \multirow{2}{*}{\multicolumn{2}{|c|}{$\begin{array}{c}\text { Nem hátrányos } \\
331\end{array}$}} & \multirow{2}{*}{\multicolumn{2}{|c|}{ Levene }} & \multirow{2}{*}{\multicolumn{2}{|c|}{ Kétmintás $t$}} \\
\hline & & & & & & & & \\
\hline & átlag & szórás & átlag & szórás & $F$ & $p$ & $t$ & $p$ \\
\hline Fiz. képességek énkép & 70,23 & 24,18 & 74,69 & 21,12 & 4,51 & 0,03 & 2,10 & 0,04 \\
\hline Testkép & 61,95 & 24,40 & 65,33 & 22,24 & 1,26 & 0,26 & 1,60 & 0,11 \\
\hline Olvasás énkép & 61,36 & 25,01 & 71,04 & 22,59 & 3,36 & 0,07 & 4,48 & 0,001 \\
\hline Matematika énkép & 62,43 & 26,69 & 65,58 & 26,11 & 0,04 & 0,84 & 1,30 & 0,19 \\
\hline Kortárskapcsolat énkép & 68,28 & 20,96 & 71,09 & 16,78 & 13,84 & 0,001 & 1,56 & 0,12 \\
\hline Szülőkapcsolat énkép & 84,43 & 14,79 & 86,68 & 11,82 & 4,43 & 0,04 & 1,77 & 0,08 \\
\hline Általános énkép & 73,16 & 17,57 & 77,48 & 16,27 & 1,66 & 0,20 & 2,81 & $\mathbf{0 , 0 1}$ \\
\hline Iskolai énkép & 59,43 & 19,98 & 64,85 & 19,96 & 0,18 & 0,68 & 2,95 & $\mathbf{0 , 0 0 3}$ \\
\hline
\end{tabular}

Megjegyzés: A 0,05 szinten szignifikáns eltéréseket félkövér szedés jelzi.

A családi háttér másik mutatója, a szülők iskolai végzettsége szintén megmutatkozik a tanulók énképében (18. táblázat). Adatbázisunkban az anya és az apa iskolai végzettsége között erős összefüggést találtunk, ezért a továbbiakban a szülők közül csak az apa iskolai végzettsége szerinti bontásban vizsgáljuk a tanulók énképkomponenseit. Azon tanulók olvasás és általános énképe, akiknek édesapja alacsonyabb képzettségü, általános iskolát vagy szakmunkásképzőt végzett, kevésbé elégedettek saját magukkal, kevésbé tartják magukat cselekvőképes, hatékony embernek. A negatív általános énkép mellett az apa iskolai végzettsége az olvasás énképre is hatással van, csakúgy, mint a hátrányos anyagi helyzet. Annak felderítése, hogy milyen háttértényezők játszhatnak közre e két változó együttjárásában, további vizsgálatokra lenne szükség. Feltételezhető, hogy az alacsonyabb végzettségű szülők szókincse, nyelvi kifejezőkészsége elmarad a magasabban képzett szülőkétöl, így a tanuló olyan hátránnyal indul az iskolában, mely végigkíséri iskolai pályafutását és negatív hatással van énképére. 
18. táblázat Az énképkomponensek átlaga az apa iskolai végzettsége szerinti bontásban

\begin{tabular}{lcccccc}
\hline \hline Énképösszetevök & Ált. isk. & Szakiskola & Érettségi & Felsöfok & $F^{*}$ & $p$ \\
\hline Fiz. képességek énkép & $74,41(20)$ & $73,88(22)$ & $70,44(23)$ & $73,46(18)$ & 0,50 & 0,81 \\
Testkép & $64,38(23)$ & $66,07(21)$ & $62,13(24)$ & $67,28(25)$ & 0,44 & 0,85 \\
Olvasási énkép & $62,02(23)$ & $67,60(24)$ & $76,38(20)$ & $75,28(12)$ & $\mathbf{3 , 3 7}$ & $\mathbf{0 , 0 1}$ \\
Matematika énkép & $58,81(25)$ & $62,80(27)$ & $66,91(26)$ & $69,17(15)$ & 1,79 & 0,10 \\
Kortárskapcsolat énkép & $68,43(19)$ & $70,70(17)$ & $70,59(18)$ & $76,54(17)$ & 0,43 & 0,86 \\
Szülőkapcsolat énkép & $83,59(15)$ & $86,16(12)$ & $88,03(10)$ & $83,33(15)$ & 1,05 & 0,39 \\
Általános énkép & $72,54(18)$ & $77,39(15)$ & $78,70(17)$ & $81,94(16)$ & $\mathbf{3 , 3 1}$ & $\mathbf{0 , 0 1}$ \\
Iskolai énkép & $58,34(20)$ & $62,21(20)$ & $66,27(19)$ & $64,44(10)$ & 1,74 & 0,11 \\
\hline \hline
\end{tabular}

Megjegyzés: * Varianciaanalízis F-próbájának értéke és szignifikanciája. A 0,05 szinten szignifikáns eltéréseket félkövér szedés jelzi. Zárójelben a szórások láthatók.

A hátrányos helyzet a tanulók énképében is megmutatkozik. Az anyagi nehézségek és az apa alacsony iskolai végzettsége legnagyobb mértékben az olvasási énképben nyilvánulnak meg, feltételezhetően azáltal, hogy a gyermek nyelvi képességei fejletlenebbek, mint társaié, amely sorozatos sikertelenségekhez vezet. A sikertelenségek a reciprokhatás-modell értelmében (Marsh, 1990) hatással lesznek elsősorban a tanuló olvasás képességspecifikus énképére, másodsorban általános és iskolai énképére is.

Az egyes énképkomponensek átlagát és szórását nemenkénti felbontásban is vizsgáltuk (19. táblázat). Öt énkép esetén nem mutatható ki szignifikáns különbség a két nem között, három komponens esetében azonban igen. A fizikális képességek énkép esetén a fiúk szignifikánsan jobbnak ítélik meg saját képességeiket a testmozgás és a sportok területén, mint a lányok, akik viszont az olvasás és a szülökapcsolat területén rendelkeznek szignifikánsan elönyösebb énképpel. Ez összhangban van azokkal a nemzetközi kutatási eredményekkel, amelyek mind az olvasási képesség, mind az olvasási motiváció és énkép esetében a lányok jelentős előnyéröl számolnak be. Az olvasás területén feltétlenül érdemes lenne vizsgálni a kimutatott különbségeket abból a szempontból, hogy az egyes nemi sztereotípiák mennyiben befolyásolják a tanulók ilyen jellegü gondolkodásmódját, illetve, hogy a kapott visszajelzések mint az énkép alakítói az adott területeken összhangban vannak-e ezekkel a sztereotípiákkal. 
19. táblázat Az énképkomponensek átlaga nemenkénti bontásban

\begin{tabular}{|c|c|c|c|c|c|c|c|c|}
\hline \multirow{3}{*}{$\begin{array}{c}N \\
\text { Énképösszetevők }\end{array}$} & \multirow{2}{*}{\multicolumn{2}{|c|}{$\frac{F i u ́}{248}$}} & \multirow{2}{*}{\multicolumn{2}{|c|}{$\frac{\text { Lány }}{246}$}} & \multirow{2}{*}{\multicolumn{2}{|c|}{ Levene }} & \multirow{2}{*}{\multicolumn{2}{|c|}{ Kétmintás $t$}} \\
\hline & & & & & & & & \\
\hline & átlag & szórás & átlag & szórás & $F$ & $p$ & $t$ & $p$ \\
\hline Fiz. képességek énkép & 77,18 & 21,53 & 68,11 & 21,14 & 0,20 & 0,66 & 4,73 & $\mathbf{0 , 0 1}$ \\
\hline Testkép & 65,43 & 23,11 & 63,57 & 22,38 & 0,13 & 0,72 & 0,91 & 0,36 \\
\hline Olvasás énkép & 62,60 & 25,32 & 70,97 & 22,45 & 5,04 & 0,03 & $-3,89$ & 0,001 \\
\hline Matematika énkép & 63,92 & 26,15 & 62,97 & 26,56 & 0,51 & 0,47 & 0,40 & 0,69 \\
\hline Kortárskapcsolat énkép & 69,32 & 18,85 & 71,54 & 18,37 & 0,01 & 0,94 & $-1,33$ & 0,19 \\
\hline Szülőkapcsolat énkép & 83,73 & 13,89 & 87,60 & 12,15 & 4,65 & 0,03 & $-3,29$ & 0,01 \\
\hline Általános énkép & 75,18 & 17,00 & 76,52 & 16,68 & 0,15 & 0,70 & $-0,88$ & 0,38 \\
\hline Iskolai énkép & 60,47 & 20,79 & 63,48 & 19,82 & 2,07 & 0,15 & $-1,65$ & 0,10 \\
\hline
\end{tabular}

Megjegyzés: A 0,05 szinten szignifikáns eltéréseket félkövér szedés jelzi.

\subsection{Részösszefoglalás: Az első pilot mérés}

Első pilot mérésünkben az olvasási énkép jellemzőit, énképstruktúrában elfoglalt helyét, valamint teljesítménnyel és tantárgyi attitüdökkel való kapcsolatát vizsgáltuk. Kutatásunk eredményei alátámasztották az énkép hierarchikus jellegét, melyen belül az olvasási énkép legszorosabban az iskolai általános énképhez kapcsolódva központi szerepet tölt be a tanulók saját tanulmányi eredményességével, képességeivel kapcsolatos meggyőződésrendszerében. Az énképkomponensek és a teljesítmény összefüggésének vizsgálatakor az olvasásteljesítmény két indikátorát vontuk be az elemzésbe: az osztályzatokat és a szövegértés teszten nyújtott eredményt. A korrelációelemzés eredményei alapján mindkét mutató öszszefügg az olvasási énképpel, azonban a regresszióanalízis szerint arra hatással csak az osztályzatok vannak. Ez az eredmény az osztályzatok énképformáló hatására hívja fel a figyelmet. A további elemzések a nemek közötti szignifikáns eltérésekre, valamint a családi háttér szerepére mutattak rá a tanulók olvasási énképét illetően.

\section{A második pilot mérés}

\subsection{A második pilot mérés kérdései és hipotézisei}

Egy másik vizsgálatunkban tanulásban akadályozott (továbbiakban alsó indexben „tanak”) és többségi tanulók olvasás iránti motivációját vizsgáltuk. A kutatás célja kettős volt: egyrészt, az egydimenziós olvasási motiváció életkori alakulásának feltérképezése, másrészt a tanulásban akadályozott és a többségi tanulók olvasási attitüdjeinek összehasonlítása.

A motivációkutatások a tanulás iránti motiváció csökkenéséről számolnak be az iskolai évek teltével (lásd Józsa, 2007), és hasonló képet mutatnak a tantárgyi attitüdök élet- 
kori változásának vizsgálatai is. Hazánkban az olvasás tanítása az irodalomtörténeti oktatásba integrálva történik. A több száz éve íródott szövegek, amelyen a hazai tanulók az olvasást gyakorolják, kevéssé építenek a tanulók egyéni érdeklődésére. A tankönyvi szövegek és a kötelező olvasmányok olvastatása mellett ritkán adódik lehetőség arra, hogy a tanulók saját maguk választotta szövegeket olvassanak tanórai keretek között.

A kutatási eredmények és a hazai helyzetből kiindulva így feltételezzük, hogy a tanulók az iskolai évek folyamán egyre inkább elvesztik az érdeklödésüket az olvasás mint tevékenység iránt is, és egyre averzívabb attitüdöt alakítanak ki. Az olvasási motiváció terén tehát egy csökkenő tendenciát várunk.

Az olvasás motivátora az élmény, a megértés, ezért az olvasás iránti magas motiváció elöfeltétele az olvasási képesség megfelelö szintü fejlettsége, azaz az olvasástechnikai készségek és a szövegértés fejlettsége, a mnesztikus funkciók megfelelő müködése és a meglévő ismeretek mozgósításának képessége. Ezek elmaradottsága miatt várható, hogy a tanulásban akadályozott gyermekek olvasás iránti motivációja minden életkorban alacsonyabb, mint többségi társaiké, emellett számos kudarcélmény miatt, az évek folyamán rohamosan csökkenő tendenciát mutat.

Kutatásunk során a következő kérdésekre keressük a választ:

1. Mi jellemzi a hazai tanulók olvasási motivációját a vizsgált életkori szakaszokban?

2. Van-e a különbség a tanulásban akadályozott és a többségi tanulók olvasási motivációjában?

3. Hogyan alakul a többségi és a tanulásban akadályozott tanulók olvasási motivációja a vizsgált életkori csoportokban?

4. Van-e összefüggés az olvasás teljesítmény és az olvasási motiváció között?

5. Van-e összefüggés a tanulók olvasási motivációja, IQ-ja és szüleik iskolai végzettsége között?

A szakirodalom alapján a következő hipotéziseket fogalmazzuk meg:

$\mathrm{H}_{1}$ : A tanulók olvasási motivációja az életkor növekedésével csökken.

$\mathrm{H}_{2}$ : A tanulásban akadályozott és a többségi tanulók olvasási motivációja között jelentős különbség van. A tanulásban akadályozott tanulók olvasási motivációja minden évfolyamon alacsonyabb, mint a többségi tanulóké.

$\mathrm{H}_{3}$ : Az olvasás-szövegértés teljesítmény és a szóolvasási készség fejlettsége is pozitív összefüggést mutat a tanulók olvasási motivációjával.

$\mathrm{H}_{4}$ : A családi háttér és az IQ is pozitív összefüggésben áll az olvasási motivációval: a magasabb iskolai végzettségü szülők gyermekei, valamint a magasabb IQ-val rendelkező gyermekek motiváltabbak az olvasás iránt. 


\subsection{Adatfelvétel, minta és mérőszközök a második pilot mérés során}

Kérdöíves felmérésünkben 3. ( $\left.\mathrm{N}_{\text {többségi }}=298 ; \mathrm{N}_{\text {tanak }}=236\right)$, 5. ( $\left.\mathrm{N}_{\text {többségi }}=323 ; \mathrm{N}_{\text {tanak }}=148\right)$ és 7. $\left(\mathrm{N}_{\text {többségi }}=319 ; \mathrm{N}_{\text {tanak }}=226\right)$ osztályos többségi és tanulásban akadályozott tanulók vettek részt (20. táblázat).

20. táblázat A második pilot mérés mintája

\begin{tabular}{lccc}
\hline \multicolumn{1}{c}{ Korcsoport } & $n$ & Tanulásban akadályozott & Többségi \\
\hline 3. évfolyam & 534 & 236 & 298 \\
5. évfolyam & 471 & 148 & 323 \\
7. évfolyam & 545 & 226 & 319 \\
Összesen & 1550 & 610 & 940 \\
\hline \hline
\end{tabular}

Az olvasási motiváció egydimenziós mérésére egy háromfokú Likert-skálás kérdőívtételeket tartalmazó mérőeszközt használtunk, ami Falus és Kimmel (2003) alapján fejlesztettünk (3. melléklet). Az összesen 21 kérdöívtételböl álló mérőeszköz megbízhatósága a Cronbach- $\alpha$ mutató alapján a teljes mintán 0,78 , a többségi mintán 0,83 , a tanulásban akadályozott tanulók mintáján 0,71 . Az olvasáskészség fejlettségének vizsgálatára képes szóolvasás tesztet alkalmaztunk (Nagy, 2006, 4. melléklet), a szövegértési képesség fejlettségét három folyamatos és nem folyamatos szövegeket is tartalmazó szövegértés-feladat alapján állapítottuk meg (Fazekasné, Józsa és Nagy, 2009, 5. melléklet). A képes szóolvasás teszt reliabilitása 0,87 , a szövegértésé pedig 0,9 . Az IQ mérésére a Raven-féle progresszív mátrixokat alkalmaztuk.

\subsection{A második pilot mérés eredményei}

A második pilot mérés alkalmával többségi és tanulásban akadályozott tanulók olvasási motivációját vizsgáltuk. Az egydimenziós olvasási motiváció gyakorisági eloszlását a két vizsgált részmintán a 13 . ábra mutatja.

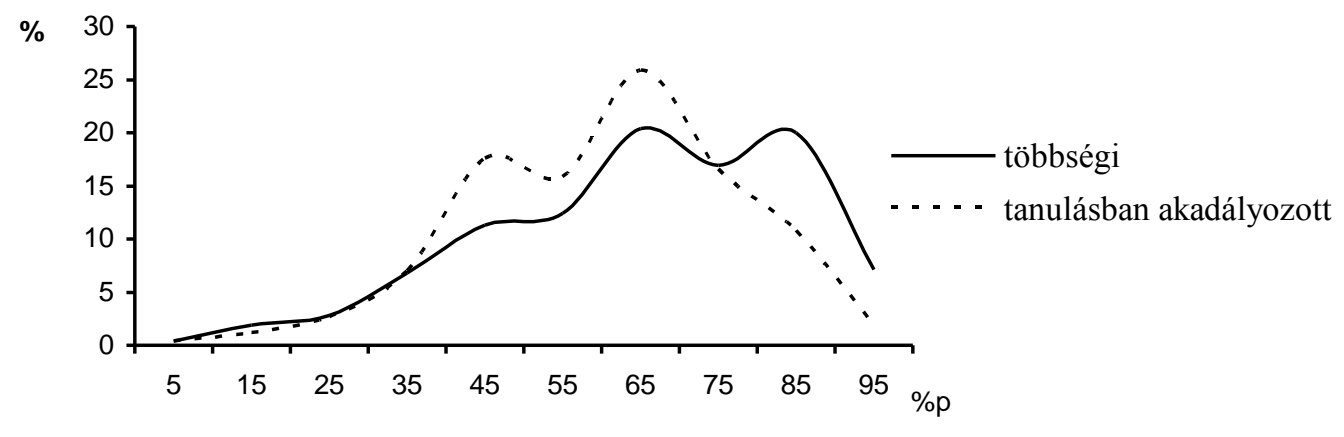

13. ábra

Az egydimenziós olvasási motiváció gyakorisági eloszlása, többségi és tanulásban akadályozott tanulók 
A gyakorisági eloszlás alapján megállapítható, hogy mind a többségi, mint a tanulásban akadályozott tanulók esetében a görbe kissé jobbra tolódott, ami azt jelenti, hogy a tanulók többsége motivált az olvasás iránt. A két görbe közötti legfeltünőbb különbség, hogy ez az eltolódás a többségi tanulók esetében erőteljesebb. A többségi tanulók között nagyobb arányban vannak jelen az erős olvasás iránti motivációt mutató tanulók, esetükben a $80 \%$ p feletti olvasási motivációval rendelkező tanulók aránya 27\%. Ugyanez az arány a tanulásban akadályozott tanulók esetében mindössze 13\%. Viszont nem találunk jelentős különbséget a legkevésbé motivált tanulók arányában: a többségi tanulók mintáján a 40\%p alatti olvasási motivációval rendelkező tanulók aránya $11 \%$, ugyanez a tanulásban akadályozott diákok esetében 12\%. Azonban a tanulásban akadályozott tanulók között többen vannak, akik közepes erősségü olvasás iránti motivációval rendelkeznek, ök a minta 76\%-át teszik ki. A többségi diákok esetében ez az arány $62 \%$.

Keresztmetszeti vizsgálatunk lehetővé teszi, hogy a tanulók olvasás iránti motivációját évfolyamonként is összehasonlítsuk. A 14. ábra a tanulásban akadályozott és a többségi tanulók olvasási motivációját mutatja harmadik, ötödik és hetedik osztályban. Látható, hogy mind a többségi, mind a tanulásban akadályozott populáció olvasási motivációja egyre csökkenő tendenciát mutat az egyes életkorokban. A többségi tanulók olvasás iránti motivációjának átlaga harmadik osztályban $73 \%$ p, hatodik osztályban $66 \%$, hetedik osztályban pedig már csak 58\%p. A varianciaanalízis eredményei szerint (21. táblázat) mindhárom életkori csoport olvasási motivációja között a különbség szignifikáns. A csökkenés ugyanígy tetten érhető a tanulásban akadályozott tanulók esetében is, azonban mértéke jóval kisebb. Harmadik és ötödik osztály között a csökkenés statisztikailag nem szignifikáns, mindössze 1 százalékpontos. Ötödik osztály és hetedik osztály között a tanulásban akadályozott tanulók esetében is szignifikáns a motivációbeli különbség; míg ötödik évfolyamon az olvasási motiváció átlaga $62 \%$ p, addig hetedikben már csak $58 \%$ p.

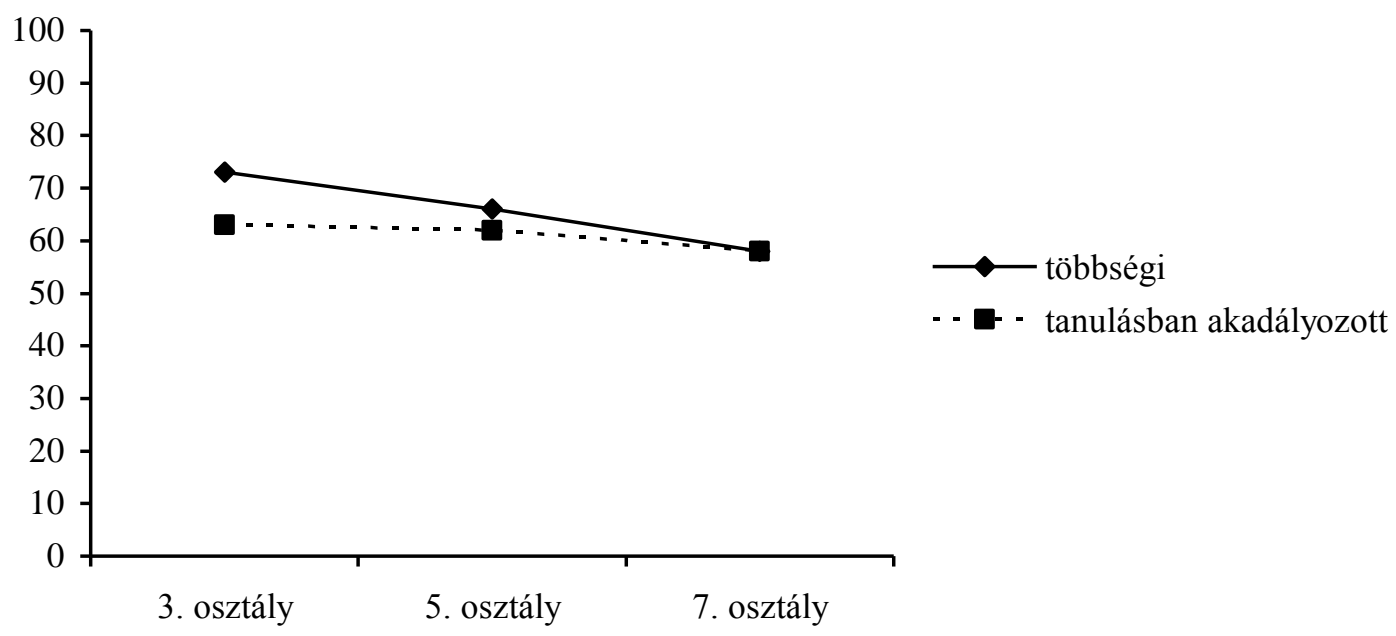

14. ábra

Az olvasás iránti motiváltság alakulása 3., 5. és 7. évfolyamon, többségi és tanulásban akadályozott tanulók 
21. táblázat. Az olvasási motiváció 3., 5. és 7. évfolyamon, többségi és tanulásban akadályozott tanulók, ANOVA

\begin{tabular}{llllllll}
\hline \hline Minta & 3. évfolyam & 5. évfolyam & 7.évfolyam & Levene & $p$ & $F$ & $p$ \\
\hline Többségi & $73(17)$ & $66(19)$ & $58(20)$ & 5,87 & 0,00 & $\mathbf{4 9 , 8 0}$ & $\mathbf{0 , 0 1}$ \\
Tanulásban akadályozott & $63(17)$ & $62(15)$ & $58(16)$ & 0,58 & 0,56 & $\mathbf{4 , 9 7}$ & $\mathbf{0 , 0 1}$ \\
\hline
\end{tabular}

Megjegyzés: Varianciaanalízis F-próbájának értéke és szignifikanciája. A 0,05 szinten szignifikáns eltéréseket félkövér szedés jelzi. Zárójelben a szórások láthatók.

A többségi és a tanulásban akadályozott tanulók átlagainak összehasonlítása céljából kétmintás-t próbát végeztünk. Az eredményeket a 22. táblázat tartalmazza.

22. táblázat Többségi és tanulásban akadályozott tanulók olvasás iránti motivációja

\begin{tabular}{lcccccc}
\hline \hline & Többségi & $\begin{array}{c}\text { Tanulásban } \\
\text { akadályozott }\end{array}$ & Levene & $p$ & $t / d$ & $p$ \\
\hline 3. osztály & $73(17)$ & $63(17)$ & 0,17 & 0,68 & $\mathbf{6 , 5 6}$ & $\mathbf{0 , 0 1}$ \\
5. osztály & $66(19)$ & $62(15)$ & 3,55 & 0,60 & $\mathbf{2 , 0 9}$ & $\mathbf{0 , 0 4}$ \\
7. osztály & $58(20)$ & $58(16)$ & 12,09 & 0,00 & 0,04 & 0,97 \\
\hline \hline
\end{tabular}

Megjegyzés: A 0,05 szinten szignifikáns eltéréseket félkövér szedés jelzi.

A kétmintás-t próba eredményei alapján a két részminta, azaz a tanulásban akadályozott és a többségi tanulók olvasási motivációjának különbsége harmadik és ötödik osztályban szignifikáns: a tanulásban akadályozott tanulók olvasás iránti motivációja szignifikánsan alacsonyabb. Harmadik évfolyamon a két részminta átlagának különbsége még $10 \%$, ami jelentősnek tekinthető. Hetedik osztályra a tanulásban akadályozott és a többségi tanulók olvasás iránti motivációja is csökken, a csökkenés nagysága ugyanakkor eltérö. A többségi tanulók olvasási motivációjának erőteljesebb csökkenése következtében hetedik évfolyamon már nincs különbség a két vizsgált részminta között, azaz a többségi és a tanulásban akadályozott tanulók olvasási motivációja hetedik évfolyamon azonos erősségü.

Ennek az eredménynek számos magyarázata lehet. Az egyik legvalószínübb az oktatási módszerekben és a tanulási környezetben rejlik. A tanulásban akadályozott tanulók, amennyiben enyhén értelmi fogyatékosnak minősítik őket, külön iskolába kerülnek, ahol többek között - az olvasástanítási módszerek is eltérőek az jobban igazodik a tanulók egyéni sajátosságaihoz. Az enyhe értelmi fogyatékosnak nem minősített, tanulási nehézséggel küzdő tanulók szintén olyan többletsegítséget kaphatnak az iskolában, amely motivációs szempontból előnyt jelenthet számukra.

Összegzésként, a feltételezésünk, miszerint a sorozatos kudarcélmények következtében a tanulásban akadályozott tanulók olvasási motivációja minden évfolyamon alacsonyabb lesz, nem igazolt. Feltételezhetjük, hogy a teljesítményészleletek nincsenek olyan nagy hatással a tanulásban akadályozott tanulók olvasás iránti motiváltságára, mint azt gondoltuk.

A képességfejlettség és a motiváció közötti kapcsolat feltárására korrelációanalízist végeztünk a tanulók képes szóolvasás és olvasás-szövegértés teszteken nyújtott teljesítményének és olvasási motiváció mutatójának bevonásával. Az eredmények (23. táblázat) alapján a képes szóolvasás teszt által mért olvasási készségfejlettség egyik évfolyamon és egyik részminta esetében sem mutat szignifikáns összefüggést az olvasási motivációval. 
Azzal összefüggésben csak a szövegértés van, amely viszont minden évfolyamon és mindkét populáció esetében gyenge, 0,1-0,2 körüli összefüggést mutat.

23. táblázat. Az olvasási motiváció és az olvasási képesség összefüggése, korrelációk

\begin{tabular}{lcccc}
\hline \hline \multirow{2}{*}{ Évfolyam } & \multicolumn{2}{c}{ Tanulásban akadályozott } & \multicolumn{2}{c}{ Többségi } \\
\cline { 2 - 5 } & Szóolvasás & Szövegértés & Szóolvasás & Szövegértés \\
\hline 3. & 0,08 & 0,11 & 0,11 & $0,13^{*}$ \\
5. & 0,07 & $0,21^{*}$ & 0,08 & $0,19^{* *}$ \\
7. & 0,01 & $0,20^{* *}$ & 0,10 & $0,18^{* *}$ \\
\hline
\end{tabular}

Megjegyzés:** 0,01 szinten szignifikáns; *0,05 szinten szignifikáns

A szakirodalomban fellelhető források alapján nem egyértelmü, hogy vajon az olvasási motiváció és az olvasási képesség közötti kapcsolat egyirányú vagy kétirányú, azaz hatással van-e az olvasási motiváció az olvasási képesség fejlettségére és fordítva. Az olvasási képesség és az olvasási motiváció közötti kapcsolat mélyebb rétegeinek feltárására regresszióanalízist végeztünk, melyben először a szövegértés képesség fejlettségét, majd az olvasási motivációt tettük meg függő változóként. Az eredményeket a 24. és a 25. számú táblázatokban közöljük.

24. táblázat Az olvasás iránti attitüd és az olvasási képesség összefüggése, regresszióanalizis. Függő változó: szövegértés

\begin{tabular}{lcccccc}
\hline \hline & \multicolumn{3}{c}{ Tanulásban akadályozott } & \multicolumn{2}{c}{ Többségi } \\
\cline { 2 - 7 } & 3. évf. & 5. évf. & 7. évf. & 3. évf. & 5. évf. & 7. évf. \\
\cline { 2 - 6 } Független változók & 24 & $\mathrm{r} \beta$ & & & $\mathrm{r} \beta$ & \\
\hline Képes szóolvasás & & 6 & 11 & 27 & 16 & 11 \\
Olvasási motiváció & & 5 & 4 & & 3 & 2 \\
\hline
\end{tabular}

25. táblázat Az olvasás iránti attitüd és az olvasási képesség összefüggése, regresszióanalízis. Függő változó: olvasási motiváció.

\begin{tabular}{|c|c|c|c|c|c|c|}
\hline \multirow[b]{3}{*}{ Független változók } & \multicolumn{3}{|c|}{ Tanulásban akadályozott } & \multicolumn{3}{|c|}{ Többségi } \\
\hline & 3. évf. & 5. évf. & 7. évf. & 3. évf. & 5. évf. & 7. évf. \\
\hline & \multicolumn{3}{|c|}{$\mathrm{r} \beta$} & \multicolumn{3}{|c|}{$\mathrm{r} \beta$} \\
\hline \multicolumn{7}{|l|}{ Képes szóolvasás } \\
\hline Olvasási motiváció & & 4 & & & 4 & 3 \\
\hline
\end{tabular}

A regresszióanalízis eredményei mind a tanulásban akadályozott mind a többségi tanulók részmintáján egy gyenge kétirányú kapcsolatot támasztanak alá az olvasási motiváció és az olvasás-szövegértés képesség fejlettsége között. Ez részben megerősíti azoknak az olvasási motiváció modelleket, amelyek az olvasás és az olvasás területspecifikus motiváció között reciprok kapcsolatot feltételeznek (pl. Guthrie és Wigfield, 2000), ugyanakkor a gyenge, mindössze 2-5\%-os magyarázóerők nem jelentenek erőteljes hatást. Az az eredmény, hogy 
a szövegértés teljesítmény kevés hatással van az olvasási motiváció alakulására, sőt a hetedik osztályos tanulásban akadályozott tanulók esetében egyáltalán nincs szignifikáns magyarázóereje, megerősíti azon feltételezésünket, hogy az olvasási motivációt elsősorban egyéb tényezők, feltételezhetően például az alkalmazott módszerek és olvasmányok befolyásolják.

Ugyanakkor az egydimenziós olvasási motiváció vizsgálata csak egy nagyon átfogó képpel szolgál az olvasási teljesítmény és az olvasási motiváció kapcsolatát illetően. Nem szolgál elegendő információval, hogy el tudjuk dönteni, mely olvasási motívumok befolyásolják leginkább vagy legkevésbé a teljesítményt, illetve mely motívumok alakulására van hatással az olvasás területén elért eredményesség. Ehhez további kutatásokra van szükség.

Kutatásunkban ugyanakkor lehetőségünk nyílt arra, hogy az IQ és a családi háttér hatásait is vizsgáljuk az olvasási motivációra. A tanulásban akadályozott tanulók egy része enyhén értelmi fogyatékos, azaz IQ-ja az átlag alatti, másik részük pedig annak ellenére, hogy IQ-ja a normál övezetbe tartozik, tanulási nehézséggel küzd, sokszor éppen a nem megfelelö családi háttér okozta környezeti ártalmak miatt. Nézzük meg, milyen kapcsolatban állnak az említett tényezők a tanulók olvasás iránti motivációjára. A 26. táblázat az egydimenziós olvasási motiváció, a szövegértés, az apa iskolai végzettsége mint a családi háttér egyik gyakori jellemzője és a Raven-féle IQ teszt eredményeinek korrelációját mutatja tanulásban akadályozott és többségi tanulók esetén. Az alsó háromszögben a tanulásban akadályozott, a felső háromszögben a többségi tanulók korrelációs együtthatóit tüntettük fel.

26. táblázat. A szövegértés, az olvasási motiváció, az IQ és az apa iskolai végzettségének összefüggései

\begin{tabular}{|c|c|c|c|c|}
\hline Korrelációk & Szövegértés & $\begin{array}{l}\text { Olvasási motivá- } \\
\text { ció }\end{array}$ & Raven IQ & $\begin{array}{c}\text { Apa iskolai vég- } \\
\text { zettsége }\end{array}$ \\
\hline Szövegértés & & 0,04 & $0,50 * *$ & $0,23 * *$ \\
\hline Olvasási motiváció & 0,07 & & $0,07 *$ & $0,13 * *$ \\
\hline Raven IQ & $0,43 * *$ & $-0,08$ & & $0,43 * *$ \\
\hline Apa isk. végz. & 0,05 & 0,06 & $0,10^{*}$ & \\
\hline
\end{tabular}

Megjegyzés: Az alsó háromszög a tanulásban akadályozott tanulók, a felső háromszög a többségi tanulók korrelációs együtthatóit tartalmazza. $* * 0,01$ szinten szignifikáns; *0,05 szinten szignifikáns

A korrelációs együtthatókat tartalmazó 26. táblázat egyértelmü különbségeket mutat a tanulásban akadályozott és a többségi tanulók között. A tanulásban akadályozott populáció esetében az olvasási motiváció sem az IQ-val, sem az apa iskolai végzettségével nem mutat szignifikáns korrelációt, míg a többségi mintában mindkét változóval szignifikáns az öszszefüggés. A többségi tanulók esetében az olvasási motiváció gyenge pozitív összefüggést mutat az IQ-val és az apa iskolai végzettségével is, melynek értelmében a magasabb IQ pontszámot elérő vagy magasabb iskolai végzettségü apával rendelkező tanulók motiváltabbak az olvasásra. Az, hogy a tanulásban akadályozott tanulóknál ez az összefüggés nem áll fenn, szintén arra utal, hogy olvasási motivációjukat egyéb tényezők alakítják. 


\subsection{Részösszefoglalás: A második pilot vizsgálat}

Második pilot vizsgálatunkban az olvasási motiváció egydimenziós vizsgálatát valósítottuk meg egy olyan tanulói kérdőív fejlesztésével, amely az attitüdbeli és viselkedéses jellemzők alapján következtet az olvasás iránti motiváció mint komplex egész erősségére. Nem tettünk különbséget az egyes motívumok között, az olvasási motivációt egy mérőszámmal jellemeztük. Az egydimenziós vizsgálatot többségi és tanulásban akadályozott, azaz enyhén értelmi fogyatékos és tanulási nehézségekkel küzdő tanulókkal is elvégeztük, így lehetőségünk nyílt az eredmények összehasonlítására.

Eredményeink alátámasztották, hogy a fejlesztett mérőeszköz segítségével az olvasás iránti motivációról megbízható becslés adható. A harmadik, ötödik és hetedik osztályos tanulókkal végzett kutatás eredményei arra is rámutattak, hogy a magasabb évfolyamokon a tanulók olvasás iránti motivációja egyre alacsonyabb, azaz az olvasási motiváció harmadiktól hetedik osztályig folyamatosan csökken. Ez az állítás érvényes a többségi és a tanulásban akadályozott tanulókra is, habár a csökkenés üteme a két populáció esetében eltérö. A tanulásban akadályozott tanulók harmadik és ötödik évfolyamon szignifikánsan alacsonyabb motivációt mutatnak az olvasás iránt, azonban hetedik évfolyamon nem mutatható ki különbség a többségi és a tanulásban akadályozott tanulók olvasási motivációjában. A szövegértés képessége, az IQ és az apa iskolai végzettsége sem mutatott erős korrelációt az olvasási motivációval, a tanulásban akadályozott tanulók esetében pedig az IQ és az apa iskolai végzettsége egyáltalán nem mutatott szignifikáns összefüggést az olvasási motivációval. Ezen eredmények alapján feltételezhetjük, hogy az olvasási motivációt egyéb tényezők, például az otthoni és iskolai olvasásfejlesztő tevékenységek egyes jellemzői alakíthatják. 


\section{A központi empirikus vizsgálat}

\subsection{A központi empirikus vizsgálat célja és koncepciója}

Szakirodalmi áttekintésünkben az olvasási motiváció mint területspecifikus motívumok összességének nemzetközi és hazai megközelítéseit elemeztük. A hazai kutatásokban az olvasás iránti motiváltság általában egy adott tartalom vagy müfaj - leggyakrabban a szépirodalom - iránti érdeklődésként jelenik meg, míg a nemzetközi szakirodalom a jelenség egy tágabb, az OECD által is alapul vett értelmezését adja. Ez utóbbi szerint az olvasási motiváció egy sokösszetevős rendszer, melynek kutatása elsősorban a tanulási motiváció elméletét követve indult meg. Az olvasási motiváció összetevői közül számos a tanulási motiváció szakirodalmából ismert motívumot és néhány kifejezetten az olvasáshoz kapcsolódó területspecifikus motívumot azonosítottak. Ugyanakkor nem ismeretes az olvasási motiváció egy olyan átfogó modellje sem, amely a tanulási motiváció jól megalapozott elméletein alapul, és amelyet empirikus adatok is igazolnának. A rendelkezésre álló mérőeszközök egyszerre csak néhány motívum vizsgálatára alkalmasak, és megbízhatóságuk is sok esetben alacsony. További kutatási feladat marad tehát a tanulásimotívum-rendszer adaptálása az olvasás területére, az így feltárt motívumok együttes, területspecifikus mérési lehetőségeinek kidolgozása, a motívumrendszeren belüli kapcsolatok feltárása.

Az olvasási motiváltság és az olvasási képesség fejlődése között az empirikus kutatások egyirányú kapcsolatot mutattak ki, melyben az olvasási motiváltság meghatározója a szövegértés későbbi fejlettségének, ugyanakkor a fejlett szövegértés még nem feltétlenül eredményez magas fokú motiváltságot az olvasás iránt. Mivel az olvasási képesség fejlesztése a formális oktatás befejeztével a minél szélesebb körü és gyakoribb olvasással megvalósítható, illetve fenntartható (Nagy, 2005), az iskoláknak a képességfejlesztés mellett a motívumfejlesztésre is hangsúlyt kellene fektetni. Ehhez azonban szükséges egyrészt a már említett módon a motívumok feltárása, másrészt a tanulók olvasási motiváltsá gának, annak képességfejlettséggel való összefüggéseinek vizsgálata. A fejlesztés szempontjából továbbá alapvető fontosságú azoknak a tényezöknek az azonosítása, amelyek az olvasás különböző kontextusaiban hatással lehetnek a motívumok fejlödésére, majd az azonosított területeken végzett helyzetelemzés.

Két korábbi kutatásunkban egy-egy olvasási motívum vizsgálatát végeztük el. A kutatások eredményeként megismertük a hazai tanulók olvasási énképét és olvasás iránti attitüdjeit. Jelen kutatásunk célja, hogy átfogó képet kapjunk a hazai általános iskolás tanulók olvasás iránti motivációjáról, az azt befolyásoló tényezőkről és olvasási teljesítménnyel való összefüggéséről. Ehhez olyan vizsgálatra van szükség, amely több olvasási motívum müködésének együttes megismerését teszi lehetővé.

Központi kutatásunkban az olvasási motivációt olyan sokösszetevős rendszerként definiáljuk, amely magában foglalja mindazokat a területspecifikus tanulási motívumokat, amelyek az olvasási tevékenység megkezdésében és folytatásában, az olvasásban való elmélyülésben és az az iránt való elköteleződésben tartalomtól függetlenül szerepet játszanak. Az olvasási motiváció mint önálló konstruktum motívumok rendszere, azaz azon belső pszichikus komponensek összessége, amelyek az olvasási viselkedés viszonyítási alapjai. A motívumokra irányuló hatásokat és a motivátorokat csak mint a motívumokat befo- 
lyásoló tényezőket értelmezzük. Az olvasási motivációt rendszernek tekintjük, azaz feltételezzük, hogy az egyes olvasási motívumok között kapcsolatok vannak. Megközelítésünkben az olvasási motiváció területspecifikus tanulási motiváció, azaz összetevői megegyeznek a tanulási motiváció elméletei által azonosított motívumokkal, ugyanakkor tartalmukban szükebbek, minthogy kizárólag az olvasásra és az olvasás elsajátítására vonatkoznak, valamint több olyan elemet is tartalmaznak, amelyek csak az olvasás területére vonatkoznak, azaz olvasásspecifikusak. Koncepciónkban az olvasási motivációt az olvasott tartalomtól függetlenül definiáljuk, azaz - követve a nemzetközi rendszerszintü mérések koncepcióját - olvasási tevékenység alatt bármely írott tartalom bármilyen céllal történő dekódolását és értelmezését értjük, nem teszünk ezek között különbséget.

Vizsgálódásunk az általános iskola kezdeti szakaszától az alapfokú oktatás-nevelés végéig terjed. Választásunk azért esett e populációjára, mert a szakirodalom alapján az olvasás elsajátítása, az e területen szerzett affektív tapasztalatok hatással vannak a későbbiekben a többi tantárgy tanulására, az azok iránti motivációra. Az olvasási motiváció jellemzőinek, fejlődésének megismerése feltételezhetőleg, alapul szolgál a tanulási motiváció más területekre is kiterjedő területspecifikus vizsgálataihoz.

Tekintve, hogy a hazai szakirodalom nem rendelkezik az olvasási motiváció tartalomfüggetlen, sokösszetevős rendszerének modelljével és az annak vizsgálatára alkalmas mérőeszközzel, első célunk, hogy a nemzetközi szakirodalom megismerésével, a nemzetközi olvasási motiváció modellek adaptálásával a konstruktum általános iskolai mérésére alkalmas mérőeszközöket fejlesszünk. Ehhez alapul Möller és Schiefele (2010) olvasásimotiváció-modellje szolgált, amit a tanulási motiváció elméletei alapján egészítettünk ki. A motívumok müködését, fejlödését befolyásoló, a szakirodalom által tárgyalt tényezők vizsgálatára a felsőbb évfolyamokon szülői és tanári kérdőíveket dolgoztunk ki. Ugyanakkor feltételezzük, hogy az alsóbb évfolyamokon a szülői és a tanári meggyőződések és visszajelzések internalizálása még kezdeti fázisban van, ezért a tanulói megnyilvánulásokban tetten érhetőek. Mivel a szociális környezet hatótényezői szubjektív feldolgozáson mennek keresztül, a szociális környezet egyes jellemzőinél informatívabb az, hogy mit dolgoz fel ebből a tanuló. Így az alsóbb évfolyamokon félig strukturált interjúkkal igyekszünk feltárni az internalizálandó extrinzik motívumokat. Az olvasási képesség vizsgálatára olvasáskészség tesztet, valamint folyamatos és nem folyamatos szöveget is tartalmazó szövegértés tesztet használtunk. A háttérkérdőívek a tanuló nemére, osztályzataira és családi hátterére vonatkozó kérdéseket tartalmazták. Az adatokat kvantitatív és kvalitatív módszerekkel elemeztük. Az empirikus mérés koncepcióját a 15. ábra szemlélteti. 


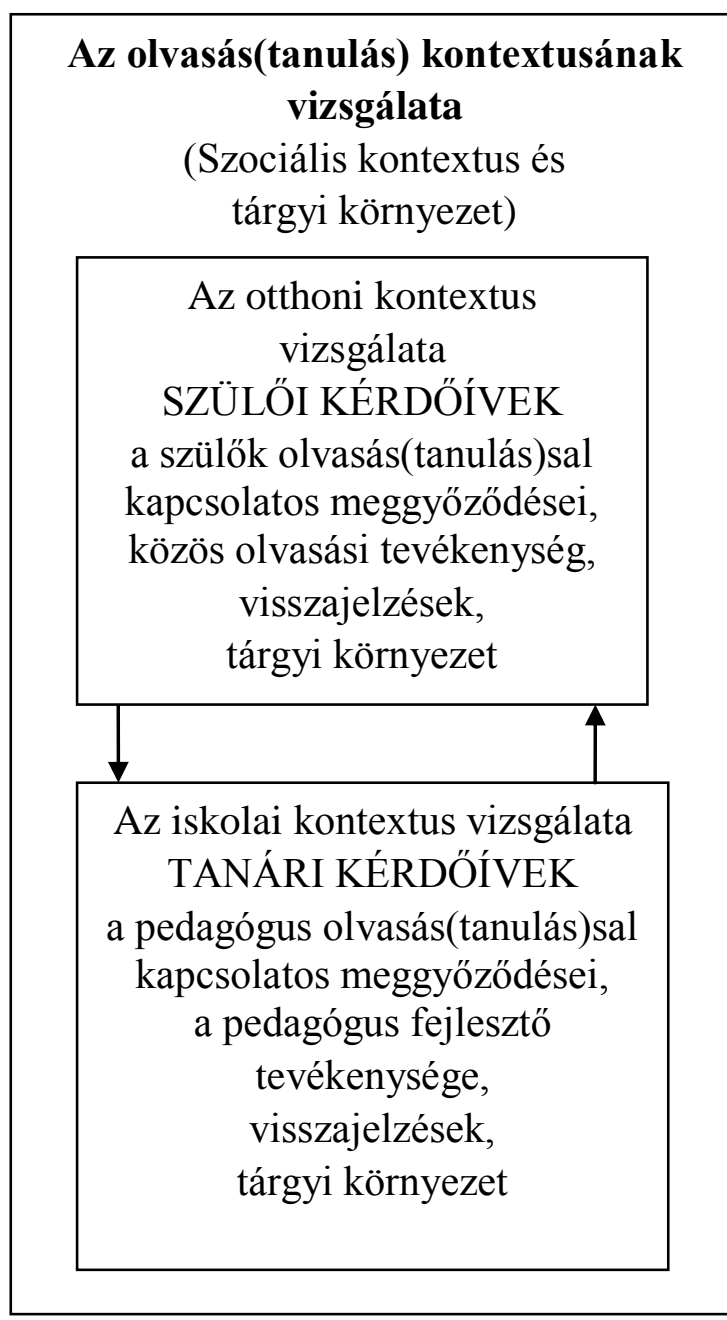

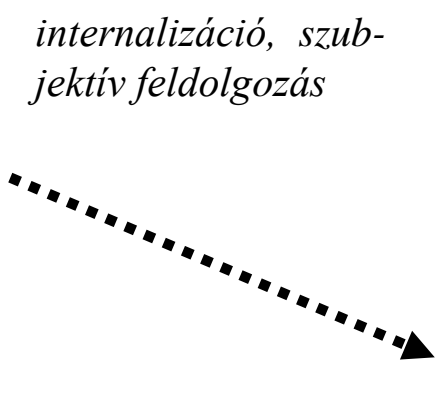
A tanuló szociális
környezet észleletének vizsgálata

TANULÓI INTERJÚK

az olvasás(tanulás) célja, értéke

olvasás énkép forrásai

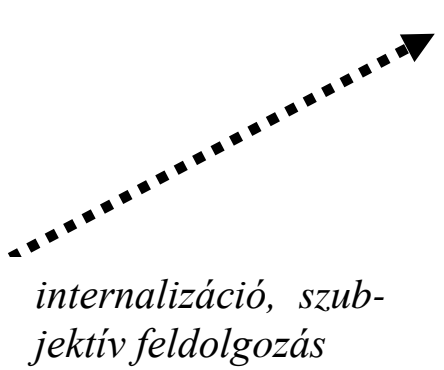

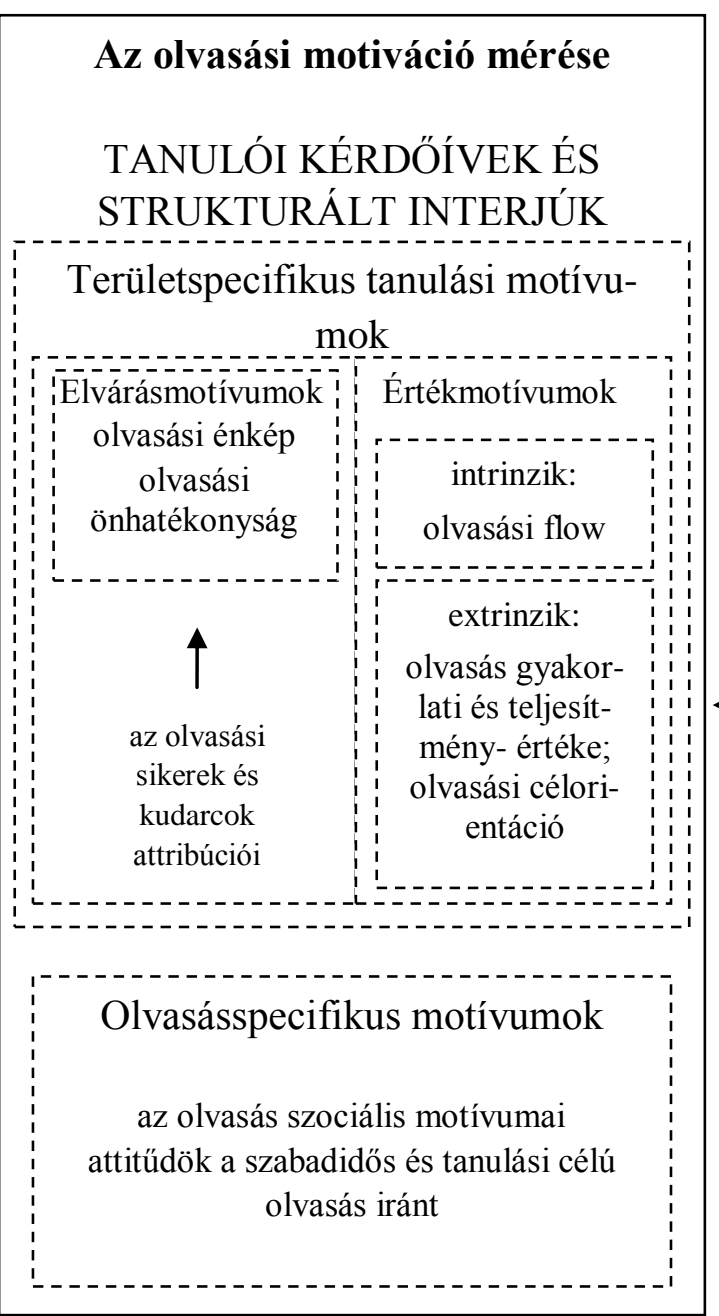

15. ábra

A központi empirikus mérés rendszere

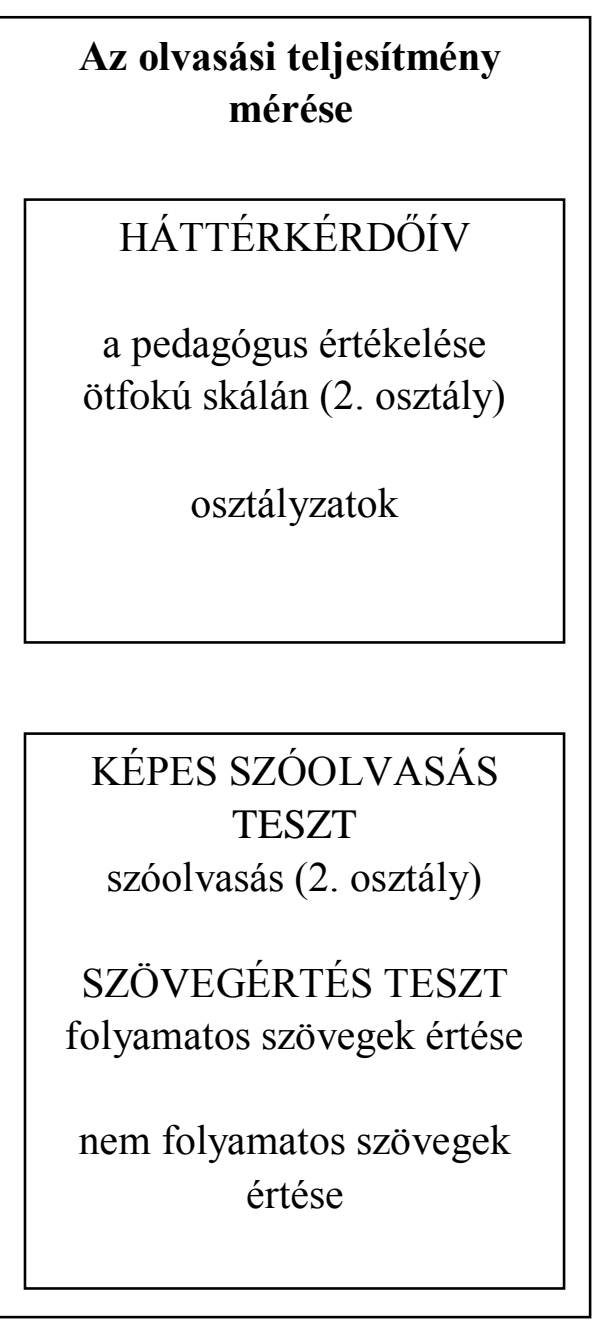

SZÖVEGÉRTÉS TESZT nem folyamatos szövegek értése 


\subsection{A központi vizsgálat kérdései, hipotézisei}

Az alapkutatás öt problémakör köré szerveződik, melyekhez külön-külön kapcsolódnak kutatási kérdések. Kutatásunkban az alábbi kérdésekre kerestük a választ:

1. Mérés: az olvasási motiváció többmotívumos mérése

- Azonosíthatók-e a szakirodalom által tárgyalt motívumok, elkülöníthetőek-e az olvasás területén müködő egyes motívumok?

- Mérhetőek-e eredményesen az általános iskolás korú tanulók olvasási motívumai?

- Mérhetőek-e eredményesen az olvasási motiváció összetevői már az olvasástanulás kezdetén?

- Vizsgálható-e az elvárás-érték modell két alapelemének, az olvasási énképnek és az olvasásnak tulajdonított értéknek a forrása az olvasástanulás kezdetén?

2. Motívumok: az olvasási motívumok életkori, nemi jellemzői

- Mi jellemzi az olvasástanulás kezdetén a tanulók olvasási motívumait?

- Milyen forrásai vannak az elvárás-érték modell két alapelemének, az olvasás énképnek és az olvasásnak tulajdonított értéknek az olvasástanulás kezdetén?

- Hogyan alakul az általános iskola folyamán a tanulók olvasás iránti motiváltsága?

- Hogyan alakulnak az általános iskola folyamán az egyes olvasási motívumok jellemzői?

- Van-e különbség a nemek között az olvasás iránti motiváltság mértékét illetően?

- Van-e különbség a nemek között az egyes olvasási motívumok jellemzőit illetően?

3. Belső összefüggésrendszer: az olvasási motiváció belső struktúrájának, a motívumok öszszefüggésrendszere

- Hogyan jellemezhető az olvasási motívumok egymáshoz való viszonya az egyes évfolyamokon?

- Kimutatható-e különbség az olvasási motiváció belső struktúrájában, a motívumok összefüggésrendszerében az életkori csoportok között?

4. Motívumok és képességfejlettség kapcsolata: az olvasási motívumok összefüggése az olvasásteljesítménnyel és az olvasási képesség fejlettségével

- Milyen összefüggés áll fenn az olvasási motívumok és az olvasási képesség fejlettsége között?

- Milyen összefüggés áll fenn az olvasási motívumok és a tanár értékelése, valamint az olvasás/magyar nyelv és irodalom osztályzatok között? 
5. Külső összefüggésrendszer: a motívumok összefüggése a külső, környezeti tényezőkkel

- Mi jellemzi az olvasási képesség és az olvasási motívumok otthoni fejlesztését?

- Van-e összefüggés a családi háttér, a családi nevelés és az olvasási motívumok között?

- Mi jellemzi az olvasási képesség és az olvasási motívumok óvodai és iskolai fejlesztését?

- Van-e összefüggés az óvodai és iskoláskori fejlesztés és az iskoláskori olvasási motiváció között?

- Tettenérhetők-e az olvasástanulás kezdetén a tanulók megnyilatkozásaiban a szociális kontextus hatásai?

- Mi alakítja a tanulók sikerelvárással kapcsolatos motívumait motívumait az olvasástanulás kezdetén?

- Milyen értéket, célokat tulajdonítanak a tanulók az olvasástanulás kezdeti szakaszában az olvasás(tanulás)nak, és mi alakítja ezt a folyamatot?

A szakirodalom és korábbi kutatásaink eredményei alapján az egyes problémakörökhöz kapcsolódóan a következő hipotéziseket fogalmazzuk meg:

1. Mérés

$\mathrm{H}_{1}$ : Strukturált interjúk keretében felvett kérdőívekkel megbízható becslés adható az olvasási motívumok müködéséről az olvasástanulás kezdeti szakaszában.

$\mathrm{H}_{2}$ : Kérdőíves módszerrel megbízható becslés adható a motívumok müködéséről az olvasástanulás későbbi szakaszában.

$\mathrm{H}_{3}$ : A faktoranalízis eredménye alapján a tanulási motiváció és az olvasási motiváció irodalma által tárgyalt motívumok azonosíthatók és elkülöníthetők.

$\mathrm{H}_{4}$ : Félig strukturált interjúmódszerrel megbízhatóan vizsgálható a tanulók énképének forrása és az általuk az olvasás(tanulás)nak tulajdonított célok.

$\mathrm{H}_{5}$ : Képes szóolvasás teszttel megbízható becslés adható a szóolvasó készség müködéséröl.

$\mathrm{H}_{6}$ : Szövegértés teszttel megbízható becslés adható az olvasás-szövegértés képességének müködéséröl.

2. Motívumok

$\mathrm{H}_{7}$ : Az olvasástanulás kezdeti szakaszában a tanulókat az olvasás iránti magas motiváltság jellemzi.

$\mathrm{H}_{8}$ : A motívumok erőssége a felsőbb évfolyamokon egyre alacsonyabb.

$\mathrm{H}_{9}$ : A motívumok müködését illetően az évfolyamok között jelentős különbségek vannak.

$\mathrm{H}_{10}$ : Már az olvasástanulás kezdeti szakaszában számos különbség lelhető fel a nemek között a motívumok erősségét illetően. 
3. Belső összefüggésrendszer

$\mathrm{H}_{11}$ : Az olvasás motívumai között már az olvasástanulás kezdeti szakaszában is összefüggések vannak.

$\mathrm{H}_{12}$ : Az egyes kategóriákba tartozó motívumok között (értékmotívumok és elvárásmotívumok) a kapcsolat erősebb, mint a kategóriák között.

$\mathrm{H}_{13}$ : A magasabb évfolyamokon a kategóriák közötti kapcsolat erösebb, mint az alacsonyabb évfolyamokon.

4. Motívumok és teljesítmény:

$\mathrm{H}_{14}$ : Az olvasási motívumok és az olvasási teljesítmény között pozitív irányú összefüggés van.

$\mathrm{H}_{15}$ : Az olvasási motívumok és az olvasási teljesítmény közötti összefüggés erőssége függ attól, hogy az olvasási motiváció mely indikátorát használjuk.

$\mathrm{H}_{16}$ : Az olvasási motívumok erősebben korrelálnak az osztályzatokkal, mint az olvasási képesség fejlettségével.

$\mathrm{H}_{17}$ : A magas képességfejlettségü tanulók nem feltétlenül motiváltabbak az olvasásra.

$\mathrm{H}_{18}$ : Az olvasás iránti motiváció meghatározója a képességfejlettség egyéni különbségeinek.

5. Külső összefüggésrendszer

$\mathrm{H}_{19}$ : A tanulók olvasási motívumai összefüggést mutatnak az otthoni és az iskolai olvasási tevékenységek egyes aspektusaival.

$\mathrm{H}_{20}$ : A tanulók olvasási motívumait az olvasástanulás kezdetén erősen befolyásolják a tanító és a szülők visszajelzései.

$\mathrm{H}_{21}$ : A tanulók olvasástanulással kapcsolatos céljait a szülői és pedagógusi tevékenységek alakítják.

$\mathrm{H}_{22}$ : A családi háttér egyes jellemzői és az olvasási motívumok fejlettsége között kapcsolat van.

\subsection{Adatfelvétel és mérőeszközök}

Az adatokat 2010 novemberében vettük fel Csongrád, Pest és Bács-kiskun megyei általános iskolákban. Az olvasási motiváció mérésére tanulói kérdőíveket, az olvasási képesség vizsgálatára teszteket, az olvasástanulás kontextusának felmérésére szülői és pedagógusi kérdőíveket alkalmaztunk. A vizsgálatban általános iskolás korú tanulók vettek részt, azaz a 7-14 éves korosztály. A viszonylag széles életkori spektrum miatt nem alkalmazhattunk azonos méröeszközöket minden életkori csoportban, így az általános iskola kezdő szakaszára és a felsőbb évfolyamokra az olvasási motiváció mérése céljából azonos modell alapján, de számos jellemzőjében eltérő mérőeszközt fejlesztettünk. A két kérdőívváltozat - az 1-2. osztály és a 3-8. osztály számára készített változatok - skálái megegyeznek, és a legtöbb skála esetében az itemek is csupán a modalitás tekintetében térnek el. Egy motívum - a célorientáció - esetében 
a szakirodalom tanulmányozása után úgy döntöttünk, a fiatalabb korosztály esetében a konkrétumok szintjén fogalmazzuk meg a kérdéseket, így itt az egyes célorientációkra vonatkozó tételek nem alkotnak skálát. Az olvasás értéke esetében hasonlóan jártunk el: az alsóbb évfolyamokon a teljesítmény- és gyakorlati értékre egy-egy tétel vonatkozott, a felsőbb éveseknél egy-egy skála. A különbségtételt itt a kérdőívtételek megfogalmazása, logikai feldolgozása indokolta.

Mind az első-második osztály, mind a felsőbb évfolyamok olvasási motiváció kérdőíveinek fejlesztésekor hazai és külföldi méröeszközöket vettünk alapul. A kérdőívek skálái megfelelnek az általuk vizsgált motívumoknak. Egy-egy skála fejlesztésekor egy az adott motívumot vizsgáló már meglévő és kipróbált külföldi vagy hazai mérőeszközre támaszkodtunk. A skálák adaptálása kétféle módon történt. Egyrészt, az olvasási motiváció nemzetközi többmotívumos vizsgálatainak mérőeszközeit felhasználva, az angol nyelvü, olvasás területére vonatkozó skálák magyar nyelvre fordításával és adaptálásával; másrészről a tanulási motiváció vizsgálataiban használatos hazai vagy külföldi kérdöívek skáláinak olvasás területre - és szükség esetén magyar nyelvre - történő adaptálásával. A felhasznált kérdőívek listáját a hozzá tartozó skála feltüntetésével a 27. sz. táblázat tartalmazza. A skálák adaptálásához az eredeti mérőeszközök szerzőinek engedélyét kikértük.

\section{7. táblázat. Az olvasási motiváció kérdőivek skálái és a skálák kidolgozásához felhasznált mérōeszközök}

\begin{tabular}{|c|c|}
\hline Skála & Méröeszköz \\
\hline Olvasás önhatékonyság & Early Literacy Motivation Survey (Wilson és Trainin, 2007) \\
\hline Flow az olvasásban & Flow Kérdőív (Oláh, 2005) \\
\hline Olvasási énkép & Self-Description Questionnaire I (Marsh, 1992) \\
\hline $\begin{array}{l}\text { Az olvasás sikerek és kudarcok } \\
\text { attribúciói }\end{array}$ & Early Literacy Motivation Survey (Wilson és Trainin, 2007) \\
\hline Olvasás célorientáció & a célorientáció skálái (Meece és Miller, 2001) \\
\hline $\begin{array}{l}\text { Az olvasás(tanulás) teljesítmény- és } \\
\text { gyakorlati értéke }\end{array}$ & $\begin{array}{l}\text { az olvasás szerepe az iskolai előhaladásban és az életben (Szinger, } \\
\text { 2009) (4.,6. és 8. évfolyamok) és Wigfield és Eccles (2000) } \\
\text { (2. évfolyam) }\end{array}$ \\
\hline Az olvasás szociális motívumai & Motivations for Reading Questionnaire (Wigfield és Guthrie, 1997) \\
\hline $\begin{array}{l}\text { Attitüdök a szabadidős és } \\
\text { a tanulási célú olvasás iránt }\end{array}$ & Elementary Reading Attitude Survey (McKenna és Kear, 1990) \\
\hline
\end{tabular}

\subsubsection{Az első és második évfolyam mérőeszközei}

Az alsóbb évfolyamosok mérőeszközeit a korosztály életkori jellemzőinek megfelelően fejlesztettük. Az olvasási motívumok kérdőív skáláit és felépítését tekintve azonos a felsőbb évfolyamok mérőeszközével. Azonban az egyes tételek megfogalmazása és egyes esetekben a 
skálákhoz tartozó tételek eltérőek. Az elsős-másodikos mérés továbbá az adatfelvétel módja tekintetében is eltér a felsőbb évfolyamon történt vizsgálatoktól.

Az olvasási motívumok mérése: Az olvasás motívumainak vizsgálatára az első és a második évfolyam számára strukturált és félig strukturált interjúk keretében felvehető kérdőívet fejlesztettünk. Az 50 kérdőívtételből álló mérőeszköz (6. melléklet) az olvasási motiváció nyolc komponensét vizsgálja. A tételek modalitásukat tekintve kérdések. A modalitás megválasztását korábbi kutatások eredményei indokolták, amelyek rámutattak, hogy szóbeli interjúk alkalmával a kijelentő mondatok használata a kisebb gyermekek számára értelmezési nehézségeket okoz. A kérdések megértésének folyamata ezzel szemben kevésbé összetett, hiszen a természetes beszédhelyzetnek inkább megfelelö (Chapman és Tunmer, 1995).

Az 50 tételből 48 Likert-skálás, a válaszadás négyfokú skálán történik. A négyfokú skála használatát az indokolta, hogy az adott korosztály számára egy középső érték nehezen értelmezhetö lett volna és könnyen azonosíthatták volna a „nem tudom” vagy „nem értem a kérdést” jelentéssel. A négyfokú skála használatával megerösítettük bennük, hogy döntést várunk. Mindemellett hangsúlyoztuk, hogy nem probléma, ha nem tudnak válaszolni, ezt bármikor jelezhetik. A válaszadás így egyértelmüen a kérdés értelmezésére utalt, míg a válaszadás elkerülése a meg nem értésre engedett következtetni. A szóbeli kikérdezés indokolta továbbá azon döntésünket is, hogy több motívum vizsgálatához csupán néhány kérdőívtétel kapcsolódjon, ugyanis a mérőeszköz kipróbálásakor többször felmerült az a probléma, hogy a tanulók nem értették vagy félreértették, miért tesszük fel ugyanazt a kérdést kicsit más formában. Iskolai kontextusban a tanulók hozzá vannak szokva, hogy a kérdésekre vannak jó és rossz válaszok, és a tanító akkor fogalmazza újra a kérdést, ha az arra elsőként kapott válasz nem megfelelő. A gyermekek így a többszöri, azonos tartalmú, de más megfogalmazású kérdésekből így arra következtettek, hogy előző válaszuk nem volt jó, és valami teljesen más választ próbáltak megfogalmazni. Az olyan skálák ezért, amelyek nem komplex skálák (mint például a flow), hanem az olvasási motiváltság csupán egyetlen aspektusára kérdeznek rá (például önhatékonyság) csak 2-3 kérdőívtételt tartalmaznak.

A skálán történő válaszadást segédeszközökkel tettük egyszerübbé a gyermekek számára (7. melléklet). A kérdéseket először mindig eldöntendő formában tettük fel a gyermekeknek, akik először igennel vagy nemmel válaszoltak. Ezután a válaszaikat a piktogramok segítségével pontosíthatták, finomíthatták. A skálák használatát a tanulóknak az interjúk kezdete elött egyszerü példákon keresztül tanítottuk meg. A mosolygós arcos válaszadó lap a jegyzökönyv első (attitüdök és szociális motívumok) skálájának felvételéhez használandó, és érzelmi viszonyulást fejez ki. A többi skála esetében segédeszközként az oszlopos ábrát alkalmaztuk; ez az intenzitás, a gyakoriság és a mennyiség kifejezésére volt alkalmas.

Három motívum - az önhatékonyság, a teljesítmény-attribúciók és a célorientáció vizsgálata feladatspecifikusan történt, a többi motívum esetében a tételek az olvasás területére vonatkoznak, azonban ezen belül nem kapcsolódnak egy specifikus olvasásfeladathoz. Az önhatékonyság definíciójából eredendően feladatspecifikus, vizsgálatához szükséges egy jövőbeni feladat kitüzése, specifikálása. Esetünkben ez egy hangos olvasást igénylő feladat volt, melyben arra kértük a tanulókat, hogy két szókártyán lévő kilenc-kilenc különböző hosszúságú szót olvassanak fel hangosan. Az egyik szókártya valós szavakat, a másik álszavakat tartalma- 
zott, ezzel fokozva a kihívás nagyságát. Mielőtt megkapták volna a szókártyát, rövid időre felmutattuk nekik, majd arra kértük öket, becsüljék meg, mennyit tudnak majd a szavak közül hibátlanul felolvasni a valós szavak és az álszavak esetében külön-külön. A választ a négyfokú skálán adhatták meg. A teljesítményattribúciók-skála feladatspecifikusságát az indokolta, hogy feltételeztük, a tanulók még nehezen gondolkodnak el ebben az életkorban saját sikereik és kudarcaik okán, mely nehézséget még tovább fokozhatja az, ha nem tudják az adott sikert vagy kudarcot konkrét eseményhez kötni. A teljesítményattribúciók vizsgálatára így közvetlenül a hangos olvasás feladat után kerítettünk sort, kérdéseink pedig a hangos olvasás közben elkövetett hibákra és az összteljesítmény sikerére vonatkoztak. A harmadik feladatspecifikusan vizsgált motívum, a célorientáció esetében a viszonyítási feladatot a képes szóolvasás teszt jelentette, amit a tanulók közvetlenül az interjúk elött töltöttek ki. A feladatspecifikus vizsgálatot itt ismét a kérdések elvontsága, a viszonyítási pontok hiánya indokolta. A célorientációra vonatkozó kérdések előtt arra kértük a tanulókat, emlékezzenek vissza, mi járt a fejükben, miközben ezen a feladaton dolgoztak. Ezt követően a kérdések erre a specifikus helyzetre vonatkoztak. Az olvasási motiváció iskola kezdetekor történő mérésére fejlesztett méröeszköz szerkezetét a 28. táblázat mutatja.

28. táblázat. Az olvasási motiváció méröeszközének felépitése a második évfolyam vizsgálatában

\begin{tabular}{lcl}
\hline \multicolumn{1}{c}{ Motívumok } & $\begin{array}{c}\text { Kérdöívtételek } \\
\text { száma }\end{array}$ & \multicolumn{1}{c}{ Példa kérdöivtételre } \\
\hline Attitüdök & 5 & Szereted gyakorolni az iskolában az olvasást? \\
Szociális motívumok & 4 & Szereted, amikor közösen olvasol valamit valakivel? \\
Önhatékonyság & 2 & Mennyit tudnál felolvasni a szavak közül? \\
Sikerattribúciók & 5 & Azért sikerült kiolvasnod, mert szerencséd volt? \\
Kudarcattribúciók & 5 & Azért nem sikerült kiolvasnod, mert nehéz volt a szó? \\
Flow & 7 & $\begin{array}{l}\text { Amikor olvasásórán egy feladaton dolgozol, akkor csak a } \\
\text { feladatra figyelsz? } \\
\text { Amikor olvasásórán egy feladaton dolgozol, akkor szoktad } \\
\text { úgy érezni, hogy nem érdekel az egész? }\end{array}$ \\
Antiflow & 9 & $\begin{array}{l}\text { Fontos neked, hogy jól tudj olvasni? } \\
\text { Érték }\end{array}$ \\
Énkép & 3 & Jó olvasó vagy? \\
Célorientáció & 4 & $\begin{array}{l}\text { Mikor a feladatokon dolgoztál, azt kívántad, bárcsak ne } \\
\text { kellene megcsinálnod öket? }\end{array}$ \\
\hline \hline
\end{tabular}

Három motívum vizsgálatához a zárt kérdések mellett nyílt végű kérdések is kapcsolódtak annak érdekében, hogy pontosabb képet kapjunk arról, mi alakítja a tanulók elvárás és érték motívumait, mi alapján alakítják ki meggyőződéseiket és pontosan mit takarnak ezek a meggyőződések. Az egyik ilyen motívum az olvasási énkép volt, melynek esetében a zárt kérdést követő nyílt végü kérdés az énkép forrásaira kérdezett rá, a másik esetben az olvasás(tanulás) 
teljesítmény- és gyakorlati értékére vonatkozó kérdés után a nyílt végü kérdés az értéktulajdonítás okára, azaz az olvasási célokra irányult. A válaszokat hangfelvételen rögzítettük, majd két független elemző segítségével kategorizáltuk. A harmadik motívum, amely vizsgálatára nyílt végü kérdést is alkalmaztunk, az olvasásteljesítmény-attribúciók voltak. Ez esetben a nyílt és a zárt végü kérdések egymás ellenőrzésére, azaz a válaszok megbízhatóságának biztosítására irányultak. A nyílt végü kérdésre adott választ ebben az esetben a jegyzökönyv rögzítésekor az interjú készítője kategorizálta a szakirodalom által meghatározott négy kategória (lásd Weiner, 1985) egyikébe.

Az olvasásteljesitmény mérése: Az olvasásteljesítményt kétféle mutató alapján határoztuk meg. Egyrészt a képességfejlettség vizsgálatára ebben az életkorban szóolvasás tesztet alkalmaztunk (Nagy, 2006, 4. melléklet). A szójelentés-olvasás vizsgálatára alkalmazott teszt kitöltésekor a tanulóknak megadott szavak közül kell kiválasztaniuk azokat, amelyek illenek egy megadott képhez. Egy képhez több szójelentés is kapcsolódhat, de akár az is előfordulhat, hogy egyetlen szó jelentése sem illik a megadott képre. A teszt kitöltésekor a tanulóknak a helyes jelentéssel bíró szavak betűjelét karikázni, a helytelen válaszokét áthúzni kell. Ez a válaszadási forma eltér az iskolákban általában használt módoktól, főként a helytelen válasz jelölése esetében, ezért a gyermekek figyelmét többször felhívtuk az áthúzás fontosságára. Egy feladat akkor ért pontot, ha a tanuló minden helyes szójelentéssel bíró szó jelét bekarikázta és minden helytelen jelentéssel bíróét áthúzta. A szóolvasó készség fejlettségének mutatóját a teszt összpontszáma alapján kiszámolt százalékos teljesítmény adta. A teljesítmény másik mutatóját a tanítói értékelése alapján határoztuk meg. A tanulók osztálytanítóját arra kértük egy ötfokú skálán értékelje egyesével a kiválasztott tanulók olvasásteljesítményét. Az így kapott számadatot tekintettük az olvasásteljesítmény másik mutatójának.

Háttérkérdőiv: A tanulók családi hátterével és nemével kapcsolatos háttérinformációkat tartalmazó kérdőívet a tanulók osztálytanítója - szükség esetén szülői segítséggel - töltötte ki. A rövid tanulói adatlapokon a pedagógust arra is meg kértük, értékelje a felmérésben részt vevő tanulók olvasási teljesítményét egyesével egy ötfokú skálán.

\subsubsection{Adatfelvétel az első-második évfolyamon}

Az olvasási motívumok vizsgálatára első és második évfolyamon strukturált és félig strukturált interjúk keretében került sor. Az interjúkat pedagógia szakos (SZTE BTK) hallgatók vették fel, akik az adatfelvételt megelőzően egy másfél órás felkészítő tréningen vettek részt. A tréning során elsajátították és gyakorolták a felvétel módszereit és technikáit, ötleteket kaptak a gyermekkel való kapcsolatteremtés formáira. Munkájukat segítette az adatfelvételi jegyzőkönyv hosszú változata (8. melléklet), amelyben megtalálható a teljes interjú anyaga, továbbá ötletek a skálahasználat megtanítására, a szituáció által esetlegesen keltett feszültség oldására. További segítséget jelentett számukra a mérö- és segédeszközök részletes leírását tartalmazó segédlet és a folyamatos internetes kapcsolattartás, a kérdésfeltevés lehetősége.

Az interjúk során fontos szempont volt, hogy a kérdező ne irányítsa a tanuló gondolkodását, de semleges segítő kérdésekkel segíthette az értelmezést, bátoríthatta a válaszadást. 
Azokat az eseteket, ahol a kérdező esetleg valamilyen módon irányítani próbálta a tanulót, a hangfelvételek alapján az elemzésből kizártuk.

Az egyéni interjúk felvétele tanulónként 10-15 percet vett igénybe. A kérdőív felvételének monotonitását megszakította az önhatékonyság és teljesítményattribúciók skálák referenciapontját adó hangos olvasás feladat, valamint a nyílt végủ kérdések, amelyekre a gyermekek szabadon válaszolhattak. Az adatfelvétel az iskolákban tanítási időben történt az iskola épületén belül egy szeparált helyen (üres tanterem, tanári szoba stb.). Az interjúfelvételről az érintett szülöket az iskola előzetesen tájékoztatta, a szülőknek lehetősége volt ez alól gyermekük felmentését kérni. Az adatfelvétel név nélkül történt.

\subsubsection{A negyedik, hatodik és nyolcadik évfolyamok mérőeszközei}

A felsőbb évfolyamokon az olvasási motiváció mérésére egy kérdőívet, az olvasás-szövegértés vizsgálatára egy olvasás tesztet alkalmaztunk. Mind a kérdőívet, mind a tesztet a tanulók egyénileg töltötték ki.

Az olvasási motívumok mérése: Az olvasási motiváció mérésére fejlesztett kérdőív (9. melléklet) ugyanazokat a motívumokat vizsgálja, mint az alsóbb évfolyamok mérőeszköze. Azonban e kérdőív műfaji jellemzőinek megfelelően az egy skálához tartozó itemek száma magasabb. Az összesen 75 kérdőívtételt tartalmazó mérőeszköz az olvasási motiváció nyolc összetevőjét vizsgálja (29. táblázat). A 75 tételből kettő nyílt végủ kérdés, 73 ötfokú Likertskálán értékelhető állítás vagy kérdés. Tekintve, hogy ebben az életkorban a tanulók olvasási képességének fejlettsége már lehetővé teszi a gyakori élményszerző és tudásszerző olvasást, a kérdőív az attitüdök tekintetében különbséget tesz a tanulási célú olvasás iránti attitüdök és a szabadidős olvasás iránti attitüdök között. Az attribúciók mérése a másodikos méréshez hasonló módon történt: az olvasási sikerek és kudarcok okára elsőként egy nyílt végủ kérdés kérdezett rá, majd ezt követte a szakirodalom által meghatározott négy dimenziót leképező négynégy kérdőívtétel. Az önhatékonyság mérése definíciójából adódóan ismét feladatspecifikusan történt egy kérdéssel, ami arra vonatkozott, hogy a kutatás részét képező tesztet a tanulók saját megítélésük szerint milyen sikerrel fogják megoldani. Hasonlóképp a másodikosok méréséhez, a flow, az antiflow élmények és az olvasási célorientáció vizsgálatára szintén feladatspecifikus tételeket fejlesztettünk, ezek a tételek is a kutatás részét képező szövegértés

tesztre vonatkoztak. A többi motívumot területspecifikusan, általánosságban véve az olvasásra vonatkozóan vizsgáltuk. 
29. táblázat. Az olvasási motiváció mérőeszközének felépítése a felsőbb évfolyamok vizsgálataiban

\begin{tabular}{|c|c|c|}
\hline Motívumok & $\begin{array}{l}\text { Kérdöívté- } \\
\text { telek száma }\end{array}$ & Példa kérdöivtételre \\
\hline Attitüdök - tanulási célú & 5 & Mennyire szeretsz a tankönyveidből olvasni? \\
\hline Attitűdök -szabadidős & 5 & Mennyire szeretsz egy esős szombati napon történeteket olvasni? \\
\hline Szociális motívumok & 7 & Szeretek másokkal beszélgetni arról, amiket olvastam. \\
\hline Önhatékonyság & 1 & Mit gondolsz, hány feladatot tudsz majd helyesen megoldani? \\
\hline Sikerattribúciók & 4 & $\begin{array}{l}\text { Milyen gyakran okozták a sikeredet a következő tényezők? } \\
\text { könnyü volt a szöveg }\end{array}$ \\
\hline Kudarcattribúciók & 4 & $\begin{array}{l}\text { Milyen gyakran okozták a nehézséget a következő tényezők? } \\
\text { nehéz volt a szöveg }\end{array}$ \\
\hline Flow & 8 & $\begin{array}{l}\text { Mikor ehhez hasonló olvasásfeladatokon dolgozom, általában úgy } \\
\text { érzem, világosan tudom, mit kell tennem. }\end{array}$ \\
\hline Antiflow & 11 & $\begin{array}{l}\text { Mikor ehhez hasonló olvasásfeladatokon dolgozom, általában úgy } \\
\text { érzem, figyelmem elkalandozik. }\end{array}$ \\
\hline Érték & 6 & Az olvasás alapos megtanulása segít a felnőtt életben. \\
\hline Énkép & 7 & Bármit megértek, amit elolvasok. \\
\hline Célorientáció - elsajátítási & 5 & $\begin{array}{l}\text { Mikor az olvasásfeladatokon dolgoztam, szerettem volna minél } \\
\text { jobban megérteni a feladatokat. }\end{array}$ \\
\hline Célorientáció - teljesítmény & 5 & $\begin{array}{l}\text { Mikor az olvasásfeladatokon dolgoztam, szerettem volna dicsére- } \\
\text { tet kapni. }\end{array}$ \\
\hline Célorientáció - munkakerülő & 5 & $\begin{array}{l}\text { Mikor az olvasásfeladatokon dolgoztam, szerettem volna a lehető } \\
\text { legkevesebbet foglalkozni a feladatokkal. }\end{array}$ \\
\hline
\end{tabular}

Az olvasásteljesitmény mérése: Az olvasásteljesítményt a felsőbb évfolyamok esetében is két mutatóval jellemeztük. Az egyik az olvasás-szövegértés teszten (10. melléklet) elért eredmény, a másik a tanár által adott előző év végi irodalom és nyelvtan osztályzat, valamint tanulmányi átlag. A szövegértés tesztet Józsa Krisztián és Hrabovszky Mihály fejlesztette, a PISAvizsgálatok koncepciójával összhangban folyamatos és nem folyamatos szövegeket is tartalmazott. A szövegértés teszt első feladatában egy menetrend alapján kellett a tanulóknak nyílt végü kérdésekre válaszolniuk. A második feladat hasonló kérdéseket tartalmazott egy narratív szöveg kapcsán. A teszt itemei az egyszerü információvisszakereséstől a lényeg megfogalmazásáig különböző bonyolultságú olvasási tevékenységet követeltek meg a tanulóktól.

Szülői háttérkérdöivv: A szülői háttérkérdőívet (11. melléklet) a PIRLS háttérkérdöívei alapján fejlesztettük, amely az olvasástanulás otthoni kontextusának egyes jellemzőire kérdez rá. A PIRLS-kérdőívből azokat a részeket vettük át, amelyek az iskola előtti otthoni fejlesztés, az iskoláskori otthoni fejlesztés, az iskola és a szülö közötti kapcsolat egyes aspektusaira vonatkozik. Az átvett elemeket kiegészítettük kifejezetten az olvasási motivációra vonatkozó kérdésekkel. Ezek között egyrészt a szülő saját olvasás iránti motivációjára, másrészt pedig a gyermeke olvasásteljesítményével és olvasás iránti motivációjával kapcsolatos elvárásaira 
vonatkozó kérdések szerepeltek. A szülői háttérkérdőíveket a gyermek szülője vagy gondviselője, vagy a szülök/gondviselök közösen töltötték ki.

Tanári háttérkérdőiv: A tanári/tanítói háttérkérdőívet (12. melléklet) szintén a PIRLS háttérkérdőíve alapján fejlesztettük. Ez a kérdőív az iskolai kontextus egyes jellemzővel kapcsolatos kérdéseket tartalmaz. A szövegértés tanításának módszerei mellett a pedagógus olvasási motivációval kapcsolatos elképzelésére, a tanulók olvasásteljesítményével és olvasás iránti motivációjával kapcsolatos elvárásaira is rákérdez. A tanári háttérkérdőíveket a negyedik osztályos tanulók esetében az osztálytanító, a hatodik és a nyolcadik évfolyamosok esetében az osztály magyar nyelv és irodalom szakos tanára töltötte ki.

\subsubsection{Adatfelvétel a negyedik, hatodik és nyolcadik évfolyamokon}

A kérdőívek kipróbálásakor a felsőbb évfolyamok mérőeszközeit a harmadik osztályos tanulók csoportos adatfelvétel keretében töltötték ki, melynek során a tanulóknak felolvastuk az egyes kérdöívtételeket. A többi évfolyamon egyéni adatfelvételre került sor. A nagymintás mérés során a tanulói kérdőíveket negyedik, hatodik és nyolcadik osztályos tanulók egyénileg töltötték ki. A szülöi kérdőíveket a tanulók hazavihették, így a szülök otthon töltötték ki azokat.

\subsection{A kérdőívek kipróbálása, próbamérés}

Az olvasási motiváció kérdőívek kipróbálásában összesen 91 fő első $(n=17)$, harmadik $(n=19)$, ötödik ( $n=28)$ és hetedik ( $n=27)$ osztályos tanuló vett részt. Az adatfelvételre 2010 májusában került sor. A három újonnan kidolgozott mérőeszköz közül az elsőt első osztályos tanulókkal vettük fel félig strukturált egyéni interjúk keretében. A második kérdőívet az általános iskola felsőbb tagozatos osztályai számára terveztük, és a próbamérés során harmadik osztályos tanulókkal csoportosan vettük fel, az ötödik és hetedik osztályos tanulóknak pedig egyedül kellett kitölteniük. Harmadik osztályban azért döntöttünk a csoportos felvétel mellett, melynek keretében a tanulóknak felolvastuk az egyes kérdőívtételeket, hogy biztosítsuk, a tanulók megértik a kijelentéseket. Feltételeztük, hogy a csoportos kitöltés sok időt vesz majd igénybe, mivel a tanulóknak ugyanolyan ütemben kell haladniuk, és bármilyen nehézség tovább növelheti a kérdőív kitöltéséhez szükséges időt. Mindemellett az is fontos szempont egy motivációs kérdőív esetén, hogy kitöltése ne legyen unalmas, egy hosszú adatgyüjtési folyamat ugyanis negatív hatással lehet a válaszokra. Mivel az elsődleges célunk annak a vizsgálata volt, hogy lehetséges-e az olvasási motiváció mint sokösszetevős rendszer kérdőívvel történő mérése ebben az életkorban, az adatfelvétel során a harmadikosoknál rövidített kérdöívet használtunk, amely csak kevesebb motívumhoz kapcsolódóan tartalmazott kérdéseket. A harmadikosoknál a válaszadást ugyanazok a piktogramok segítették, amelyeket az első osztályos tanulókkal is használtunk, de ebben az esetben a piktogramokat az oldal tetejére helyeztük el.

A felsőbb évfolyamokon a célorientáltságot, a flow-t és az önhatékonyságot feladatspecifikusan mértük, az énképet, az attribúciókat, és az attitüdöket területspecifikus kérdésekkel vizsgáltuk. Emiatt a kérdőív két részből állt. Az első rész az olvasással kapcsola- 
tos általános kérdéseket tartalmazott, és a tanulók az óra elején töltötték ki. Ezután a tanulóknak egy szövegértési feladatot kellett megoldaniuk. Ezt követte a kérdöív második része, ami a feladatspecifikus flow-ra, az önhatékonyságra és célorientáltságra vonatkozó tételeket tartalmazta. Ezek a kérdések képezték a kérdőív második részét, amit a tanulók az óra végén töltöttek ki, a harmadikosok csoportosan, a felsőbb évfolyamosok pedig egyénileg.

Az elsősök esetében az egyéni interjúk fontos tapasztalatokat szolgáltattak a kérdöív további fejlesztéséhez. Általában egy interjú 10-15 percig tartott, amit egy feladat szakított meg, aminek során a tanulónak fel kellett olvasnia egy szólistát. A megszakítás nem csupán azért volt fontos, hogy a következő kérdésekhez referenciát szolgáltassunk, hanem azért is, hogy megszakítsuk az adatfelvétel monotonitását. A 10-15 perces adatfelvétel tapasztalataink szerint a gyermekeknek nem volt túlzottan megterhelö, többségük végig figyelni tudott, a kérdéseket megértette és válaszolt is rájuk. A tapasztalat azt mutatta, hogy a piktogramok használata hasznos eszköz volt a tanulók kezében, emiatt a válaszadási ráta is magas volt.

Definíciójának megfelelően az olvasási önhatékonyságot egy rendelkezésre álló feladat segítségével mértük: a tanulóknak hangosan kellett felolvasniuk egy listát, mely valódi és álszavakat tartalmazott. A tanulókat előzetesen arról kérdeztük, vajon hány szót tudnak majd felolvasni. Általában a tanulók pozitívan értékelték a teljesítményüket, ami azt jelenti, hogy megbíztak a saját képességeikben. Csak két tanuló mutatott az oszlopdiagram ,inkább nem” oldalára, pontosabban a „csak néhány”, és az „egyáltalán nem, vagy majdnem soha” oszlopra.

Az első osztályos tanulók kérdőívében található két skála a Likert-típusú tételeken kívül nyíltvégü kérdést is tartalmazott. Ezek az olvasásnak tulajdonított érték és az olvasási énkép skála voltak. Az olvasás értéke esetében azt kérdeztük a tanulóktól, hogy fontosnak tartják-e az olvasást és az olvasástanulást, illetve azt, hogy miért igen vagy miért nem. A 17 tanulóból 15 tudott válaszolni a kérdésre. Egy tanuló nem válaszolt a kérdésre, egy pedig irreleváns választ adott. A kérdésre csupán egy gyermek adott negatív választ. A releváns válaszokat két fő csoportba lehet sorolni: nagyjából a tanulók harmada gyakorlati hasznot tulajdonított az olvasásnak, szerintük az olvasás fontos a felnőtt élethez. A gyermekek kétharmada viszont csak szubjektív értékét látja az olvasásnak, ilyen például az elismerés megszerzése vagy a jó iskolai teljesítmény. Az olvasási énkép vonatkozásában azt kérdeztük a tanulóktól, hogy jól tudnak-e olvasni és miért gondolják így. A tanulók többsége magas olvasási énképről tett tanúbizonyságot, és az információ forrásaként a szüleit vagy a tanítót jelölte meg. Néhány tanuló leírta a jó olvasó viselkedéses jellemzőit is: például „folyamatosan tudok olvasni” vagy „gyorsan tudok olvasni”.

Kizárólag az oksági attribúció skála bizonyult problematikusnak. A 17 tanulóból csupán 10 tudta értékelni ezeket a kérdéseket a mellékelt skálán, ami azt valószínüsíti, hogy az első osztályos tanulók még nem képesek a sikereik vagy kudarcaik okainak elemzésére, vagy legalábbis nem a megadott formában. Ezért úgy döntöttünk, hogy ezt a skálát kihagyjuk az elemzésböl. A többi skála megbízhatósága a Cronbach- $\alpha$ mutatók alapján 0,64 és 0,80 közötti, ami alacsony, de figyelembe véve a válaszadók életkorát, elfogadható.

A harmadik osztályos kérdőívet a tanulók csoportosan töltötték ki, ami azt jelenti, hogy a kérdéseket hangosan feolvastuk nekik, a válaszadással pedig közösen, egy ütemben haladtak. A mérések megbízhatósági mutatói $0,74-0,86$ közöttiek. A faktoranalízis eredményei a skálák 
létezését bizonyították. A várakozásainkkal ellentétben a csoportos kitöltés gyorsan haladt, a tanulók gyorsan és könnyen megtanulták a skála használatát, és a papír tetejére fénymásolt piktogramok is segítették őket a válaszadásban.

Az önhatékonyságot egy olyan kérdéssel mértük, amelyben a tanulókat saját elvárt teljesítményükről kérdeztük az előttük álló szövegértési feladat kapcsán. Nagyjából a tanulók fele válaszolta azt, hogy képes lesz a szövegértési teszt valamennyi feladatát megoldani, és egyetlen tanuló sem válaszolt úgy, hogy képtelen lesz megoldani egyet is.

Az ötödik és hatodikos osztályos tanulóknak kiadott eszköz szintén megfelelő méröeszköznek bizonyult az olvasási motiváció területén. A skálák Cronbach- $\alpha$ mutatói $0,70-0,83$ között voltak, az olvasási érték kivételével, ami valamivel alacsonyabb megbízhatóságot mutatott $(\alpha=0,47)$. Az egyik oka az alacsony megbízhatóságnak az lehet, hogy e skála kérdéseinek $50 \%$-a negatívan szerkesztett tétel volt, ami hátráltathatta a megértést (pl. Akkor is lehet jó jegyet szerezni az iskolában, ha valaki nem tud jól olvasni). Az alacsony megbízhatóság további lehetséges okainak tisztázása miatt további elemzések elvégzése és a negatív megfogalmazású tételek újragondolása, arányának csökkentése mellett döntöttünk. A korrelációk a vizsgált motívumok között közepes erősségüek voltak.

Összességében véve, az újonnan kidolgozott eszközök megfelelőnek bizonyultak az olvasási motiváció mérésére az iskolás kor elejétől az általános iskola felső tagozatáig. Az adatgyüjtés kivitelezése, ami az első osztályos tanulók esetében egyedi interjúkkal, a harmadik osztályos tanuló esetében a kérdőívek csoportos kitöltésével történt, lehetővé tette a motívumok vizsgálatát már az olvasástanulás kezdeti szakaszában is. Az alkalmazott segédeszközök felgyorsították az adatgyüjtést az alsós osztályokban. Mindazonáltal bizonyos skálák és tételek átgondolásra szorulnak. Az attribúciós skála nem látszik megfelelő eszköznek az olvasási siker vagy kudarc oksági attribúciós mérésére. Így a következő mérésben nyíltvégủ attribúciós kérdéseket is beillesztünk, amelyek lehetővé fogják tenni a tanulóknak, hogy a saját szavaikkal fejezzék ki meglátásaikat. A felsőbb évfolyamosok mérőeszköze esetében gyakorlati érték skála további elemzése és fejlesztése látszik szükségesnek, hogy növeljük a megbízhatóságot. A negatív megfogalmazású tételek felülvizsgálata és egyszerüsítése is szükségszerünek látszik.

Az első osztályban bizonyos skálák esetében, például az oksági attribúcióknál, problémát jelentett a tanulók életkora, az olvasási tapasztalatok hiánya. A harmadik osztályosok esetében dilemma volt, hogy a háromoldalas kérdőívet felolvassuk-e a tanulóknak vagy az egyéni kitöltést válasszuk. A próbamérés alkalmával a felolvasás segítette az értelmezést és gördülékenyebbé, kevésbé megterhelővé tette a tanulók számára az adatfelvételt. Ugyanakkor ez az adatfelvételi mód felveti a torzítás lehetőségének kérdését, tudniillik azt, hogy az ilyen módon felvett kérdőívek eredményei összehasonlíthatók-e a felsőbb évfolyamokon egyénileg felvett mérőeszközökkel nyert eredményekkel. A négyfokú skálán történő adatfelvétel szintén ellehetetleníti az összevetést.

A fent felsorakoztatott problémák megoldására egy átfogó lehetőségként jelentkezett a vizsgálati minta életkorának növelése. Ez megoldotta a tapasztalatok hiányának a kérdését az alsóbb évfolyamokon, valamint az adatfelvételi mód egységesítési igényét is kielégíthetővé tette a felsőbb évfolyamokon. A nagymintás mérésben így az adatfelvétel időpontját az első, 
harmadik, ötödik és hetedik osztály vége helyett a második, negyedik, hatodik és nyolcadik osztály elejében határoztuk meg.

\subsection{A központi vizsgálat mintája}

Központi vizsgálatunkban 24 Csongrád, Pest és Bács-kiskun megyei általános iskolából vettek részt második, negyedik, hatodik és nyolcadik osztályos tanulók, összesen 890 fö. A minta korcsoportonkénti pontos elemszámát a 30. táblázat tartalmazza. Az adatfelvételre 2010 novemberében került sor.

30. táblázat. A központi mérés mintája

\begin{tabular}{lccc}
\hline \hline \multicolumn{1}{c}{ Korcsoport } & $n$ & Fiú & Lány \\
\hline 2. évfolyam & 135 & 60 & 75 \\
4. évfolyam & 218 & 111 & 107 \\
6. évfolyam & 278 & 152 & 126 \\
8. évfolyam & 259 & 116 & 143 \\
Összesen & 890 & 439 & 451 \\
\hline
\end{tabular}

Második évfolyamon az egyéni adatfelvétel miatt a minta elemszáma némelyest alacsonyabb a többi évfolyamhoz képest. Az adatfelvételi eljárás eltérése miatt azonban a másodikosok eredményeinek a felsőbb évfolyamok adataival történő összevetését nem fogjuk elvégezni, így az elemszámbeli eltérésnek sincs jelentősége. A felsőbb évfolyamok részmintáinak elemszáma közel azonos. A fiúk és lányok aránya az egyes évfolyamokon szintén megközelítőleg azonos, ami lehetőséget ad az évfolyamok összehasonlítására, illetve az évfolyamon belüli nemek közötti különbségek feltárására.

A vizsgálatban részt vevő tanulók szociokulturális hátteréről az anya és az apa iskolai végzettsége alapján tájékozódtunk. A felsőbb évfolyamok eredményeinek összehasonlításához elengedhetetlen, hogy az egyes korcsoportonkénti részmintákban a különböző iskolai végzettségü szülök aránya megegyezzen. Mintánkban sem az anya, sem az apa iskolai végzettsége alapján nincs szignifikáns különbség a különböző évfolyamos tanulók szociokulturális hátterét illetően, a részminták tehát összevethetők (31. és 32. táblázat).

31. táblázat. A minta korcsoportonkénti elemszáma és az anya iskolai végzettségének a Kruskal-Wallis próba alapján számított szignifikanciája

\begin{tabular}{lcccc}
\hline \hline Korcsoport & $n$ & Rangátlag & $\chi^{2}$ & $p$ \\
\hline 4. osztály & 218 & 363,36 & & $0,96^{\mathrm{NS}}$ \\
6. osztály & 278 & 368,59 & 0,09 & \\
8. osztály & 259 & 368,39 & & \\
\hline
\end{tabular}

Megjegyzés: NS: nem szignifikáns 
32. táblázat. A minta korcsoportonkénti elemszáma és az apa iskolai végzettségének a Kruskal-Wallis próba alapján számított szignifikanciája

\begin{tabular}{lcccc}
\hline \hline Korcsoport & $n$ & Rangátlag & $\chi^{2}$ & $p$ \\
\hline 4. osztály & 218 & 358,03 & & \\
6. osztály & 278 & 338,34 & 3,13 & $0,21^{\mathrm{NS}}$ \\
8. osztály & 259 & 369,00 & & \\
\hline \hline
\end{tabular}

Megjegyzés: NS: nem szignifikáns 


\section{A központi vizsgálat eredményei}

\subsection{A második évfolyamon végzett vizsgálat eredményei}

\subsubsection{A második évfolyam mérőeszközeinek érvényessége és megbízhatósága}

A próbamérés eredményei alapján átdolgozott, az iskola kezdetén az olvasási motiváció mérésére fejlesztett kérdöiv érvényességét faktoranalízissel ellenőriztük. A faktoranalízis esetünkben azért tekinthető érvényességvizsgálatnak, mert jelzi az elméleti modell helyességét azáltal, hogy feltérképezi, elkülönülnek az elméletileg elkülönített konstruktumok. A változórendszer faktoranalízisre való alkalmasságát a Kaiser-Meyer-Olkin index jelzi, melynek értéke 0,75, ami elfogadható, így jogosan feltételezhetjük, hogy a változórendszer hátterében faktorok vannak.

Az elvégzett faktoranalízis eredményeképp a változórendszer 11 egynél nagyobb sajátértékủ faktorba rendeződött. A faktorok a változórendszer varianciájának 63\%-át magyarázzák. Az általánosan elfogadott eljárás alapján a 0,4 vagy annál nagyobb faktorsúly esetén tekintettünk egy kérdőívtételt az adott faktorba tartozónak. A 11 faktor közül öt egyértelmüen megfeleltethető a vizsgált motívumoknak, ezek az olvasási énkép, az olvasásórán átélt flow, antiflow, az olvasás értéke és az önhatékonyság motívumok. A szociális motívumok és az olvasási attitüdök skála kérdőívtételei két faktorba rendeződtek, a két faktor azonban nem feleltethető meg az olvasás szociális motívumainak és az olvasási attitűdöknek, ugyanis a kérdéses változók aszerint rendeződtek két faktorba, hogy aktív olvasásról, azaz az olvasás gyakorlásáról, hangos olvasásról, olvasásfeladatok megoldásáról vagy a mások által felolvasott szöveg hallgatásáról, esetleg közös olvasásról van-e szó. Úgy tünik, ebben az életkorban sokkal inkább fontos az, hogy az olvasás aktív eröfeszítést igényel-e, minthogy társas folyamatok kapcsolódnak-e hozzá vagy sem. Ezt bizonyítja, hogy mind az aktív olvasás, mind a mesehallgatás iránti skálához sorolódtak olyan tételek, amelyek társas élményre vonatkoznak. Így a továbbiakban olvasási attitüdök és az olvasás szociális motívumai skálák helyett az aktív olvasás és mesehallgatás iránti attitüd skálákat vettük az elemzés alapjául.

Három kérdőívtétel, amely közül egy-egy eredendően az olvasásórán átélt antiflow és flow élmény lehetőségére, egy pedig az olvasás attitüdökre vonatkozott, három önálló faktort hozott létre, azaz nem kapcsolódnak szorosan az adott változórendszerhez. Ilyen az olvasásórán átélt szorongásra vonatkozó tétel. Ez a kérdés már a próbamérés során is problémásnak bizonyult, minthogy a gyermekek a szorongás szót nem értették, az izgulás pedig számukra pozitív élményként jelent meg. Az új változatban szereplő nyugtalanság, idegeskedés kifejezések, úgy tünik, ismét nem bizonyultak megfelelőnek: a faktoranalízis eredménye alapján szintén nem kapcsolódnak az antiflow élményéhez. A további elemzésből ezt a tételt kihagytuk, minthogy az átdolgozás után sem mérte az általa mérni hivatott élményt.

A második önálló faktort alkotó kérdőívtétel az olvasásórán töltött idő gyors múlására vonatkozott, azaz a flow élmény egyik jellemzőjének mérésére szolgált volna. Feltételezhetőleg az idő fogalma, annak gyors múlása a gyermekek számára még mást jelent, esetleg nincs 
tudásuk az időészlelés szubjektivitásáról és nem feltétlenül monitorozzák még saját időészlelésüket. A kérdés számukra így nem jelent mást, minthogy az olvasásóra addig tart-e, mint bármely más óra, azaz nem méri az élvezet, az elmélyülés okozta szubjektív időérzék torzulást. Emiatt a további elemzésből ezt a tételt is kihagytuk.

Végül a harmadik tétel, amely nem kapcsolódik szorosan az általa mért motívumhoz, az attitüdök vizsgálatára szánt „Szeretsz könyvet kapni ajándékba?” kérdés. A kérdés feltételezi, hogy a gyermekek kapnak könyvet ajándékba, és az ehhez füződő viszonyukra kérdez rá. Azonban elképzelhető, hogy ez a gyakorlat nem kapcsolódik szorosan a gyermekek mindennapjaihoz, nem kapnak gyakran könyvet ajándékba, így nem is tudnak róla nyilatkozni. Egy másik lehetséges magyarázat, hogy a kijelentés nem specifikálja kellőképpen a jelenséget, azaz nem határozza meg, hogy milyen könyvröl van szó, milyen alkalomra kapja a gyermek stb., ezért tág teret ad a találgatásra, egy-egy merőben eltérő saját élményhez való kapcsolásra. Az említett okok miatt a további elemzésből az említett tételt is kihagytuk.

A célorientáció-skála esetében a teljesítmény- és az elsajátítási célokra vonatkozó itemek konkrétságuk miatt a további elemzésben külön-külön szerepelnek, habár a faktorelemzés alapján az elkerülő céloktól elkülönültek. A teljesítmény- és elsajátítási célokra vonatkozó itemek a flow skálába, az elkerülő célok az antiflow skálába szerveződtek, amely érthető, tekintve, hogy a két-két elméleti konstruktum is nagyon hasonló.

Az egyes skálák reliabilitása, a Cronbach- $\alpha$ mutatók szerint 0,7 körüli. Kivételt képez ez alól a két rövid skála: a hallgatás iránti attitüdök és az olvasásnak tulajdonított érték skála, ahol a reliabilitás alacsonyabb 0,5 és 0,6 közötti. Tekintve, hogy a vizsgált minta életkora alacsony, és az adatfelvétel módja is viszonylag újdonságnak tekinthető, a skálák reliabilitása megfelelőnek mondható. Azonban az eredmények értelmezésekor figyelembe kell venni a két rövid skála alacsony megbízhatóságát és a tételszámból adódó korlátokat.

A flow skála esetében egy tétel, a „Könnyünek tartod az olvasásórát?” kérdés jelentősen rontotta a teljes skála reliabilitását, így kihagyása mellett döntöttünk. A faktoranalízis és a megbízhatósági mutatók alapján az elemzésben az eredeti 48 Likert-skálás tételből így 44 tételt tartottunk meg. A 44 kérdőívtételből 8 a sikerek és kudarcok oksági attribúcióira vonatkozik, melyek megbízhatóságát a nyílt végü és a zárt végü kérdésekre adott válaszok megfeleltetése alapján állapítjuk meg. További 6 tétel a célorientációkat vizsgálja, melyeket konkrétságuk miatt egyesével fogunk elemezni.

Az olvasás önhatékonyság vizsgálatára két itemet alkalmaztunk. Ennek oka, hogy az önhatékonyság definíciója szerint egy kilátásban lévő olvasásfeladat megoldási valószínűségére utal, ennek értelmében mérése csakis feladatspecifikusan történhet. Ennek megfelelöen, hogy elkerüljük ugyanannak a kérdésnek a többszöri, átfogalmazott ismétlését, minden kérdőívtételhez egy olvasási feladatot is kapcsolnunk kell. Kettőnél több olvasásfeladat, azon túl, hogy túlzottan megterhelte volna a gyermekeket, az interjúfelvétel idejét is növelte volna. Egy 10-15 percnél hosszabb adatfelvétel során a gyermekek figyelme és érdeklődése is feltételezhetően csökkent volna, amely egy motivációt vizsgáló kutatás során nem megengedhető. Ezért úgy döntöttünk, hogy az önhatékonyságot az említett két kérdőívtétel alapján határozzuk meg. Mindazonáltal az elemzésnél és az eredmények interpretációjánál figyelembe vesszük, hogy a két item nem feltétlenül ad megbízható becslést a motívum egyéni jellemzőiről. 
Az egyes skálák a hozzájuk tartozó kérdőívtételek számával és megbízhatósági mutatóikkal a 33. táblázatban láthatók. Az önhatékonyság, az attribúciókra vonatkozó és a célorientációs skálák megbízhatósága a kérdőívtételek számára és az egyes tételek specifikusságára tekintettel a Cronbach- $\alpha$ mutatóval nem megadható. Ezen skálák esetében csak az itemszámokat közöljük.

33. táblázat Az egyes motívumokat vizsgáló skálákhoz tartozó kérdöivtételek száma és megbizhatósági mutatóik

\begin{tabular}{lcc}
\multicolumn{1}{c}{ Motívumok } & Kérdöív-tételek száma & $\begin{array}{c}\text { Megbízhatóság } \\
\text { (Cronbach- } \alpha)\end{array}$ \\
\hline Attitüdök az aktív olvasás iránt & 5 & 0,73 \\
Attitüdök a mesehallgatás iránt & 3 & 0,53 \\
Önhatékonyság & 2 & - \\
Sikerattribúciók & 5 & - \\
Kudarcattribúciók & 5 & - \\
Flow & 5 & 0,71 \\
Antiflow & 8 & 0,76 \\
Érték & 3 & 0,55 \\
Énkép & 4 & 0,72 \\
Célorientáció & 6 & - \\
\hline \hline
\end{tabular}

Az olvasásteljesítmény mérésére alkalmazott képes szóolvasás teszt itemszámát és megbízhatóságát a 34. táblázat mutatja. Ez alapján megállapíthatjuk, hogy a teszt megbízhatóan méri a második osztályos tanulók szóolvasás készségének fejlettségét. Megemlítendő azonban, hogy az alkalmazott teszt ebben az életkorban nem differenciált kellöképpen, feltételezhetőleg a tanulók szóolvasás készsége már a plafonszintet közelíti. A tanulók teszten elért átlaga 91,69\% p, 4,99\%p-os szórás mellett. Az eredmények értelmezésekor ezt figyelembe vesszük.

34. táblázat A képes szóolvasás teszt itemszáma és megbízhatósága

\begin{tabular}{ccc} 
Teszt & Itemek száma & Megbízhatóság (Cronbach- $\alpha)$ \\
\hline Képes szóolvasás teszt & 55 & 0,86 \\
\hline
\end{tabular}

\subsubsection{Második osztályos tanulók olvasási motívumai}

A második osztályos tanulók olvasási motívumainak jellemzőit először egyesével tárgyaljuk. Az egyes olvasási motívumok bemutatásakor a motívumok átlagát és szórását, és az ez alapján létrehozott gyakorisági eloszlásokat közöljük.

A mesehallgatás iránti attitüdökkel kapcsolatos eredményeink arra vonatkoznak, hogyan viszonyulnak a mintában szereplö második osztályos tanulók a passzív befogadáson ala- 
puló olvasási élményekhez, azaz a mesehallgatáshoz, a közös olvasáshoz. A 16. számú ábráról leolvasható, hogy a megkérdezett második évfolyamos tanulók meglehetősen pozitívan viszonyulnak a mesehallgatáshoz, az eloszlásgörbe erőteljesen jobbra tolódott. A tanulóknak mintegy $43 \%$-a válaszolt $95 \%$ p-os szint fölött, azaz adott valamennyi kérdésünkre olyan választ, amely a legmagasabb értéket takarta.

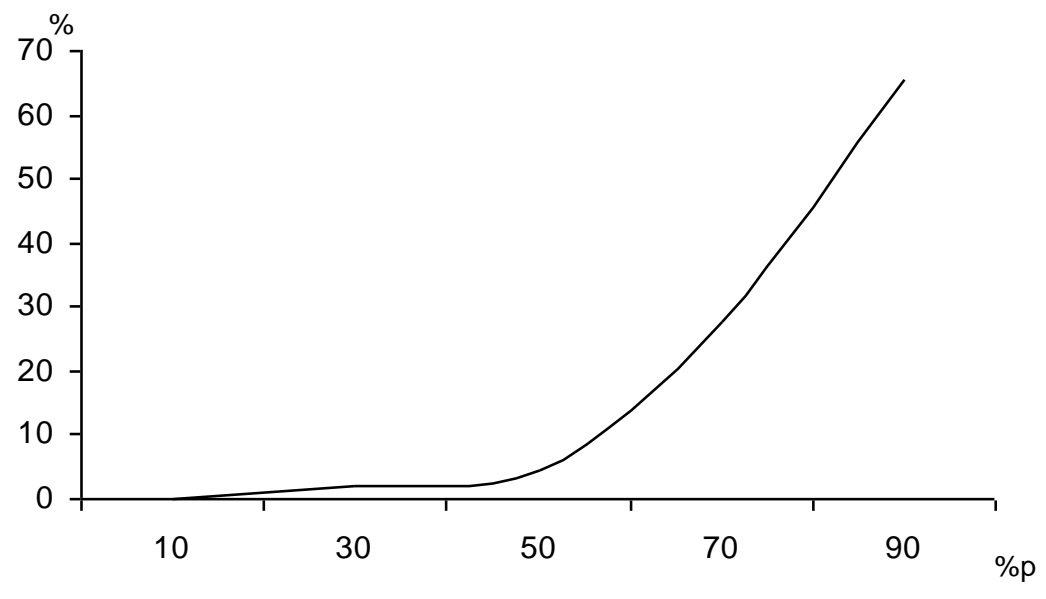

16. ábra

A mesehallgatás iránti attitüd eloszlásgörbéje, második osztály

Az aktív olvasás iránti attitüdök, azaz az olvasási feladatok megoldása és az egyéni olvasástevékenység kedveltségének az eloszlásgörbéje szintén jobbra tolódott (17. ábra). A második osztályos tanulók többsége meglehetösen pozitívan viszonyul az aktív olvasáshoz is, e motívum esetében azonban már ezzel egy időben jelentősebb egyéni különbségekröl beszélhetünk, mint a hallgatás esetében.

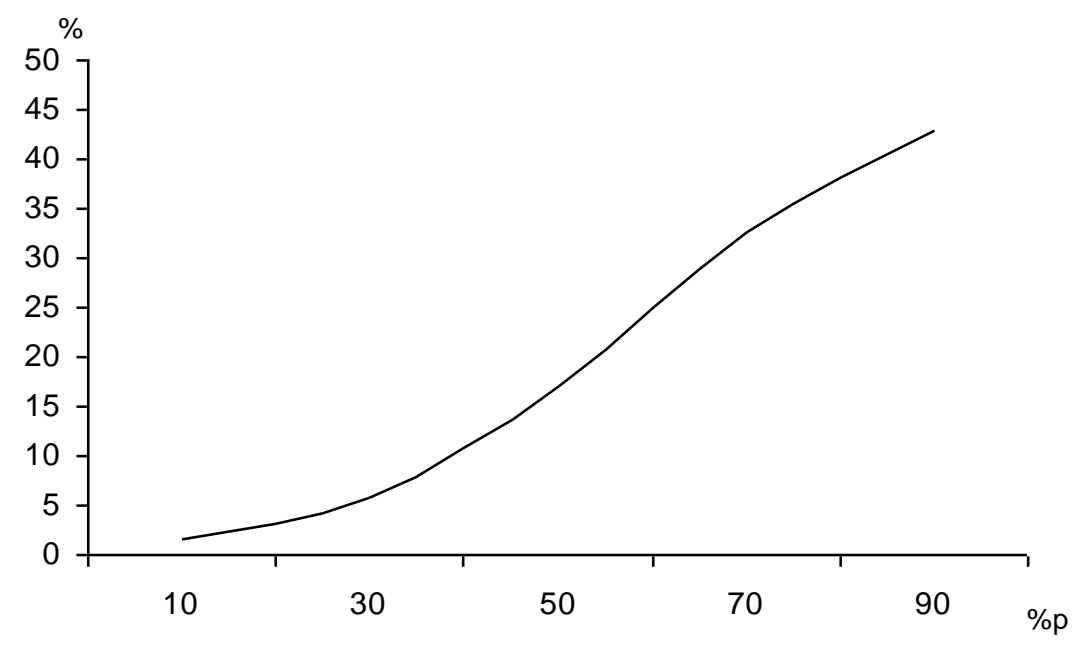

17. ábra

Az aktiv olvasás iránti attitüdök eloszlásgörbéje, második osztály

Az olvasási önhatékonyság kapcsán arról kérdeztük a tanulókat, néhány kilátásba helyezett feladatból (hangos olvasás) mennyit tudnak majd sikeresen teljesíteni, így az önhatékonyság a 
saját szóolvasási készségükre vonatkozott. Az eredmények szerint a második osztályos tanulók többsége pozitívan vélekedik és bízik saját olvasási készségeiben; az eloszlásgörbe ebben az esetben is jobbra tolódott. Ugyanakkor nem elhanyagolható azok aránya sem, akik kevéssé látják pozitívan saját jövendöbeli eredményességüket: már második osztályban a tanulók mintegy 18\%-a nyilatkozott úgy, hogy inkább nem lesz sikeres a feladatmegoldásban. Ök azok, akik 50\% p-nál alacsonyabb önhatékonysággal rendelkeznek az olvasás terén (18. ábra).

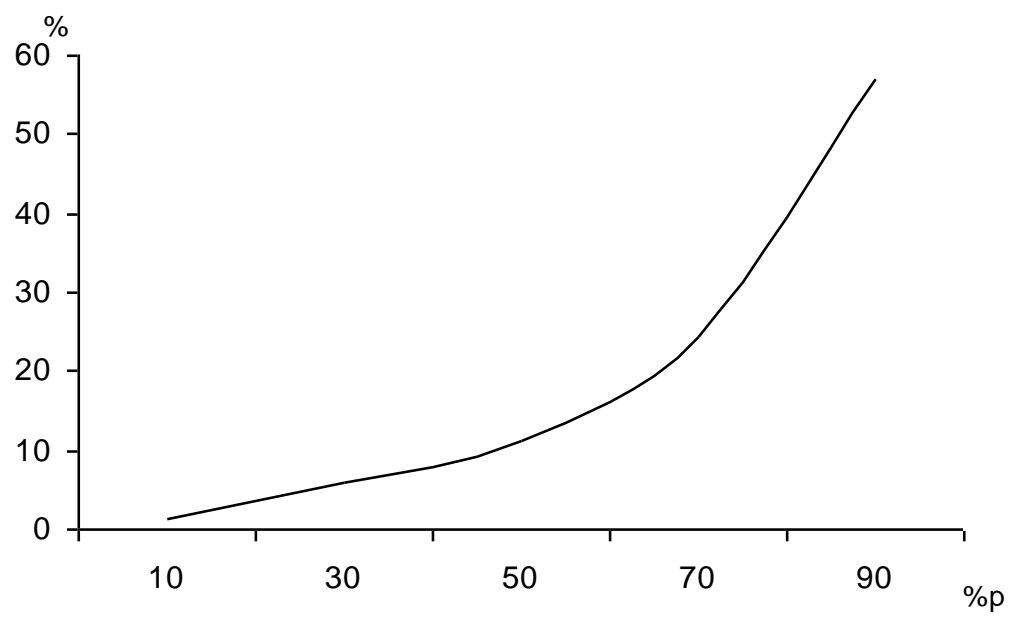

18. ábra Az olvasás önhatékonyság eloszlásgörbéje, második osztály

Második évfolyamon az olvasási sikerek és kudarcok attribúcióit egy nyílt végü kérdéssel és négy-négy, azt ellenőrző Likert-skálás kérdöívtétellel vizsgáltuk. Az eredmények szerint a második osztályos tanulók megértették a kérdést, és a kudarcok esetében $86 \%$-uk, a sikerek esetében 92\%-uk adott értékelhető, a négy kategória (külső-állandó, külső-változó, belsőállandó, belső változó ok) egyikébe beilleszthető választ.

Az olvasási sikerek okára vonatkozó kérdésre a tanulók többsége (61\%) olyan választ adott, amely valamely külső és állandó okát írta le az olvasás során átélt kudarcnak. A második legnépszerübb kategória szintén külső, de már valamely változó okot írt le (17\%). A tanulók 11\%-a belső változó, 10\%-uk belső állandó okoknak tulajdonítja az olvasás során átélt kudarcait.

A sikerek oktulajdonítása esetében a válaszok megoszlása a négy kategória között merőben eltérő képet mutat. A másodikos tanulóknak mintegy fele $(48 \%)$ belső és állandó okoknak tulajdonítja olvasási sikereit. 34\%-uk említett inkább külső és állandó okokat, és mindöszsze $11 \%$-uk külső, változó okokat.

A másodikos tanulók többsége tehát sikereit belső, állandó okoknak tulajdonítja, például annak, hogy okos. Mindössze 11\%-uk magyarázza külső, változó okokkal sikereit, például a szerencsével, vagy, hogy könnyü volt a szöveg. Ez egy pozitív mintázatnak tekinthető. Ugyanakkor a kudarcok oktulajdonításában a külső és állandó okok gyakorisága nem tekinthető ilyen pozitív eredménynek, hiszen ha a tanuló azt gondolja, hogy kudarcai rajta kívül álló 
okok miatt történnek, az nem feltétlenül sarkallja arra, hogy legközelebb több energiát fektessen az olvasás gyakorlásába, tanulásába. Ez a tendencia inkább az énkép védésének tekinthető.

A nyílt és zárt végü kérdések összevetése alapján a tanulók oktulajdonítással kapcsolatos válaszai nem túl konzisztensek. A kudarcokra vonatkozó kérdések esetében a tanulók mindössze $31 \%$-a válaszolt konzisztens módon a nyílt és zárt végü kérdésekre, a sikerek okaira vonatkozó kérdések esetében ez az arány szintén alacsony: 62\%. Az inkonzisztencia egyik oka a kérdések meg nem értése lehet. Valószínübb ugyanakkor, a problémát az okozta, hogy míg a nyílt végü kérdések nem korlátozták a tanulókat az okok keresésében, addig a zárt végü kérdések minden válaszkategória esetében csak egy példát említettek okként, így nem fedték le teljes mértékben a kategóriarendszert. A válaszok megbízhatóságának ellenőrzése hiányában az olvasási sikerek és kudarcok attribúcióit a további elemzésből kihagytuk.

Az olvasás során átélt flow élményt elemeinek összességével definiáljuk, azaz a magas flow élmény azt jelenti, hogy a tanuló gyakran éli át a flow egyes elemeit olvasási tevékenység, olvasás feladatok végzése közben. Ilyen elemek például a elmélyülés, amikor úgy gondolják, hogy tudják, mit kell tenniük, és úgy érzik, jól megy, amit csinálnak, továbbá amikor úgy érzik, hogy semmi másra nem figyelnek.

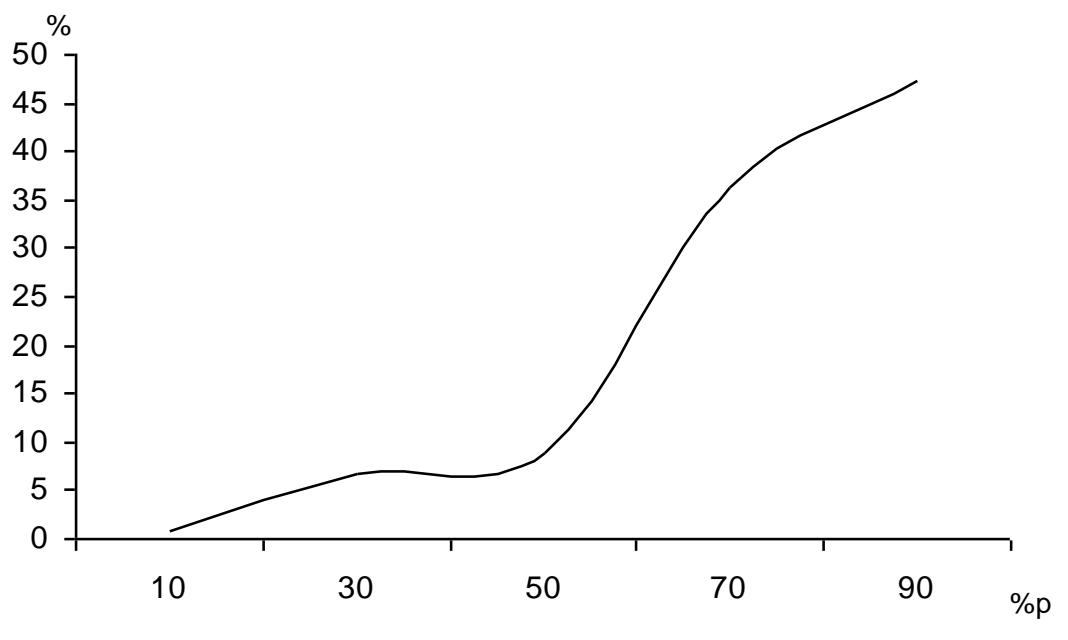

19. ábra

Az olvasás során átélt flow eloszlásgörbéje, második osztály

A flow gyakorisági eloszlásgörbéje (19. ábra) szerint a második osztályos tanulók olvasásfeladatok végzésekor gyakran élik át a flow élmény elemeit, többségük számára az olvasás tanulása áramlatélményt és elmélyülést nyújtó tevékenység. A másodikosok 40\%-a nyilatkozott úgy, hogy olvasás közben mindig teljesen elmélyül. Azonban van egy olyan tanulópopuláció (15\%-a a mintában szereplő tanulóknak), akik csak ritkán élik át ezt az élményt. Az ő átlaguk $50 \%$ p alatti.

Az olvasás során átélt antiflow élményként definiáltuk az apátiát és az unalmat, amelyek ellentétei és ugyanakkor gátlói a flow élmények létrejöttének. Az antiflow élmény elemei a figyelem elkalandozása, az érdektelenség vagy a szorongás, az elkeseredés. 
A második osztályos tanulók olvasás során átélt antiflow élményének eloszlásgörbéjét a 20. ábra mutatja. Ez esetben a görbe eröteljesen balra tolódott, amely azt jelenti, hogy a tanulók többsége nem, vagy csak nagyon ritkán él át antiflow élményt. A második osztályos tanulók közül szinte senki nem nyilatkozott úgy, hogy gyakran él át unalmat vagy apátiát olvasás feladatok végzésekor. A tanulók mintegy egynegyede ugyanakkor már találkozott ezekkel az élményekkel ilyen helyzetben (50\%p fölött).

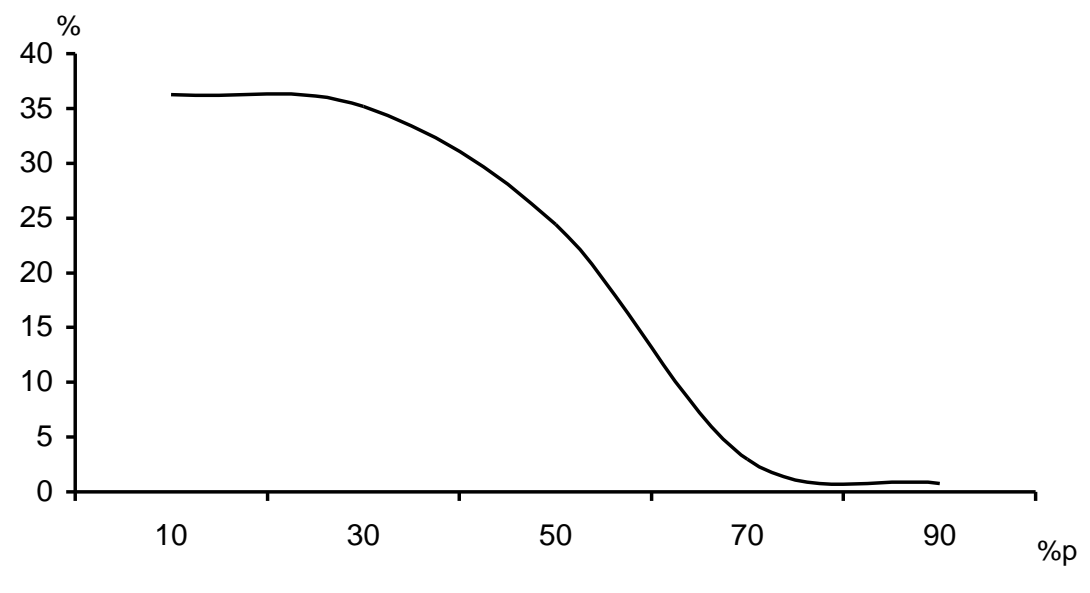

20. ábra

Az olvasás során átélt antiflow eloszlásgörbéje, második osztály

Az olvasásnak tulajdonított érték skála alig differenciált a tanulók között. Egyetlen tanuló sem nyilatkozott úgy, hogy inkább nem tartja fontosnak az olvasást és annak megtanulását. 74\%-uk gondolta viszont úgy, hogy az olvasás megtanulása, az olvasásban nyújtott jó teljesítmény nagyon fontos számára.

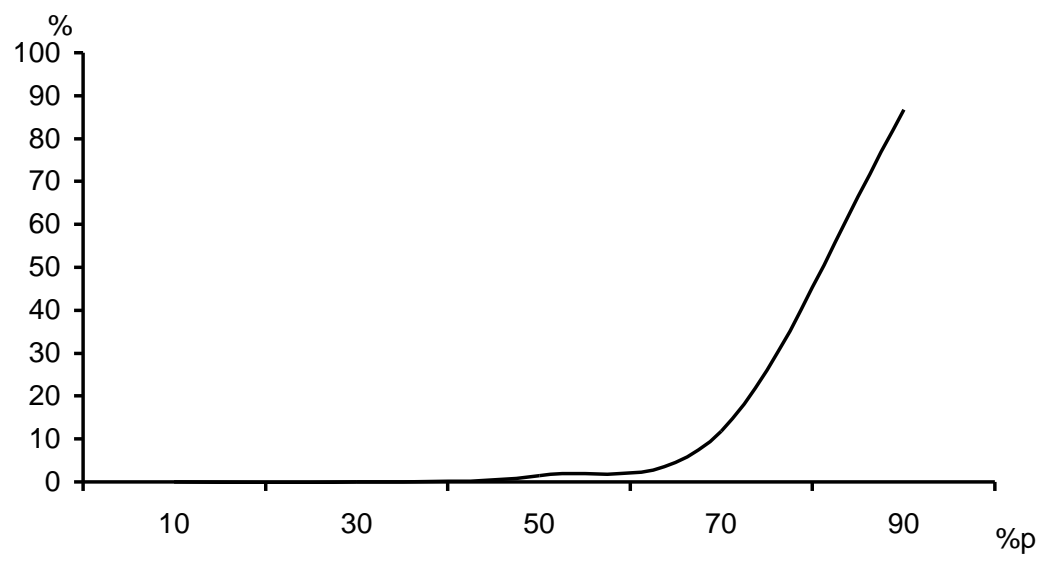

21. ábra

Az olvasásnak tulajdonitott érték eloszlásgörbéje, második osztály 
Második évfolyamon az olvasásiénkép-skála sem differenciált igazán (22. ábra), a skála alsóbb kategóriáit szinte senki sem válaszotta. A tanulók többsége pozitívan ítéli meg saját olvasási képességét és általában véve jó olvasónak tartja magát. 44\% azoknak az aránya, akik a legmagasabbra értékelik saját olvasási képességüket, az énképük átlaga $90 \%$ p feletti. A tanulóknak ugyanakkor mintegy $18 \%$-a már az általános iskola második évfolyamának elejére átélt annyi kudarcélményt, hogy saját olvasási teljesítményét és képességét inkább negatívan ítéli meg (50\%p alatt).

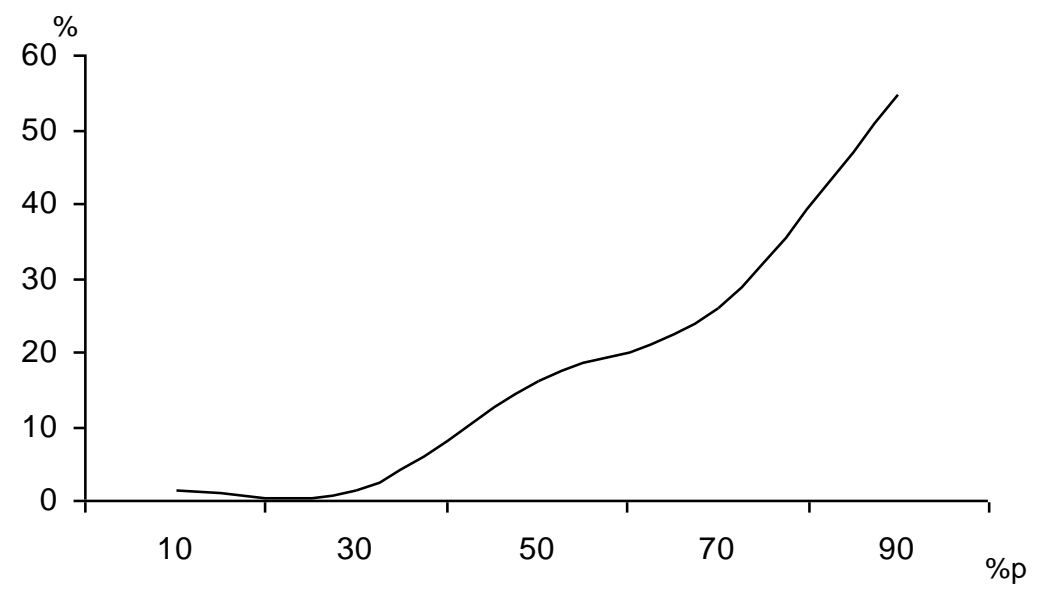

22. ábra

Az olvasási énkép eloszlásgörbéje, második osztály

A célorientáció vizsgálata feltételezi a vizsgálati alanyok metakognitív készségeinek olyan szintủ fejlettségét, ami lehetővé teszi, hogy saját mentális tevékenységeik céljáról gondolkodjanak. A vizsgálatunkban szereplő gyermekektől életkoruk miatt nem várható el ez a gondolkodás, így az olvasási célorientáció vizsgálatára olyan célokat fogalmaztunk meg a gyermekek számára, amelyek a szakirodalom alapján beilleszthetők egy-egy célorientációba. A célorientáció vizsgálatára az olvasás területén összesen hat kérdőívtételt fejlesztettünk. A hat tétel közül kettő az elsajátítási célokra, kettő a teljesítménycélokra, kettő a munkakerülő célokra vonatkozó konkrét kérdést tartalmazott. Az elsajátítási célok kapcsán a megértés és a fejlődés érzésének motivációs hatásaira, a teljesítménycélok kapcsán a piros pont és a felnőttek elismerése mint jutalom motiváló erejére, a munkakerülő célok esetében a gyors feladatletudás és az energiabefektetés elkerülésének vágyára kérdeztünk rá. Az egyes célok erősségét feladatspecifikusan vizsgáltuk, azaz azt néztük, hogy az említett célok mennyire érvényesültek egy általunk adott olvasásfeladat megoldásakor.

A faktoranalízis eredménye rámutatott, hogy az általunk az egyes célorientációs típusokba sorolt kérdőívtételek nem alkottak külön faktorokat, így a kérdőívtételek egyedi elemzése mellett döntöttünk. A következökben ennek az elemzésnek az eredményeit mutatjuk be.

A 35. táblázat azt mutatja, hogy az egyes célok átlagosan milyen mértékben vannak jelen a másodikos tanulók feladatvégzésében. Az átlagok az egyes kérdőívtételekre a négyfokú skálán adott válaszok átlagait jelentik. 


\begin{tabular}{lcc}
\hline & & \\
Célok & 2. osztály \\
\cline { 2 - 3 } & átlag & szórás \\
\hline Megértés & 3,70 & 0,70 \\
Elismerés megszerzése & 3,70 & 0,67 \\
Feladatelkerülés & 1,46 & 0,81 \\
Piros pont & 3,36 & 1,05 \\
Tudásszerzés & 3,63 & 0,69 \\
Túl lenni, összecsapni & 1,29 & 0,63 \\
\hline \hline
\end{tabular}

A második osztályos tanulókat saját bevallásuk szerint a feladat megoldásakor leginkább a megértés vágya és a felnőtt elismerésének megszerzése motiválta. Ezt követi a tanulás- a tudásszerzés iránti vágy. Csak harmadik helyen jelenik meg ugyanakkor a piros pont mint jutalom megszerzésének vágya. A feladat elkerülésének reménye és a minél hamarabbi feladatletudás pedig szinte alig volt megtalálható a gyermekek céljai között; a legtöbben úgy nyilatkoztak, erre egyáltalán nem gondoltak.

Eredményeink szerint a második osztályos tanulók többsége olvasási motívumaikat tekintve pozitívnak nevezhető jellemzőkkel rendelkezik. Az egyes motívumok átlagai minden esetben meghaladják a 75\%p-ot (36. táblázat). Kivétel ez alól az olvasásórán átélt antiflow élmény, amely esetében a 26,75\%p-os átlag szintén kedvezőnek mondható. Kiváltképp magas a gyermekek által az olvasásnak tulajdonított érték, melynek alacsony szórásértéke miatt kijelenthető, hogy a gyermekek nagy többsége magas értéket tulajdonít az olvasásnak és az olvasás tanulásának.

36. táblázat Az olvasási motívumok átlagai és szórása 2. évfolyamon

\begin{tabular}{lcc}
\hline \multirow{2}{*}{ Olvasási motívumok } & \multicolumn{2}{c}{ 2. osztály } \\
\cline { 2 - 3 } & átlag & szórás \\
\hline Attitűd-aktív olvasás & 75,89 & 20,05 \\
Attitűd-mesehallgatás & 86,77 & 16,19 \\
Énkép & 79,17 & 19,23 \\
Flow & 79,31 & 19,81 \\
Antiflow & 26,75 & 19,37 \\
Érték & 95,13 & 9,46 \\
Önhatékonyság & 76,04 & 20,72 \\
\hline \hline
\end{tabular}

Az aktív olvasás és a mese- vagy történethallgatás iránti attitüdök különbsége is szembetűnő. A mintában szereplő második osztályos tanulók jobban kedvelik a történetek hallgatását vagy 
közös olvasását, mint az önálló olvasáson alapuló tevékenységeket. Feltételezhetően az értő olvasás még nehézséget okoz számukra, erőfeszítést igényel, amely az élmény, az élvezet rovására megy. A passzív befogadás azok számára is meghozza az élmény lehetőségét, akik önmaguk még kevésbé képesek az élményszerző olvasásra.

Az önhatékonyság és az énkép $80 \%$ p körüli átlaga arra enged következtetni, hogy már az olvasástanulás ilyen korai szakaszában is vannak olyanok, akiknek saját képességeik megítélését negatív élmények alakítják. Nem minden második osztályos tanuló tekinti saját olvasási képességeit megfelelően fejlettnek. Vannak, akik úgy látják, kevéssé képesek egy olvasásfeladat megoldására, és ebböl következően az elöttük álló feladatnak úgy kezdenek neki, hogy azt feltételezik, nem járnak majd teljes sikerrel.

Összességében véve az eloszlásgörbékröl az is leolvasható, hogy az általunk feltett, az egyes olvasási motívumok vizsgálatára szánt kérdések nem differenciáltak jól második osztályban, azaz tulajdonképpen nem mérték a leginkább pozitív motívumokkal rendelkező tanulókat. Az eredmény nem meglepö, ugyanis hipotézisünk szerint az olvasás motívumai az évek folyamán csökkennek, így az alacsonyabb évfolyamok esetében alacsonyabb differenciáló erőre számíthattunk. A felsőbb évfolyamokon az ezekkel megegyező tartalmú kérdőívtételek alkalmazása a vizsgált tanulói populáció olvasás területét érintő motivációját várhatóan jobban lefedi majd, egyúttal lehetőséget ad az alsóbb évfolyamok fent bemutatott eredményeihez való viszonyításra.

\subsubsection{Az olvasási motívumok összefüggésrendszere második osztályban}

Az eddigiekben az olvasási motívumok jellemzőit egyesével, egymástól függetlenül vizsgáltuk. Szakirodalmi tájékozódásunk alapján azonban feltételezzük, hogy a tárgyalt olvasási motívumok között kapcsolat van és a motívumok motívumrendszerré szerveződnek, habár ennek jellemzőiről a szakirodalom sem árul el sokat. Van-e kapcsolat a szakirodalom által elvárás motívumoknak nevezett konstruktumok és az olvasásnak való értéktulajdonítás között? Vajon együtt jár-e az olvasás iránti pozitív attitüd és a jó olvasási énkép?

A 37. táblázat a motívumok közötti korrelációkat tartalmazza. A korrelációs mátrixban két csillaggal jelöltük a 0,05 szinten szignifikáns, egy csillaggal a 0,01 szinten szignifikáns összefüggéseket. Látható, hogy néhány kivétellel a motívumok kapcsolatban állnak egymással. Az aktív olvasás iránti attitűd például valamennyi másik motívummal 0,05 szinten szignifikáns korrelációt mutat. A korrelációs együtthatók közepes erősségünek mondhatók, és az antiflow kivételével pozitívak. A mesehallgatás ezzel szemben gyengébb pozitív összefüggést mutat a flow élménnyel és az olvasás értékével, és szintén gyengébb, de negatív összefüggést az antiflow-val. Nem meglepő módon a mesehallgatás iránti attitüdök nem állnak kapcsolatban a saját képességekre vonatkozó meggyőződésekkel, azaz az énképpel és az önhatékonysággal. 
37. táblázat. Az olvasási motívumok összefüggése 2. évfolyamon

\begin{tabular}{|c|c|c|c|c|c|c|c|}
\hline $\begin{array}{l}\text { Olvasási motívu- } \\
\text { mok }\end{array}$ & $\begin{array}{l}\text { Attitüd- } \\
\text { aktív }\end{array}$ & $\begin{array}{l}\text { Attitüd- } \\
\text { hallgatás }\end{array}$ & Énkép & Flow & Antiflow & Érték & $\begin{array}{l}\text { Önhaté- } \\
\text { konyság }\end{array}$ \\
\hline \multicolumn{8}{|l|}{ Attitűd-aktív } \\
\hline Attitűd-hallgatás & $0,23 * *$ & & & & & & \\
\hline Énkép & $0,46^{* *}$ & 0,16 & & & & & \\
\hline Flow & $0,57 * *$ & $0,30 * *$ & $0,46^{* *}$ & & & & \\
\hline Antiflow & $-0,45 * *$ & $-0,18 * *$ & $-0,34 * *$ & $-0,27 * *$ & & & \\
\hline Érték & $0,54 * *$ & $0,20 *$ & $0,32 * *$ & $0,47 * *$ & $-0,45 * *$ & & \\
\hline Önhatékonyság & $0,24 * *$ & 0,09 & 0,17 & 0,11 & $-0,32 * *$ & 0,02 & \\
\hline
\end{tabular}

Megjegyzés:** 0,01 szinten szignifikáns; *0,05 szinten szignifikáns.

Az olvasási önhatékonyság és az olvasási énkép között nincs szignifikáns összefüggés, aminek számos magyarázata lehet. Levonhatnánk azt a következtetést, hogy az általában véve vett terület-, de nem feladatspecifikus olvasási képességekre vonatkozó meggyőződések nem állnak kapcsolatban az egy adott jövőbeni feladatra vonatkozó képességészleletekkel. Ez megerősíti a szakirodalom alapján felvázolt eredeti modellünket, miszerint az olvasási énkép és az olvasási önhatékonyság kettő, egymástól független, önálló pszichikus komponens. Ugyanakkor nem feledkezhetünk meg arról, hogy az önhatékonyság mérésére alkalmazott két kérdés kontextusát két olyan feladat adta, amely a hangos olvasásra vonatkozott. Az olvasási önhatékonyság és az olvasási énkép közötti összefüggés hiánya tehát esetünkben csak arra mutat rá, hogy a hangos olvasás terén észlelt önhatékonyság és az általában vett olvasási énkép között nincs összefüggés.

Ugyanakkor azonban az olvasási énkép közepesen erős összefüggést mutat az olvasásórán átélt flow élménnyel és az aktív olvasás iránti attitüdökkel. Eszerint azok, akik olvasásórán átélik a flow élmény elemeit és szeretnek olvasni, fejlettebbnek is érzik saját olvasási képességeiket. Az énkép- és az értékmotívumok közötti gyengébb összefüggés az elvárás és az értékmotívumok elkülönülésére mutat rá, alátámasztva ezzel elméleti modellünk koncepcióját.

A motívumok közötti kapcsolatrendszer feltárására klaszteranalízist végeztünk. Az eredményt megjelenítő dendrogramot a 23. ábrán közöljük. Látható, hogy az olvasás motívumai az elsődleges kapcsolatok alapján két fürtbe szerveződnek. Az egyik fürtöt az olvasásórán átélt flow elemek (flow), az aktív olvasás iránti attitüd (aktivatt) és az olvasási énkép (enkep) alkotja, míg a másikat az olvasásnak tulajdonított érték (ertek) és a mesehallgatás iránti attitüd (hallatt). Tulajdonképp egyik fürt létrejötte sem meglepő, az olvasásban átélt flow élmény feltétele, hogy a tanuló úgy érezze, sikeres lehet az olvasásban és jól megy neki. Az olvasás iránti pozitív attitüd szintén értelmezhető az olvasás flow elemeként. Az áramlatélmény olyan tevékenységek során élhető át, amelyeket az egyén szívesen végez, és megfordítva, az olyan tevékenységek, amelyek flow élménnyel járnak, a pozitív élmények miatt kedveltté is válnak. Az olvasásnak tulajdonított érték, a mesehallgatás és a közös olvasás iránti attitűdök első szinten való kapcsolódása és fürtté szerveződése feltételezhetően arra utal, hogy a gyermekek által az olvasásnak tulajdonított érték ebben az életkorban ugyanúgy az egyén számára fontos má- 
sok - felnőttek - értéktulajdonításához kapcsolódik, mint ahogyan a mesehallgatás és a közös olvasás is.

Az említett két fürt a következő kapcsolódási pontnál egymáshoz kapcsolódik, amely közös fürthöz csak távolabbról kapcsolódik az önhatékonyság (önhat) mint motívum. Tehát az egy feladathoz kapcsolódó sikerelvárások nem szorosan függnek össze a többi motívummal, a várt teljesítményt valószínüleg más tényezők is befolyásolják. Az antiflow elemek (antiflow) a többi motívumhoz, érthető módon, csak távolabbról kapcsolódnak.

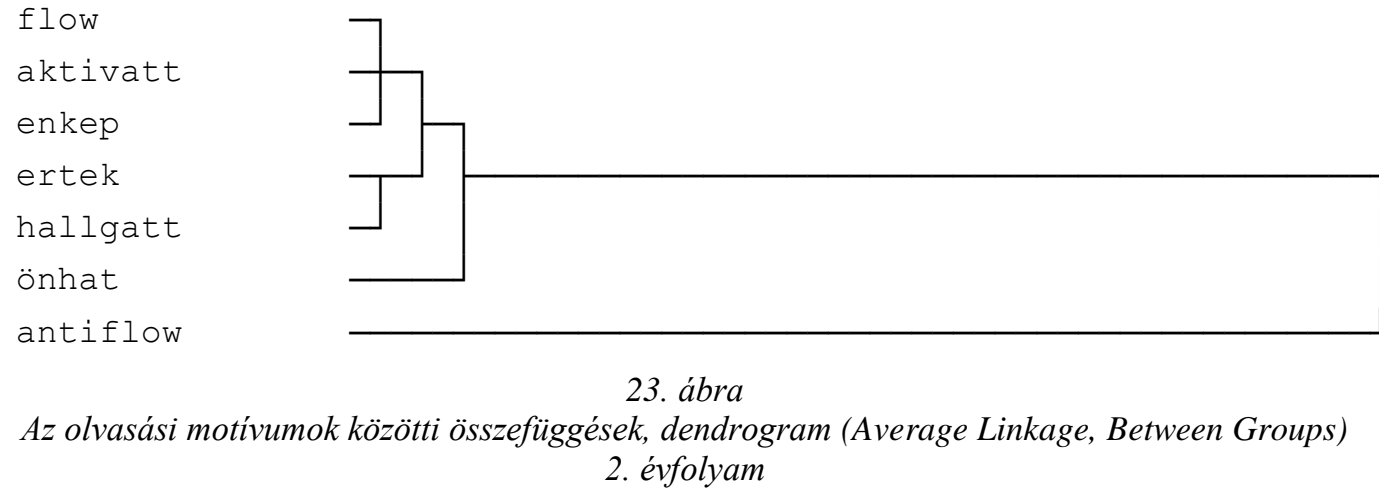

Az olvasási motívumok összefüggésrendszerének mélyebb rétegeit, a motívumok egymásra való hatását regresszióanalízissel tártuk fel. Minden olvasási motívumot szerepeltettünk függő változóként, független változónak pedig minden esetben az összes többi motívumot bevontuk. Ez az elrendezés összesen hét regresszióanalízist eredményezett. Az eredményeket a 38. táblázat tartalmazza. Helytakarékosság és a jobb áttekinthetőség érdekében a táblázatban csak a szignifikáns $\mathrm{r} \beta \%$ értékeket szerepeltetjük. Az egyes elemzések az oszlopokban szerepelnek, a független változók a sorokban helyezkednek el.

38. táblázat A motívumok közötti összefüggések, regresszióanalízis, 2. osztály

\begin{tabular}{|c|c|c|c|c|c|c|c|}
\hline \multirow{3}{*}{ Független változók } & \multicolumn{7}{|c|}{ Függő változók } \\
\hline & \multicolumn{7}{|c|}{$r \beta \%$} \\
\hline & $\begin{array}{l}\text { attitüd - } \\
\text { aktív }\end{array}$ & $\begin{array}{l}\text { attitüd - } \\
\text { hallgatás }\end{array}$ & énkép & flow & anti-flow & érték & $\begin{array}{l}\text { önhaté- } \\
\text { konyság }\end{array}$ \\
\hline Attitüd - aktív & & & & 20 & 12 & 19 & \\
\hline Attitűd - hallgatás & & & & 5 & & & \\
\hline Énkép & & & & 11 & & & \\
\hline Flow & 18 & 7 & 13 & & & & \\
\hline Antiflow & 8 & & & & & 10 & 9 \\
\hline Érték & 15 & & & 9 & & & \\
\hline Önhatékonyság & & & & & 7 & & \\
\hline Összesen $\left(\mathrm{R}^{2}\right)$ & 41 & 7 & 13 & 45 & 19 & 29 & 9 \\
\hline
\end{tabular}


A regresszió által magyarázott varianciák $7-45 \%$ közöttiek. A rendszertöl a legfüggetlenebb az önhatékonyság motívuma, amelyet csupán az antiflow élmény elemei magyaráznak, és amely maga is csak az antiflow élményt magyarázza. A függetlenség oka feltételezhetően, hogy az itt szerepeltetett motívumok közül ez az egyetlen feladatspecifikus motívum. A flow élmény varianciájában a motívumrendszer számos eleme szignifikáns magyarázóerővel bír. Ez nem meglepö, hiszen a flow élmény egy komplex jelenség, melynek megjelenéséhez számos, az általunk vizsgált motívumrendszerben is megjelenő pszichikus komponens járul hozzá. Így feltételezi a magas énképet, a tevékenységhez való pozitív viszonyulást és a tevékenység relatív fontosságának pozitív megítélését. Az olvasásórán átélt flow élmény szintén magyarázója számos más motívum varianciájának, így az aktív olvasás iránti és a mesehallgatáshoz kapcsolódó attitüdöknek és az énképnek is. A mesehallgatás iránti attitüdök is viszonylag függetlenek a motívumrendszertől. Ez is várható volt, hiszen a többi motívum a saját olvasási képességekre és olvasási tevékenységre vonatkozik, míg a mesehallgatás iránti attitüd ezeket a tényezőket nem feltételezi. A regresszióanalízis eredménye összességében véve az egyes motívumok relatív függetlenségére, ugyanakkor a motívumok egymásra hatását mutatja.

\subsubsection{Második osztályos tanulók olvasási énképének forrásai}

Az egyéni interjúk során három olvasási motívumhoz kapcsolódóan nyílt végü kérdéseket is feltettünk a gyermekeknek. A három említett motívum közül először az énképhez kapcsolódó kérdésre adott válaszokat elemezzük.

Az énkép jellemzőjére vonatkozó kérdésre (Jó olvasó vagy?) adott válasznak megfelelően azt kérdeztük a tanulóktól, miből gondolják, hogy ők jó vagy kevésbé jó olvasók. A válaszokat hangfelvételen rögzítettük, majd legépeltük és a tartalomelemzés módszerével elemeztük. Ennek során a szakirodalom, valamint az interjúk megismerése alapján létrehoztunk egy előzetes kategóriarendszert, amelybe az egyéni válaszokat be tudtuk illeszteni. Az elözetes kategóriarendszer (13. melléklet) helyességét a két elemző egymástól függetlenül ellenőrizte. Ezt követően hoztuk létre a végleges kategóriarendszert, amelybe a tanulók egyes válaszait a két elemző ismét egymástól függetlenül sorolta be. A két független elemző között az egyetértés $86 \%$-os volt.

Tekintve, hogy - tudomásunk szerint - jelen vizsgálat az első ilyen módszerekkel dolgozó hazai kutatás a témában, első kérdésként felmerült, vajon tudnak-e egyáltalán a tanulók az énkép forrására vonatkozó kérdésre válaszolni, megértik-e a kérdező szándékát. Eredményeink szerint az énkép forrására vonatkozó kérdésre a tanulók többsége válaszolni tudott, a válaszok mindösszesen $4 \%$-a volt irreleváns, és a tanulók 7\%-a jelezte, hogy nem érti a kérdést. Ez a válaszadók életkorát tekintve nagyon jó aránynak számít.

Arra a kérdésre, hogy miből gondolják, ők jó vagy kevésbé jó olvasók, a tanulók változatos válaszokat adtak. Az énkép forrására vonatkozó kijelentéseket végül hat átfogó kategóriába soroltuk: (1) szülői visszajelzések; (2) tanítói dicséret; (3) osztályzatok; (4) saját normatív viszonyítás; (5) saját kritériumhoz viszonyítás; (6) azonosítás az erőfeszítéssel. A teljes kategóriarendszer leírását példaválaszokkal a 39. táblázat tartalmazza. 
39. táblázat Az énkép forrásaival kapcsolatos kérdésre adott válaszok alapján létrehozott kategóriák

Kategória neve Kategória leírása Példaválasz

\begin{tabular}{|c|c|c|}
\hline Szülői visszajelzés & utalás a szülő által adott visszajelzésre & „Mert hogy anya is dicsér” \\
\hline Tanítói dicséret & $\begin{array}{l}\text { utalás a tanár által nyújtott szóbeli vissza- } \\
\text { jelzésre }\end{array}$ & $\begin{array}{l}\text { „Mert amikor a tanító néni felszólít, akkor } \\
\text { azt mondja, hogy ügyes vagyok." }\end{array}$ \\
\hline Osztályzatok & $\begin{array}{l}\text { utalás az olvasás-teljesítményre kapott } \\
\text { osztályzatokra }\end{array}$ & $\begin{array}{l}\text { „Mert amikor legutóbb olvastunk, ötöst } \\
\text { kaptam rá.” }\end{array}$ \\
\hline $\begin{array}{l}\text { Saját normatív } \\
\text { viszonyítás }\end{array}$ & $\begin{array}{l}\text { utalás mások olvasás-teljesítményére és az } \\
\text { ahhoz való viszonyításra }\end{array}$ & $\begin{array}{l}\text { „Onnan, hogy a Zsoltihoz egy kicsit közel } \\
\text { vagyok. Zsolti, az is egy jó olvasó.” }\end{array}$ \\
\hline $\begin{array}{l}\text { Saját kritériumhoz } \\
\text { viszonyítás }\end{array}$ & $\begin{array}{l}\text { utalás a ,jó olvasó" jellemzőire és az ahhoz } \\
\text { való viszonyításra }\end{array}$ & „Hát mondjuk.... folyékonyan olvasok.” \\
\hline $\begin{array}{l}\text { Azonosítás az erő- } \\
\text { feszítéssel }\end{array}$ & $\begin{array}{l}\text { utalás az olvasási képesség fejlesztése ér- } \\
\text { dekében tett erőfeszítésre }\end{array}$ & „Onnan, hogy sokat gyakorolok.” \\
\hline
\end{tabular}

A 24. ábra az egyes források megjelenésének gyakoriságát mutatja a tanulói válaszokban. Egy tanuló gyakran több forrást is említett, erre bátorítottuk is a gyermekeket. Például a szülők dicsérete mellett gyakran megjelentek a tanítói visszajelzések is. Ilyenkor az adott választ mindkét kategóriához besoroltuk. A válaszok megjelenési arányai ennek következtében viszont együttesen nem 100\%-ot tesznek ki.

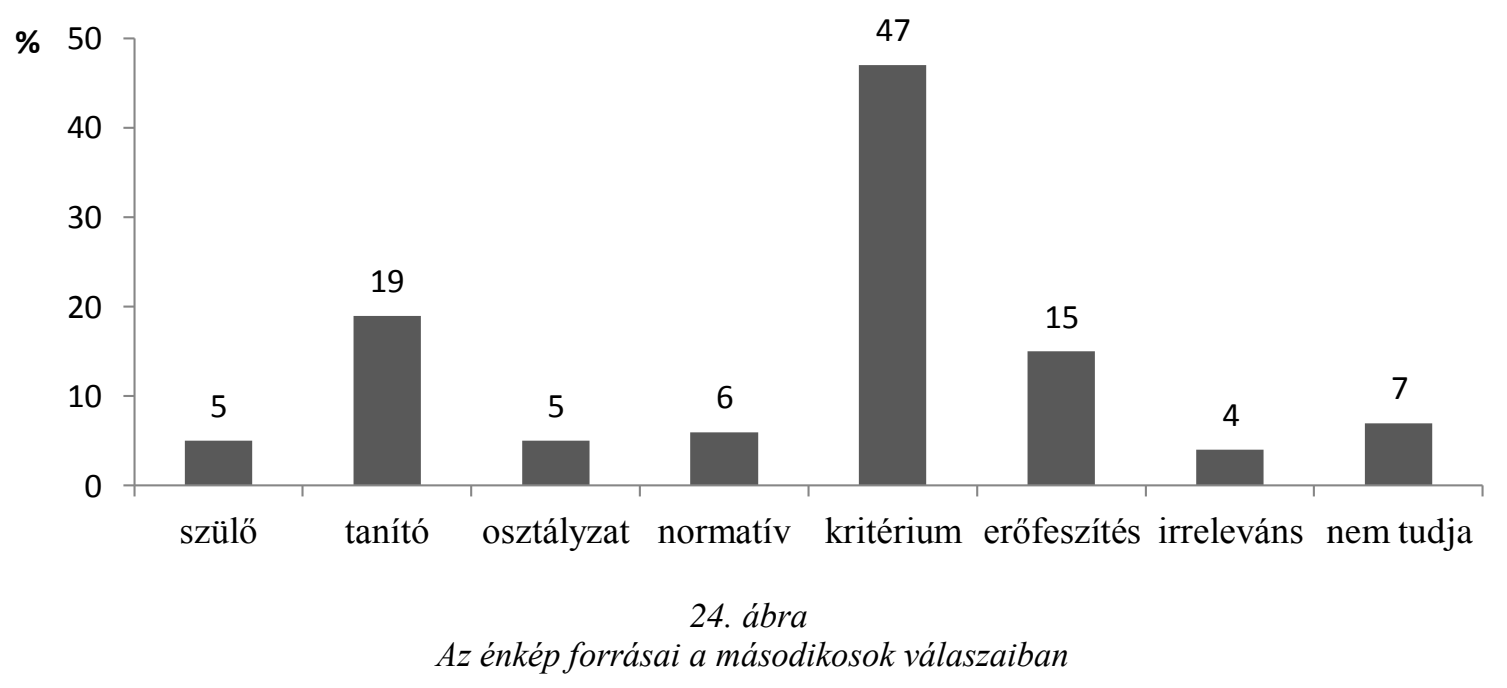

A leggyakoribb válasz a valamilyen saját kritériumhoz való viszonyítás volt: a tanulók 47\%-a gondolta magát jó vagy kevésbé jó olvasónak az alapján, hogy valamilyen maga által állított kritériumnak mennyiben felelt meg. A tanulók által a ,jó olvasó” kategóriába tartozás leggyakoribb kritériuma a folyékonyság volt, ritkábban említették a gyorsaságot, még ritkábban a pontosságot. Gyakran merültek fel válaszaikban olyan jellemzők, amelyeket tipikus hibának 
tartanak, ilyen volt például az akadozás vagy a hangsúlyozás helytelensége. A válaszok áttekintése után kijelenthetjük, hogy a tanulók által említett kritériumok és a tipikus hibák is a hangos olvasás egy-egy aspektusára mutattak rá. Ugyanakkor egyetlen válaszban sem merült fel a jó olvasó jellemzőjeként a megértés, a szövegértelmezés vagy hibaként a szöveg meg nem értése vagy félreértése.

Második leggyakoribb válaszként az énkép forrásának a tanítói dicséretet említették a tanulók, amelyre az osztályzatokkal mint visszajelzésekkel együtt a másodikosok $25 \%$-a utalt. A tanulók mintegy egynegyede tehát a tanító valamilyen formában adott visszajelzése alapján ítéli meg saját olvasási képességét, vagy legalábbis megemlíti azt saját olvasási képességészleletének forrásaként.

Viszonylag magas volt azoknak is az aránya, akik az olvasás teljesítményüket az eröfeszítéseik alapján ítélték meg (15\%), alátámasztva ezzel a szakirodalom azon állítását, miszerint ez az életkori populáció gyakran azonosítja a képességfejlettséget az erőfeszítéssel (Nicholls, 1978), azaz feltételezi, hogy az energiabefektetés minden esetben a képességek magas fejlettségi szintjéhez vezet.

\subsubsection{Második osztályos tanulók az olvasástanulás céljáról}

A második motívum, melynek vizsgálatára nyílt végü kérdéseket is alkalmaztunk, az olvasásnak tulajdonított érték volt. A szakirodalom alapján a tanulókat egyrészt arról kérdeztük, hogy miért fontos számukra, jól teljesítsenek olvasásból (szubjektív teljesítményérték), illetve, miért tartják fontosnak, hogy valaki jól megtanuljon olvasni (gyakorlati érték, hasznosság). A válaszokat az olvasási énkép forrására vonatkozó kérdéshez hasonló módon hangfelvételen rögzítettük és a tartalomelemzés módszerével elemeztük. A kategóriarendszer felállítása és a válaszok kategorizálása hasonló eljárással történt, mint az énkép forrása esetében. Minthogy egy tevékenység vagy az arra való képesség elsajátítása az egyén számára elsősorban valamilyen cél elérése miatt lehet fontos (Deci és Ryan, 1985), a kérdések egyúttal az olvasás és az olvasástanulás céljára vonatkoznak

Az olvasás teljesítmény- és gyakorlati értékére vonatkozó kérdések - bár a tanulók többsége tudott releváns választ adni - nehezebbnek bizonyultak az énkép forrására vonatkozó kérdésnél: a szubjektív teljesítményértékre vonatkozó válaszok 18\%-a, a hasznosságra vonatkozó válaszoknak 24\%-a volt irreleváns. A tanulók válaszait arra a kérdésre, hogy miért fontos számukra, hogy jól megtanuljanak olvasni, hat nagyobb kategóriába tudtuk besorolni: (1) másoknak való megfelelés; (2) rövid távú célok elérése; (3) hosszú távú célok elérése; (4) élvezet; (5) praktikus okok; (6) a fejlődés érzése. A kategóriarendszer leírását példaválaszokkal a 40. táblázat tartalmazza. 
40. táblázat. Az olvasásteljesitmény értékére vonatkozó kérdésre adott válaszok alapján létrehozott kategóriák

\begin{tabular}{|c|c|c|}
\hline Kategória neve & Kategória leirása & Példaválasz \\
\hline $\begin{array}{l}\text { Másoknak való } \\
\text { megfelelés }\end{array}$ & $\begin{array}{l}\text { utalás a szülőnek, a tanítónak vagy az } \\
\text { osztálytársaknak való megfelelés vá- } \\
\text { gyára }\end{array}$ & $\begin{array}{l}\text { „anyának szeretnék minél jobb jegyeket haza- } \\
\text { vinni” }\end{array}$ \\
\hline Rövid távú célok & utalás a tanuló rövidtávú céljaira & $\begin{array}{l}\text { „nekem úgyis lesz egy testvérem, hogy tudjak } \\
\text { neki felolvasni a mesekönyvemből” }\end{array}$ \\
\hline Hosszú távú célok & $\begin{array}{l}\text { utalás a tanuló hosszú távú - a munka, } \\
\text { a tanulás vagy a családi élet világával } \\
\text { kapcsolatos - céljaira }\end{array}$ & $\begin{array}{l}\text { „mert ha felnőtt leszek, akkor a dolgozáshoz is } \\
\text { tudnom kell olvasni” }\end{array}$ \\
\hline Élvezet & $\begin{array}{l}\text { utalás az olvasás által nyújtott élmény- } \\
\text { re, a tevékenység élvezetére }\end{array}$ & „mert szeretek mesét olvasni.” \\
\hline Praktikus okok & $\begin{array}{l}\text { utalás bizonyos praktikus, a mindenna- } \\
\text { pi életben megjelenő okokra }\end{array}$ & $\begin{array}{l}\text { „hát, mert ha valami rosszul van, akkor ki van } \\
\text { írva a táblára, hogy oda tilos menni.” }\end{array}$ \\
\hline A fejlődés érzése & utalás a fejlődés érzésének vágyára & $\begin{array}{l}\text { „hát mert még elsőben nem tudtam annyira, } \\
\text { nem ismertem a betűket, de jó, hogy most már } \\
\text { folyékonyan jönnek ki a számból a szavak” }\end{array}$ \\
\hline
\end{tabular}

Az egyes kategóriák említési gyakoriságát a 25. ábra mutatja. Itt is előfordult, hogy egy tanuló több okot is említett, amiért fontos számára az olvasás megtanulása, így egy tanulói válasz több kategóriában is megjelenhet.

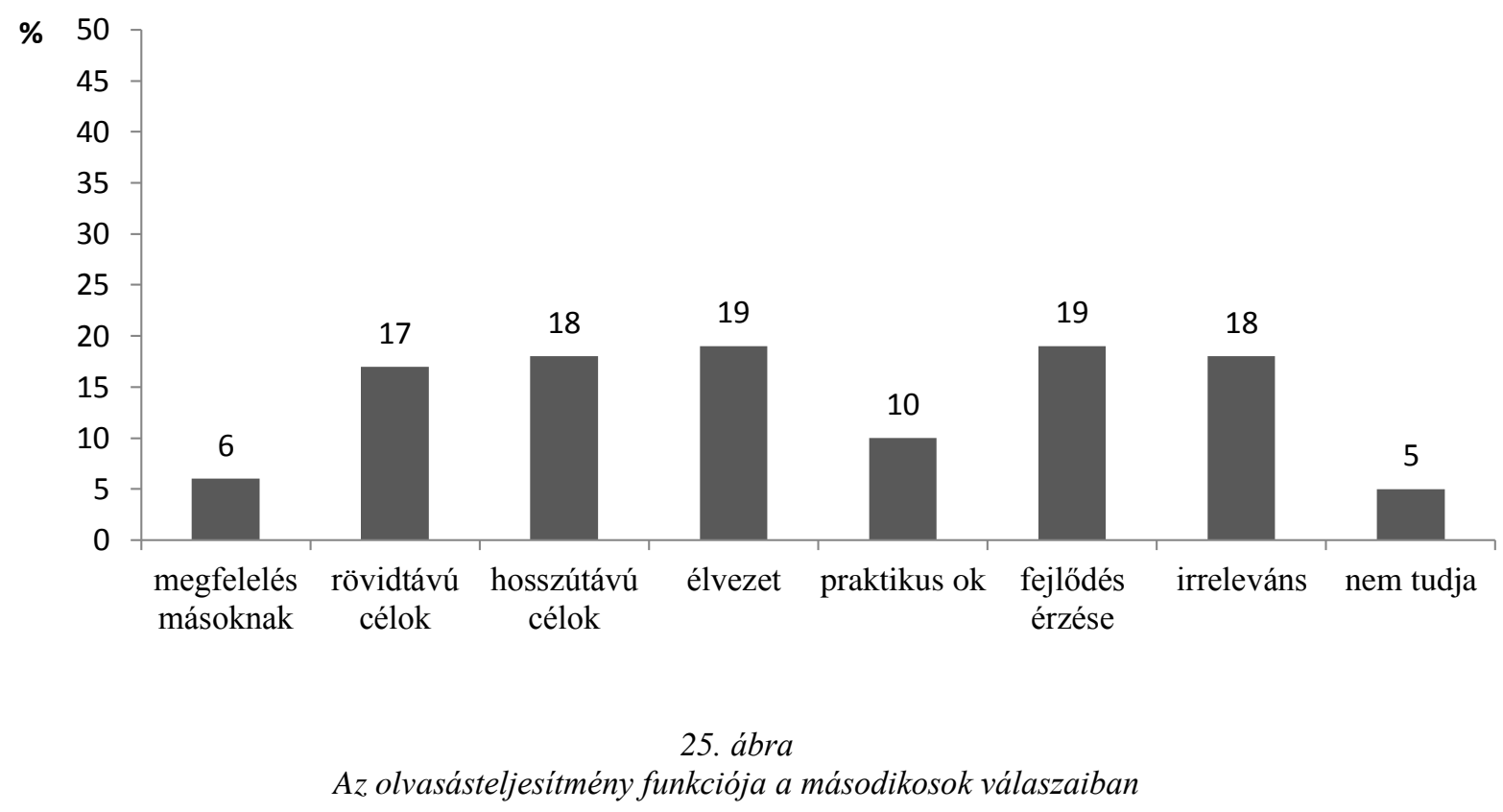

A tanulók válaszaiban megjelenő leggyakoribb kategória a fejlődés érzése volt (19\%); ide soroltunk minden olyan választ, amely az olvasási képesség vagy az általános értelmesség fejlődésére vonatkozott. Ezt követte szorosan az élvezet (19\%), a hosszú távú célok (18\%) és a rövid távú célok elérése (17\%). Viszonylag alacsony volt azoknak az aránya, akik saját beval- 
lásuk szerint a másoknak való megfelelés miatt szeretnének jól megtanulni olvasni (6\%); ők leggyakrabban a szülöknek való megfelelést, ritkábban a tanító kedvében járást, még ritkábban az osztálytársak rosszallásának elkerülését említették.

Az olvasás hasznosságára vonatkozó kérdésre adott válaszokat öt kategóriába soroltuk: (1) rövid távú érték; (2) hosszú távú érték; (3) tudásszerzés lehetősége; (4) praktikus érték; (5) élmény mint érték (41. táblázat).

41. táblázat. Az olvasás hasznosságának okára vonatkozó kérdésekre adott válaszok alapján létrehozott kategóriák

\begin{tabular}{|c|c|c|}
\hline Kategória neve & Kategória leírása & Példaválasz \\
\hline Rövid távú érték & utalás az olvasás iskolai értékére & $\begin{array}{l}\text { „Hát azért, hogy nehogy egyes legyen az } \\
\text { olvasás” }\end{array}$ \\
\hline Hosszú távú érték & $\begin{array}{l}\text { utalás az olvasás hosszú távú - továbbta- } \\
\text { nulással, munka világával és családi } \\
\text { élettel kapcsolatos - értékére }\end{array}$ & $\begin{array}{l}\text { „Ha színészek szeretnénk lenni, akkor azt } \\
\text { a produkciót nem tudnánk elolvasni, meg- } \\
\text { tanulni, ha nem tudnánk olvasni.” }\end{array}$ \\
\hline Tudásszerzés & utalás az olvasás tudásszerző funkciójára & „Hogy felnőttkorában ne legyen buta.” \\
\hline $\begin{array}{l}\text { Praktikus érték, infor- } \\
\text { mációszerzés }\end{array}$ & $\begin{array}{l}\text { utalás az olvasás praktikus, mindennapi } \\
\text { életben is fontos szerepére, az olvasás } \\
\text { információszerző funkciójára }\end{array}$ & $\begin{array}{l}\text { „Mert ha valahova elmennek, és nem tud- } \\
\text { ják, hogy kell visszajönni, akkor el tudják } \\
\text { olvasni, hogy merre van.” }\end{array}$ \\
\hline Élményszerzés & $\begin{array}{l}\text { utalás az olvasás élményszerző funkció- } \\
\text { jára }\end{array}$ & $\begin{array}{l}\text { „Azért, mert ha nem tud olvasni, nem } \\
\text { tudja élvezni a könyveket.” }\end{array}$ \\
\hline
\end{tabular}

A kategóriarendszerben a hosszú és rövid távú célok mellett megjelenik az olvasás hármas funkciója: a tudásszerzés, az információszerzés és az élményszerzés (Nagy, 2006). A válaszok kategóriarendszerben való megoszlását a 26. ábra szemlélteti.

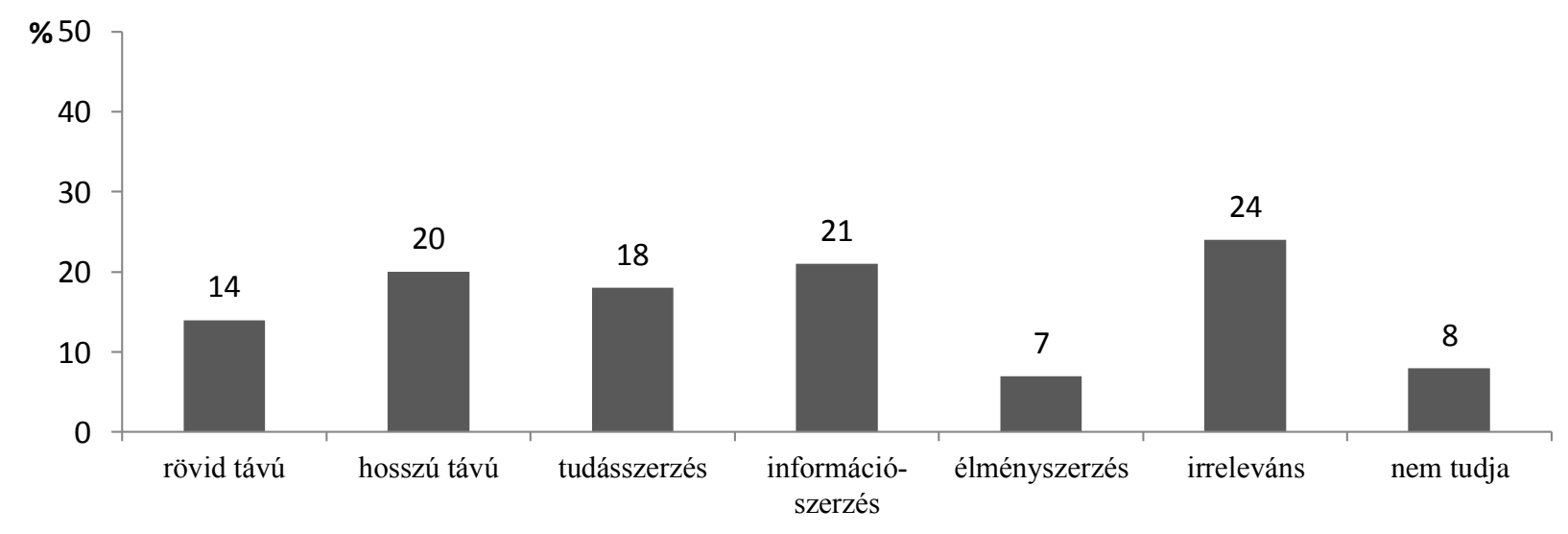

26. ábra

Az olvasástanulás funkciója a másodikosok válaszaiban

A legtöbb tanuló az iskolán kívül is látta értékét az olvasásnak, ök leggyakrabban változatos, praktikus információszerző funkciót tulajdonítottak neki (21\%), például egy levél elolvasása 
vagy a tej szavatosságának megállapítása. Mások hosszú távú - a tanulásban, a munka világában vagy családi körben betöltött - szerepét hangsúlyozták (20\%). A tanulók 18\%-a az olvasás elsajátítását mint a tudásszerzés eszközét tartja fontosnak, 7\%-uk az élményszerzés lehetőségét látja benne. A másodikosok 14\%-a nem tudott az olvasásnak az iskolán kívül értéket tulajdonítani, számukra az olvasás elsajátítása csupán az iskolában való megfelelés eszköze; ők azok, akik bíztató kérdéseink ellenére sem látták az olvasás iskolán kívüli funkcióját.

\subsubsection{Az olvasási motívumok nemek közötti különbségei}

A motívumok jellemzőit nemek szerint is megvizsgáltuk (42. táblázat). A másodikosok esetében a lányok motívumai általában magasabbak a fiúkénál, azonban a különbség csak egyetlen motívum esetében szignifikáns. A második osztályos lányok szignifikánsan jobban kedvelik a felolvasott szövegek hallgatását és a közös olvasást, mint a fiúk. A lányok és fiúk olvasásteljesítményében nem találtunk szignifikáns különbséget sem a szóolvasás teszten, sem az osztálytanító értékelése alapján meghatározott teljesítményváltozó esetében.

42. táblázat. Az olvasási motívumok átlagai nemenkénti bontásban

\begin{tabular}{lcccccccc}
\hline & \multicolumn{2}{c}{ Fiú } & \multicolumn{2}{c}{ Lány } & \multicolumn{2}{c}{ Levene } & \multicolumn{2}{c}{ Kétmintás $t$} \\
\hline $\mathrm{N}$ & \multicolumn{2}{c}{60} & \multicolumn{2}{c}{75} & & & & \\
Olvasási motívumok & átlag & szórás & átlag & szórás & $\mathrm{F}$ & $\mathrm{p}$ & $\mathrm{t}$ & $\mathrm{p}$ \\
\hline Attitüd - aktív & 74 & 21 & 77 & 19 & 0,73 & 0,40 & $-0,75$ & 0,45 \\
Attitüd - mesehallgatás & 84 & 19 & 89 & 13 & 4,90 & 0,03 & $\mathbf{- 2 , 0 4}$ & $\mathbf{0 , 0 4}$ \\
Énkép & 79 & 19 & 80 & 19 & 0,01 & 0,92 & $-0,31$ & 0,76 \\
Flow & 78 & 20 & 80 & 20 & 0,18 & 0,67 & $-0,71$ & 0,48 \\
Antiflow & 29 & 19 & 25 & 20 & 0,02 & 0,89 & 1,03 & 0,30 \\
Érték & 94 & 9 & 96 & 9 & 0,61 & 0,44 & $-0,77$ & 0,44 \\
Önhatékonyság & 74 & 23 & 78 & 19 & 2,13 & 0,15 & $-1,08$ & 0,28 \\
\hline \hline
\end{tabular}

Megjegyzés: A 0,05 szinten szignifikáns eltéréseket félkövér szedés jelzi.

A tanulók három nyílt végü kérdésre - az énkép forrására, az olvasásteljesítmény értékére és az olvasástanulás hasznosságára - vonatkozó válaszait a nemek függvényében is megvizsgáltuk. A 27. ábra az énkép forrásaival kapcsolatos kérdésre adott válaszok gyakoriságát mutatja nemek szerinti bontásban. Látható, hogy az egyes kategóriák a fiúk és a lányok válaszaiban megközelítőleg azonos gyakorisággal szerepeltek; jelentősebb nemek közötti különbséget a kétmintás t-próba eredményei alapján nem találtunk (43. táblázat). 


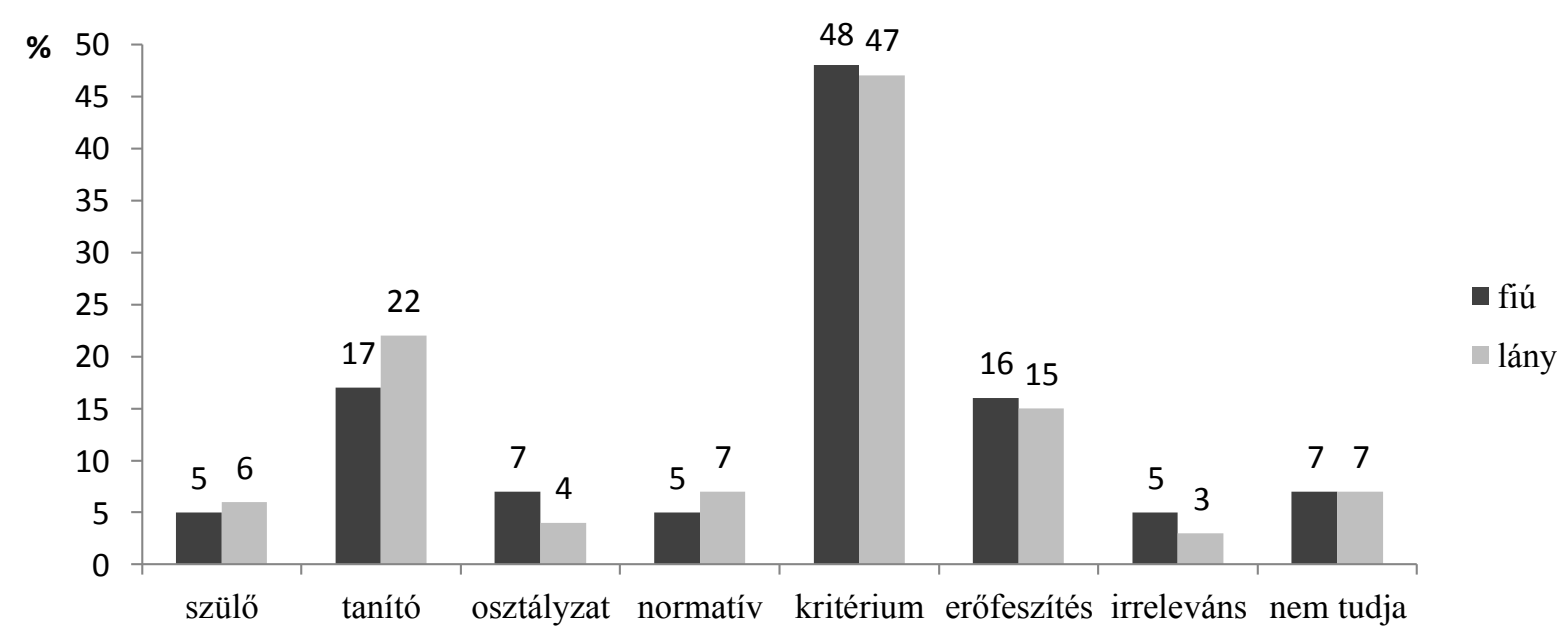

27. ábra

Az énkép forrásai a másodikosok válaszaiban nemek szerinti bontásban

43. táblázat Az énkép forrásai, nemek közötti különbségek

\begin{tabular}{|c|c|c|c|c|c|c|c|c|}
\hline \multirow{3}{*}{$\begin{array}{l}\mathrm{N} \\
\text { Énkép forrásai }\end{array}$} & \multirow{2}{*}{\multicolumn{2}{|c|}{$\frac{F i u ́}{60}$}} & \multirow{2}{*}{\multicolumn{2}{|c|}{$\begin{array}{c}\text { Lány } \\
75\end{array}$}} & \multirow{2}{*}{\multicolumn{2}{|c|}{ Levene }} & \multirow{2}{*}{\multicolumn{2}{|c|}{ Kétmintás $t$}} \\
\hline & & & & & & & & \\
\hline & átlag & szórás & átlag & szórás & $\mathrm{F}$ & $\mathrm{p}$ & $\mathrm{t}$ & $\mathrm{p}$ \\
\hline Szülö & 5 & 22 & 6 & 23 & 0,02 & 0,88 & $-0,08$ & 0,94 \\
\hline Tanító & 17 & 38 & 22 & 42 & 1,80 & 0,18 & $-0,66$ & 0,51 \\
\hline Osztályzat & 7 & 26 & 4 & 20 & 1,98 & 0,16 & 0,70 & 0,49 \\
\hline Normatív & 5 & 22 & 7 & 25 & 0,63 & 0,43 & $-0,40$ & 0,69 \\
\hline Kritérium & 48 & 50 & 47 & 50 & 0,13 & 0,72 & 0,19 & 0,85 \\
\hline Erőfeszítés & 16 & 37 & 15 & 36 & 0,02 & 0,89 & 0,07 & 0,94 \\
\hline Irreleváns & 5 & 22 & 3 & 16 & 2,08 & 0,15 & 0,72 & 0,47 \\
\hline Nem tudja & 7 & 26 & 7 & 25 & 0,00 & 0,98 & 0,01 & 0,99 \\
\hline
\end{tabular}

Az olvasásteljesítmény fontosságának okára vonatkozó kérdés esetében több különbséget is találunk a lányok és a fiúk válaszai között. Az egyik ilyen, hogy a lányok szignifikánsan többször említettek rövid távú és praktikus célokat, mint a fiúk, akik válaszaiban viszont gyakrabban jelennek meg hosszú távú célok, valamint az élvezet mint a teljesítmény motivátora. Szintén a fiúk említették gyakrabban a fejlődés érzését, mint az olvasás terén nyújtott jó teljesítmény fontosságának okát (28. ábra). Azonban a szignifikanciavizsgálat eredményei rámutattak, hogy egyetlen eltérés sem szignifikáns. Ez azt jelenti, hogy a fiúk és a lányok válaszai között statisztikai szempontból nincsen különbség, az egyes kategóriákat ugyanolyan gyakorisággal említették a két nem képviselői (44. táblázat). 


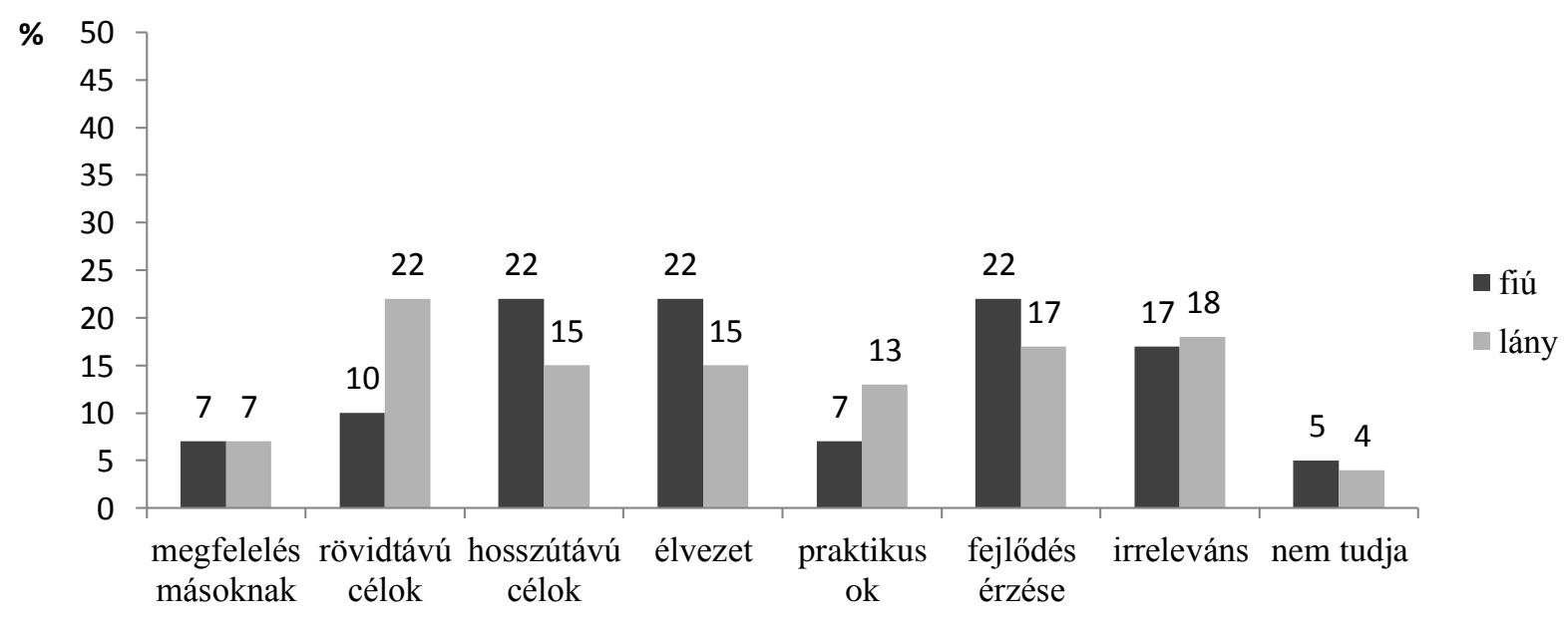

28. ábra

Az olvasásteljesítmény funkciója a másodikosok válaszaiban nemek szerinti bontásban

44. táblázat Az olvasásteljesítmény funkciója, nemek közötti különbségek

\begin{tabular}{|c|c|c|c|c|c|c|c|c|}
\hline \multirow[b]{3}{*}{ Olvasástelj. értéke } & \multirow{2}{*}{\multicolumn{2}{|c|}{$\frac{\text { Fiú }}{60}$}} & \multirow{2}{*}{\multicolumn{2}{|c|}{$\begin{array}{c}\text { Lány } \\
75\end{array}$}} & \multirow{2}{*}{\multicolumn{2}{|c|}{ Levene }} & \multirow{2}{*}{\multicolumn{2}{|c|}{ Kétmintás $t$}} \\
\hline & & & & & & & & \\
\hline & átlag & szórás & átlag & szórás & $F$ & $p$ & $t / d$ & $p$ \\
\hline Szülőnek megfelelés & 2 & 13 & 3 & 16 & 0,64 & 0,43 & $-0,40$ & 0,69 \\
\hline Osztálynak megfelelés & 3 & 18 & 3 & 16 & 0,19 & 0,67 & 0,22 & 0,83 \\
\hline Tanítónak megfelelés & 0 & 0 & 1 & 12 & 3,32 & 0,07 & $-0,90$ & 0,37 \\
\hline Rövidtávú célok & 10 & 10 & 22 & 42 & 14,67 & 0,00 & $-1,87$ & 0,06 \\
\hline Hosszútávú célok & 22 & 22 & 15 & 36 & 4,61 & 0,03 & 1,06 & 0,29 \\
\hline Élvezet & 22 & 22 & 15 & 36 & 4,30 & 0,04 & 1,02 & 0,31 \\
\hline Praktikus & 7 & 7 & 13 & 33 & 4,66 & 0,03 & $-1,09$ & 0,29 \\
\hline Fejlődés & 22 & 22 & 17 & 38 & 2,68 & 0,10 & 0,82 & 0,41 \\
\hline Irreleváns & 17 & 17 & 18 & 39 & 0,06 & 0,81 & $-0,12$ & 0,91 \\
\hline Nem tudja & 5 & 5 & 4 & 20 & 0,29 & 0,59 & 0,27 & 0,79 \\
\hline
\end{tabular}

Az olvasástanulás funkciójára vonatkozó kérdésünk esetében a lányok és fiúk válaszait tekintve ismét nem találtunk szignifikáns különbségeket, azaz a fiúk és lányok válaszaiban ugyanolyan gyakran jelentek meg az egyes válaszkategóriák. 


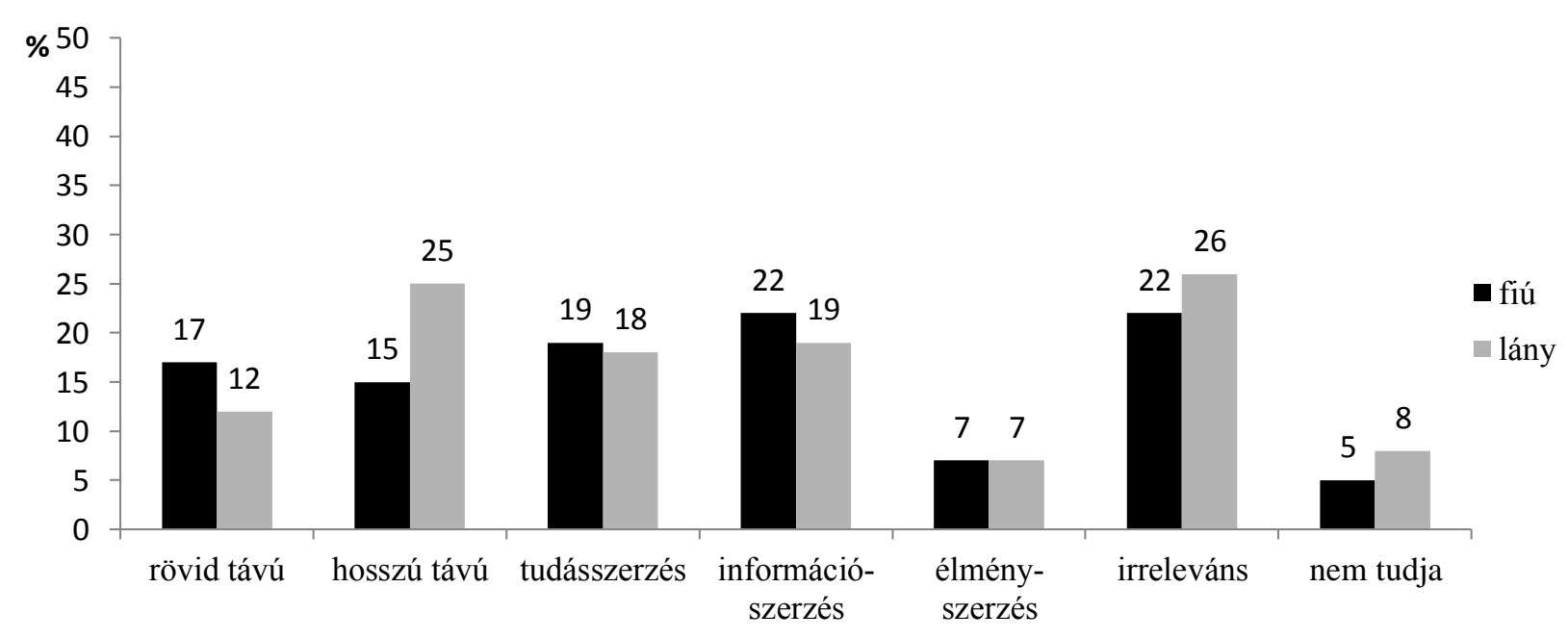

29. ábra

Az olvasástanulás funkciója a másodikosok válaszaiban nemek szerinti bontásban

45. táblázat. Az olvasástanulás funkciója, nemek közötti különbségek

\begin{tabular}{|c|c|c|c|c|c|c|c|c|}
\hline \multirow[b]{3}{*}{ Olvasástanulás értéke } & \multicolumn{2}{|c|}{ Fiú } & \multicolumn{2}{|c|}{ Lány } & \multirow{2}{*}{\multicolumn{2}{|c|}{ Levene }} & \multirow{2}{*}{\multicolumn{2}{|c|}{ Kétmintás $t$}} \\
\hline & \multicolumn{2}{|c|}{60} & \multicolumn{2}{|c|}{75} & & & & \\
\hline & átlag & szórás & átlag & szórás & $F$ & $p$ & $t / d$ & $p$ \\
\hline Rövid távú célok & 17 & 38 & 12 & 33 & 2,24 & 0,14 & 0,75 & 0,46 \\
\hline Hosszú távú célok & 15 & 36 & 25 & 43 & 5,59 & 0,02 & $-1,17$ & 0,24 \\
\hline Tudásszerzés & 19 & 39 & 18 & 39 & 0,06 & 0,81 & 0,12 & 0,90 \\
\hline Információszerzés & 22 & 42 & 19 & 40 & 0,64 & 0,43 & 0,40 & 0,69 \\
\hline Élményszerzés & 7 & 25 & 7 & 25 & 0,00 & 0,98 & $-0,02$ & 0,99 \\
\hline Irreleváns & 22 & 42 & 26 & 44 & 1,14 & 0,29 & $-0,53$ & 0,60 \\
\hline Nem tudja & 5 & 22 & 8 & 16 & 1,96 & 0,16 & 0,70 & 0,49 \\
\hline
\end{tabular}

Összességében a második osztályos lányok és a fiúk motívumait tekintve egyetlen esetben, a mesehallgatás iránti attitüdökben találtunk csak szignifikáns eltérést. A többi esetben a nemek között nincs jelentős különbség. Ez az eredmény meglepő, hiszen a szakirodalom az olvasási motívumok közötti jelentős nemi különbségekről számol be. Nem ismerünk ugyanakkor olyan kutatást, ami az iskolázás ilyen korai szakaszában számolt volna be az olvasás egyes motívumait érintő nemi különbségekről. Feltételezhető, hogy az olvasás motívumai közötti szignifikáns eltérés hiányáért a tapasztalatok hiánya és az alcsony életkor a felelős. Egy másik lehetséges magyarázat az adatfelvétel módjával kapcsolatos. Elképzelhető, hogy az egyéni 
adatfelvétel hatással volt a tanulók önbeszámoló jellemzésére, és ez okozta a szakirodalommal ellentétes eredményeket.

\subsubsection{Családi háttér és olvasási motiváció}

A családi háttér és a szociális státusz egyik mutatója a szülök iskolai végzettsége. Elemzésünkben azt vizsgáltuk, vajon a szülők iskolai végzettsége és a tanulók olvasási motívumai között van-e összefüggés második osztályban. Az összefüggés-vizsgálatok eredménye szerint egyetlen olvasási motívum sem korrelál szignifikánsan a szülők iskolai végzettségével. Ez meglepő eredmény, tekintve, hogy a szakirodalom alapján azt feltételeztük, a magasabb iskolai végzettségü szülők gyermekei gyakrabban és korábban találkoznak az írásbeliséggel, ezért az olvasásnak nagyobb értéket is tulajdonítanak. Ez az összefüggés azonban jelen kutatásban nem bizonyult szignifikánsnak. Ennek egyik lehetséges oka a gyermekek életkorából adódik, elképzelhető, hogy a második osztályos tanulók motívumaiban még nem mutatkoznak meg ezek a hatások, hiszen még kevés tapasztalattal rendelkeznek. Egy másik lehetséges magyarázat az olvasás értéke skála gyenge differenciáló erejével kapcsolatos. Amint azt saját eredményeink is mutatták, a másodikos gyermekek szinte mindannyian magas értéket tulajdonítanak az olvasásnak, egyéni különbségek alig vannak.

\subsubsection{A motívumok és a teljesítmény összefüggései}

A tanulók olvasásteljesítményének két indikátorát vettük alapul a teljesítmény és a motívumok közötti összefüggés elemzésekor. Az egyik a tanító által ötfokú skálán nyújtott értékelés, a másik a képes szóolvasás teszten nyújtott tanulói teljesítmény volt. A teljesítmények és a motívumok közötti korrelációs együtthatókat tartalmazó 46. táblázatban előbbi olvasásteljesítmény, utóbbit olvasáskészség néven szerepeltetjük. Az elemzésbe a szülők iskolai végzettségének mutatóját is bevontuk.

46. táblázat Összefüggések az olvasási motívumok, a teljesitménymutatók és a családi háttér között

\begin{tabular}{lcccccccc}
\hline \hline Korrelációk & $\begin{array}{c}\text { Attitüd- } \\
\text { aktív }\end{array}$ & $\begin{array}{c}\text { Attitüd- } \\
\text { hallgatás }\end{array}$ & Énkép & Flow & Antiflow & Érték & $\begin{array}{c}\text { Önhaté- } \\
\text { konyság }\end{array}$ & $\begin{array}{c}\text { Szülök } \\
\text { végzett- } \\
\text { sége }\end{array}$ \\
\hline Pedagógusi értékelés & 0,08 & $-0,06$ & $0,18^{*}$ & 0,10 & $-0,19^{*}$ & $0,23^{* *}$ & $-0,11$ & $0,46^{* *}$ \\
Olvasáskészség & $-0,06$ & $0,17^{*}$ & $-0,03$ & 0,01 & $-0,11$ & 0,06 & 0,00 & 0,14 \\
\hline \hline
\end{tabular}

Megjegyzés:** 0,01 szinten szignifikáns; * 0,05 szinten szignifikáns

Az eredmények szerint a tanulók olvasásteljesítményéröl adott tanári értékelés gyenge összefüggést mutat az olvasási motiváció három összetevőjével. Az összefüggés az olvasási énképpel és az olvasásnak tulajdonított értékkel pozitív, az antiflow esetében negatív. A többi motívum esetében a korreláció nem szignifikáns. Szignifikáns közepes erősségü összefüggést találtunk az olvasásteljesítmény tanári értékelése és a szülők iskolai végzettsége között. A 
regresszióanalízis eredményei arra is rámutattak, hogy az említett változók közül csak a szülők iskolai végzettsége bír magyarázóerővel az olvasásteljesítmény tanár által adott minősítésében.

Az olvasáskészség teszten nyújtott teljesítmény a vizsgált olvasási motívumok közül egyedül a mesehallgatás iránti attitüddel mutat szignifikáns összefüggést. A korreláció a két változó között itt is gyenge. A képes szóolvasás teszt eredménye és a tanár által nyújtott értékelése között szintén nem találtunk szignifikáns összefüggést. Megjegyezzük ugyanakkor, hogy a szóolvasás teszt nem differenciált a gyerekek között kellő mértékben, mely erőteljesen korlátozza a teljesítmény és a motívumok közötti összefüggések értelmezésének lehetőségét.

\subsubsection{Részösszefoglalás: Olvasási motiváció az általános iskola második évfolyamán}

Központi kutatásunk első részében második osztályos tanulók olvasási motívumait vizsgáltuk strukturált interjúk keretében felvett kérdőívek és félig strukturált interjúk segítségével. A fejlesztett kérdőív és a hozzá tartozó segédeszközök segítségével megbízható becslést kaptunk már az olvasástanulás kezdeti fázisában a tanulók olvasási motívumairól. Eredményeink megerősítették, hogy azonosíthatók azok az elméleti konstruktumok, amelyeket az olvasási motiváció mint sokösszetevős rendszer hátterében feltételeztünk, és hogy ezek a konstruktumok az általunk választott módszerrel eredményesen mérhetők.

Az eredmények alátámasztották, hogy a tanulók gondolkodásában már második osztályban elkülönülnek például az énkép- és az értékmotívumok, vagy az érték és az attitüdök, vagyis az a meggyőződés, hogy jók-e olvasásból, és fontosnak tartják-e azt, vagy, hogy fontosnak tartják-e és szeretik-e az olvasásfeladatokat. Ez az eredmény cáfolja azokat a feltételezéseket, melyek szerint az iskoláskor kezdeti szakaszában a tanulók differenciálatlan motívumokkal rendelkeznek, azaz amit kedvelnek, azt tartják egyben fontosnak, abban tartják magukat jónak és abban mélyülnek el leggyakrabban.

Az adatok elemzése arra is rámutatott, hogy a második évfolyamos tanulók meglehetösen pozitív olvasási motívumokkal rendelkeznek, és a motívumok között közepesen erös kapcsolatok vannak. Ugyanakkor a motívumok közötti összefüggésrendszer elemzése nem támasztotta alá teljes mértékben a kutatásunk hátterében álló elméleti modellt. Bár valóban vannak összefüggések a motívumok között, a motívumkategóriák, azaz az elvárás- és értékmotívumok vagy az intrinzik és extrinzik motívumok nem különülnek el egymástól olyan mértékben, mint ahogyan azt vártuk.

Az interjúk során a tanulók énképének forrása és a tanulók által az olvasásnak tulajdonított érték és funkciók feltárása érdekében nyílt végü kérdéseket is alkalmaztunk. Minthogy a szóban forgó két motívum internalizált meggyőződéseken alapuló tanult motívum, feltételeztük, hogy a tanulói válaszok az internalizáció folyamatáról is árulkodnak. Eredményeink szerint a tanulók többsége bizonyos saját maga által állított kritérium mentén ítéli meg saját olvasási képességét, ugyanakkor e kritériumok többsége a hangosolvasás-teljesítményre vonatkozik, azaz arra a területre, amellyel kapcsolatosan a legtöbb visszajelzést kapják a tanítótól és a szülőtől. Ez az eredmény megerősíti azt a feltételezést, miszerint a motívumok fejlődése során 
a tanulók egyre inkább magukénak éreznek bizonyos külső hatásokat, azaz internalizálják azokat, míg végül saját meggyőződésrendszerükbe teljesen beépítik azokat.

Vizsgálatunk kezdetén azt is feltételeztük, hogy már az olvasástanulás kezdeti szakaszában számos különbség lelhető fel a nemek között a motívumok erősségét illetően. Ez a feltételezésünk szintén nem igazolódott be. Csupán egyetlen motívum esetében mutatkozott szignifikáns különbség a fiúk és a lányok olvasási motívumai között, ez a hallgatás - azaz a mások által felolvasott szöveg hallgatása - iránti attitüd volt. E motívum esetében a lányok pozitívabb viszonyulásáról beszélhetünk. A többi olvasási motívum fejlettsége terén nem mutatható ki különbség a nemek között: a fiúk és a lányok hasonló erősségü olvasási motívumokkal rendelkeznek.

Szintén nem találtunk különbséget a különböző iskolai végzettségü szülők gyermekeinek olvasási motívumai között, mely eredmény ismét előzetes várakozásainkkal ellentétes. Második osztályban a tanulók olvasási motívumaiban még nincs különbség az apa iskolai végzettsége szerint, mely eredmény arra enged következtetni, hogy az iskoláskor elötti és az iskola kezdetén kapott otthoni támogatás nincs olyan mértékü hatással az olvasási motívumokra, mint azt vártuk. A tanulók olvasási motívumai családi háttértöl függetlenül magasabb.

Kutatásunkban az olvasási teljesítmény mutatójaként a tanári által adott értékelést és a képes szóolvasás teszten nyújtott teljesítményt vettük alapul. Az olvasásteljesítmény e két mutatója és az olvasási motívumok között nem találtunk szignifikáns összefüggést, azaz a tanár értékelése szerint a magas motívumokkal rendelkező tanulók nem jobbak olvasásból. Szintén nem teljesítettek jobban a magasabban motivált tanulók a képes szóolvasás teszten. Azonban ez nem jelenti azt, hogy az olvasási teljesítmény egy másik, általunk nem vizsgált aspektusa, például a szövegértés sem áll kapcsolatban a vizsgált motívumokkal. E két tényezö közötti összefüggés feltárása további kutatási feladat.

\subsection{A negyedik, hatodik és nyolcadik évfolyamon végzett vizsgálat eredményei}

\subsubsection{A negyedik, hatodik és nyolcadik évfolyam mérőeszközeinek érvényessége és megbízhatósága}

Az általános iskola felsőbb évfolyamai számára fejlesztett mérőeszköz tizenhárom motívum vizsgálatára alkalmas, melyek közül tíz mérésére önálló skálát fejlesztettünk, illetve adaptáltunk, egy vizsgálatára - definíciójából adódóan - csupán egyetlen kérdést alkalmaztunk (önhatékonyság), kettő vizsgálatára nyílt és zárt végü kérdéseket tettünk fel (siker- és kudarcattribúciók). A kérdőív struktúrájának ellenőrzésére faktoranalízist végeztünk a tizenegy motívum vizsgálatára szánt tételek bevonásával. A kérdés az volt, azonosíthatók-e a vizsgálandó motívumok és az azok mérésére szánt skálák, azaz helytálló-e elméleti modellünk. A faktoranalízist validitásvizsgálatnak tekintettük. A változórendszer faktoranalízisre való alkalmasságát a Kaiser-Meyer-Olkin-index alapján határoztuk meg, mely esetünkben 0,92. Ennek értelmében a változórendszer hátterében nagy valószínűséggel faktorok állnak. 
Az elvégzett faktoranalízis a várt tizenegy helyett tizennégy egynél nagyobb sajátértékü, önálló faktort hozott létre. Az így létrejött faktorok a változórendszer varianciájának 60\%át magyarázzák. A tizennégy faktor közül négy egyértelműen megfeleltethető egy-egy motívumnak; ezek a munkakerülő célok, az antiflow, az iskolai olvasás iránti attitüd és az énkép skálák. A szociális motívumok és a szabadidős olvasás iránti attitüd skálákhoz tartozó tételek egy faktorba rendeződtek, melyhez azonban a szabadidős olvasás iránti attitüdre vonatkozó kérdések rendre alacsonyabb faktorsúllyal kapcsolódnak. A két motívumra vonatkozó faktorokat ezért a továbbiakban külön kezeljük. Kivételt képez ez alól az interneten történő olvasásra vonatkozó tétel, amely önálló faktort hozott létre. A tanulók, ennek értelmében, amikor az olvasásról kérdezzük őket általánosságban, feltételezhetően még mindig a papíralapú szövegek olvasására gondolnak, és gondolkodásukban elkülönül ettöl az elektronikus szövegek olvasása. Az érték skála negatív megfogalmazású két tétele szintén külön faktorba rendeződött, feltételezhetően a megértési nehézségek miatt. Az olvasás értékére vonatkozó többi állítás ettől eltekintve egy faktort alkotott. Az antiflow skála azon tétele, mely az idő gyors múlásának észleletére vonatkozott, a felsőbb évfolyamok esetében is külön skálába szerveződött, és nem kapcsolódott az egyébként egységet alkotó flow tételekhez. A teljesítmény- és elsajátítási célokra vonatkozó tételek egy faktorba rendeződtek, azonban az elsajátítási célokra utaló tételek rendre hasonló súllyal kapcsolódnak a flow skálához is. Az önhatékonyság mérésére szánt kérdés, az alsóbb évfolyammal ellentétben, a felsőbb éveseknél az énkép faktorba szerveződött.

A skálák teljes mintára vonatkozó megbízhatósági mutatóit a 47. táblázatban közöljük. A megbízhatósági mutatók legtöbbje 0,7 fölötti, ami elfogadható. Kivétel ez alól az énkép, a szabadidős olvasás iránti attitűd és az érték skálák. Az első kettő esetében a reliabilitás kevéssé marad el a 0,7-es szinttől, míg az érték skála esetében jóval alatta marad. Mind a faktoranalízis, mind az itemkihagyásos reliabilitásvizsgálat indokolta néhány kérdőívtétel kihagyását a további vizsgálatokból. Az énkép skála esetében két tételt hagytunk ki (sorszámuk a 9. melléklet szerint: 8. és 11.). A szabadidős olvasás skála esetében az internetes olvasásra vonatkozó tétel (35) már a faktoranalízisben is elkülönült a többi tételtől és a megbízhatóságot is csökkentette, így szintén kihagytuk a további elemzésből. Az érték skála esetében a már említett két negatív megfogalmazású tétel (37. és 38.) jelentősen rontotta a megbízhatóságot, így szintén elhagyásuk mellett döntöttünk. Végül a flow mérése esetében az idő gyors múlására vonatkozó tételt (77.) szintén a reliabilitás javítása céljából töröltük. Az itemek elhagyása után az említett skálák Cronbach- $\alpha$ mutató szerinti megbízhatósága is elfogadható, habár az érték skála 0,60-as reliabilitása még mindig gyengének tekinthető. Az itemkihagyás után a kérdőív öszszesen 69 tételt tartalmaz, az egyes skálák reliabilitása 0,6 és 0,87 közötti. 
47. táblázat Az olvasási motiváció kérdöiv skáláinak megbizhatósága az itemkihagyás elött és után

\begin{tabular}{lcccc}
\hline \hline \multicolumn{1}{c}{ Olvasási motívumok } & $\begin{array}{c}\text { Kérdölv-tételek } \\
\text { száma }\end{array}$ & $\begin{array}{c}\text { Megbizhatóság } \\
\text { (Cronbach- } \alpha)\end{array}$ & $\begin{array}{c}\text { Tételek száma } \\
\text { tételkihagyással }\end{array}$ & $\begin{array}{c}\text { Megbizhatóság } \\
\text { (Cronbach- } \alpha)\end{array}$ \\
\hline Énkép & 7 & 0,60 & 5 & 0,81 \\
Szociális motívumok & 7 & 0,82 & 7 & 0,82 \\
Attitúd a szabadidős olvasás iránt & 5 & 0,67 & 4 & 0,75 \\
Attitüd az iskolai olvasás iránt & 5 & 0,80 & 5 & 0,80 \\
Érték & 6 & 0,25 & 4 & 0,60 \\
Elsajátítási cél & 5 & 0,79 & 5 & 0,79 \\
Teljesítménycél & 5 & 0,87 & 5 & 0,87 \\
Elkerülő cél & 5 & 0,78 & 5 & 0,78 \\
Flow & 8 & 0,78 & 7 & 0,82 \\
Antiflow & 11 & 0,84 & 11 & 0,85 \\
Sikerattribúciók & 5 & - & 5 & - \\
Kudarcattribúciók & 5 & - & 5 & - \\
Önhatékonyság & 1 & - & 1 & - \\
\hline
\end{tabular}

A skálák megbízhatóságát évfolyamonkénti bontásban a 48. táblázat mutatja. Várakozásainkkal ellentétben a Cronbach- $\alpha$ mutatók nem minden esetben az alsóbb évfolyamokon a leggyengébbek, több esetben éppen a legmagasabb osztályban mutatnak alacsonyabb megbízhatóságot. Azonban a mutatók míg így is minden évfolyamon elfogadhatóak, a mérőeszköz minden évfolyamon megbízhatóan méri a tanulók olvasási motívumait. 
48. táblázat Az olvasási motiváció kérdőiv skáláinak megbizhatósága évfolyamonkénti bontásban

\begin{tabular}{lccc}
\hline \multirow{2}{*}{ Olvasási motívumok } & \multicolumn{3}{c}{ Megbizhatóság (Cronbach- $\alpha)$} \\
\cline { 2 - 4 } & $\begin{array}{c}4 . \text { évfolyam } \\
(\mathrm{n}=218)\end{array}$ & $\begin{array}{c}\text { 6. évfolyam } \\
(\mathrm{n}=278)\end{array}$ & $\begin{array}{c}\text { 8. évfolyam } \\
(\mathrm{n}=260)\end{array}$ \\
\hline Énkép & 0,83 & 0,79 & 0,82 \\
Szociális motívumok & 0,80 & 0,83 & 0,82 \\
Attitűd a szabadidős olvasás iránt & 0,79 & 0,72 & 0,77 \\
Attitüd az iskolai olvasás iránt & 0,75 & 0,81 & 0,78 \\
Érték & 0,56 & 0,60 & 0,62 \\
Elsajátítási cél & 0,71 & 0,80 & 0,77 \\
Teljesítménycél & 0,77 & 0,89 & 0,84 \\
Elkerülő cél & 0,77 & 0,77 & 0,78 \\
Flow & 0,84 & 0,83 & 0,80 \\
Antiflow & 0,84 & 0,86 & 0,83 \\
\hline
\end{tabular}

Az olvasás-szövegértés teszt megbízhatósági mutatóit évfolyamonkénti bontásban a 49. táblázat tartalmazza. A táblázatban a reliabilitásmutatókat külön a folyamatos és a nem folyamatos szövegre, illetve a teljes tesztre vonatkozóan is feltüntettük.

49. táblázat Az olvasás-szövegértés teszt megbizhatósága évfolyamonkénti bontásban

\begin{tabular}{lccc}
\hline \hline & \multicolumn{3}{c}{ Megbizhatóság (Cronbach- $\alpha)$} \\
\cline { 2 - 4 } & $\begin{array}{c}\text { 4. évfolyam } \\
(\mathrm{n}=218)\end{array}$ & $\begin{array}{c}\text { 6. évfolyam } \\
(\mathrm{n}=278)\end{array}$ & $\begin{array}{c}\text { 8. évfolyam } \\
(\mathrm{n}=260)\end{array}$ \\
\hline Folyamatos szöveg & 0,71 & 0,73 & 0,71 \\
Nem folyamatos szöveg & 0,77 & 0,73 & 0,51 \\
Teljes teszt & 0,80 & 0,80 & 0,73 \\
\hline \hline
\end{tabular}

\subsubsection{A negyedik, hatodik és nyolcadik évfolyamos tanulók olvasási motívumai}

A negyedik, hatodik és nyolcadik évfolyamos tanulók olvasási motívumainak jellemzőit először egyenként tárgyaljuk. Az egyes motívumok kapcsán a tanulói válaszok gyakorisági eloszlásait mutatjuk be. Az összevetést megkönnyítendő az egyes évfolyamok gyakorisági eloszlásait motívumonként egy ábrán szerepeltetjük (30-40. ábra).

Az olvasási énkép gyakorisági eloszlását a negyedik, hatodik és nyolcadik osztály esetében a 30. ábra mutatja. Már első ránézésre is észrevehető, hogy az eloszlásgörbék mindhárom évfolyam esetében jobbra tolódtak, ami azt jelenti, hogy a tanulók többsége 
pozitív olvasási énképpel rendelkezik. A három évfolyam eloszlásgörbéje majdnem fedi egymást, azaz a három vizsgált életkori populáció olvasási énképének eloszlásában jelentős különbség nincs. Enyhén csökkenő tendenciát mutat ugyanakkor az életkor emelkedésével a nagyon jó, 90\%p fölötti énképpel rendelkezők aránya: negyedik osztályban a tanulók 12\%-a, hatodikban 7\%-uk, nyolcadikban már csak 5\%-uk tartozik ebbe a kategóriába.

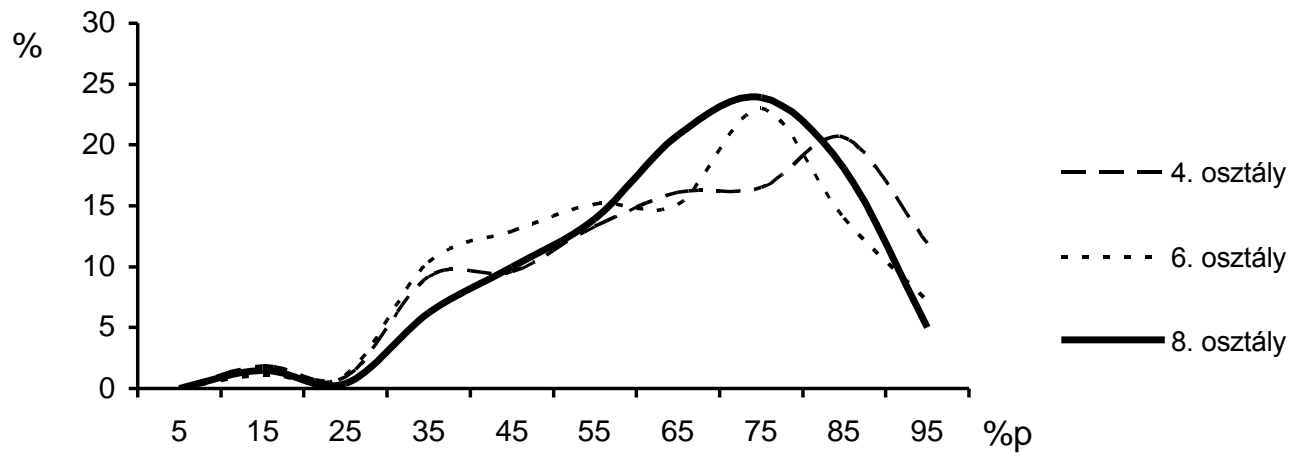

30. ábra

Az olvasási énkép eloszlásgörbéje

Az olvasás szociális motívumainak eloszlása (31. ábra) negyedik és hatodik évfolyamon normál eloszlást mutat, nyolcadik évfolyamon a görbe enyhén balra tolódik. Ez az eltolódás azt jelzi, hogy nyolcadik osztályban valamivel magasabb azoknak az aránya, akiket nem, vagy legalábbis kevésbé motiválnak a társas élmények és az olvasmányélmények megosztása.

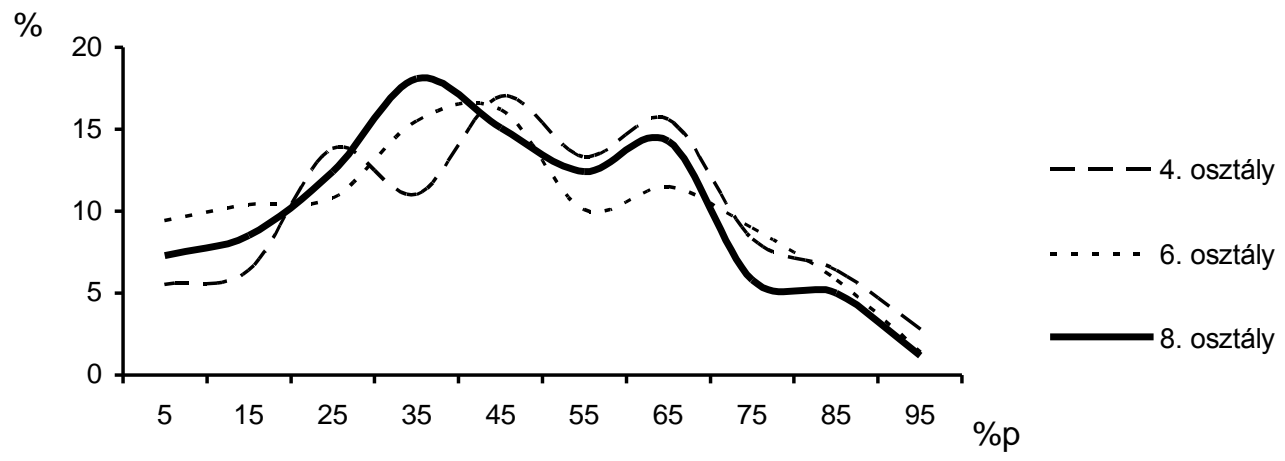

31. ábra

Az olvasás szociális motívumainak eloszlásgörbéje 
A szabadidős olvasás iránti attitüd eloszlása (32. ábra) hatodik és nyolcadik osztályban többmóduszú. A tanulók többsége minden évfolyamon a középmezőnyben helyezkedik el, de minden évfolyamon jól elkülönül a tanulóknak egy a teljes mintának mintegy 15-20\%-át kitevő csoportja, akik kifejezetten kedvelnek szabadidejükben olvasni ( $70 \%$ p felett), és egy 10\%-nyi csoport, akik kifejezetten nem kedveli azt (20\%p alatt).

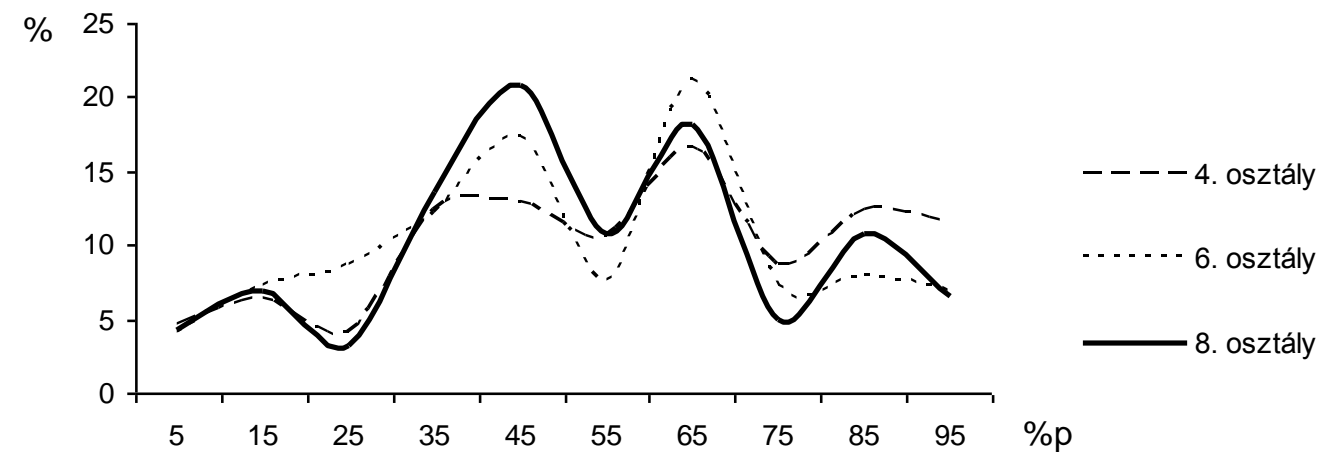

32. ábra

A szabadidős olvasás iránti attitüd eloszlásgörbéje

Az iskolai olvasás iránti attitüdök esetében az egyes évfolyamok eloszlásainak tekintetében már több különbséget találunk (33. ábra), mint a szabadidős olvasás iránti attitüd esetében. Ezek közül a legszembetünőbb, hogy hatodik és nyolcadik osztályban szignifikánsan alacsonyabb azoknak az aránya, akik kifejezetten pozitívan viszonyulnak az iskolai olvasáshoz (70\%p felett). Viszont megnő azoknak az aránya, akik nagyon negatív attitüdökkel rendelkeznek az iskolához kötődő olvasási tevékenységek iránt (20\%p alatt).

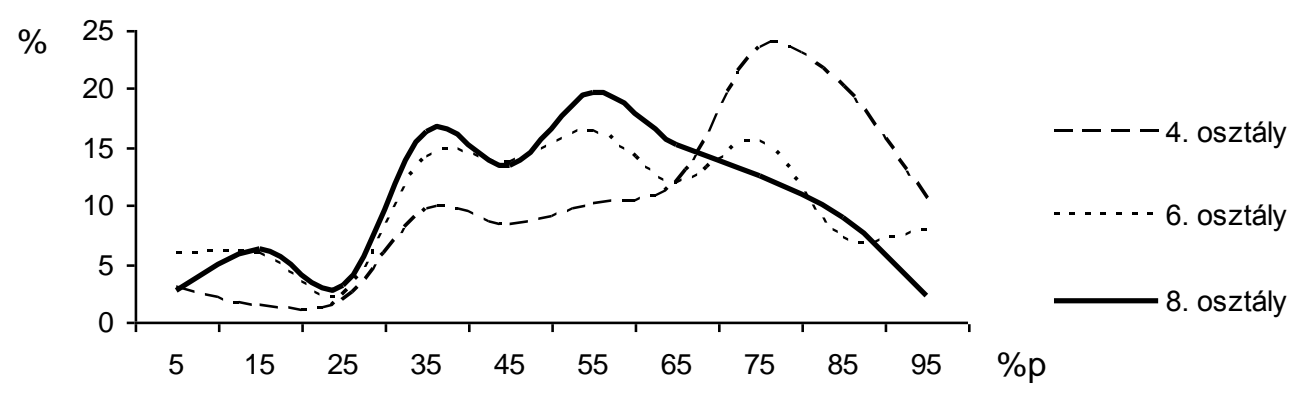

33. ábra

Az iskolai olvasás iránti attitüd eloszlásgörbéje 
Az olvasásnak tulajdonított gyakorlati érték skála egyik évfolyam esetében sem differenciált kellöképpen, mind a három görbe erősen jobbra tolódott (34. ábra). E szerint szinte valamennyi tanuló magas értéket tulajdonított az olvasásnak.

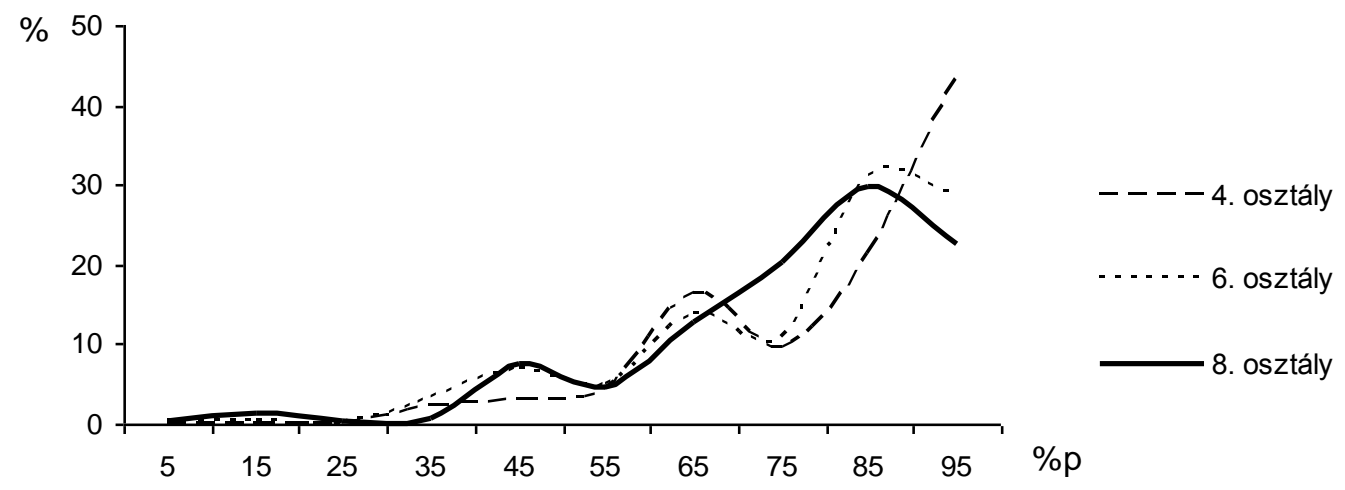

34. ábra

Az olvasásnak tulajdonitott gyakorlati érték eloszlásgörbéje

Az elsajátítási célok eloszlásgörbéje (35. ábra) a negyedik, hatodik és nyolcadik évfolyamon is jobbra tolódott, azonban a nyolcadik évfolyamra a görbe csúcspontja áthelyeződik: kevesebben lesznek azok, akik szinte mindig elsajátítási célokat követnek olvasási feladatok megoldásakor. Ez a csökkenés fokozatosnak mondható, hasonló különbség figyelhető meg a negyedik és a hatodik évfolyam eloszlágörbéje között is.

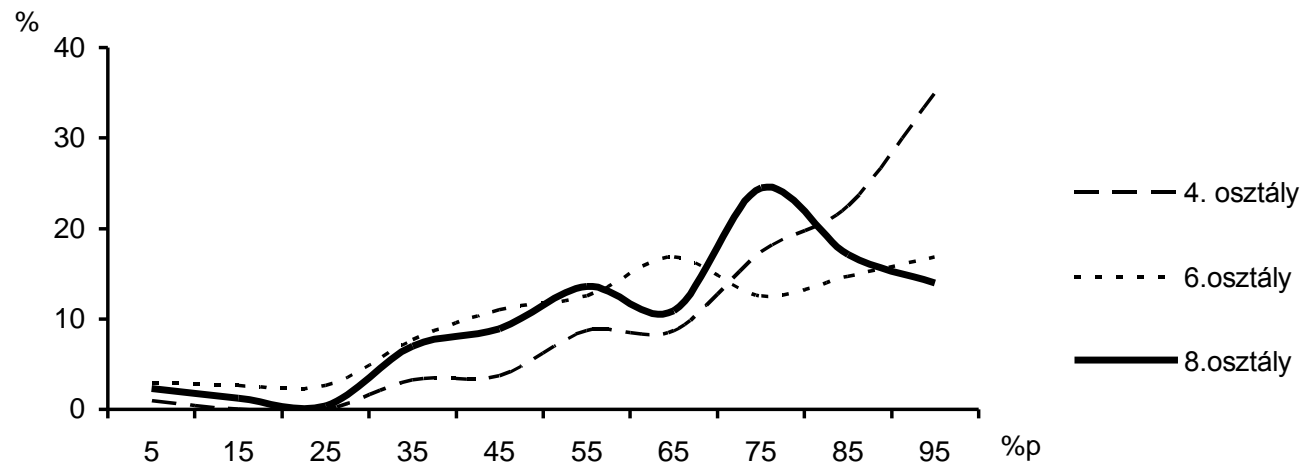

35. ábra

Az elsajátitási célok eloszlásgörbéje 
A teljesítménycélok esetében mind a három évfolyamon ellaposodott eloszlásgörbét láthatunk (36. ábra). A lapos eloszlásgörbe arra utal, hogy az átlag nagyon alacsony, a szórás pedig nagy, az elméleti görbének így tulajdonképpen nincs is értelme.

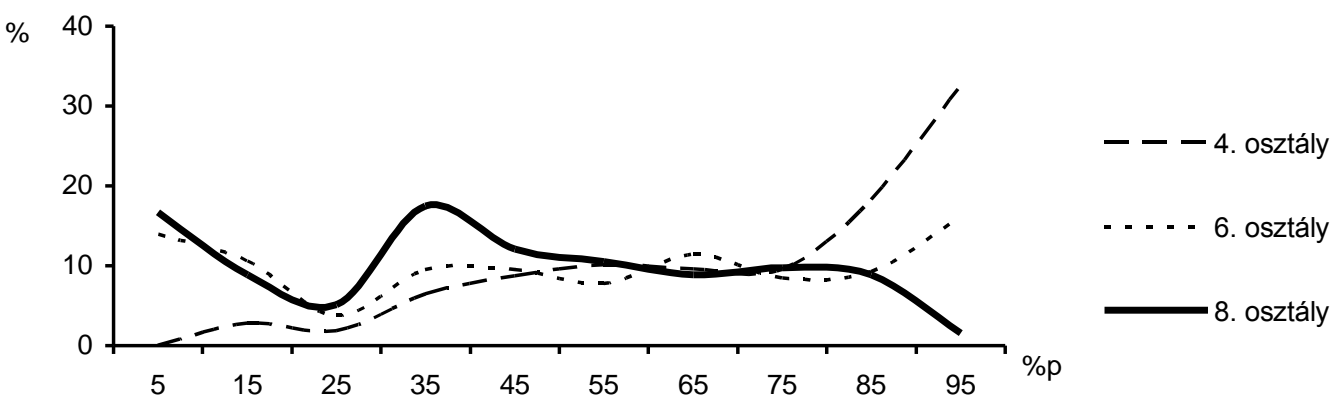

36. ábra

A teljesitménycélok eloszlásgörbéje

A munkakerülő célok eloszlásgörbéje (37. ábra) balról csonkolt. Nagyon sokan vannak tehát azok a tanulók, akik egyáltalán nem követnek elkerülő célokat, arányuk nyolcadik évfolyamra csak nő. Ezzel párhuzamosan csökken azoknak az aránya, akiket nagyon gyakran motivál az energiabefektetés elkerülése, a feladat letudása.

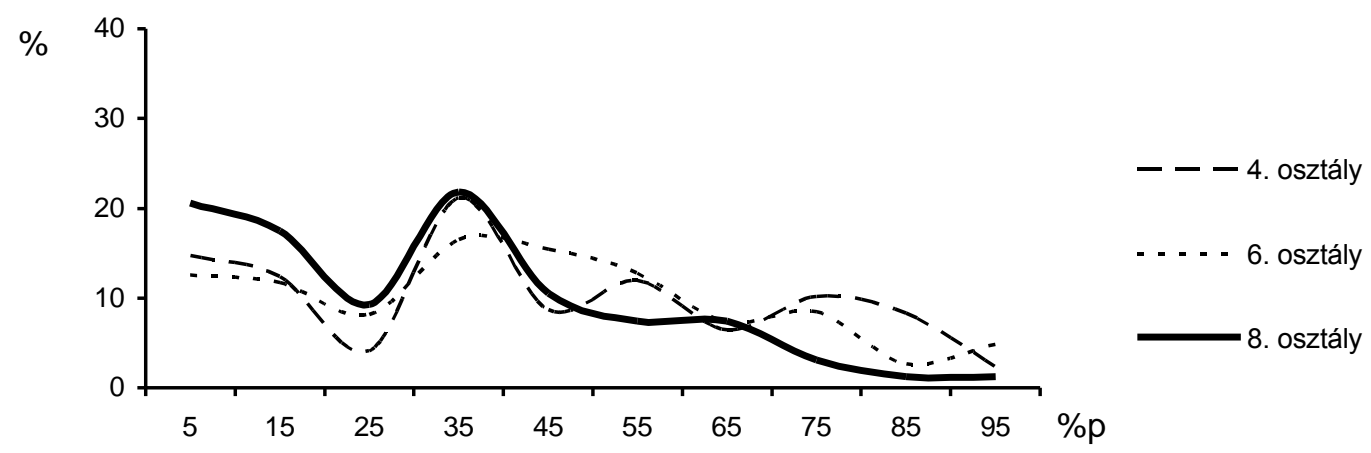

37. ábra

A munkakerülö célok eloszlásgörbéje

Az olvasás során átélt flow élmények eloszlásgörbéje (38. ábra) erősen jobbra tolódott minden évfolyamon, azaz többségben vannak azok, akik gyakran élik át a flow élmény elemeit olvasásfeladatok végzése közben. A negyedik, hatodik és nyolcadik évfolyamok közötti különbségként említhető, hogy a magasabb évfolyamokon a középmezőny erősödik, azaz 
többen lesznek azok a tanulók, akik többnyire elmélyülnek az olvasásban és ritkábban zökkennek abból ki.

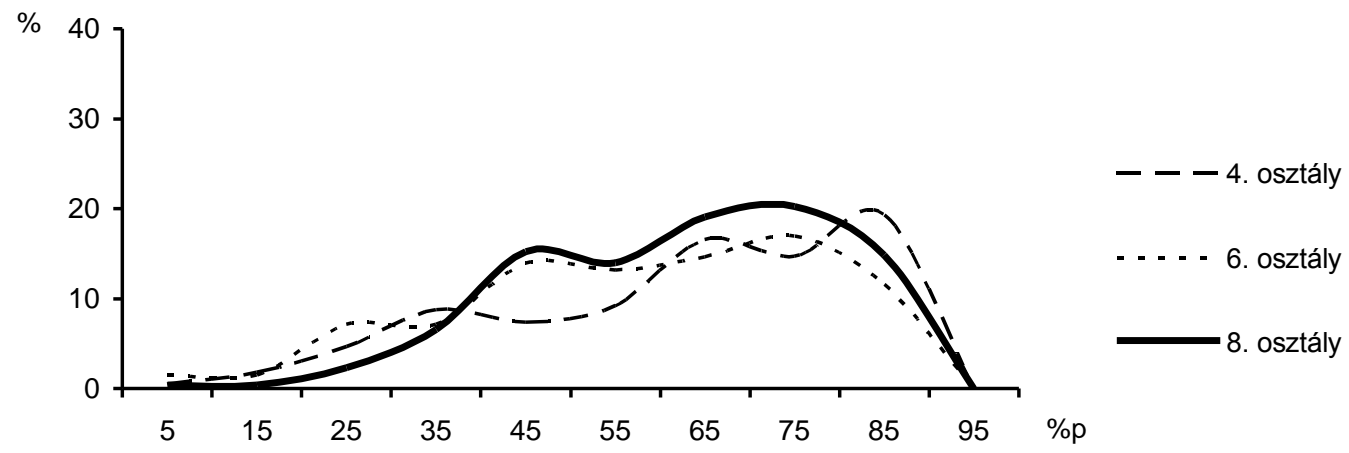

38. ábra

Az olvasás során átélt flow élmények eloszlásgörbéje

A tanulói válaszok megoszlása szerint a tanulók többsége nem vagy csak ritkán él át antiflow élményeket olvasás feladatok megoldása során (39. ábra). A görbe balról csonkolt, azaz nem tesz kellöképp különbséget az antiflow élményeket ritkán és soha át nem élök között. Az viszont megállapítható, hogy a tanulóknak negyedik osztályban mintegy 5\%-a, hatodik osztályban 10\%-a, nyolcadik osztályban 3\%-a többnyire ilyen élményeket él át olvasás közben (70\%p fölött).

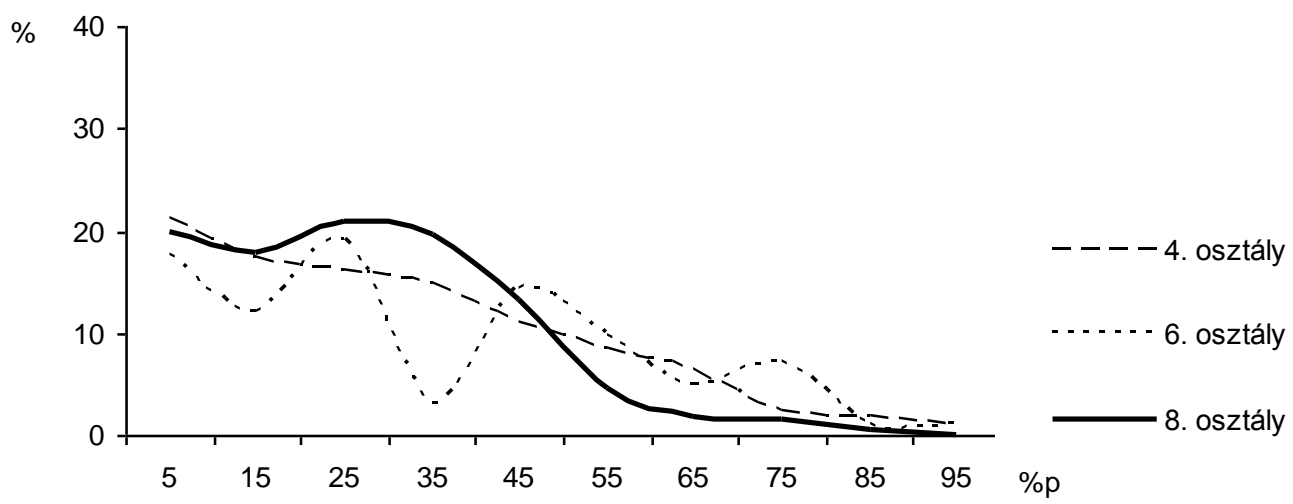

39. ábra

Az olvasás során átélt antiflow élmények eloszlásgörbéje

Az olvasási önhatékonyság eloszlásgörbéje (40. ábra) enyhén jobbra tolódott. Ennek értelmében többen vannak azok a tanulók, akik pozitív teljesítményelvárásokkal kezdenek neki egy-egy olvasási feladatnak, azaz feltételezik, hogy sikeresek lesznek annak megoldásában. Nem elhanyagolható viszont azoknak az aránya sem, akik már a feladat 
megpillantásakor előre vetítik a kudarcot, azaz úgy vélik, nem tudnak majd jó teljesítményt nyújtani. Ezen tanulóknak az aránya negyedik évfolyamon megközelítőleg 30\%, hatodik és nyolcadik évfolyamon $40 \%$.

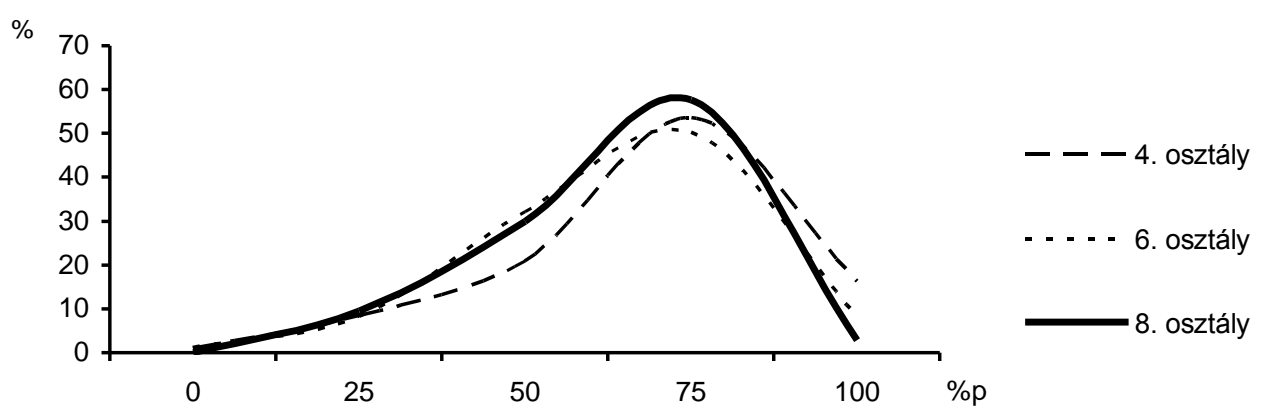

40. ábra

Az olvasási önhatékonyság eloszlásgörbéje

Az olvasási sikerek és kudarcok attribúcióit a felsőbb évfolyamokon az egyénileg kitöltött kérdőíveken 1-1 nyílt végü kérdés és 4-4 zárt végü kérdőív segítségével vizsgáltuk. A válaszok reliabilitásának ellenőrzésére a zárt és a nyílt végü kérdések közötti konzisztenciát ellenöriztük.

Az eredmények szerint a nyílt végü kérdésre adott válaszok aránya nagyon alacsony (kudarcok: 30\%, sikerek: 46\%). A tanulók többsége a nyílt végü kérdésre egyáltalán nem válaszolt. Azok között, akik válaszoltak, a leggyakoribb ok a belső és állandó volt az olvasási sikerek és a kudarcok esetében is. Ezt követték a külső és változó okok mind a két esetben, végül a belső, változó okok. Sem a kudarcok, sem a sikerek esetében nem említett egyetlen tanuló sem külső, állandó, azaz tőle független, megváltoztathatatlan okot.

Csakúgy, mint a másodikosok esetében, a válaszok konzisztenciájának ellenőrzése nem támasztotta alá, hogy a tanulók megbízhatóan elemzik a sikereik és kudarcaik okait. A kudarcok esetében a konzisztens válaszok aránya mindössze $39 \%$, a sikerek esetében $71 \%$. Ismét megemlítendő, hogy a zárt végü kérdések az egyes okkategóriák egyetlen jellemző elemére kérdeztek rá, míg a nyílt végü kérdés változatos okfelsorolást eredményezett. A válaszok konzisztenciája tehát a választott módon nem megfelelő biztossággal elemezhető. Emiatt, valamint a viszonylag alacsony válaszadói ráta miatt a siker- és kudarcattribúciók összefüggéseit a többi motívummal, valamint a teljesítménnyel nem vizsgáljuk.

\subsubsection{Az olvasási motívumok fejlődése}

Keresztmetszeti vizsgálatunkban lehetőségünk nyílik arra, hogy a negyedik, hatodik és nyolcadik osztályos tanulók olvasási motívumainak jellemzőit összehasonlítsuk. A 41. ábra a vizsgálatban részt vevő három életkori csoport olvasási motívumainak fejlettségét mutatja. Az 
ábrán az egyes évfolyamokhoz tartozó átlagokat a könnyebb összehasonlítás érdekében összekötöttük. Tekintve azonban, hogy a mérésünk nem longitudinális, a vonalak nem jelentenek fejlődést.

Mindhárom évfolyamon az olvasásnak tulajdonított érték meglehetősen magas, a motívumok közül ez mutatja a legmagasabb értéket. Ezt követik az elsajátítási célok, az énkép és a flow. A motívumok erösségét tekintve az évfolyamok között alig fedezhetö fel különbség. Mindhárom évfolyam esetében az érték motívum a legmagasabb, ezt követik az elsajátítási célok. Negyedik évfolyamon a teljesítménycél mint motívum még meglehetősen magas, azonban hatodik és nyolcadik évfolyamra folyamatosan veszít jelentőségéből.

Az ábráról leolvasható, hogy az egyes olvasási motívumok az életkor növekedésével csökkenő tendenciát mutatnak. Jelentősen romlik az iskolai olvasás iránti attitüd és gyengülnek az olvasáselsajátítási célok. Kismértékü romlást mutat az olvasásnak tulajdonított érték és az olvasás szociális motívumai. Növekvő tendenciát mutat ezzel szemben negyediktől hatodik évfolyamig a munkát elkerülö célorientáció mint motívum alakulása; ez azonban nem tekinthető pozitív változásnak.

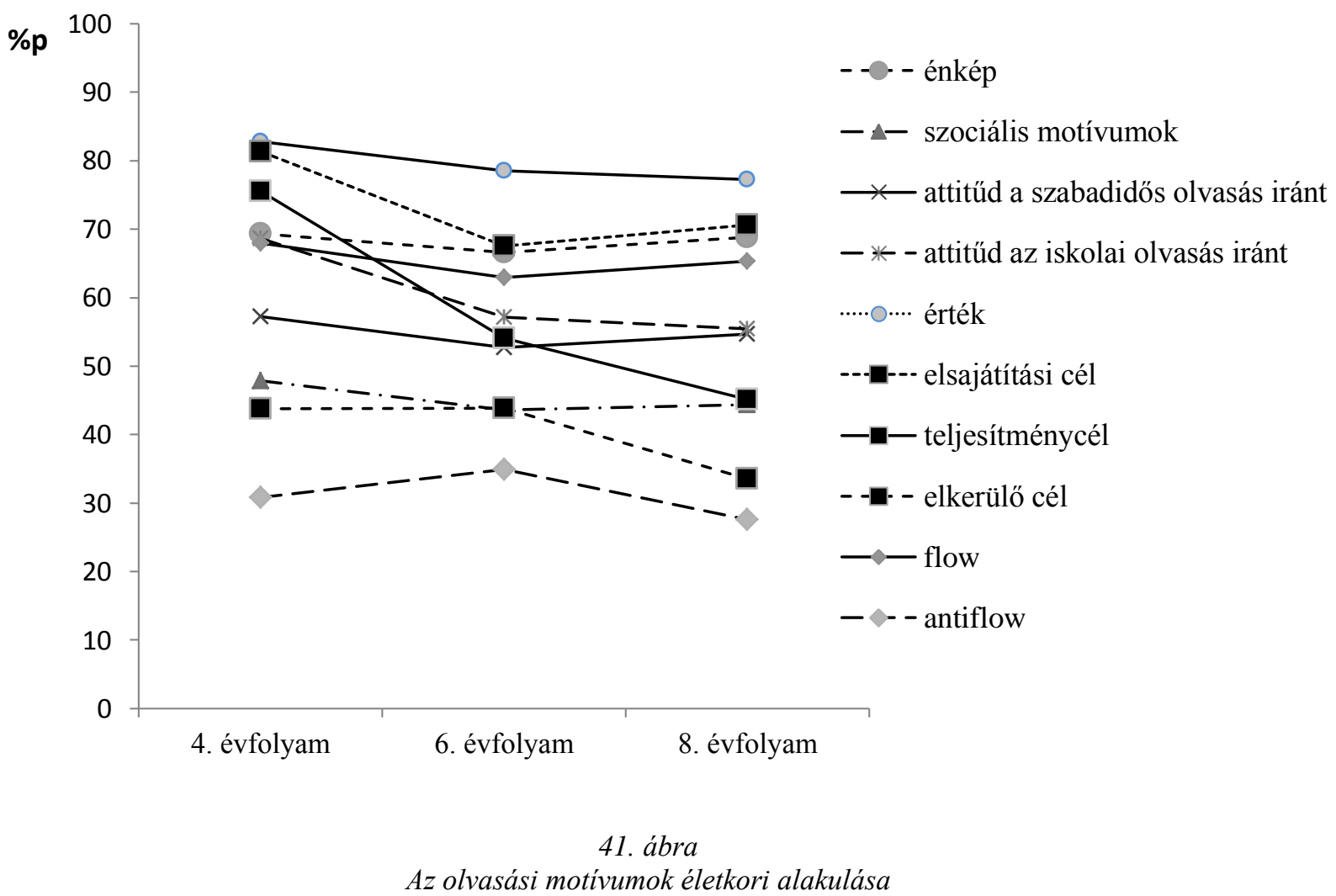

A varianciaanalízis eredményei (50. táblázat) szerint három motívum esetében a vizsgált életkori csoportok között nincs szignifikáns különbség. Ezek az olvasási énkép, az olvasás szociális motívumai és a szabadidős olvasás iránti attitűd. A többi hét olvasási motívum fejlettségében az életkorok között szignifikáns különbség van. 
50. táblázat. Az olvasási motívumok életkori alakulása (\%p), ANOVA

\begin{tabular}{lccccccc}
\hline \multicolumn{1}{c}{ Olvasási motívumok } & $\begin{array}{c}\text { 4. évfolyam } \\
(n=218)\end{array}$ & $\begin{array}{c}\text { 6. évfolyam } \\
(n=278)\end{array}$ & $\begin{array}{c}\text { 8. évfolyam } \\
(n=260)\end{array}$ & Levene & $p$ & $F$ & $p$ \\
\hline Énkép & $69(20)$ & $67(19)$ & $69(18)$ & 4,47 & 0,01 & 1,86 & 0,16 \\
Szociális motívumok & $48(23)$ & $44(24)$ & $44(23)$ & 1,25 & 0,27 & 2,57 & 0,08 \\
Attitüd szabadidős & $57(26)$ & $53(24)$ & $55(25)$ & 0,83 & 0,26 & 2,36 & 0,10 \\
Attitüd iskolai & $68(23)$ & $57(26)$ & $55(22)$ & 3,47 & 0,07 & $\mathbf{2 3 , 3 7}$ & $\mathbf{0 , 0 0 1}$ \\
Érték & $83(17)$ & $79(18)$ & $77(17)$ & 0,70 & 0,36 & $\mathbf{7 , 0 3}$ & $\mathbf{0 , 0 0 1}$ \\
Elsajátítási cél & $81(18)$ & $68(25)$ & $71(22)$ & 11,80 & 0,00 & $\mathbf{2 8 , 6 6}$ & $\mathbf{0 , 0 0 1}$ \\
Teljesítménycél & $76(23)$ & $54(32)$ & $45(29)$ & 18,40 & 0,00 & $\mathbf{7 3 , 4 6}$ & $\mathbf{0 , 0 0 1}$ \\
Elkerülö cél & $44(28)$ & $44(26)$ & $34(24)$ & 5,61 & 0,00 & $\mathbf{1 5 , 3 0}$ & $\mathbf{0 , 0 0 1}$ \\
Flow & $68(23)$ & $63(23)$ & $65(18)$ & 9,01 & 0,00 & $\mathbf{4 , 2 1}$ & $\mathbf{0 , 0 2}$ \\
Antiflow & $31(22)$ & $35(23)$ & $28(18)$ & 8,53 & 0,00 & $\mathbf{8 , 4 2}$ & $\mathbf{0 , 0 1}$ \\
\hline \hline
\end{tabular}

Megjegyzés: A 0,05 szinten szignifikáns eltéréseket félkövér szedés jelzi.

Az iskolai olvasás iránti attitüd negyediktől hatodik évfolyamig szignifikáns mértékben csökken, azonban a hatodik és a nyolcadik osztályosok között e tekintetben nem mutatható ki szignifikáns különbség. Hasonlóan alakul az olvasásnak tulajdonított érték mint motívum évfolyamonkénti átlaga is: a hatodik osztályosok szignifikánsan alacsonyabb értéket tulajdonítanak az olvasásnak, mint a negyedikesek, azonban a hatodik és a nyolcadik osztály közötti különbség nem jelentős. Ez az eredmény meglepő, hiszen az életkor növekedésével várhatnánk, hogy a tanulók egyre gyakrabban kerülnek olyan helyzetbe, ahol a mindennapi életben is szükségük van olvasási képességük használatára, ezért könnyebben felismerik annak fontosságát. Ez azonban eredményeink szerint éppen fordítva alakul, az alsó tagozatosok szerint az olvasás gyakorlati értéke nagyobb, mint a felső tagozatosok szerint. Az elsajátítási célorientáció szintén negyedik és hatodik osztály között mutat szignifikáns csökkenést, hatodik és nyolcadik osztály között a különbség nem jelentős.

Az olvasás motívumainak szignifikáns mértékü csökkenése az alsó tagozatból a felső tagozatba való lépéskor - esetünkben negyediktől hatodik évfolyamra - a szakirodalommal összhangban a felső tagozat megváltozott körülményeinek negatív hatására hívja fel a figyelmet. Különösen fontos ez az olvasás esetében, amit a felső tagozaton a tanulók már nem önálló tantárgyként tanulnak, hanem az irodalomtörténeti oktatásba beágyazottan. Eredményeink azt mutatják, hogy ez a változás a hazai tanulók esetében sem kedvező motivációs szempontból.

Az előzőektől eltérő mintázatot mutat a teljesítménycélok mint motívumok alakulása a vizsgált életkori szakaszban. A teljesítménycélok jelentőségének csökkenése mindhárom évfolyam között szignifikáns, tehát negyedikről hatodikra és hatodikról nyolcadikra is jelentős mértékü csökkenés figyelhető meg. Ennek értelmében az életkor előrehaladtával a tanulókat egyre kevésbé motiválják az olvasás területén a jutalmak, a dicséretek és az elismerés meg- 
szerzése. A munkakerülést célzó motívumok ugyanakkor nem az alsó tagozatból a felső tagozatba lépéskor, hanem a hatodik és a nyolcadik évfolyamok között változnak szignifikánsan csökkenő irányba. A nyolcadik évfolyamos tanulók ritkábban követnek munkakerülő célokat, mint hatodikos vagy negyedikes társaik, azaz ritkábban érzik úgy, hogy elsődleges céljuk, hogy minél kevesebb energiát fektessenek az olvasásba. Az antiflow élmények gyakorisága is negyedikről hatodik évfolyamra nő szignifikánsan, azaz a hatodikos tanulók gyakrabban érzik úgy, hogy untatják vagy apátiás érzéseket okoznak számukra az olvasási tevékenységek, mint negyedikes társaik. Ugyanakkor az olvasás közben átélt áramlatélmény negyedik osztályról hatodikra csökken, míg nyolcadik évfolyamra kis mértékben nő. Ez a növekedés ugyan hatodikról nyolcadikra nem szignifikáns, viszont eredményeképp a negyedik és nyolcadik osztályosok flow élményeinek gyakorisága között nincs szignifikáns különbség.

\subsubsection{Az olvasási motívumok összefüggésrendszere}

Elméleti modellünkben feltételeztük, hogy az olvasási motívumok között összefüggések vannak. Hipotézisünk tesztelésére korrelációanalízist végeztünk a tíz olvasási motívum bevonásával. Az egyes olvasási motívumok közötti összefüggéseket az 51. táblázat mutatja. Az 51. táblázat felső háromszögében a teljes mintára vonatkozó, az alsó háromszögben pedig a negyedik évfolyam korrelációs együtthatóit tüntettük fel. Hasonlóképp, az 52. táblázat felső háromszöge a hatodik évfolyamra vonatkozóan, alsó háromszöge a nyolcadik évfolyam esetében mutatja az egyes motívumok közötti korrelációkat.

51. táblázat Az olvasási motívumok közötti összefüggések, teljes minta és negyedik évfolyam

\begin{tabular}{|c|c|c|c|c|c|c|c|c|c|c|}
\hline $\begin{array}{c}\text { Olvasási motí- } \\
\text { vumok }\end{array}$ & énkép & $\begin{array}{l}\text { szoc. } \\
\text { mot. }\end{array}$ & $\begin{array}{l}\text { attitüd } \\
\text { szab. }\end{array}$ & $\begin{array}{l}\text { attitüd } \\
\text { iskolai }\end{array}$ & érték & $\begin{array}{l}\text { elsaj. } \\
\text { cél }\end{array}$ & telj. cél & $\begin{array}{c}\text { elker. } \\
\text { cél }\end{array}$ & flow & $\begin{array}{l}\text { anti- } \\
\text { flow }\end{array}$ \\
\hline Énkép & & $0,30 * *$ & $0,37 * *$ & $0,31 * *$ & $0,27 * *$ & $0,17 * *$ & n. s. & $-0,18 * *$ & $0,37 * *$ & $-0,27 * *$ \\
\hline Szociális mot. & $0,35 * *$ & & $0,66^{* *}$ & $0,51 * *$ & $0,29 * *$ & $0,41 * *$ & $0,24 * *$ & $-0,23 * *$ & $0,50 * *$ & $-0,23 * *$ \\
\hline $\begin{array}{l}\text { Attitüd szabad- } \\
\text { idős }\end{array}$ & $0,42 * *$ & $0,67 * *$ & & $0,48 * *$ & $0,28 * *$ & $0,35 * *$ & $0,17 * *$ & $-0,29 * *$ & $0,50 * *$ & $-0,34 * *$ \\
\hline Attitűd iskolai & $0,45^{* *}$ & $0,54 * *$ &, $59 * *$ & & $0,32 * *$ & $0,46^{* *}$ & $0,30 * *$ & $-0,22 * *$ & $0,53 * *$ & $-0,30 * *$ \\
\hline Érték & $0,18 * *$ & $0,15^{*}$ & $0,20 * *$ & $0,22 * *$ & & $0,30 * *$ & $0,18 * *$ & $-0,11 * *$ & $0,28 * *$ & $-0,17 * *$ \\
\hline Elsajátítási cél & $0,22 * *$ & $0,32 * *$ & $0,25 * *$ & $0,39 * *$ & $0,19 * *$ & & $0,55^{* *}$ & $-0,17 * *$ & $0,58 * *$ & $-0,23 * *$ \\
\hline Teljesítménycél & $0,23 * *$ & $0,35^{* *}$ & $0,32 * *$ & $0,34 * *$ & $0,22 * *$ & $0,55^{* *}$ & & $0,15^{* *}$ & $0,34 * *$ & $0,10 * *$ \\
\hline Elkerülő cél & n. s. & n. s. & $-0,22 * *$ & $-0,25 * *$ & n. s. & $-0,13^{*}$ & n. s. & & $-0,40 * *$ & $0,65 * *$ \\
\hline Flow & $0,40 * *$ & $0,51 * *$ & $0,52 * *$ & $0,53 * *$ & n. s. & $0,51 * *$ & $0,50 * *$ & $-0,35 * *$ & & $-0,47 * *$ \\
\hline Antiflow & $-0,26 * *$ & $-0,19 * *$ & $-0,28 * *$ & $-0,36 * *$ & n. s. & $-0,26 * *$ & n. s. & $0,59 * *$ & $-0,48 * *$ & \\
\hline
\end{tabular}

Megjegyzés: A felső háromszög a teljes minta, az alsó háromszög a negyedik évfolyam korrelációs együtthatóit tartalmazza;* 0,01 szinten szignifikáns, * 0,05 szinten szignifikáns, n. s. nem szignifikáns. 
52. táblázat Az olvasási motívumok közötti összefüggések, hatodik és nyolcadik évfolyam

\begin{tabular}{|c|c|c|c|c|c|c|c|c|c|c|}
\hline $\begin{array}{c}\text { Olvasási motívu- } \\
\text { mok }\end{array}$ & énkép & $\begin{array}{l}\text { szoc. } \\
\text { mot. }\end{array}$ & $\begin{array}{c}\text { attitüd } \\
\text { szab. }\end{array}$ & $\begin{array}{l}\text { attitüd } \\
\text { iskolai }\end{array}$ & érték & $\begin{array}{l}\text { elsaj. } \\
\text { cél }\end{array}$ & telj. cél & $\begin{array}{c}\text { elker. } \\
\text { cél }\end{array}$ & flow & $\begin{array}{l}\text { anti- } \\
\text { flow }\end{array}$ \\
\hline Énkép & & $0,26 * *$ & $0,30 * *$ & $0,23 * *$ & $0,28 * *$ & n. s. & n. s. & $-0,17 * *$ & $0,28 * *$ & $-0,25 * *$ \\
\hline Szociális mot. & $0,29 * *$ & & $0,65 * *$ & $0,55^{* *}$ & $0,32 * *$ & $0,39 * *$ & $0,25^{* *}$ & $-0,25 * *$ & $0,50 * *$ & $-0,20 * *$ \\
\hline Attitűd szabadidős & $0,39 * *$ & $0,66^{* *}$ & & $0,49 * *$ & $0,31 * *$ & $0,35^{* *}$ & & $-0,35 * *$ & $0,52 * *$ & $-0,38 * *$ \\
\hline Attitűd iskolai & $0,2^{\prime}$ & $0,43 * *$ & $0,37 * *$ & & $0,32 * *$ & $0,46 * *$ & & $-0,28 * *$ & $0,56 * *$ & $-0,37 * *$ \\
\hline Érték & $0,33 * *$ & $0,35 * *$ & $0,37 * *$ & $0,32 * *$ & & $0,29 * *$ & & $-0,25 * *$ & $0,36^{* *}$ & $-0,23 * *$ \\
\hline Elsajátítási cél & $0,22 * *$ & $0,47 * *$ & $0,42 * *$ & $0,42 * *$ & $0,33 * *$ & & & $-0,13^{*}$ & $0,60 * *$ & $-0,15^{* *}$ \\
\hline Teljesítménycél & n. s. & $0,13^{*}$ & n. s. & $0,18 * *$ & n. s. & $0,42 * *$ & & $0,16^{* *}$ & $0,33 * *$ & $0,17 * *$ \\
\hline Elkerülő cél & $-0,26 * *$ & $-0,36 * *$ & $-0,33 * *$ & $-0,24 * *$ & $-0,16^{*}$ & $-0,35 * *$ & $0,14^{*}$ & & $-0,43 * *$ & $0,69 * *$ \\
\hline Flow & $0,45^{* *}$ & $0,46^{* *}$ & $0,45 * *$ & $0,46 * *$ & $0,30 * *$ & $0,62 * *$ & $0,24 * *$ & $-0,48 * *$ & & $-0,44 * *$ \\
\hline Antiflow & $-0,31 * *$ & $-0,31 * *$ & $-0,35 * *$ & $-0,18 * *$ & $-0,23 * *$ & $-0,35 * *$ & $0,14^{*}$ & $0,65 * *$ & $-0,52 * *$ & \\
\hline
\end{tabular}

Megjegyzés: A felső háromszög a hatodik évfolyam, az alsó háromszög a nyolcadik évfolyam korrelációs együtthatóit tartalmazza;** 0,01 szinten szignifikáns, *0,05 szinten szignifikáns, n. s. nem szignifikáns.

A korrelációs együtthatók alapján az olvasási motívumok között többségében szignifikáns közepes erősségü összefüggések vannak. Ez alátámasztja azon feltételezésünket, hogy az olvasási motívumok nem egymástól független konstruktumok, hanem rendszert alkotnak. A teljes mintát tekintve összességében a flow mint motívum mutatja a legtöbb motívummal a legerősebb összefüggést, amely eredmény nem meglepö, hiszen a flow élmény több motívum együttes müködését is feltételezi. Szintén nem meglepő, hogy a teljes mintában az elsajátítási célok mutatják a legerősebb összefüggést az áramlatélménnyel: az elsajátítási célok alapját képező elsajátítási motívumot és a flowt is az intrinzik motívumok közé sorolja a szakirodalom.

Szintén erős összefüggést találtunk az olvasás iránti attitüdök - szabadidős és iskolai és a szociális motívumok között, valamint az elkerülő célorientáció és az antiflow élmények között. Előbbi esetében az összefüggés hátterében feltételezhetőleg a pozitív olvasásélmények gyakorisága, utóbbi esetében éppen a negatív élmények állnak. A negatív motivációs mintázatot feltételező munkakerülő célok és antiflow élmények negatívan korrelálnak a legtöbb motívummal, azaz azok a tanulók, akiknél erőteljesebben érvényesülnek ezek a motívumok, alacsonyabb értéket tulajdonítanak az olvasásnak, kevesebb élvezettel jár számukra az, negatívabb attitüdökkel rendelkeznek, rosszabbnak értékelik saját olvasási képességüket és kevésbé követnek elsajátítási célokat. Meglepő eredmény, hogy mind a munkakerülő célok, mind az antiflow is gyenge, de szignifikáns pozitív irányú összefüggést mutatnak a teljesítménycélokkal. Ennek értelmében azok a tanulók, akik gyakran élnek át olvasás közben antiflow élményt, unalmat vagy apátiát, valamint gyakran mutatnak munkakerülö magatartást, gyakrabban követnek teljesítmény célokat, azaz jobban motiválja őket mások elismerése vagy egy-egy jutalom megszerzése. Az évfolyamonkénti korrelációanalízis eredményeiből az is kitünik, hogy a teljesítménycélok jelenőségük csökkenésével párhuzamosan az évek folyamán egyre kisebb mértékben függnek össze más motívumokkal. Míg negyedik évfolyamon még erős összefüg- 
gést mutatnak a flow élmény gyakoriságával, közepes erősségüt az énképpel, az attitüdökkel, a szociális motívumokkal és az olvasásnak tulajdonított értékkel, addig nyolcadik évfolyamra ugyanezen összefüggések már gyengék vagy nem szignifikánsak. Látható az is, hogy a negyedik évfolyamon még erőteljesen érvényesülő teljesítménycélok a munkakerülő és az antiflow motívumokkal nem mutatnak szignifikáns kapcsolatot, az összefüggés hatodik és nyolcadik osztályra válik szignifikáns negatívvá.

A korrelációs együtthatók évfolyamonkénti összehasonlítása szerint az iskolai és a szabadidős olvasás iránti attitüdök között negyedik és nyolcadik évfolyam között egyre gyengül az összefüggés. Míg negyedik évfolyamon az 0,5 körüli korrelációs együttható arra enged következtetni, hogy a két tevékenység kedveltsége között szoros az összefüggés, a nyolcadik évfolyam adatai alapján kapott gyengébb együttható $(\mathrm{r}=0,37)$ szerint a felsőbb évfolyamos tanulók gondolkodásában élesebben kettéválik a két olvasási kontextus.

A motívumok összefüggését szemléltetik az évfolyamonkénti klaszteranalízis eredményeképp létrehozott dendrogramok. A 42. ábra a negyedik, a 43. ábra a hatodik, a 44. ábra a nyolcadik évfolyam eredményeit mutatja. A dendrogramok alapján jól látszik, hogy a motívumrendszer struktúrája a vizsgált életkori részmintákban eltérő.

Negyedik évfolyamon az első szinten az elsajátítási célok és a teljesítménycélok alkotnak egy fürtöt, az iskolai olvasás iránti attitüd és a flow egy másik fürtöt, valamint a szociális motívumok és a szabadidős olvasás iránti attitüdök egy harmadikat. A második kapcsolódási szinten az olvasásnak tulajdonított gyakorlati érték az elsajátítási célokhoz, az énkép pedig az iskolai olvasás iránti attitüdhöz csatlakozik. Jól látható, hogy a negatív motivációs mintázatot tükröző antiflow élmények és elkerülési célok egy fürtöt alkotva távolabbról kapcsolódnak a motívumrendszerhez.

A hatodik évfolyamosok dendrogramja makrostruktúrájában nem tér el a negyedik osztályétól; lényegében ugyanazok a nagy fürtök találhatók itt is. Jelentős eltérés viszont, hogy itt már az olvasásnak tulajdonított érték az énképpel alkot egy fürtöt első szinten. Ez a nyolcadikosok dendrogramján is hasonló: az érték motívum itt is az énképhez kapcsolódik legszorosabban. Ez az eredmény összhangban van a szakirodalom állításával, miszerint az évek folyamán a tanulók egyre inkább annak tulajdonítanak értéket, amiben jónak tartják magukat ( $\mathrm{Ja}$ cobs, Lanza, Osgood, Eccles és Wigfield, 2002).

További eltérést jelent az évfolyamok motívumstruktúráját tekintve a teljesítménycélok más motívumokkal való kapcsolatrendszerének alakulása. Negyedik évfolyamon a teljesítménycélok az elsajátítási célokhoz kapcsolódnak legközelebbröl. Hatodik osztályban a teljesítménycélok már csak távolabbról kapcsolódnak a motívumok rendszeréhez, nyolcadik osztályban pedig a munkakerülő célorientációval és az antiflow élménnyel alkotnak egy fürtöt. 


celels
celtelj
ertek
iskatt
flow
enkep
szocmot
szabatt
celelker
antiflow

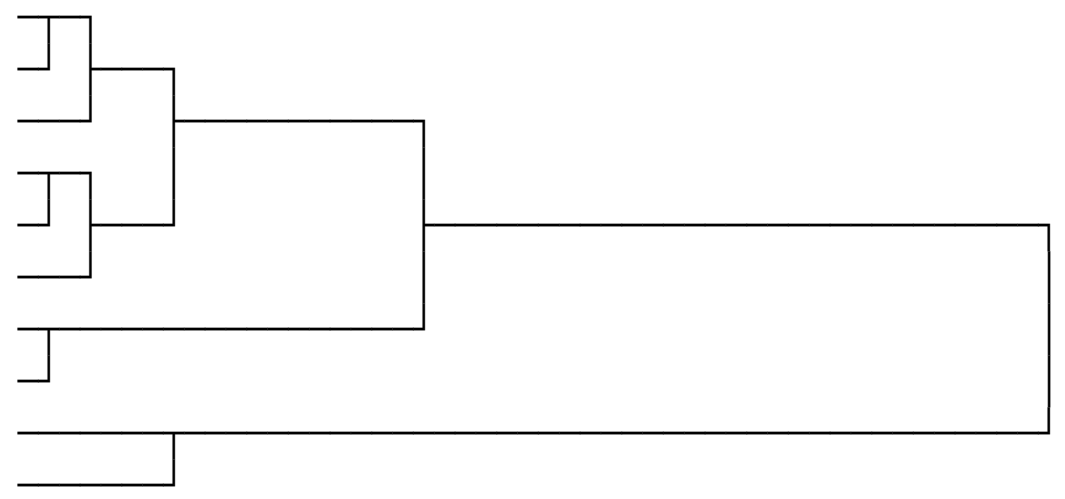

42. ábra

Az olvasási motívumok közötti összefüggések, dendrogram (Average Linkage, Between Groups), 4. évfolyam

celelker
antiflow
szocmot
szabatt
enkep
ertek
celels
flow
iskatt
celtelj

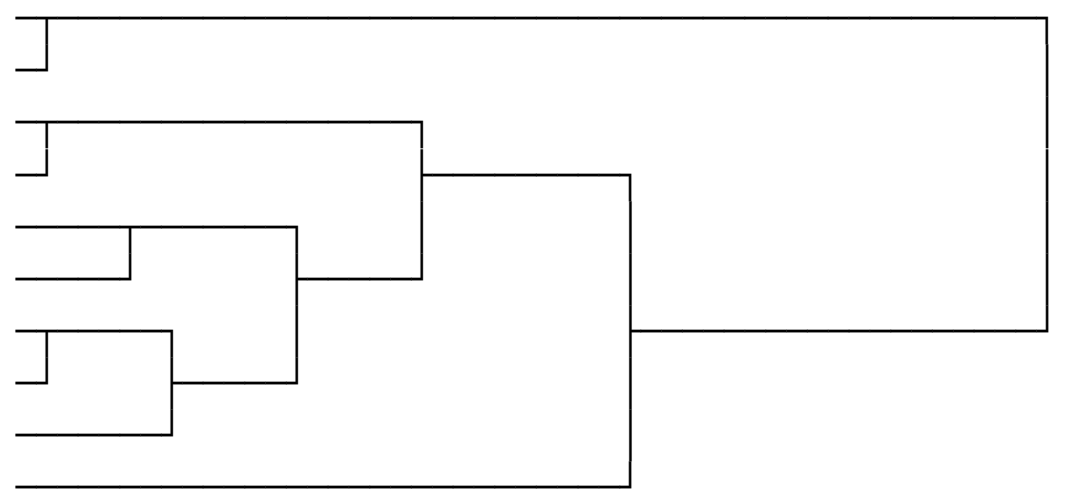

43. ábra

Az olvasási motívumok közötti összefüggések, dendrogram (Average Linkage, Between Groups), 6. évfolyam
celels
flow
enkep
ertek
szocmot
szabatt
iskatt
celelker
antiflow
celtelj

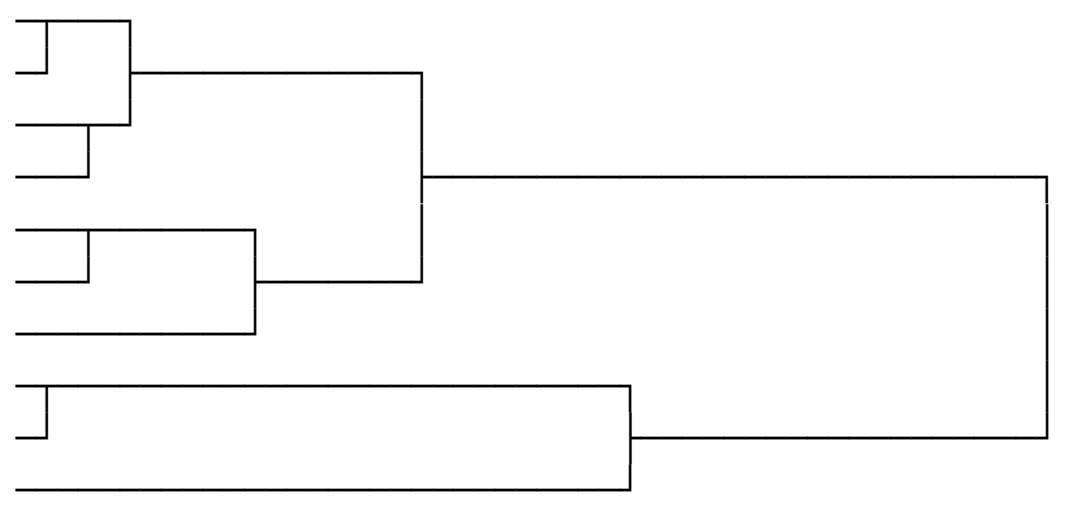

44. ábra

Az olvasási motívumok közötti összefüggések, dendrogram (Average Linkage, Between Groups), 8. évfolyam 
A motívumok közötti összefüggésrendszer mélyebb struktúráját regresszióanalízissel tártuk fel. Minden évfolyam esetében minden motívumot megtettünk függő változóként, s független változóként az összes többi motívumot vontuk be az elemzésbe. Ez az elrendezés így évfolyamonként tíz regresszióanalízist eredményezett.

Az 53. táblázat a negyedik évfolyamon vizsgált olvasási motívumok összefüggésrendszerét, az 54. táblázat a hatodik évfolyam, az 55. táblázat a nyolcadik évfolyam eredményeit mutatja. A táblázatokban a könnyebb átláthatóság érdekében csak a szignifikáns hatásokat tüntettük fel. A lineáris regressziók alapján az egyes motívumok közötti összefüggés hatásrendszerként is értelmezhető, az egyes motívumok több esetben magyarázzák más motívumok varianciáját.

53. táblázat A motivumok közötti összefüggések, regresszióanalizis, 4. osztály

\begin{tabular}{|c|c|c|c|c|c|c|c|c|c|c|}
\hline \multirow{3}{*}{$\begin{array}{l}\text { Független válto- } \\
\text { zók }\end{array}$} & \multicolumn{10}{|c|}{ Függő változók } \\
\hline & \multicolumn{10}{|c|}{$r \beta \%$} \\
\hline & Énkép & $\begin{array}{c}\text { Szoc. } \\
\text { mot. }\end{array}$ & $\begin{array}{c}\text { Attitüd } \\
\text { szab. }\end{array}$ & $\begin{array}{c}\text { Attitüd } \\
\text { isk. }\end{array}$ & Érték & $\begin{array}{c}\text { Elsaj. } \\
\text { cél }\end{array}$ & $\begin{array}{c}\text { Telj. } \\
\text { cél }\end{array}$ & $\begin{array}{c}\text { Elker. } \\
\text { cél }\end{array}$ & Flow & $\begin{array}{l}\text { Anti- } \\
\text { flow }\end{array}$ \\
\hline Énkép & & & & 7 & & & & & & \\
\hline Szociális mot. & & & 30 & 9 & & & & & 8 & \\
\hline Attitűd szab. & & 33 & & 16 & & & & & & \\
\hline Attitűd iskolai & 11 & 9 & 14 & & & 7 & & & & \\
\hline \multicolumn{11}{|l|}{ Érték } \\
\hline Elsajátítási cél & & & -3 & 6 & & & 20 & & 10 & \\
\hline Teljesítménycél & & & & & & 20 & & & 11 & \\
\hline Elkerülő cél & & & & & & & & & & 26 \\
\hline Flow & & 9 & & & & 14 & 16 & & & 14 \\
\hline Antiflow & & & & & & & & 30 & 11 & \\
\hline $\mathrm{R}^{2}(\%)$ & 11 & 51 & 47 & 38 & 0 & 41 & 36 & 30 & 40 & 40 \\
\hline
\end{tabular}


54. táblázat A motívumok közötti összefüggések, regresszióanalízis, 6. osztály

\begin{tabular}{|c|c|c|c|c|c|c|c|c|c|c|}
\hline \multirow{3}{*}{$\begin{array}{l}\text { Független válto- } \\
\text { zók }\end{array}$} & \multicolumn{10}{|c|}{ Függö változók } \\
\hline & \multicolumn{10}{|c|}{$r \beta \%$} \\
\hline & Énkép & $\begin{array}{c}\text { Szoc. } \\
\text { mot. }\end{array}$ & $\begin{array}{c}\text { Attitüd } \\
\text { szab. }\end{array}$ & $\begin{array}{c}\text { Attitüd } \\
\text { isk. }\end{array}$ & Érték & $\begin{array}{c}\text { Elsaj. } \\
\text { cél }\end{array}$ & $\begin{array}{c}\text { Telj. } \\
\text { cél }\end{array}$ & $\begin{array}{c}\text { Elker. } \\
\text { cél }\end{array}$ & Flow & $\begin{array}{l}\text { Anti- } \\
\text { flow }\end{array}$ \\
\hline Énkép & & & & & 5 & 1 & & & 3 & \\
\hline Szociális mot. & & & 31 & 16 & & & & & & 3 \\
\hline Attitüd szab. & & 31 & & & & & & & 6 & 5 \\
\hline Attitüd iskolai & & 14 & & & & 7 & & & 8 & 6 \\
\hline Érték & 5 & & & & & & & & & \\
\hline Elsajátítási cél & -1 & & & 8 & & & 31 & & 20 & \\
\hline Teljesítménycél & & & & & & 24 & & 2 & 4 & 3 \\
\hline Elkerülő cél & & & & & & & 3 & & 8 & 37 \\
\hline Flow & 5 & & 7 & 11 & & 21 & 5 & 9 & & 7 \\
\hline Antiflow & & 4 & 6 & 8 & & & 4 & 40 & 6 & \\
\hline $\mathrm{R} 2(\%)$ & 11 & 49 & 44 & 43 & 5 & 53 & 43 & 51 & 55 & 61 \\
\hline
\end{tabular}

55. táblázat A motívumok közötti összefüggések, regresszióanalizis, 8. osztály

\begin{tabular}{|c|c|c|c|c|c|c|c|c|c|c|}
\hline \multirow{3}{*}{$\begin{array}{c}\text { Független válto- } \\
\text { zók }\end{array}$} & \multicolumn{10}{|c|}{ Függő változók } \\
\hline & \multicolumn{10}{|c|}{$r \beta \%$} \\
\hline & Énkép & $\begin{array}{l}\text { Szoc. } \\
\text { mot. }\end{array}$ & $\begin{array}{c}\text { Attitüd } \\
\text { szab. }\end{array}$ & $\begin{array}{l}\text { Attitüd } \\
\text { isk. }\end{array}$ & Érték & $\begin{array}{c}\text { Elsaj. } \\
\text { cél }\end{array}$ & $\begin{array}{c}\text { Telj. } \\
\text { cél }\end{array}$ & $\begin{array}{c}\text { Elker. } \\
\text { cél }\end{array}$ & Flow & $\begin{array}{l}\text { Anti- } \\
\text { flow }\end{array}$ \\
\hline Énkép & & & 7 & & 7 & 3 & & & 10 & \\
\hline Szociális mot. & & & 34 & 8 & 6 & & & & & \\
\hline Attitüd szab. & 10 & 33 & & & & & & & & \\
\hline Attitüd iskolai & & 6 & & & 5 & & & & 2 & 2 \\
\hline Érték & 6 & 4 & & 4 & & 3 & & & & \\
\hline Elsajátítási cél & 4 & & & & 6 & & 21 & & 19 & \\
\hline Teljesítménycél & & & & & & 14 & & 2 & 3 & 2 \\
\hline Elkerülő cél & & & & & & & 3 & & 6 & 30 \\
\hline Flow & 17 & & & 13 & & 21 & 5 & 8 & & 14 \\
\hline Antiflow & & & & 3 & & & 3 & 32 & 12 & \\
\hline $\mathrm{R}^{2}(\%)$ & 37 & 43 & 41 & 28 & 24 & 41 & 32 & 42 & 50 & 48 \\
\hline
\end{tabular}


Szinte minden évfolyamon az olvasás során átélt flowt magyarázza a legtöbb másik motívum. Ennek feltételezhetően az az oka, hogy az áramlatélmény létrejöttéhez számos más motívum müködésére szükség van, így például a magas énképre, a pozitív attitüdökre és az intrinzik motiváció müködésére. Empirikus eredményeink alátámasztani látszanak a flow feltételrendszerét. Negyedik évfolyamon az olvasás során átélt flow mint motívum varianciájának $8 \%$-át magyarázzák az olvasás szociális motívumai, vagyis az igény, hogy valakivel olvasmányélményeinket és magát az olvasási tevékenységet megosszuk. Az elsajátítási célok 10\%-ot, a teljesítménycélok 11\%-ot magyaráznak a flow varianciájából, azaz közel ugyanolyan mértékben járulnak hozzá a flow élmények gyakoriságához. A felsőbb évfolyamokon ez az arány jelentősen eltolódik, mégpedig olyan irányba, mely szerint az elsajátítási célok jóval nagyobb mértékben (20\% és 19\%) magyarázzák az áramlatélmény gyakoriságát, mint a teljesítménycélok. Szintén jelentős különbség még az évfolyamok között a flow tekintetében, hogy az énkép magyarázó ereje megnő az életkor növekedésével, és így az énkép mint motívum a nyolcadik évfolyamosok által átélt flow élmény varianciájának 10\%-át magyarázza. Hatodik évfolyamon továbbá az iskolai és a szabadidős olvasás iránti attitüdök is rendelkeznek szignifikáns magyarázóerővel, míg nyolcadik évfolyamon csak az iskolai olvasás iránti attitüd magyaráz.

Az olvasási énkép varianciáját a magasabb évfolyamokon szintén egyre több másik motívum magyarázza. Míg negyedik évfolyamon csak az iskolai olvasás iránti attitüd rendelkezik szignifikáns magyarázóerővel, addig hatodik évfolyamon három másik motívum szerepe erősödik meg. Ezek az olvasásnak tulajdonított gyakorlati érték, az olvasás elsajátítási célok és a flow. Nyolcadik évfolyamon a hatásrendszer újból átrendeződik: itt a szabadidős olvasás iránti attitüdök az egyéni különbségek 10\%-át, a flow a 17\%-át magyarázza. Szignifikáns, de alacsonyabb magyarázóerővel rendelkeznek az olvasásnak tulajdonított érték és az olvasás elsajátítási célok.

Az olvasás szociális motívumainak varianciáját minden évfolyamon magyarázzák az olvasás iránti attitüdök: a szabadidős olvasáshoz való értékelő viszonyulás a szociális motívumok varianciájának több mint 30\%-át magyarázza minden évfolyamon, míg a szabadidős olvasás iránti attitűd negyedik évfolyamon 9\%-ot, hatodik évfolyamon 14\%-ot, nyolcadik évfolyamon 6\%-ot magyaráz. A szociális motívumok maguk is ugyanilyen arányban magyarázzák a szabadidős olvasás iránti attitüdök egyéni különbségeit, a két motívum közötti összefüggés szoros.

A szabadidős olvasás iránti attitüdök egyéni különbségeit csak negyedik osztályban magyarázzák az iskolai olvasás iránti attitüdök, hatodik évfolyamon a szociális motívumok mellett a flow és antiflow élmények, nyolcadik osztályban pedig az olvasási énkép rendelkezik szignifikáns magyarázóerővel. Ez az eredmény szintén az olvasás két kontextusának eltávolodására enged következtetni az évek során.

Negyedik évfolyamon az érték motívumot egyetlen másik olvasási motívum sem magyarázza, és egyetlen másik olvasási motívumot sem magyaráz. A motívumrendszertől való függetlenségéből arra következtethetünk, hogy a tanulók mekkora jelentőséget tulajdonítanak az olvasás elsajátításának más tényezőktől függ, mintsem attól, hogy hogyan látják olvasásteljesítményüket vagy épp mennyire szeretnek olvasni. Ez a viszonylagos függetlenség ugyanakkor hatodik és nyolcadik évfolyamra megszünik, és ekkor már az olvasásnak tulajdonított ér- 
téket is számos más motívum magyaráz, valamint az értéktulajdonítás hatással van más motívumok alakulására is. Figyelemre méltó eredmény, hogy az olvasási énkép például szignifikáns magyarázóerővel rendelkezik az olvasásnak tulajdonított érték alakulásában, azaz, ha a tanuló jó olvasónak tartja magát, nagyobb valószínüséggel tulajdonít magasabb értéket az olvasás megtanulásának. Ez az eredmény szintén alátámasztja a szakirodalom korábban már tárgyalt állítását, miszerint a tanulók nagyobb értéket tulajdonítanak azoknak a tevékenységeknek, amelyek területén jónak ítélik saját képességeiket.

A különböző olvasási célorientációk közül az elsajátítási és a teljesítménycélok minden évfolyamon magyarázzák egymást, habár a magyarázóerő nyolcadik évfolyamra jelentősen csökken. Ennek oka lehet, hogy a két célorientáció egy ugyanazon cél, azaz a megközelítő (approach) motiváció két dimenzióját jelenti (Fejes, 2011). Az életkor növekedésével az öszszefüggés és hatásrendszer erejének csökkenése feltételezhetően a teljesítménycélok hangsúlyának relatív csökkenésére vezethető vissza.

A célorientáció másik nagy dimenziója, a munkakerülés, legeröteljesebben az olvasási tevékenység közben átélt antiflow élményekkel függ össze, a két konstruktum egymás variancáját szignifikáns mértékben magyarázza minden évfolyamon. Ennek értelmében minél inkább a munkakerülés a cél egy tanuló olvasási tevékenysége során, annál több antiflow élményt él át, és megfordítva, minél több antiflow élményt él át egy tanuló olvasás során, annál erőteljesebben fog érvényesülni nála az energiabefektetés elkerülésének motívuma.

\subsubsection{Az olvasási motívumok és az olvasási teljesítmény összefüggése negyedik, hatodik és nyolcadik évfolyamon}

Az előző részben áttekintettük az olvasási motívumok jellemzőit és az egyes motívumok közötti összefüggéseket az általános iskola negyedik, hatodik és nyolcadik osztályában. A következőkben az egyes olvasási motívumok olvasási teljesítménnyel való összefüggésének jellemzőit tárgyaljuk. Az olvasási teljesítmény indikátoraként a szakirodalom eltérő teljesítménymutatókat alkalmaz, melynek eredményeként a kutatási eredmények összehasonlítása nehézkessé válik. Kutatásunkban ezért igyekeztünk bevonni minden olyan teljesítménymutatót, amely a szakirodalomban is gyakran felbukkan. Az olvasási teljesítmény leírására az osztályzatok mellett az olvasás-szövegértés tesztek eredményét alkalmaztuk. Ennek eredményeképp összesen hat teljesítménymutató állt rendelkezésünkre. Az osztályzatok közül az olvasás, valamint a magyar nyelv és irodalom év végi jegyeket, továbbá a teljes iskolai eredményességet leíró tanulmányi átlagot vontuk be az elemzésbe. A szövegértést folyamatos és nemfolyamatos szövegek esetében is vizsgáltuk, ennek eredményeképp rendelkezésünkre áll a két szövegtípus esetén elért eredmény, valamint a kettő átlagából képzett szövegértés mutató.

Az olvasási motívumok és a különböző olvasási teljesítménymutatók közötti összefüggéseket negyedik évfolyamon az 56. táblázat, hatodik évfolyamon az 57. táblázat, nyolcadik évfolyamon pedig az 58. táblázat mutatja. Az összefüggéseket évfolyamonként és évfolyamok közötti összehasonlításban is tárgyaljuk. 
56. táblázat. Összefüggések az olvasási motívumok és a teljesitménymutatók között, 4. évfolyam

\begin{tabular}{|c|c|c|c|c|c|c|c|c|c|c|}
\hline Korrelációk & Énkép & $\begin{array}{l}\text { Szoc. } \\
\text { mot. }\end{array}$ & $\begin{array}{c}\text { Attitüd } \\
\text { szab. }\end{array}$ & $\begin{array}{l}\text { Attitüd } \\
\text { iskolai }\end{array}$ & Érték & $\begin{array}{l}\text { Elsaj. } \\
\text { cél }\end{array}$ & Telj. cél & $\begin{array}{l}\text { Elker. } \\
\text { cél }\end{array}$ & Flow & $\begin{array}{l}\text { Anti- } \\
\text { flow }\end{array}$ \\
\hline Szövegértés & $0,38 * *$ & $0,17^{*}$ & $0,25 * *$ & $0,25^{* *}$ & 0,07 & 0,13 & 0,07 & $-0,33^{* *}$ & $0,18 * *$ & $-0,41 * *$ \\
\hline $\begin{array}{l}\text { Szövegértés - } \\
\text { folyamatos }\end{array}$ & $0,34 * *$ & 0,08 & 0,20 ** & $0,23 * *$ & $-0,01$ & 0,10 & 0,09 & $-0,30 * *$ & $0,14^{*}$ & $-0,36^{* *}$ \\
\hline $\begin{array}{l}\text { Szövegértés - } \\
\text { nem folyamatos }\end{array}$ & $0,30 * *$ & $0,24 * *$ & $0,22 * *$ & $0,18^{* *}$ & $0,16^{*}$ & 0,13 & 0,03 & $-0,26^{* *}$ & $0,17 *$ & $-0,33 * *$ \\
\hline $\begin{array}{l}\text { Tanulmányi } \\
\text { átlag }\end{array}$ & $0,49 * *$ & $0,25 * *$ & $0,25 * *$ & $0,23 * *$ & 0,07 & 0,11 & 0,05 & $-0,18^{*}$ & $0,16^{*}$ & $-0,31 * *$ \\
\hline Irodalom jegy & $0,52 * *$ & $0,21 * *$ & $0,21 * *$ & $0,22 * *$ & 0,05 & 0,13 & 0,05 & $-0,17 *$ & $0,18^{*}$ & $-0,31 * *$ \\
\hline Nyelvtan jegy & $0,47 * *$ & $0,20 * *$ & $0,20 * *$ & $0,23 * *$ & 0,02 & $0,15^{*}$ & 0,06 & $-0,20 * *$ & $0,18^{*}$ & $-0,30 * *$ \\
\hline
\end{tabular}

Megjegyzés: ** 0,01 szinten szignifikáns, * 0,05 szinten szignifikáns

57. táblázat. Összefüggések az olvasási motívumok és a teljesitménymutatók között, 6. évfolyam

\begin{tabular}{|c|c|c|c|c|c|c|c|c|c|c|}
\hline Korrelációk & Énkép & $\begin{array}{l}\text { Szoc. } \\
\text { mot. }\end{array}$ & $\begin{array}{l}\text { Attitüd } \\
\text { szab. }\end{array}$ & $\begin{array}{l}\text { Attitüd } \\
\text { iskolai }\end{array}$ & Érték & $\begin{array}{c}\text { Elsaj. } \\
\text { cél }\end{array}$ & Telj. cél & $\begin{array}{c}\text { Elker. } \\
\text { cél }\end{array}$ & Flow & $\begin{array}{l}\text { Anti- } \\
\text { flow }\end{array}$ \\
\hline Szövegértés & $0,35^{* *}$ & 0,11 & $0,23 * *$ & 0,02 & $0,17 * *$ & $-0,03$ & $-0,15^{*}$ & $-0,25 * *$ & $0,15^{*}$ & $-0,30 * *$ \\
\hline $\begin{array}{l}\text { Szövegértés - } \\
\text { folyamatos }\end{array}$ & $0,33 * *$ & 0,10 & $0,19 * *$ & 0,04 & $0,15^{*}$ & $-0,05$ & $-0,17 * *$ & $-0,25$ & $0,13^{*}$ & $-0,30 * *$ \\
\hline $\begin{array}{l}\text { Szövegértés - } \\
\text { nem folyamatos }\end{array}$ & $0,25 * *$ & 0,09 & $0,21 * *$ & $-0,01$ & $0,13 *$ & 0,02 & $-0,15^{*}$ & $-0,16$ & $0,13^{*}$ & $-0,19 * *$ \\
\hline $\begin{array}{l}\text { Tanulmányi } \\
\text { átlag }\end{array}$ & $0,47 * *$ & 0,11 & $0,19 * *$ & $0,12 *$ & $0,31 * *$ & 0,05 & $-0,11$ & $-0,22$ & $0,17 * *$ & $-0,26 * *$ \\
\hline Irodalom jegy & $0,45^{* *}$ & $0,14^{*}$ & $0,22 * *$ & $0,13^{*}$ & $0,23 * *$ & 0,06 & $-0,09$ & $-0,21$ & $0,13^{*}$ & $-0,26 * *$ \\
\hline Nyelvtan jegy & $0,43 * *$ & $0,13^{*}$ & $0,24 * *$ & 0,11 & $0,22 * *$ & 0,03 & $-0,10$ & $-0,20$ & $0,17 * *$ & $-0,26 * *$ \\
\hline
\end{tabular}

Megjegyzés: ** 0,01 szinten szignifikáns, * 0,05 szinten szignifikáns 
58. táblázat. Összefüggések az olvasási motívumok és a teljesítménymutatók között, 8. évfolyam

\begin{tabular}{|c|c|c|c|c|c|c|c|c|c|c|}
\hline Korrelációk & Énkép & $\begin{array}{l}\text { Szoc. } \\
\text { mot. }\end{array}$ & $\begin{array}{c}\text { Attitüd } \\
\text { szab. }\end{array}$ & $\begin{array}{l}\text { Attitüd } \\
\text { iskolai }\end{array}$ & Érték & $\begin{array}{c}\text { Elsaj. } \\
\text { cél }\end{array}$ & Telj. cél & $\begin{array}{c}\text { Elker. } \\
\text { cél }\end{array}$ & Flow & $\begin{array}{l}\text { Anti- } \\
\text { flow }\end{array}$ \\
\hline Szövegértés & $0,45^{* *}$ & $0,24 * *$ & $0,31 * *$ & 0,05 & $0,31 * *$ & $0,26 * *$ & $-0,07$ & $-0,32 * *$ & $0,38 * *$ & $-0,45^{* *}$ \\
\hline $\begin{array}{l}\text { Szövegértés - } \\
\text { folyamatos }\end{array}$ & $0,42 * *$ & $0,24 * *$ & $0,32 * *$ & 0,04 & $0,31 * *$ & $0,26 * *$ & $-0,08$ & $-0,34 * *$ & $0,35 * *$ & $-0,43 * *$ \\
\hline $\begin{array}{l}\text { Szövegértés - } \\
\text { nem folyamatos }\end{array}$ & $0,30 * *$ & $0,14 *$ & $0,17 * *$ & 0,04 & $0,17 * *$ & $0,13 *$ & $-0,01$ & $-0,15^{*}$ & $0,26 * *$ & $-0,30 * *$ \\
\hline $\begin{array}{l}\text { Tanulmányi } \\
\text { átlag }\end{array}$ & $0,38 * *$ & $0,14 *$ & $0,32 * *$ & 0,03 & $0,23 * *$ & $0,17 *$ & $-0,15^{*}$ & $-0,19 * *$ & $0,19 *$ & $-0,24 * *$ \\
\hline Irodalom jegy & $0,45^{* *}$ & $0,18^{*}$ & $0,34 * *$ & 0,12 & $0,17 *$ & $0,18 * *$ & $-0,15^{*}$ & $-0,23 * *$ & $0,31 * *$ & $-0,27 * *$ \\
\hline Nyelvtan jegy & $0,44 * *$ & $0,16^{*}$ & $0,29 * *$ & 0,09 & $0,20 * *$ & $0,17 *$ & $-0,14^{*}$ & $-0,22 * *$ & $0,25 * *$ & $-0,22 * *$ \\
\hline
\end{tabular}

Megjegyzés: ** 0,01 szinten szignifikáns, *0,05 szinten szignifikáns

A legtöbb olvasási motívum az egyes évfolyamokon gyenge és közepes erősségü összefüggést mutat a teljesítménymutatókkal, azonban az egyes motívumok olvasási teljesítménnyel való összefüggése eltérő mintázatot mutat. Negyedik évfolyamon a legerősebb összefüggést a teljesítménymutatókkal az olvasási énkép és az olvasás során átélt antiflow élmények mutatják. Előbbi esetében az összefüggés iránya pozitív, azaz a jobb énképpel rendelkező tanulók teljesítménye is jobb, míg utóbbi esetében az összefüggés fordított, azaz minél több antiflow élményt él át a tanuló, annál alacsonyabb az olvasás terén nyújtott teljesítménye is. További különbség, hogy az énkép esetében az összefüggések a tanár által adott osztályzatokkal erösebbek, míg az antiflow élmények a szövegértés teszten nyújtott teljesítménnyel korrelálnak erősebben. Gyenge és közepes erősségü negatív összefüggést találunk az elkerülő célok és a teljesítmény között is, a mintázat pedig hasonlóan alakul az antiflow és a teljesítménymutatók közötti összefüggésekéhez; a teszteredményekkel való összefüggés némileg szorosabb az osztályzatokkal való korrelációknál.

Negyedik osztályban az iskolai olvasás és a szabadidős olvasás iránti attitüdök egyaránt gyenge pozitív összefüggést mutatnak az olvasási teljesítmény valamennyi mutatójával; a korrelációs együtthatók rendre 0,2 körüliek. Azonban hatodik és nyolcadik osztályban az iskolai olvasás kedveltsége és az olvasásteljesítmény között nem találtunk szignifikáns kapcsolatot, azonban a szabadidős olvasás iránti attitüdök és a teljesítménymutatók között korrelációs együtthatók nyolcadik osztályra, a nem folyamatos szövegek megértését kivéve, erősebbek, 0,3 körüliek.

A korrelációs együtthatók évfolyamonkénti összehasonlítása alapján az olvasás motívumai és az olvasás terén nyújtott eredményesség kapcsolata a magasabb évfolyamokon szorosabb, mint az alacsonyabb évfolyamokon. Kivétel ez alól a már említett iskolai olvasás kedveltsége és az elsajátítási célok, amelyek utóbbiak negyedik évfolyamon csak a nyelvtanjegygyel mutatnak szignifikáns gyenge összefüggést, hatodik évfolyamon pedig egyetlen teljesítménymutatóval sem. Viszont az olvasási eredményességgel való összefüggésük nyolcadik évfolyamon szignifikáns. 
A teljesítménycélok olvasási teljesítménnyel való összefüggése szintén figyelmet érdemel. Negyedik évfolyamon az olvasás területén a teljesítménycélok követése egyetlen teljesítménymutatóval sem áll szignifikáns kapcsolatban. Hatodik évfolyamon a kapcsolat a szövegértései teszten nyújtott teljesítménnyel szignifikáns, nyolcadik évfolyamon éppen az osztályzatokkal. Az összefüggés mindkét esetben gyenge, negatív irányú.

Összességében az olvasás motívumai összefüggésben állnak az olvasási teljesítménynyel. Az, hogy milyen teljesítménymutatót választunk az elemzés alapjául ebben az esetben is hatással van a kapcsolatok jellemzőire. A motívumok és a teljesítmény közötti összefüggések erősödése a felsőbb évfolyamokon a motívumfejlesztés fontosságára hívja fel a figyelmet.

A szakirodalom az olvasási motiváció és az olvasási teljesítmény kapcsolatát illetően nem rendelkezik egyértelmü eredményekkel. Bizonyos kutatások szerint a két tényező között a kapcsolat egyirányú, melynek értelmében az olvasási motívumok fejlettsége hatással van az olvasás terén nyújtott teljesítményre (lásd például Guthrie, Hoa, Wigfield, Tonks, Humenick és Littles, 2006), míg más eredmények szerint a kapcsolat iránya reciprok, azaz egyfajta odavissza hatás áll fenn az olvasási teljesítmény és az olvasási motiváció között (lásd például Onatsu-Arvillomi és Nurmi, 2000). A szakirodalom ellentmondásos eredményeinek hátterében egyrészről az áll, hogy különböző teljesítménymutatókat alkalmaztak, másrészről különböző életkorú tanulókat vizsgáltak. További problémát okoz, hogy magának az olvasási motivációnak sem találunk egy elfogadott definícióját, amely meghatározná mely olvasási motívumok alkotják magát a konstruktumot. Olvasási motiváció alatt így a szakirodalom sok esetben más és más motívumok együttesét feltételezi.

Kutatásunkban az olvasási motiváció és az olvasási teljesítmény kapcsolatrendszerének, egymásra gyakorolt hatásának feltárása céljából az általunk azonosított tíz olvasási motívum, valamint az osztályzatok és a szövegértés teszt eredményének kapcsolatát egyesével vizsgáljuk. Minden egyes olvasási motívum hatását vizsgáljuk minden teljesítménymutatóra és megfordítva. A motívumok és a teljesítménymutatók bevonásával lineárisregresszióelemzéseket végeztünk. Minden motívumot és minden teljesítménymutatót szerepeltettünk függő változóként. Független változóknak a motívumok esetében a teljesítményváltozókat tettük meg, a teljesítményváltozók esetében a motívumokat. Az elemzéseket évfolyamonként végeztük el, mutatjuk be. 
59. táblázat. Az egyes olvasási motívumok és teljesitménymutatók közötti összefüggések, regresszióanalizis, függö változók: motívumok, 4. osztály

\begin{tabular}{|c|c|c|c|c|c|c|c|c|c|c|}
\hline \multirow{3}{*}{$\begin{array}{l}\text { Független válto- } \\
\text { zók }\end{array}$} & \multicolumn{10}{|c|}{ Függő változók } \\
\hline & \multicolumn{10}{|c|}{$r \beta \%$} \\
\hline & Énkép & $\begin{array}{l}\text { Szoc. } \\
\text { mot. }\end{array}$ & $\begin{array}{c}\text { Attitüd } \\
\text { szab. }\end{array}$ & $\begin{array}{c}\text { Attit. } \\
\text { isk. }\end{array}$ & Érték & $\begin{array}{c}\text { Elsaj. } \\
\text { cél }\end{array}$ & $\begin{array}{c}\text { Telj. } \\
\text { cél }\end{array}$ & $\begin{array}{c}\text { Elker. } \\
\text { cél }\end{array}$ & Flow & $\begin{array}{l}\text { Anti- } \\
\text { flow }\end{array}$ \\
\hline Szövegértés & 7 & & & & & & & 10 & & 12 \\
\hline Tan. átlag & & 6 & & & & & & & & \\
\hline Irodalomjegy & 15 & & & & & & & & & \\
\hline \multicolumn{11}{|l|}{ Nyelvtanjegy } \\
\hline $\mathrm{R}^{2}(\%)$ & 22 & 6 & - & - & - & - & - & 10 & - & 12 \\
\hline
\end{tabular}

60. táblázat. Az egyes olvasási motívumok és teljesitménymutatók közötti összefüggések, regresszióanalizis, függő változók: motívumok, 6. osztály

\begin{tabular}{|c|c|c|c|c|c|c|c|c|c|c|}
\hline \multirow{3}{*}{$\begin{array}{c}\text { Független válto- } \\
\text { zók }\end{array}$} & \multicolumn{10}{|c|}{ Függő változók } \\
\hline & \multicolumn{10}{|c|}{$r \beta \%$} \\
\hline & Énkép & $\begin{array}{c}\text { Szoc. } \\
\text { mot. }\end{array}$ & $\begin{array}{c}\text { Attitüd } \\
\text { szab. }\end{array}$ & $\begin{array}{c}\text { Attit. } \\
\text { isk. }\end{array}$ & Érték & $\begin{array}{c}\text { Elsaj. } \\
\text { cél }\end{array}$ & $\begin{array}{c}\text { Telj. } \\
\text { cél }\end{array}$ & $\begin{array}{c}\text { Elker. } \\
\text { cél }\end{array}$ & Flow & $\begin{array}{l}\text { Anti- } \\
\text { flow }\end{array}$ \\
\hline Szövegértés & 8 & & 4 & & & & & 3 & & 6 \\
\hline Tan. átlag & \multicolumn{10}{|c|}{20} \\
\hline Irodalomjegy & 8 & & & & & & & & & \\
\hline \multicolumn{11}{|l|}{ Nyelvtanjegy } \\
\hline $\mathrm{R}^{2}(\%)$ & 16 & - & 4 & - & 20 & - & - & 3 & - & 6 \\
\hline
\end{tabular}

61. táblázat. Az egyes olvasási motívumok és teljesitménymutatók közötti összefüggések, regresszióanalizis, függő változók: motívumok, 8. osztály

\begin{tabular}{|c|c|c|c|c|c|c|c|c|c|c|}
\hline \multirow{3}{*}{$\begin{array}{l}\text { Független válto- } \\
\text { zók }\end{array}$} & \multicolumn{10}{|c|}{ Függő változók } \\
\hline & \multicolumn{10}{|c|}{$r \beta \%$} \\
\hline & Énkép & $\begin{array}{c}\text { Szoc. } \\
\text { mot. }\end{array}$ & $\begin{array}{c}\text { Attitüd } \\
\text { szab. }\end{array}$ & $\begin{array}{c}\text { Attit. } \\
\text { isk. }\end{array}$ & Érték & $\begin{array}{c}\text { Elsaj. } \\
\text { cél }\end{array}$ & $\begin{array}{l}\text { Telj. } \\
\text { cél }\end{array}$ & $\begin{array}{c}\text { Elker. } \\
\text { cél }\end{array}$ & Flow & $\begin{array}{l}\text { Anti- } \\
\text { flow }\end{array}$ \\
\hline Szövegértés & 16 & 6 & 7 & & 8 & 5 & & 14 & 15 & 24 \\
\hline Tan. átlag & & & & & & & & & 4 & \\
\hline Irodalomjegy & 11 & & 8 & & & & & & 11 & \\
\hline \multicolumn{11}{|l|}{ Nyelvtanjegy } \\
\hline $\mathrm{R}^{2}(\%)$ & 27 & 6 & 15 & - & 8 & 5 & - & 14 & 30 & 24 \\
\hline
\end{tabular}


Az olvasási teljesítmény olvasási motívumokra gyakorolt hatását elemezzük először. Az 59., a 60. és a 61. táblázatok a motívumok mint függő változók és a teljesítménymutatók mint független változók bevonásával végzett regresszióelemzések eredményeit mutatják negyedik, hatodik és nyolcadik osztályban. Az egyes elemzések az oszlopokban szerepelnek, a független változók pedig a sorokban kaptak helyet. A táblázatokban a helytakarékosság és a könnyebb áttekinthetőség érdekében csak a szignifikáns magyarázóerőket (r $\beta \%)$ tüntettük fel.

Negyedik évfolyamon a vizsgált tíz motívum közül csupán négyet magyaráznak kisebb-nagyobb mértékben az olvasási teljesítmény mutatói; azonban az összmegmagyarázott varianciák ezek esetén is alacsonyak. Az olvasási énkép egyéni különbségeit eredményeink szerint mind a szövegértés teszten nyújtott teljesítmény, mind az irodalom év végi osztályzat szignifikánsan magyarázza, az irodalomjegy magyarázóereje azonban több mint kétszerese a szövegértésének. A szociális motívumok egyéni különbségeinek 8\%-át magyarázza a tanulmányi átlag; a többi mutató nem rendelkezik szignifikáns magyarázóerővel. A két további motívum melyre az olvasási teljesítmény hatással van a negatív orientációt tükröző elkerülő célok és a szintén negatív motivációs jellemzőnek tekinthető antiflow élmények. Mindkét motívumra a szövegértés-teljesítmény van befolyással, azaz azok a tanulók, akiknek a szövegértés képessége alacsonyabb több antiflow élményt fognak átélni, és erőteljesebben fognak érvényesülni olvasási tevékenységükben az elkerülő célok.

A hatodik osztályos tanulók esetében az olvasási teljesítmény mutatói már öt motívum egyéni különbségeit magyarázzák, azonban az összmegmagyarázott varianciák azonban itt is viszonylag alacsonyak: 3-20 közöttiek. Hatodik évfolyamon az énkép egyéni különbségeit az irodalom osztályzat és a szövegértés képesség fejlettsége azonos mértékben magyarázza. A szabadidős olvasás iránti attitüdöket a szövegértés kismértékben, az olvasásnak tulajdonított értéket a tanulmányi átlag jelentősebb mértékben magyarázza. Az elkerülő célok és az antiflow varianciáját ezúttal is a szövegértés magyarázza, a magyarázóerő hatodik évfolyamon azonban gyengébb, mint a negyedikesek esetében.

Nyolcadik osztályban nyolc motívum varianciáját magyarázzák a teljesítménymutatók, az összmegmagyarázott varianciák 8-30 közöttiek. Mind a nyolc motívum esetében szignifikáns magyarázóereje van a szövegértés teljesítménynek, két esetben ezen kívül az irodalom osztályzat, egy esetben, a flownál, pedig az irodalom osztályzat és a tanulmányi átlag is magyaráz. Az olvasás énkép egyéni különbségeit nyolcadik osztályban már a szövegértés teljesítmény magyarázza nagyobb mértékben (16\%) szemben az irodalom osztályzat 11\%-os magyarázóerejével. A munkakerülő célok és az antiflow varianciáját jelentősebb mértékben magyarázza a szövegértés teljesítmény.

Az alacsony összmegmagyarázott varianciák összességében arra hívják fel a figyelmet, hogy az olvasási motívumok egyéni jellemzőit elsősorban nem a teljesítmény magyarázza, habár bizonyos motívumokra hatással van. A motívumok egyéni különbségeit a teljesítményen kívül feltételezhetően számos más tényező is alakítja. Ezek között lényeges szerepet töltenek be feltételezetően a családi háttér és az iskolai oktató-nevelő munka egyes aspektusai, melyek motívumokra gyakorolt hatását a következő fejezetben tárgyaljuk.

Mielőtt megvizsgálnánk, milyen egyéb tényezők alakítják az olvasási motívumokat, nézzük meg, vajon az olvasási motívumok is hatással vannak-e az olvasásteljesítményre, és ha 
igen, milyen mértékben. Milyen hatásrendszer áll fenn az egyes olvasási motívumok és az egyes teljesítménymutatók között? Vajon a tanári visszajelzésként funkcionáló osztályzatokra vagy a szövegértés objektív mutatójára vannak-e hatással inkább az olvasás motívumai? Alátámasztják-e az adatok a teljesítmény és a motívumok összefüggésrendszerében a területspecifikusságot, azaz erőteljesebb befolyással vannak-e az olvasási motívumok az olvasási teljesítményre, mint a területeken átívelő iskolai teljesítmény mutatójaként funkcionáló tanulmányi átlagra?

A 62., a 63. és a 64. táblázatok az olvasási teljesítmény mutatói mint függő változók és a motívumok mint független változók bevonásával végzett regresszióelemzések eredményeit mutatják negyedik, hatodik és nyolcadik osztályban. Az egyes elemzéseket az oszlopokban szerepeltetjük, a független változók pedig a sorokban kaptak helyet. A táblázatokban a könynyebb áttekinthetőség érdekében ez esetben is csak a szignifikáns magyarázóerőket (r $\beta \%)$ tüntettük fel.

62. táblázat Az egyes olvasási motívumok és teljesitménymutatók közötti összefüggések, regresszióanalízis, függő változók: teljesitménymutatók, 4. osztály

\begin{tabular}{|c|c|c|c|c|}
\hline \multirow[b]{3}{*}{ Független változók } & \multicolumn{4}{|c|}{ Függő változók } \\
\hline & \multicolumn{4}{|c|}{$r \beta \%$} \\
\hline & Szövegértés & $\begin{array}{c}\text { Tanulmányi } \\
\text { átlag }\end{array}$ & Irodalomjegy & Nyelvtanjegy \\
\hline Énkép & 12 & 22 & 28 & 22 \\
\hline \multicolumn{5}{|l|}{ Szociális motívumok } \\
\hline \multicolumn{5}{|l|}{ Attitűd a szabadidős olvasás iránt } \\
\hline \multicolumn{5}{|l|}{ Attitűd az iskolai olvasás iránt } \\
\hline \multicolumn{5}{|l|}{ Érték } \\
\hline \multicolumn{5}{|l|}{ Elsajátítási cél } \\
\hline \multicolumn{5}{|l|}{ Teljesítménycél } \\
\hline Elkerülő cél & 6 & & & \\
\hline Flow & 4 & 4 & & \\
\hline Antiflow & 12 & 5 & 7 & 6 \\
\hline $\mathrm{R}^{2}(\%)$ & 34 & 31 & 35 & 28 \\
\hline
\end{tabular}


63. táblázat. Az egyes olvasási motívumok és teljesitménymutatók közötti összefüggések, regresszióanalizis, függö változók: teljesitménymutatók, 6. osztály

\begin{tabular}{|c|c|c|c|c|}
\hline \multirow[b]{3}{*}{ Független változók } & \multicolumn{4}{|c|}{ Függő változók } \\
\hline & \multicolumn{4}{|c|}{$r \beta \%$} \\
\hline & Szövegértés & $\begin{array}{l}\text { Tanulmányi } \\
\text { átlag }\end{array}$ & Irodalomjegy & Nyelvtanjegy \\
\hline Énkép & 9 & 21 & 20 & 18 \\
\hline \multicolumn{5}{|l|}{ Szociális motívumok } \\
\hline Attitűd a szabadidős olvasás iránt & 4 & & & \\
\hline Attitüd az iskolai olvasás iránt & 4 & & & \\
\hline Érték & & 5 & & \\
\hline \multicolumn{5}{|l|}{ Elsajátítási cél } \\
\hline \multicolumn{5}{|l|}{ Teljesítménycél } \\
\hline \multicolumn{5}{|l|}{ Elkerülő cél } \\
\hline \multicolumn{5}{|l|}{ Flow } \\
\hline Antiflow & 5 & & & \\
\hline $\mathrm{R} 2(\%)$ & 23 & 26 & 20 & 18 \\
\hline
\end{tabular}

64. táblázat. Az egyes olvasási motívumok és teljesitménymutatók közötti összefüggések, regresszióanalizis, függö változók: teljesitménymutatók, 8. osztály

\begin{tabular}{|c|c|c|c|c|}
\hline \multirow[b]{3}{*}{ Független változók } & \multicolumn{4}{|c|}{ Függő változók } \\
\hline & \multicolumn{4}{|c|}{$r \beta \%$} \\
\hline & Szövegértés & $\begin{array}{l}\text { Tanulmányi } \\
\text { átlag }\end{array}$ & Irodalom jegy & Nyelvtan jegy \\
\hline Énkép & 14 & 11 & 17 & 17 \\
\hline \multicolumn{5}{|l|}{ Szociális motívumok } \\
\hline Attitűd a szabadidős olvasás iránt & & 9 & 6 & \\
\hline Attitüd az iskolai olvasás iránt & 1 & 1 & & \\
\hline Érték & 5 & & & \\
\hline Elsajátítási cél & & 3 & & \\
\hline Teljesítménycél & & 3 & 4 & 3 \\
\hline \multicolumn{5}{|l|}{ Elkerülő cél } \\
\hline \multicolumn{5}{|l|}{ Flow } \\
\hline Antiflow & 12 & & & \\
\hline $\mathrm{R}^{2}(\%)$ & 32 & 27 & 27 & 20 \\
\hline
\end{tabular}


A motívumok a teljesítménymutatók varianciájának átlagosan 20-30\%-át magyarázzák. Öszszességében véve tehát a motívumok együttesen valamivel nagyobb arányban magyarázzák a teljesítmények egyéni különbségeit, mint a teljesítménymutatók a motívumok egyéni különbségeit, ugyanakkor az egyes motívumok magyarázóereje nem tekinthető magasnak. Szintén megállapítható, hogy a megmagyarázott varianciák tekintetében nagy különbségek vannak az egyes motívumok és az évfolyamok között is. A vizsgált motívumok közül a szociális motívumok kivételével valamennyi rendelkezik szignifikáns magyarázóerővel valamely teljesítménymutatóra valamely évfolyamon. Az összmegmagyarázott varianciák minden teljesítménymutató mint függő változó esetében negyedik osztályban a legmagasabbak, viszont a legtöbb motívum nyolcadik osztályban magyaráz.

A negyedik, a hatodik és a nyolcadik osztályban is az énkép magyarázza legnagyobb arányban a teljesítményváltozók varianciáját. Azonban jelentős életkori különbség, hogy míg negyedik és hatodik évfolyamon az énkép hatása erőteljesebben az osztályzatokban nyilvánul meg, addig nyolcadik évfolyamon az olvasási énkép által magyarázott variancia a szövegértés és a jegyek esetében közel azonos.

Az antiflow élmények gyakorisága negyedik évfolyamon minden más motívum varianciáját szignifikánsan magyarázza, azonban hatodik és nyolcadik osztályban már csak a szövegértés eredményre van hatással. A flow élmények szintén csak negyedikben magyarázzák kis mértékben a teljesítménymutatók közül a szövegértést és a tanulmányi átlagot.

Eredményeink nem támasztják alá egyértelmúen a területspecifikusságot, azaz azt a feltételezést, hogy az olvasás motívumai erőteljesebben korrelálnak az olvasási teljesítménnyel és nagyobb mértékben magyarázzák az olvasás teljesítménymutatókat, mint az általános teljesítmény indikátorának tekintett tanulmányi átlagot. Nem vethetjük el ez alapján ugyanakkor a motívumok területspecifikusságát, hiszen az olvasás számos tantárgynak az alapját képezi. További kutatásra van ahhoz szükség, hogy a területspecifikusság vizsgálatának érdekében megvizsgáljuk, vajon az olvasási motívumok milyen kapcsolatban állnak más területekkel, például a matematikával és a természettudományokkal

\subsubsection{Az olvasási motívumok nemek közötti különbségei}

Az olvasási motívumok fejlettségét a nemek szerint is vizsgáltuk. A 65-67. táblázatok az olvasási motívumok nemek szerinti különbségeit mutatják az egyes évfolyamokon. 
65. táblázat. Az olvasási motívumok átlagai nemenkénti bontásban, 4. évfolyam

\begin{tabular}{|c|c|c|c|c|c|c|c|c|}
\hline \multirow{3}{*}{$\begin{array}{c}N \\
\text { Olvasási motívumok }\end{array}$} & \multirow{2}{*}{\multicolumn{2}{|c|}{$\frac{F i u ́}{111}$}} & \multirow{2}{*}{\multicolumn{2}{|c|}{$\begin{array}{r}\text { Lány } \\
107\end{array}$}} & \multirow{2}{*}{\multicolumn{2}{|c|}{ Levene }} & \multirow{2}{*}{\multicolumn{2}{|c|}{ Kétmintás $t$}} \\
\hline & & & & & & & & \\
\hline & átlag & szórás & átlag & szórás & $F$ & $p$ & $t / d$ & $p$ \\
\hline Énkép & 68 & 18 & 71 & 22 & 2,92 & 0,89 & $-0,87$ & 0,38 \\
\hline Szociális motívumok & 41 & 22 & 55 & 23 & 0,07 & 0,80 & $-4,57$ & 0,001 \\
\hline Attitűd szabadidős & 51 & 26 & 64 & 25 & 0,21 & 0,65 & $-3,63$ & 0,001 \\
\hline Attitűd iskolai & 63 & 23 & 75 & 20 & 4,00 & 0,05 & $-4,09$ & 0,001 \\
\hline Érték & 81 & 17 & 84 & 16 & 0,53 & 0,47 & $-1,39$ & 0,17 \\
\hline Elsajátítási cél & 78 & 19 & 85 & 16 & 3,47 & 0,06 & $-3,16$ & $\mathbf{0 , 0 1}$ \\
\hline Teljesítménycél & 71 & 24 & 80 & 22 & 3,73 & 0,06 & $-2,75$ & $\mathbf{0 , 0 1}$ \\
\hline Elkerülő cél & 44 & 29 & 44 & 27 & 0,52 & 0,47 & 0,08 & 0,94 \\
\hline Flow & 67 & 21 & 69 & 24 & 3,24 & 0,07 & 0,07 & 0,43 \\
\hline Antiflow & 32 & 23 & 29 & 21 & 2,27 & 0,13 & 0,13 & 0,33 \\
\hline
\end{tabular}

Megjegyzés: A 0,05 szinten szignifikáns eltéréseket félkövér szedés jelzi.

66. táblázat Az olvasási motívumok átlagai nemenkénti bontásban, 6. évfolyam

\begin{tabular}{|c|c|c|c|c|c|c|c|c|}
\hline \multirow{3}{*}{$\begin{array}{c}N \\
\text { Olvasási motívumok }\end{array}$} & \multirow{2}{*}{\multicolumn{2}{|c|}{$\begin{array}{l}\text { Fiú } \\
152\end{array}$}} & \multirow{2}{*}{\multicolumn{2}{|c|}{$\begin{array}{r}\text { Lány } \\
126\end{array}$}} & \multirow{2}{*}{\multicolumn{2}{|c|}{ Levene }} & \multirow{2}{*}{\multicolumn{2}{|c|}{ Kétmintás $t$}} \\
\hline & & & & & & & & \\
\hline & átlag & szórás & átlag & szórás & $F$ & $p$ & $t / d$ & $p$ \\
\hline Énkép & 65 & 18 & 68 & 19 & 0,27 & 0,60 & $-1,56$ & 0,12 \\
\hline Szociális motívumok & 36 & 23 & 52 & 22 & 0,85 & 0,36 & $-5,65$ & 0,001 \\
\hline Attitűd szabadidős & 43 & 23 & 64 & 20 & 5,15 & 0,02 & $-8,51$ & 0,001 \\
\hline Attitűd iskolai & 52 & 24 & 63 & 25 & 0,25 & 0,62 & $-3,91$ & 0,001 \\
\hline Érték & 76 & 19 & 82 & 16 & 4,86 & 0,03 & $-2,86$ & 0,001 \\
\hline Elsajátítási cél & 65 & 25 & 70 & 23 & 0,44 & 0,51 & $-1,87$ & 0,06 \\
\hline Teljesítménycél & 54 & 33 & 54 & 31 & 0,37 & 0,54 & 0,00 & 0,99 \\
\hline Elkerülő cél & 47 & 26 & 39 & 25 & 0,06 & 0,80 & 2,64 & 0,001 \\
\hline Flow & 58 & 22 & 68 & 23 & 0,35 & 0,56 & $-3,63$ & 0,001 \\
\hline Antiflow & 39 & 23 & 28 & 22 & 0,66 & 0,42 & 3,90 & 0,001 \\
\hline
\end{tabular}

Megjegyzés: A 0,05 szinten szignifikáns eltéréseket félkövér szedés jelzi. 
67. táblázat Az olvasási motívumok átlagai nemenkénti bontásban, 8. évfolyam

\begin{tabular}{|c|c|c|c|c|c|c|c|c|}
\hline \multirow{3}{*}{$\begin{array}{c}N \\
\text { Olvasási motívumok }\end{array}$} & \multirow{2}{*}{\multicolumn{2}{|c|}{$\frac{F i u ́}{116}$}} & \multirow{2}{*}{\multicolumn{2}{|c|}{$\begin{array}{r}\text { Lány } \\
143\end{array}$}} & \multirow{2}{*}{\multicolumn{2}{|c|}{ Levene }} & \multirow{2}{*}{\multicolumn{2}{|c|}{ Kétmintás $t$}} \\
\hline & & & & & & & & \\
\hline & átlag & szórás & átlag & szórás & $F$ & $p$ & $t / d$ & $p$ \\
\hline Énkép & 66 & 19 & 71 & 16 & 5,11 & 0,03 & $-2,13$ & $\mathbf{0 , 0 3}$ \\
\hline Szociális motívumok & 34 & 20 & 52 & 21 & 0,84 & 0,36 & $-6,71$ & 0,001 \\
\hline Attitűd szabadidős & 41 & 21 & 64 & 21 & 0,00 & 0,97 & $-8,74$ & 0,001 \\
\hline Attitűd iskolai & 51 & 23 & 59 & 20 & 3,65 & 0,06 & $-2,95$ & 0,001 \\
\hline Érték & 76 & 18 & 78 & 16 & 1,31 & 0,25 & $-1,09$ & 0,28 \\
\hline Elsajátítási cél & 64 & 24 & 74 & 19 & 7,56 & 0,01 & $-3,70$ & 0,001 \\
\hline Teljesítménycél & 44 & 28 & 44 & 28 & 0,03 & 0,87 & $-0,01$ & 0,99 \\
\hline Elkerülő cél & 38 & 24 & 28 & 21 & 1,17 & 0,29 & 3,60 & $\mathbf{0 , 0 1}$ \\
\hline Flow & 62 & 21 & 67 & 16 & 12,73 & 0,00 & $-2,26$ & $\mathbf{0 , 0 2}$ \\
\hline Antiflow & 31 & 19 & 23 & 15 & 4,47 & 0,04 & 3,68 & 0,001 \\
\hline
\end{tabular}

Megjegyzés: A 0,05 szinten szignifikáns eltéréseket félkövér szedés jelzi.

Negyedik osztályban öt motívum esetében találtunk szignifikáns különbséget a lányok és a fiúk között. Ezek az olvasás szociális motívumai, a szabadidős és az iskolai olvasás iránti attitüdök, az olvasás elsajátítási célok és az olvasás teljesítmény célok. Mind az öt esetben a lányok motívumai az erősebbek, azaz a negyedikes lányok szignifikánsan gyakrabban osztják meg olvasásélményeiket és jobban kedvelik a közös olvasási feladatokat, pozitívabb attitüdökkel rendelkeznek a szabadidős és az iskolai olvasás iránt, valamint gyakrabban követnek olvasási feladatok során elsajátítási és teljesítménycélokat, mint fiú kortársaik.

Hatodik évfolyamon már hét motívum esetén tudtunk kimutatni szignifikáns nemek közötti különbségeket. Érdekes módon a hét motívum között nem szerepelnek a negyedik évfolyamon szignifikáns különbséget mutató elsajátítási és teljesítménycélok, azaz hatodik évfolyamon nincs különbség a tekintetben a lányok és fiúk között, hogy milyen gyakran követnek elsajátítási és teljesítménycélokat olvasás közben. Ugyanakkor szignifikáns különbséget találtunk ismét a szociális motívumok, és a szabadidős és iskolai olvasás iránti attitüdök tekintetében. A hatodikos lányok és fiúk ezen túl az elkerülö célok érvényesülésének, valamint a flow és antiflow élmények átélésének gyakorisága tekintetében is különböznek. A pozitív motivációs konstruktumok esetében a lányok, a negatív orientációk és élményeket illetően pedig a fiúk fölénye mutatkozik meg. Ez a mintázat egyértelmüen a lányok pozitívabb olvasás iránti motivációjára mutat rá.

A nyolcadik osztályos tanulók válaszai alapján csupán két motívum esetében nem mutatható ki szignifikáns különbség a nemek között. Ezek az olvasásnak tulajdonított érték, amely még nyolcadik osztályban is viszonylag magas mindkét nem esetében, és az olvasás teljesítménycélok, amelyek a többi motívumhoz képest alacsonyak ebben az életkorban. A 
többi motívum esetében szignifikáns nemek közötti különbségekről beszélhetünk, amely különbségek ismét a lányok pozitívabb motivációjára mutatnak rá.

A magasabb életkorokban a nemek közötti különbségek mértékének növekedése, az egyes motívumokat illető eltérések jelentőssé válása arra enged következtetni, hogy a különbségek tanultak, azaz évek folyamán szerzett tapasztalatok vannak eltérő hatással a fiúk és a lányok olvasási motívumaira. Ez a hatásrendszer egyértelműen a fiúkra nézve negatív.

\subsubsection{Az olvasási motívumok és családi háttér összefüggése}

A családi háttér olvasási motívumokra gyakorolt hatását az apa iskolai végzettsége, mint a családi szocioökonómiai státuszának egyik mutatója alapján vizsgáljuk. Mintánkban az apa és az anya iskolai végzettsége közötti korrelációs együttható meglehetősen magas $(0,79)$ ezért döntöttünk úgy, hogy az adatismétlés elkerülése érdekében csak az apa iskolai végzettségének függvényében elemezzük a tanulók motívumait. A 68. táblázat a legfeljebb általános iskolát végzett, a szakiskolát végzett, az érettségizett és a felsőfokú végzettségű apák gyermekeinek olvasási motívumait mutatja.

68. táblázat. Az olvasási motívumok fejlettsége az apa iskolai végzettsége szerinti bontásban

\begin{tabular}{lcccccc}
\hline \multicolumn{1}{c}{ Olvasási motívumok } & Ált. isk. & Szakiskola & Érettségi & Felsöfok & $F^{*}$ & $p$ \\
\hline Énkép & $61(20)$ & $66(19)$ & $73(18)$ & $74(18)$ & $\mathbf{1 4 , 0 4}$ & $\mathbf{0 , 0 1}$ \\
Szociális motívumok & $44(24)$ & $46(23)$ & $43(24)$ & $48(21)$ & 1,49 & 0,22 \\
Attitüd szabadidős & $52(24)$ & $54(25)$ & $53(26)$ & $62(23)$ & $\mathbf{3 , 6 4}$ & $\mathbf{0 , 0 1}$ \\
Attitűd iskolai & $60(25)$ & $61(23)$ & $59(25)$ & $59(24)$ & 0,31 & 0,82 \\
Érték & $76(19)$ & $80(16)$ & $80(18)$ & $81(15)$ & 1,86 & 0,14 \\
Elsajátítási cél & $72(20)$ & $73(22)$ & $70(25)$ & $74(23)$ & 0,74 & 0,53 \\
Teljesítménycél & $58(29)$ & $57(30)$ & $57(32)$ & $54(35)$ & 0,30 & 0,82 \\
Elkerülő cél & $42(26)$ & $42(26)$ & $39(26)$ & $36(26)$ & 1,63 & 0,18 \\
Flow & $64(23)$ & $64(20)$ & $64(23)$ & $69(21)$ & 1,82 & 0,14 \\
Antiflow & $35(23)$ & $32(21)$ & $30(21)$ & $25(18)$ & $\mathbf{4 , 2 0}$ & $\mathbf{0 , 0 1}$ \\
\hline
\end{tabular}

*Varianciaanalízis F-próbájának értéke és szignifikanciája. Megjegyzés: A 0,05 szinten szignifikáns eltéréseket félkövér szedés jelzi. Zárójelben a szórások láthatók.

A varianciaanalízis eredményei szerint az említett csoportok között három motívum esetében van szignifikáns különbség. Ezek az olvasási énkép, a szabadidős olvasás iránti attitüd és az antiflow élmények gyakorisága. Mindhárom motívum esetében a magasabb végzettségü apák gyermekei jellemezhetők pozitívabb motívumokkal, azaz ők rendelkeznek jobb olvasási énképpel, kedvelik jobban az olvasást mint szabadidős elfoglaltságot, és élnek át kevesebb antiflow élményt olvasás közben. A post hoc elemzés szerint szignifikáns különbség van a legfeljebb nyolc általános iskolai osztályt végzett apák és a szakiskolát végzett apák, valamint a szakiskolát végzett apák és az érettségizett vagy felsőfokú végzettséggel rendelkező apák 
gyermekeinek olvasási énképe között. A főiskolát vagy egyetemet végzett apák gyermekeinek szabadidős olvasás iránti attitüdjei szignifikánsan pozitívabbak, mint az alacsonyabb végzettségü apák gyermekeié, ugyanakkor az alacsonyabb iskolai végzettségekkel rendelkező, például az érettségizett és a nyolc osztályt végzett apák gyermekeinek attitüdjei nem mutatnak szignifikáns különbséget. Az antiflow élmények gyakoriságát illetően a különbség a felsőfokú végzettséggel rendelkező és a legfeljebb szakiskolát végzett apák gyermekei között szignifikáns. A felsőfokú végzettségủ apák gyermekei tehát szignifikánsan kevesebb unalmat vagy apátiát élnek át olvasásfeladatok végzése során.

Az, hogy a magasabb iskolai végzettségü apák gyermekei jobban kedvelik a szabadidős olvasást, magasabb énképpel rendelkeznek, és kevesebb negatív élményt élnek át olvasás közben, egyrészről magyarázható a magasabban fejlett olvasási képességgel, amely általában a magasabban képzett apák gyermekeit jellemzi. A fejlett olvasási képesség lehetővé teszi a tanulók számára, hogy az olvasás ne elsősorban erőfeszítést jelentsen, hanem élményszerzést. Egy másik lehetséges magyarázat, hogy a magasabb iskolai végzettségü szülők úgy nevelik gyermekeiket, hogy az az említett motívumok fejlettségéhez vezet. Például a gyakori közös olvasás vagy a családon belül az olvasmányélmények megbeszélése eredményezhet pozitív attitüdöket a szabadidős olvasás iránt.

\subsubsection{Részösszefoglalás: Olvasási motiváció az általános iskola negyedik, hatodik és nyolcadik évfolyamán}

Központi kutatásunk második részében az általános iskola negyedik, hatodik és nyolcadik osztályában vizsgáltuk az olvasás motívumait. Kérdőíves felmérésünk középpontjában ugyanazok a motívumok szerepeltek, mint a másodikos mérés esetében, az adatfelvétel módja azonban eltérő volt. Eredményeink szerint az általános iskola felsőbb évfolyamai számára fejlesztett sokösszetevős olvasási motiváció kérdőívünk az olvasási motívumok vizsgálatára megfelelő eszköznek bizonyult, segítségével megbízható becslést adhatunk az egyes motívumok jellemzőiröl.

A felsőbb évfolyamosok esetében az olvasási motívumok tekintetében már nagyobb egyéni különbségekről számolhattunk be, mint a második osztályosok esetében, az egyes motívumok évfolyamonkénti átlagát tekintve stagnáló vagy csökkenő tendenciáról beszélhetünk. Azon motívumok esetében, ahol a magasabb évfolyamokon az átlagok egyre alacsonyabbak, a legtöbb esetben a legnagyobb különbséget a negyedik és hatodik évfolyam között találtuk. Ez az eredmény az alsó tagozatból a felső tagozatba kerülés, a megváltozott körülmények negatív motivációs hatására hívja fel a figyelmet az olvasás területén.

Az olvasási motívumok között a felsőbb évfolyamokon is közepes erősségü összefüggések állnak fel, azonban a motívumrendszer struktúrája évfolyamonként eltérő. Az egyik legfigyelemreméltóbb különbség a teljesítménycélok strukturális átrendeződése negyedikről nyolcadik évfolyamra. Míg negyedik osztályban a jutalomért, dicséretért és elismerésért tanulás legszorosabban az elsajátítási célokhoz kötődik, addig hatodik évfolyamra a teljesítménycélok követése eltávolodik a többi pozitív, megközelítő motívumtól. Nyolcadik évfolyamon a teljesítménycélok már legszorosabban az elkerülő célokhoz és az antiflow élményhez kapcsolódnak. 
Kutatásunk kezdetén feltételeztük, hogy az olvasás terén nyújtott teljesítmény és az olvasás motívumai között kapcsolat van és a két tényező közötti összefüggés a felsőbb évfolyamokon erősebb. Második évfolyamon nem találtunk szignifikáns összefüggést a két teljesítménymutató, a tanári értékelés és a szóolvasásteszten nyújtott eredmény között. Negyedik, hatodik, nyolcadik évfolyamon azonban több motívum is kapcsolatban áll a szövegértés teljesítménnyel és az osztályzatokkal is. Azonban negyediktöl az összefüggés nem feltétlenül erösebb az egyre magasabb évfolyamokon, viszont egyre több motívum áll kapcsolatban a teljesítménymutatókkal. Az olvasási motívumok és az olvasási teljesítmény közötti összefüggés szintén függvénye az olvasási teljesítmény indikátorának, azaz a teljesítmény indikátoraként a tanár által adott osztályzatot vagy a képességteszten elért eredményt vesszük alapul. A két tényezö közötti hatásrendszer feltárása arra is rámutatott, hogy a kapcsolat kétirányú, azaz a motívumok hatással vannak a teljesítményre és a teljesítmény pedig hatással van a motívumok alakulására. A motívumok ugyanakkor összességében véve valamivel nagyobb arányban magyarázzák a teljesítményt, mint fordítva.

Második évfolyamon még csupán egyetlen olvasási motívum fejlettségében találtunk különbséget a lányok és a fiúk között. Negyedik évfolyamon már öt, hatodikban pedig hét motívum esetében. Nyolcadikban már csupán két motívum, a teljesítménycélok és az olvasás értéke területén nem volt különbség. Amellett, hogy egyre több motívumban mutatkozik különbség a lány és fiú tanulók között, a nemek közötti eltérés mértéke is nő az egyre magas abb évfolyamokon. Ezen eredményekböl arra következtethetünk, hogy a nemek közötti különbségek alakulásában nagy szerepe van a tapasztalatnak, azaz a különbségek tanultak. 


\section{Az olvasási motívumok fejlödésének kontextusa}

Az olvasási képesség és olvasási motívumok fejlödésének két legfőbb kontextusa az otthon és az iskola. Elsőként a szülői kérdőívek alapján az otthoni kontextus jellemzőit mutatjuk be, majd a tanári háttérkérdőívek alapján az osztálytermi kontextust elemezzük. A kontextusok egyes jellemzőinek összefüggését az olvasási motívumokkal szintén tárgyaljuk.

\section{$5.1 \mathrm{Az}$ otthoni kontextus jellemzői és összefüggése az olvasási motívumokkal}

\subsubsection{Iskola előtti fejlesztés}

A gyermekek az írásbeliséggel már az iskoláskor kezdete előtt találkoznak. Az otthoni tevékenységek során számos formában foglalkozhatnak különböző írott szövegekkel. Az ilyen jellegü tevékenységek, amelyeket gyakran a szülőkkel közösen végeznek, hatással lehetnek olvasási motivációjukra. Szülői kérdőívünkben az írásbeliséghez kapcsolódó kétféle tevékenységfajtát különböztettünk meg: (1) az olvasmányélményeken alapuló tevékenységeket, ilyen például a mesehallgatás, a mesék megbeszélése és (2) az olvasás előfeltétel készségeit fejles ztő játékokat, ide tartoznak például a szójátékok vagy a különböző betüjátékok.

A 45. ábra az olvasásélményen alapuló tevékenységek végzésének gyakoriságát mutatja a vizsgált mintán a szülők válaszai alapján. Az ábráról leolvasható, hogy a szülők saját bevallásuk alapján gyakran végezték az említett tevékenységeket gyermekükkel az iskolakezdés előtt, többségük a „hetente egyszer vagy kétszer” vagy a „minden nap vagy majdnem minden nap" válaszkategóriák egyikét jelölte meg. A legnépszerübb a felolvasás volt: a szülők 47\%-a állította azt, hogy mindennap vagy majdnem mindennap, 37\%-a pedig hogy hetente egyszer vagy kétszer olvasott fel gyermekének óvodáskora előtt. A válaszok alapján valamivel kisebb arányban vannak azok az anyák és apák, akik szinte mindennap beszélgettek is az olvasmányélményről (37\%), jóval kevesebben azok, akik saját fantáziájukra hagyatkoztak a meséléskor (14\%). A szülök 3\%-a soha vagy szinte soha nem olvasott fel gyermekének, 4\%-a szinte soha nem beszélgetett vele olvasmányélményekröl. 


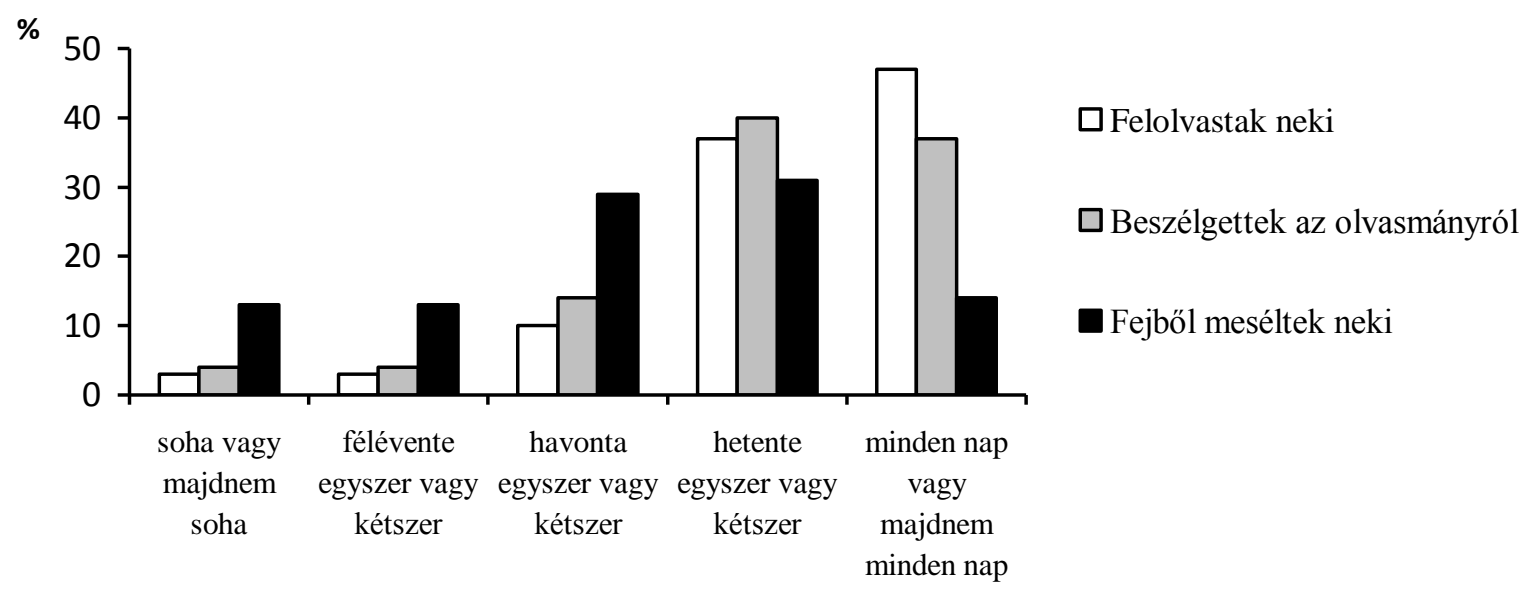

45. ábra

Az olvasásélményen alapuló otthoni tevékenységek gyakorisága az iskoláskor előtt

Az olvasást előkészítő tevékenységek, készségfejlesztő játékok végzésének gyakorisága tekintetében a szülői válaszok már jobban megoszlottak (46. ábra). Itt a leggyakoribb válaszkategóriák a „havonta egyszer vagy kétszer” és a „hetente egyszer vagy kétszer” kategóriák voltak, de nem elenyésző azoknak a szülőknek az aránya sem, akik soha vagy szinte soha nem végeztek ilyen jellegü tevékenységet a gyermekükkel az iskolakezdés előtt. Ez az arány meglehetősen magas az ábécésjátékok (16\%) és a szójátékok esetében (19\%), és valamivel alacsonyabb a betürajzolás $(7 \%)$ és a címkék, feliratok olvasgatása $(8 \%)$ esetében.

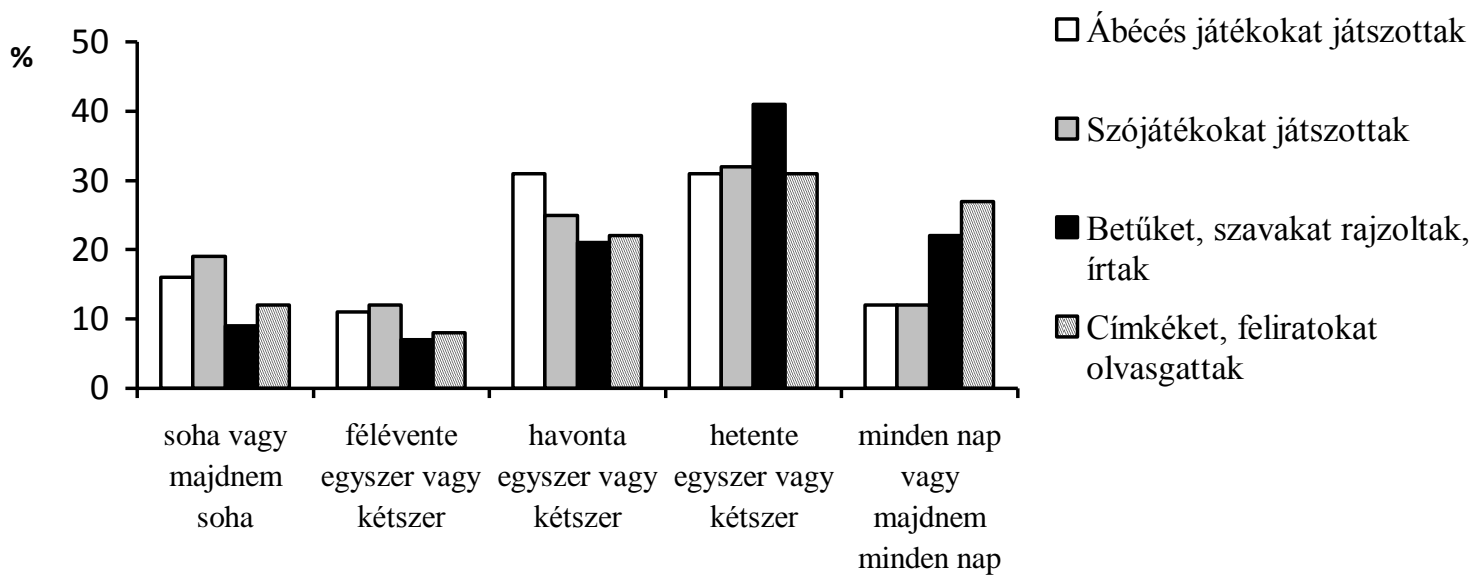

Ha megnézzük, hogy van-e különbség a tevékenységek végzési gyakoriságában a szülők végzettsége szerint (69. táblázat), akkor azt találjuk, hogy az alacsonyabb és a magasabb iskolai végzettségü szülök között az olvasmányélményen alapuló tevékenységek mindegyike esetében szignifikáns a különbség, és minden esetben a magasabb iskolai végzettségü szülők javára. A 
varianciaanalízis post hoc elemzése szerint a középiskolai végzettségü szülök szignifikánsan gyakrabban olvasnak fel a gyermekeiknek, mint az alacsonyabban képzettségüek, a felsőfokú végzettségü apák családjai pedig még náluk is gyakrabban végzik ezt a közös tevékenységet. Az olvasmányélményekröl folytatott beszélgetés területén a legfeljebb általános iskolát végzett és az érettségizett, valamint a legfeljebb érettségizett és az egyetemet vagy főiskolát végzett szülök között szignifikáns a különbség. A saját képzelőeröt szintén a felsőfokú végzettségü szülők alkalmazzák gyakrabban a többieknél a mesélés során.

69. táblázat. Az olvasásfejlesztésre irányuló otthoni tevékenységek az apa iskolai végzettsége szerinti bontásban

\begin{tabular}{lcccccc}
\hline Tevékenységek & Ált. isk. & Szakiskola & Érettségi & Felsöfok & $F^{*}$ & $p$ \\
\hline Felolvasás & $3,90(0,10)$ & $4,21(0,90)$ & $4,40(0,85)$ & $4,61(0,75)$ & $\mathbf{1 3 , 1 2}$ & $\mathbf{0 , 0 0 1}$ \\
Beszélgetés & $3,82(1,18)$ & $4,03(1,01)$ & $4,14(0,98)$ & $4,43(0,85)$ & $\mathbf{6 , 6 2}$ & $\mathbf{0 , 0 0 1}$ \\
Mesélés & $3,15(1,32)$ & $3,09(1,23)$ & $3,18(1,21)$ & $3,60(1,14)$ & $\mathbf{4 , 1 4}$ & $\mathbf{0 , 0 0 1}$ \\
Ábécés játék & $3,01(1,20)$ & $3,18(1,30)$ & $3,22(1,22)$ & $3,00(1,30)$ & 1,18 & 0,32 \\
Szójáték & $3,14(1,39)$ & $3,08(1,32)$ & $3,11(1,28)$ & $3,05(1,30)$ & 0,08 & 0,97 \\
Betürajzolás & $3,85(1,04)$ & $3,63(1,14)$ & $3,54(1,16)$ & $3,31(1,30)$ & $\mathbf{3 , 9 4}$ & $\mathbf{0 , 0 0 1}$ \\
Feliratok olvasása & $3,70(1,21)$ & $3,53(1,30)$ & $3,56(1,32)$ & $3,44(1,40)$ & 2,52 & 0,06
\end{tabular}

*Varianciaanalízis F-próbájának értéke és szignifikanciája. Megjegyzés: A 0,05 szinten szignifikáns eltéréseket félkövér szedés jelzi. Zárójelben a szórások láthatók.

További egy esetben találunk szignifikáns különbséget a családok iskola előtti közös olvasási tevékenységét illetően az iskolai végzettség szerint, ez a betük rajzoltatása, szavak írása. Ezt a tevékenységet viszont az alacsonyabb iskolai végzettségü szülők kedvelték jobban saját bevallásuk szerint. Eredményeink alapján a legfeljebb általános iskolát végzett szülők szignifikánsan többször rajzolgattak betüket és írogattak szavakat gyermekükkel már az iskoláskor előtt, mint a felsőfokú végzettségü családok.

Az előkészítő tevékenységek végzésének gyakorisága és a tanulók olvasási motívumai közötti kapcsolat felderítése céljából korrelációelemzést végeztünk, melynek eredményeit a 70. táblázatban közöljük. A korrelációs együtthatók alapján az előkészítő tevékenységek és a motívumok fejlettsége között vagy egyáltalán nem mutatható ki kapcsolat, vagy csupán gyenge összefüggést találunk; a regresszióelemzés alapján szignifikáns hatásról nincs. Az iskoláskor előtti fejlesztő tevékenységek tehát kevés összefüggést mutatnak a 4-8. osztályos tanulók olvasási motívumainak fejlettségével, ez alapján azonban nem zárhatjuk ki, hogy rövid távon sem lennének hatással a tanulók olvasási motívumainak alakulására. Ugyanis figyelembe kell vennünk, hogy a vizsgált minta életkorából adódóan a kérdéses tevékenységek hatását több, adott esetben akár 10 év távlatában vizsgáltuk. Jelen eredmények csupán arra mutattak rá, hogy a végzett tevékenységeknek hosszú távon kevés hatása van a tanulók motívumfejlettségére. 
70. táblázat Az olvasásfejlesztésre irányuló otthoni tevékenységek összefüggése az olvasási motívumokkal

\begin{tabular}{|c|c|c|c|c|c|c|c|c|c|c|}
\hline Olvasási motívumok & Énkép & $\begin{array}{c}\text { Szoc. } \\
\text { mot. }\end{array}$ & $\begin{array}{c}\text { Attitüd } \\
\text { szab. }\end{array}$ & $\begin{array}{l}\text { Attitüd } \\
\text { iskolai }\end{array}$ & Érték & $\begin{array}{c}\text { Elsaj. } \\
\text { cél }\end{array}$ & Telj. cél & $\begin{array}{c}\text { Elker. } \\
\text { cél }\end{array}$ & Flow & $\begin{array}{l}\text { Anti- } \\
\text { flow }\end{array}$ \\
\hline Felolvasás & $0,15 * *$ & 0,05 & $0,11 * *$ & 0,01 & 0,05 & 0,06 & 0,01 & $-0,05$ & 0,06 & $-0,08 *$ \\
\hline Beszélgetés & $0,13 * *$ & $0,08^{*}$ & $0,09 *$ & 0,03 & 0,05 & $0,08^{*}$ & 0,04 & $-0,04$ & 0,06 & $-0,05$ \\
\hline Mesélés & $0,08 *$ & $0,09 *$ & $0,09 *$ & 0,04 & $-0,01$ & 0,05 & 0,04 & $-0,05$ & $0,10 * *$ & $-0,07$ \\
\hline Ábécés játék & 0,04 & $0,11 * *$ & $0,07 *$ & 0,06 & 0,02 & $0,08^{*}$ & 0,05 & $-0,01$ & $0,07 *$ & $-0,02$ \\
\hline Szójáték & 0,06 & $0,11 * *$ & $0,10^{* *}$ & 0,07 & 0,05 & $0,08^{*}$ & 0,04 & $-0,02$ & $0,08^{*}$ & $-0,01$ \\
\hline Betűrajzolás & 0,03 & $0,12 * *$ & 0,06 & $0,10 * *$ & 0,04 & $0,09^{*}$ & 0,07 & $-0,02$ & 0,06 & 0,04 \\
\hline Feliratok olvasása & 0,04 & $0,09 *$ & $0,11^{* *}$ & 0,03 & $-0,01$ & 0,07 & 0,03 & $-0,06$ & 0,07 & $-0,06$ \\
\hline
\end{tabular}

Megjegyzés: ** 0,01 szinten szignifikáns, *0,05 szinten szignifikáns

\subsubsection{Iskoláskori fejlesztés}

Az iskoláskori otthoni fejlesztő, támogató tevékenységek közül a kontextus jellemzőjeként az olvasmányélmények megbeszélését, a hangos olvasás gyakorlását és a közös olvasási tevékenységeket, beleértve az iskolai feladatokban történő segítségnyújtást emeltük ki. A 47. ábra az olvasmányélmények megosztásán alapuló tevékenységek gyakoriságát mutatja a szülők válaszai alapján. Saját bevallása szerint a szülők körülbelül $60 \%$-a beszélget legalább heti egyszer gyermekével olvasmányokról, legyen az iskolai olvasmány, a gyermek által egyedül olvasott szöveg vagy egy közös olvasmányélmény. A szülök többsége iskolai olvasmányokat beszéli meg leggyakrabban a gyermekével, a szülök 33\%-a saját bevallása szerint mindennap vagy majdnem mindennap beszélget gyermekével arról, hogy mit olvastak az iskolában.

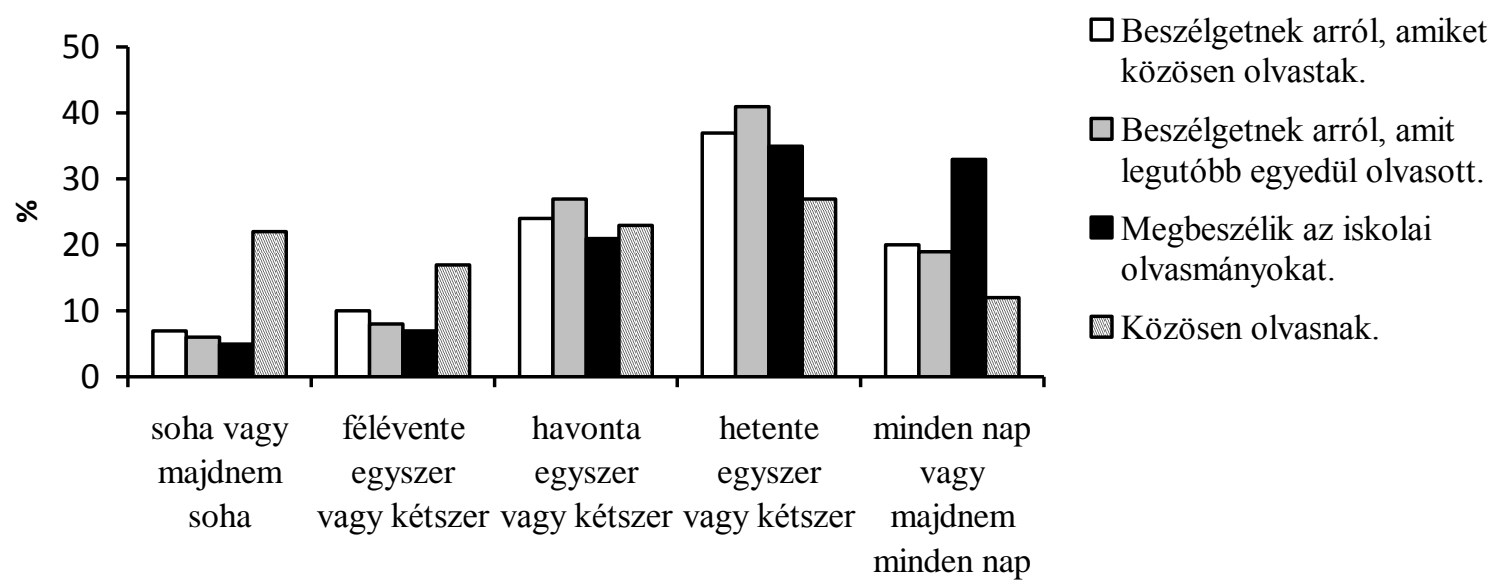

47. ábra

Az olvasmányélményen alapuló otthoni tevékenységek gyakorisága iskoláskorban 
Ami a hangos olvasás gyakoroltatásának, ellenőrzésének gyakoriságát illeti (48. ábra), a szülök 63\%-a hallgatja hetente legalább egyszer, ahogyan általános iskolás gyermeke hangosan olvas, és 53\%-uk olvastat fel gyermekével, valamit szándékosan heti rendszerességgel. 25\%uk minden nap vagy majdnem mindennap segít gyermekének az iskolai olvasási feladatok megoldásában, amely - figyelembe véve a gyermekek életkorát - viszonylag magas arány. A közös könyvtár- vagy könyvesbolt-látogatás már nem ilyen népszerü a szülök körében, 30\%uk soha vagy szinte soha nem viszi gyermekét ezekre a helyekre, 34\%-uk legfeljebb félévente egyszer vagy kétszer teszi meg.

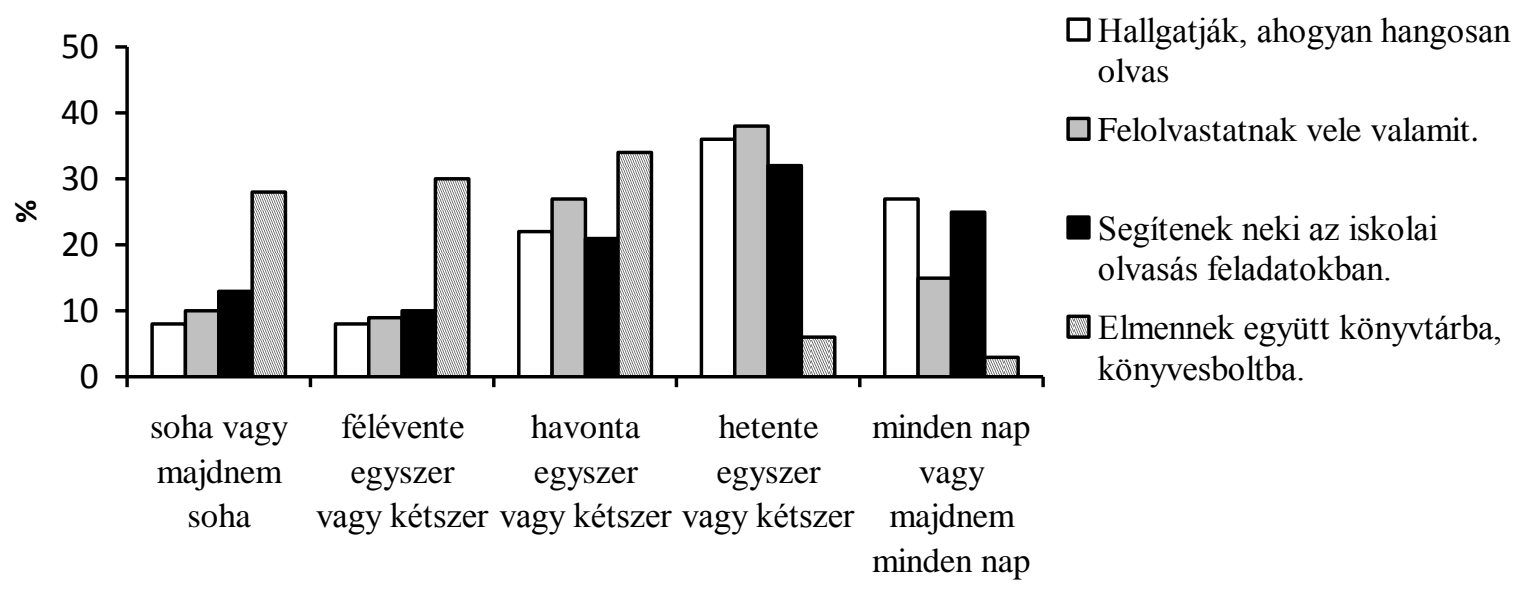

48. ábra

Az olvasási képesség fejlesztésére irányuló otthoni, szülői tevékenységek gyakorisága iskoláskorban

A fenti tevékenységek gyakoriságát az apa iskolai végzettségének függvényében is vizsgáltuk (71. táblázat). Az olvasmányélmények megbeszélésére, megosztására vonatkozó kérdéseinkre adott válaszok közül egy esetben találtunk szignifikáns különbséget a különböző iskolai végzettségü apák családjai között. Ez pedig a kifejezetten az iskolai olvasmányok megbeszélésére vonatkozó kérdés volt. Eredményeink szerint a szakiskolát végzett apák családjai szignifikánsan gyakrabban beszélnek az iskolai olvasmányokról, mint a felsőfokú végzettségü szülők. Szintén az alacsonyabb iskolai végzettségü apák esetében beszélhetünk gyakoribb segítségnyújtásról és olvastatásról, és szintén ők hallgatják meg gyakrabban, hogyan olvas hangosan gyermekük. Azonban a könyvtárba és könyvesboltba járás gyakorisága éppen a magasabb iskolai végzettségü szülők esetében magasabb. 
71. táblázat. Az olvasmányélményen alapuló és az olvasási képesség fejlesztését célzó otthoni tevékenységek az apa iskolai végzettsége szerinti bontásban

\begin{tabular}{lcccccc}
\hline \hline Tevékenységek & Ált. isk. & Szakiskola & Érettségi & Felsőfok & $F^{*}$ & $p$ \\
\hline Beszélgetés - közös & $3,46(1,15)$ & $3,62(1,05)$ & $3,51(1,16)$ & $3,56(1,24)$ & 0,63 & 0,60 \\
Beszélgetés - egyéni & $3,60(1,10)$ & $3,60(1,01)$ & $3,62(1,06)$ & $3,53(1,08)$ & 0,15 & 0,97 \\
Beszélgetés - iskolai & $3,70(1,19)$ & $3,99(0,94)$ & $3,86(1,16)$ & $3,68(1,21)$ & $\mathbf{2 , 9 0}$ & $\mathbf{0 , 0 3}$ \\
Közös olvasás & $2,94(1,33)$ & $2,89(1,30)$ & $2,94(1,32)$ & $2,87(1,39)$ & 0,10 & 0,96 \\
Hangos olv. hallgatása & $3,81(1,04)$ & $3,71(1,15)$ & $3,63(1,18)$ & $3,38(1,36)$ & $\mathbf{2 , 6 3}$ & $\mathbf{0 , 0 4}$ \\
Felolvastatás & $3,67(1,14)$ & $3,39(1,11)$ & $3,41(1,12)$ & $3,13(1,26)$ & $\mathbf{3 , 8 2}$ & $\mathbf{0 , 0 1}$ \\
Segítés & $3,58(1,29)$ & $3,59(1,22)$ & $3,41(1,12)$ & $3,13(1,26)$ & $\mathbf{4 , 1 2}$ & $\mathbf{0 , 0 1}$ \\
Könyvtár, könyvesbolt & $2,05(1,08)$ & $2,21(0,98)$ & $2,36(0,93)$ & $2,57(1,02)$ & $\mathbf{5 , 4 5}$ & $\mathbf{0 , 0 1}$ \\
\hline \hline
\end{tabular}

*Varianciaanalízis F-próbájának értéke és szignifikanciája. Megjegyzés: A 0,05 szinten szignifikáns eltéréseket félkövér szedés jelzi. Zárójelben a szórások láthatók.

Az iskolai feladatokban való segítségnyújtás, a szövegek felolvastatása, a hangos olvasás fejlődésének ellenőrzése mind-mind nagyfokú közvetlen szülöi kontrollal járó tevékenységek. Az alacsonyabb iskolai végzettségü szülök eredményeink szerint többet akarnak tudni, jobban akarják kontrollálni gyermekeik olvasástanulását és kevesebb önálló teret biztosítanak gyermeküknek, hogy felelősséget vállaljon saját tanulásáért. De vajon milyen hatással van ez a tanuló olvasási motívumaira? A 72. táblázat a tanuló olvasási motívumainak összefüggéseit mutatja az egyes tevékenységek gyakoriságával. Látható, hogy a korrelációs együtthatók csak némileg magasabbak az iskolakezdés előtti tevékenységek korrelációs együtthatóinál, és kifejezetten néhány motívumra korlátozódnak. A legmagasabb korrelációs együtthatókat a telejsítménycélok esetében találjuk. Azok a tanulók, akiknek szülei gyakran vállalnak szerepet gyermekük olvasási képességének fejlesztésében, ellenőrzésében, ennek megfelelően szignifikánsan gyakrabban követnek teljesítménycélokat az olvasás területén.

Az érték és a flow motívumok egyetlen tevékenységgel sem mutatnak szignifikáns öszszefüggést; az antiflow csak a segítségnyújtással mutat szignifikáns pozitív összefüggést. A segítségnyújtás meglepő irányú összefüggést mutat az antiflow mellett az elkerülö célokkal és az énképpel is: az énképpel negatív irányú, az elkerülő célokkal és az antiflow élményekkel pozitív irányú. Ez azt jelenti, hogy azok a tanulók, akiknek gyakrabban segítenek az olvasást igénylő feladatok megoldásában, alacsonyabb olvasási énképpel rendelkeznek, gyakrabban követnek elkerülö célokat és gyakrabban élnek át antiflow élményeket olvasási feladatok megoldásakor. 
72. táblázat Az olvasmányélményen alapuló és az olvasási képesség fejlesztését célzó otthoni tevékenységek öszszefüggése az olvasási motívumokkal

\begin{tabular}{|c|c|c|c|c|c|c|c|c|c|c|}
\hline $\begin{array}{c}\text { Olvasási } \\
\text { motívumok }\end{array}$ & Énkép & $\begin{array}{l}\text { Szoc. } \\
\text { mot. }\end{array}$ & $\begin{array}{c}\text { Attitüd } \\
\text { szab. }\end{array}$ & $\begin{array}{l}\text { Attitüd } \\
\text { iskolai }\end{array}$ & Érték & $\begin{array}{c}\text { Elsaj. } \\
\text { cél }\end{array}$ & $\begin{array}{l}\text { Telj. } \\
\text { cél }\end{array}$ & $\begin{array}{c}\text { Elker. } \\
\text { cél }\end{array}$ & Flow & $\begin{array}{l}\text { Anti- } \\
\text { flow }\end{array}$ \\
\hline $\begin{array}{l}\text { Beszélgetés - } \\
\text { közös }\end{array}$ & 0,01 & $0,10 * *$ & $0,10^{* *}$ & $0,12 * *$ & 0,01 & $0,11 * *$ & $0,17 * *$ & 0,01 & 0,07 & $-0,02$ \\
\hline $\begin{array}{l}\text { Beszélgetés - } \\
\text { egyéni }\end{array}$ & 0,06 & $0,14 * *$ & $0,13^{* *}$ & $0,12 * *$ & 0,04 & $0,11 * *$ & $0,15^{* *}$ & $-0,01$ & 0,06 & 0,01 \\
\hline $\begin{array}{l}\text { Beszélgetés - } \\
\text { iskolai }\end{array}$ & 0,01 & 0,06 & 0,07 & $0,13 * *$ & 0,05 & $0,10 * *$ & $0,16^{* *}$ & 0,03 & 0,05 & $-0,02$ \\
\hline Közös olvasás & $-0,06$ & 0,04 & 0,04 & $0,11 * *$ & $-0,03$ & $0,13 * *$ & $0,23 * *$ & $0,08^{*}$ & 0,04 & 0,05 \\
\hline $\begin{array}{l}\text { Hangos olvasás } \\
\text { hallgatása }\end{array}$ & $-0,09^{*}$ & 0,05 & 0,02 & $0,20 * *$ & 0,02 & $0,13 * *$ & $0,19 * *$ & $0,07 *$ & 0,04 & 0,04 \\
\hline Felolvastatás & $-0,01$ & 0,03 & 0,07 & $0,10 * *$ & $-0,02$ & 0,07 & $0,08^{*}$ & $-0,01$ & 0,07 & $-0,01$ \\
\hline Segítés & $-0,12 * *$ & 0,01 & $-0,06$ & $0,12 * *$ & $-0,02$ & $0,10 * *$ & $0,23 * *$ & $0,12 * *$ & 0,03 & $0,10 * *$ \\
\hline $\begin{array}{l}\text { Könyvtár, köny- } \\
\text { vesbolt látog. }\end{array}$ & $0,07 *$ & $0,14 * *$ & $0,18^{* *}$ & 0,04 & 0,04 & $0,10 * *$ & 0,05 & $-0,05$ & 0,07 & $-0,04$ \\
\hline \multicolumn{11}{|c|}{$\begin{array}{l}\text { 73. táblázat Az olvasmányélményen alapuló és az olvasási képesség fejlesztését célzó otthoni tevékenységek ösz } \\
\text { szefüggése az olvasási motívumokkal, regresszióanalizis }\end{array}$} \\
\hline \multirow[b]{3}{*}{ Független változók } & \multicolumn{10}{|c|}{ Függő változók } \\
\hline & \multicolumn{10}{|c|}{$r \beta \%$} \\
\hline & Énkép & $\begin{array}{l}\text { Szoc. } \\
\text { mot. }\end{array}$ & $\begin{array}{l}\text { Attitüd } \\
\text { szab. }\end{array}$ & $\begin{array}{l}\text { Attit. } \\
\text { isk. }\end{array}$ & Érték & $\begin{array}{c}\text { Elsaj. } \\
\text { cél }\end{array}$ & $\begin{array}{l}\text { Telj. } \\
\text { cél }\end{array}$ & $\begin{array}{c}\text { Elker. } \\
\text { cél }\end{array}$ & Flow & $\begin{array}{l}\text { Anti- } \\
\text { flow }\end{array}$ \\
\hline $\begin{array}{l}\text { Beszélgetés - } \\
\text { közös } \\
\text { Beszélgetés - } \\
\text { egyéni } \\
\text { Beszélgetés - } \\
\text { iskolai }\end{array}$ & & 2 & & & & & & & & \\
\hline Közös olvasás & & & & & & & 3 & 1 & & \\
\hline $\begin{array}{l}\text { Hangos olvasás } \\
\text { hallgatása }\end{array}$ & & & & 4 & & & & & & \\
\hline Felolvastatás & & & & & & & & & & \\
\hline Segítés & 3 & & 1 & & & & 3 & 2 & & 1 \\
\hline Könyvtárlátogatás & & 2 & 3 & & & & & & & \\
\hline $\mathrm{R}^{2}(\%)$ & 3 & 4 & 4 & 4 & & & 6 & 3 & & 1 \\
\hline
\end{tabular}

Annak felderítésére, hogy a segítségnyújtás gyakorisága felelős a motívumok fejletlenségéért vagy fordítva, azaz a motívumok fejletlensége indokolja a gyakoribb segítségnyújtást, regresszióanalízist végeztük. Az elemzésekben függő változóként megtettük az összes olvasási motívumot, független változóként az összes tárgyalt tevékenységet. Az eredményeket a 73. táblázat mutatja. A táblázatban csak a szignifikáns $\mathrm{r} \beta$ értékeket tüntettük fel. Ezek szerint a szülő tárgyalt tevékenységei, beleértve a segítségnyújtást, csak alacsony magyarázóerővel rendelkeznek a motívumok fejlettségének alakulásában. 


\subsubsection{A szülök olvasási szokásai, motivációja és összefüggésük a tanulók olvasási motívumaival}

A szülők olvasási szokásait kutatásunkban három mutatóval jellemeztük, amelyekhez az adatokat szintén a szülői kérdőív segítségével gyüjtöttük. A három mutató közül az első az egy átlagos héten olvasással eltöltött órák száma, beleértve a rekreációs célú olvasást és a munkával kapcsolatos dokumentumok olvasását, valamint a papíralapú és az elektronikus szövegeket is. A második mutató csak a szabadidős olvasáshoz kapcsolódik, annak gyakoriságára kérdez rá, míg a harmadik mutató a megkérdezettek otthonában található könyvek számára vonatkozik. Szülői kérdőívünkben mind a három mutatóhoz egy-egy kérdés kapcsolódott, a kérdésekre adott egyes válaszok gyakoriságát a 49-51. ábrák mutatják.

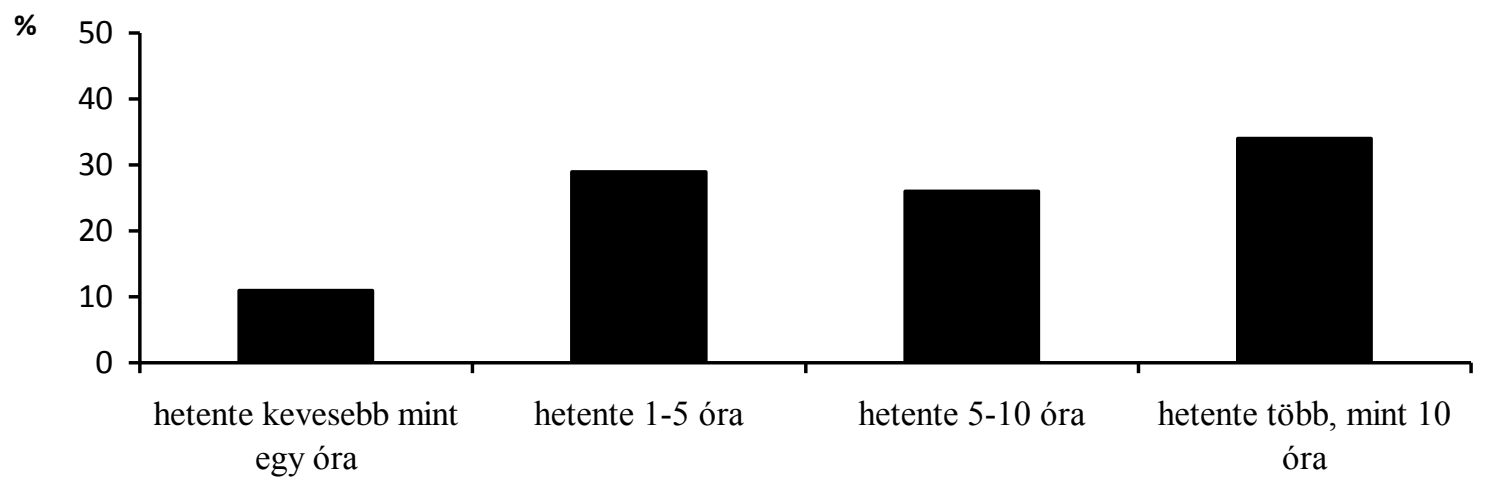

49. ábra

A szülők által egy áltagos héten olvasással töltött órák száma

A szülők olvasási szokásait tekintve meglehetősen heterogén a minta, de némileg többen vannak a sokat olvasó szülök. 34\%-uk hetente több mint 10 órát tölt olvasással, 26\%-uk minimum 5 órát. Körülbelül 10\%-ra tehető azoknak az aránya, akik hetente kevesebb, mint egy órát olvasnak saját bevallásuk szerint, feltételezhetőleg ök azok, akiknek munkájuk során is kevés kapcsolatuk van írott szövegekkel.

A szülők által olvasással töltött idő és a tanulók olvasási motívumai közötti kapcsolatot a 74. táblázatban jelenítettük meg. A szülői olvasás mennyisége szerint képzett részminták motívumainak átlagát varianciaanalízissel hasonlítottuk össze. Három motívum esetében van szignifikáns különbség az egyes csoportok között, ezek az olvasási énkép, a szabadidős olvasás iránti attitüd és az antiflow élmények gyakorisága. Mindhárom esetben azon gyermekek rendelkeznek negatívabb orientációra utaló olvasási motívumokkal, akiknek szülei egy óránál kevesebbet olvasnak hetente. 
74. táblázat. Az olvasási motívumok átlaga a szülök olvasással töltött idejének függvényében, ANOVA

\begin{tabular}{lcccccc}
\hline \multicolumn{1}{c}{$\begin{array}{c}\text { Olvasás mennyisége } \\
\text { hetente }\end{array}$} & $\begin{array}{c}\text { Kevesebb, } \\
\text { mint egy óra }\end{array}$ & l-5 óra & $5-10$ óra & $\begin{array}{c}\text { Több, mint } \\
10 \text { óra }\end{array}$ & $F^{*}$ & $p$ \\
\hline Énkép & $62(20)$ & $68(19)$ & $68(18)$ & $70(18)$ & $\mathbf{3 , 8 1}$ & $\mathbf{0 , 0 1}$ \\
Szociális motívumok & $42(24)$ & $43(23)$ & $46(22)$ & $45(23)$ & 1,16 & 0,32 \\
Attitűd szabadidős & $48(23)$ & $55(24)$ & $53(25)$ & $57(26)$ & $\mathbf{2 , 6 5}$ & $\mathbf{0 , 0 4}$ \\
Attitűd iskolai & $61(24)$ & $60(25)$ & $61(23)$ & $58(24)$ & 0,54 & 0,65 \\
Érték & $77(18)$ & $72(22)$ & $73(22)$ & $72(24)$ & 1,71 & 0,16 \\
Elsajátítási cél & $63(30)$ & $56(31)$ & $58(29)$ & $55(33)$ & 0,06 & 0,98 \\
Teljesítménycél & $63(30)$ & $56(31)$ & $58(30)$ & $55(33)$ & 1,21 & 0,31 \\
Elkerülő cél & $45(26)$ & $39(24)$ & $41(27)$ & $38(26)$ & 1,87 & 0,13 \\
Flow & $60(23)$ & $65(21)$ & $65(20)$ & $66(22)$ & 1,26 & 0,29 \\
Antiflow & $38(22)$ & $30(20)$ & $31(20)$ & $29(21)$ & $\mathbf{3 , 6 0}$ & $\mathbf{0 , 0 1}$
\end{tabular}

*Varianciaanalízis F-próbájának értéke és szignifikanciája. Megjegyzés: A 0,05 szinten szignifikáns eltéréseket félkövér szedés jelzi. Zárójelben a szórások láthatók.

A szabadidős olvasás gyakoriságára vonatkozó válaszok meglehetősen pozitívak: a szülők 39\%-a saját bevallása szerint mindennap vagy majdnem mindennap olvas saját örömére, 35\%uk hetente legalább egyszer teszi ezt. A szülők 6\%-a saját állítása szerint soha vagy szinte soha nem olvas szabadidejében. A szülői szabadidős olvasás gyakorisága és a tanulói motívumok közötti kapcsolatot ismét a szülők szabadidős olvasási szokásai szerint képzett részminták összehasonlításával vizsgáljuk. Az eredmények egyetlen motívum esetében mutatnak szignifikáns különbséget az egyes részminták között, méghozzá a szabadidős olvasás tekintetében. Az tehát, hogy a szülő milyen gyakran olvas saját örömére, befolyással van arra, hogy gyermeke hogyan viszonyul ehhez a szabadidős tevékenységhez. A különbség itt is a soha vagy majdnem soha választ adók és az egyéb választ karikázók gyermekei között szignifikáns (75. táblázat).

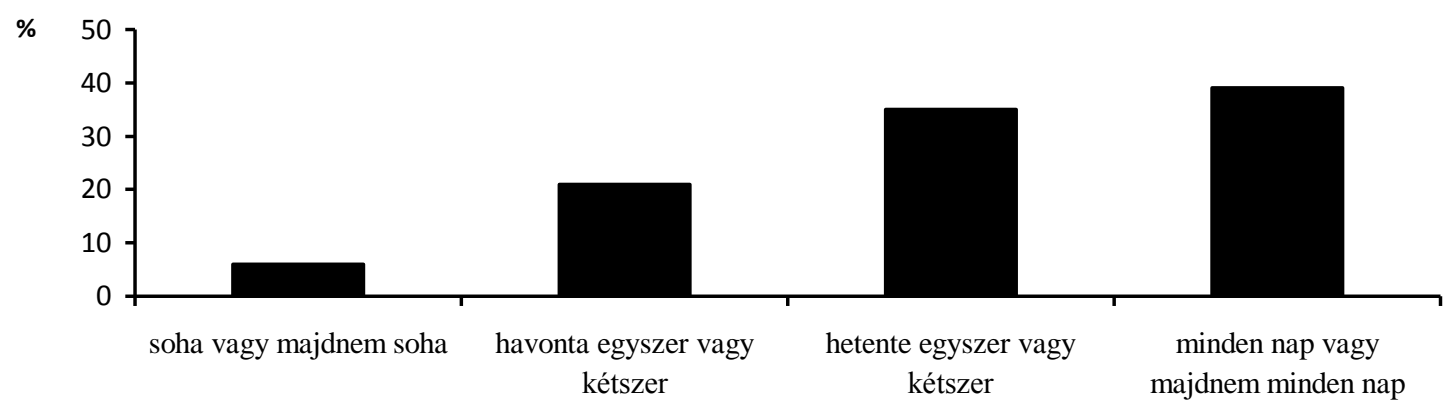

50. ábra

A szülök által a „Milyen gyakran olvas saját örömére?” kérdésre adott válaszok gyakorisága 
75. táblázat Az olvasási motívumok átlaga a szülök szabadidős olvasásának gyakorisága függvényében, ANOVA

\begin{tabular}{lcccccc}
\hline \multicolumn{1}{c}{ Szabadidős olvasás } & Soha & Havonta & Hetente & Naponta & $F^{*}$ & $p$ \\
\hline Énkép & $64(21)$ & $69(20)$ & $67(19$ & $70(18)$ & 1,81 & 0,14 \\
Szociális motívumok & $39(25)$ & $44(23)$ & $45(24)$ & $47(22)$ & 1,55 & 0,19 \\
Attitüd szabadidős & $46(25)$ & $55(27)$ & $53(24)$ & $57(24)$ & $\mathbf{2 , 9 3}$ & $\mathbf{0 , 0 3}$ \\
Attitüd iskolai & $53(29)$ & $62(26)$ & $60(23)$ & $59(22)$ & 1,82 & 0,14 \\
Érték & $76(21)$ & $80817)$ & $78(19)$ & $81(16)$ & 1,85 & 0,14 \\
Elsajátítási cél & $65(25)$ & $72(22)$ & $73(22)$ & $73(23)$ & 1,29 & 0,28 \\
Teljesítménycél & $51(30)$ & $57(32)$ & $58(30)$ & $56(32)$ & 0,63 & 0,59 \\
Elkerülő cél & $45(25)$ & $41(26)$ & $42(26)$ & $37(26)$ & 2,27 & 0,08 \\
Flow & $58(22)$ & $65(21)$ & $64(21)$ & $67(22)$ & 2,30 & 0,08 \\
Antiflow & $29(20)$ & $32(22)$ & $31(19)$ & $30(22)$ & 0,48 & 0,70 \\
\hline
\end{tabular}

*Varianciaanalízis F-próbájának értéke és szignifikanciája. Megjegyzés: A 0,05 szinten szignifikáns eltéréseket félkövér szedés jelzi. Zárójelben a szórások láthatók.

Az otthoni könyvek száma gyakran alkalmazott mutatója egy család szociokulturális hátterének. Amellett, hogy elismerjük, hogy a könyvek száma szoros kapcsolatban áll a szocioökonómiai és a szociokulturális háttérrel, kutatásunkban mi kifejezetten az olvasási szokások egyik mutatójának, jellemzőjének tekintjük. Kutatásunk célja mellett indokolja ezt az is, hogy az internet és az elektronikus szövegek elterjedése következtében, a nyomtatott könyvek funkciója napjainkra jelentősen megváltozott. Ma nem feltétlenül a szociokulturális háttér függvénye, hogy mennyi könyvet tart otthon egy család, a tudást és müveltséget a nyomtatott hordozókon kívül számos egyéb forrásból szerezzük. A könyvek beszerzése sokkal inkább a szabadidős olvasás iránti igény, az olvasás mint életmód megtestesítője.

A kutatásunkban részt vevő családok 55\%-a tart otthon száznál több könyvet, 34\%-uk otthonában 26 és 100 közötti a könyvek száma, 13\%-uk esetében legfeljebb 25. Az otthoni könyvek száma alapján képzett részminták összehasonlítása során a vizsgált tíz motívum közül kilenc esetében találtunk szignifikáns különbséget (76. táblázat).

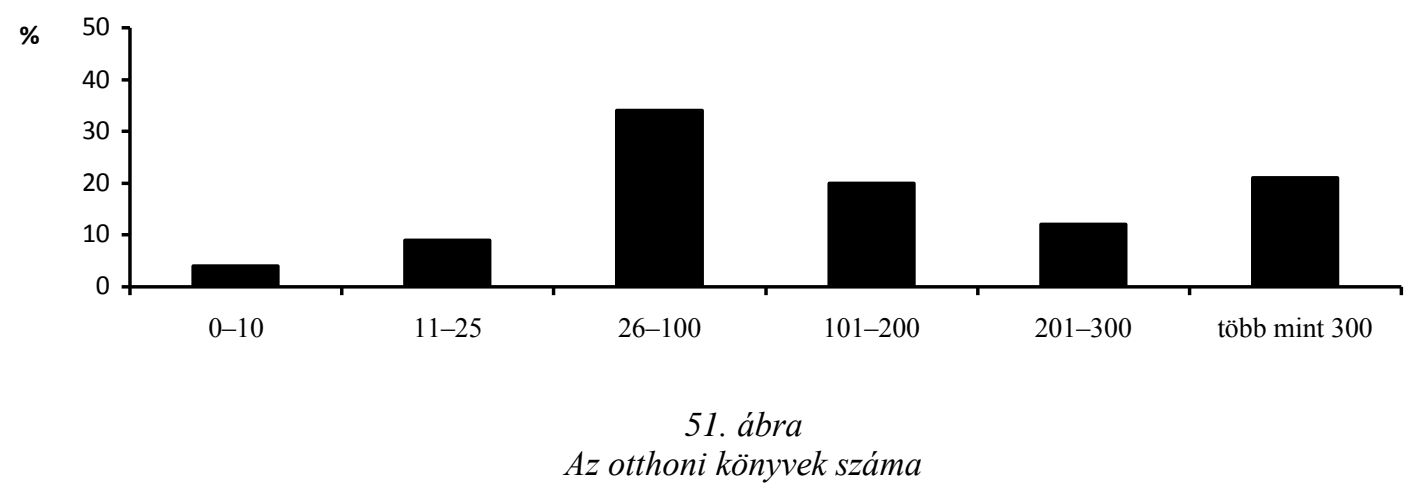


76. táblázat. Az olvasási motívumok átlaga az otthoni könyvek számának függvényében

\begin{tabular}{lcccccc}
\hline \multicolumn{1}{c}{ Könyvek száma } & $\begin{array}{c}\text { Legfeljebb } \\
25\end{array}$ & $26-100$ & $101-300$ & 300 -nál több & $F^{*}$ & $p$ \\
\hline Énkép & $60(19)$ & $67(19)$ & $69(18)$ & $74(18)$ & $\mathbf{1 1 , 3 6}$ & $\mathbf{0 , 0 1}$ \\
Szociális motívumok & $46(24)$ & $45(23)$ & $41(22)$ & $50(23)$ & $\mathbf{4 , 7 1}$ & $\mathbf{0 , 0 0 1}$ \\
Attitüd szabadidős & $47(24)$ & $53(25)$ & $52(23)$ & $63(25)$ & $\mathbf{1 0 , 3 4}$ & $\mathbf{0 , 0 0 1}$ \\
Attitüd iskolai & $61(25)$ & $62(24)$ & $56(25)$ & $62(22)$ & $\mathbf{3 , 4 8}$ & $\mathbf{0 , 0 2}$ \\
Érték & $74(20)$ & $81(16)$ & $79(18)$ & $81(15)$ & $\mathbf{3 , 4 8}$ & $\mathbf{0 , 0 2}$ \\
Elsajátítási cél & $71(22)$ & $72(22)$ & $71(24)$ & $75(22)$ & 1,06 & 0,37 \\
Teljesítménycél & $61(29)$ & $61(30)$ & $53(31)$ & $54(33)$ & $\mathbf{3 , 1 1}$ & $\mathbf{0 , 0 3}$ \\
Elkerülő cél & $47(28)$ & $40(26)$ & $39(25)$ & $36(25)$ & $\mathbf{3 , 9 5}$ & $\mathbf{0 , 0 0 1}$ \\
Flow & $63(23)$ & $64(21)$ & $63(21)$ & $70(21)$ & $\mathbf{3 , 5 0}$ & $\mathbf{0 , 0 2}$ \\
Antiflow & $39(25)$ & $31(21)$ & $31(20)$ & $25(19)$ & $\mathbf{9 , 1 0}$ & $\mathbf{0 , 0 0 1}$ \\
\hline
\end{tabular}

*Varianciaanalízis F-próbájának értéke és szignifikanciája. Megjegyzés: A 0,05 szinten szignifikáns eltéréseket félkövér szedés jelzi. Zárójelben a szórások láthatók.

A szülők olvasás iránti motivációját két motívummal jellemeztük, ezek a szabadidős olvasás iránti attitüd és az olvasásnak tulajdonított érték. Azért választottuk ezt a két motívumot, mert feltételeztük, hogy az ezek által motivált viselkedés manifeszt a gyermek számára, ezáltal pedig közvetlen hatással lehet a gyermek olvasás iránti motivációjára is. Ezen kívül mindkét motívum internalizált motívum, tehát esetükben feltételezhető, hogy a motívumok alapját képező, a gyermekek által internalizált meggyőződések nagymértékben a szülők hasonló meggyőződéseire vezethetők vissza.

A szülők említett két olvasási motívumának jellemzőit az 52. ábrán mutatjuk be. Az eloszlásgörbék alapján jól látható, hogy a szülők többsége saját bevallása szerint szívesen olvas szabadidejében, 25\%-uk viszont inkább választ más foglalatosságot, ők azok, akik 50\%p alatti attitüddel rendelkeznek. Az érték tekintetében e mintázattól eltérően oszlottak meg a szülői válaszok. A szülők mintegy 50\% nagyon magas, 95\% p fölötti értéket tulajdonít az olvasásnak, 33\%-uk válaszai alapján 50 és $80 \%$ p közöttire tehető az olvasásnak tulajdonított érték, és körülbelül $8 \%$ azoknak az aránya, akik inkább nem értenek egyet azzal, hogy az olvasás az élet számos területén gyakorlati értékkel rendelkezik (50\%p alatt). 


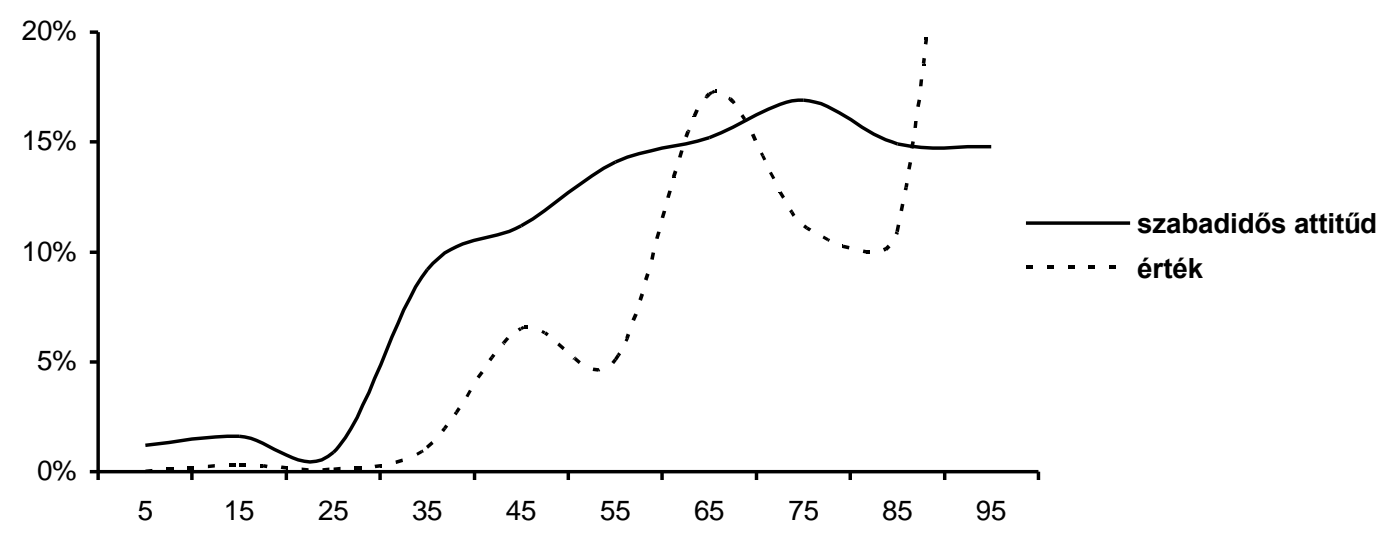

52. ábra

A szülők két vizsgált olvasási motívumának eloszlása

Mind a két vizsgált olvasási motívum esetében szignifikáns különbséget találtunk a különböző iskolai végzettségű szülők között (77. táblázat). A szabadidős olvasás iránti attitüd esetében a különbség az általános iskolát végzett és a magasabb iskolai végzettségü szülők, valamint a felsőfokú végzettségü és az ennél alacsonyabban képzett szülök esetében szignifikáns. A legfeljebb általános iskolát végzett szülők emellett szignifikánsan kevesebb értéket is tulajdonítanak az olvasásnak, mint az egyéb végzettségü szülők.

77. táblázat. A szülők olvasási motívumainak átlaga az apa iskolai végzettségének függvényében, ANOVA

\begin{tabular}{lcccccc}
\hline \multicolumn{1}{c}{ Olvasási motívumok } & Ált. isk. & Szakiskola & Érettségi & Felsöfok & $F^{*}$ & $p$ \\
\hline Attitűd-szabadidős & $57(23)$ & $67(23)$ & $72(18)$ & $80(20)$ & $\mathbf{2 0 , 8 7}$ & $\mathbf{0 , 0 0 1}$ \\
Érték & $78(21)$ & $83(17)$ & $84(17)$ & $86(18)$ & $\mathbf{3 , 5 9}$ & $\mathbf{0 , 0 1}$
\end{tabular}

*Varianciaanalízis F-próbájának értéke és szignifikanciája. Megjegyzés: A 0,05 szinten szignifikáns eltéréseket félkövér szedés jelzi. Zárójelben a szórások láthatók.

A szülök és a gyerekek olvasási motívumai között csupán gyenge összefüggéseket találtunk. Az anya és az apa szabadidős olvasás iránti attitüdje gyenge pozitív összefüggést mutat a tanuló olvasási énképével, szabadidős olvasás iránti attitüdjével, és az általa az olvasásnak tulajdonított értékkel, valamint negatív összefüggést az elkerülő célokkal. A szülő által az olvasásnak tulajdonított érték gyenge pozitív kapcsolatban áll a gyermek olvasási énképével, szabadidős olvasás iránti attitüdjével, az olvasás értékével. Ugyanezen motívum gyenge negatív összefüggést mutat az munkakerülő célokkal és az antiflow élmények gyakoriságával.

78. táblázat. A szülők és gyermekeik olvasási motívumainak összefüggései

\begin{tabular}{lccccccccccc}
\hline \hline $\begin{array}{c}\text { Olvasási } \\
\text { motívumok }\end{array}$ & Énkép & $\begin{array}{c}\text { Szoc. } \\
\text { mot. }\end{array}$ & $\begin{array}{c}\text { Attitüd } \\
\text { szab. }\end{array}$ & $\begin{array}{c}\text { Attitüd } \\
\text { iskolai }\end{array}$ & Érték & $\begin{array}{c}\text { Elsaj. } \\
\text { cél }\end{array}$ & $\begin{array}{c}\text { Telj. } \\
\text { cél }\end{array}$ & $\begin{array}{c}\text { Elker. } \\
\text { cél }\end{array}$ & $\begin{array}{c}\text { Flow } \\
\text { Anti- } \\
\text { flow }\end{array}$ \\
\hline $\begin{array}{l}\text { Attitüd szab. - } \\
\text { szülö } \\
\text { Érték - szülö }\end{array}$ & $0,10^{* *}$ & 0,04 & $0,09 *$ & 0,05 & $0,12^{* *}$ & 0,02 & $-0,01$ & $-0,07 *$ & 0,07 & $-0,07$ \\
\hline \hline
\end{tabular}

Megjegyzés: ** 0,01 szinten szignifikáns, * 0,05 szinten szignifikáns 


\subsubsection{A szülők gyermekük olvasásteljesítményével és olvasási motivációjával szemben támasztott elvárásai}

A szülök saját olvasási szokásai és motivációja mellett az otthoni környezet egy további fontos eleme az anya és az apa gyermekével szemben támasztott elvárásai. Ilyen elvárások az olvasási teljesítményre és motivációra vonatkozóan például a jegyekkel kapcsolatos elvárások, a szabadidős olvasás irányába támasztott követelmények, a gyermek saját olvasási céljaira vonatkozó igények vagy a gyermek által olvasott müfajokkal kapcsolatos elvárások. A szülői kérdőíven kilenc általunk megfogalmazott elvárással való egyetértésük vagy egyet nem értésük kifejezésére kértük a szülőket. Az eredmények alapján a résztvevők valamennyi elvárással inkább egyetértettek, mintsem ellenezték: az átlagok rendszerint 4,00 fölöttiek. Azonban több elvárás esetében találtunk szignifikáns különbséget az egyetértés mértékét illetően a különböző iskolai végzettségü szülők között (79. táblázat).

79. táblázat. A szülök elvárásainak átlaga az apa iskolai végzettségének függvényében, ANOVA

\begin{tabular}{lcccccc}
\hline \multicolumn{1}{c}{ Szülői elvárások } & Ált. isk. & Szakiskola & Érettségi & Felsöfok & $F^{*}$ & $p$ \\
\hline Jó jegyek & $4,61(0,78)$ & $4,76(0,54)$ & $4,76(0,53)$ & $4,77(0,50)$ & 2,02 & 0,11 \\
Magabiztos olvasás & $4,67(0,72)$ & $4,83(0,45)$ & $4,88(0,34)$ & $4,83(0,46)$ & $\mathbf{4 , 4 7}$ & $\mathbf{0 , 0 1}$ \\
Legjobb legyen & $3,95(0,94)$ & $4,11(0,95)$ & $4,17(0,90)$ & $4,24(0,90)$ & 1,93 & 0,12 \\
Szabadidejében olvasson & $3,82(1,09)$ & $4,10(0,83)$ & $4,25(0,85)$ & $4,51(0,73)$ & $\mathbf{1 1 , 5 0}$ & $\mathbf{0 , 0 0 1}$ \\
Megértse, amit olvas & $4,63(0,76)$ & $4,82(0,44)$ & $4,86(0,52)$ & $4,89(0,40)$ & $\mathbf{5 , 5 6}$ & $\mathbf{0 , 0 1}$ \\
Jó olvasás énkép & $4,38(0,87)$ & $4,57(0,73)$ & $4,72(0,52)$ & $4,68(0,63)$ & $\mathbf{6 , 3 3}$ & $\mathbf{0 , 0 1}$ \\
Szabadidős olv. öröme & $4,09(0,99)$ & $4,44(0,75)$ & $4,53(0,77)$ & $4,72(0,58)$ & $\mathbf{1 1 , 7 6}$ & $\mathbf{0 , 0 0 1}$ \\
Válasszon olvasmányt & $4,34(0,89)$ & $4,32(0,77)$ & $4,44(0,72)$ & $4,47(0,70)$ & 1,57 & 0,20 \\
Szépirodalmat is olvas & $3,91(1,10)$ & $3,99(0,88)$ & $4,10(0,93)$ & $4,37(1,00)$ & $\mathbf{5 , 0 0}$ & $\mathbf{0 , 0 0 1}$ \\
\hline
\end{tabular}

*Varianciaanalízis F-próbájának értéke és szignifikanciája. Megjegyzés: A 0,05 szinten szignifikáns eltéréseket félkövér szedés jelzi. Zárójelben a szórások láthatók.

A legmagasabb átlagokat a jegyekkel kapcsolatos, a magabiztos olvasásra vonatkozó és a megértést célzó elvárások esetében találjuk, azonban utóbbi kettő esetében szignifikáns különbség van a szülők között az elvárások erősségét illetően az apa iskolai végzettsége szerint. A legfeljebb általános iskolát végzett szülők kevésbé várják gyermeküktől, hogy magabiztosan olvasson, mint magasabb iskolai végzettségü szülőtársaik, és szintén ők azok, akik valamelyest alacsonyabb elvárásokat kommunikálnak a megértés követelményét illetően is.

A szabadidős olvasás igénye szintén a magasabban képzett apák családjaiban jelenik meg erőteljesebben: szignifikáns különbséget találtunk a legfeljebb általános iskola nyolc osztályát végzett és a szakiskolai végzettségü szülők, valamint a maximum érettségivel rendelkező és felsőfokú végzettségú szülők között is. A szépirodalom olvasása az elvárások közül az egyik legkevésbé támogatott, habár még így is minden részmintában 3,9 fölötti átlaggal ren- 
delkező követelmény, ami az egyetemi vagy a főiskolai végzettségü szülőknél ismét erőteljesebben megjelenik, mint a többieknél.

Az az elvárás, hogy a gyermek jó jegyeket vigyen haza olvasásból vagy irodalomból, szinte minden szülő számára kiemelkedően fontos; a különböző iskolai végzettségü szülök között nincs szignifikáns különbség e tekintetben. A gyermek teljesítménycéljára vonatkozó elvárás az, hogy a tanuló vágyai között szerepeljen a legjobbak közé tartozás olvasásból/irodalomból, már kevésbé fontos a kutatásban részt vevő szülök számára: az átlagok itt az előzőhöz képest alacsonyabbak minden részminta esetében. Szintén nem találunk különbséget a részminták között a saját olvasmányválasztásra vonatkozó elvárás kapcsán.

Az olvasásteljesítménnyel és olvasási motivációval kapcsolatos szülői elvárások, valamint az olvasási motívumok közötti kapcsolat feltárása céljából korrelációelemzést végeztünk. Az eredményeket a 80. táblázatban közöljük. A korrelációs együtthatók alapján az egyes elvárások és az egyes motívumok közötti kapcsolat legtöbb esetben szignifikáns, azonban az összefüggés erőssége legtöbb esetben gyenge, legfeljebb közepes erősségü. Az egyes elvárások legszorosabban a kapcsolódó motívumokkal korrelálnak, így például a jó olvasás énképre vonatkozó követelmény 0,22 szinten korrelál a tanuló olvasási énképével, és ugyanilyen erősségü összefüggés mutatható ki a szabadidős olvasással kapcsolatos szülői elvárások és tanulói attitüdök között is.

Meglepő módon a teljesítménycélok egyetlen szülői elvárással sem mutatnak szignifikáns korrelációt, viszont az elkerülő célok gyenge negatív összefüggésben állnak szinte valamennyi szülői elvárással. Még a tipikusan teljesítménycélokra utaló elvárások, mint például a jó jegyekkel és a legjobbak közé történő bekerüléssel kapcsolatos követelmények is inkább az olvasásnak tulajdonított értékkel és az énképpel mutatnak összefüggést. A szülő elvárások tehát a tanulók az érték- és elvárásmotívumaiban képeződnek le, és nem feltétlenül az extrinzik motívumokat erősítik. 
80. táblázat. A szülői elvárások és a tanulók olvasási motívumainak összefüggései

\begin{tabular}{|c|c|c|c|c|c|c|c|c|c|c|}
\hline $\begin{array}{c}\text { Olvasási motí- } \\
\text { vumok }\end{array}$ & Énkép & $\begin{array}{l}\text { Szoc. } \\
\text { mot. }\end{array}$ & $\begin{array}{l}\text { Attitüd } \\
\text { szab. }\end{array}$ & $\begin{array}{l}\text { Attitüd } \\
\text { iskolai }\end{array}$ & Érték & $\begin{array}{l}\text { Elsaj. } \\
\text { cél }\end{array}$ & Telj. cél & $\begin{array}{l}\text { Elker. } \\
\text { cél }\end{array}$ & Flow & $\begin{array}{l}\text { Anti- } \\
\text { flow }\end{array}$ \\
\hline Jó jegyek & 0,19 & 0,05 & $0,10 * *$ & 0,06 & 0 & 0,06 & 0,02 & $-0,08^{*}$ & $0,08 *$ & $-0,08 *$ \\
\hline $\begin{array}{l}\text { Magabiztos } \\
\text { olvasás }\end{array}$ & $0,17 * *$ & 0,03 & $0,11 * *$ & 0,07 & $0,13 * *$ & $0,10 * *$ & 0,04 & $-0,07$ & $0,10 * *$ & $-0,10 * *$ \\
\hline Legjobb legyen & $0,28^{* *}$ & $0,10 * *$ & $0,15^{* *}$ & $0,16^{* *}$ & 0,17 & $0,10 * *$ & 0,14 & $-0,15^{* *}$ & $0,13 * *$ & $0,15^{* *}$ \\
\hline $\begin{array}{l}\text { Szabadidejében } \\
\text { olvasson }\end{array}$ & $0,19 * *$ & $0,14 * *$ & $0,22 * *$ & $0,11^{* *}$ & $0,18^{* *}$ & 0,06 & $-0,03$ & $-0,13 * *$ & $0,12 * *$ & $-0,14 * *$ \\
\hline $\begin{array}{l}\text { Megértse, amit } \\
\text { olvas }\end{array}$ & 0,1 & 0,03 & 0,06 & 0,04 & $0,09 *$ & 0,06 & 1 & $-0,07$ & $0,09 *$ & $-0,10 * *$ \\
\hline $\begin{array}{l}\text { Jó olvasás én- } \\
\text { kép }\end{array}$ & $0,22 * *$ & 0,04 & $0,13 * *$ & 0,07 & $0,13 * *$ & $0,07^{*}$ & $-0,01$ & $-0,12 * *$ & $0,10 * *$ & $-0,17 * *$ \\
\hline $\begin{array}{l}\text { Szabadidős olv. } \\
\text { öröme }\end{array}$ & $0,11^{* *}$ & 0,04 & $0,13 * *$ & 0,06 & $0,18^{* *}$ & 0,05 & 0,02 & $-0,07$ & 0,07 & $-0,12 * *$ \\
\hline $\begin{array}{l}\text { Válasszon ol- } \\
\text { vasmányt }\end{array}$ & $0,10^{* *}$ & 0,01 & $0,11 * *$ & 0,02 & 0,01 & 0,03 & $0-, 04$ & $-0,08^{*}$ & $0,09 *$ & $-0,10 * *$ \\
\hline $\begin{array}{l}\text { Szépirodalmat } \\
\text { is olvas }\end{array}$ & $0,12^{* *}$ & $0,12 * *$ & $0,19 * *$ & $0,13 * *$ & $0,17^{* *}$ & $0,08^{*}$ & 0,03 & $-0,12 * *$ & $0,09^{*}$ & $-0,13 * *$ \\
\hline
\end{tabular}

Megjegyzés: ** 0,01 szinten szignifikáns, *0,05 szinten szignifikáns

\subsubsection{Részösszefoglalás: Az otthoni kontextus és összefüggése az olvasási motívumokkal}

A fejezetben az olvasási motívumok fejlödésének két legfőbb kontextusa - az otthoni és az iskolai kontextusok - közül elsőként az otthoni kontextus jellemzőit és olvasási motívumokkal való összefüggéseit elemeztük. Az eredmények szerint a szülök többsége figyelmet fordít gyermeke olvasási képességének fejlesztésére, saját bevallása szerint gyakran végez az iskoláskor elött és után is különböző fejlesztő tevékenységet gyermekével. Jelentős különbségeket találtunk azonban a különböző iskolai végzettségü szülők között az említett tevékenységének végzési gyakoriságát, csakúgy, mint a szülők saját olvasási szokásait és motívumait illetően is. Az alacsonyabb iskolai végzettségü apák családjai szignifikánsan kevesebb fejlesztő tevékenységet végeznek, és maguk is alacsonyabb olvasási motívumokkal rendelkeznek. Hasonlóképp, a legfeljebb általános iskolát végzett szülők alacsonyabb elvárásokat fogalmaznak meg a gyermekük olvasásteljesítményét és olvasási motívumait illetően, míg a legmagasabb elvárásokkal az egyetemet vagy föiskolát végzett szülők rendelkeznek.

Az otthoni kontextus egyes jellemzői a tanulók olvasási motívumaiban is érvényesülnek. Az olvasási szokásokat illetően például a ritkábban vagy kevesebbet olvasó szülő gyermekei például rendre alacsonyabb olvasási motívumokkal rendelkeznek, mint a többet olvasó szülők gyermekei. Az iskoláskor előtti és alatti fejlesztő tevékenységek gyenge összefüggést mutatnak bizonyos olvasási motívumokkal, a szülők által támasztott elvárások azonban már szinte valamennyi motívummal korrelálnak. Míg az egyes fejlesztő tevékenységek, mint pél- 
dául a segítségnyújtás, negatív hatással lehet például a gyerekek olvasási énképére, céljaira, addig az elvárások a pozitív motivációs jellemzőket erösítik. Ennek értelmében arra következtethetünk, hogy a gyermekek olvasási motívumainak fejlődése szempontjából kevésbé a szülők olvasási szokásai, gyermekekkel végzett tevékenységei vagy saját olvasási motívumai, mintsem az általuk a gyermekkel szemben támasztott elvárásai a fontosak.

\section{$5.2 \mathrm{Az}$ iskolai kontextus jellemzői és összefüggése az olvasási motívumokkal}

Az olvasási motívumok és az olvasási képesség fejlesztésének másik legfontosabb kontextusa az iskola. Az iskolai fejlesztő tevékenységek, a pedagógus meggyőződései, az olvasott szövegek jellemzői és az iskolai környezet szinte teljes egésze hatással lehet a tanulók olvasás iránti motiváltságára. A következőkben ezért az iskolai kontextus egyes jellemzőit és azok olvasási motívumokkal való összefüggéseit tárgyaljuk a pedagógusok által kitöltött kérdőívek elemzése alapján.

Az olvasási motívumok kapcsolatát az iskolai kontextus és fejlesztés egyes aspektusaival osztályszintü vizsgálatok keretében elemeztük, azaz azt vizsgáltuk, hogy a pedagógus és a gyermekek által végzett tevékenységek és az őket körülvevő környezet milyen hatással van az osztály mint csoport egészére. Az alábbi összefüggés-elemzések ennek megfelelően a kutatásban résztvevő 41 osztály olvasási motívumainak átlagán és az őket tanító egyes pedagógusok - tanítók illetve magyar nyelv és irodalom szakos tanárok - válaszain alapulnak. Az évfolyamonkénti részminták között a részt vevő pedagógusok életkora alapján a Kruskal-Wallis-próba eredményei szerint nincsen szignifikáns különbség.

81. táblázat. A pedagógusok mintájának korcsoportonkénti elemszáma és a pedagógusok életkorának a KruskalWallis próba alapján számitott szignifikanciája

\begin{tabular}{lcccc}
\multicolumn{1}{c}{ Korcsoport } & $n$ & Rangátlag & $\chi^{2}$ & $p$ \\
\hline 4. osztály & 12 & 20,42 & & $0,77^{\mathrm{NS}}$ \\
6. osztály & 14 & 18,27 & 0,53 & \\
8. osztály & 15 & 21,25 & & \\
\hline \hline
\end{tabular}

Megjegyzés: NS: nem szignifikáns

\subsubsection{Az olvasástanítás jellemzői és összefüggése az olvasási motívumokkal}

Az olvasástanítás jellemzői alatt azokat a tevékenységeket értjük, amelyeket a pedagógus végez/végeztet a diákokkal az olvasás-szövegértés képesség fejlesztése céljából, továbbá ezek megszervezésének, kivitelezésének és ellenőrzésének formáit.

Az olvasástanítással kapcsolatos első kérdésünk a tanári kérdőívben a mennyiségi mutatókra koncentrál. Arra irányult, hogy adott pedagógus hetente általában mennyi időt fordít olvasásfejlesztésre. A kapott válaszok szerint a kutatásban résztvevő pedagógusok átlagosan 2,8 órát fordítanak a tanulók olvasás-szövegértés képességének fejlesztésére. A minimum óra- 
szám, amely a pedagógusok válaszaiban megjelent, az egy óra volt, a maximum pedig hét. Átlagosan a negyedikes osztályt tanító pedagógusok fordítják a legtöbb időt az olvasásra (átlag=5,00; szórás=1,29), a legkevesebbet pedig a nyolcadik osztályokat tanító pedagógusok (átlag=1,43; szórás=1,09), habár ez utóbbi csoport és a hatodik évfolyam tanárai között (átlag=1,62; szórás=1,19) szignifikáns különbség nem mutatható ki e tekintetben. Jelentős a különbség ugyanakkor a negyedik és a hatodik, valamint a negyedik és a nyolcadik évfolyam között: az átlagok között több, mint háromórányi a különbség.

A ráfordított idő mennyiségének drasztikus csökkenése a felső tagozatban egyrészt magyarázható a tantárgyi rendszer változásával, az olvasásóra felső tagozatban való megszünésével, másrészt a pedagógusok megváltozott funkciójával. Alsó tagozatban egy adott osztály számára az osztálytanító tanítja szinte valamennyi tárgyat, így sokkal inkább lehetősége van a tanítási-tanulási folyamaton belül az idő beosztására, a tantárgyakon átívelő fejlesztési feladatok ellátására. Felső tagozatban a magyar nyelv és irodalom szakos pedagógus a rábízott órakerettel gazdálkodhat csupán. Tekintve azonban, hogy a magyar nyelv és irodalom tantárgyak nagy óraszámban tanult tárgyak az általános iskola felső tagozatában, a tanárok válaszaiban megjelenő olvasásfejlesztésre fordított időkeret meglepően alacsony.

Az iskolai olvasástanulás mennyiségi mutatója mellett minőségi szempontból is elemezzük az osztályok és a pedagógusok közötti különbségeket. Elsőként az olvasástanítás során alkalmazott tanulásszervezési formák megjelenési gyakoriságát vizsgáljuk az 53. számú ábra alapján.

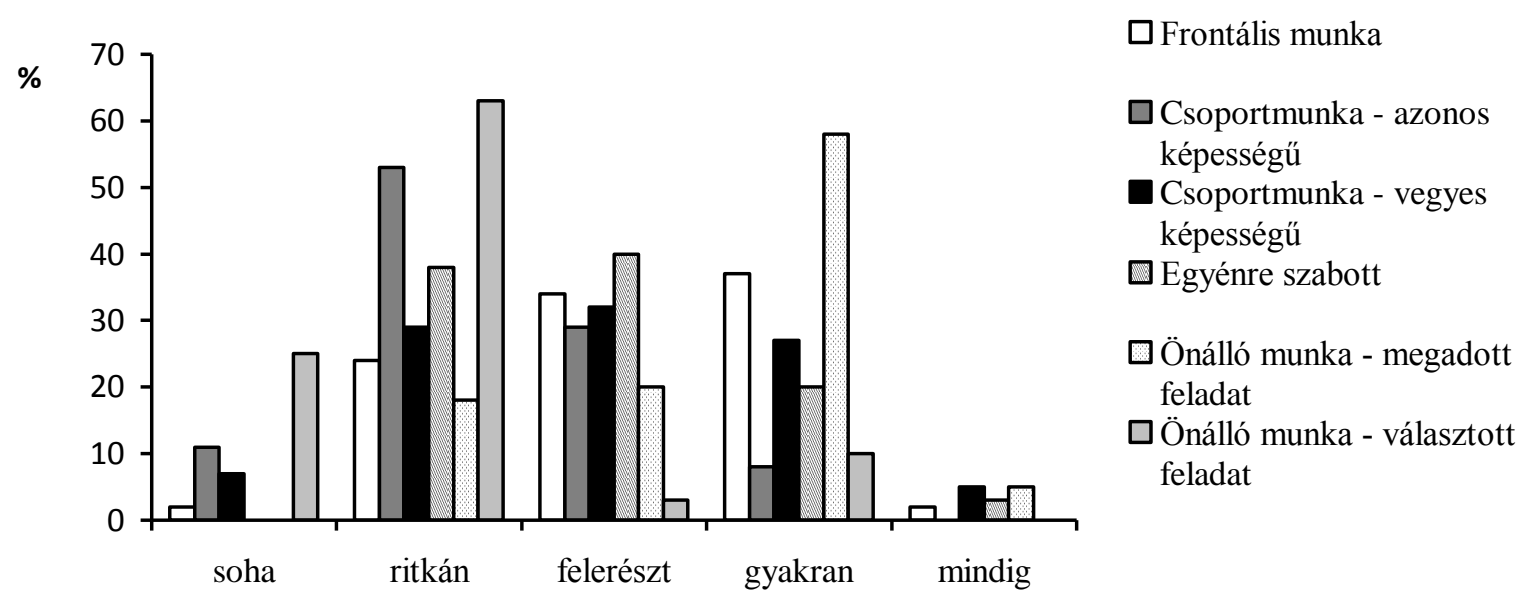

53. ábra

A különbözö tanulásszervezési formák alkalmazási gyakorisága

Az olvasás szociális motívumainak müködése szempontjából kiemelkedő fontosságú, hogy a tanulóknak legyen lehetőségük az olvasmányélmények megosztására, az együttmüködésre és a közös olvasásra, ezért a csoportmunka alkalmazása az olvasásórán hozzájárulhat a szociális motívumok fejlődéséhez.

A tanulói autonómia biztosítása, az önállóság támogatása az önhatékonyság szempontjából fontos, míg a képesség-kihívás egyensúlyának biztosítását szolgáló egyénre szabott fel- 
adatok az intrinzik motívumok müködését támogatják. A szabad olvasmány- és feladatválasztás számos olvasási motivációt célzó fejlesztő program része, az olvasóvá nevelés alapja.

E feltételezésekből kiindulva kérdőívünkben a legelterjedtebb tanulásszervezési forma, a frontális oktatás mellett az azonos képességfejlettségü tanulókkal és az eltérő képességfejlettségü tanulókkal csoportban végzett olvasási tevékenységek, valamint az autonómiát és intrinzik motivációt támogató tanulásszervezési formák gyakoriságára is rákérdeztünk. Az eredmények azt mutatják, hogy a pedagógusok saját bevallásuk szerint az olvasásszövegértés tanítását elöre megadott önálló munkát igénylő feladatokon keresztül valósítják meg. Ezt követi gyakoriság szempontjából a frontális munka, majd a vegyes képességü tanulókból szervezett csoportban folyó munka. A megkérdezett pedagógusok egynegyede saját bevallása szerint soha nem ad lehetőséget a tanulóknak, hogy saját maguk választotta olvasási feladaton dolgozzanak, 63\%-uk csak ritkán teszi ezt. A pedagógusok többsége a kiadott olvasás feladatok felét (40\%) vagy annál kisebb arányát (38\%) szabja az egyén igényeinek megfelelöre.

Az egyes tanulásszervezési formák gyakoriságának összefüggését a tanulók olvasási motívumainak fejlettségével a 82. táblázat tartalmazza. A két leggyakrabban alkalmazott munkaforma, a frontális munka és az előre megadott feladaton történő önálló munka, összefüggést mutat több motívummal is. A frontális munka közepes erősségü pozitív összefüggést mutat az elkerülő célokkal és szintén közepes erősségü, de negatív kapcsolatot a flow élmények gyakoriságával. Ennek értelmében azok az osztályok, ahol a pedagógus gyakrabban alkalmaz frontális munkát olvasásfejlesztés során, gyakrabban követnek elkerülö célokat és kevesebb áramlatélményt élnek át olvasás közben. A másik népszerü munkaforma, az önálló feladatvégzés, ha az a tanár által megadott feladatra vonatkozik, erős negatív irányú összefüggésben áll az olvasásnak tulajdonított értékkel és, valamivel gyengébb, de szintén negatív irányú kapcsolatban az elsajátítási célokkal és a flowval. Azok az osztályok tehát, ahol a pedagógus gyakran alkalmazza ezt a munkaformát, szignifikánsan kevesebb értéket tulajdonítanak az olvasásnak, ritkábban céljuk feladatvégzés közben a megértés, az elsajátítás és szintén kevesebb alkalommal élik át a teljes elmélyülés érzését olvasás közben.

A csoportmunka két megvalósítási formája ezzel szemben pozitív összefüggésben áll egy-egy motívummal. Az azonos képességü tanulókból alakított csoportokban történő feladatmegoldás olvasásórán együtt jár az olvasásnak való magasabb értéktulajdonítással, a vegyes csoportokban történő munka pedig az erősebb elsajátítási célokkal.

A regresszióanalízis eredményei szerint a frontális munka alkalmazásának gyakorisága az elkerülő célok varianciájának mintegy $22 \%$-áért, a tanár által választott feladat önálló végzésének gyakorisága 13\%-áért felelős. Az osztályok által az olvasásnak tulajdonított érték varianciáját a megadott feladaton való önálló feladatvégzés gyakorisága 31\%-ban magyarázza. A flow élményre szintén az önálló feladatvégzés van negatív, az antiflow élményre a frontális munka és az önálló feladatvégzés gyakorisága van pozitív hatással. Ugyanakkor az egyénre szabott feladatok hátráltatják az antiflow élmény kialakulását. 
82. táblázat. A tanulásszervezési formák és az olvasási motívumok összefüggései

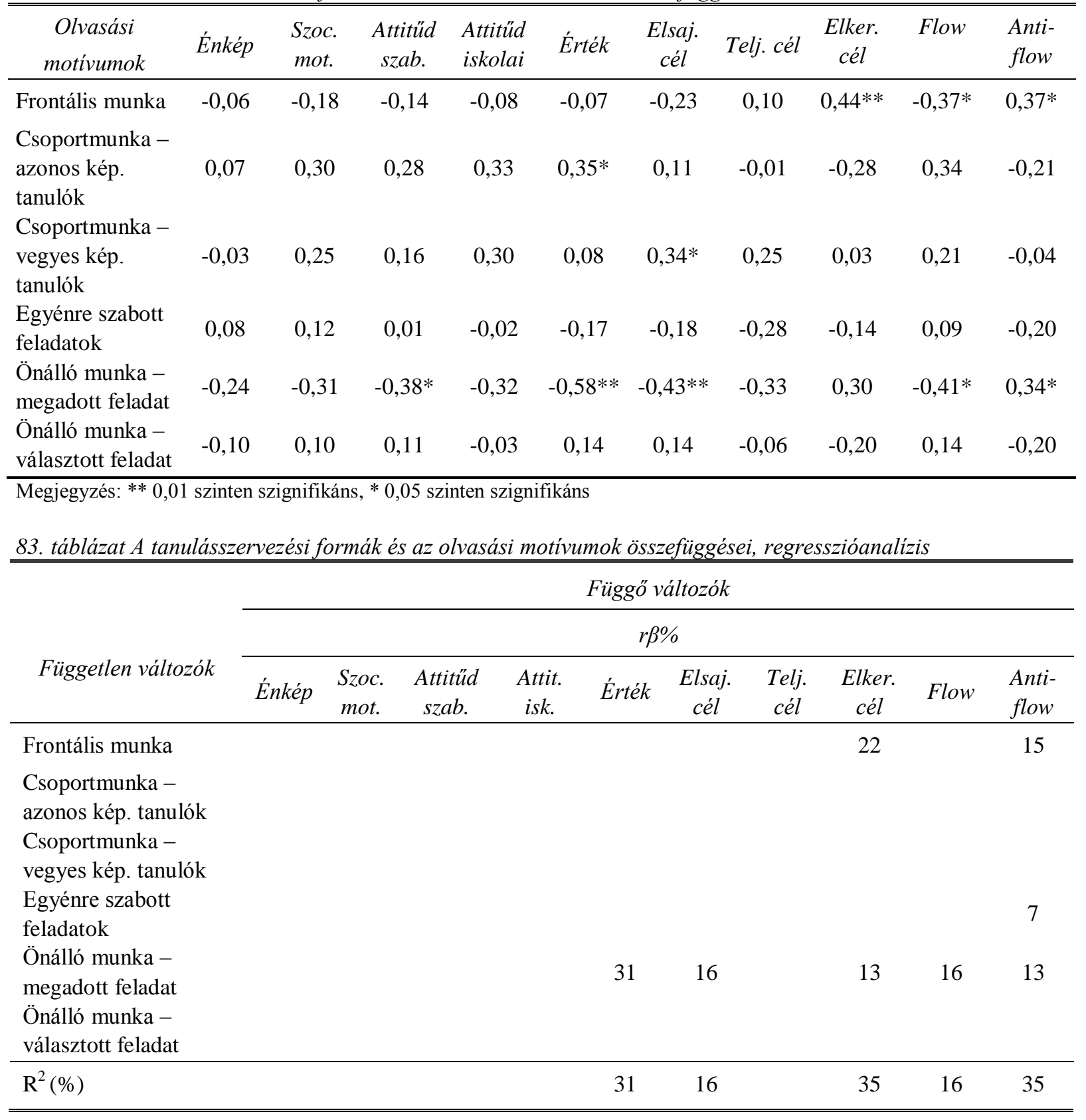

A szövegek megismerésének lehetőségei (54. ábra) közül a hangos és a néma olvasás körülbelül ugyanolyan gyakorisággal jelennek meg olvasás-, illetve (vagy) magyar nyelv és irodalom órán, de a pedagógusok közel 60\%-a maga is mindennap vagy majdnem minden nap felolvas az osztálynak. A hangos olvasás gyakoroltatásának népszerübb módja, amikor egy tanuló az egész osztálynak olvas fel, a tanulói csoportokban történő hangos olvasás ritkábban jelenik meg. A megkérdezett pedagógusok többsége heti vagy havi rendszerességgel tanít különböző olvasási stratégiákat, de jelentős azoknak is az aránya, akik csak félévente egyszer vagy kétszer (25\%), valamint soha vagy majdnem soha (8\%) nem fordítanak időt erre. A saját kérdések 
megfogalmazásának ösztönzése a pedagógusok 35\%-nak szintén nem tartozik a heti rendszerességgel alkalmazott eszköztárába.

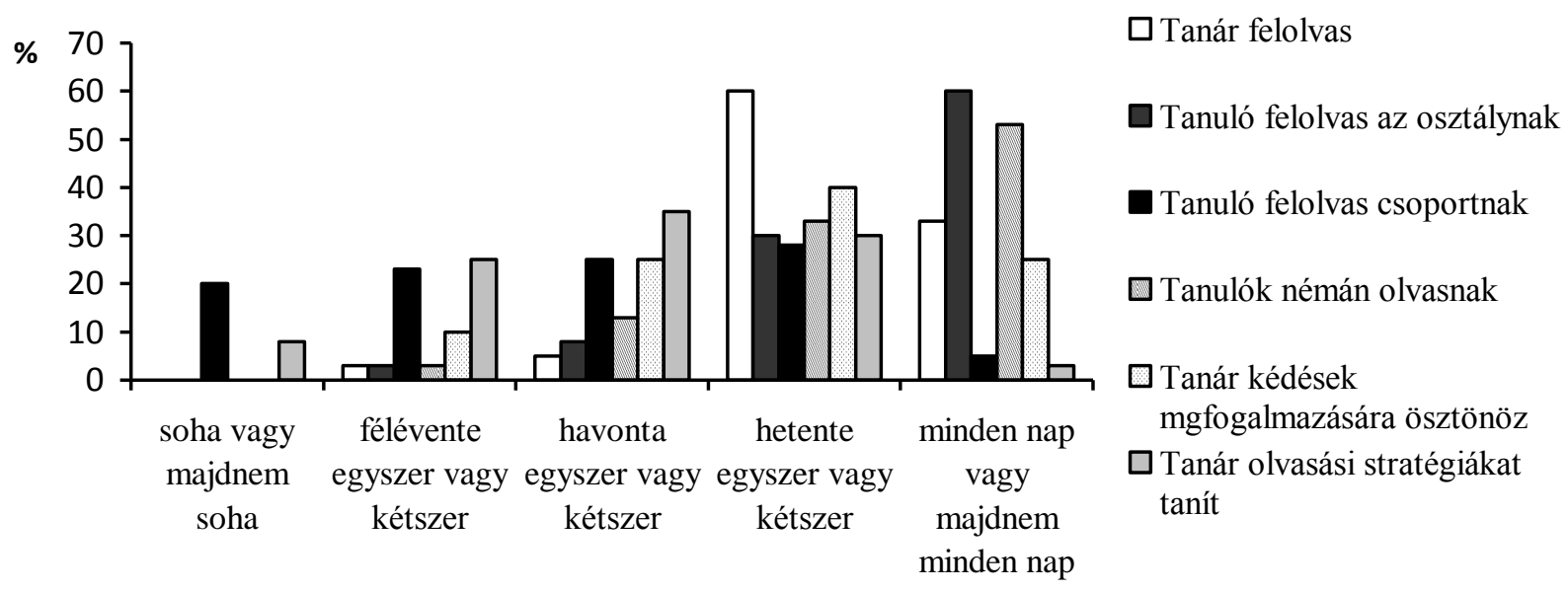

54. ábra

A szövegek megismerési, feldolgozási formáinak gyakorisága

A fenti tevékenységek végzésének gyakorisága és az osztály tanulóinak átlagos motívumfejlettsége között egyetlen esetben találtunk csupán szignifikáns összefüggést, ezért a korrelációs táblázatot ez esetben nem közöljük. Az egyetlen szignifikáns összefüggés az osztálynak történő hangos olvasás gyakorisága és az elkerülö célok között mutatkozott meg. E szerint azok az osztályok, ahol a pedagógus gyakrabban kéri a tanulókat, hogy olvassanak fel hangosan az egész osztály elött, gyakrabban követnek elkerülő célokat, azaz többször igyekeznek távol maradni a teljesítményszituációktól és az energia befektetéstől.

Az olvasott szövegek megértésének ellenőrzése céljából a legtöbb pedagógus leggyakrabban a szöveggel kapcsolatos kérdések szóbeli megválaszolását igénylő feladatokat alkalmaz: a pedagógusok 85\%-a válaszolt úgy, hogy mindennap vagy szinte mindennap él ezzel a lehetőséggel. Szintén népszerűek az írásbeli válaszadást igénylő technikák, valamint az olvasottakról való szövegalkotás. A beszélgetés kezdeményezése, az egyéni vagy csoportos alkotások készítésének ösztönzése és a vita generálása a ritkábban alkalmazott módszerek közé tartoznak (55. ábra). 


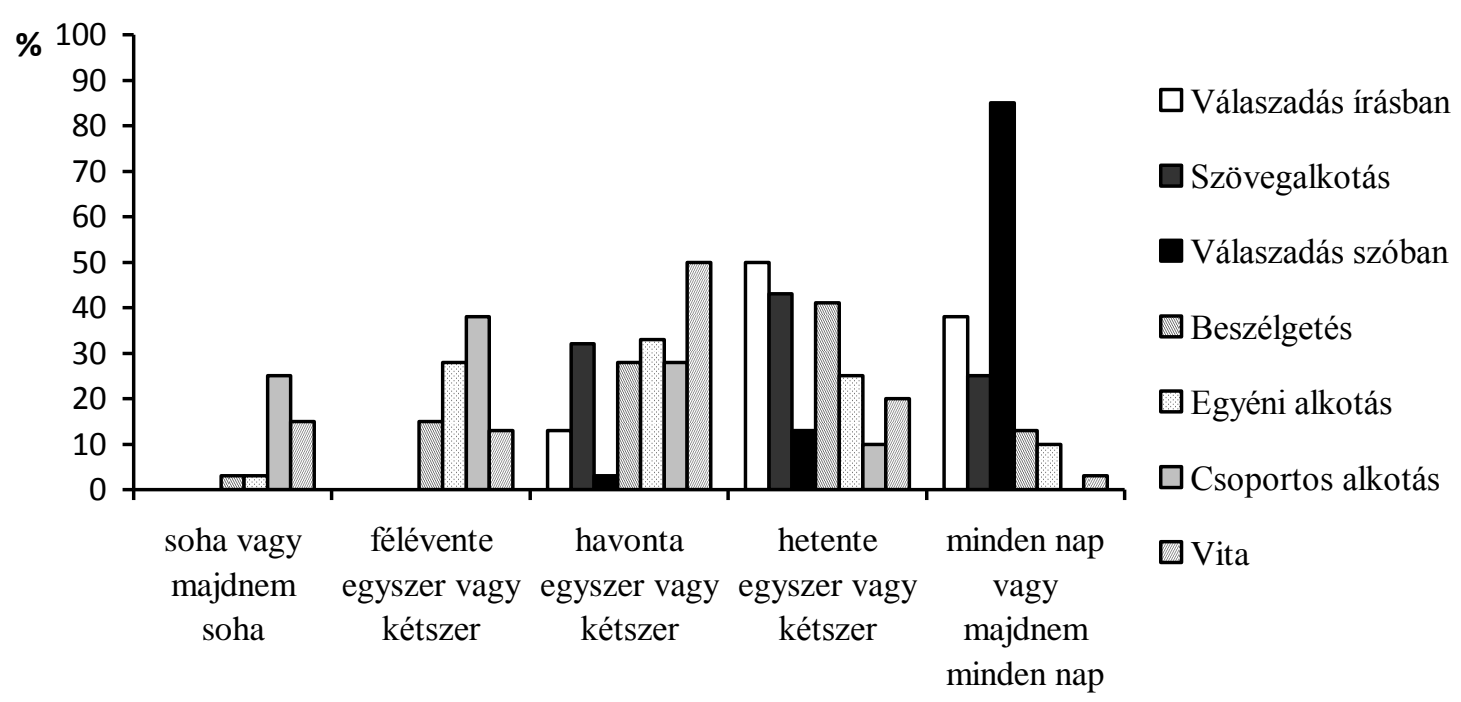

55. ábra

A szöveg megértésének ellenőrzési módjai, gyakoriságok

A feldolgozási formák és az osztály olvasási motívumainak fejlettsége között kevesebb összefüggést találunk, mint a munkaformák és a motívumok között (83. táblázat). A szöveggel kapcsolatos kérdésekre való írásban történő válaszadás három motívummal, a szóbeli válaszadás pedig két motívummal mutat szignifikáns összefüggést. A szöveg alapján történő csoportos alkotás készítése egy motívummal korrelál szignifikánsan.

Az összefüggések közül az írásban és szóban történő válaszadás is negatív motivációs jellemzőkkel jár együtt. E technikák gyakoribb alkalmazása esetén a tanulók gyakrabban követnek elkerülő célokat, valamint élnek át antiflow élményeket. Az írásos válaszadás gyakoribb alkalmazása a flow élmények csökkent gyakoriságával jár együtt. A csoportos alkotás ezzel szemben pozitív összefüggést mutat a teljesítménycélokkal, azaz azok az osztályok, amelyek esetében a pedagógus gyakrabban ad olyan olvasás feladatot, melynek keretén belül csoportban kell valamit alkotniuk, szignifikánsan gyakrabban követnek teljesítménycélokat.

Az említett összefüggések mindegyike esetében a regresszióanalízisek eredményei szerint hatásmechanizmusról is beszélhetünk, ahol az alkalmazott módszerek vannak hatással a tanulók motívumaira és nem fordítva. A viszonylag alacsony számú szignifikáns $r \beta$-érték miatt a regresszióanalízis eredményeit táblázatos formában nem közöljük. 
84. táblázat. A szövegértés ellenörzésének módjai és az olvasási motívumok összefüggése

\begin{tabular}{lcccccccccc}
\hline \multicolumn{1}{c}{$\begin{array}{c}\text { Olvasási } \\
\text { motívumok }\end{array}$} & Énkép & $\begin{array}{c}\text { Szoc. } \\
\text { mot. }\end{array}$ & $\begin{array}{c}\text { Attitüd } \\
\text { szab. }\end{array}$ & $\begin{array}{c}\text { Attitüd } \\
\text { iskolai }\end{array}$ & Érték & $\begin{array}{c}\text { Elsaj. } \\
\text { cél }\end{array}$ & $\begin{array}{c}\text { Telj. } \\
\text { cél }\end{array}$ & $\begin{array}{c}\text { Elker. } \\
\text { cél }\end{array}$ & $\begin{array}{c}\text { Flow } \\
\text { Anti- } \\
\text { Válaszadás írásban }\end{array}$ \\
\hline Szövegalkotás & $-0,15$ & $-0,33$ & $-0,31$ & 0,11 & $-0,28$ & $-0,06$ & 0,11 & $0,49 * *$ & $-0,36^{*}$ & $0,59^{* *}$ \\
Válaszadás szóban & $-0,04$ & 0,18 & 0,11 & 0,13 & 0,24 & $-0,05$ & 0,09 & 0,07 & $-0,16$ & 0,13 \\
Beszélgetés & $-0,17$ & $-0,25$ & $-0,36^{*}$ & $-0,14$ & $-0,31$ & $-0,23$ & $-0,03$ & $0,47 * *$ & $-0,18$ & 0,27 \\
Egyéni alkotás & 0,02 & 0,02 & $-0,06$ & $-0,11$ & $-0,23$ & 0,13 & 0,09 & 0,02 & 0,04 & $-0,03$ \\
Csoportos alkotás & $-0,31$ & 0,04 & $-0,03$ & 0,05 & 0,31 & 0,15 & 0,27 & 0,17 & $-0,10$ & 0,13 \\
Vita & $-0,16$ & 0,11 & 0,04 & 0,04 & 0,27 & 0,22 & $0,36 *$ & 0,08 & 0,12 & $-0,08$ \\
\hline \hline
\end{tabular}

Megjegyzés: ** 0,01 szinten szignifikáns, *0,05 szinten szignifikáns

\subsubsection{Az olvasott szövegek jellemzői, alkalmazásuk és összefüggésük az olvasási motívumokkal}

Az olvasott szöveg jellemzői feltételezhetően aktuálisan hatnak a tanulók olvasás iránti motiváltságára. Az azonban, hogy rendszeresen milyen szövegekkel találkoznak a diákok, hosszú távon is befolyásolhatja motívumaik alakulását, az olvasás iránti érdeklődésük alakulását. A szövegekkel kapcsolatos első kérdésünk az alkalmazott szövegek forrására vonatkozott, azaz arra, hogy milyen forrásból választják ki a pedagógusok az órán olvasott szövegeket. Az 55. ábrán a különböző források használatának gyakoriságát láthatjuk a pedagógusok válaszai alapján. A legnépszerübb források egyértelmüen a tankönyvek, ezt követik a szöveggyüjtemények és olvasókönyvek, valamint a munkafüzetek és munkalapok. Lényegesen ritkábban használnak a tanárok és tanítók különböző gyermek- és képes újságból származó szövegeket, valamint internetes szövegeket. A legnépszerütlenebbek az olvasásoktató számítógépes szoftverek: a pedagógusok 73\%-a soha vagy majdnem soha nem alkalmazza ezeket. 


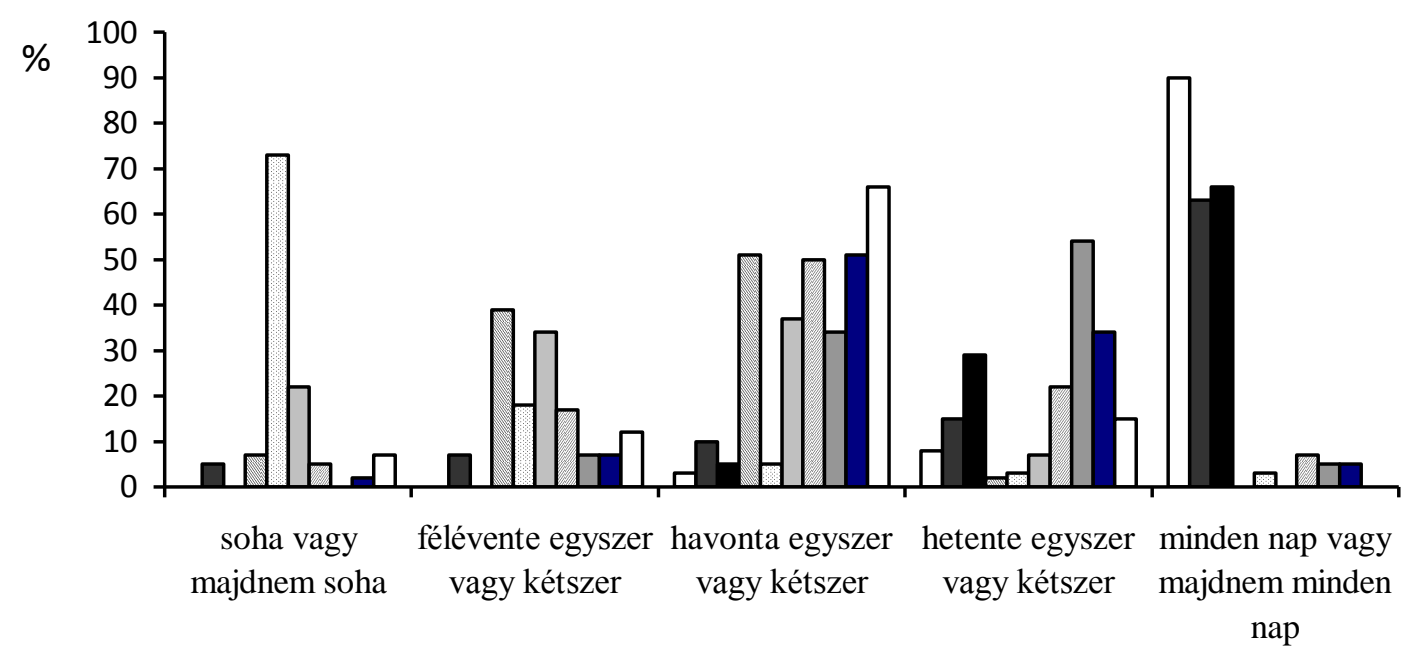

Tankönyv

Munkafüzet, munkalap

$\square$ Számítógépes szoftver

$\square$ Gyermekirodalom

— Más tantárgyak szövege
Szöveggyűjtemény vagy olvasókönyv

$\square$ Gyermek- és képes újságok

$\square$ Internetes szöveg

$\square$ Ismeretterjesztő szöveg

$\square$ Tanulók által írt szöveg

56. ábra

A források használatának gyakorisága

A források használata és az osztály olvasási motívumai közötti összefüggés feltárása érdekében korrelációelemzést végeztünk, melynek eredményeit a 85. táblázatban közöljük. Összességében véve elmondható, hogy azokban az osztályokban, ahol a gyakrabban használják a tankönyveket, a tanulók olvasási motívumai átlagosan alacsonyabbak. Igaz ez az olvasási énképre, az olvasás szociális motívumaira, a szabadidős olvasás iránti attitűdre, és az olvasásnak tulajdonított értékre is. Ezzel szemben a tanárok többsége által ritkán vagy szinte soha nem alkalmazott számítógépes szoftverek alkalmazása azokban az osztályokban, ahol ez előfordul, pozitívabb iskolai olvasás iránti attitűdökkel és az olvasásnak tulajdonított magasabb értékkel jár együtt. 
85. táblázat A források használata és az olvasási motívumok összefüggései

\begin{tabular}{|c|c|c|c|c|c|c|c|c|c|c|}
\hline $\begin{array}{c}\text { Olvasási } \\
\text { motívumok }\end{array}$ & Énkép & $\begin{array}{l}\text { Szoc. } \\
\text { mot. }\end{array}$ & $\begin{array}{l}\text { Attitüd } \\
\text { szab. }\end{array}$ & $\begin{array}{l}\text { Attitüd } \\
\text { iskolai }\end{array}$ & Érték & $\begin{array}{l}\text { Elsaj. } \\
\text { cél }\end{array}$ & Telj. cél & $\begin{array}{l}\text { Elker. } \\
\text { cél }\end{array}$ & Flow & $\begin{array}{l}\text { Anti- } \\
\text { flow }\end{array}$ \\
\hline Tankönyv & $-0,34 * *$ & $-0,36 * *$ & $-0,47 * *$ & $-0,22$ & $-0,53 * *$ & $-0,27$ & $-0,19$ & 0,28 & $-0,26$ & 0,23 \\
\hline $\begin{array}{l}\text { Szöveg- } \\
\text { gyüjtemény, } \\
\text { olvasókönyv }\end{array}$ & 0,02 & $-0,08$ & 0,01 & 0,12 & $-0,21$ & $-0,02$ & $-0,01$ & 0,04 & 0,04 & $-0,09$ \\
\hline $\begin{array}{l}\text { Munkafüzet, } \\
\text { munkalap }\end{array}$ & 0,01 & 0,06 & $-0,03$ & 0,30 & 0,02 & 0,21 & 0,13 & 0,06 & 0,05 & $-0,14$ \\
\hline $\begin{array}{l}\text { Gyermek- és } \\
\text { képes újságok }\end{array}$ & $-0,13$ & $-0,06$ & $-0,08$ & 0,23 & 0,05 & 0,14 & 0,15 & 0,02 & 0,17 & $-0,01$ \\
\hline $\begin{array}{l}\text { Számítógépes } \\
\text { szoftver }\end{array}$ & 0,22 & 0,24 & 0,31 & $0,50 * *$ & $0,47 * *$ & 0,29 & 0,19 & $-0,18$ & 0,30 & $-0,12$ \\
\hline $\begin{array}{l}\text { Internetes szö- } \\
\text { veg }\end{array}$ & $-0,14$ & $-0,09$ & $-0,09$ & 0,17 & 0,24 & 0,25 & 0,24 & 0,02 & 0,14 & $-0,02$ \\
\hline $\begin{array}{l}\text { Gyermekiroda- } \\
\text { lom }\end{array}$ & $0,35^{*}$ & $-0,01$ & 0,21 & $-0,01$ & 0,20 & 0,14 & 0,25 & 0,04 & 0,14 & $-0,14$ \\
\hline $\begin{array}{l}\text { Ismeretterjesztő } \\
\text { szöveg }\end{array}$ & 0,21 & 0,14 & 0,22 & 0,19 & 0,14 & 0,16 & 0,12 & 0,09 & 0,05 & 0,01 \\
\hline $\begin{array}{l}\text { Más tantárgy } \\
\text { szövegei }\end{array}$ & 0,15 & 0,12 & 0,03 & 0,17 & 0,10 & $0,39 *$ & $0,35^{*}$ & 0,13 & 0,14 & $-0,17$ \\
\hline $\begin{array}{l}\text { Tanulók által írt } \\
\text { szövegek }\end{array}$ & 0,04 & $-0,11$ & 0,03 & $-0,01$ & $-0,04$ & $-0,15$ & $-0,24$ & 0,01 & $-0,10$ & $-0,02$ \\
\hline
\end{tabular}

Megjegyzés: ** 0,01 szinten szignifikáns, *0,05 szinten szignifikáns

Ami az egyes szövegtípusok használati gyakoriságát illeti (57. ábra), jobban megoszlanak a pedagógusi válaszok. A legnépszerübb a versek olvastatása: a pedagógusok $78 \%$-a mondta azt, hogy hetente többször vagy akár minden nap olvas verseket tanítványaival. Ezt követik a történetek, a novellák, az elbeszélések és az ismeretterjesztők. A legritkábban alkalmazott szövegtípusok a színdarabok: a pedagógusok 55\%-a állítása szerint a rá bízott tanulók soha vagy szinte soha nem találkoznak ezzel a müfajjal. Hosszabb, fejezetekből álló könyvek szintén csak félévente kerülnek feldolgozásra; feltételezhetően ezek a kötelező olvasmányok.

A különböző szövegtípusok alkalmazásának gyakorisága eredményeink szerint nem mutat szignifikáns összefüggést az egy osztályba járó tanulók olvasási motívumainak átlagával. Az egyetlen kivétel ez alól a hosszabb, fejezetekböl álló könyvek olvasása és az énkép közötti szignifikáns, pozitív irányú kapcsolat (86. táblázat). 


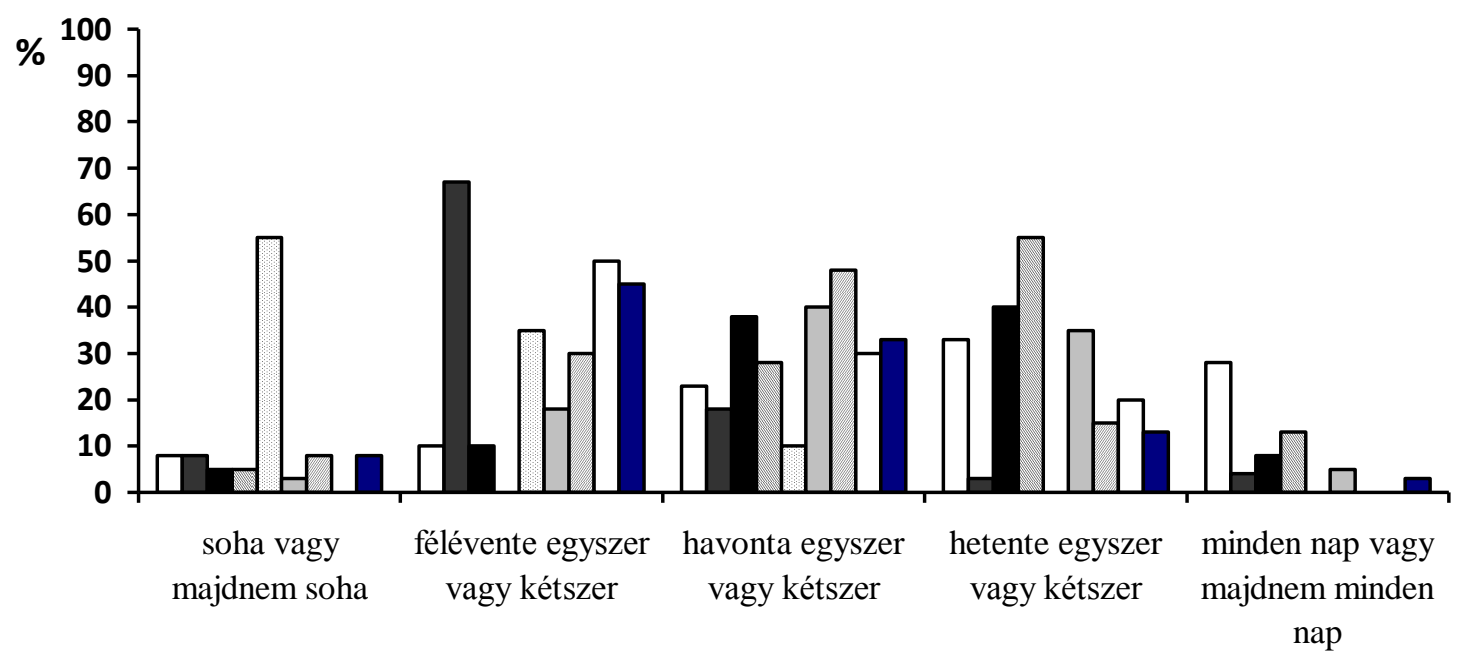

Történetek

Novellák, elbeszélések

$\square$ Színdarabok

$\square$ Használati utasítások
Fejezetekböl álló könyvek

$\square$ Versek

$\square$ Ismeretterjesztők

$\square$ Ábra, diagram, grafikon

Egyéb nem folyamatos szövegek

57. ábra

A különbözö szövegtípusok használatának gyakorisága

86. táblázat. A szövegtípusok és az olvasási motívumok összefüggései

\begin{tabular}{|c|c|c|c|c|c|c|c|c|c|c|}
\hline $\begin{array}{c}\text { Olvasási } \\
\text { motívumok }\end{array}$ & Énkép & $\begin{array}{l}\text { Szoc. } \\
\text { mot. }\end{array}$ & $\begin{array}{l}\text { Attitüd } \\
\text { szab. }\end{array}$ & $\begin{array}{l}\text { Attitüd } \\
\text { iskolai }\end{array}$ & Érték & $\begin{array}{c}\text { Elsaj. } \\
\text { cél }\end{array}$ & $\begin{array}{c}\text { Telj. } \\
\text { cél }\end{array}$ & $\begin{array}{c}\text { Elker. } \\
\text { cél }\end{array}$ & Flow & $\begin{array}{l}\text { Anti- } \\
\text { flow }\end{array}$ \\
\hline Történetek & 0,12 & 0,05 & 0,08 & 0,24 & 0,06 & 0,16 & $0,35^{*}$ & 0,19 & 0,04 & 0,13 \\
\hline $\begin{array}{l}\text { Fejezetekből álló } \\
\text { könyvek }\end{array}$ & $0,46^{* *}$ & 0,03 & 0,23 & 0,16 & 0,04 & 0,11 & 0,17 & 0,01 & 0,02 & $-0,01$ \\
\hline $\begin{array}{l}\text { Novellák, } \\
\text { elbeszélések }\end{array}$ & $-0,26$ & $-0,11$ & $-0,03$ & $-0,20$ & $-0,09$ & $-0,14$ & $-0,06$ & $-0,02$ & $-0,15$ & 0,16 \\
\hline Versek & 0,04 & 0,04 & 0,05 & $-0,25$ & $-0,06$ & $-0,19$ & $-0,21$ & $-0,23$ & $-0,02$ & $-0,12$ \\
\hline Színdarabok & $-0,25$ & 0,16 & 0,16 & $-0,01$ & 0,30 & 0,20 & 0,19 & $-0,26$ & 0,06 & $-0,17$ \\
\hline Ismeretterjesztők & 0,03 & $-0,03$ & $-0,05$ & 0,07 & 0,06 & 0,07 & 0,24 & 0,27 & $-0,08$ & 0,16 \\
\hline $\begin{array}{l}\text { Használati } \\
\text { utasítások }\end{array}$ & $-0,12$ & 0,15 & $-0,02$ & 0,27 & 0,18 & 0,19 & 0,15 & $-0,04$ & 0,14 & $-0,04$ \\
\hline $\begin{array}{l}\text { Ábra, diagram, } \\
\text { grafikon }\end{array}$ & $-0,20$ & $-0,05$ & $-0,21$ & $-0,02$ & $-0,14$ & 0,08 & $-0,07$ & $-0,08$ & 0,05 & 0,05 \\
\hline $\begin{array}{l}\text { Egyén nem folya- } \\
\text { matos szöveg }\end{array}$ & $-0,13$ & 0,02 & 0,02 & $-0,01$ & 0,05 & 0,05 & 0,08 & $-0,16$ & 0,05 & $-0,14$ \\
\hline
\end{tabular}

Megjegyzés: ** 0,01 szinten szignifikáns, *0,05 szinten szignifikáns

Tanári kérdöívünkben rákérdeztünk arra is, hogy az említett szövegeket hogyan dolgozzák fel a tanulók a tanórán, azaz milyen módon igyekszik a pedagógus differenciálni az olvasás- 
szövegértés képességének fejlesztésekor. A pedagógusok 74\%-a saját állítása szerint minden gyermekkel ugyanazokat a szövegeket dolgoztatja fel, de a tanulók különböző sebességgel dolgozhatnak, azaz az időfaktorral való manipulálással igyekszik megvalósítani a differenciálást. 16\%-uk az időfelhasználás mellett arra is gondot fordít, hogy a tanulók eltérő, saját igényeiknek megfelelő szövegeket olvashassanak. 5\% azoknak az aránya, akik bár különböző szövegeket olvastatnak különböző tanulókkal, a tanulók azonos sebességgel dolgoznak az órán, és szintén 5\% azoknak az aránya, akik elmondásuk szerint egyik említett módon sem differenciálnak.

\subsubsection{A pedagógus elvárásai és összefüggésük az olvasási motívumokkal}

Az iskolai, ezen belül az osztálytermi kontextus egy további fontos elemét alkotják a pedagógusok tanítványaik olvasási teljesítményével és motivációjával kapcsolatos elvárásai. A szülők elvárásaihoz hasonló módon a pedagógusok ilyen jellegű meggyőződései is kommunikálódnak a tanulók felé, akik feltételezhetően beépítik azokat saját meggyőződésrendszerükbe.

A tanári kérdőíven néhány általunk megfogalmazott elvárással kapcsolatos egyetértésük vagy egyet nem értésük kifejezésére kértük a pedagógusokat. Ezek az elvárások egyébként megegyeztek a szülői kérdőíven szereplőkkel, így lehetőségünk nyílik az összehasonlításra is. A pedagógusok válaszainak átlagait a 87. táblázatban foglaltuk össze.

87. táblázat A pedagógusok elvárásai

\begin{tabular}{lcc}
\hline \multicolumn{1}{c}{ Elvárások } & Atlag & Szórás \\
\hline Jó jegyek & 4,45 & 0,71 \\
Magabiztos olvasás & 4,93 & 0,27 \\
Legjobbak legyenek & 3,73 & 0,82 \\
Szabadidejükben olvassanak & 4,88 & 0,91 \\
Megértsék, amit olvasnak & 5,00 & 0,00 \\
Jó olvasás énkép & 4,58 & 0,59 \\
Szabadidős olv. öröme & 4,80 & 0,61 \\
Válasszanak olvasmányt & 4,43 & 0,71 \\
Szépirodalmat is olvassanak & 4,48 & 0,68 \\
\hline \hline
\end{tabular}

A megkérdezett pedagógusok többsége általában egyetértett az egyes elvárásokkal, egyetlen kivétellel $(3,73)$ az átlagok 4 fölöttiek. Az egyetlen állítás, amellyel kevésbé értettek egyet a tanítók és tanárok a tanulók azon törekvésére vonatkozó elvárás volt, hogy a legjobbak legyenek az osztályban olvasásból. A pedagógusok fontosabbnak tartják a szabadidős olvasást és a szépirodalom olvasásának igényét is, mint a szülők. Szemben a szülőkkel a megkérdezett pedagógusok valamennyien maximálisan egyetértettek azzal az kijelentéssel, hogy fontos, hogy a tanuló megértse, amit olvas. 
A pedagógusok elvárásai és az általuk tanított osztályok olvasási motívumainak összefüggés-elemzése alapján nem találtunk szignifikáns kapcsolatot a motívumok fejlettsége és az elvárások között. Ennek egyik legfőbb oka lehet, hogy a tanulókkal szemben támasztott elvárások erősségét illetően szinte alig találtunk különbséget a pedagógusok között. További kutatási feladat marad tehát a pedagógusok olvasási motívumokkal kapcsolatos elvárásainak és meggyőződéseinek feltárása, a finomabb különbségek felderítése, valamint ezek olvasási motívumokkal mutatott összefüggéseinek vizsgálata.

\subsubsection{Részösszefoglalás: $A z$ iskolai kontextus és összefüggése az olvasási motívumokkal}

A fejezetben az iskolai kontextus néhány jellemzöjét elemeztük a pedagógusok által kitöltött kérdőívek alapján. A vizsgált jellemzők között szerepeltek az olvasástanítás módszerei, a legygyakrabban alkalmazott tanulásszervezési formák, a fejlesztés alapjául szolgáló források és szövegtípusok, valamint a pedagógus elvárásai a teljesítményt és a motívumfejlődést illetően.

Eredményeink szerint a megkérdezett pedagógusok olvasásfejlesztés során leggyakrabban a frontális munkaformát és az egyéni munkát alkalmazzák. Ez utóbbi esetében legtöbbször a tanulók a tanár által megadott feladaton dolgoznak. A tanítók és tanárok közül csak kevesen és ritkán engedik meg, hogy a tanuló saját maga számára válasszon feladatot vagy olvasmány, az autonómiának kevés teret engednek. Szintén kevés hangsúlyt fektetnek a differenciálásra, többségük az időfaktorral igyekszik differenciálni, azaz szükség esetén engedi, hogy a tanulók tovább dolgozzanak egy-egy feladaton, azaz, hogy saját ütemükben haladjanak. Nem jellemző, hogy a különböző képességfejlettségü tanulóknak különböző feladatot vagy szöveget adnának, ritkán veszik figyelembe az egyéni igényeket.

A munkaformák és tevékenységek gyakorisága és a tanulói motívumok közötti összefüggések elemzése arra is rámutatott, hogy a frontális munkaforma és a megadott feladaton történő egyéni munkavégzés alkalmazásának gyakorisága meglehetősen nagymértékben magyarázza, hogy az osztály mennyi antiflow élményt él át olvasás feladatok végzése közben, illetve, hogy mennyiben követnek elkerülő célokat olvasás közben. Minél magasabb az említett munkaformák aránya az órákon, annál több antiflow élményt él át, valamint annál gyakrabban követ elkerülő célokat az osztály.

A források közül a tankönyvek, a szöveggyüjtemények és olvasókönyvek, valamint a munkafüzetek, munkalapok a legnépszerübbek. A legritkábban használt források a számítógépes oktató szoftverek, holott ezek alkalmazási gyakorisága pozitív összefüggést mutat az iskolai olvasás iránti attitüdökkel és az olvasásnak tulajdonított értékkel is. Az órán alkalmazott szövegtípusok és a tanári elvárások kevésbé hatnak az osztályok olvasási motívumaira, mint a feldolgozás módjai és az alkalmazott munkaforma. 


\section{Kiegészítő vizsgálat: Leendó és gyakorló pedagógusok olvasással és olvasási motivációval kapcsolatos meggyőződései}

A pedagógusok meggyőződéseinek kutatása hosszú múltra tekint vissza. A tanítássaltanulással kapcsolatos meggyőződések nehezen változtathatók és nagyban meghatározzák a pedagógusok osztálytermi tevékenységét (Pajares, 1992). A tanári meggyőződések kutatásai segítenek megérteni, milyen elvek mentén szervezik a tanárok pedagógiai tevékenységüket. Központi mérésünk eredményei szerint a pedagógus módszerei, az általa alkalmazott tanulásszervezési formák hatással vannak az osztályba járó tanulók olvasási motívumaira. Kiegészítő vizsgálatunkban ezért kísérletet tettünk arra, hogy megismerjük, hogyan vélekednek a pedagógusok az olvasásról, az olvasási képességről, mit gondolnak az olvasási motivációról, kit tartanak az olvasás iránt motiváltnak, és hogyan, milyen módszerekkel látják azt fejleszthetőnek.

\subsection{A kiegészítő vizsgálat célja, kérdései és hipotézisei}

Kutatásunk célja a pálya előtt álló és gyakorló tanítók olvasással és olvasási motivációval kapcsolatos meggyőződéseinek vizsgálata. Azért választottuk ezt a két populációt, hogy felderítsük vajon az említett kérdéskörökhöz kapcsolódó vélekedések alakulásában mennyi szerepe van a tanárképzésnek és a gyakorlat nyújtotta tapasztalatnak.

Kutatási kérdéseink:

1. Hogyan értelmezik a pedagógusok és a pedagógusjelöltek az olvasást és az olvasási motivációt?

2. Hogyan látják az olvasás iránt motivált tanulót?

3. Milyen módszereket tartanak megfelelőnek az olvasási motiváció fejlesztésére?

4. Fellelhetö-e különbség a leendő és gyakorló pedagógusok meggyőződései között, milyen szerepet játszik a tapasztalat a meggyőződések alakulásában?

Hipotézisek:

$\mathrm{H}_{1}$ : A pedagógusok és a pedagógusjelöltek is képességként értelmezik az olvasást, melynek két legfőbb komponense a dekódolás és a megértés.

$\mathrm{H}_{2}$ : A pedagógusok és a pedagógusjelöltek is egy szűk definícióját adják az olvasási motivációnak, mely elsősorban bizonyos szövegek iránti érdeklődéssel és az olvasás gyakoriságával azonosítja a jelenséget.

$\mathrm{H}_{3}$ : Az olvasási motiváció definíciójával összhangban a pedagógusok és a pedagógusjelöltek is az érdeklődés felkeltését, a gyerekek számára érdekes szövegek olvastatását tartják majd a legmegfelelőbb eszköznek az olvasási motiváció fejlesztésére. 
$\mathrm{H}_{4}$ : A leendő és gyakorló pedagógusok definíciói és a módszerekkel való egyetértésük mértéke között szignifikáns különbségeket feltételezünk, melyek hátterében a tapasztalat mennyisége áll.

\subsection{Adatfelvétel és mérőeszközök a kiegészítő vizsgálatban}

A kismintás felmérésben 37 tanítási tapasztalattal nem rendelkező másod- és harmadéves tanító szakos hallgató és 60 gyakorló pedagógus vett részt. A gyakorló pedagógusoknak mintegy fele rendelkezett tíz évnél hosszabb gyakorlattal. A nemzetközi mintára fejlesztett Likertskálás tételeket és nyílt végü kérdéseket tartalmazó kérdőívvel történő adatfelvételre 2011 elején került sor (14. melléklet). Az adatfelvétel online történt.

\subsection{A kiegészítő vizsgálat eredményei}

A kérdőív első része két nyílt végü kérdést tartalmazott, melyben arra kértük az alanyokat, hogy definiálják elsőként az olvasást, másodjára pedig az olvasási motivációt. A definíciók elemzését két független személy végezte a tartalomelemzés módszerével. Az olvasásdefiníciók tartalomelemzésének eredményét az 58. és az 59. ábrán közöljük.

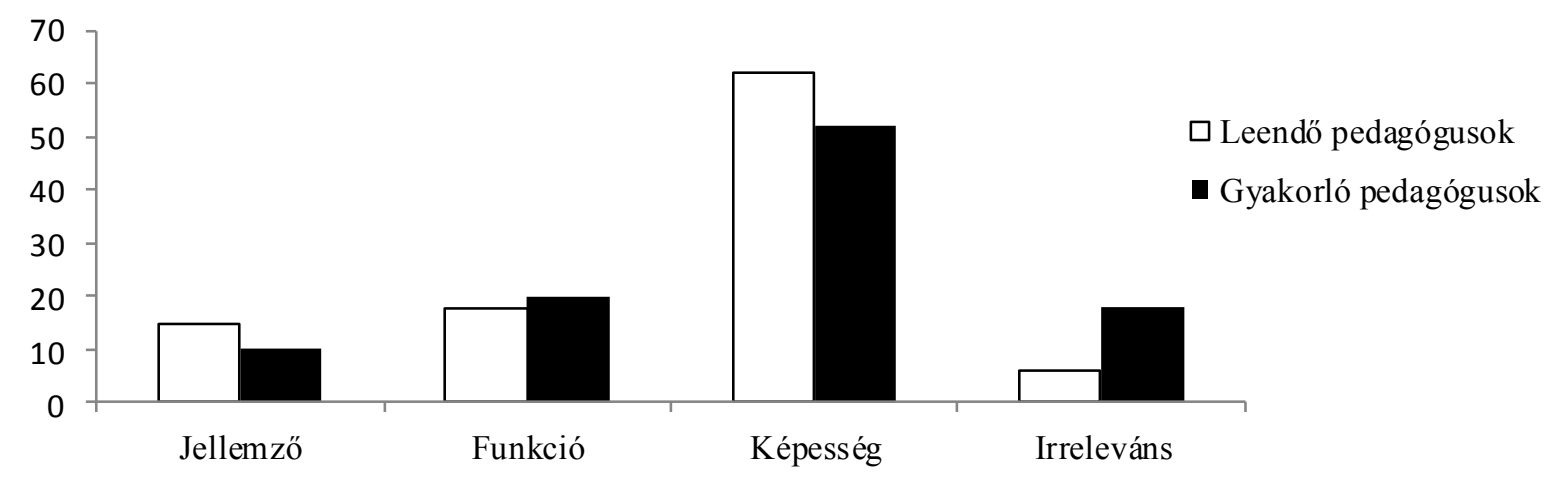

58. ábra

Az olvasás definícióinak tartalomelemzése, átfogó kategóriák

Az olvasás definícióit első lépésként nagyobb kategóriákba soroltuk be aszerint, hogy az olvasást jellemzőjével, funkciójával vagy képességként definiálták az alanyok. A válaszok kategorizálása rámutatott, hogy a leendő és gyakorló pedagógusok többsége is elsősorban képességként definiálta az olvasást. Emellett a leendő pedagógusok 15\%-a, a gyakorló pedagógusoknak pedig 10\%-a azonosította az olvasást valamely jellemzöjével, például ,jobbá teszi a mindennapokat". A pedagógusjelöltek $18 \%$-a, a pedagógusoknak $20 \%$-a valamely funkcióját ragadta meg az olvasásnak, és írta azt például, hogy az olvasás „,az ismeretszerzés eszköze” vagy ,jó szórakozás”. A gyakorló pedagógusoknál kifejezetten magas volt az irreleváns válaszok ará- 
nya (18\%), de a jelöltek között is akadtak többen, akik nem adtak valós definíciót (6\%). Az irreleváns kategóriába soroltuk például az olyan válaszokat, mint ,,a betüt a szemmel összehozni” vagy „,a szövegértés szövegértelmezése”.

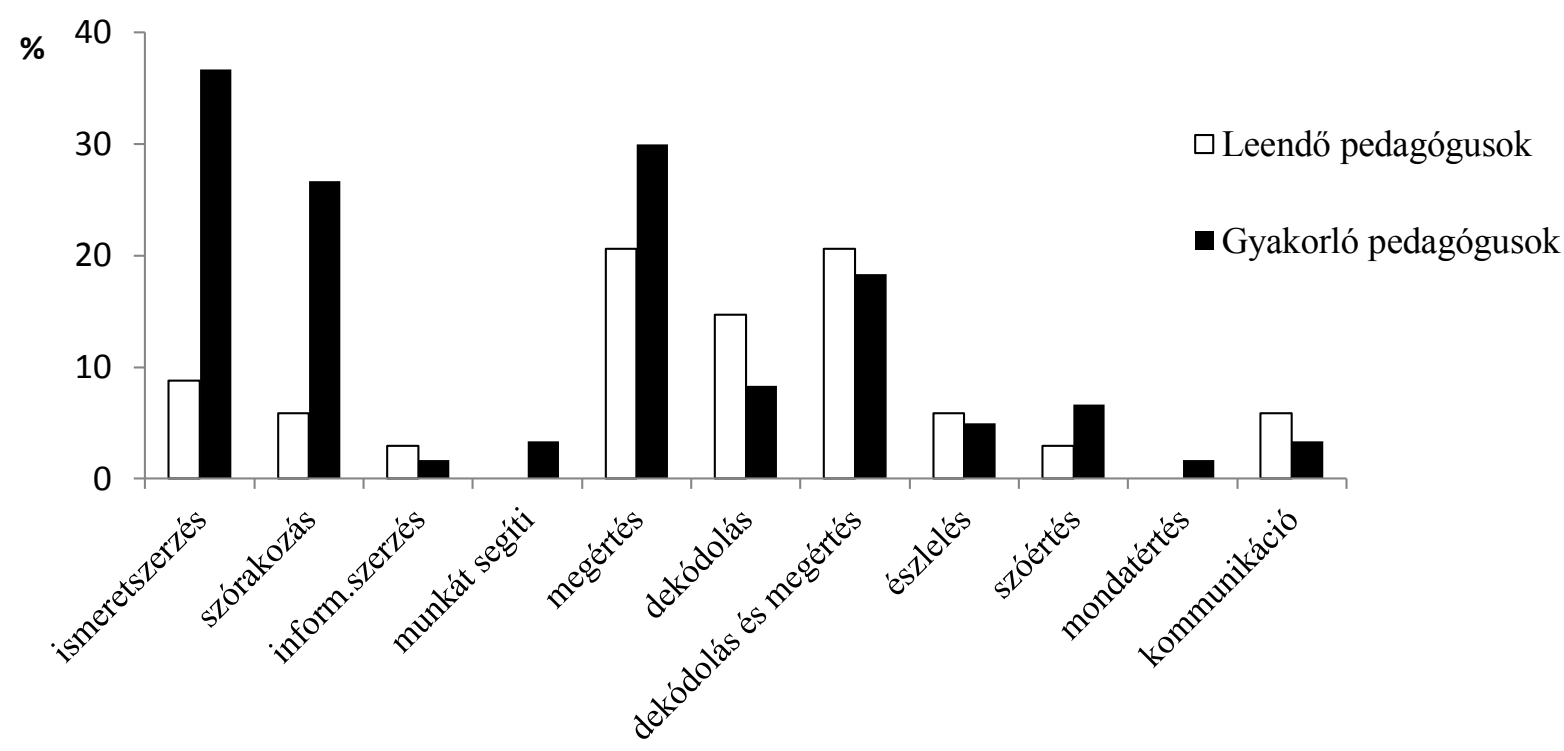

59. ábra

Az olvasás definicióinak tartalomelemzése, részletes kategóriák

A részletes elemzés eredményei szerint a leendő és a gyakorló pedagógusok is leggyakrabban az olvasás ismeretszerző funkcióját emelték ki, amennyiben funkciót említettek. Ennél lényegesen kevesebben értelmezték szabadidős tevékenységként, és mindössze egy-egy fő említette az információszerzést mint az olvasás célját. A pedagógusok és a jelöltek is közel azonos arányban említették a dekódolást és a megértés kettősét, de mindkét csoportban voltak olyanok, akik csak a megértéssel vagy csak a dekódolással azonosították az olvasást (60. ábra). 


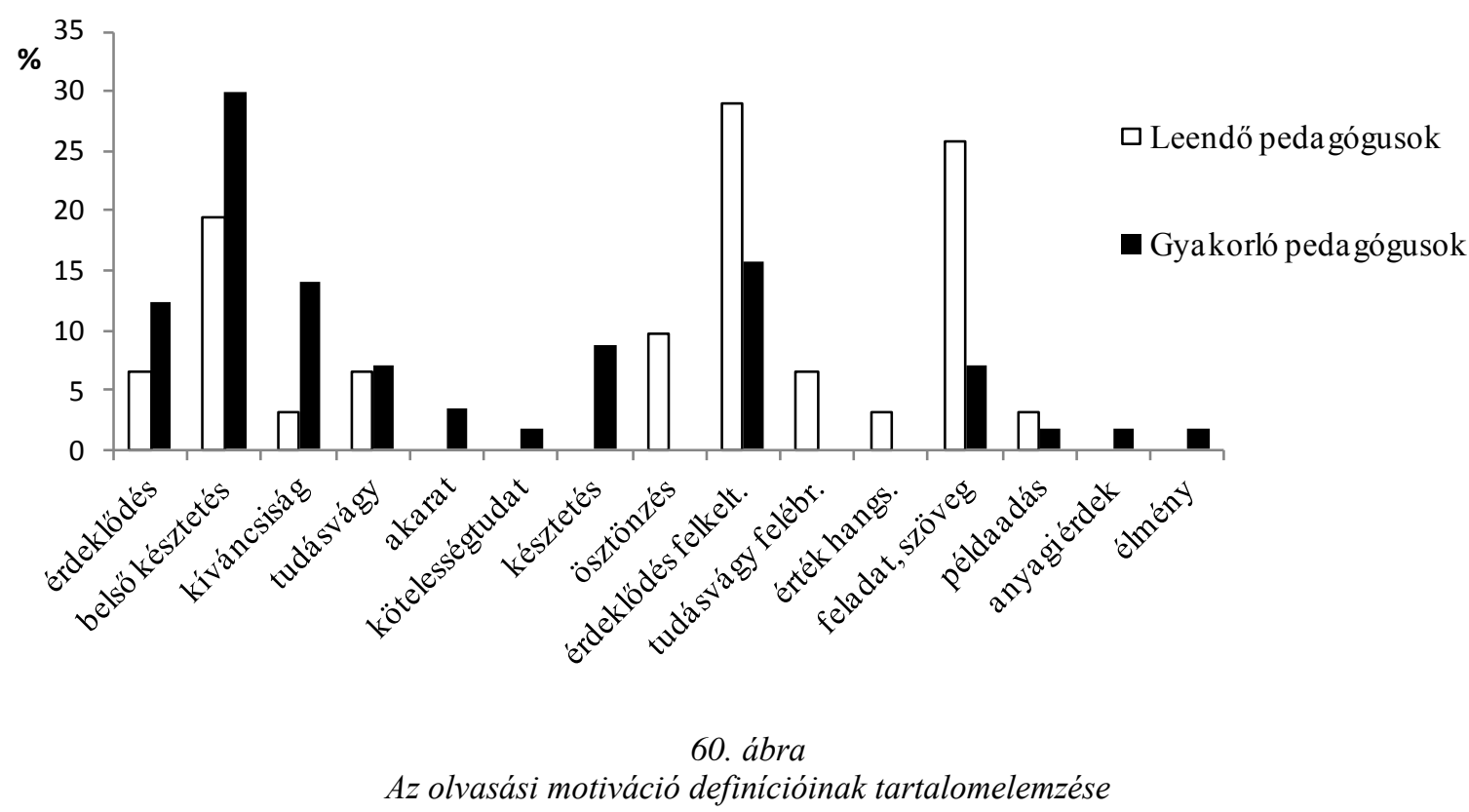

Az olvasási motivációt a pedagógusok többsége belső késztetésként, érdeklődésként vagy kíváncsiságként definiálta, mások a tanári munka egy aspektusát ragadták meg benne. A leendő tanítók ezzel szemben szignifikánsan nagyobb arányban közelítették meg a tanár szemszögéből a jelenséget, azaz azonosították a motivációt azzal a hatásrendszerrel, ami a pedagógus gyakorol a diákokra. Így az ö válaszaikban gyakrabban jelentek meg olyan definíciók, mint az érdeklődés felkeltése, egy jó szöveg megválasztása vagy a tudásvágy felébresztése, egy szóval a motiválás bizonyos eszközei. Az alanyok 10\%-a az olvasási motivációt annak eredményével, például a gyakori olvasással definiálta.

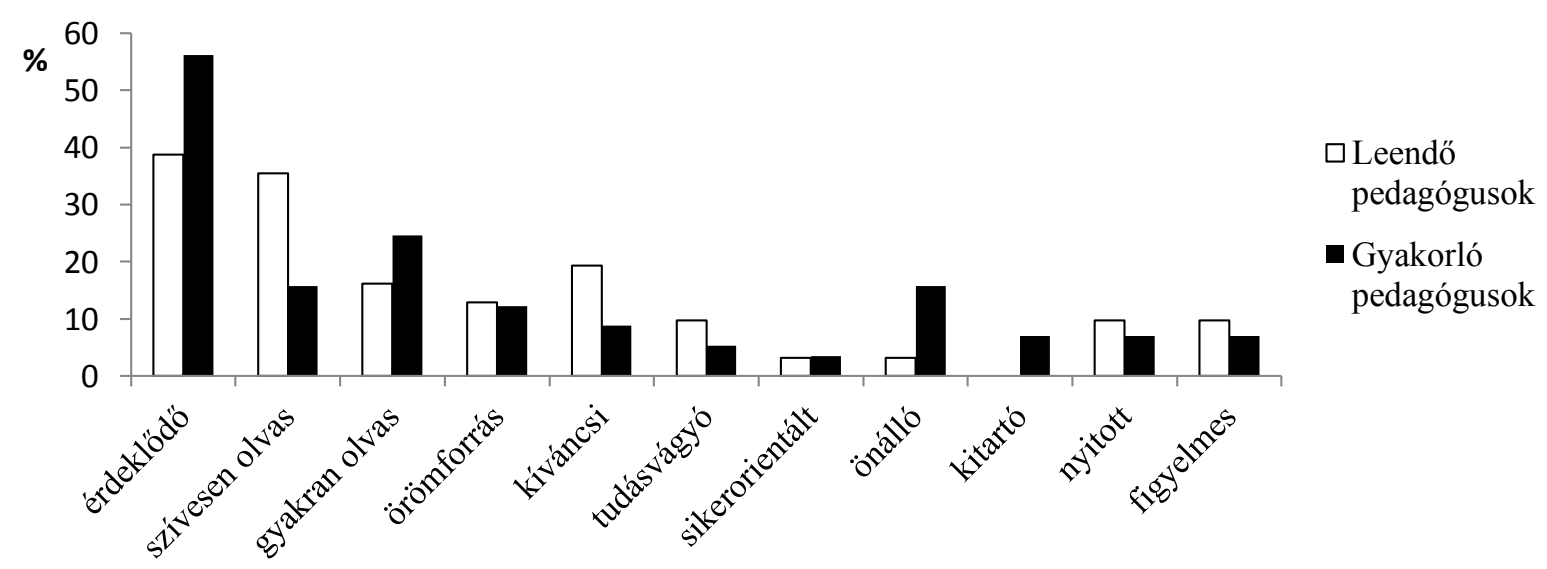

61. ábra

Az olvasás iránt motivált tanuló jellemzői a pedagógusok válaszaiban 
Az olvasás iránt motivált tanuló jellemzésében elözetes feltevéseinknek megfelelően mindkét minta esetében leggyakrabban az érdeklődés és a kíváncsiság jelent meg. Az elvárás vagy az érték motívumok (pl. énkép, fontosság) egyetlen jellemzésben sem szerepeltek. Megjelentek azonban a jellemzésekben az olvasási motiváció viselkedésben visszatükröződő eredményei, például a gyakori olvasás és a kitartás. Többen említették az intrinzik motiváció elemeit is, például, hogy az olvasás örömforrás a tanuló számára (61. ábra).

88. táblázat Leendö és gyakorló pedagógusok az olvasási motiváció fejlesztésének módszereiről

\begin{tabular}{|c|c|c|c|c|c|c|c|c|}
\hline \multirow{3}{*}{$\begin{array}{c}N \\
\text { Módszerek }\end{array}$} & \multirow{2}{*}{\multicolumn{2}{|c|}{$\frac{\text { Leendö pedagógus }}{37}$}} & \multirow{2}{*}{\multicolumn{2}{|c|}{$\frac{\text { Gyakorló pedagógus }}{60}$}} & \multirow{2}{*}{\multicolumn{2}{|c|}{ Levene }} & \multirow{2}{*}{\multicolumn{2}{|c|}{ Kétmintás $t$}} \\
\hline & & & & & & & & \\
\hline & átlag & szórás & átlag & szórás & $F$ & $p$ & $t / d$ & $p$ \\
\hline Célok kitűzése & 3,94 & 1,01 & 4,28 & 0,83 & 2,17 & 0,14 & $-1,77$ & 0,08 \\
\hline Életszerűség erősítése & 4,09 & 0,82 & 4,27 & 0,76 & 0,16 & 0,69 & $-1,02$ & 0,31 \\
\hline Autonómia támogatása & 3,28 & 0,89 & 3,28 & 0,92 & 0,24 & 0,63 & $-0,01$ & 0,99 \\
\hline Érdekes szövegek & 4,25 & 0,72 & 4,33 & 0,80 & 1,75 & 0,19 & $-0,50$ & 0,62 \\
\hline Olvasási stratégiák tan. & 3,53 & 1,02 & 3,18 & 1,11 & 0,01 & 0,97 & 1,47 & 0,15 \\
\hline Együttmúködés bizt. & 3,78 & 0,91 & 3,63 & 0,89 & 0,01 & 0,96 & 0,79 & 0,44 \\
\hline Jutalmazás, értékelés & 3,25 & 1,02 & 3,15 & 1,08 & 0,01 & 0,92 & 0,42 & 0,68 \\
\hline Gyakoroltatás naponta & 4,13 & 1,07 & 4,28 & 0,90 & 2,45 & 0,12 & $-0,75$ & 0,46 \\
\hline Könyvek ajánlása & 4,25 & 0,80 & 4,23 & 0,77 & 0,03 & 0,85 & 0,10 & 0,92 \\
\hline Szerzők megismertetése & 3,53 & 1,16 & 3,10 & 0,92 & 4,57 & 0,04 & 1,82 & 0,08 \\
\hline Életkornak megf. szöveg & 4,63 & 0,66 & 4,56 & 0,69 & 0,13 & 0,72 & 0,45 & 0,66 \\
\hline Könyvtárlátogatás & 4,28 & 0,89 & 4,27 & 0,83 & 0,07 & 0,79 & 0,05 & 0,96 \\
\hline Osztálytermi könyvtár & 4,44 & 0,80 & 4,12 & 0,89 & 0,01 & 0,94 & 1,71 & 0,09 \\
\hline Könyvbemutató & 4,25 & 0,84 & 4,17 & 0,89 & 0,00 & 0,99 & 0,42 & 0,68 \\
\hline IKT bekapcsolása & 3,41 & 1,04 & 3,44 & 0,86 & 1,05 & 0,31 & $-0,17$ & 0,87 \\
\hline Mesék, tört. olvastatása & 4,28 & 0,88 & 3,97 & 0,84 & 0,52 & 0,47 & 1,68 & 0,10 \\
\hline Vált. müfajok olvastatása & 4,09 & 0,78 & 4,10 & 0,95 & 0,99 & 0,32 & $-0,05$ & 0,96 \\
\hline Erőfeszítés jutalmazása & 4,16 & 0,95 & 3,86 & 1,04 & 0,01 & 0,93 & 1,31 & 0,19 \\
\hline Legjobbak kiemelése & 3,38 & 1,19 & 3,20 & 1,05 & 0,84 & 0,36 & 0,71 & 0,48 \\
\hline Jó telj. jutalmazása & 3,97 & 0,82 & 3,66 & 1,12 & 5,24 & 0,02 & 1,49 & 0,14 \\
\hline
\end{tabular}

Az olvasási motiváció fejlesztésére a gyakorló és leendő pedagógusok is a direkt módszereket, például a gyakori gyakoroltatást vagy a bizonyos szövegek olvastatását tartották a legmegfele- 
löbbnek (88. táblázat). Szintén jó eszköznek tartották a gyerekek érdeklődését felkeltő és az életkoruknak megfelelö szövegek alkalmazását, valamint a könyvtárlátogatást és az osztálytermi könyvtár létrehozását. A kevésbé népszerủ motivátorok közé tartoztak a jutalmak és a dicséret, azaz a legjobbak kiemelése, valamint a tanulói autonómia támogatása is.

A pedagógusok és a leendő pedagógusok meggyőződése, hogy az IKT-eszközök bekapcsolása az olvasás-szövegértés tanításába nem kifejezetten alkalmas eszköz az olvasási motiváció fejlesztésére. Ez az eredmény arra utal, hogy az IKT-eszközök viszonylag ritka alkalmazása olvasásórán a pedagógusok meggyőződésrendszeréből is fakad, és nem feltétlenül csak az eszközhiány okozza a jelenséget. Az IKT és az internetes szövegek mint motivátorok iránti averzív attitüd egy lehetséges magyarázatát adja Schnotz és Molnár (2012) megközelítése, mely szerint az elektronikus és a papíralapú szövegek olvasása nem csupán a médium tekintetében tér el, hanem az olvasó szándékait illetően is. Az olvasási tevékenységet szüken értelmezö, az olvasást szövegelsajátításként definiáló paradigma az interneten nagy számban megjelenő, főként információforrásként funkcionáló szövegek előbbi megközelítéshez képest felületes olvasását fenyegetésként, az említett szövegeket pedig alsóbbrendủnek értékeli.

Az egyes módszerekkel és eszközökkel való egyetértés mértékében nem találtunk különbséget a leendő és gyakorló pedagógusok között. A két csoport megközelítőleg azonos mértékben értett egyet az egyes technikák alkalmazásával. Feltételezésünk, miszerint a tapasztalatok és a tanítással eltöltött évek megmutatkoznak a pedagógusok meggyőződéseiben, nem igazolódott be.

\subsection{Részösszefoglalás: Leendő és gyakorló pedagógusok meggyőződései az olvasási motivációról}

Központi kutatásunkat kiegészítő vizsgálatunkban leendő és gyakorló pedagógusokat kértünk, hogy definiálják az olvasást és az olvasási motivációt. A definíciók tartalomelemzése alapján megállapítottuk, hogy a legtöbb megkérdezett az olvasást képességként definiálta, mind a két részmintában voltak azonban olyanok, akik nem tudtak egyértelmü definíciót adni. Az alanyok közül többen említették az olvasás két komponensét a dekódolást és a megértést, kevesen voltak azonban, akik mind a két tényezöt megemlítették.

Az olvasási motivációt a többség az érdeklődéssel azonosította, ennek megfelelően az olvasás iránt motivált tanuló leggyakoribb jellemzője az is az érdeklődés és a kíváncsiság volt. Az említett két jellemző mellett többen voltak, akiknek válaszában bizonyos intrinzik motívumok leírásai is helyet kaptak.

Eredményeink rámutattak, hogy az olvasás motívumait, a motívumfejlesztést a gyakorló és leendő pedagógusok is viszonylag szüken értelmezik. A pedagógusképzésben és továbbképzésben az olvasási motívumok fejlesztési lehetőségeinek ezért nagyobb szerepet kellene kapniuk. 


\section{III. ÖSSZEGZÉS}

A dolgozat hazai tanulók olvasási motivációját vizsgálta általános iskolás korban. Az olvasási motivációt területspecifikus tanulási motivációként definiáltuk, ennek megfelelően az elméleti rész az olvasási motiváció mint területspecifikus motívumok összességének szakirodalmát tekintette át. Az elméleti áttekintésben a hazai és nemzetközi szakirodalom feldolgozásával azonosítottuk azokat az olvasási és olvasásspecifikus tanulási motívumokat, amelyek a tanulók olvasási tevékenységének, feladatvégzésének megindításában, fenntartásában és az olvasás iránti hosszú távú elköteleződésében szerepet játszhatnak. Ehhez elsőként a tanulási motiváció elméleteit és irányadó modelljeit tekintettük át. Részletesen tárgyaltuk az olvasási motiváció értelmezési kereteit, az olvasási motívumokat és azok hipotetikus rendszerét. Az olvasási motiváció és az olvasási képesség és teljesítmény kapcsolatát a nemzetközi kutatási eredmények rendszerezésével tártuk fel. Végül az elméleti modellekből kiindulva összegyüjtöttük azokat a tényezőket, amelyek az olvasási képesség fejlődésének két kontextusa - az otthoni és az iskolai kontextus - elemeiként hatással lehetnek a tanulók olvasási motívumainak fejlődésére.

A hazai tanulók olvasási motívumainak megismerését egy központi vizsgálat és három kisebb kutatás tette lehetővé. Empirikus kutatásunk középpontjában egy központi vizsgálat áll, amelyet két pilot vizsgálat előzött meg, valamint egy kiegészítő vizsgálat követett. Az empirikus kutatások eredményeit a következőben a vizsgálat céljának rövid összefoglalása után a kutatás kiindulópontjául szolgáló elméleti hipotézisek mentén tekintem át.

Az első pilot vizsgálatban egy olvasási motívum, az olvasási énkép fejlődését, teljesítménnyel, attitüdökkel és egyéb énképkomponensekkel való kapcsolatát elemeztük. A motívumok területspecifikusságát elsőként az énkép kapcsán mutatták ki. Az énkép szerkezetét, komponenseit vizsgáló kutatások eredményei szerint nem létezik egyetlen átfogó tanulmányi énkép; az egyes énképek a tantárgyi területek és képességek szerint jól elkülönülnek. Pilot vizsgálatunkban a nemzetközi modell alapján vizsgáltuk a hazai tanulók énképét azzal a céllal, hogy megtudjuk vajon azonosíthatók és elkülöníthetők-e a hazai mintán is az énképkomponensek, és amennyiben igen, milyen helyet foglal el a tanulók hierarchikus énképstruktúrájában az olvasási énkép. Pilot vizsgálatunk adatfelvételére 2008-ban került sor.

Kutatásunk kezdetén a szakirodalom alapján öt problémakörhöz kapcsolódóan fogalmaztunk meg hipotéziseket. A következőkben az egyes problémakörök szerint ismertetjük a kutatás eredményeit.

$\mathrm{H}_{1}$ : Területspecifikusság: Eredményeink szerint a szakirodalom által azonosított énképkomponensek a hazai tanulóknál is azonosíthatók, az egyes énképkomponensek jól elkülönülnek a tanulók gondolkodásában. Ez az eredmény alátámasztja a tanulási motívumok közül az énkép területspecifikusságát, mely alapján joggal feltételezhetjük, hogy a többi motívum esetében is szerepet játszik a tartalomspecifikusság.

$\mathrm{H}_{2}$ : Az énképkomponensek jellemzői: Adataink szerint az általános iskolás tanulók többnyire pozitív énképpel rendelkeznek, de az egyes énképkomponensek jellemzöi eltérnek egymástól. Az életkor növekedésével az énképkomponensek romló tendenciát mutatnak, a 
magasabb osztályfokokon a tanulók énképe egyre alacsonyabb. A tanulmányi énképkomponensek közül az olvasási énkép kevésbé romlik a matematika énképhez képest az évek folyamán, a csökkenés azonban itt is számottevő.

$\mathrm{H}_{3}$ : Belső összefüggésrendszer: Az énképkomponensek között közepes erősségü kapcsolatok állnak fenn. Az énkép struktúrájának elemzése rámutatott, hogy az egyes tanuláshoz kapcsolódó énképkomponensek nem alkotnak egy felsőbb szinten egy tanulmányi énképet. Az iskolai énképhez a felsőbb évfolyamokon legszorosabban az olvasási énkép kapcsolódik, míg a matematika énkép teljesen függetlenné válik a rendszertől. Ez az eredmény alátámasztotta azokat a nemzetközi kutatási eredményeket, mely szerint az iskolai énkép alakulásában az olvasás énképnek nagy szerepe van, és feltételezhetően erre épül a többi tanuláshoz kötődő énkép. Ezen eredmény alapján joggal feltételezhetjük, hogy az olvasás központi szerepe a többi tanulási motívum esetében is fennáll.

$\mathrm{H}_{4}$ : Az énképkomponensek és a teljesitmény összefüggése: Az énkép és a teljesítmény között kapcsolat van. Az egyes területspecifikus énképkomponensek legszorosabban az adott területen nyújtott teljesítménnyel függnek össze, így például az olvasási énkép szoros kapcsolatban áll az olvasás-szövegértés teljesítménnyel és az olvasás/irodalom osztályzattal. A teljesítmény mutatója, azaz hogy az osztályzatot vagy a képességfejlettséget vesszük alapul, nagyban befolyásolja a kapcsolat erősségét és irányát. Az olvasási énképre hatással csak az osztályzat van.

$\mathrm{H}_{5}$ : Külsö összefüggésrendszer: Az énképkomponensek összefüggésben állnak a családi háttér egyes jellemzőivel és az IQ-val. Ezek hatását az énképkomponensekre azonban csak bizonyos esetekben tudtuk kimutatni. A különböző iskolai végzettségü szülők gyermekeinek olvasási énképe között szignifikáns különbség van: a magasabb iskolai végzettségü szülők gyermekei magasabb énképpel rendelkeznek az olvasás terén. A tantárgyak kedveltsége és a megfelelö tantárgyi énképek között szintén kapcsolat van, a felsőbb évfolyamokon a tanulók azokat a tantárgyakat kedvelik, amelyekben jónak látják saját teljesítményüket.

Második pilot vizsgálatunkban az olvasási motiváció egydimenziós vizsgálatára tettünk kísérletet. Ez azt jelentette, hogy nem az egyes olvasási motívumokat vizsgáltuk, hanem az olvasási motiváció mint önálló, homogén rendszer egészét. Célunk az volt, hogy feltárjuk, általánosságban véve milyen fejlődési tendenciája figyelhető meg az olvasási motivációnak, illetve milyen kapcsolatban áll a teljesítménnyel és egyéb egyéni változókkal, mint például az IQ-val és a nemmel. Kutatásunkban lehetőségünk nyílt arra is, hogy az eltérő fejlődés hatását elemezzük az olvasási motivációra mint komplex egészre. Vizsgálatunkban többségi és tanulásban akadályozott tanulók vettek részt, az adatgyüjtésre 2008-ban került sor.

Az eredmények alátámasztották, hogy az olvasási motiváció a fejlesztett mérőeszközzel mérhető többségi tanulók és tanulásban akadályozott tanulók esetében. Az egyszerüsített, háromfokú válaszadó skála a tanulásban akadályozott tanulók számára megkönnyítette a válaszadást, a mérőeszköz megbízhatósága az ő esetükben is kielégítő. A további eredmények a hipotézisek szerint rendezve a következők:

$\mathrm{H}_{1}$ : Életkori változás: Keresztmetszeti kutatásunkban lehetőségünk nyílt a különböző életkorú tanulók olvasási motivációjának mennyiségi mutatóinak összevetésére. Ez alapján a 
tanulók olvasási motivációja az életkor növekedésével, azaz az egyre magasabb osztályfokokon, egyre alacsonyabb.

$\mathrm{H}_{2}$ : Az eltérö fejlődés hatása: Feltételezésünk, miszerint a tanulásban akadályozott és többségi tanulók olvasási motivációja között jelentős különbség van, csak részben igazolódott be. Harmadik és ötödik évfolyamon a két populáció között a különbség valóban szignifikáns. Ezekben az osztályokban a tanulásban akadályozott tanulók olvasási motivációja számottevően alacsonyabb, mint a többségi tanulóké. Nyolcadik osztályban ez az eltérés ugyanakkor már nem szignifikáns: a tanulásban akadályozott tanulók olvasási motivációja megegyezik a többségi tanulókéval.

$\mathrm{H}_{3}$ : Olvasási motiváció és teljesitmény: Kutatásunk kezdetekor feltételeztük, hogy az olvasás-szövegértés teljesítmény és a szóolvasás készség fejlettsége is összefüggést mutat a tanulók olvasási motivációjával. Eredményeink ezt a hipotézist csak részben támasztották alá. A szóolvasás készség fejlettsége nem, az olvasás-szövegértés képessége csak gyenge kapcsolatban áll az olvasási motiváció fejlettségével. A teljesítményészleletek szintén nem állnak kapcsolatban a tanulásban akadályozott tanulók esetében a motivációval.

$\mathrm{H}_{4}$ : A családi háttér, a nem és az IQ is összefügg az olvasási motivációval, az összefüggés azonban nem erős. Az IQ és az apa iskolai végzettsége gyenge kapcsolatban áll az olvasási motivációval, a tanulásban akadályozott tanulók esetében pedig az IQ és az apa iskolai végzettsége egyáltalán nem mutatott szignifikáns összefüggést azzal. Ezen eredmények alapján feltételezhetjük, hogy az olvasási motivációt egyéb tényezők, például az otthoni és iskolai olvasásfejlesztő tevékenységek egyes jellemzői alakíthatják.

Központi mérésünk koncepcióját a szakirodalmi áttekintésre, valamint a két pilot vizsgálat eredményeire alapoztuk. A célunk az volt, hogy átfogó képet kapjunk a hazai általános iskolás tanulók olvasás iránti motivációjáról, az azt befolyásoló tényezőkről, és olvasási teljesítménnyel való összefüggéséről. Központi kutatásunkban a nemzetközi szakirodalom alapján az olvasási motivációt sokösszetevős rendszerként definiáltuk, melynek komponensei az olvasási motívumok. Második, negyedik, hatodik és nyolcadik osztályos tanulókkal végzett felmérésünkben tíz olvasási motívum együttes vizsgálatára tettünk kísérletet. Az eredményeket ismét a vizsgálat alapjául szolgáló hipotézisek mentén összegezzük.

$\mathrm{H}_{1}-\mathrm{H}_{6}$ : Mérés: A kutatás középpontjában álló problémakör első eleme az olvasási motívumok mérhetőségével kapcsolatos. Kutatásunk kezdetén feltételeztük, hogy a szakirodalmi feltárás által azonosított motívumok az alsóbb évfolyamokon strukturált interjúk keretében felvett, a felsőbb évfolyamokon pedig egyénileg kitöltött kérdőívekkel megbízhatóan vizsgálhatók. A kérdőívek validitásának és reliabilitásának vizsgálatai rámutattak, hogy a strukturált interjúk keretében felvett kérdőívekkel valóban megbízható becslés adható az olvasási motívumok müködéséről az olvasástanulás kezdeti szakaszában. A felsőbb évfolyamok számára fejlesztett, egyéni kitöltéses kérdőíves módszerrel pedig megbízható becslés adható a motívumok müködéséről az olvasástanulás későbbi szakaszában. A faktoranalízis eredménye alapján a tanulási motiváció és az olvasási motiváció irodalma által tárgyalt motívumok azonosíthatók és elkülöníthetők már az olvasástanulás kezdeti fázisában is. Félig strukturált interjúmódszerrel továbbá megbízhatóan vizsgálható a tanulók énképének forrása és az általuk az olvasás(tanulás)nak tulajdonított funkciók. Második évfolyamon a képes szóolvasás teszttel meg- 
bízható becslés adható a szóolvasó készség müködéséről. A magas átlagteljesítmény miatt a készség és a motívumok közötti összefüggés azonban csak korlátozottan értelmezhetö. Szövegértés teszttel megbízható becslés adható az olvasás-szövegértés képességének működéséről az általános iskola negyedik, hatodik és nyolcadik évfolyamán.

$\mathrm{H}_{7}-\mathrm{H}_{10}$ : Az olvasási motívumok jellemzői: Kutatásunkban az olvasási motívumokat második, illetve negyedik, hatodik és nyolcadik évfolyamokon néhány aspektusában eltérő méröeszközökkel és két különböző adatfelvételi eljárás során vizsgáltuk. A második és a felsőbb évfolyamok eredményeinek statisztikai eszközökkel történő összehasonlítására így nincs lehetőség. Ennek megfelelően az eredményeket is külön tárgyaltuk. Második évfolyamon, azaz az olvasástanulás kezdeti szakaszában a tanulókat az olvasás iránti magas motiváltság jellemzi. A tanulók többségének minden olvasási motívuma magas, azaz többek között jó olvasás énképpel rendelkezik, magas értéket tulajdonít az olvasástanulásnak, szeret olvasni, az elsajátítási és a teljesítménycélok is motiválják, és gyakran él át flow élményt olvasás vagy olvasás feladatok megoldása során. Szinte minden motívum esetében találkozhatunk azonban a tanulóknak egy szük rétegével, akik már az olvasástanulás ilyen korai szakaszában negatív orientációt tükröző motívumokkal rendelkeznek az olvasás területén, így például alacsony önhatékonyság vagy énkép jellemzi őket, gyakran követnek elkerülő célokat, negatívan viszonyulnak az olvasáshoz, és előfordul, hogy antiflow élményeket, unalmat vagy apátiát élnek át olvasási feladatok megoldása vagy olvasás közben.

A felsőbb évfolyamokon a motívumok összességében véve alacsonyabbak, mint második osztályban és több egyéni különbséget is találunk a motívumok fejlettségében. A motívumok az egyre magasabb évfolyamokon vagy nem változnak vagy csökkenő tendenciát mutatnak, azaz a felsőbb évfolyamokon egyre alacsonyabbak. A legtöbb motívum esetében a legnagyobb különbség a negyedik és a hatodik évfolyam között mutatható ki, amely a felső tagozatba való átmenet negatív hatásaira hívja fel a figyelmet. Az olvasás motívumai közül a szabadidős olvasás iránti attitüdre, az antiflow élmények gyakoriságára és az olvasás énképre is hatással van a családi háttér. A motívumok fejlettségében a második évfolyamon nem találtunk a nemek között különbséget, a felsőbb évfolyamokon azonban egyre több motívumban és egyre nagyobb különbségek fedezhetők fel.

$\mathrm{H}_{11}-\mathrm{H}_{13}$ : Belső összefüggésrendszer: A motívumok között már az olvasástanulás kezdeti szakaszában is összefüggések vannak. A motívumok közötti összefüggésrendszer a felsőbb évfolyamokon is fennáll. Nem állja meg a helyét ugyanakkor az a feltételezésünk, hogy az egyes kategóriákba tartozó motívumok között (értékmotívumok és elvárásmotívumok) a kapcsolat erősebb, mint a kategóriák között. A különböző évfolyamokon a motívumok közötti kapcsolatrendszer eltérő. A motívumrendszer struktúráját illetően az eredmények közül külön kiemelendő, hogy míg az alsóbb évfolyamokon a teljesítménycélok a pozitív motivációs orientációra utaló motívumokhoz kapcsolódnak (legközelebbről az elsajátítási célokhoz), addig a felsőbb évfolyamokon a negatív, elkerülö motívumokhoz kapcsolódnak legszorosabban. Ez alapján feltételezhetjük, hogy a teljesítménycélok követése az alsóbb évfolyamokon pozitív orientációhoz vezet, az általános iskola végén azonban már motivációs szempontból negatívnak tekinthetök. 
$\mathrm{H}_{14}-\mathrm{H}_{18}$ : Motívumok és teljesitmény: Kutatásunkban az olvasási teljesítmény mutatójaként a tanári által adott értékelést vagy osztályzatot, illetve a képes szóolvasás teszten vagy a felsőbb évfolyamokon - a szövegértés teszten nyújtott teljesítményt alkalmaztuk. Második évfolyamon az olvasásteljesítmény két mutatója és az olvasási motívumok között nem találtunk szignifikáns összefüggést. Azonban a felsőbb évfolyamokon a legtöbb motívum szignifikánsan korrelált a teljesítménymutatókkal, azaz a tanári értékeléssel és a képességfejlettséggel is. A korrelációs együtthatók alapján az összefüggések gyenge vagy közepes erősségüek. Egyes olvasási motívumok és az olvasási teljesítmény közötti összefüggés függvénye az olvasási teljesítmény indikátorának, azaz hogy a teljesítmény indikátoraként a tanári értékelést/osztályzatot vagy a képességteszten elért eredményt vesszük alapul. A szociális motívumokon kívül valamennyi motívum hatással van a teljesítménymutatókra valamely évfolyamon, és a magasabb évfolyamokon egyre több motívum rendelkezik magyarázóerővel. A teljesítménymutatók az egyre magasabb évfolyamokon szintén egyre több motívum egyéni különbségét magyarázzák, az összmegmagyarázott varianciák azonban összességében véve itt alacsonyabbak. Az eredmények alapján tehát az olvasási motívumok és az olvasási képesség közötti hatásrendszer kétirányú, a motívumok azonban együttesen nagyobb mértékben magyarázzák az egyéni teljesítménykülönbségeket, mint a teljesítménykülönbségek a motívumok fejlettségét. A hatásrendszer erőssége azonban motívumonként eltérő.

$\mathrm{H}_{19}-\mathrm{H}_{22}$ : Külső összefüggésrendszer: Központi kutatásunkban második osztályban tanulói interjúkkal tettünk kísérletet az otthoni és az iskolai kontextus egyes, a gyerekek meggyőződésrendszerére ható elemeinek megismerésére. Feltételeztük, hogy az internalizációs folyamat kezdetén a gyerekek válaszaiban még tetten érhetők a szülők és pedagógusok visszajelzései, az általuk fontosnak tartott és hangoztatott értékek és célok. Eredményeink szerint a gyermekek két tanult meggyőződéseken alapuló motívuma, az olvasási énkép és az olvasásnak tulajdonított érték, meglehetősen magas ebben az életkorban. A tanulók énképének legfőbb forrásai a tanár által nyújtott hangos olvasási helyzetben nyújtott visszajelzések, amelyeket a gyerekek már ebben az életkorban magukénak tekintenek. A felsőbb évfolyamokon az otthoni és az iskolai kontextus megismerése céljából szülői és tanári kérdőíveket használtunk. A tanulók olvasási motívumai összefüggést mutatnak az otthoni és az iskolai fejlesztés egyes aspektusaival. A családi háttér jellemzőjeként kiemelendő, hogy az alacsonyabb iskolai végzettségü szülők gyermekei kevesebb olvasmányélményen alapuló tevékenységet végeznek a gyerekekkel, alacsonyabb elvárásaik vannak gyermekük olvasásteljesítményével és olvasási motiváltságával szemben, ugyanakkor többször nyújtanak számukra segítséget és gyakrabban ellenőrzik gyermekük olvasási képességének fejlődését. Az iskoláskor előtti és alatti fejlesztő tevékenységek gyenge összefüggést mutatnak bizonyos olvasási motívumokkal, a szülők által támasztott elvárások azonban már szinte valamennyi motívummal korrelálnak. Míg az egyes fejlesztő tevékenységek, mint például a segítségnyújtás, negatív hatással lehet például a gyerekek olvasási énképére, céljaira, addig az elvárások a pozitív motivációs jellemzőket erösítik. Az otthoni kontextus jellemzőjeként a szülői elvárások mutatják a legszorosabb összefüggést az olvasás motívumaival, míg az iskolai kontextus kapcsán a tanár által alkalmazott tanulásszervezési formák és források szerepe kiemelendő. Azok az osztályok, akiknek tanárai vagy tanítói gyakrabban alkalmaznak frontális munkát, illetve adnak egyéni, de nem egyénre sza- 
bott feladatokat a tanulóiknak, gyakrabban követnek elkerülő célokat és szintén gyakrabban élnek át antiflow élményeket olvasás órán. Az IKT-eszközök bekapcsolása az olvasásfejlesztésbe ugyanakkor erős pozitív összefüggést mutat az iskolai olvasással kapcsolatos attitűdökkel és az olvasásnak tulajdonított gyakorlati értékkel is. A mintában résztvevő pedagógusok többsége ugyanakkor arról számolt be, hogy ritkán vagy szinte soha nem használ ilyen eszközöket.

A központi kutatás eredményei szerint a pedagógusok által alkalmazott módszerek hatással vannak az általuk tanított gyerekek olvasási motívumaira. Ez az eredmény motiválta a kiegészítő vizsgálat elvégzését, melynek célja gyakorló pedagógusok és leendő pedagógusok olvasással és olvasási motivációval kapcsolatos meggyőződések feltárása volt. A kismintás vizsgálat adatfelvétele online módon történt 2011 első negyedévében. A legfőbb eredmények a hipotézisek alapján a következők:

$\mathrm{H}_{1}$ : A pedagógusok és a pedagógusjelöltek többsége is képességként értelmezi az olvasást, a legtöbben azonban vagy csak dekódolásként vagy pedig csak szövegértésként definiálják azt. A gyakorló pedagógusok egy jelentős hányada nem adott valós definíciót, az olvasást egy jellemzőjével vagy funkciójával definiálta, esetleg irreleváns meghatározást adott.

$\mathrm{H}_{2}$ : Az olvasási motivációt a pedagógusok és a pedagógusjelöltek is szüken értelmezik, és várakozásainknak megfelelően elsősorban bizonyos szövegek iránti érdeklődéssel és az olvasás gyakoriságával azonosítják azt.

$\mathrm{H}_{3}$ : Az olvasási motiváció definíciójával összhangban a pedagógusok és a pedagógusjelöltek is az érdeklődés felkeltését, a gyerekek számára érdekes szövegek olvastatását tartják a legmegfelelőbb eszköznek az olvasási motiváció fejlesztésére. Többségük az olvasási motiváció fejlesztésének direkt eszközeit, a gyakori olvastatást, a könyvtárba járást, könyvek ajánlását tartja megfelelő módszernek, és kevésbé értenek egyet a tanulói autonómiára építő, a szabad olvasmányválasztáson alapuló módszerekkel. Fontos eredmény továbbá, hogy az IKT eszközök alkalmazásával a pedagógusok és a pedagógusjelöltek sem értenek egyet teljesen, annak fejlesztő hatását megkérdőjelezik. Ez alapján arra következtethetünk, hogy a számítógépes szoftverek ritka alkalmazása olvasás vagy magyar órán, nem csupán az eszközhiánynak, hanem a pedagógusok meggyőződésrendszerének is felróható.

$\mathrm{H}_{4}$ : A leendő és gyakorló pedagógusok olvasás és olvasási motiváció definíciói között alig találtunk szignifikáns különbségeket, a módszerekkel való egyetértésük mértékében pedig egyáltalán nincs szignifikáns eltérés. A tapasztalatnak tehát kisebb szerepe van az olvasással és olvasási motivációval kapcsolatos meggyőződések alakulásában, mint azt feltételeztük. 


\section{Az eredmények felhasználása és to- vábbi kutatási feladatok}

A központi kutatás és a három kiegészítő vizsgálat eredményeként megismertük a hazai általános iskolás korú tanulók olvasási motívumainak jellemzőit, összefüggésüket az olvasási teljesítménnyel és képességfejlettséggel, az otthoni és az iskolai kontextus jellemzőivel.

Kutatásunk eredményeként létrejött egy olyan mérőeszközcsalád, amely az olvasási motívumok vizsgálatát az általános iskola második osztályától egészen a középiskolába lépésig lehetővé teszi többségi tanulók esetében. A második pilot vizsgálatban az eltérő fejlődésű tanulók egyes olvasási motívumait nem, csupán általános egydimenziós olvasási motivációját vizsgáltuk. Szükséges lenne a fejlesztett mérőeszközök adaptálása a tanulásban akadályozott populáció számára, így ugyanis lehetővé válna az egyes olvasási motívumok vizsgálata az ő esetükben is.

Keresztmetszeti vizsgálatunkban a különböző életkorú tanulók olvasási motívumait elemeztük. Eredményeink szerint a vizsgált olvasási motívumok az általános iskola folyamán csökkenek, esetenként stagnálnak. Továbblépést jelentene a tanulók olvasási motívumainak megismerésében olyan longitudinális vizsgálatok folytatása, amelyek az általános iskola kezdetétől nyomon követnék a tanulók olvasási motívumainak fejlődését. Ehhez a szükséges eszközök és módszerek kutatásunk eredményeképp rendelkezésre állnak.

Központi vizsgálatunk és az azt kiegészítő kismintás meggyőződés-vizsgálat a pedagógusok és az iskolai olvasástanítás szerepére hívta fel a figyelmet az olvasás iránti motiváció fejlesztésében, ugyanakkor arra is rámutatott, hogy sem a leendő sem pedig a gyakorló pedagógusok nem rendelkeznek kellően mély ismeretekkel az olvasási motívumok fejlesztéséhez. Kutatásunk eredményeinek integrálása és interpretálása a tanárképzésbe előrelépést jelentene a pedagógusok témával kapcsolatos ismereteinek bővítésében, az eredményes iskolai motívumfejlesztés megalapozásában.

Végül az olvasási motívumok általános jellemzőinek, egyéni különbségeinek és az azokat befolyásoló tényezőknek a megismerése után sor kerülhet olyan fejlesztőprogramok kidolgozására, amely az olvasási motívumok erősítésével hozzájárulna a tanulók olvasás iránti elköteleződéséhez és ezáltal olvasási képességének fejlődéséhez. Ehhez jó alapot szolgáltatna az elméleti fejezetben bemutatott Concept-Oriented Reading Instruction programja, amely az olvasási motiváció fejlesztésén keresztül természettudományos tartalmakba integrálva valósítja meg - több országban már eredményesen - az olvasási képesség és az olvasási iránti motiváció fejlesztését. Szintén a fejlesztést szolgálná a bemutatott eredmények fényében olyan digitális tananyagok kidolgozása, amelyek az IKT bekapcsolásával erősítenék a tanulók iskolai olvasás iránti attitűdjét, és hoznák közelebb a mindennapi olvasást az iskolai olvasás gyakorlatához. 


\section{Köszönetnyilvánítás}

Köszönettel tartozom témavezetőmnek, Józsa Krisztiánnak az általa nyújtott szakmai és emberi támogatásért. Az ő bíztatása, konstruktív és motiváló megjegyzései nélkül a dolgozat nem jöhetett volna létre.

Köszönöm az SZTE BTK Neveléstudományi Doktori Iskolának és vezetőjének, Csapó Benőnek az az alkotó légkör és az annak hátterét adó infrastrukturális feltételek biztosítását. Köszönet illeti továbbá az SZTE BTK Neveléstudományi Doktori Iskola összes oktatóját, egykori és jelenlegi hallgatóját a doktori tanulmányaim alatt nyújtott támogatásukért, törődésükért. Külön kiemelném Barassevich Tamás, Fejes József Balázs, Kasik László, Molnár Edit Katalin és Nyitrai Ágnes ösztönző segítségét és kritikai megjegyzéseit, amelyeket a dolgozat korábbi változataihoz füztek.

Hálás vagyok Józsa Krisztiánnak, Fazekasné Fenyvesi Margitnak, Fejes József Balázsnak, Kelemen Ritának és Nagy Zsuzsannának a szakmai együttmüködésért, amely nélkül a kiegészítő vizsgálatok nem jöhettek volna létre. Köszönöm Janurik Mártának, Kasik Lászlónak, Kinyó Lászlónak, Molitorisz Anikónak, Varga Andreának, valamint összes kollégámnak a sok baráti támogatást és bíztatást, amit munkám során tőlük kaptam.

Köszönöm a kutatásban részt vevő iskolák igazgatóinak és tanárainak, valamint az ott tanuló gyerekeknek és szüleiknek a segítségét és aktív részvételét. Hálával tartozom az interjúk felvételében segédkező hallgatóknak a lelkiismeretes munkájukért. Külön köszönet illeti

Kis Noémit az interjúk elemzésében való részvételéért. Köszönöm Csomorné Benkovics Ágnes segítségét is az adatrögzítésben.

Végül, de nem utolsó sorban köszönöm családomnak és vőlegényemnek a lelki támogatást, segítséget és megértést, valamint a nyugodt hátteret, amelyet munkám során biztosítottak.

A kutatás az OTKA K83850 és a TÁMOP 3.1.9/08/01-2009-0001 pályázatok támogatásával valósult meg. 


\section{Irodalom}

Ábrahám Mónika (2006): 12-14 éves gyerekek olvasási, könyv- és könyvtárhasználati szokásai. Új Pedagógiai Szemle, 56. 1. sz. 3-23.

Adamikné Jászó Anna (1993): Nyelvi tudatosság - olvasástanítás - helyesírás. Magyar nyelvör, 117. 3. sz. 320-331.

Adamikné Jászó Anna (2006): Az olvasás múltja és jelene. Trezor Kiadó, Budapest.

Adamikné Jászó Anna (2007): Ok és okozat korunk olvasáskultúrájában. Elektronikus Könyv és Nevelés, 9. 2. sz. http://www.tanszertar.hu/eken/2007_02/aja_0702.htm 2010. január 11-i megtekintés.

Adamikné Jászó Anna (2002): Anyanyelvi nevelés az ábécétöl az érettségiig. Trezor Kiadó, Budapest.

Alexander, J. E. és Filler, R.C. (1976): Attitudes and reading. Newark, DE: International Reading Association.

Alexander, P. A., Jetton, T. L. és Kulikowich, J. M. (1995): Interrelationship of knowledge, interest and recall: Assessing a model of domain learning. Journal of Educational Psychology, 87. 4. sz. 559-575.

Almasi, J. F. (2003): Teaching Strategic Processes in Reading. The Guilford Press. New York-London.

Ames, C. (1992): Classrooms: Goals, structures, and student motivation. Journal of Educational Psychology, 84. 3. sz. 261-271.

Anmarkrud, O. és Bråten, I. (2009): Motivation for reading comprehension. Learning and Individual Differences, 19. 2. sz. 252-256.

Anderman, E. M. és Midgley, C. (1997): Changes in achievement goal orientations, perceived academic competence, and grades across the transition to middle level schools. Contemporary Educational Psychology, 22. 3. sz. 269-298.

Artelt, C., Baumert, J., Julius-McElvany, N. és Peschar, J. (2003): Learners for Life, Student approches to learning: Results from PISA 2000. OECD, Paris.

Assor, A., Kaplan, H. és Roth, G. (2002): Choice is good but relevance is excellent: Autonomy affecting teacher behaviors that predict students' engagement in learning. British Journal of Educational Psychology, 72. 261-278.

Atkinson, J. W. (1957): Motivational determinants of risk taking behavior. In: J. Atkinson (szerk..): Personality, motivation, and action: Selected papers. Praeger, New York. 101-119.

Atkinson, J. W. (1964): An introduction to motivation. Van Nostrand, Princeton.

Austin, J. T. és Vancouver, J. B. (1996): Goal constructs in psychology: Structure, process, and content. Psychological Bulletin, 120.3. sz. 338-375.

Baker, L. és Scher, D. (2002): Beginning readers' motivation for reading in relation to parental beliefs and home reading experiences. Reading Psychology, 23. 4. sz. 239-269.

Baker, L., Scher, D. és Mackler, K. (1997): Home and family influences on motivations for reading. Educational Psychologist, 32. 2. sz. 69-82.

Baker, L. és Wigfield, A. (1999): Dimensions of children's motivation for reading and their relations to reading activity and reading achievement. Reading Research Quarterly, 34. 4. sz. $452-477$. 
Balázsi Ildikó, Balkányi Péter, Felvégi Emese és Szabó Vilmos (2007): PIRLS 2006. Összefoglaló jelentés a 10 éves tanulók szövegértési képességeiröl. Oktatási Hivatal, Budapest.

Bandura, A. (1997): Self-efficacy: The exercise of control. W. H. Freeman, New York.

Barrett, K. C. és Morgan, G. A. (1995): Continuities and discontinuities in mastery motivation during infancy and toddlerhood: a conceptualization and review. In: MacTurk, R. H. és Morgan, G. A. (szerk.): Mastery motivation: Origins, conceptualizations and applications. Vol. 12. Advances in applied developmental psychology. Ablex Publishing Corporation, Norwood, New Jersey. 57-94.

Biehler, R. F. és Snowman, J. (1994): Motiváció. In: Csapó Benő, Csirikné Czachesz Erzsébet, Pukánszky Béla és Vidákovich Tibor (szerk): Neveléselméleti szöveggyüjtemény. JATEPress, Szeged. 300-361.

Bong, M. és Skaalvik, E. M. (2003): Academic self-concept and self-efficacy: How different are they really? Educational Psychology Review, 15. 1. sz. 1-40.

Bouffard, T. és Couture, N. (2003): Motivational profile and academic achievement among students enrolled in different school tracks. Educational Studies, 29. 1. sz. 19-38.

Bouffard, T., Marcoux, M.F., Vezeau, C. és Bordeleau, L. (2003): Changes in selfperceptions of competence and intrinsic motivation among elementary school children. British Journal of Educational Psychology, 73. 1. sz. 171-186.

Britner, S. L. és Pajares, F. (2001): Self-efficacy beliefs, motivation, race, and gender in middle school science. Journal of Women and Minorities in Science and Engineering, 7. 4. sz. 271-285.

Bybee, J. és Zigler, E. (1992): Is outerdirectedness employed in a harmful or beneficial manner by students with and without mental retardation? American Journal on Mental Retardation, 5. 512-521.

Byrne, B. M. (1984): The general/academic self-concept nomological network: A review of construct validation research. Review of Educational Research, 54. 3. sz. 427-456.

Byrne, B. M. (2000): Measuring Self-Concept Across Culture: Issues, Caveats, and Practice. In: Craven, R. G. és Marsh H. W. (szerk.): Self-Concept Theory, Research and Practice: Advances for the New Millennium. Collected Papers of the Inaugural Self-Concept Enhancement and Learning Facilitation (SELF) Research Centre International Conference. SELF Research Centre, University of Western Sydney.

Chan, K. és Keogh, B. (1974): Interpretation of task interruption and feelings of responsibility for failure. Journal of Special Education, 8. 175-178.

Chapman, J.W. és Tunmer, W.E. (1995): Development of young children's reading selfconcepts: An examination of emerging subcomponents and their relationship with reading achievement. Journal of Educational Psychology, 87. 154-167.

Chapman, J. W. és Tunmer, W. E. (2002): Relations between self-perceptions and literacy achievement: Developmental factors and Matthew effects. Előadás. Second International SELFConference. http://self.uws.edu.au/Conferences/2002_CD_Chapman_\&_ Tunmer.pdf. 2007. december 12-i megtekintés.

Chen, H. (2006): Flow on the net - detecting Web users' positive affects and their flow states. Computers in Human Behaviour, 22. 2. sz. 221-233.

Coddington, C. S. és Guthrie, J. T. (2009): Teacher and student perceptions of boys' and girls'reading motivation. Reading Psychology, 30. 3. sz. 225-249. 
Connell, J. P. és Wellborn, J. G. (1991): Competence, autonomy, and relatedness: A motivational analysis of self-system processes. In: R. Gunnar és L. A. Sroufe (szerk.): Minnesota symposia on child psychology, Erlbaum, Hillsdale. 43-77.

Connell, J. P. (1985): A new multidimensional measure of children's perception of control. Child Development, 6. 281-293.

Cordova, D. I. és Lepper, M. R. (1996): Intrinsic motivation and the process of learning: Beneficial effects of contextualization, personalization, and choice. Journal of Educational Psychology, 88. 4. sz. 715-730.

Covington, M.V. (1992): Making the grade: a self-worth perspective on motivation and school reform. Cambridge University Press, Cambridge, UK.

Covington, M. J. (2009): Self-worth theory: Retrospection and prospects. In: K. R. Wentzel és A. Wigfield (szerk.): Handbook of motivation at school. Routledge, New York. 141170.

Cox, K. E. és Guthrie, J. T. (2001): Motivational and Cognitive Contributions to Students' Amount of Reading. Contemporary Educational Psychology, 26. 1. sz. 116-131.

Crawford, P. A. (1995): Early literacy: Emerging Perspectives. Journal of Research in Childhood Education, 10. 1. sz. 71-86.

Cs. Chaczesz Erzsébet (1999): Az olvasásmegértés és tanítása. Iskolakultúra, 9. 2. sz. 3-15.

Csáky S. Piroska (1996): Az olvasás öröme - avagy olvasásra nevelés szépirodalommal. Könyv, könyvtár, könyvtáros. 5. 3. sz. 46-54.

Csíkos Csaba (2006): Nemzetközi rendszerszintü felmérések tanulságai az olvasástanítás számára. In: Józsa Krisztián (szerk.): Az olvasási képesség fejlödése és fejlesztése. Dinasztia Tankönyvkiadó, Budapest, 175-186.

Csíkos Csaba (2007): Metakogníció. A tudásra vonatkozó tudás pedagógiája. Müszaki Kiadó, Budapest.

Csíkszentmihályi Mihály (1991): Flow - Az áramlat. Akadémiai Kiadó, Budapest.

Csíkszentmihályi, M., Abuhamdeh, S. és Nakamura, J. (2005): Flow. In: Elliot, A. J. és Dweck, C. S. (szerk.): Handbook of competence and motivation. Guilford Publications, Inc, New York. 598-608.

Csíkszentmihályi, M. és Massimi, F. (1985): On the psychological selection of bio-cultural information. New Ideas Psychology, 3. 2. sz. 115-138.

Deci, E. L. (1992): The relation of interest to the motivation of behavior: A self-determination theory perspective. In: K. Renninger, S. Hidi, és A. Krapp (szerk.): The role of interest in learning and development. Erlbaum, Hillsdale, NJ. 43-70.

Deci, E. L. és Chandler, C. L. (1986): The importance of motivation for the future of the LD field. Journal of Learning Disabilities, 19. 10. sz. 587-594.

Deci, E. L. és Moller, A. C. (2005): The concept of competence: A starting place for understanding intrinsic motivation and self-determined extrinsic motivation). In: Elliot, A. és Dweck C. (szerk.): Handbook of Competence Motivation, New York: Plenum Press. 579-597.

Deci, E. L. és Ryan, R.M. (1985): Intrinsic motivation and self-determination in human behavior. Plenum, New York.

Deci, E. L., és Ryan, R. M. (2000): The 'what' and 'why' of goal pursuits: Human needs and the self-determination of behaviour. Psychological Inquiry, 11. 4. sz. 227-268.

Deci, E. L. és Vansteenkiste, M. (2004): Self-determination theory and basic need satisfaction: Understanding human development in positive psychology. Ricerche di Psichologia, 27. 1. sz. 17-34. 
Deci, E. L., Schwartz, A. J., Sheinman, L. és Ryan, R. M. (1981): An instrument to assess adults' orientations toward control versus autonomy with children: Reflections on intrinsic motivation and perceived competence. Journal of Educational Psychology, 73. 5. sz. 645-650.

Durik, A. M., Vida, M. és Eccles, J. S. (2006): Task values and ability beliefs as predictors of high school literacy choices: A developmental analysis. Journal of Educational Psychology, 98. 2. sz. 382-393.

Dweck, C. S. és Leggett, E. L. (1988): A social-cognitive approach to motivation and personality. Psychological Review, 95. 2. sz. 256-273.

Eccles J. S., Adler, T. F., Futterman, R., Goff, S. B., Kaczala, C. M., Meece, J. L., és Midgley, C. (1983): Expectancies, values, and academic behaviors. In: J. T. Spence (szerk.): Achievement and achievement motivation. W. H. Freeman, San Francisco, CA. 75-146.

Eccles, J. S. és Wigfield, A. (2002): Motivational beliefs, values and goals. Annual Review of Psychology, 53. 1. sz. 109-132.

Eccles, J., Wigfield, A., Harold, R. és Blumenfeld, P. (1993): Age and gender differences in children's self- and task perceptions during elementary school. Child Development, 64. 830-847.

Ehrlich, M. F., Kurtz-Costes, B., and Loridant, C. (1993): Cognitive and motivational determinants of reading comprehension in good and poor readers. Journal of Reading Behavior, 25. 4. sz. 365-381.

Elliot, A. J. (1997): Integrating the „classic” and the ,contemporary" approaches to achievement motivation. A hierarchical model of approach and avoidance achievement motivation. In: Maehr, M. L. és Pintrich, P. R. (szerk.): Advances in motivation and achievement. JAI Press Inc., Greenwich, Connecticut. 143-179.

Ely, R. B. W., Ainley, M. és Pearce, J. (2010): A new method for identifying dimensions of interest: MINE. In: Lemos, M., Goncalves, T., Verissimo, L. és Meneses, H. (szerk.): 12th International Conference on Motivation: New Directions in Mind. Porto, Portugália, September 2-4, 2010. Book of Abstracts. 90.

Falus Iván és Kimmel Magdolna (2003): A portfólió. Oktatás-módszertani Kiskönyvtár, Gondolat, Budapest.

Fazekasné Fenyvesi Margit (2000): A beszédhanghallás kritériumorientált fejlesztése. Új Pedagógiai Szemle, 50. 7-8. sz. 279-284.

Fazekasné Fenyvesi Margit (2006): A beszédhanghallás fejlesztés 4-8 éves életkorban. Mozaik Kiadó, Szeged.

Fejes József Balázs (2011): A tanulási motiváció kutatásának új iránya: A célorientációs elmélet. Magyar Pedagógia, 111. 1.sz. 25-51.

Fejes József Balázs és Józsa Krisztián (2005): A tanulási motiváció jellegzetességei hátrányos helyzetü tanulók körében. Magyar Pedagógia, 105. 2. sz. 185-205.

Fejes József Balázs és Józsa Krisztián (2007): Az iskolai eredményesség és a tanulási motiváció kulturális jellemzői: roma és többségi tanulók összehasonlítása. Iskolakultúra, 17. 67. sz. 83-96.

Fejes József Balázs és Szenczi Beáta (2010): Tanulási korlátok a magyar és az amerikai szakirodalomban. Gyógypedagógiai Szemle, 38. 4. sz. 273-287.

Findley, M. J. és Cooper, H. M. (1983): Locus of control and academic achievement: a literature review. Journal of Personality and Social Psychology, 44. 2. sz. 419-427.

Fitts, W. H. (1965): Tennessee Self-Concept Scale manual. Nashville, TN: State Department of Mental Health. 
Freedman-Doan, C., Wigfield, A., Eccles, J., Blumenfeld, P. B., Arbreton, A. és Harold, R. D. (2000): What am I best at? Gender and grade differences in elementary school-age children's beliefs about their abilities at different activities. Applied Developmental Psychology, 21. 4. sz. 379-402.

Fülöp Márta (2010): Tanulási motiváció és versengés: barátok vagy ellenségek? In: Molnár Éva és Kasik László (szerk.): PÉK 2010 - VIII. Pedagógiai Értékelési Konferencia: Program - Tartalmi összefoglalók. Szegedi Tudományegyetem, Szeged. 73.

Gambrell, L. B., Mazzoni, S. és Almasi, J. F. (2000): Promoting collaboration, social interaction, and engagement with text. In: Baker, L., Dreher, M. J. és Guthrie, J. T. (szerk.): Engaging young readers: Promoting achievement and motivation. Guilford, New York. 119-139.

Gambrell, L.B., Palmer, B.M., Codling, R.M. és Mazzoni, S.A. (1996): Assessing motivation to read. The Reading Teacher, 49. 7. sz. 219.

Gósy Mária (2005): Pszicholingvisztika. Osiris, Budapest.

Gottfried, A. E. (1990): Academic intrinsic motivation in young elementary school children. Journal of Educational Psychology, 82. 3. sz. 525-538.

Graham, S. és Williams, C. (2009): An attributional approach to motivation in school. In: K. R. Wentzel és A. Wigfield (szerk.): Handbook of motivation at school. Routledge, NY. $11-33$.

Grolnick, W. S. és Ryan, R. M. (1990): Self-perceptions, motivation, and adjustment in learning disabled children: A multiple group comparison study. Journal of Learning Disabilities, 23. 1. sz. 177-184.

Guay, F., Marsh, H. W. és Boivin, M. (2003): Academic self-concept and academic achievement: Developmental perspectives on their causal ordering. Journal of Educational Psychology, 95. 1. sz. 124-136.

Guthrie, J. T. és Cox, K. E. (2001): Classroom conditions for motivation and engagement in reading. Educational Psychology Review, 13. 3. sz. 283-302.

Guthrie, J. T., Hoa, A. L. W., Wigfield, A., Tonks, M., Humenick N. M. és E. Littles (2006): Reading motivation and reading comprehension growth in the later elementary years. Contemporary Educational Psychology, 32. 3. sz. 282-313.

Guthrie, J. T., Hoa, L. W., Wigfield, A., Tonks, S. M. és Perencevich, K. C. (2006): From spark to fire: Can situational reading interest lead to long-term reading motivation? Reading Research and Instruction, 45. 2. sz. 91-118.

Guthrie, J. T., és Wigfield, A. (2000): Engagement and motivation in reading. In: Kamil, M. L., Mosenthal, P. B., Pearson, P. D. és Barr R. (szerk.): Reading research handbook III., Erlbaum, Mahwah, New Jersey. 403-424.

Guthrie, J. T., McRae, A. és Klauda, S. L. (2007): Contributions of Concept-Oriented Reading Instruction to knowledge about interventions for motivations in reading. Educational Psychologist, 42. 4. sz. 237-250.

Hansford, B. és Hattie, J. (1982): The relationship between self and achievement/performance measures. Review of Educational Research, 52. 1. sz. 123-142.

Harter, S. (1981): A model of mastery motivation in children. In: Collins, W. A. (szerk.): Minnesota Symposia on Child Psychology. Vol. 14. Lawrence Erlbaum Associates, Hillsdale, New Jersey. 215-255.

Harter, S. (1990): Causes, correlates and the functional role of global self-worth: a life-span perspective. In: Kolligan, J. és Sternberg, R. (szerk.): Perceptions of Competence and Incompetence Across Life-Span. Yale University Press, New Haven, CT. 67-98. 
Harter, S. és Pike, R. (1984): The Pictorial Scale of Perceived Competence and Social Acceptance for Young Children. Child Development, 55. 1969-1982. http://www.ches.ua.edu/departments/hd/faculty/scofield/hd501/materials/articles/harter, \%20pike,\%201984\%20-\%20self-concept,\%20esteem.pdf 2008. április 1-i megtekintés.

Hattie, J. (1992): Self-concept. Lawrence Erlbaum Associates, Hillsdale.

Haywood, H. C. (1968): Motivational orientation of of overachieving and underachieving elementary school children. American Journal of Mental Deficiency, 72. 662-667.

Haywood, H. C. és Switzky, H. N. (1986): Intrinsic motivation and behavior effectiveness in retarded persons. In: N. R. Ellis és N. W. Bray (szerk.): International review of research in mental retardation. Academic Press, New York. 1-46.

Hidi, S. (1990): Interest and its contribution as a mental resource for learning. Review of Educational Research, 60. 4. sz. 549-571.

Hidi, S. (2001): Interest, Reading and Learning: Theoretical and Practical Considerations. Educational Psychology Review, 13. 3. sz. 191-209.

Hidi, S. és Harakiewicz, J. M. (2000): Motivating the academically unmotivated: A critical issue for the 21st century. Review of Educational Research, 70. 2. sz. 151-179.

Hidi, S. és Renninger, K. A. (2006): The four-phase model of interest development. Educational Psychologist, 41.2. sz. 111-127.

Higgins, E. T. (2007): Value. In: Kruglanski, A. W. és Higgins, E. T. (szerk.): Handbook of social psychology. Guilford, New York. 454-472.

Hornery, S., Craven, R. G., Yeung, A. S. és Ali, J. (2008): A New Multidimensional DomainSpecific Motivation Questionnaire: Measurement of Young Children's Multi-faceted Reading Motivation. Paper presented at the Australian Association for Research in Education conference, Brisbane Australia, November 2008.

http://www.aare.edu.au/08pap/hor08757.pdf, 2012. február 9.-i megtekintés

Horváth Zsuzsanna (1994): Olvasás, szövegértés. Monitor '93. Új Pedagógiai Szemle, 44. 78. sz. 97-108.

Horváth Zsuzsanna (1996): A szövegértési képesség fejlődésének vizsgálata. Monitor '95. Új Pedagógiai Szemle, 46. 7-8. sz. 74-90.

Hull, C. L. (1943): Principles of behavior. Appleton-Century-Crofts, New York.

Jackson, S. A. és Csíkszentmihályi, M. (1999): Flow in sports. Harper Collins, New York.

Jacobs, J. E., Lanza, S., Osgood, D.W., Eccles, J. S. és Wigfield, A. (2002): Ontogeny of children's self-beliefs: Gender and domain differences across grades one through 12 . Child Development, 73. 509-527.

Janurik Márta (2007): Áramlatélmény az iskolai ének-zeneórákon. Magyar Pedagógia, 107. 3. sz. 295-320.

Janurik Márta (2009): Flow-élmény az énekórákon: A többségi és a Waldorf-iskolák összehasonlító elemzése. Magyar Pedagógia, 109. 3. sz. 193-226.

Józsa Krisztián (1999): Mi alakítja az énértékelésünket fizikából? Iskolakultúra, 9. 10. sz. 7280.

Józsa Krisztián (2002): Tanulási motiváció és humán müveltség. In: Csapó Benő (szerk.): $A z$ iskolai müveltség. Osiris Kiadó, Budapest. 239-268.

Józsa Krisztián (2005): A képességek és motívumok kölcsönös fejlesztésének lehetősége. In: Kelemen Elemér és Falus Iván (szerk.): Tanulmányok a neveléstudomány köréből. Müszaki Könyvkiadó, Budapest. 283-302.

Józsa Krisztián (2006, szerk.): Az olvasási képesség fejlödése és fejlesztése. Dinasztia Tankönyvkiadó, Budapest. 
Józsa Krisztián (2007): Az elsajátítási motiváció. Müszaki Kiadó, Budapest.

Józsa Krisztián és Fazekasné Fenyvesi Margit (2007): Tanulásban akadályozott gyermekek tanulási motivációja. Iskolakultúra Online, 1. 1. sz. 76-92.

Józsa Krisztián és Fazekasné Fenyvesi Margit (2008): Az olvasás iránti motiváltság alakulása tanulásban akadályozott és többségi gyermekek esetében (szimpózium-előadás). VIII. Országos Neveléstudományi Konferencia, Budapest.

Józsa Krisztián és Fejes József Balázs (2010): A szociális környezet szerepe a tanulási motiváció alakulásában: a család, az iskola és a kultúra hatása. In: Zsolnai Anikó és Kasik László (szerk.): A szociális kompetencia fejlesztésének elméleti és gyakorlati alapjai. Tankönyvkiadó, Budapest. 134-162.

Józsa Krisztián és Steklács János (2009): Az olvasástanítás kutatásának aktuális kérdései. Magyar Pedagógia, 109. 4. sz. 365-397.

Józsa Krisztián, Szenczi Beáta és Hricsovinyi Julianna (2011): A tanulási motiváció számítógép-alapú mérési lehetőségei. In: Csapó Benő és Zsolnai Anikó (szerk.): Kognitív és affektiv fejlödési folyamatok diagnosztikus értékelésének lehetöségei az iskola kezdö szakaszában. Nemzeti Tankönyvkiadó, Budapest. 147-171.

Kage, M. és Namiki, H. (1990): The effects of evaluation structure on children's intrinsic motivation and learning. Japanese Journal of Educational Psychology, 38. 2. sz. 36-45.

Kaplan, A. és Midgley, C. (1997): The effect of achievement goals: Does level of academic efficacy make a difference? Contemporary Educational Psychology, 22. 415-435.

Kasik László (2006): A társas viselkedés, a tanulmányi teljesítmény és a tanulási-kulturális szokások összefüggése 13-16 éves korban. Magyar Pedagógia, 106. 3. sz. 231-258.

Kelemen Rita, Józsa Krisztián and Szenczi Beáta (2010): Reading motivation of students with and without learning disabilities. Presented at the 12th International Conference on Motivation, Porto, Portugalia, September 2-4, 2010. In: Lemos M., Goncalves, T., Verissimo, L. és Meneses, H. (szerk.): Motivation: New Directions in Mind. Book of Abstracts. 163-164.

Keller, J. (2008): Stereotype als Bedrohung. In: L.E. Petersen és Six, B. (szerk.): Stereotype, Vorurteile und soziale Diskriminierung. Theorien, Befundeund Interventionen. Belt PVU, Weinheim. 88-96.

Kelly, D. L. (2003): Developing the PIRLS background questionnaires. In: M. O. Martin, I. V. S. Mullis és A. M. Kennedy (szerk.): PIRLS 2001 technical report. International Study Center, Lynch School of Education, Boston College, Boston. 29-37.

Kirsch, I., de Jong, J., Lafontaine, D., McQueen, J., Mendelovits, J. és Monseur, C. (2002): Reading for change: Performance and engagement across countries: Results from PISA 2000. Organisation for Economic Cooperation and Development, Paris.

Krapp, A. (2000): Interest and human development during adolescence: An educational psychological approach. In: Heckhausen, J. (szerk.): Motivational Psychology of Human Development. Elsevier, Amsterdam. 109-128.

Lepola, J. (2000): Motivation in early school years: Developmental patterns and cognitive consequences. Turun Yliopisto, Turku.

Lepola, J. (2004): The role of gender and reading competence in the development of motivational orientations from kindergarten to grade 1. Early Education \& Development, 15. 2. sz. 215-240.

Lepola, J., Salonen, P. és Vauras, M. (2000): The development of motivational orientations as a function of divergent reading careers from pre-school to the second grade. Learning and Instruction, 10. 2. sz. 153-177. 
Linnenbrink, E. A. és Pintrich, P. R. (2001): Multiple goals, multiple contexts: The dynamic interplay between personal goals and contextual goal stresses. In: Volet, S. és Järvelä, S. (szerk.): Motivation in learning contexts: Theoretical and methodological implications. Elsevier, Amsterdam. 251-269.

Margolis H. és McCabe P. (2006): Improving self-efficacy and motivation: What to do, What to say. Intervention in School and Clinic, 41. 4. sz. 218-227.

Marsh, H. W. (1984): Relationships among dimensions of self-attribution, dimensions of selfconcept, and academic achievements. Journal of Educational Psychology, 76. 12911380.

Marsh, H. W. (1990): The structure of academic Self-Concept: The Marsh/Shavelson Model. Journal of Educational Psychology, 82. 4. sz. 623-636.

Marsh, H. W. (1993): Academic self-concept: Theory, measurement and research. In: Suls, J. (szerk.): Psychological perspectives on the self. Erlbaum, Hillsdale, NJ. 59-98

Marsh, H. W. és Craven, R.G. (1997): Academic self-concept: Beyond the dustbowl. In: Phye, G. (szerk.): Handbook of classroom assessment: Learning, achievement and adjustment. Academic Press, US.

Marsh, H. W. és Richards, G. E. (1988): The outward bound bridging course for lowachieving males: Effects on academic achievement and multidimensional selfconcepts. Australian Journal of Psychology, 40. 281-298.

Marsh, H. W., Craven, R.G. és Debus, R.L. (1991): Self-concepts of young children aged 5 to 8: Their measurement and multidimensional structure. Journal of Educational Psychology, 83. 3. sz. 377-392.

Martin, A. és Dowson, M. (2009): Interpersonal relationships, motivation, engagement, and achievement: Yields for theory, current issues, and practice. Review of Educational Research, 79. 327-365.

McKenna, M.C. (2001): Development of reading attitudes. In: Verhoeven, L. és C. Snow (szerk.): Literacy and motivation: Reading engagement in individuals and groups. Lawrence Erlbaum, Mahwah, NJ. 135-158

McKenna, M. C. és Kear, D. J. (1990): Measuring attitude towards reading: A new tool for teachers. The Reading Teacher, 43. 626-639.

McKenna, M.C., Kear, D.J. és Ellsworth, R.A. (1995): Children's attitudes toward reading: A national survey. Reading Research Quarterly, 30. 934-956.

McQuillan, J. és Au, J. (2001): The effect of print access on reading frequency. Reading Psychology, 22. 3. sz. 225-248.

McQuillan, J., és Conde, G. (1996): The conditions of flow in reading: two studies of optimal experience. Reading Psychology, 17. 2. sz. 109-135.

Meece, J. L. és Miller, S. D. (2001): A longitudinal analysis of elementary school students' achievement goals in literacy activities. Contemporary Educational Psychology, 26. 454-480.

Meece, J. L., Anderman, E. M. és Anderman, L. H. (2006): Classroom goal structures, student motivation, and academic achievement. Annual Review of Psychology 57. 487-503.

Meece, J. L., Glienke, B. B. és Burg, S. (2006): Gender and motivation. Journal of School Psychology, 44. 351-373.

Mérei Ferenc és Binét Ágnes (2003): Gyermeklélektan. Medicina Könyvkiadó, Budapest.

Mesterházi Zsuzsa (1998): A nehezen tanuló gyermekek iskolai nevelése. BGGYTF, Budapest.

Molnár Éva (2009): Az önszabályozás értelmezései és elméleti megközelítései. Magyar Pedagógia, 109. 4. sz. 343-364. 
Morena, D. A. és Litrownik, A. J. (1974): Self-concept in EMR and EH children: Relationship between behavioral indices and an attempt at modification. Journal of Abnormal Child Psychology, 87. 2. sz. 281-292.

Morgan, P. L., Fuchs, D., Compton, D. L., Cordray, D. S. és Fuchs, L. S. (2008): Does early reading failure decrease children's reading motivation? Journal of Learning Disabilities, 41. 5. sz. 387-404.

Morgan, G. A., Harmon, R.J. és Maslin-Cole, C.H. (1990): Mastery motivation: Definition and measurement. Early Education and Development, 1. 5. sz. 318-339.

Möller, J. és Schiefele, U. (2010): The Motivational foundations of reading Literacy. (Kézirat).

Mullis, I. V. S., Kennedy, A. M., Martin, M. O. és Sainsbury, M. (2006): PIRLS 2006 assessment framework and specifications. TIMSS \& PIRLS International Study Center, Boston College, Chestnut Hill, MA.

Murphy, P. K. és Alexander, P. A. (2000): A motivated exploration of motivation terminology. Contemporary Educational Psychology, 25. 2. sz. 3-53.

Nagy József (2000): XXI. század és nevelés. Osiris Kiadó, Budapest.

Nagy József (2005): A hagyományos pedagógia kultúra csődje. Iskolakultúra, 6-7. sz. melléklet.

Nagy József (2006): Olvasástanítás: A megoldás stratégiai kérdései. In: Józsa Krisztián (szerk.): Az olvasási képesség fejlödése és fejlesztése. Dinasztia Tankönyvkiadó, Budapest. $17-42$.

Nagy József (2010): Új pedagógiai kultúra. Mozaik Kiadó, Szeged.

Nagy József (2011): Az oktatási rendszer alacsony eredményességének társadalmi következményei, nem megfelelő müködésének jellemzői és folyamatos fejlesztésének létfontosságú feladatai. (Kézirat)

Natale, K., Viljaranta, J., Lerkkanen, M. K., Poikkeus, A. M. és Nurmi, J. E. (2009): Crosslagged associations between kindergarten teachers' causal attributions and children's task motivation and performance in reading. Educational Psychology, 29. 5. sz. 603-619.

Nemzeti Alaptanterv (2007). 2012. március 30-i megtekintés. http://www.nefmi.gov.hu/letolt/kozokt/nat_070926.pdf

Nemzeti Alaptanterv (2012) - Vitaanyag. 2012. március 30-i megtekintés. www. ofi.hu/nat2012

Nicholls, J. G. (1984): The development of the concepts of effort and ability, perception of own attainment, and the understanding that difficult tasks require more ability. Child Development, 49. 4. sz. 800-814.

Nolen, S. B. (2001): Constructing literacy in the kindergarten: Task structure, collaboration, and motivation. Cognition and Instruction, 19. 1. sz. 95-153.

Nyitrai Ágnes (2009): A mese, a mesélés fejlesztő hatása. Nagy József (szerk.): Fejlesztés mesékkel: Az anyanyelv, a gondolkodás fejlödésének segitése mesékkel 4-8 éves életkorban. Mozaik Kiadó, Szeged 9-31.

Programme for International Student Assessment (2006): The PISA 2006 Assessment Framework. OECD, Paris. 2010. január 21-ei megtekintés. https://www.pisa.oecd.org/dataoecd/63/35/37464175.pdf

Programme for International Student Assessment (2009): The PISA 2009 Assessment Framework. OECD, Paris. 2012. január 12-ei megtekintés. https://www.oecd.org/dataoecd/11/40/44455820.pdf 
OECD (2010): PISA 2009 Results: What students know and can do - Student performance in reading, mathematics and science. OECD, Paris.

Oláh Attila (2005): Érzelmek, megküzdés és optimális élmény: Belső világunk megismerésének módszerei. Trefort Kiadó, Budapest.

Olkinuora, E. és Salonen, P. (1992): Adaptation, motivational orientation, and cognition in a subnormally-performing child: A systemic perspective for training. In: B. Wong (szerk.): Intervention research in learning disabilities: An international perspective. Sringer-Verlag, New York. 190-213.

Onatsu-Arvilommi, T. és Nurmi, J. (2000): The role of task-avoidant and task-focused behaviors in the development of reading and mathematical skills during the first school year: a cross-lagged longitudinal study. Journal of Educational Psychology, 92. 2. sz. 478-491.

Pajares, M. F. (1992): Teachers' beliefs and educational research: cleaning up a messy construct. Review of Educational Research, 62. 3. 307-333.

Pajares, F. és Miller, D. (1994): Role of self-efficacy and self-concept beliefs in mathematical problem solving: A path analysis. Journal of Educational Psychology, 86. 2. sz. 193203.

Pap-Szigeti Róbert, Zentai Gabriella és Józsa Krisztián (2006): A szövegfeldolgozó képességfejlesztés módszerei. In: Józsa Krisztián (szerk.): Az olvasási képesség fejlődése és fejlesztése. Dinasztia Tankönyvkiadó, Budapest. 235-258.

Piers, E. (1969): Manual for the Piers-Harris Children's Self-concept Scale. Counselor Recordings and Tests, Nashville, TN.

Piers, E. és Harris, D. (1964): Age and other correlates of self-concept. Journal of Educational Psychology, 55. 91-95.

Pintrich, P. R. és Schunk, D. H. (1996): Motivation in education: Theory, research and applications. Prentice-Hall, Englewood Cliff, New Jersey.

Pintrich, P. R., Anderman, E. A. és Klobucar, C. (1994): Intraindividual differences in motivation and cognition in students with and without learning disabilities. Journal of Learning Disabilities, 27. 360-370.

Pressley, M., Symons, S., Snyder, B. I. és Cariglia-Bull, T. (1989): Strategy instruction comes of age. Learning Disability Quaterly, 12.1. sz. 16-30

Reeve, J. és Jang, H. (2006): What teachers say and do to support students' autonomy during a learning activity. Journal of Educational Psychology, 98. 1. sz. 209-218.

Renninger, A. K. (1992): Individual interest and development: Implications for theory and practice. In: A. Renninger és S. Hidi (szerk.): Role of interest in learning and development. NJ: Erlbaum, Hillsdale. 361-395.

Renninger, A. K. (2000): Individual interest and its implications for understanding intrinsic motivation. In: C. Sansone és J. M. Harackiewicz (szerk.): Intrinsic and extrinsic motivation: The search for optimal motivation and performance. Academic Press, San Diego, CA. 373-404.

Retelsdorf, J., Köller, O. és Möller, J. (2011): On the effects of motivation on reading performance growth in secondary school. Learning and Instruction, 21. 4. sz. 550-559.

Réthy Endréné (1995): Tanulási motiváció. Új Pedagógiai Közlemények. ELTE Neveléstudományi Tanszék és Pro Educatione Gentis Hungariae Alapítvány, Budapest.

Réthy Endréné (2001): A tanulási motiváció elemzése. In: Csapó Benő és Vidákovich Tibor (szerk.): Neveléstudomány az ezredfordulón: Tanulmányok Nagy József tiszteletére. Tankönyvkiadó, Budapest, 153-161. 
Réthy Endréné (2003): Motiváció, tanulás, tanítás. Miért tanulunk jól vagy rosszul? Nemzeti Tankönyvkiadó, Budapest.

Roth, G., Assor, A., Kanat-Maymon, Y. és Kaplan, H. (2007): Autonomous motivation for teaching: How self-determined teaching may lead to self-determined learning. Journal of Educational Psychology, 99. 4. sz. 761-774.

Ryan, R.M. és E. L. Deci (2000): Intrinsic and extrinsic motivations: Classic definitions and new directions. Contemporary Educational Psychology, 25. 1. sz. 54-67.

Ryan, R. M és Deci, E. L. (2009): Promoting self-determined school engagement: motivation, learning and well-being. In: K. R. Wentzel és A. Wigfield (szerk.): Handbook of motivation at school. Routledge, New York. 171-195.

Ryan, R. M. és Grolnick, W. S. (1986): Origins and pawns in the classroom: A self-report and projective assessment of children's perceptions. Journal of Personality and Social Psychology, 50. 3. sz. 550-558.

Salomon, G. és Perkins, D. N. (1998): Individual and social aspects of learning. In: Pearson, P. D. és Iran-Nejad, A. (szerk.): Review of research in education. American Educational Research Association, Washington. 1-24.

Salonen, P., Lepola, J. és Niemi, P. (1998): The develoment of first graders' reading skill as a function of pre-school motivational orientation and phonemic awareness. European Journal of Psychology in Education, 13. 2. sz. 155-174.

Schiefele, U. (1992): Topic interest and levels of text comprehension. In: Renninger, A., Hidi S. és Krapp; A. (szerk.): The role of interest in learning and development. Lawrence Erlbaum Associates, Hillsdale, New Jersey. 151-182.

Schiefele, U. (1999): Interest and learning from text. Scientific Studies of Reading, 3. 3. sz. 257-279.

Schiefele, U. és Krapp, A. (1996): Topic interest and free recall of expository text. Learning and Individual Differences, 8. 2. sz. 141-160.

Schotz, Wolfgang és Molnár Edit Katalin (2012): Az olvasás-szövegértés mérésének társadalmi és kulturális aspektusai. (Kézirat)

Schunk, D. H. (1999): Social-self interaction and achievement behavior. Educational Psychologist, 34. 4. sz. 219-227.

Schunk, D. H. és Meece, J. L. (2006): Self-efficacy in adolescence. In: Pajares, F. és Urdan, T. (szerk.): Adolescence and Education . Informatikon Age Publishing, Greenwich, CT. 71-96.

Schunk, D. H. és Pajares, F. (2009): Self-efficacy theory. In: Wentzel, K. R. és Wigfield, A. (szerk.): Handbook of motivation at school. Routledge, New York. 35-53.

Schunk, D. H. és Zimmerman, B. J. (1997): Social origins of self-regulatory competence. Educational Psychologist, 32. 4. sz. 195-208.

Shavelson, R. J., Hubner, J. J. és Stanton, G. C. (1976): Self-concept: Validation of construct interpretations. Review of Educational Research, 46. 3. sz. 407-441.

Shell, D. F., Colvin, C., Bruning, R. H. (1995): Self-efficacy, attribution, and outcome expectancy mechanisms in reading and writing achievement: Grade-level and achievement-level differences. Journal of Educational Psychology, 87. 3. sz. 386-398.

Sideridis, G. D. (2006): Classroom goal structures and hopelessness as predictors of day-today experience at school: Differences between students with and without learning disabilities. International Journal of Educational Research, 43. 4-5. sz. 308-328. 
Sideridis, G.D., Mouzaki, A. Simos, P. és Protopapas, A. (2006): Classification of students with reading comprehension difficulties: The roles of motivation, affect, and psychopathology. Learning Disability Quarterly, 29. 3. sz. 159-180.

Skinner, B. F. (1953): Science and human behavior. NewYork: Macmillan.

Skinner, E. A. (1995): Perceived control, motivation, and coping. Sage, Thousand Oaks, CA.

Sonnenschein, S. és Munsterman, K. (2002): The influence of home-based reading interactions on 5-year-olds' reading motivations and early literacy development. Early Childhood Research Quarterly, 17. 3. sz. 317-338.

Stajkovic, A. D. és Sommer, S. (2000): Self-efficacy and causal attributions: Direct and reciprocal links. Journal of Applied Social Psychology, 30. 4. sz. 707-737.

Steklács János (2005): Funkcionális analfabetizmus a hipotézisek, tények és számok tükrében. Akadémiai Kiadó, Budapest.

Steklács János (2011): Az olvasásra vonatkozó meggyőződés vizsgálata negyedik osztályos tanulók körében. Anyanyelv-pedagógia, www.anyanyelv-pedagógia.hu /cikkek.php?id=313 2012. február 13-i megtekintés

Stipek, D. J. (2002): Good instruction is motivating. In: A. Wigfield és J. S. Eccles (szerk.): Development of achievement motivation. Academic Press, San Diego, CA. 309-332.

Sweet, A. P., Guthrie, J. T., \& Ng, M. M. (1998): Teacher perceptions and student reading motivation. Journal of Educational Psychology, 90. 2. sz. 210-223.

Switzky, H.N. (2001): Personality and Motivational Differences in Persons with Mental Retardation. Lawrence Erlbaum Associates, Mahwah, NJ.

Szabó Mónika (2004): Motiváció. In: N. Kollár Katalin és Szabó Éva (Szerk.): Pszichológia Pedagógusoknak. Osiris Kiadó, Budapest. 169-191.

Szenczi Beáta (2008): Énkép és tanulás: Nemzetközi kutatási irányzatok és tendenciák. Iskolakultúra Online, 1. 2. sz. 104-118.

Szenczi Beáta (2010): Olvasási motiváció: Definíciók és kutatási irányok. Magyar Pedagógia, 110. 2. sz. 119-147.

Szenczi Beáta és Józsa Krisztián (2008): Az énképet vizsgáló SDQI kérdőív hazai adaptációja (előadás). VIII. Országos Neveléstudományi Konferencia: Hatékony tudomány, pedagógiai kultúra, sikeres iskola, Budapest. Tartalmi Összefoglalók, 328.

Szenczi Beáta és Józsa Krisztián (2009): A tanulási énkép összefüggése a tanulmányi eredményekkel és a képességfejlettséggel (előadás). PÉK 2009 - VII. Pedagógiai Értékelési Konferencia, Szeged, 2009. ápr. 24-25. Tartalmi összefoglalók, 103.

Szenczi Beáta (2011a): Measuring motivation within the domain of reading: A pilot study. Elöadás. European Association for Research on Learning and Instruction, Junior Researcher (EARLI JURE) Pre-conference. Exeter, United Kingdom, 2011. aug. 29-30.

Szenczi Beáta (2011b): Leendő és gyakorló tanítók meggyőződései az olvasási motivációról. Előadás. PÉK 2011 - IX. Pedagógiai Értékelési Konferencia, Szeged, 2011. ápr. 29-30. Tartalmi összefoglalók, 73.

Szenczi Beáta (2012): Második osztályos tanulók meggyőződései az olvasástanulás céljáról és saját olvasásteljesítményükről. Szimpóziumi előadás. PÉK 2012 - X. Pedagógiai Értékelési Konferencia, Szeged, 2012. április 26-28. Tartalmi összefoglalók, 87.

Szinger Veronika (2007): Kivárás és bontakozó írásbeliség - Hagyomány és újszerüség az óvodai írás- és olvasás előkészítésben. Elektronikus könyv és nevelés, 9. 1. sz. http://www.tanszertar.hu/eken/2007_01/seged_0701/szv.pdf 2012. január 29-i megtekintés. 
Szinger Veronika (2009): Nagycsoportos óvodások írásbeliséggel kapcsolatos tudása és tevékenységei. Elektronikus könyv és nevelés, 11. 2. sz. http://www.tanszertar.hu /eken/2009_02/szv_0902.htm 2012. január 21-i megtekintés.

Thurstone, L. L. (1928): Attitudes Can Be Measured. American Journal of Sociology, 33. 529-554.

Torgesen, J. K. (1986): Learning disabilities theory: Its current state and future prospects. Journal of Learning Disabilities, 19. 399-407.

Tóth Tibor (1999): Az olvasásra nevelésröl. Iskolakultúra, 9. 1. sz. 66-68.

Turner, J. C. (1995): The influence of classroom contexts on young children's motivation for literacy. Reading Research Quarterly, 30. 3. sz. 410-441.

Turner, J. C. (1997): Starting right: Strategies for engaging young literacy learners. In: Guthrie, J. T. és Wigfield. A. (szerk.): Reading engagement: Motivating readers through integrated instruction. International Reading Association, Newark, DE. 183-204.

Turner, L. A. (1996): Attributional beliefs of students with mental retardation. In: Lewis, M. és Sullivan, M. (szerk.): Emotional development in atypical children, Lawrence Erlbaum Publishers.

Turner, L. A. (1998): Relation of attributional beliefs to memory strategy use in children and adolescents with mental retardation. American Journal of Mental Retardation, 103. 2. sz. $162-172$.

Valentine, J. C., DuBois, D.L. és Cooper, H. (2004): The Relation Between Self-Beliefs and Academic Achievement: A Meta-Analytic Review. Educational Psychologist, 39. 111134.

Van Damme, J., Opdenakker, M. C., De Fraine, B. és Mertens, W. (2004): Academic SelfConcept and Academic Achievement: Cause and Effect. Elöadás: Third Biennial SELF Conference. Max Plank Institute, Berlin, 2004. július 4-7. http://self.uws.edu.au/Conferences/2004_Van_Damme_Opdenakker_De_Fraine_Merten s.pdf. 2007. december 12-ei megtekintés.

van de Vijver, F. J. R. és Hambleton, R. K. (1996): Translating tests: Some practical guidelines. European Psychologist, 1. 2. sz. 89-99.

van Kraayenoord, C. E. and Schneider, W. E. (1999): Reading, metacognition, motivationAn Australian/German comparison. In: 8th European Conference for Research on Learning and Instruction, Goteborg, Sweden, 24-28 Aug. 539.

Vári Péter (1997): Monitor'95. A tanulók tudásának felmérése. Országos Közoktatási Intézet, Budapest.

Vári Péter (2003): PISA-vizsgálat 2000. Müszaki Könyvkiadó, Budapest.

Verhoeven, L. és Snow, C.E. (2001): Literacy and Motivation: Bridging Congitive and Sociocultural Viewpoints. In: Verhoeven, L. és Snow, C. E. (szerk.): Literacy and Motivation: Reading Engagement in Individuals and Groups. Lawrence Erlbaum Associates, Mahwah, New Jersey.

Viljaranta, J., Lerkkanen, M. K., Poikkeus, A. M., Aunola, K. és Nurmi, J. E. (2008): Crosslagged relations between task-motivation and performance in arithmetic and literacy in kindergarten. Learning and Instruction, 19. 4. sz. 335-344.

Wang, J. H. Y., és Guthrie, J. T. (2004): Modeling the effects of intrinsic motivation, extrinsic motivation, amount of reading, and past reading achievement on text comprehension between U.S. and Chinese students. Reading Research Quarterly, 39. 162-186.

Watkins, M. W. (2005): Diagnostic validity of Wechsler subtest scatter. Learning Disabilities: A Contemporary Journal, 3. 2. sz. 20-29. 
Watkins, M. W. és Coffey, D. Y. (2004): Reading motivation: Multidimensional and indeterminate. Journal of Educational Psychology, 96. 1. sz. 110-118.

Watkins, M. W., Kush, J. C. és Glutting, J. J. (1997): Discriminant and predictive validity of the WISC-III ACID profile among children with learning disabilities. Psychology in the Schools, 34. 4. sz. 309-319.

Weiner, B. (1985): An attributional theory of achievement motivation and emotion. Psychological Review, 92. 4. sz. 548-573.

Weiner, B. (1992). Human Motivation: Metaphors, Theories, and Research, Sage, Newbury Park, CA.

White, R. (1959): Motivation reconsidered: The concept of competence. Psychological Review, 66. 297-333.

Wigfield, A., Eccles, J. S. (2000): Expectancy-Value Theory of Achievement Motivation. Contemporary Educational Psychology, 25. 1. sz. 68-81.

Wigfield, A. és Guthrie, J. T. (1997): Motivation for reading: individual, home, textual, and classroom perspective. Educational Psychologist, 32. 2. sz. 57-135.

Wigfield, A., Eccles, J. S. és Rodriguez, D. (1997): The development of children's motivation in school contexts. In: A. Iran-Nejad és P. D. Pearson (szerk.): Review of research in education 23. American Educational Research Association, Washington DC. 73-118.

Wigfield, A., Guthrie, J. T., és K. McGough (1996): A questionnaire measure of children's motivations for reading (Instructional Resource 22). Athens, GA: National Reading Research Center, University of Georgia and University of Maryland.http://eric.ed.gov/ERICDocs/data/ericdocs2sq1/content_storage_01/0000019b/80/14 /78/b0.pdf 2008.12.01-i megtekintés.

Wigfield, A., Guthrie, J. T., Perencevich, K. C., Taboada, A., Klauda, S. L., McRae, A. és Barbosa, P. (2008): The role of reading engagement in mediating effects of reading comprehension instruction on reading outcomes. Psychology in the Schools, 45. 2. sz. $432-445$.

Wigfield, A., Guthrie, J.T., S. Tonks és K. C. Perencevich (2004): Children's Motivation for Reading: Domain Specificity and Instructional Influences. The Journal of Educational Research, 97. 6. sz. 299-309.

Wigfield, A., Tonks, S. és Klauda, S. L. (2009): Expectancy-value theory. K. R. Wentzel és A. Wigfield (szerk.): Handbook of motivation at school. Routledge, New York. 55-76.

Wilson, K. M. és Trainin, G. (2007): First-grade students' motivation and achievement for reading, writing and spelling. Reading Psychology, 28. 3. sz. 257-282.

Yarrow, L. J., Rubenstein, J. L., Pedersen, F. A. (1975): Infant and environment: early cognitive and motivational development. Hemisphere Pub. Corp., New York.

Young, J. P. és Brozo, W. G. (2001): Boys will be boys, or will they? Literacy and masculinities. Reading Research Quarterly, 36. 3. sz. 316-325.

Zsolnai Anikó (1998): A szociális kompetencia kapcsolata az iskolai teljesítménnyel. Magyar Pedagógia, 98. 4. sz. 339-362.

Zsolnai Anikó (2008): A szociális készségek fejlődése és fejlesztése gyermekkorban. Iskolakultúra Online, 2. 1. sz. 119-140. 


\section{Mellékletek}

1. melléklet: A SDQ I. (Self-Description Questionnaire I.) magyar nyelvre adaptált változata 2. melléklet: Az énképösszetevők eloszlása 3., 5. és 7. évfolyamon

3. melléklet: Az egydimenziós olvasási motiváció mérőeszköze

4. melléklet: Képes szóolvasás teszt

5. melléklet: Szövegértés teszt a második pilot vizsgálatban

6. melléklet: Az olvasási motiváció mérőeszköze az általános iskola 2. osztálya számára

7. melléklet: Segédeszközök az olvasási motiváció mérésére 2. osztályosoknak

8. melléklet: Az olvasási motiváció jegyzőkönyv hosszú változata

9. melléklet: Az olvasási motiváció mérőeszköze az általános iskola felsőbb évfolyamai számára

10. melléklet: Szövegértés teszt

11. melléklet: Szülöi kérdöív

12. melléklet: Kérdőív a pedagógusok számára

13. melléklet: Elözetes kategóriarendszer a félig strukturált interjúk elemzéséhez

14. melléklet: Kérdőív pedagógusok számára az olvasással és olvasási motivációval

kapcsolatos meggyőződések vizsgálatára 
1. sz. melléklet

(C) SDQI

ELTE Bárczi Gusztáv Gyógypedagógiai Főiskolai Kar

Tanulásban akadályozott gyermekek értelmi és szociális készségeinek fejlődése

\section{KÉRDŐÍV ÖNMAGADRÓL}

A rendelkezésünkre bocsátott összes információt szigorúan bizalmasan kezeljük.

Név:

Iskola:

Osztály:

\section{ELŐSZÖR AZ ALÁBBI ÚTMUTATÓT OLVASD EL!}

Ez a felmérés egy lehetőség számodra, hogy megismerd önmagad. Nem dolgozat. Nincsenek jó vagy rossz válaszok, mindenki mást fog válaszolni. KÉRLEK VÁLASZAIDAT NE BESZÉLD MEG MÁSOKKAL!

Olvass el minden egyes mondatot és döntsd el, hogy mennyire igazak Rád. A válaszodat a Rád jellemző szám bekarikázásával jelezd! Csak egy számot karikázhatsz be. A számok jelentése a következő:

\begin{tabular}{|c|c|c|c|c|}
\hline 1 & 2 & 3 & 4 & 5 \\
Hamis & $\begin{array}{c}\mathbf{3} \\
\text { Többnyire } \\
\text { hamis }\end{array}$ & $\begin{array}{c}\text { Néha igaz, } \\
\text { néha hamis }\end{array}$ & $\begin{array}{c}\mathbf{4} \\
\text { Többnyire } \\
\text { igaz }\end{array}$ & Igaz \\
\hline
\end{tabular}

PÉLDA
A. Szeretek képregényeket olvasni.
1
$2 \quad 3 \quad 4$

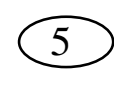

Ha tényleg nagyon szeretsz képregényeket olvasni, akkor az ötös számot karikázd be, ahogy itt is látod. Ha egyáltalán nem szeretsz képregényeket olvasni, akkor az egyes számot karikázd, ha csak kicsit vagy csak néha, akkor a kettest, ha néha igen, néha nem, akkor a hármast, ha pedig többnyire szeretsz képregényeket olvasni, de nem mindig, akkor a négyest.

\section{Ne hagyj egyetlen állítást sem megválaszolatlanul!}

Ha valamit nem értesz, kérj segítséget! 


\section{Állítás}

01. Jól nézek ki.

02. Minden tantárgyból jó vagyok.

03. Gyorsan tudok futni.

04. Irodalomból jó jegyeket kapok.

05. A szüleim megértenek.

06. Utálom a matematikát.

07. Sok barátom van.

08. Tetszik, ahogyan kinézek.

09. Szívesen foglalkozom mindegyik tantárggyal.

\section{Hamis}

Többnyire hamis

\begin{tabular}{ccc}
$\begin{array}{c}\text { Néha igaz, } \\
\text { néha hamis }\end{array}$ & $\begin{array}{c}\text { Több- } \\
\text { nyire } \\
\text { igaz }\end{array}$ & Igaz \\
3 & 4 & 5 \\
3 & 4 & 5 \\
3 & 4 & 5 \\
3 & 4 & 5 \\
3 & 4 & 5 \\
\hline 3 & 4 & 5 \\
3 & 4 & 5 \\
3 & 4 & 5 \\
3 & 4 & 5
\end{tabular}

11. Szeretem az irodalmat.

\begin{tabular}{llll}
2 & 3 & 4 & 5 \\
\hline 2 & 3 & 4 & 5 \\
2 & 3 & 4 & 5
\end{tabular}

12. A szüleim általában nem elégedettek azzal, amit teszek.

13. A matematika könnyü számomra. $\quad 1$

14. Könnyen barátkozom.

$2 \quad 3$

15. Szép arcom van.

16. Minden tartárgyból jó jegyeim vannak.

17. Utálom a testnevelés órát.

18. Jó vagyok irodalomból.

19. Szeretem a szüleimet.

$\begin{array}{lll}1 & 2 & 3 \\ 1 & 2 & 3 \\ 1 & 2 & 3\end{array}$

\begin{tabular}{ll}
1 & 2 \\
1 & 2 \\
\hline
\end{tabular}

20. Mindig elöre várom a matematika órát.

21. A legtöbb gyereknek több barátja van, mint nekem.

22. Szép külsővel rendelkezem.

23. Utálok minden tantárgyat.

24. Élvezem a testnevelés órákat.

25. Érdekel az irodalom.

26. A szüleim szeretnek engem.

27. Jó jegyeim vannak matematikából.

28. Jól kijövök társaimmal.

29. Sok fontos dolgot teszek.

$1 \quad 2$

30. Csúnya vagyok.

31. Minden tantárgyat könnyen tanulok.

32. Erös izmokkal rendelkezem.

\begin{tabular}{lllll}
1 & 2 & 3 & 4 & 5 \\
1 & 2 & 3 & 4 & 5 \\
1 & 2 & 3 & 4 & 5 \\
1 & 2 & 3 & 4 & 5 \\
\hline 1 & 2 & 3 & 4 & 5
\end{tabular}

\begin{tabular}{lllll} 
& 2 & 3 & 4 & 5 \\
& 2 & 3 & 4 & 5 \\
2 & 3 & 4 & 5 \\
& 2 & 3 & 4 & 5 \\
\hline & 2 & 3 & 4 & 5 \\
& 2 & 3 & 4 & 5 \\
& 2 & 3 & 4 & 5 \\
& 2 & 3 & 4 & 5 \\
& 2 & 3 & 4 & 5 \\
1 & 2 & 3 & 4 & 5 \\
1 & 2 & 3 & 4 & 5
\end{tabular}


33. Reménytelen vagyok irodalomból.

34. Ha lesznek saját gyerekeim, úgy szeret-

$\begin{array}{lllll}1 & 2 & 3 & 4 & 5 \\ 1 & 2 & 3 & 4 & 5\end{array}$
ném őket nevelni, ahogyan a szüleim neveltek engem.

35. Érdekel a matematika.

36. Könnyü engem megszeretni.

37. Összességében véve nem vagyok jó semmire.

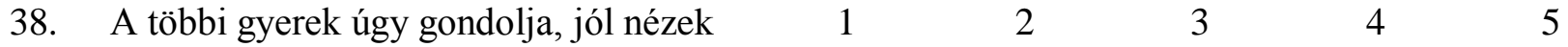
ki.

39. Minden tantárgy érdekel.

40. Jó vagyok a sportokban.

41. Szeretek az irodalommal foglalkozni.

42. A szüleim és én sok időt töltünk együtt.

43. Gyorsan tanulom a matematikát.

44. A többi gyerek szeretné, ha a barátja lennék.

45. Összességében véve szeretek az lenni, aki vagyok.

46. Jó testfelépítésű vagyok.

47. Reménytelen vagyok minden tantárgyból.

48. Sokat tudok futni megállás nélkül.

1

49. Az irodalom könnyü számomra.

50. Szüleimmel könnyü beszélni.

51. Szeretem a matematikát.

52. Több barátom van, mint a többi gyereknek.

53. Összességében véve sok mindenre büszke lehetek.

54. Jobban nézek ki, mint a legtöbb barátom.

\begin{tabular}{|c|c|c|c|c|c|c|}
\hline 55. & A legtöbb órát előre várom. & 1 & 2 & 3 & 4 & 5 \\
\hline 56. & Jó sportoló vagyok. & 1 & 2 & 3 & 4 & 5 \\
\hline 57. & Mindig elöre várom a magyar órát. & 1 & 2 & 3 & 4 & 5 \\
\hline 58. & Jól kijövök a szüleimmel. & 1 & 2 & 3 & 4 & 5 \\
\hline 59. & Jó vagyok matematikából. & 1 & 2 & 3 & 4 & 5 \\
\hline 60. & $\begin{array}{l}\text { Népszerü vagyok a korombeli gyerekek } \\
\text { körében. }\end{array}$ & 1 & 2 & 3 & 4 & 5 \\
\hline
\end{tabular}




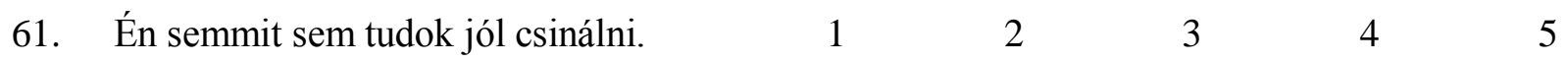

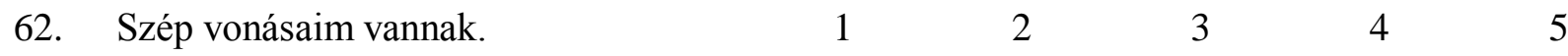

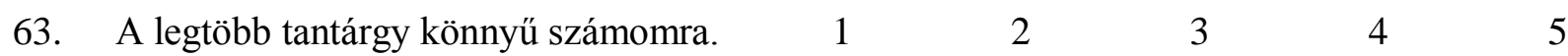

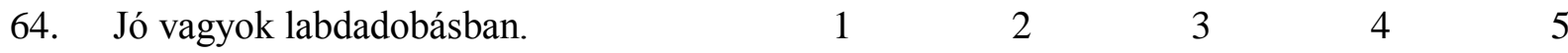

\begin{tabular}{lllllll} 
65. & Gyülölöm az irodalmat. & 1 & 2 & 3 & 4 & 5 \\
\hline 66. & Szüleim és én gyakran töltünk vidám & 1 & 2 & 3 & 4 & 5
\end{tabular} perceket együtt.

67. A legtöbb dolgot ugyanolyan jól meg $\quad 1 \quad 3 r \begin{array}{llll}2 & 3 & 5\end{array}$ tudom csinálni, mint bárki más.

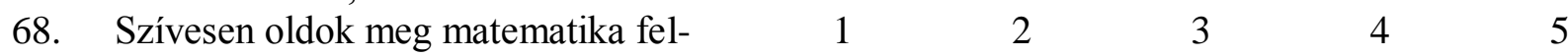
adatokat.

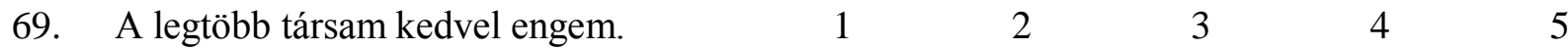

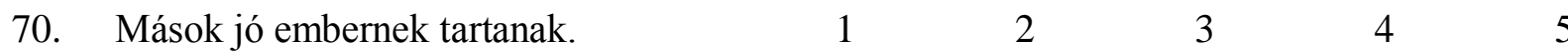

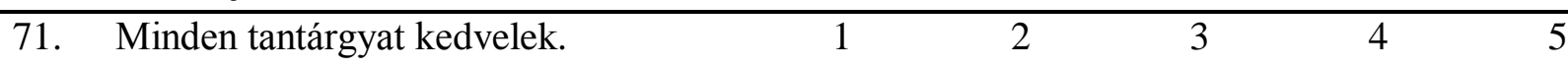

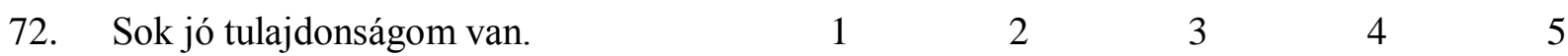

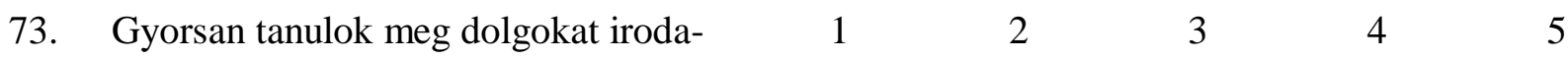
lomból.

74. Ugyanolyan jó vagyok, mint a többi $\quad \begin{array}{llllll}1 & 2 & 3 & 4\end{array}$ ember.

\begin{tabular}{cllllll} 
75. & Reménytelen vagyok matematikából. & 1 & 2 & 3 & 4 & 5 \\
\hline 76. & Ha valamit csinálok, akkor azt jól & 1 & 2 & 3 & 4 & 5
\end{tabular} csinálom.

Mennyire szereted a következő tárgyakat? Minden sorban karikázz be egy számot, ami kifejezi a véleményedet!

$\begin{array}{lccccc} & \begin{array}{c}\text { Nagyon } \\ \text { nem szeretem }\end{array} & \begin{array}{c}\text { Nem } \\ \text { szeretem }\end{array} & \text { Közömbös } & \text { Szeretem } & \begin{array}{c}\text { Nagyon } \\ \text { szeretem }\end{array} \\ \text { Matematika } & 1 & 2 & 3 & 4 & 5 \\ \text { Nyelvtan } & 1 & 2 & 3 & 4 & 5 \\ \text { Irodalom (Olvasás) } & 1 & 2 & 3 & 4 & 5\end{array}$

Mennyire vagy elégedett az iskolai teljesítményeiddel?

Nagyon elégedetlen Elégedetlen Közepesen elégedett

1 yire szeretsz iskolába járni?

Mennyire szeretsz iskolába járni?

Egyáltalán nem

Kicsit

Elégedett

4

Nagyon elégedett

5

1

Közepesen

3

Szeretek

4

Nagyon szeretek 5

\section{Milyen osztályzatod volt most félévkor a következő tárgyakból?}

Matematika

Nyelvtan

Irodalom

Magatartás

Szorgalom

Tanulmányi átlagod

Köszönjük, hogy kitöltötted a kérdöívet! 
2. sz. melléklet

Az énképösszetevők évfolyamok szerinti gyakorisági eloszlásai

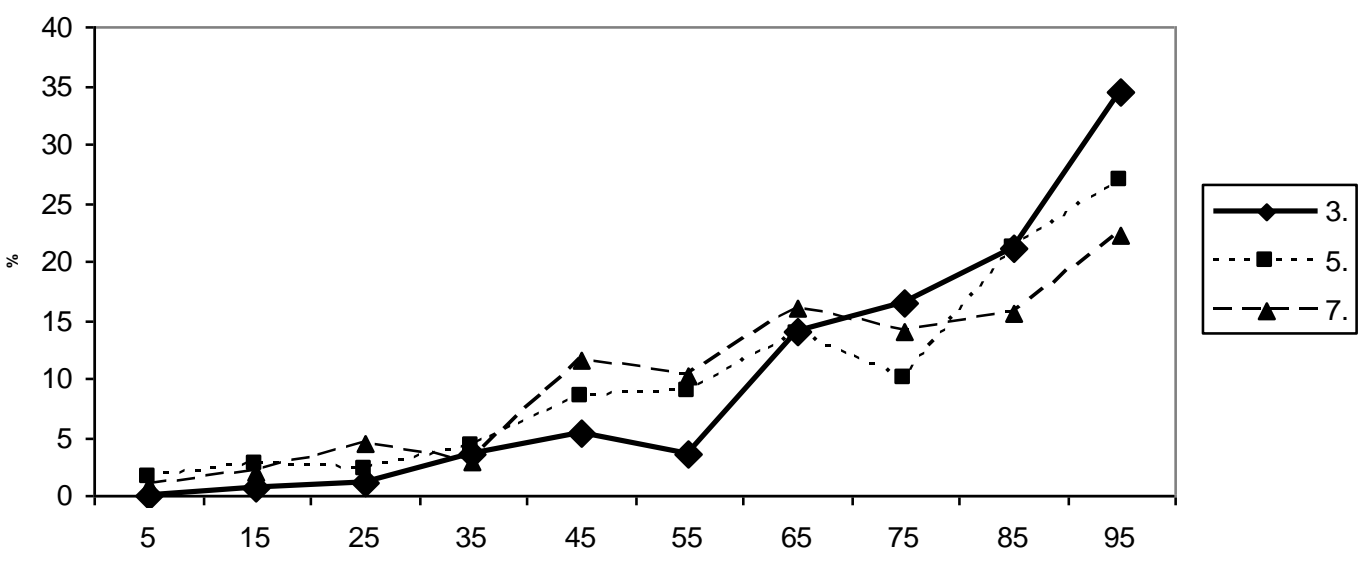

Fizikális képességek énkép
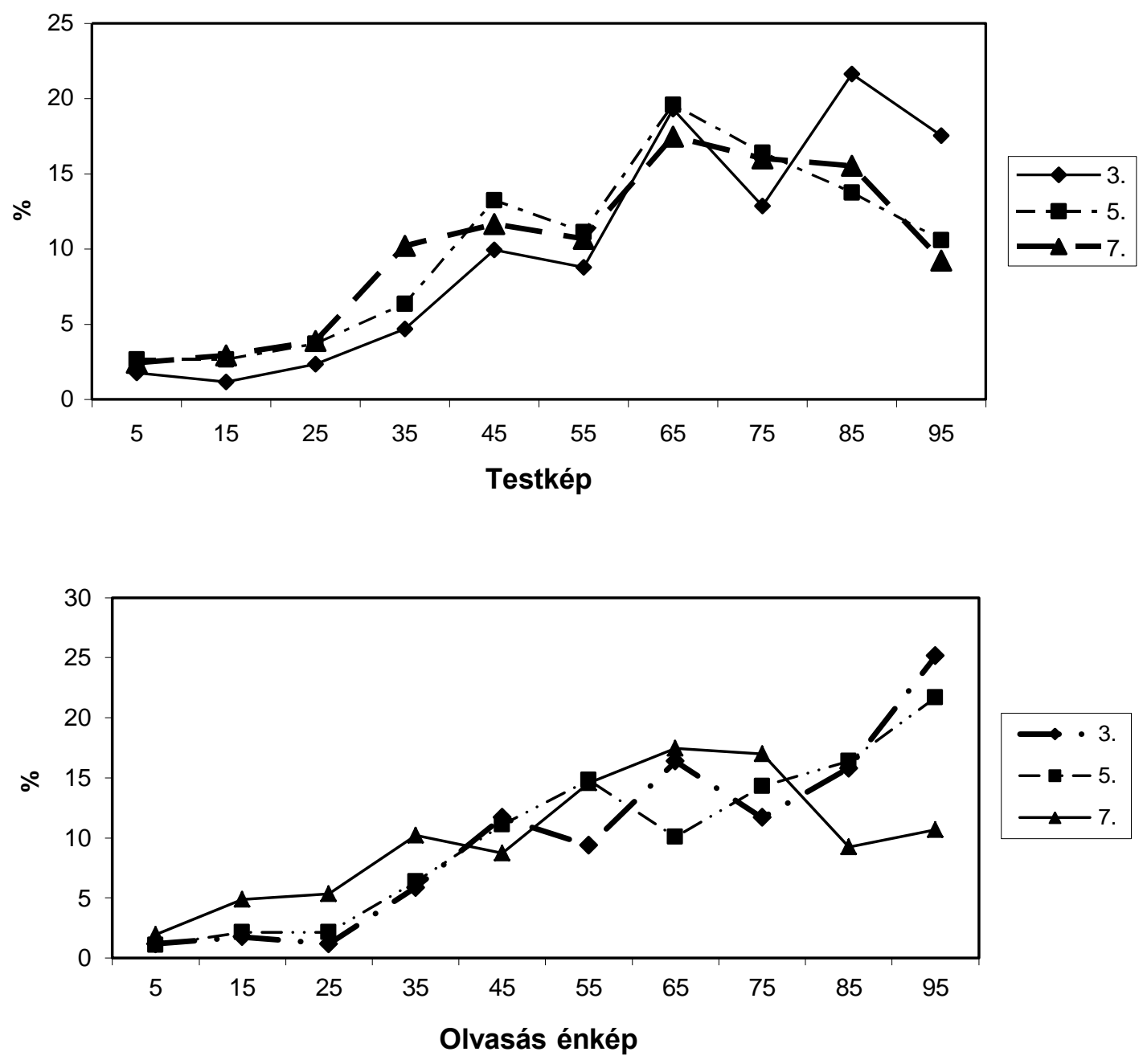

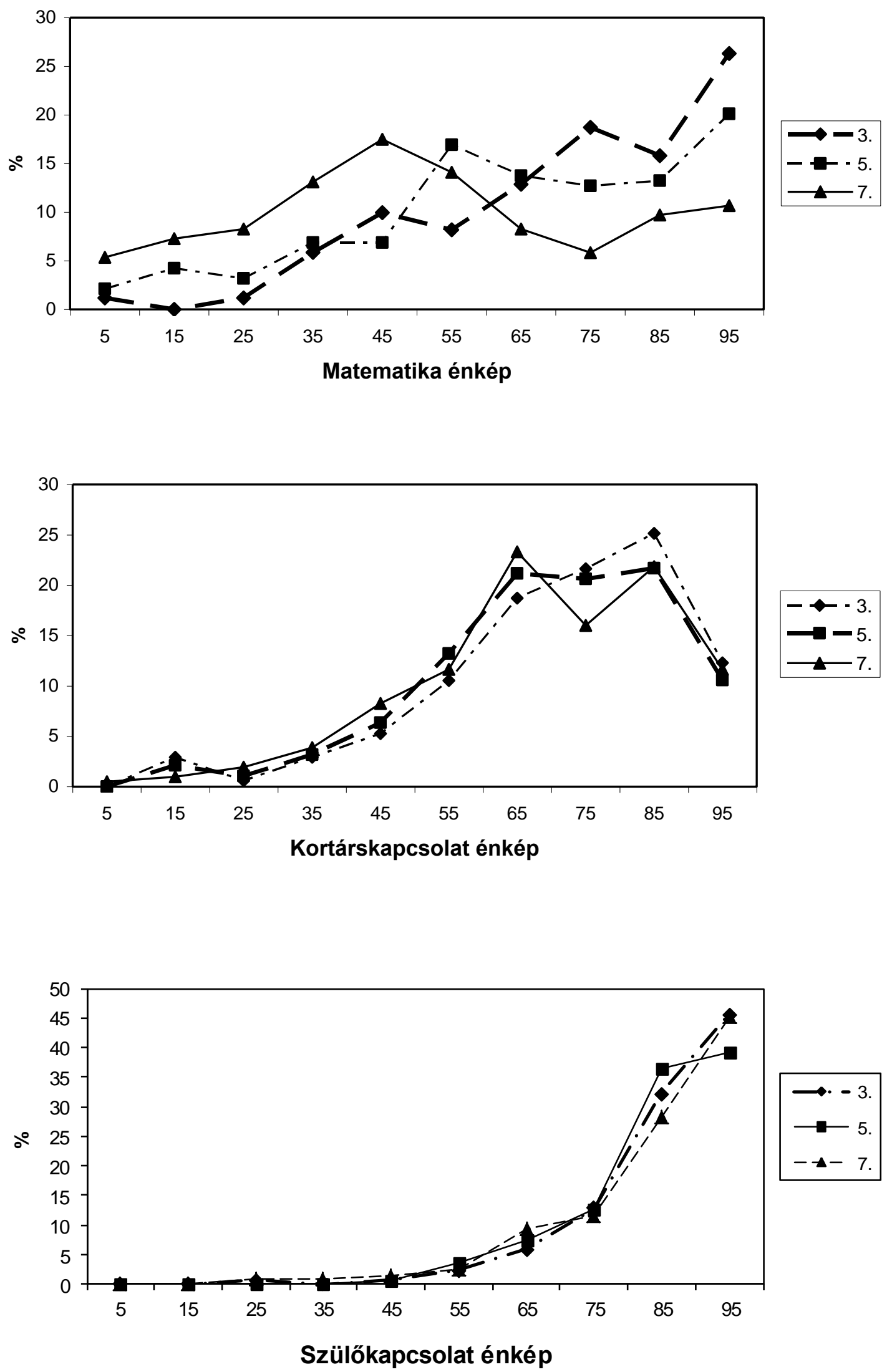

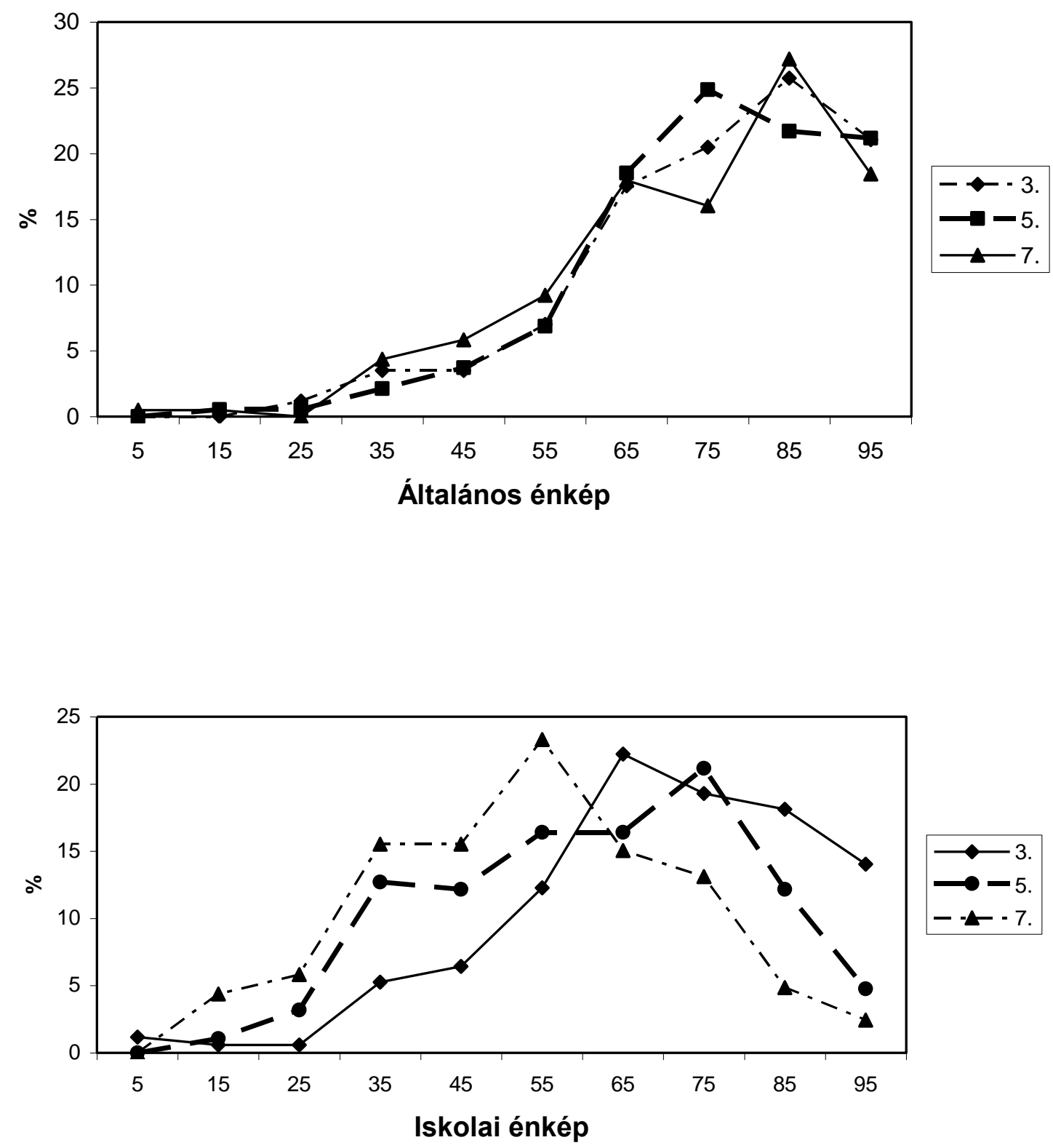
3. sz. melléklet

Az egydimenziós olvasási motiváció mérőeszköze

Válaszvariációk:

1 ; nem

2; kicsit / nem mindig /

3; Igen

1. Szeretek hangosan olvasni.

2. Büszke vagyok magamra, amikor befejezek egy könyvet.

3. Néha csak a borító alapján választok könyvet.

4. Nem tudok mindig a kérdésekre válaszolni, mert nem emlékszem, mit olvastam.

5. Amikor olyan szó van a szövegben, amit nem értek, átugrom.

6. Nem szeretek olvasni.

7. Ha az olvasás közben kérdéseket kapok, segít a megértésben.

8. Ha az olvasmány unalmas, nem haladok vele.

9. Szeretek magamban olvasni.

10. A munkafüzet vezetése az olvasás mellett, időpocsékolás.

11. Ha tetszik egy könyv, keresek ugyanattól a szerzőtől másik könyvet is.

12. Néha az osztálytársaim javaslata alapján választok olvasnivalót.

13. Szeretem, ha a hangosan felolvasnak nekem.

14. Meg sem próbálok olyan könyvet olvasni, amelyik kicsi betükkel van írva.

15. Sokszor lerajzolom azt, amit olvastam.

16. Olyan könyveket szeretek olvasni, amelyekben sok kép van és kevés szöveg.

17. Félek hangosan olvasni.

18. Harminc percet olvasni egyfolytában, ez túl hosszú idő.

19. Jobban szeretek csoportosan olvasni, a többi gyerekkel együtt.

20. Szeretek beszélgetni arról, hogy mit olvastam.

21. Jobban szeretem, ha filmen láthatom a történetet, mint elolvasni.

22. Magamtól sosem olvasok, csak ha muszáj.

23. Szeretnék a legjobb olvasó lenni az osztályban.

24. Ha találok könyvet, sosem unatkozom.

25. A szüleim sokat olvasnak.

26. Ha áruházban vásárolunk, a könyveket is megnézem. 


\section{ELEMI OLVASÁSKÉSZSÉG}

\section{KÉPES SZÓOLVASÁS}

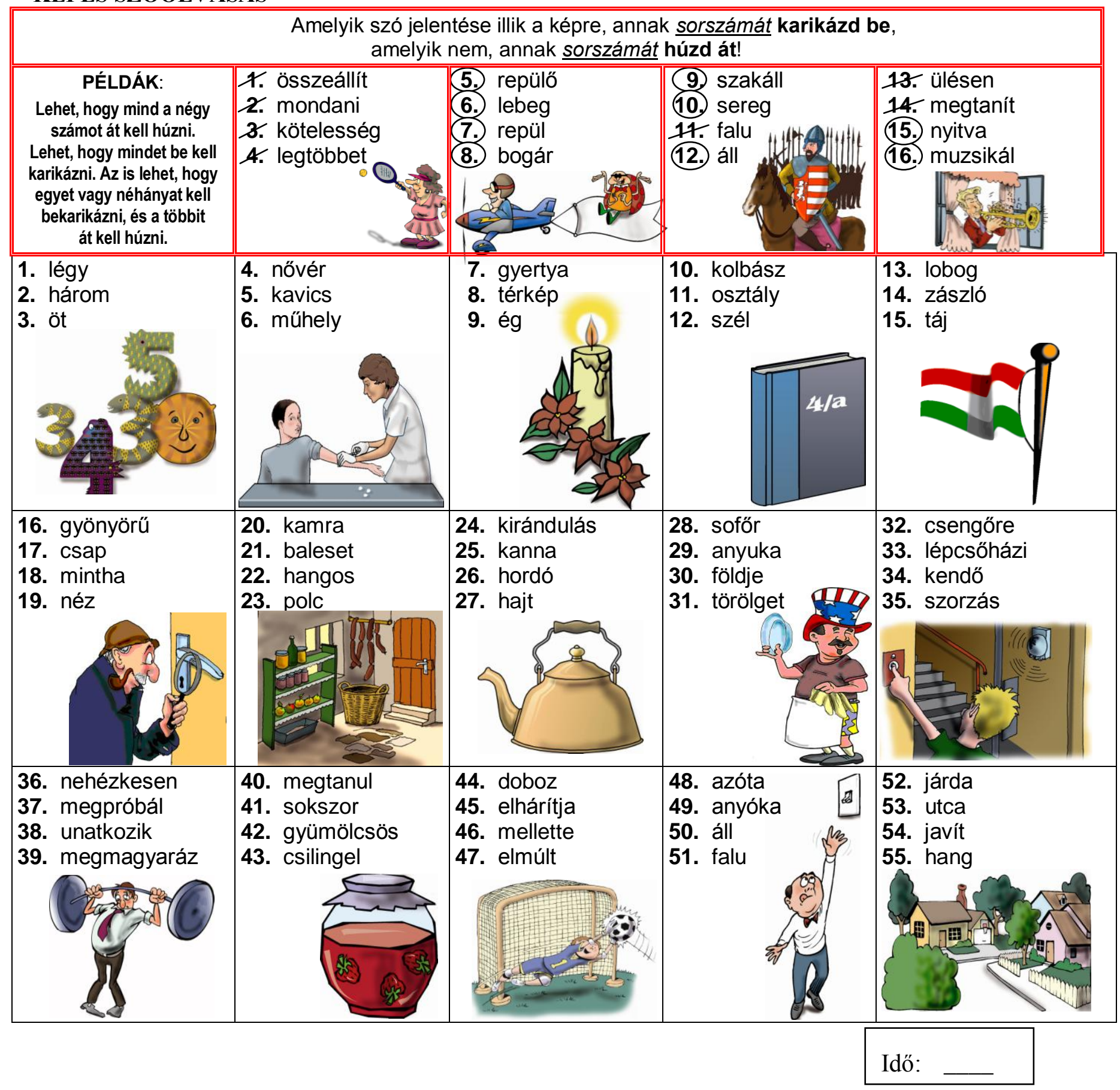


5. sz. melléklet

(C) FFM, JK, NJ

Tanulásban akadályozott gyermekek

ELTE Bárczi Gusztáv Gyógypedagógiai Kar értelmi és szociális készségeinek fejlődése

\section{SZÖVEGÉRTÉS}

Olvasd el figyelmesen a színlapot, majd válaszolj a kérdésekre!

Szegedi Nemzeti Színház

2007. április 17-én 19 órakor

Dés László - Geszti Péter - Békés Pál:

A DZSUNGEL KÖNYVE

Rudyard Kipling regénye nyomán

Zenés játék két részben

Maugli: Gömöri Krisztián

Balu: Lörincz Zoltán

Sirkán: Szalma Tamás

Csil: Rácz Tibor

Bagira: Fekete Gizi

Akela: Borovics Tamás

Ká: Tari Teréz

Tuna: Rácz Rita

Buldeo: Szücs Lajos

Közremüködik a Szegedi Nemzeti Színház és a Szabadtéri Játékok tánckara

Rendező: Bal József

Koreográfus: Ladányi Andrea Jelmez: Földi Andrea Díszlet: Kiss Anna

Zenei vezető: Kardos Gábor

Jegyek a jegyirodában vagy a színház pénztárában válthatók:

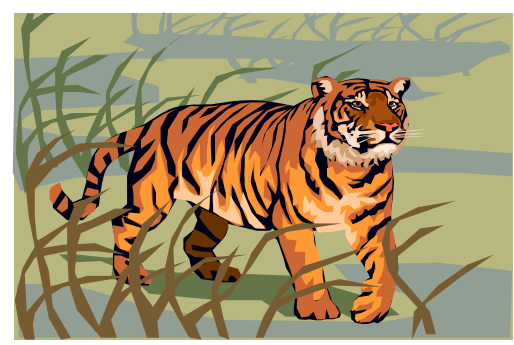

hétköznap: 9 órától 19 óráig

hétvégén: 10 órától 18 óráig 
1. A színlap alapján válaszolj a következő kérdésekre!

Hol lesz az előadás?

a)

Mikor lesz az előadás?

b)

Mi a darab címe?

c)

Ki a rendező?

d)

Kinek a regényéből készült a zenés mü?

e)

Hány szünet van az előadás közben?

f)

Kinek a szerepét játssza...

g) Lőrincz Zoltán?

h) Fekete Gizi?

2. IÍrj „,' betűt az igaz, „H”-t a hamis állítások mögé!

A szereplők a szegedi színház tagjai.

A darab díszletét és jelmezeit hölgyek készítették.

Az összes szereplő férfi.

Az előadás délelőtt van.

Rudyard Kipling regénye nyomán készült a zenés játék.

3. Döntsd el, lehetséges-e! Húzd alá a helyes választ!

Kedden reggel 8 órakor lehet jegyet venni. igen - nem

A pénztár az előadás napján is nyitva van. igen - nem

Szombaton 15 órakor is vehetnek jegyet az érdeklődők. igen - nem 
Olvasd el a következő történetet, utána válaszolj a kérdésekre!

\section{Az elefánt}

Szárazföldi emlős, a ma élő legnagyobb testű állat.

Külsejére jellemző a nagynak mondható füle és a hosszú, mozgékony ormánya. Az ormány nem más, mint a felső ajak és az orr meghosszabbodása. Ez a testrésze segíti a táplálkozásban és az ivásban. Átnyalábolja a leveles ágakat, letépi és a szájába teszi. Naponta több mint 200 kg növényi táplálékra van szüksége. Iváskor ormányával felszívja a vizet és a szájába fecskendezi.

Felső metszőfogai agyarrá alakultak. Nagy testét oszlopszerü lábak tartják. Bőre vastag, majdnem teljesen csupasz. Ha vizet talál, meghemperedik benne, így védekezik a kiszáradás ellen. Ormányával locsolja a testét.

A vadonban csordában él, állandóan vándorol. Járása jellegzetes. A fejét állandóan himbálja, ezzel tartja hatalmas testét egyensúlyban.

Hatalmas erejét az ember is kihasználja. Az indiai elefánt jól szelídíthető. Néhol háziállatnak is tekintik, s a nehezebb munkák elvégzésére használják (pl. teherhordás).

Hosszú életű állat. 
1. Válaszolia a következő kérdésekre a szöveg alapján!

a)-b) Milyen az elefánt ormánya?

c)-d) Miben segíti az elefántot az ormány?

e) Hány kg növényi táplálékot képes elfogyasztani naponta?

f) Mivé alakult felső metszőfoga?

g) Hogyan védi a bőrét a kiszáradástól?

h) Melyik elefánt szelídíthető jól?

i) Hogyan tartja egyensúlyban testét?

2. Számozd be, milyen sorrendben követik egymást az alábbi állítások a szövegben! Felső metszőfoguk agyarrá alakult.

Szárazföldi emlős.

Járása jellegzetes.

Az indiai elefánt jól szelídíthető.

3. A szöveg alapján válaszolj! Mire használja az ember a szelídített elefántokat?

4. Karikázd be, mely tulajdonságok jellemzik az elefántot!

A hamis tulajdonságokat húzd át!
a) nagy testü
g) testét szőr borítja
b) bőre érzékeny
h) jellegzetes járású
c) vándorló
d) vaskos lábú
e) rövid életü
i) füle nagy
j) húsevő állat
f) bőre vastag
k) agyara van 
Olvasd el a termékismertető címkéket, majd válaszolj a kérdésekre!

\section{Györi Édes \\ Jó Reggelt! \\ $50 \mathrm{~g}$}

Törökmogyorós és mézes, gabonás omlós keksz.

Összetevők:

Teljes értékü gabonák $\quad 36,6 \%$

(búzaliszt, zabpehely, búzapehely, rozs-

liszt, árpaliszt)

Cukor $13,0 \%$

Növényi zsír, törökm.

Csokoládé darabok

$3,1 \%$

$3,2 \%$

Méz

$2,1 \%$

Búzacsíra

$1,3 \%$

Hozzáadott vitaminokat tartalmaz!

B1, B2, B6- vitamin

Fénytől védve, száraz, hűvös helyen tartandó!

Energiatartalom:

$1880 \mathrm{~kJ} / 448 \mathrm{kcal}$

Minőségét megőrzi:

2008. 08. 31.

Származási hely: Csehország

\section{Sissy}

Öszibarackos

joghurt

$150 \mathrm{~g}$

Gyártó:

Alföldi Tej Értékesítő Kft.

8000 Székesfehérvár

Seregélyes út 127.

Hütve tárolandó!

(0-6 ${ }^{\circ} \mathrm{C}$ között)

Fogyasztható:

2008. 01. 20.

Összetevők:

Tej, őszibarackos gyümölcskészítmény, cukor, joghurt, étkezési keményítő.

Zsírtartalom: $\quad 2,6 \%$

Gyümölcstartalom:16\%

Energiatartalom:

368 kJ /87 kcal 
1. A termékismertető címkék alapján válaszolj a következő kérdésekre!

a) Melyik termék tartalmaz különféle vitaminokat?

b) Melyik terméknek nagyobb a tömege?

c) Melyiket együk, ha sok energiára van szükségünk?

d) Melyik terméket kell hütőszekrényben tárolni?

2. Melyik termékért hová kell elutazni, ha a gyárból szeretnéd megvásárolni?

a) Győri Édes Jó Reggelt!

b) Sissy joghurt

3. A termékismertetők szerint meddig lehet fogyasztani a

a) Győri Édes Jó Reggelt! kekszet?

b) a Sissy joghurtot?

c) Melyik terméket fogyaszthatjuk el 2008 őszén? 
6. sz. melléklet

SZEGEDI TUDOMÁNYEGYETEM

$\mathrm{R}$ 繁

OKTATÁSELMÉLETI KUTATÓCSOPORT

www.edu.u-szeged.hu/ok

\section{Motiváció az olvasás iránt - jegyzőkönyv /Rövid/}

\section{Attitűdök és szociális motívumok}

1. Szereted gyakorolni az iskolában az olvasást?

$\begin{array}{llll}1 & 2 & 3 & 4\end{array}$

2. Szeretsz másokkal beszélgetni arról, amit olvastatok?

$\begin{array}{llll}1 & 2 & 3 & 4\end{array}$

3. Szereted, ha otthon felolvasnak neked?

$\begin{array}{llll}1 & 2 & 3 & 4\end{array}$

4. Szereted, ha az iskolában a tanító néni felolvas nektek?

$\begin{array}{llll}1 & 2 & 3 & 4\end{array}$

5. Szereted az olvasás órát?

$\begin{array}{llll}1 & 2 & 3 & 4\end{array}$

6. Szeretsz másoknak felolvasni?

$\begin{array}{llll}1 & 2 & 3 & 4\end{array}$

7. Szereted az olvasást otthon gyakorolni?

$\begin{array}{llll}1 & 2 & 3 & 4\end{array}$

8. Szereted, amikor közösen olvasol valamit valakivel?

9. Szeretsz könyvet kapni ajándékba?

$\begin{array}{llll}1 & 2 & 3 & 4\end{array}$

\section{Önhatékonyság}

10. Mennyit tudnál felolvasni közülük? (valós)

11. Mennyit tudnál felolvasni közülük? (álszó)

$\begin{array}{llll}1 & 2 & 3 & 4 \\ 1 & 2 & 3 & 4\end{array}$

\section{Attribúciók}

12. Mit gondolsz, miért voltak nehézségeid a szó kiolvasásával?
a) külső, állandó
b) belső, változó
c) belső, állandó
d) külső, változó 
13. Mit gondolsz, miért tudtad ilyen ügyesen kiolvasni a többi szót?
a) külső, állandó
b) belső, változó
c) belső, állandó
d) külső, változó

14. Azért nem sikerült, mert nehéz volt a szó?

15. Vagy azért voltak nehézségeid, mert nem próbáltad eléggé?

16. Azért nem sikerült, mert nem vagy elég okos?

17. Vagy azért, mert nem volt szerencséd?

$\begin{array}{llll}1 & 2 & 3 & 4 \\ 1 & 2 & 3 & 4 \\ 1 & 2 & 3 & 4 \\ 1 & 2 & 3 & 4\end{array}$

18. Azért sikerült kiolvasni, mert szerencséd volt?

$\begin{array}{llll}1 & 2 & 3 & 4 \\ 1 & 2 & 3 & 4 \\ 1 & 2 & 3 & 4 \\ 1 & 2 & 3 & 4\end{array}$

19. Azért mert elég okos vagy hozzá?

20. Vagy azért, mert eléggé próbáltad?

21. Vagy azért, mert ezt a szót könnyü kiolvasni?

\section{Flow}

22. Szereted mikor olvasás órán vagy és egy feladaton dolgozol? _

23. Amikor olvasás órán egy feladaton dolgozol, akkor csak a feladatra figyelsz?

24. Az olvasás órán kapott feladatokat akkor is csinálnád, ha nem kellene?

25. Unatkozol olvasás órán?

26. Nehezen tudsz figyelni olvasás órán?

27. Amikor olvasás órán egy feladaton dolgozol,akkor úgy érzed, hogy jól megy?

28. Izgalmas számodra az olvasás óra ?_

29. Olvasás órán szoktad úgy érezni, hogy távol áll tőled, amit csinálni kell?

30. Élvezed az olvasás órát?

31. Amikor olvasás órán egy feladaton dolgozol, akkor szoktad úgy érezni, hogy nem érdekel az egész?

32. Nehéznek tartod az olvasás órát?

33. El szokott kalandozni a figyelmed olvasás órán?

34. Könnyünek tartod az olvasás órát?

35. Szoktál valami miatt nyugtalan, ideges lenni olvasás órán? 
36. Mindig tudod, hogy mit kell csinálni, amikor olvasás órán vagy?_

37. Amikor olvasás órán egy feladaton dolgozol, akkor szoktad úgy érezni, hogy nem tud lekötni?

38. Fáraszt az olvasás óra és az olvasás órai feladatok?

39. Gyorsan telik az idő, amikor olvasás órán vagy?

40. Ügyesnek érzed magad olvasás órán?

\section{Érték és énkép}

41. Fontos neked, hogy jól tudj olvasni?

Miért?

42. Jó olvasó vagy?

$\begin{array}{llll}1 & 2 & 3 & 4\end{array}$

Honnan gondolod?

43. Fontosnak tartod az olvasás órákat?

$\begin{array}{llll}1 & 2 & 3 & 4\end{array}$

Miért?

44. Szerinted fontos, hogy valaki jól megtanuljon olvasni? $\quad \begin{array}{lllll}1 & 2 & 3 & 4\end{array}$

Miért? Miért fontos/nem fontos?

\section{Célorientáció}

Mikor a feladatokon dolgoztál...

45. szeretted volna minél jobban megérteni a feladatokat?

46. szeretted volna megmutatni nekem milyen ügyes vagy?

47. azt kívántad bárcsak ne kellene megcsinálnod őket?

48. szerettél volna piros pontot kapni?

49. szerettél volna minél többet tanulni a feladatokból, ezért olyan keményen dolgoztál, ahogy csak tudtál?

50. szeretted gyorsan összecsapni, hogy minél kevesebbet kelljen foglalkoznod a feladatokkal?

Egyéb: 
NEM

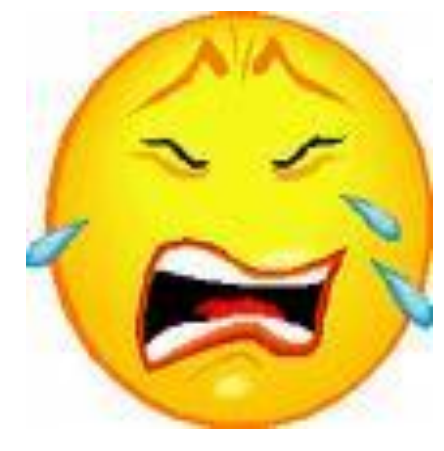

1

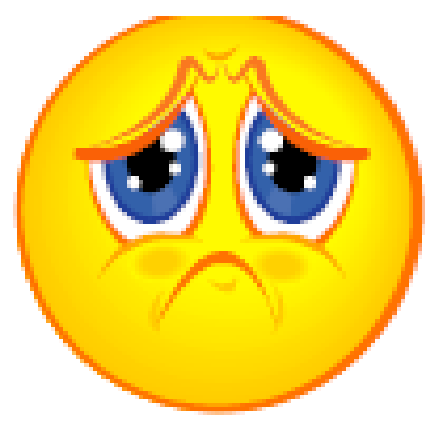

2

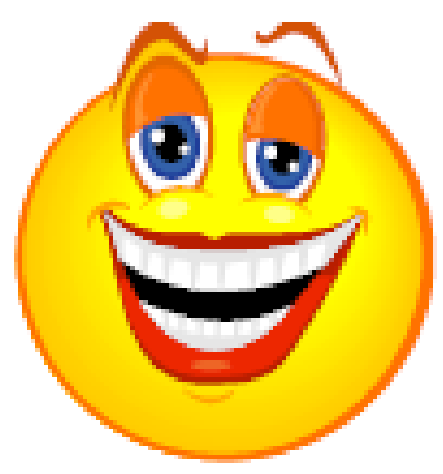

3

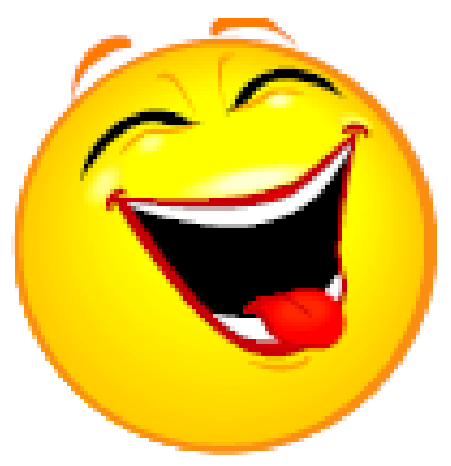

4

"egyáltalán nem"

"nagyon" 
NEM

IGEN

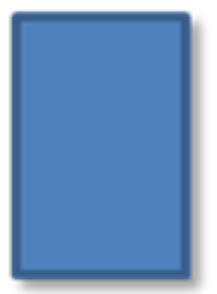

2

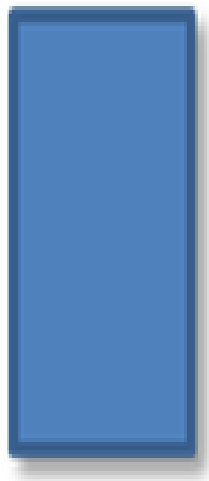

3

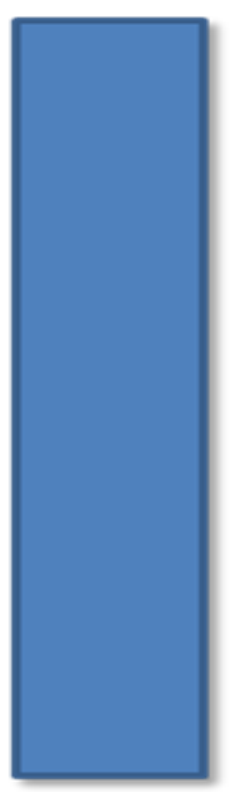

4

„mindig” "mindet” „nagyon” 
8. sz. melléklet

\section{Motiváció az olvasás iránt - jegyzőkönyv, 2.osztály}

(Szükséges segédeszközök: szólista (valós és álszó lista), oszlopdiagram, mosolygós arcok)

"Néhány kérdést fogok feltenni az olvasással kapcsolatban. Az érdekel, hogy mit gondolnak a gyerekek, amikor olvasnak és az olvasásról általában. Fontos, hogy megértsd, hogy ez nem dolgozat. Nincsenek jó vagy rossz válaszok. Ezen kívül azt is tudnod kell, hogy rajtam kívül senki más nem fogja megtudni, hogy mit válaszoltál a kérdésekre. A válaszaid csupán engem segitenek abban, hogy megértsem VALÓJÁBAN mit gondolsz az olvasásról. Ezért is fontos, hogy öszintén válaszolj a kérdésekre. Rendben? Kezdhetjük?"

A kérdőívtételek felvétele egyénileg történik. A kutatásvezetö hangosan olvassa fel a tételeket a tanulóknak. A válaszokat négyfokú skálán rögzítjük.

"Ezek a rajzok segíteni fognak Neked a kérdések megválaszolásában (rámutatni a mosolygós arcok ábrájára). Például, ha megkérdezem 'szeretsz rajzolni?', akkor elöször válaszolj igennel vagy nemmel. Ha ezt eldöntötted, utána mutass rá egy arcocskára attól függően, hogy mennyire szeretsz vagy nem szeretsz rajzolni. Ha mindig szeretsz rajzolni, akkor mutass rá erre a nagyon mosolygós arcra. Ha csak általában szeretsz, de nem mindig, akkor erre a kicsit mosolygósra. Ha soha nem szeretsz rajzolni, akkor erre a szomorú arcra, ha pedig csak általában nem szeretsz rajzolni, de néha azért igen, akkor erre a kicsit szomorkás arcra mutass rá. Tegyünk egy próbát! ,,Szeretsz rajzolni? ” ... Jó. „,Szeretsz békás szendvicset reggelizni?”

Ha a gyermek értelmes válaszokat ad, tehát láthatóan érti a válaszadás módját, akkor léphetünk tovább a kérdöívtételekre. Ha nem, akkor elmodellezünk még néhány válaszadást.

Minta kérdöivtételek:

„Szeretsz focizni?"

„Szeretsz fagyit enni?"

„Szeretsz lekváros egeret vacsorázni?

1. Szereted gyakorolni az iskolában az olvasást?

2. Szeretsz másokkal beszélgetni arról, amit olvastatok?

$\begin{array}{llll}1 & 2 & 3 & 4\end{array}$

3. Szereted, ha otthon felolvasnak neked?

$\begin{array}{llll}1 & 2 & 3 & 4\end{array}$

4. Szereted, ha az iskolában a tanító néni felolvas nektek?

$\begin{array}{llll}1 & 2 & 3 & 4\end{array}$

5. Szereted az olvasás órát?

6. Szeretsz másoknak felolvasni?

7. Szereted az olvasást otthon gyakorolni?

8. Szereted, amikor közösen olvasol valamit valakivel?

$\begin{array}{llll}1 & 2 & 3 & 4\end{array}$

9. Szeretsz könyvet kapni ajándékba?

$\begin{array}{llll}1 & 2 & 3 & 4 \\ 1 & 2 & 3 & 4 \\ 1 & 2 & 3 & 4 \\ 1 & 2 & 3 & 4 \\ 1 & 2 & 3 & 4\end{array}$

"Mutatok neked néhány szót, amit majd szeretnék, hogy felolvass. Még mielött elkezdenéd azonban, szeretném, ha elgondolkoznál azon, hogy szerinted fel tudod-e olvasni ezeket a szavakat. Elöször válaszolj igennel vagy nemmel. Ezután ezen a rajzon (oszlopdiagramra mutatni) mutasd meg nekem, hogy szerinted mennyit tudnál felolvasni? Ha mindet, mutass erre a legmagasabb oszlopra. Ha a legtöbbet, de nem mindet tudnád felolvasni, akkor a kicsit alacso- 
nyabbra. Ha csak néhányat, akkor erre a még alacsonyabbra, és ha szerinted egyet se tudnál felolvasni, akkor mutass erre a legalacsonyabb oszlopra? Rendben? Kezdhetjük?"

„Itt van néhány szó, amelyek létezö szavak (odaadni a szavak listáját). Mit gondolsz, fel tudnád öket olvasni hangosan?

10. Mennyit tudnál felolvasni közülük? (valós)

$\begin{array}{llll}1 & 2 & 3 & 4\end{array}$

„Itt van néhány szó, amelyek nem létezö szavak (odaadni a szavak listáját), én találtam ki öket. Mit gondolsz, fel tudnád öket olvasni hangosan?

11. Mennyit tudnál felolvasni közülük? (álszó)

$\begin{array}{llll}1 & 2 & 3 & 4\end{array}$

„Felolvasod nekem a szavakat?”

„Köszönöm. Nemrég beszélgettem néhány gyerekkel arról, hogy miért nehéz számukra bizonyos szavak kiolvasása, és jó néhány okot mondtak. Most gondolj vissza azokra az alkalmakra, amikor egy a -hoz hasonló szót nem tudtál kiolvasni (rámutatni egy olyan szóra, amivel a tanulónak nehézségei voltak)! Te mit gondolsz, miért volt nehéz kiolvasnod ezt a szót?"

„,Mondok néhány okot, hogy miért nem sikerülhetett kiolvasni a szót. Használd a rajzot a válaszadáshoz: elöször válaszolj igennel vagy nemmel, majd mutass rá az egyik oszlopra. Ha mindig ez volt az oka annak, hogy egy szót nem tudtál kiolvasni, akkor mutass a legnagyobb oszlopra, ha gyakran, de nem mindig ez volt az oka, akkor a kicsit alacsonyabbra, ha néha ez volt az ok, akkor a még alacsonyabbra, és ha soha nem emiatt nem tudtál kiolvasni valamit, akkor a legalacsonyabbra. Rendben? Kezdhetjük?"

„,Köszönöm. A gyerekek, akikkel beszélgettem, mondtak néhány ötletet azzal kapcsolatban is, hogy miért könnyü számukra bizonyos szavak kiolvasása. Most gondolj vissza azokra az alkalmakra, amikor egy a ...................-hoz hasonló szót könnyen ki tudtál olvasni (rámutatni egy olyan szóra, amit a tanuló könnyedén felolvasott)! Te mit gondolsz, miért tudtad ilyen ügyesen kiolvasni ezt a szót?(hagyjuk gondolkozni)

12. Mit gondolsz, miért voltak nehézségeid a szó kiolvasásával?
e) külső, állandó
f) belső, változó
g) belső, állandó
h) külső, változó

13. Mit gondolsz, miért tudtad ilyen ügyesen kiolvasni a többi szót?
e) külső, állandó
f) belső, változó
g) belső, állandó
h) külső, változó 
Mondok néhány okot, hogy vajon miért sikerülhetett kiolvasni a szót. Használd a rajzot a válaszadáshoz: elöször válaszolj igennel vagy nemmel, majd mutass rá az egyik oszlopra. Ha mindig ez volt az oka annak, hogy egy szót ki tudtál olvasni, akkor mutass a legnagyobb oszlopra, ha gyakran, de nem mindig ez volt az oka, akkor a kicsit alacsonyabbra, ha néha ez volt az ok, akkor a még alacsonyabbra, és ha soha nem emiatt tudtál kiolvasni valamit, akkor a legalacsonyabbra. Rendben? Kezdhetjük?"

14. Azért nem sikerült, mert nehéz volt a szó? $\begin{array}{llll}1 & 2 & 3 & 4\end{array}$

15. Vagy azért voltak nehézségeid, mert nem próbáltad eléggé? $1 \begin{array}{lllll}1 & 2 & 3 & 4\end{array}$

16. Azért nem sikerült, mert nem vagy elég okos? $\begin{array}{llll}1 & 2 & 3 & 4\end{array}$

17. Vagy azért, mert nem volt szerencséd?

$\begin{array}{llll}1 & 2 & 3 & 4\end{array}$

18. Azért sikerült kiolvasni, mert szerencséd volt? $\begin{array}{llll}1 & 2 & 3 & 4\end{array}$

19. Azért mert elég okos vagy hozzá? $\begin{array}{llll}1 & 2 & 3 & 4\end{array}$

20. Vagy azért, mert eléggé próbáltad? $\begin{array}{llll}1 & 2 & 3 & 4\end{array}$

21. Vagy azért, mert ezt a szót könnyü kiolvasni?

$\begin{array}{llll}1 & 2 & 3 & 4\end{array}$

„Felteszek még néhány kérdést. Ugyanígy használd az oszlopos rajzot a válaszadáshoz. Arról fogok kérdezni, hogy hogy érzed magad olvasás órán. Elöször döntsd el, hogy szoktál-e így érezni olvasás órán. Válaszolj igennel vagy nemmel. Ezt követöen, mutass rá egy oszlopra aszerint, hogy milyen gyakran érzel így. Ha mindig úgy érzel, ahogy mondom, akkor mutass a legmagasabb oszlopra, ha általában, de nem mindig, akkor erre az alacsonyabb oszlopra. Ha csak néha érzel így, akkor a még alacsonyabb oszlopra, és ha soha nem érzel igy, akkor erre a legalacsonyabbra. Rendben? Kezdhetjük?”

22. Szereted mikor olvasás órán vagy és egy feladaton dolgozol?

23. Amikor olvasás órán egy feladaton dolgozol, akkor csak a feladatra figyelsz?

24. Az olvasás órán kapott feladatokat akkor is csinálnád, ha nem kellene?

25. Unatkozol olvasás órán?

26. Nehezen tudsz figyelni olvasás órán?

27. Amikor olvasás órán egy feladaton dolgozol,akkor úgy érzed, hogy jól megy?

28. Izgalmas számodra az olvasás óra ?

29. Olvasás órán szoktad úgy érezni, hogy távol áll tőled, amit csinálni kell?

30. Élvezed az olvasás órát? 
31. Amikor olvasás órán egy feladaton dolgozol, akkor szoktad úgy érezni, hogy nem érdekel az egész?

32. Nehéznek tartod az olvasás órát?

33. El szokott kalandozni a figyelmed olvasás órán?

34. Szoktál valami miatt nyugtalan, ideges lenni olvasás órán?

35. Könnyünek tartod az olvasás órát?

36. Mindig tudod, hogy mit kell csinálni, amikor olvasás órán vagy?

37. Amikor olvasás órán egy feladaton dolgozol, akkor szoktad úgy érezni, hogy nem tud lekötni?

38. Fáraszt az olvasás óra és az olvasás órai feladatok?

39. Gyorsan telik az idő, amikor olvasás órán vagy?

40. Ügyesnek érzed magad olvasás órán?

„Már csak néhány kérdésem van."

41. Fontos neked, hogy jól tudj olvasni?

$\begin{array}{llll}1 & 2 & 3 & 4\end{array}$

42. Jó olvasó vagy?

$\begin{array}{llll}1 & 2 & 3 & 4\end{array}$

43. Fontosnak tartod az olvasás órákat?

$\begin{array}{llll}1 & 2 & 3 & 4\end{array}$

44. Szerinted fontos, hogy valaki jól megtanuljon olvasni?

$\begin{array}{llll}1 & 2 & 3 & 4\end{array}$

Köszönöm. Arra is kíváncsi vagyok, mi járt a fejedben, mikor a feladatokon dolgoztál, amiket hoztam. Emlékszel rájuk? Rendben. Megint válaszolj igennel vagy nemmel, majd attól függöen, hogy mennyire, válassz egy oszlopot."

Mikor a feladatokon dolgoztál...

45. szeretted volna minél jobban megérteni a feladatokat?

46. szeretted volna megmutatni nekem milyen ügyes vagy?

47. azt kívántad bárcsak ne kellene megcsinálnod őket?

48. szerettél volna piros pontot kapni?

49. szeretted volna megérteni a feladatot, ezért olyan keményen dolgoztál, ahogy csak tudtál?

50. szeretted volna gyorsan összecsapni, hogy minél kevesebbet kelljen foglalkoznod a feladatokkal? 
Azonosító :

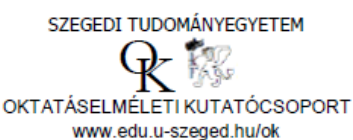

Diagnosztikus mérések fejlesztése TÄMOP 3.1.9/08/01-2009-0001 w.edu.u-szeged.hu/ok

Kedves Tanuló!

A Szegedi Tudományegyetem kutatásában veszel részt, melyben általános iskolás korú tanulókat kérdezünk arról, mit gondolnak az olvasásról.

Mindvégig gondolj arra, hogy olvasás alatt nem csak könyvek olvasását értjük, hanem minden olyan tevékenységet, amely írott szövegek megértését igényli. Így például akkor is olvasol, ha a történelem tankönyvet bújod, a netet böngészed vagy épp a mozimüsort nézegeted.

Különböző állításokat fogsz olvasni, amelyekről el kell döntened, hogy mennvire igazak Rád. Kérünk, hogy válaszodat a Rád jellemző szám bekarikázásával jelezd! A számok jelentése a következő:

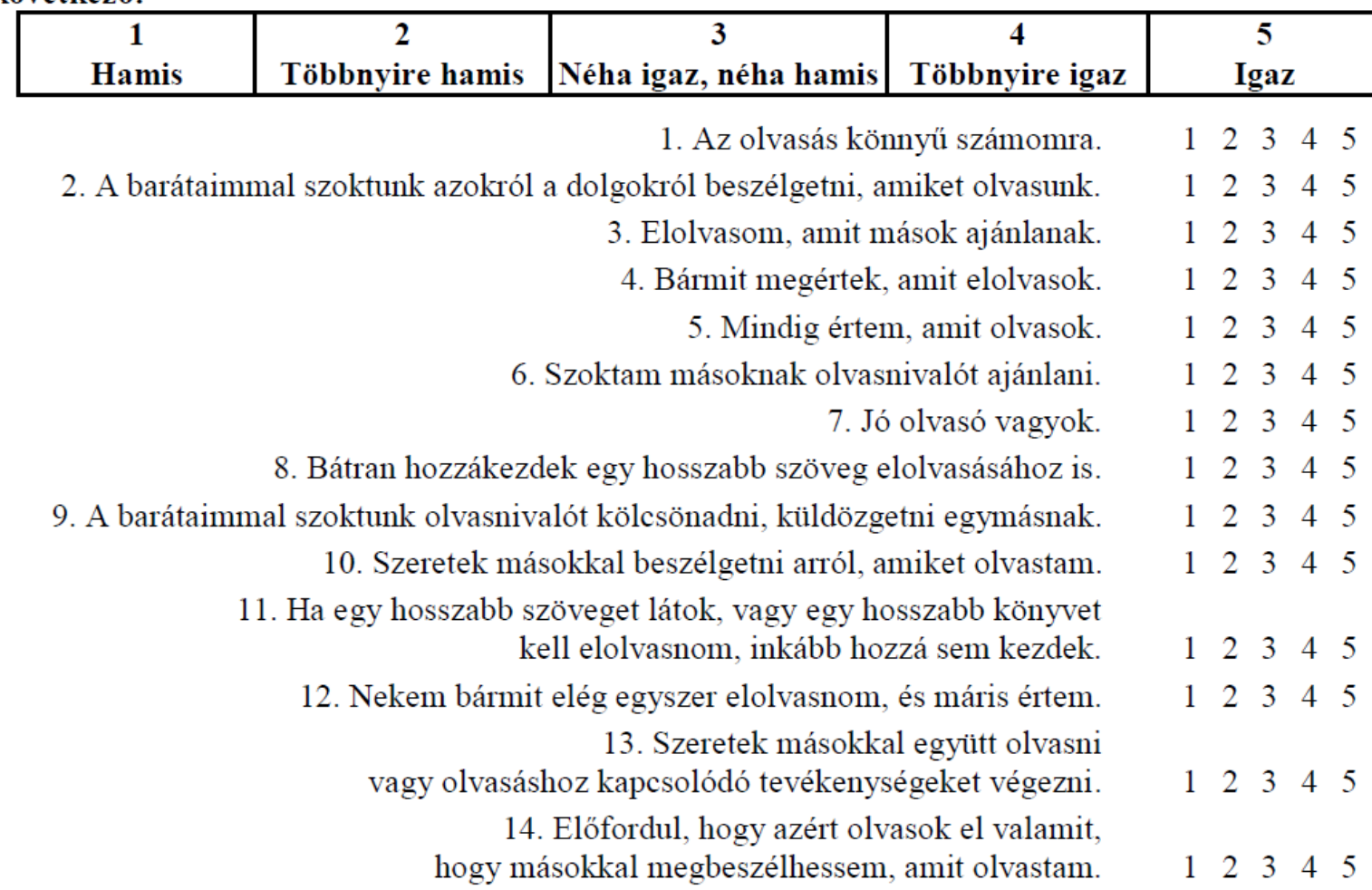

15. Előfordult már Veled, hogy hiába olvastál el valamit sokadszorra is, mégsem értetted?

1) igen

2) nem

16. Ha igen, mit gondolsz, mi lehetett az oka?

Milyen gyakran okozták a nehézséget a következő tényezők?

\begin{tabular}{|c|c|c|c|cccc|}
\hline $\begin{array}{c}\mathbf{2} \\
\text { Soha }\end{array}$ & Ritkán & $\begin{array}{c}\mathbf{3} \\
\text { Esetek kb. felében }\end{array}$ & $\begin{array}{c}\mathbf{4} \\
\text { Gyakran }\end{array}$ & \multicolumn{3}{c|}{ Mindig } \\
\hline
\end{tabular}


21. Bizonyára előfordult már Veled, hogy egy szöveget épp csak átfutottál, máris tudtad mirôl szól. Mit gondolsz, mi lehetett az oka?

\section{Milyen gyakran okozták a sikeredet a következő tényezők?}

\begin{tabular}{|c|c|c|c|c|}
\hline 1 & 2 & 3 & 4 & 5 \\
Soha & Ritkán & Esetek kb. felében & Gyakran & Mindig \\
\hline
\end{tabular}

22. könnyü volt a szöveg $\quad \begin{array}{llllll}1 & 2 & 3 & 4 & 5\end{array}$

23. eléggé próbáltam $\quad \begin{array}{llllll}1 & 2 & 3 & 4 & 5\end{array}$

24. elég okos vagyok $\quad \begin{array}{llllll}1 & 2 & 3 & 4 & 5\end{array}$

25. szerencsém volt $\quad \begin{array}{lllll}1 & 2 & 3 & 4 & 5\end{array}$

Az alábbiakban különböző tevékenységekröl fogsz olvasni, amelyekröl el kell döntened, hogy mennvire szereted azokat csinálni.

\begin{tabular}{|c|c|c|c|c|}
\hline 1 & 2 & 3 & 4 & 5 \\
Egyáltalán nem & Kevéssé & Néha igen, néha nem & Eléggé & Teljes mértékben \\
\hline
\end{tabular}

Mennyire szeretsz...

26. egy esős szombati napon történeteket olvasni? $\quad \begin{array}{lllll}1 & 2 & 3 & 4 & 5\end{array}$

27. szabadidődben olvasni? $\quad \begin{array}{llllll}1 & 2 & 3 & 4 & 5\end{array}$

28. csak úgy saját örömödre otthon történetet vagy regényt olvasni? $\quad \begin{array}{lllll}1 & 2 & 3 & 4 & 5\end{array}$

29. irodalom órán olvasni? $\quad \begin{array}{llllllll}1 & 2 & 3 & 4 & 5\end{array}$

30. más órákon (pl. történelem, biológia órán) olvasni? $\quad \begin{array}{lllll}1 & 2 & 3 & 4 & 5\end{array}$

31. kötelező olvasmányt olvasni? $\quad \begin{array}{llllll}1 & 2 & 3 & 4 & 5\end{array}$

32. magazinokat, képregényeket olvasni? $\quad \begin{array}{llllll}1 & 2 & 3 & 4 & 5\end{array}$

33. irodalom óráról ismert szövegeket olvasni? $\quad \begin{array}{llllll}1 & 2 & 3 & 4 & 5\end{array}$

34. a tankönyveidböl olvasni? $\quad \begin{array}{llllll}1 & 2 & 3 & 4 & 5\end{array}$

35. az Interneten olvasgatni? $\quad \begin{array}{lllllll}1 & 2 & 3 & 4 & 5\end{array}$

Az alábbiakban különböző állításokat fogsz olvasni, amelyekrôl el kell döntened, hogy mennvire értesz velük egyet. A számok jelentése az elôbbiekkel megegyező.

36. Az olvasás megtanulása nagyon fontos, ha valaki jó tanuló szeretne lenni. $\quad \begin{array}{lllll}1 & 2 & 3 & 4 & 5\end{array}$

37. Ahhoz, hogy valaki sikeres legyen az életben, nem kell jól olvasnia. $\quad \begin{array}{lllll}1 & 2 & 3 & 4 & 5\end{array}$

38. Ha valaki jó jegyeket szeretne, nem feltétlenül kell jól olvasnia. $\quad \begin{array}{lllll}1 & 2 & 3 & 4 & 5\end{array}$

39. Ahhoz, hogy valaki az életben boldoguljon, fontos, hogy jól tudjon olvasni. $\quad \begin{array}{lllll}1 & 2 & 3 & 4\end{array}$

40. Az olvasás alapos megtanulása segít a felnőtt életben. $\begin{array}{lllll}1 & 2 & 3 & 4 & 5\end{array}$

41. Csak az lehet jó tanuló, aki jól tud olvasni. $\quad \begin{array}{llllll}1 & 2 & 3 & 4 & 5\end{array}$

Hamarosan arra kérünk, oldj meg néhány olvasás feladatot.

42. Mit gondolsz, hány feladatot tudsz majd helyesen megoldani?
1) Egyet sem.
2) Néhányat.
3) Felét.
4) Sokat.
5) Mindet. 
Most arra vagyunk kíváncsiak, mire gondoltál, míg az olvasás feladatokon dolgoztál. Az alábbiakban különböző állításokat fogsz olvasni, amelyekről el kell döntened, hogy mennvire voltak igazak Rád. A számok jelentése a következő:

\begin{tabular}{|c|c|c|c|c|}
\hline 1 & 2 & 3 & 4 & 5 \\
Hamis & Többnyire hamis & Néha igaz, néha hamis & Többnyire igaz & Igaz \\
\hline
\end{tabular}

Mikor a feladatokon dolgoztam...

43. szerettem volna minél jobban megérteni a feladatokat.

44. szerettem volna dícséretet kapni.

$\begin{array}{lllll}1 & 2 & 3 & 4 & 5\end{array}$

45. szerettem volna jobban teljesíteni, mint a többiek.

$\begin{array}{lllll}1 & 2 & 3 & 4 & 5\end{array}$

46. szerettem volna minél többet tanulni a feladatokból.

$\begin{array}{lllll}1 & 2 & 3 & 4 & 5\end{array}$

47. azt kívántam, bárcsak ne kellene megcsinálnom őket.

$\begin{array}{lllll}1 & 2 & 3 & 4 & 5\end{array}$

48. szerettem volna piros pontot kapni.

$\begin{array}{lllll}1 & 2 & 3 & 4 & 5\end{array}$

49. szerettem volna a többieknek megmutatni, hogy milyen okos vagyok.

$\begin{array}{lllll}1 & 2 & 3 & 4 & 5\end{array}$

50. meg akartam csinálni, mert muszáj, és túl akartam esni rajta.

$\begin{array}{lllll}1 & 2 & 3 & 4 & 5\end{array}$

51. szerettem volna jobban teljesíteni, mint máskor, hogy bizonyítsak magamnak.

52. szerettem volna megérteni a feladatot, ezért olyan keményen dolgoztam, ahogy csak tudtam.

$\begin{array}{lllll}1 & 2 & 3 & 4 & 5\end{array}$

53. szerettem volna a lehetö legkevesebbet foglalkozni a feladatokkal.

54. szerettem volna a lehetö leghamarabb befejezni a feladatokat,

hogy ne kelljen sokat gondolkodni rajtuk.

55. szerettem volna mindenkinek megmutatni, milyen okos vagyok.

$\begin{array}{lllll}1 & 2 & 3 & 4 & 5\end{array}$

56.szerettem volna minél kevesebbet foglalkozni a kérdésekkel.

$\begin{array}{lllll}1 & 2 & 3 & 4 & 5\end{array}$

57. szeretettem volna próbára tenni magam.

58. egyéb:

$\begin{array}{lllll}1 & 2 & 3 & 4 & 5\end{array}$

$\begin{array}{lllll}1 & 2 & 3 & 4 & 5\end{array}$

$\begin{array}{lllll}1 & 2 & 3 & 4 & 5\end{array}$

Mikor ehhez hasonló olvasás feladatokon dolgozom, általában úgy érezem....

59. szeretem az ilyen alkalmakat. 60. belemerülök abba, amit csinálok.

$\begin{array}{lllll}1 & 2 & 3 & 4 & 5\end{array}$

$\begin{array}{lllll}1 & 2 & 3 & 4 & 5\end{array}$

61. jól mennek a dolgok.

$\begin{array}{lllll}1 & 2 & 3 & 4 & 5\end{array}$

62. akkor is csinálnám, ha nem kellene.

$\begin{array}{lllll}1 & 2 & 3 & 4 & 5\end{array}$

63. érdektelen számomra az egész.

$\begin{array}{lllll}1 & 2 & 3 & 4 & 5\end{array}$

64. nem tud lekötni.

$\begin{array}{lllll}1 & 2 & 3 & 4 & 5\end{array}$

65. unalom fog el.

66. erőfeszítésembe kerül, hogy arra összpontosítsak, ami éppen történik.

$\begin{array}{lllll}1 & 2 & 3 & 4 & 5\end{array}$

$\begin{array}{lllll}1 & 2 & 3 & 4 & 5\end{array}$

67. magammal foglalkozom.

$\begin{array}{lllll}1 & 2 & 3 & 4 & 5\end{array}$

68. izgalmas próbatétel számomra, és élvezem, hogy tudom csinálni, amit kell.

$\begin{array}{lllll}1 & 2 & 3 & 4 & 5\end{array}$

69. távol áll tőlem, amit csinálni kell.

$\begin{array}{lllll}1 & 2 & 3 & 4 & 5\end{array}$

70. élvezem az élményt és képességeim használatát.

$\begin{array}{lllll}1 & 2 & 3 & 4 & 5\end{array}$

71. nagyok a követelmények, és ez elkeserít.

$\begin{array}{lllll}1 & 2 & 3 & 4 & 5\end{array}$

72. figyelmem elkalandozik.

73. mivel félkézzel is meg tudom csinálni, unalommal tölt el.

$\begin{array}{lllll}1 & 2 & 3 & 4 & 5\end{array}$

$\begin{array}{lllll}1 & 2 & 3 & 4 & 5\end{array}$

74. ideges leszek.

$\begin{array}{lllll}1 & 2 & 3 & 4 & 5\end{array}$

75. világosan tudom, mit kell tennem.

$\begin{array}{lllll}1 & 2 & 3 & 4 & 5\end{array}$

76. fáraszt az egész.

$\begin{array}{lllll}1 & 2 & 3 & 4 & 5\end{array}$

77. az idő észrevétlenül gyorsan szalad.

$\begin{array}{lllll}1 & 2 & 3 & 4 & 5\end{array}$ 


\section{0. sz. melléklet}

SZEGEDI TUDOMÁNYEGYETEM<smiles>[18OH]</smiles>

OKTATÁSELMÉLETI KUTATÓCSOPORT

www.edu.u-szeged.hu/ok
Diagnosztikus mérések fejlesztése TÁMOP 3.1.9/08/01-2009-0001

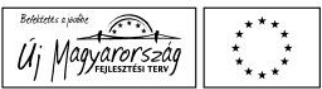

Felmérés 2010. ősz - @ J.K, H.K.

SZÖVEGÉRTÉS

AZONOSÍTÓ:

$\mathrm{A}$ - változat

1. Az alábbi menetrend segítségével válaszolj a kérdésekre!

\begin{tabular}{|c|c|c|c|c|c|c|c|}
\hline \multicolumn{8}{|c|}{ BÉKÉSCSABA } \\
\hline \multicolumn{4}{|c|}{ INDUL } & \multicolumn{4}{|c|}{ ÉRKEZIK } \\
\hline Idő & Állomás & Idö & Állomás & Idő & Állomás & Idö & Állomás \\
\hline 1.56 & Bucuresti & 5.50 & Mezöhegyes & 1.51 & Bucuresti & 6.11 & Vésztő \\
\hline 1.59 & Wien & 6.30 & Kötegyán & 1.54 & Wien & 6.19 & Orosháza \\
\hline 4.20 & Szolnok & 6.33 & Budapest & H 4.15 & Szolnok & 6.24 & Mezőhegyes \\
\hline 4.56 & Orosháza & 6.38 & Szeged & 4.54 & Lökösháza & 6.27 & Arad \\
\hline 5.23 & Lökösháza & 6.49 & Lökösháza & 5.13 & Orosháza & 6.28 & Szolnok \\
\hline 5.25 & Budapest & 7.27 & Budapest & 5.15 & Mezöhegyes & 7.04 & Szeged \\
\hline 5.25 & Szalonta & O 7.28 & Szeged & 5.16 & Kötegyán & H 7.12 & Vésztő \\
\hline H5.26 & Szeged & 7.30 & Orosháza & 5.20 & Gyoma & 7.12 & Gyoma \\
\hline \multicolumn{8}{|c|}{ Jelmagyarázat: vastag betü = gyorsvonat } \\
\hline
\end{tabular}

a) Mikor érkezik vonat Kötegyánból?

b) Vésztőröl az első vonattal érkezve mikor lehet tovább utazni Budapestre?

c) Hova megy az 5.25-kor induló gyorsvonat?

d) Honnan indul a hétköznap 7.12-kor érkező vonat?

e) Mikor indul a legkorábbi vonat Orosházára?

2. Az iskolában minden tanév végén összesítik az érkezett tanulók számát. Az utolsó hat év adatait az alábbi ábra szemlélteti.

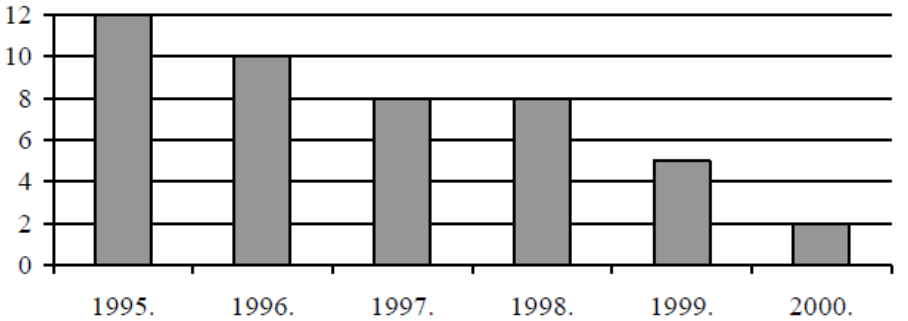

a) Melyik évben érkezett 10 gyerek?

b) Hány tanuló érkezett 1997-ben?

c) Mely években érkezett ugyanannyi gyermek?

Egészitsd ki a következö mondatot!

A legtöbb gyermekek

(d) érkezett az iskolába, számuk azonban az évek fo-

lyamán (1995-2005)

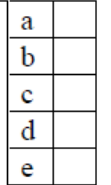


Olvasd el figyelmesen a szöveget, és a szöveg alapján oldd meg a feladatokat!

\section{Wilbur Smith:}

\section{A leopárd sötétben vadászik} (részlet)

Nyomban a madarak vészes rikoltozása után, fülsiketítő pöfögés-horkantás hangzott fel, mintha csak gözmozdony közeledne, majd éles reccsenéssel szétvált a bozót, Craig pedig megpillanthatta a sóvárogva várt állatot. Hatalmas termetü szürke orrszarvú rohant ki az ösvényre, alig harminclépésnyire töle, hogy továbbra is felháborodott, röfögö hangokat hallatva, rövidlátó apró szemeivel kémlelje hosszú, fényes, kettős szarvai közül, kit is kellene megrohannia.

Mivel tisztában volt vele, hogy a gyenge látású vad tizenöt lépésnél távolabbról nem képes azonosítani egy mozdulatlan emberalakot, ráadásul a könnyủ szellö épp szembefújt vele, Craig álltában megmerevedett, de készen rá, hogy oldalra ugorjék, ha a szürke hústömeg mégis rárohanna. A rinocérosz jobbra-balra facsarta a testét, ráadásul megdöbbentő fürgeséggel mocorogva, miközben pillanatig sem szünt dühös dörmögése, Craig pedig izgalmában azt képzelte: az állat szarvai minden pillanatban mintha egyre nőnének és hegyesebbek lennének. Óvatosan zsebében lapuló rugós kése felé nyúlt. Az állat, ha nem is látta, megérezte a mozdulatot, és ekkor vagy tíz lépést tett a mozdulat forrása felé, így azután Craig szinte hajszálpontosan az állat látótávolságának szélére került: innen a támadó már észreveheti; most valóban komollyá vált a veszély.

Rövid csuklómozdulattal magasan elhajította hát a kést az állat feje fölött, az ellenfél mögötti ébenfaligetbe; a kés hangosan csattant, amikor az ágaknak ütközött.

A rinocérosz nyomban megpördült a tengelye körül, és óriási, szürke tömegével rohanni kezdett a zörej irányába. A bozót úgy nyílt meg elötte, mintha csak tank rohant volna a sürübe, aztán az ágak suhogása és patáinak dübörgő hangja lassan halkulni kezdett, amint az orrszarvú fölrohant a domboldalban, majd a gerincen át utat tört magának a túlnani lejtőn, ellenségét keresve. Craig lerogyott az ösvény kellős közepén, és szinte kettégörnyedve hangos nevetésben tört ki, bár hahotájában titkon ott bujkált a hisztéria.

\section{1. Írj I betüt az igaz, H-t a hamis állítások elé!}

a) A feldühödött orrszarvú kereste az ellenfelét.

b) A könnyü szellő szembefújt az orrszarvúval.

c) A kés egy ébenfa ágain csattant hangosan.

d) Craig az ösvény melletti füre rogyott megkönynyebbülésében.

\section{Karikázd be az igaz állítás betủjelét!}

Az olvasmányból megtudtuk, hogy a rinocérosz...
A) jól lát.
B) mindig ösvényen közlekedik.
C) veszélyes az emberre.
D) veszélyben mozdulatlanná dermed

\section{Egészítsd ki a mondatokat a szöveg alapján!}

Craig tisztában volt vele, hogy a

(a) vad harminc lépés távolságból nem képes

azonosítani egy

(b) emberalakot.

A rinocérosz megdöbbentö

mozog, miközben folyamatosan

(d).

4. Számozással jelöld az események helyes időrendjét!

...... Az óriási rinocérosz elrohant a zörej irányába.

...... Az állat szarvai pillanatól-pillanatra nagyobbnak tüntek.

..... A madarak éles rikoltozással riasztották a rinocéroszt.

..... Az óvatosan eldobott kés hangosan csattant egy fa ágain.

...... Craig megpillanthatta a régen várt állatot.

5. Miért nyúlt Craig a késéért? Karikázd be a helyes válasz betújelét!

Azért nyúlt a késéért, mert ...

A) le akarta szúrni a támadó állatot.

B) azzal akarta a nap fényét a rinocérosz szemébe irányítani, hogy összezavarja az állatot.

C) tudta, hogy ha eldobja, azzal távolabb üt zajt, és az orrszarvú abba az irányba indul.

D) egy faágat akart levágni, hogy azzal tartsa távol magától a dühös rinocéroszt.

6. Sorold fel a rinocérosz három tulajdonságát!

7. Egészítsd ki az alábbi mondatot úgy, hogy kifejezze az olvasmány lényegét!

A rinocérosz támadásától úgy menekülhetünk meg,
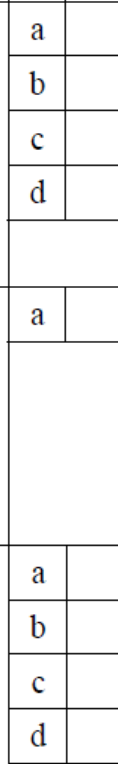

(1) 
11. sz. melléklet

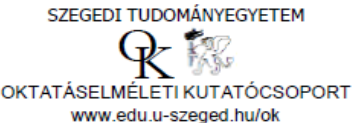

Diagnosztikus mérések fejlesztés TẢMOP 3.1.9/08/01-2009-0001. www.edu.u-szeged.hu/ok

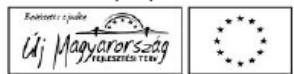

AZONOSÍTÓ:

Olvasásvizsgálat 2010

\section{Tisztelt Szülő!}

Ezúton tájékoztatjuk, hogy gyermeke osztálya is kiválasztásra került, hogy részt vegyen a Szegedi Tudományegyetem Neveléstudományi Intézetének kutatásában, mely azt vizsgálja, hogyan mit gondolnak az általános iskolás tanulók az olvasásról. A felmérés keretén belül gyermeke egy olvasástesztet és egy kérdőívet tölt ki. Azt is szeretnénk azonban megtudni, hogy Ön hogyan vélekedik az iskolával és az olvasással kapcsolatos kérdésekröl. Kérjük, válaszoljon minden kérdésre, amely nem érinti kellemetlenül. A kérdésekre adott válaszait bizalmasan kezeljük. KÉRJÜK, HOGY A KÉRDÖÍVET A GYERMEK SZÜLÖJE/GONDVISELŐJE TÖLTSE KI VAGY A SZÜLÖK/GONDVISELÖK KÖZÖSEN! KÉRJÜK, MINDEN ESETBEN A MEGFELELŐ SZÁM VAGY BETÚJEL BEKARIKÁZÁSÁVAL VAGY AZ ADATOK BEÍRÁSÁVAL VÁLASZOLJON!

1. Mielốtt gyermeke elkezdte volna az általános iskolát, milyen gyakran végezte Ön vagy valaki más otthon a következó tevékenységeket vele együtt?

\begin{tabular}{|c|c|c|c|c|}
\hline $\begin{array}{c}1 \\
\begin{array}{c}\text { Soha vagy } \\
\text { majdnem soha }\end{array}\end{array}$ & $\begin{array}{c}2 \\
\text { Félévente } \\
\text { egyszer vagy } \\
\text { kétszer }\end{array}$ & $\begin{array}{c}\text { Havonta egyszer } \\
\text { vagy kétszer }\end{array}$ & $\begin{array}{c}\text { Hetente egyszer } \\
\text { vagy kétszer }\end{array}$ & $\begin{array}{c}\text { Minden nap } \\
\text { vagy majdnem } \\
\text { minden nap }\end{array}$ \\
\hline
\end{tabular}

a) Felolvastak neki.

$\begin{array}{llllll}1 & 2 & 3 & 4 & 5\end{array}$

b) Beszélgettek vele arról, amit olvastak neki.

$\begin{array}{lllll}1 & 2 & 3 & 4 & 5\end{array}$

c) Fejböl meséltek neki.

$\begin{array}{lllll}1 & 2 & 3 & 4 & 5\end{array}$

d) Énekeltek neki vagy vele.

$\begin{array}{lllll}1 & 2 & 3 & 4 & 5\end{array}$

e) Ábécés játékokat játszottak (pl. betükockákkal).

$\begin{array}{llllll}1 & 2 & 3 & 4 & 5\end{array}$

f) Beszélgettek olyan dolgokról, amelyeket Ön olvasott. $\quad \begin{array}{lllll}1 & 2 & 3 & 4 & 5\end{array}$

g) Szójátékokat játszottak (pl. betűfelcserélős). $\quad \begin{array}{lllll}1 & 2 & 3 & 4 & 5\end{array}$

h) Betüket vagy szavakat rajzoltak, írtak. $\quad \begin{array}{lllll}1 & 2 & 3 & 4 & 5\end{array}$

i) Feliratokat, címkéket olvastak el. $\quad \begin{array}{lllll}1 & 2 & 3 & 4 & 5\end{array}$

j) Könyvtárat látogattak.

$\begin{array}{lllll}1 & 2 & 3 & 4 & 5\end{array}$

2. Hány évig járt gyermeke óvodába?

1) 3 vagy több mint 3 évig

2) 2 és 3 év között

3) 2 évig

4) 1 és 2 év között

5) 1 évig vagy annál rövidebb ideig

6) Nem járt

3. Mennyi idôs volt gyermeke, mikor elkezdte az iskolát? éves és hónapos

4. Tudott gyermeke olvasni mielött elkezdte az iskolát?
a) Ismert néhány betüt
b) Minden betüt ismert
c) Szavakat olvasott
d) Folyékonyan olvasott 
5. Hány éves jelenleg gyermeke? éves és hónapos

6. Milyen rendszerességgel végzi Ön vagy valaki más otthon gyermekével a következő tevékenységeket?

\begin{tabular}{|c|c|c|c|c|}
\hline $\begin{array}{c}\text { Soha vagy } \\
\text { majdnem soha }\end{array}$ & $\begin{array}{c}2 \\
\text { Félévente } \\
\text { egyszer vagy } \\
\text { kétszer }\end{array}$ & $\begin{array}{c}\text { Havonta egyszer } \\
\text { vagy kétszer }\end{array}$ & $\begin{array}{c}\text { Hetente egyszer } \\
\text { vagy kétszer }\end{array}$ & $\begin{array}{c}\text { Minden nap } \\
\text { vagy majdnem } \\
\text { minden nap }\end{array}$ \\
\hline
\end{tabular}

a) Hallgatom, ahogyan gyermekem hangosan olvas.

$\begin{array}{lllll}1 & 2 & 3 & 4 & 5\end{array}$

b) Beszélgetek vele arról, amiket közösen olvastunk.

$\begin{array}{lllll}1 & 2 & 3 & 4 & 5\end{array}$

c) Beszélgetek vele arról, amit legutóbb egyedül olvasott.

$\begin{array}{lllll}1 & 2 & 3 & 4 & 5\end{array}$

d) Megbeszélem vele az iskolai olvasmányokat.

$\begin{array}{lllll}1 & 2 & 3 & 4 & 5\end{array}$

e) Közösen olvasunk.

$\begin{array}{lllll}1 & 2 & 3 & 4 & 5\end{array}$

f) Felolvastatok valamit gyermekemmel (pl. újságot, receptet)

$\begin{array}{lllll}1 & 2 & 3 & 4 & 5\end{array}$

g) Segítek neki az iskolai olvasás feladatokban.

h) Elmegyünk együtt könyvtárba, könyvesboltba.

$\begin{array}{lllll}1 & 2 & 3 & 4 & 5\end{array}$

\section{Mi a véleménye gyermeke iskolájáról?}

\begin{tabular}{|c|c|c|c|c|}
\hline $\begin{array}{c}\text { Egyáltalán nem } \\
\text { értek egyet }\end{array}$ & $\begin{array}{c}2 \\
\text { Általában nem } \\
\text { értek egyet }\end{array}$ & $\begin{array}{c}3 \\
\text { Is-is }\end{array}$ & $\begin{array}{c}4 \\
\text { Általában } \\
\text { egyetértek }\end{array}$ & $\begin{array}{c}\text { Teljesen } \\
\text { egyetértek }\end{array}$ \\
\hline
\end{tabular}

a) Az iskola tájékoztat engem gyermekem iskolai elömeneteléről. $\quad \begin{array}{lllll}1 & 2 & 3 & 4 & 5\end{array}$

b) Az iskolának nagyobb erőfeszítést kellene tennie annak érdekében, hogy tájékoztasson gyermekem elömeneteléröl. $\begin{array}{lllll}1 & 2 & 3 & 4 & 5\end{array}$

c) A tanítót/tanárokat érdekli gyermekem tanulmányi elömenetele. $\begin{array}{lllll}1 & 2 & 3 & 4 & 5\end{array}$

d) Gyermekem tanítója/tanárai sokat tesz(nek) azért, hogy gyermekem jobban olvasson.

8. Egy átlagos héten általában mennyi időt tölt Ön olvasással beleértve a könyveket, hírlapokat, munkájával kapcsolatos dokumentumokat, Internetes szövegeket?

a) Hetente kevesebb, mint egy órát

b) Hetente 1-5 órát

c) Hetente $5-10$ órát

d) Hetente több, mint 10 órát

9. Amikor otthon van, milyen gyakran olvas saját örömére?
a) Minden nap vagy majdnem minden nap
b) Egy héten egyszer vagy kétszer
c) Havonta egyszer vagy kétszer
d) Soha vagy majdnem soha

10. Nagyjából hány könyv van az otthonukban?
a) $0-10$
d) $101-200$
b) $11-25$
e) $201-300$
c) $26-100$
f) több mint 300 
11. Kérjük, jelölje meg, menyire ért egyet az alábbi kijelentésekkel!

\begin{tabular}{|c|c|c|c|c|}
\hline $\begin{array}{c}\text { Egyáltalán nem } \\
\text { értek egyet }\end{array}$ & $\begin{array}{c}2 \\
\text { Általában nem } \\
\text { értek egyet }\end{array}$ & $\begin{array}{c}3 \\
\text { Is-is }\end{array}$ & $\begin{array}{c}4 \\
\text { Általában } \\
\text { egyetértek }\end{array}$ & $\begin{array}{c}5 \\
\text { Teljesen } \\
\text { egyetértek }\end{array}$ \\
\hline
\end{tabular}

a) Csak akkor olvasok, ha muszáj.

$\begin{array}{lllll}1 & 2 & 3 & 4 & 5\end{array}$

b) Szeretek másokkal arról beszélgetni, amit olvastam.

$\begin{array}{lllll}1 & 2 & 3 & 4 & 5\end{array}$

c) Szeretem a szabadidőmet olvasással tölteni

$\begin{array}{lllll}1 & 2 & 3 & 4 & 5\end{array}$

d) Csak információszerzés céljából olvasok.

$\begin{array}{lllll}1 & 2 & 3 & 4 & 5\end{array}$

e) Az olvasás fontos foglalatosság az otthonunkban.

$\begin{array}{lllll}1 & 2 & 3 & 4 & 5\end{array}$

f) Az olvasás alapos megtanulása alapvető fontosságú, ha valaki sikeres szeretne lenni.

g) Ahhoz, hogy valaki sikereket érjen el az életben, nem kell feltétlenül jól olvasnia.

h) Ahhoz, hogy valaki az életben boldoguljon, fontos, hogy meg is értse, amit olvas.

i) Fontos számomra, hogy gyermekem jó jegyeket szerezzen olvasásból/irodalomból.

j) Fontos számomra, hogy gyermekem magabiztosan olvasson.

k) Fontos számomra, hogy gyermekem egyike legyen a legjobbaknak olvasásból/irodalomból.

$\begin{array}{lllll}1 & 2 & 3 & 4 & 5\end{array}$

1) Fontos számomra, hogy gyermekem szabadidejében is olvasson. $\quad \begin{array}{lllll}1 & 2 & 3 & 4 & 5\end{array}$

m) Fontos számomra, hogy gyermekem megértse, amit olvas. $\quad \begin{array}{lllll}1 & 2 & 3 & 4 & 5\end{array}$

n) Fontos számomra, hogy gyermekem jó olvasónak érezze magát. $\quad \begin{array}{lllll}1 & 2 & 3 & 4 & 5\end{array}$

o) Fontos számomra, hogy gyermekem megtapasztalja a szabadidős olvasás örömét.

p) Fontos számomra, hogy gyermekem maga válasszon olvasmányokat. $1 \quad 2 \quad 3 \quad 4 \quad 5$

q) Fontos számomra, hogy gyermekem szépirodalmat is olvasson. $\quad \begin{array}{lllll}1 & 2 & 3 & 4 & 5\end{array}$

12. Mi a gyermek édesapjának (nevelőapjának, gyámjának) és édesanyjának (nevelőanyjának, gyámjának) a legmagasabb iskolai végzettsége?

$\begin{gathered}\text { Apa } \\ \text { (vagy nevelőapa) } \\ \square\end{gathered}$
nem fejezte be az általános iskolát
8 szakmunkásképző $\begin{gathered}\text { Anya } \\ \text { (vagy nevelöanya) }\end{gathered}$

13. Gyermeke tanulmányi átlaga tavaly év végén:

14. Gyermeke osztályzata magyar irodalomból tavaly év végén:

15. Gyermeke osztályzata magyar nyelvből tavaly év végén:

KÖSZÖNJÜK, HOGY KITÖLTÖTTE A KÉRDÖÍVET! 
12. sz. melléklet

Osztály kódja:
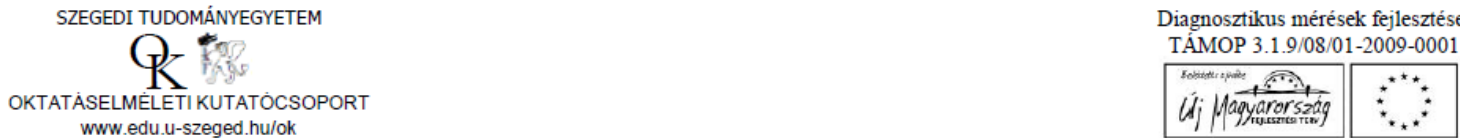

\section{TANÁRI KÉRDÖÍV}

\section{A felmérésben részt vevó osztály tanulói}

1. Hány tanuló van a felmérésben részt vevő osztályban? tanuló

2. Az iskolai év végére összesen hány éve fogja tanítani a felmérésben részt vevő osztályt? éve

3. Tapasztalatai alapján hogyan jellemezné az osztály tanulóinak olvasási szintjét?

1) Többségüké átlagon felüli

2) Többségüké átlagos

3) Többségüké átalagon aluli

4) Nagyon különböző az olvasás szintjük

\section{A KÖVETKEZÖ KÉRDÉSEK A FELMÉRÉSBEN RÉSZT VEVŐ OSZTÁLYBAN TANULÓ TANULÓK OLVASÁSTANÍTÁSÁHOZ KAPCSOLÓDNAK}

\section{Számítógép- és könyvtárhasználat}

4. Van-e lehetősége az osztálynak számítógépet használni?
1) igen
2) nem

5. Van-e könyvtár vagy könyvsarok az osztályteremben?
1) igen
2) nem

\section{Olvasástanítás}

6. Függetlenül attól, hogy az órarendben van-e olvasás óra elöírva, hetente általában mennyi időt tölt a tanulókkal, amit olvasásfejlesztésre fordít?

Hetente órát

7. Amikor olvasásórát tart, illetve olvasásfeladatot ad fel, milyen gyakran szervezi meg a tanulók munkáját az alábbiak szerint?

\begin{tabular}{|c|c|c|c|c|}
\hline 1 & 2 & 3 & 4 & 5 \\
Soha & Ritkán & Felerészt & Gyakran & Mindig \\
\hline
\end{tabular}
a) Az olvasástanítás frontális módon folyik.
$\begin{array}{lllll}1 & 2 & 3 & 4 & 5\end{array}$
b) Csoportmunkát végzünk, azonos képességü csoportokat alakítok.
$\begin{array}{lllll}1 & 2 & 3 & 4 & 5\end{array}$
c) Csoportmunkát végzünk, vegyes képességü csoportokat alakítok.
$\begin{array}{lllll}1 & 2 & 3 & 4 & 5\end{array}$
d) Egyénre szabott feladatokat adok.
$\begin{array}{lllll}1 & 2 & 3 & 4 & 5\end{array}$
e) A tanulók önállóan dolgoznak elöre megadott feladaton.
$\begin{array}{lllll}1 & 2 & 3 & 4 & 5\end{array}$
f) A tanulók önállóan dolgoznak, saját maguk választotta feladaton.
$\begin{array}{lllll}1 & 2 & 3 & 4 & 5\end{array}$ 
8. Olvasástanítás, valamint azzal kapcsolatos tevékenységek során milyen gyakran használja az alábbi forrásokat?

\begin{tabular}{|c|c|c|c|c|}
\hline $\begin{array}{c}\text { Soha vagy } \\
\text { majdnem soha }\end{array}$ & $\begin{array}{c}2 \\
\text { Félévente } \\
\text { egyszer vagy } \\
\text { kétszer }\end{array}$ & $\begin{array}{c}\text { Havonta } \\
\text { egyszer vagy } \\
\text { kétszer }\end{array}$ & $\begin{array}{c}\text { Hetente } \\
\text { egyszer vagy } \\
\text { kétszer }\end{array}$ & $\begin{array}{c}\text { Minden nap } \\
\text { vagy majdnem } \\
\text { minden nap }\end{array}$ \\
\hline
\end{tabular}
a) Tankönyvek
b) Szöveggyüjtemény vagy olvasókönyv
c) Munkafüzetek, munkalapok
d) Gyermek és képes újságok
e) Olvasásoktató számítógépes szoftverek
f) Internetes szövegek
g) Gyermekirodalom
h) Ismeretterjesztő szövegek
i) Más tantárgyhoz tartozó szövegek
j) Tanulók által írt szövegek

$\begin{array}{lllll}1 & 2 & 3 & 4 & 5\end{array}$

$\begin{array}{lllll}1 & 2 & 3 & 4 & 5\end{array}$

$\begin{array}{lllll}1 & 2 & 3 & 4 & 5\end{array}$

$\begin{array}{lllll}1 & 2 & 3 & 4 & 5\end{array}$

$\begin{array}{lllll}1 & 2 & 3 & 4 & 5\end{array}$

$\begin{array}{lllll}1 & 2 & 3 & 4 & 5\end{array}$

$\begin{array}{lllll}1 & 2 & 3 & 4 & 5\end{array}$

$\begin{array}{lllll}1 & 2 & 3 & 4 & 5\end{array}$

$\begin{array}{lllll}1 & 2 & 3 & 4 & 5\end{array}$

$\begin{array}{lllll}1 & 2 & 3 & 4 & 5\end{array}$

9. Olvasástanítás, valamint azzal kapcsolatos tevékenységek közben milyen gyakran kell a tanulóknak az alábbi szövegtípusokat olvasniuk?

\begin{tabular}{|c|c|c|c|c|}
\hline 1 & 2 & 3 & 4 & 5 \\
$\begin{array}{c}\text { Soha vagy } \\
\text { majdnem soha }\end{array}$ & $\begin{array}{c}\text { Félévente } \\
\text { egyszer vagy } \\
\text { kétszer }\end{array}$ & $\begin{array}{c}\text { Havonta } \\
\text { egyszer vagy } \\
\text { kétszer }\end{array}$ & $\begin{array}{c}\text { Hetente } \\
\text { egyszer vagy } \\
\text { kétszer }\end{array}$ & $\begin{array}{c}\text { Minden nap } \\
\text { vagy majdnem } \\
\text { minden nap }\end{array}$ \\
\hline
\end{tabular}

a) Történeteket (pl. meséket, tudományos-fantasztikus történeteket, detektívtörténeteket)

b) Hosszabb, fejezetekből álló könyveket

c) Novellákat, elbeszéléseket

$\begin{array}{lllll}1 & 2 & 3 & 4 & 5\end{array}$

d) Verseket

$\begin{array}{lllll}1 & 2 & 3 & 4 & 5\end{array}$

e) Színdarabokat

f) Embereket, eseményeket, jelenségeket bemutató, magyarázó szövegeket (ismeretterjesztők)

g) Használati utasításokat és kézikönyveket, amelyek a dolgok müködését mutatják be (pl. játékszabály) $\quad \begin{array}{lllll}1 & 2 & 3 & 4 & 5\end{array}$

h) Ábrákat, diagramokat, grafikonokat

i) Egyéb nem folyamatos szövegeket (pl. meghívók, hirdetések, képregények)

j) Egyéb: 
10. Olvasástanítás, valamint azzal kapcsolatos tevékenységek közben milyen gyakran végzi Ön az alábbi tevékenységeket?

\begin{tabular}{|c|c|c|c|c|}
\hline $\begin{array}{c}\text { Soha vagy } \\
\text { majdnem soha }\end{array}$ & $\begin{array}{c}2 \\
\text { Félévente } \\
\text { egyszer vagy } \\
\text { kétszer }\end{array}$ & $\begin{array}{c}\text { Havonta egyszer } \\
\text { vagy kétszer }\end{array}$ & $\begin{array}{c}\text { Hetente egyszer } \\
\text { vagy kétszer }\end{array}$ & $\begin{array}{c}\text { Minden nap } \\
\text { vagy majdnem } \\
\text { minden nap }\end{array}$ \\
\hline
\end{tabular}

a) Felolvas az osztálynak

b) Megkéri a tanulókat, hogy olvassanak fel az osztálynak.

$\begin{array}{lllll}1 & 2 & 3 & 4 & 5\end{array}$

c) Megkéri a tanulókat, hogy kis csoportokban olvassanak fel egymásnak. $\begin{array}{lllll}1 & 2 & 3 & 4 & 5\end{array}$

d) Megkéri a tanulókat, hogy magukban, némán olvassanak.

e) A tanulókat saját kérdéseik megfogalmazására, azokkal kapcsolatos gyüjtőmunkára ösztönzi.

f) Megmutat, megtanít különböző olvasási stratégiákat. (pl. gyorsolvasás/átolvasás, önfigyelés)

11. Az alábbi állítások közül melyik fejezi ki a legjobban azt, ahogyan Ön az olvasástanításhoz használt szövegeket a különböző olvasási szinteken alkalmazza? Válasszon egyet a felsoroltak közül!

1) Ugyanazokat a szövegeket használom minden tanulónál, és a tanulók ugyanolyan sebességgel dolgoznak.

2) Ugyanazokat a szövegeket használom minden tanulónál, de a tanulók különböző sebességgel dolgoznak.

3) Különböző szövegeket használok a különböző szinteken álló tanulókkal, de a tanulók ugyanolyan sebességgel dolgoznak.

4) Különböző szövegeket használok a különböző szinteken álló tanulókkal, és a tanulók különböző sebességgel dolgoznak.

12. Miután a tanulók elolvastak egy szöveget, milyen gyakran kéri őket az alábbiakra?

\begin{tabular}{|c|c|c|c|c|}
\hline $\begin{array}{c}\text { Soha vagy } \\
\text { majdnem soha }\end{array}$ & $\begin{array}{c}2 \\
\text { Félévente } \\
\text { egyszer vagy } \\
\text { kétszer }\end{array}$ & $\begin{array}{c}3 \\
\text { Havonta egyszer } \\
\text { vagy kétszer }\end{array}$ & $\begin{array}{c}4 \\
\text { Hetente egyszer } \\
\text { vagy kétszer }\end{array}$ & $\begin{array}{c}\text { Minden nap } \\
\text { vagy majdnem } \\
\text { minden nap }\end{array}$ \\
\hline
\end{tabular}

a) Írásban válaszoljanak az olvasottakkal kapcsolatos kérdésekre. $\quad \begin{array}{lllll}1 & 2 & 3 & 4 & 5\end{array}$

b) Alkossanak szöveget arról vagy azzal kapesolatban, amit olvastak. $\quad \begin{array}{lllll}1 & 2 & 3 & 4 & 5\end{array}$

c) Szóban válaszoljanak kérdésekre. $\quad 1 \begin{array}{llll}2 & 3 & 4 & 5\end{array}$

d) Beszéljék meg egymással az olvasottakat. $\quad 1 \quad 2 \quad 3 \quad 4 \quad 5$

e) Egyénileg tervezzenek és készítsenek el valamit azzal kapcsolatban, amit olvastak (pl. rajz, képzőmüvészeti tárgy). $\quad \begin{array}{lllll}1 & 2 & 3 & 4 & 5\end{array}$

f) Csoportban tervezzenek és készítsenek el valamit azzal kapcsolatban, amit olvastak (pl. színdarab).

g) Vitázzanak azzal kapesolatban, amit olvastak. 


\section{A KÖVETKEZŐ KÉRDÉSEK NEM CSAK A FELMÉRÉSBEN RÉSZT VEVŐ OSZTÁLYBAN TANULÓ TANULÓK OLVASÁSTANÍTÁSÁHOZ KAPCSOLÓDNAK}

\section{Az olvasásról}

13. Hogyan definiálná Ön az olvasást?

\section{Olvasási motiváció}

14. Kérjük, jelölje meg, menyire ért egyet az alábbi kijelentésekkel!

\begin{tabular}{|c|c|c|c|c|}
\hline $\begin{array}{c}\text { Egyáltalán nem } \\
\text { értek egyet }\end{array}$ & $\begin{array}{c}2 \\
\text { Általában nem } \\
\text { értek egyet }\end{array}$ & $\begin{array}{c}3 \\
\text { Is-is }\end{array}$ & $\begin{array}{c}4 \\
\text { Általában } \\
\text { egyetértek }\end{array}$ & $\begin{array}{c}5 \\
\text { Teljesen } \\
\text { egyetértek }\end{array}$ \\
\hline
\end{tabular}

Fontos számomra, hogy tanulóim...
a) ...törekedjenek arra, hogy
jó jegyeket szerezzenek olvasásból/irodalomból.
$\begin{array}{lllll}1 & 2 & 3 & 4 & 5\end{array}$
b) ...magabiztosan olvassanak.
$\begin{array}{lllll}1 & 2 & 3 & 4 & 5\end{array}$
c) ....arra törekedjenek, hogy
a legjobbak legyenek olvasásból/irodalomból.
$\begin{array}{lllll}1 & 2 & 3 & 4 & 5\end{array}$
d) ...szabadidejükben is olvassanak.
$\begin{array}{lllll}1 & 2 & 3 & 4 & 5\end{array}$
e) ...megértsék, amit olvasnak.
$\begin{array}{lllll}1 & 2 & 3 & 4 & 5\end{array}$
f) ...jó olvasónak érezzék magukat.
$\begin{array}{lllll}1 & 2 & 3 & 4 & 5\end{array}$
g) ...megtapasztalják a szabadidős olvasás örömét.
$\begin{array}{lllll}1 & 2 & 3 & 4 & 5\end{array}$
h) ...maguk válasszanak olvasmányokat.
$\begin{array}{lllll}1 & 2 & 3 & 4 & 5\end{array}$
i) ...olvassanak szépirodalmat.
$\begin{array}{lllll}1 & 2 & 3 & 4 & 5\end{array}$
j) ...más tantárgyak szövegeit is hatékonyan olvassák.
$\begin{array}{lllll}1 & 2 & 3 & 4 & 5\end{array}$
k) ...fontosnak tartsák az olvasást.
$\begin{array}{lllll}1 & 2 & 3 & 4 & 5\end{array}$
1) ....a hétköznapi életben is használni tudják olvasási képességüket.
$\begin{array}{lllll}1 & 2 & 3 & 4 & 5\end{array}$

\section{ÖNNEL KAPCSOLATOS KÉRDÉSEK}

15. Ezt a tanévet is beleszámítva, összesen hány éve tanít?

éve

16. Hány éves Ön?
1) 25 évesnél fiatalabb
2) 25-29 éves
3) 30-39 éves
4) 40-49 éves
5) 50-59 éves
6) 60 éves vagy idősebb

17. Ön nő vagy férfí?
1) férfi
2) nő 
13. sz. melléklet

\section{Elözetes kategóriarendszer a másodikos interiúk elemzéséhez}

\section{Olvasás(-tanulás) szubjektív értéke (subjective value), célok}

"Fontos neked, hogy jól tudj olvasni? Miért?"

- társas célok, társas megfelelés miatt (teljesítménycél)

○ szülök miatt (szubj_szulo) anyának szeretnék minél jobb jegyeket hazavinni

○ osztálytársak miatt (szubj_oszttars) az osztálytársaim ne nevessenek $k i$

○ tanár személye miatt (szubj_tanar) Hogy megdicsérjen Judit néni

- egyéni célok miatt (személyes cél):

○ rövidtávú célok (szubj_rovid)

nekem úgyis lesz egy testvérem, hogy tudjak neki felolvasni a mesekönyvemböl.

○ hosszútávú célok (szubj hosszu)

mert ha felnött leszek, akkor a dolgozáshoz is tudnom kell olvasni.

Hát az életben is, meg olvasás nélkül nincs is nagyon élet.

Azért hogy megtanuljak olvasni, és el tudjam majd a családomat tartani, tudjak dolgozni. Mert az állatorvoshoz is nagyon sokat kell dolgozni.

- élvezet miatt (szubj_elv)

mert szeretek olvasni

- praktikus célok miatt (szubj_prakt)

Hát, mert ha valami rosszul van, akkor ki van irva a táblára, hogy oda tilos menni.

- a fejlődés érzése miatt (elsajátítási cél) (szubj_fejl)

Hát mert még elsöben nem tudtam annyira, nem ismertem a betüket, de most már folyékonyan jönnek ki a számból a nem ismert szavak.

\section{Olvasás énkép, az énkép forrása}

„Jó olvasó vagy? Miből gondolod?”

- fontos másik visszajelzése

○ szülö (enkep_szulo)

Mert, hogy anya is dicsér

○ tanár (enkep_tanar)

Mert tanitó néni megmondta, hogy ha gyakorolok sokat, akkor majd talán jól megy az olvasás. És gyakoroltam most sokat, és jól megy most.

- jegyek (enkep_jegyek)

Mert amikor olvastunk ötöst kaptam rá.

- saját, egyéni viszonyítás

○ társas összehasonlítás, normatív viszonyítás (enkep_norm) Onnan, hogy a Zsoltihoz egy kicsit közel vagyok. Zsolti, az is egy jó olvasó. 
○ a jó olvasó jellemzőinek, kritériumoknak való megfelelés (enkep_krit) néha az olvasásomban vannak hibáim néha nem tudom kiolvasni a betüket akadozva olvasok... Hát mondjuk.... folyékonyan olvasok.

○ erőfeszítéssel való azonosítás (enkep_erofesz) mert sokat olvasok, gyakorolok

\section{Az olvasás(-tanulás) objektív értéke, használhatósága (utility value)}

„Szerinted fontos, hogy valaki jól megtanuljon olvasni? Miért?”

- rövid távú célok elérése(obj_rovid)

o iskolai

Hát azért, hogy nehogy egyes legyen az olvasás.

Hogy ne kapjon fekete pontot.

○ családi

- hosszú távú célok elérése

○ munka világával kapcsolatos (obj_hosszmunka) Azért, mert például, ha dolgozunk és ad valaki nekünk egy papirt és egy fél óra múlva visszajön érte és nem tudjuk kiolvasni, akkor nem tudjuk, hogy miröl van szó benne. Ezért is fontos megtanulni.

Azért, mert, ha nagyok leszünk akkor, akkor majd például akkor ö ö, ha elébe raknának egy könyvet, vagy ha színész szeretnénk lenni, akkor azt a produkciót nem tudnánk elolvasni,megtanulni, ha nem tudnánk olvasni.

○ tanulási, továbbtanulási (obj_hossztanul)

mert a gimiben nem lesz sok időnk elolvasni a felméréseket, meg a dogákat.

- családi (obj_hosszcsalad)

Hát azért, hogy aztán például, ha olvasni kell a gyerekének egy könyvet, akkor ne úgy olvassa például, hogy amikor eleredt az esö, ne úgy olvassa, hogy e-l-e-r-e-d-t-a-z-e s-ö /lassan mondjal, hanem úgy, hogy eleredt az esö /hangsúlyoz/

- saját képességek, tudás fejlesztése (obj_tudas)

Hogy felnöttkoromban ne legyek buta

Mert akkor megismer mindent, állatokat meg természetet.

Mert akkor okos lesz.

- mindennapi élethez, praktikus célok (obj_prakt)

Hát, hogy el tudja olvasni, hogy ott mit lehet venni és mit nem szabad csinálni Mert ha valahova elmennek, és nem tudják, hogy kell visszajönni, akkor el tudják olvasni, hogy merre van.

- élményszerzésre (obj_elmeny)

Mert olvasni jó.

Azért, mert, ha nem tud olvasni, nem tudja élvezni a könyveket. 
14. sz. melléklet

\section{Olvasás és olvasási motiváció kérdőív}

(az online kérdőív alapján)

Kedves Hallgató! Kedves Kolléga!

Az alábbi kérdöivvel pedagógusok, valamint pedagógusjelöltek olvasás-szövegértéssel, olvasási motivációval és ezek fejlesztésével kapcsolatos vélekedéseit vizsgáljuk. Kérjük, a kérdésekre minden esetben a megfelelö szám bekarikázásával vagy az adatok, definiciók beírásával válaszoljon.

\section{Az olvasásról}

1. Hogyan definiálná Ön az olvasást?

\section{Olvasási motiváció}

2. Hogyan definiálná Ön az olvasási motivációt? Hogyan jellemezné az olvasás iránt motivált tanulót?

Az olvasási motiváció.

Az olvasás iránt motivált tanuló

3. Ön szerint milyen módszerekkel célszerü az olvasás iránti motivációt fejleszteni?

\begin{tabular}{|c|c|c|c|c|}
\hline $\begin{array}{c}\text { Egyáltalán nem } \\
\text { értek egyet }\end{array}$ & $\begin{array}{c}\text { Általában nem } \\
\text { értek egyet }\end{array}$ & $\begin{array}{c}3 \\
\text { Is-is }\end{array}$ & $\begin{array}{c}4 \\
\text { Általában egyet- } \\
\text { értek }\end{array}$ & $\begin{array}{c}\text { Teljesen egyetér- } \\
\text { tek }\end{array}$ \\
\hline
\end{tabular}

a) Megfelelő célok kitüzésével (az olvasás eszköz valamely cél elérésében)

b) Az életszerüség erősítésével (pl. életszerü szövegekkel, életszerü helyzetekkel) $1124 \quad 3 \quad 4 \quad 5$

c) A tanulói autonómia támogatásával (pl. szabad szövegmegválasztással) $\quad 12345$

d) Érdekes szövegekkel

$\begin{array}{lllll}1 & 2 & 3 & 4 & 5\end{array}$

e) Olvasási stratégiák tanításával (pl. gyorsolvasás, átolvasás)

$\begin{array}{lllll}1 & 2 & 3 & 4 & 5\end{array}$

f) A kollaboráció lehetőségének biztosításával (pl. csoportmunka)

$\begin{array}{lllll}1 & 2 & 3 & 4 & 5\end{array}$

g) A jutalmazás és az értékelés eszközeivel és módjaival (pl. osztályozás)

$\begin{array}{lllll}1 & 2 & 3 & 4 & 5\end{array}$

h) Naponta történő olvastatással

$\begin{array}{lllll}1 & 2 & 3 & 4 & 5\end{array}$

i) Könyvjegyzék ajánlásával

$\begin{array}{lllll}1 & 2 & 3 & 4 & 5\end{array}$

j) Müvek szerzőinek megismertetésével, életútjuk elemzésével

$\begin{array}{lllll}1 & 2 & 3 & 4 & 5\end{array}$

k) Életkornak megfelelő irodalmak olvastatásával

$\begin{array}{lllll}1 & 2 & 3 & 4 & 5\end{array}$

1) Könyvtárlátogatással

$\begin{array}{lllll}1 & 2 & 3 & 4 & 5\end{array}$

m) Saját osztálytermi könyvtár létrehozásával

$\begin{array}{lllll}1 & 2 & 3 & 4 & 5\end{array}$

n) Könyvbemutatókkal (pl. ahol a tanulók ajánlanak könyveket egymásnak)

$\begin{array}{lllll}1 & 2 & 3 & 4 & 5\end{array}$

o) Az információs-kommunikációs technológiák bekapcsolásával

$\begin{array}{lllll}1 & 2 & 3 & 4 & 5\end{array}$

p) Mesék, történetek, narratívák olvastatásával

$\begin{array}{lllll}1 & 2 & 3 & 4 & 5\end{array}$

q) Változatos müfajú szövegek olvastatásával

$\begin{array}{lllll}1 & 2 & 3 & 4 & 5\end{array}$

r) Az erőfeszítés jutalmazásával

s) A legjobbak kiemelésével, dicsérésével

t) A jó teljesítmény jutalmazásával 